Tertiary Marine

Pelecypods of California

and Baja California:

Propeamussiidae and

Pectinidae

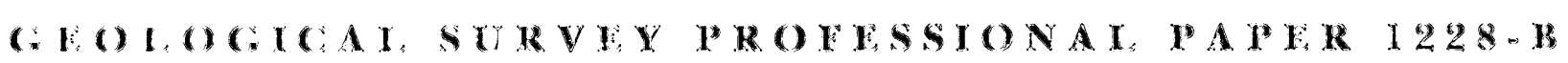




\section{Tertiary Marine}

Pelecypods of California

and Baja California:

Propeamussiidae and

Pectinidae

BY ELLEN JAMES MOORE

PALEONTOLOGY OF CALIFORNIA AND BAJA CALIFORNIA

GEOLOGICAL SURVEY PROFESSIONAL PAPER 1228-B

A total of 139 species of

Pectinacea (Propeamussiidae

and Pectinidae) are illustrated,

original descriptions quoted,

taxonomy revised and updated,

comparisons made with other

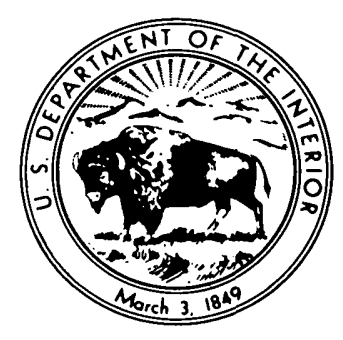

species, geographic and geologic

ranges given, occurrence by

geologic ranges given,

occurrence by geologic

formation cited, and habitat

included when it can be

confidently inferred

$\overline{\text { UNITED STATES GOVERNMENT PRINTING OFFICE; WASHINGTON : } 1984}$ 


\section{UNITED STATES DEPARTMENT OF THE INTERIOR \\ WILLIAM P. CLARK, Secretary}

\section{GEOLOGICAL SURVEY}

Dallas L. Peck, Director

Library of Congress Cataloging in Publication Data

Moore, Ellen James

Tertiary marine pelecypods of California and Baja California Peninsula.

(Paleontology of California and Baja California) (Geological Survey Professional Paper 1228-B)

Bibliography: p. B91-B99

Supt. of Docs. no.: I 19/16:1228-B

Includes index.

1. Lamellibranchiata, Fossil. 2. Paleontology_Tertiary. 3. PaleontologyCalifornia. 4. Paleontology-Mexico-Baja California. I. Title. II. Series. III. Series: Geological Survey. Professional Paper 1228-B.

QE811.M64 1983

$564^{\prime} .11$

$83-600022$

For sale by the Distribution Branch, U.S. Geological Survey, 604 South Pickett Street, Alexandria, VA 22304 


\section{CONTENTS}

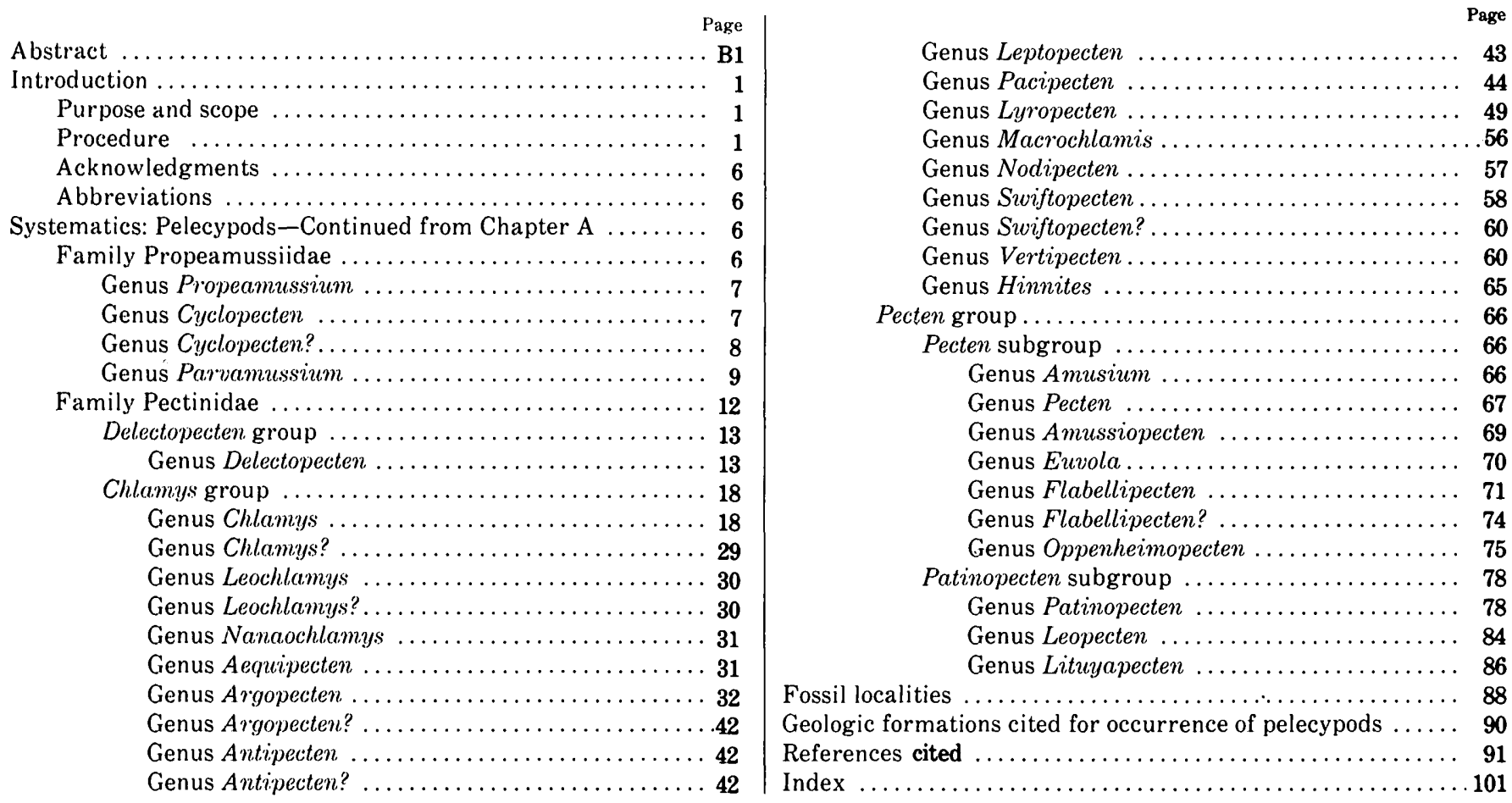

\section{ILLUSTRATIONS}

[Plates follow index]

Pl.Aik 1. Propeamussium, Cyclopecten, Parvamussium.

2. Parvamussium, Delectopecten, Amusium.

3. Delectopecten, Chlamys.

4-5. Chlamys.

6. Chlamys, Nodipecten.

7. Chlamys, Chlamys?

8. Leochlamys?. Nanaochlamys

9. Argopecten. Aequipecten.

10. Argopecten, Argopecten?

11-12. Argopecten.

13. Argopecten, Antipecten?, Leptopecten.

14. Pacipecten.

15. Pacipecten, Leptopecten.

16-19. Lyropecten.

20. Lyropecten, Pacipecten.

21. Lyropecten, Vertipecten, Macrochlamis.

22-23. Nodipecten, Swiftopecten.
24. Vertipecten, Swiftopecten?

25. Vertipecten.

26-27. Hinnites, Vertipecten.

28. Lyropecten, Pecten, Vertipecten.

29. Pecten, Amussiopecten.

30. Amussiopecten, Euvola.

31. Flabellipecten., Flabellipecten?

32. Flabellipecten, Flabellipecten?, Oppenheimopecten

33. Flabellipecten?, Oppenheimopecten.

34. Patinopecten, Oppenheimopecten.

35-36. Patinopecten.

37. Lituyapecten, Patinopecten.

38. Patinopecten.

39. Patinopecten, Leopecten, Vertipecten.

40. Patinopecten, Leopecten.

41-42. Lituyapecten, Patinopecten. 
FIGURE 1. Map showing divisions used in California for geographic range of species of pelecypods,

Propeamussiidae and Pectinidae .

2. Map showing divisions used in Baja California Peninsula for geographic ranges of species of pelecypods,

\section{TABLES}

TABl.E 1. Geographic distribution of genera in the families Propeamussiidae and Pectinidae.in the eastern Pacific region ..........B2

2. Geologic distribution of genera in the families Propeamussiidae and Pectinidae based exclusively on Tertiary and

Pleistocene species in the Californias .................
elogic and geographic distribution of large genera:

3-20. Geologic and geographic distribution of large genera:

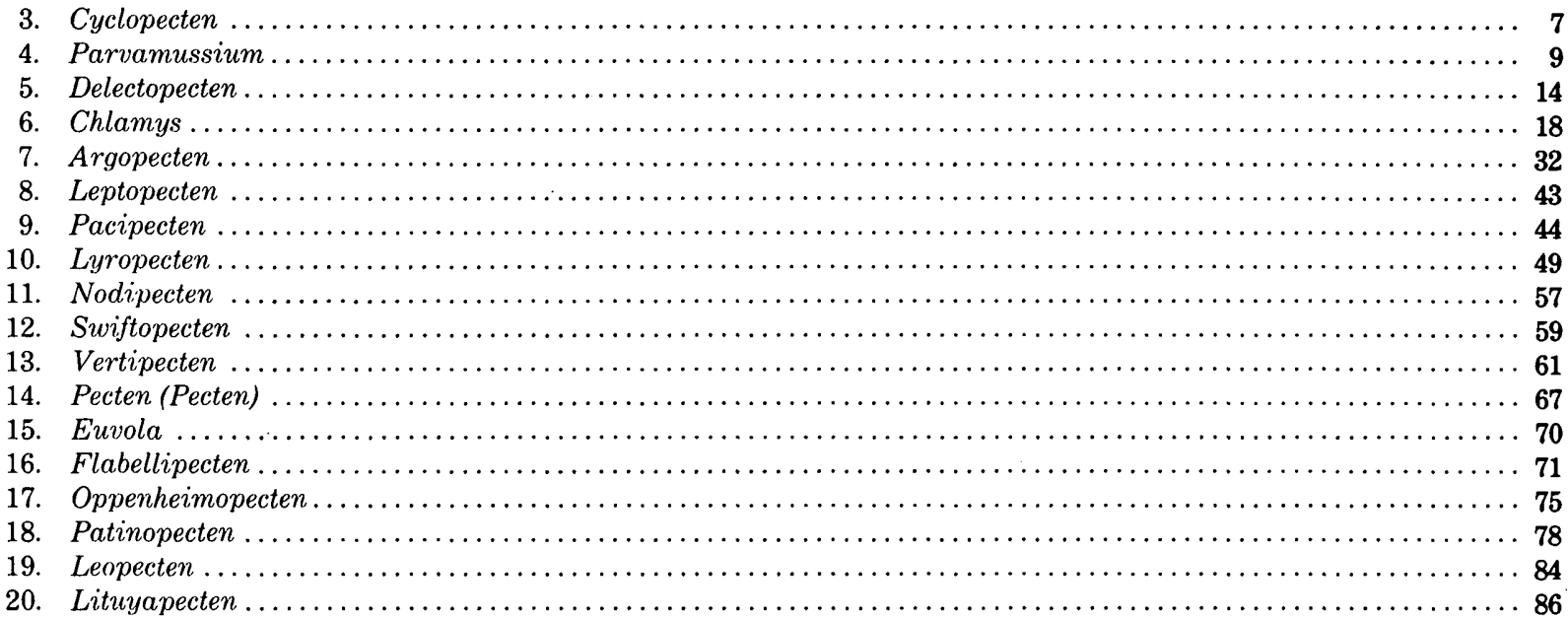




\title{
TERTIARY MARINE PELECYPODS OF CALIFORNIA AND BAJA CALIFORNIA : PROPEAMUSSIIDAE AND PECTINIDAE
}

\author{
By Ellen JAmes MoOre
}

\begin{abstract}
The description of the mollusks in the Tertiary formations of California and Baja California is continued from Chapter A. One hundred and thirty-nine species in the families Propeamussiidae and Pectinidae, representing 27 genera, are covered in this chapter; other chapters will follow in systematic order. Three genera are in the Family Propeamussiidae; the remainder are in the family Pectinidae.

The holotypes of all species are illustrated when feasible, the original description quoted, the taxonomy revised and updated, comparisons made with other species, geographic and geologic ranges given, the occurrence by formation in the Californias cited, and the habitat described when known from living specimens or inferred from related species. Tables for the larger genera are incorporated to show geographic and age ranges of the included species.

Of the 27 included genera, one occurs in the Paleocene, 6 in the Eocene. 9 in the Oligocene, 20 in the Miocene, 20 in the Pliocene, 11 in the Pleistocene, and 10 in the Holocene of the included geographic area. Eleven genera are extinct or locally extinct.

Most of the species formerly assigned to Aequipecten are placed here in Argopecten and many of those that were assigned to Leptopecten and also to Aequipecten, are placed in Pacipecten.

Antipecten, a Miocene genus in France, may be represented by Antipecten? pracvalidus (Jordan and Hertlein) from the Almejas Formation (Pliocene) of Baja California Sur. Nanaochlamys is reported for the first time outside of Japan and is represented by the species Nana.ochlamys nutteri (Arnold) from Miocene to Pleistocene strata in middle and southern California.
\end{abstract}

\section{INTRODUCTION}

PURPOSE AND SCOPE

The description and illustration of the Tertiary marine mollusks of California, Baja California Norte, and Baja California Sur started in Chapter A is continued in this chapter, which treats the families Propeamussiidae and Pectinidae (tables 1, 2). A total of 139 species occur in the geographic area covered. For convenience of reference, the figures showing the geo- graphic divisions used for the Californias are reproduced (figs. 1, 2).

Hertlein (1969) chose a conservative approach and placed supraspecific units in groups within the Pectinidae. These "groups" are retained here to show his interpretation of the relations between genera. However, most subgeneric categories used by Hertlein are elevated to generic rank for simplicity and ease of usage. This is a pragmatic approach and not a biological revision of the subgenera so treated.

\section{PROCEDURE}

All Tertiary marine mollusks originally described from California and the Baja California peninsula, and all species originally described from other geographic localities but known to occur in the Tertiary of the Californias, are included in this study. All positively identified species that have been found on faunal lists are also included. If a species is not positively identified or is questioned or only compared, it is generally not included. In genera that are extremely rare in the fossil record, however, I have included species that are only questionably identified.

In this work, species are arranged systematically following the order of families, genera, and subgenera given in the Treatise (Moore, 1969). The order in which families are arranged and the generic and subgeneric categories have generally not been modified, except in a few cases. Most modifications made reflect either definitive papers published after publication of the Treatise in 1969 or works published earlier but not cited in it. Within the systematic groups, species are arranged by geologic age, beginning with the oldest species and ending with the youngest.

Some of the names of genera and subgenera used in the Treatise and adopted in this paper have not been 
TABLE 1. ${ }^{\cdots \cdot . . . G e o g r a p h i c ~ d i s t r i b u t i o n ~ o f ~ g e n e r a ~ i n ~ t h e ~ f a m i l i e s ~ P r o p e a m u s s i i d a e ~ a n d ~ P e c t i n i d a e ~ i n ~ t h e ~ e a s t e r n ~ P a c i f i c ~ r e g i o n ~}$

$[\mathrm{F}=$ Tertiary and Pleistocene species in the Californias; $\mathrm{H}=$ living species $]$

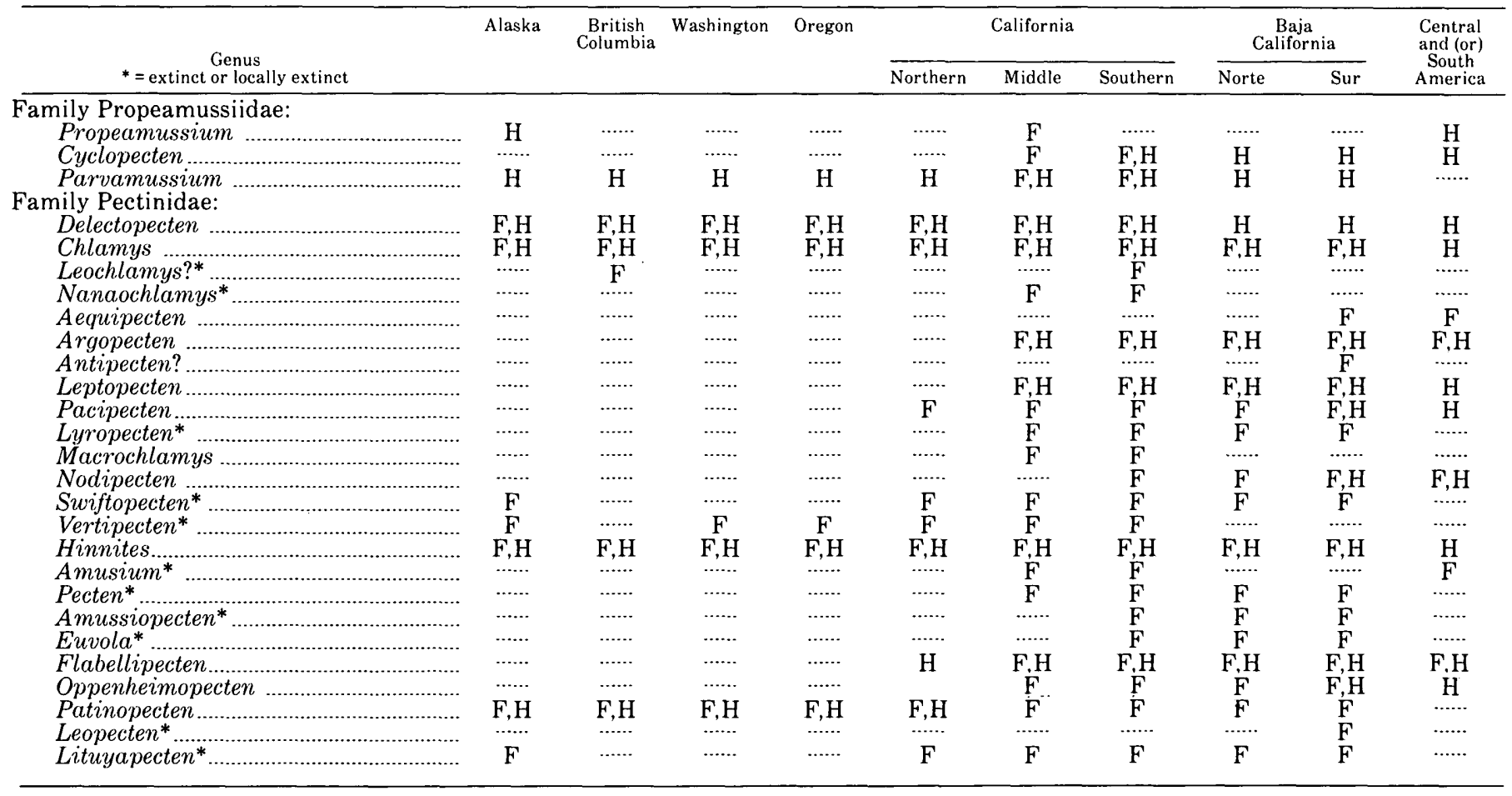

TABLE 2.-Geologic distribution of genera in the families Propeamussiidae and Pectinidae based exclusively on Tertiary and Pleistocene species in the Californias

[ $\times$ = reported occurrence; $0=$ no reported occurrence; ? = generic assignment uncertain]

\begin{tabular}{|c|c|c|c|c|c|c|c|}
\hline Genus & Paleocene & Eocene & Oligocene & Miocene & Pliocene & Pleistocene & Holocene \\
\hline \multicolumn{8}{|l|}{ Family Propeamussiidae: } \\
\hline Propeamussium & ....... & $x$ & ...... & $\cdots \cdots$ & 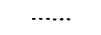 & ....... & $\cdots \cdots$ \\
\hline Cyclopecten & $?$ & $\cdots \cdots$ & ...... & $\times$ & $\times$ & $x$ & $\times$ \\
\hline Parvassium & $\dot{x}$ & $x$ & 0 & $x$ & $x$ & $x$ & $x$ \\
\hline \multicolumn{8}{|l|}{ Family Pectinidae: } \\
\hline Delectopecten & $\cdots \cdots$ & $x$ & $x$ & $x$ & $x$ & $x$ & $x$ \\
\hline Chlamys ............... & $?$ & $x$ & $x$ & $x$ & $x$ & $x$ & $x$ \\
\hline Leochlamys? ............ & ....... & $\times$ & $x$ & $x$ & ....... & ....... & ....... \\
\hline Nanaochlamys & ....... & $\cdots \cdots$ & $\cdots \cdots$. & $x$ & $x$ & $\times$ & $\cdots \cdots$. \\
\hline Aequipecten & 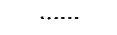 & ....... & $\cdots \cdots$ & $\cdots \cdots$ & $x$ & ....... & $\cdots \cdots$ \\
\hline 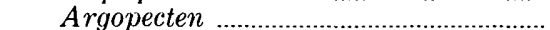 & ....... & ....... & ...... & $x$ & 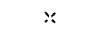 & $x$ & $x$ \\
\hline Antipecten? & $\cdots \cdots$ & $\cdots \cdots$ & $\cdots \cdots$ & ….. & $x$ & …... & $\cdots \cdots$ \\
\hline Leptopecten & ....... & ....... & ....... & $x$ & $\dot{x}$ & $x$ & $x$ \\
\hline Pacipecten & ....... & ....... & $x$ & $x$ & $x$ & $x$ & $x$ \\
\hline Lyropecten & $\cdots \cdots$ & ....... & $x$ & $x$ & $x$ & ....... & ....... \\
\hline Macrochlamis & $\cdots \cdots$ & ....... & $x$ & $x$ & …... & ....... & ...... \\
\hline Nodipecten & ....... & ....... & ....... & ....... & $x$ & $\times$. & ...... \\
\hline Swiftopecten & ....... & ...... & ...... & $x$ & $x$ & $x$ & ...... \\
\hline Vertipecten & $\cdots \cdots$ & $\times$ & $x$ & $x$ & $\cdots \cdots$ & $\cdots \cdots$. & $\cdots \cdots$ \\
\hline 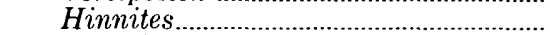 & ....... & ...... & $\cdots \cdots$ & $x$ & $x$ & $x$ & $x$ \\
\hline Amusium … & ....... & ...... & ...... & $x$ & ....... & $\ldots \ldots$ & ....... \\
\hline Pecten & $\cdots \cdots$ & $\cdots+.$. & $\therefore \cdots$ & $x$ & $\times$ & $x$ & $x$ \\
\hline Amussiopecten & …... & ....... & $\times$ & $x$ & ....... & $\cdots \cdots$ & $\cdots \cdots$ \\
\hline Euvola & ....... & ...... & ....... & $x$ & $x$ & ........ & ....... \\
\hline (1) & ...... & $\ldots \ldots$ & $x$ & $x$ & $x$ & $x$ & $\times$ \\
\hline Oppenheimopecten & ...... & $\cdots \cdots$ & $x$ & $x$ & $x$ & $x$ & $x$ \\
\hline Patinopecten & ....... & $\cdots \cdots$ & $x$ & $x$ & $x$ & $x$ & $x$ \\
\hline Leopecten & ....... & ...... & ....... & ...... & $x$ & ....... & ...... \\
\hline Lituyapecten & $\cdots \cdots$ & $\cdots \cdots$ & $\cdots \cdots$ & $x$ & $x$ & $x$ & $\ldots \ldots .$. \\
\hline
\end{tabular}




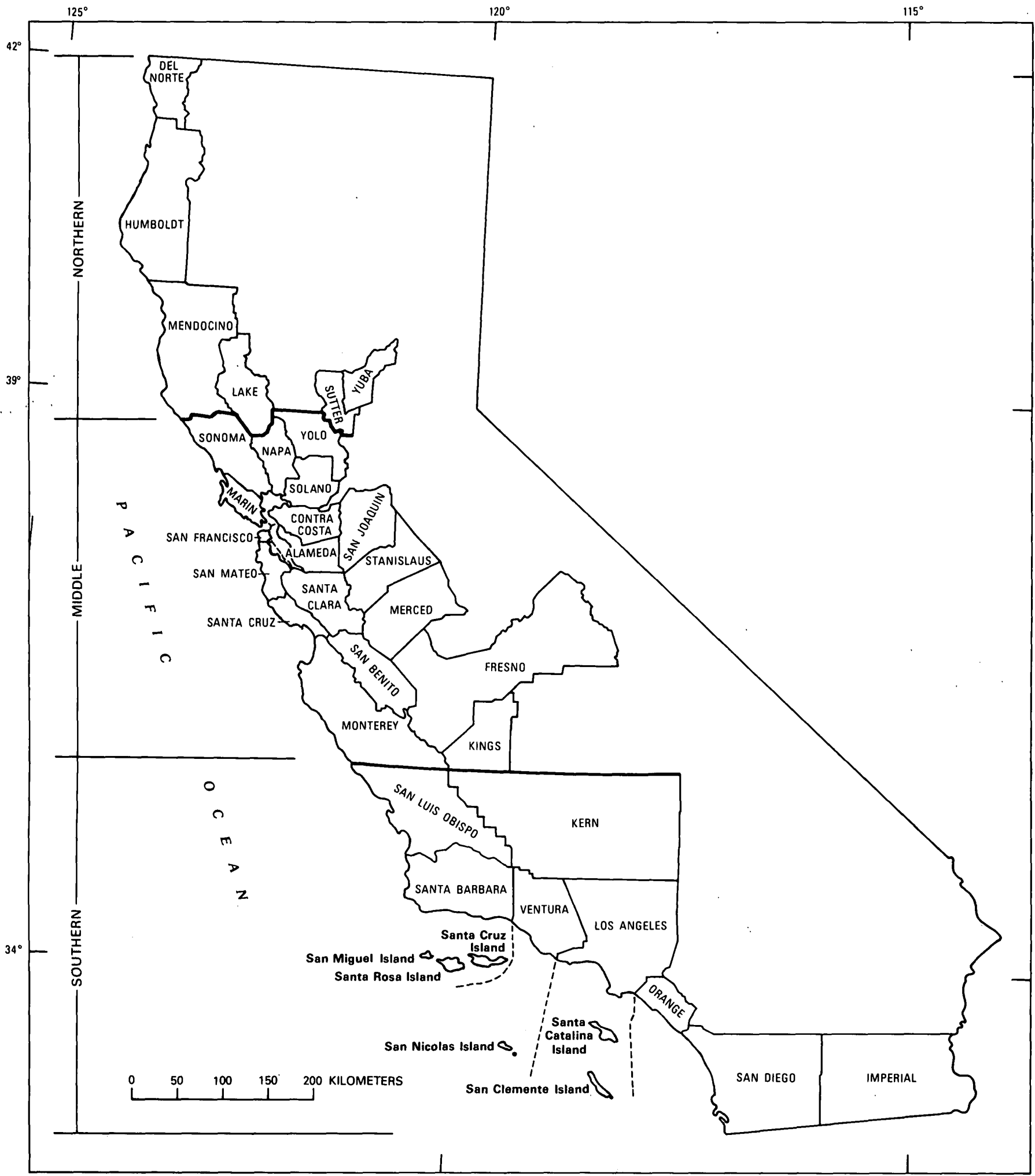

FIGURE 1.-Divisions used in California for geographic ranges of species of pelecypods, Propeamussiidae, and Pectinidae. Heavy solid lines indicate Northern, Middle, and Southern Divisions; dashed lines within southern region divide Channel Islands area: 


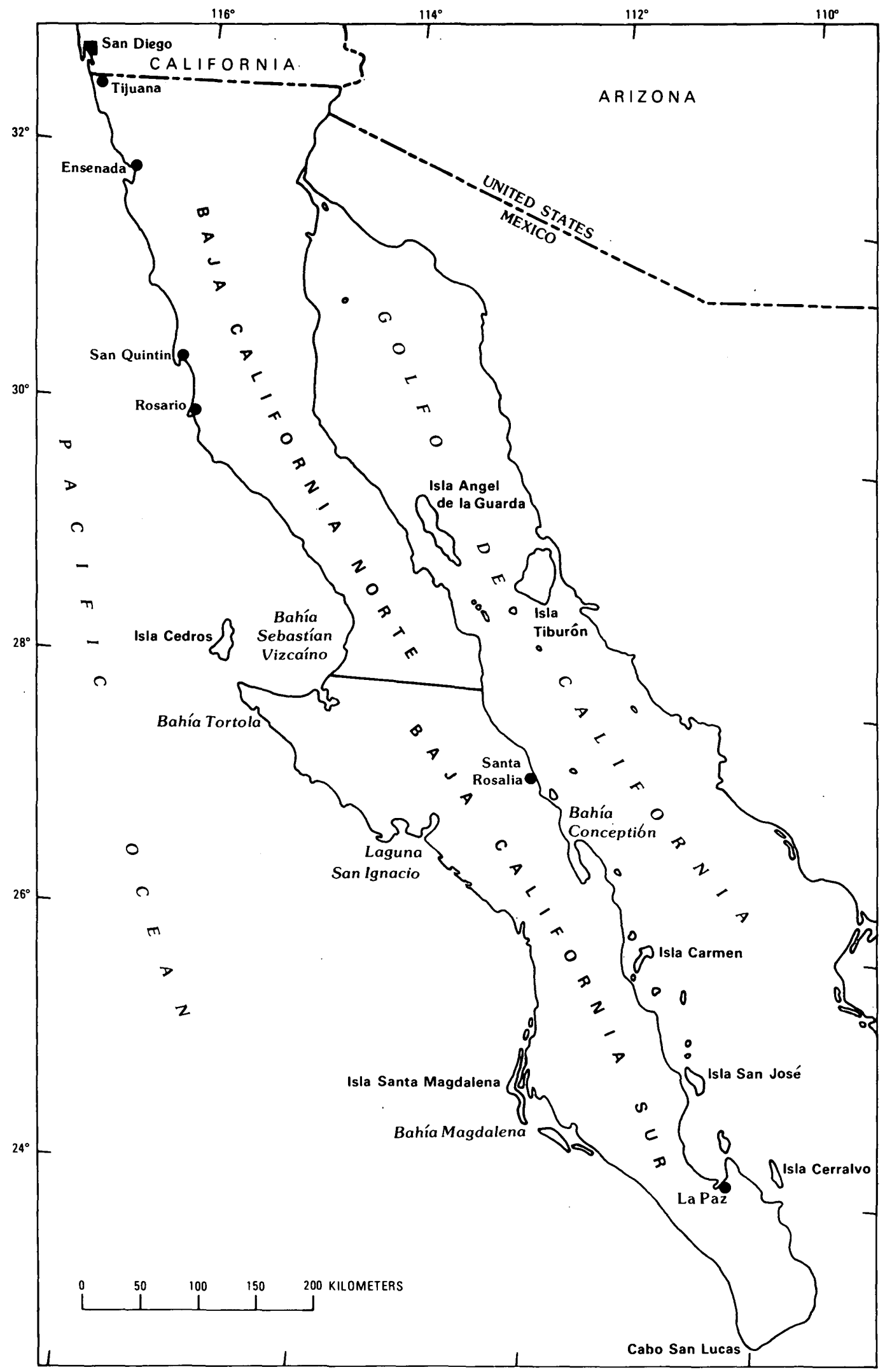

Figure 2.- Divisions used in Baja California Peninsula for geographic ranges of species of pelecypods, Propeamussiidae and Pectinidae.. 
used before for west coast Tertiary species. Brief synopses of generic and subgeneric characters are given in the appropriate places; more complete synopses will be found in the Treatise (Moore, 1969), in Keen (1971), and in Olsson (1961). For genera and subgenera that are not included in the Treatise, complete descriptions are given in the text.

For large families, a distribution table is included to show graphically the geographic and geologic distribution of species within the family. To facilitate finding a specific taxon, the species are listed alphabetically under genus and subgenus in the tables.

The synonymy for each species includes the original citation and subsequent substantive references, with particular emphasis on papers published after the checklist of Keen and Bentson (1944). The accuracy of identifications cited in subsequent references in the synonymy has not been verified. No attempt is made to include all references to a species, but the reader is referred to any citations that include extensive synonymies.

The original description is quoted from the author of the species and is not modified, nor is it translated if in a language other than English.

The type is usually that of the author of the original description or of later workers who selected a lectotype or neotype. In some instances, where syntypes or cotypes are cited but only one originally figured, I have herein designated the figured specimen as the lectotype. Lectotypes have also been designated for some species originally based on many unfigured syntypes. Where any confusion exists concerning the type specimen, the most logical specimen is selected as the lectotype.

Where the original locality description is so vague that it is of little use, the type locality is described as corrected or modified by other workers such as Keen and Bentson (1944) and the modifications given within brackets. All other localities are cited as originally described except that the formation given is that currently used.

Previously published supplementary descriptions and comparisons are included where this information adds to the original description of the species. Where such information is not available or inclusive, I have supplemented the original description in the section headed "Comments." For most descriptions, my comments are based only on examination of primary type material.

All available published data for each species have been included in the section on geographic and geo- logic age range, including that contained in faunal lists when the identification is unqualified. Range extensions into Alaska are based on written communications from Scott McCoy, Jr., Amoco Production Co., and Richard C. Allison, University of Alaska, on data not previously published. I am deeply indebted to them for making their material available to me.

Age ranges have not been refined within epochs. Where a stage name the same as a formation name is used, it is placed in quotes to distinguish it from the rock unit.

The divisions used here to indicate the approximate geographic range of species within California based on county distribution are northern, middle, and southern (fig. 1); the divisions for the Baja California Peninsula, norte and sur (fig. 2) (tables 1-7).

An attempt has been made to include all citations to a species that are unqualified and every geologic formation in which it is reported to occur in the Californias. The assumption has been made that all identifications of species are correct unless there is strong evidence to the contrary. The stratigraphic nomenclature used herein is that of the author(s) cited and does not necessarily agree with that of the U.S. Geological Survey. The age given for the stratigraphic units follows the classification of geologic time currently used by the U.S. Geological Survey. (See "Geologic Formations Cited for Occurrence of Pelecypods" at end of paper.) If the age of a formation is more than one epoch and a species is known to occur in only one part of that formation, this information is added. Except for the type locality of the species, each formation listed is followed by the name of the author and date of publication of the work from which it was obtained. More than one reference to a formation is given where it might be useful to the reader. The list of formations given for species occurrence should not be considered complete or necessarily accurate. Many western American Tertiary faunas have not been monographed, and their species content is not fully known. It is hoped that the list of formational occurrences reported will serve as a framework upon which the true distribution of each species can be built.

Most of the data on habitat have been compiled from Abbott (1974), Burch (1944), Hertlein and Grant (1972), Keen (1971), Smith and Gordon (1948), Stanley (1970), and Yonge and Thompson (1976).

The type specimens were all photographed by Kenji Sakamoto, U.S. Geological Survey, with the exception of those housed in the National Museum of Natural History, which were photographed by Robert $\mathrm{H}$. 
McKinney. Owing to the fact that the specimens photographed by Sakamoto were borrowed from other institutions, he did not use his usual technique of opaquing specimens for photography (Sakamoto, 1973). Photographs of a few specimens were furnished by other individuals or institutions; credit is given them on the plate explanations. The holotype of each Tertiary species is figured if the type is extant. Some Holocene type specimens retained in museums outside the United States have not been figured; specimens considered to be of the same species by authors such as Keen (1971) or Hertlein and Grant (1972), or Holocene specimens from the type locality, are used for these illustrations, and this information is included in the plate explanation. A few substitutions are made for missing Tertiary types, as noted in the plate explanations along with their source.

\section{ACKNOWLEDGMENTS}

Barry Roth, California Academy of Sciences, and Thomas R. Waller, National Museum of Natural History, reviewed the manuscript and their pertinent suggestions and consultation were most helpful.

Judith T. Smith loaned me photographs and specimens and gave generously of her time and advice concerning Lyropecten, Macrochlamis, Nodipecten, and Vertipecten, and I am indebted to her.

The following individuals made available or loaned type material or made arrangements for photography, and I am indebted to them: Barbara A. Bedette, U.S. Geological Survey; Federick J. Collier, National Museum of National History; Vickie Kohler, Museum of Comparative Zoology; Joseph E. Peck, University of California at Berkeley; Barry Roth, California Academy of Science; LouElla Saul, University of California, Los Angeles; Elizabeth V. Scott, Philadelphia Academy of Sciences; Frederick R. Schram, San Diego Natural History Museum; and Edward C. Wilson, Los Angeles Natural History Museum.

Mildred P. James made up cards for each species and its occurrences as noted on faunal lists. This was a time consuming task, and I thank her for her patience and support.

\section{ABBREVIATIONS}

ANSP: The Academy of Natural.Sciences of Philadelphia, Philadelphia, Pa.

BM (NH): British Museum of Natural History, London, England.
CAS: California Academy of Sciences, San Francisco, Calif.

LAM: Los Angeles Museum of Natural History, California.

MCZ: Harvard Museum of Comparative Zoology, Cambridge, Mass.

SDNM: San Diego Natural History Museum, California.

CAS/SU: Stanford University, Stanford, Calif. [The Stanford University collections are now housed at the California Academy of Sciences.]

SU: Stanford University, Stanford, Calif.

UC: University of California, Berkeley.

UCMP: University of California, Museum of Paleontology, Berkeley.

UCR: University of California at Riverside.

USGS: U.S. Geological Survey, Washington, D. C., Cenozoic locality register.

USGS M: U.S. Geological Survey, Menlo Park, Calif., Cenozoic locality register.

USNM: National Museum of Natural History, Washington, D. C.

UW: University of Washington, Seattle, Wash.

\section{SYSTEMATICS: PELECYPODS-CONTINUED FROM CHAPTER A}

\section{Family PROPEAMUSSIIDAE}

"Byssate or free Pectinacea with outer simple-prismatic calcitic layer on right valve present on main portion of disk throughout ontogeny; crossed-lamellar aragonite extending outside of pallial line, in some cases nearly to distal margins, and commonly covering hinge plate. Byssal notch without ctenolium even in early growth stages. Mantle curtains commonly without guard tentacles." (Waller, 1978, p. 353)

Waller (in Bernard, 1978, p. 65) states that he includes Cyclopecten Verrill in his expanded concept of the Family Propeamussiidae, whereas Delectopecten Stewart remains a member of the family Pectinidae.

"Dissection of propeamussiids reveals that there are numerous anatomical surprises, only some of which have been reported by previous investigators. [In Propeamussium]. There is a total lack of ocelli; there are no guard tentacles on the edges of the velum; and there is no trace of any pedal retractor insertion on the left valve. These, and other features as yet undescribed, are unknown in the common Pectinidae.

"Shell microstructure and soft-part anatomy $* * *$ provide ample evidence for the separation of the Propeamussiidae and the Pectinidae. The Propeamussiidae, today largely restricted to waters of the continental slopes and abyssal regions, most closely resemble the Pernopectinidae of the Paleozoic, and available evidence strongly suggests that the living forms may actually be surviving relicts of the group thought to have been extinct for 225 million years." (Waller, 1971, p. 7) 


\section{Genus PROPEAMUSSIUM de Gregorio, 1884}

Valves rather flattened, usually gaping along lateral margins; byssal notch slight; internal ribs extend about halfway (farther in some) to ventral shell margin.

Geologic range.-Jurassic through Holocene.

Habitat. -275-2,740 m (Waller, 1971).

\section{Propeamussium interradiatum (Gabb) \\ Plate 1, figure 1}

Pecten interradiatus Gabb, 1869, p. 199-200, pl. 33, fig. 98; not? fig. 98a. Dickerson, 1914, p. 108, 151, pl. 9, fig. 5.

Pecten. (Propeamussium) interradiatus Gabb. Arnold, 1906, p. 53-54, pl. 2, figs. 9-11. G. D. Hanna and Hertlein, 1943, fig. 62-28.

Propeamussium interradiatum (Gabb). Stewart, 1930, p. 123-124 pl. 8, fig. 10. Stewart, 1946, pl. 12, figs. 8, 9. Schenck and Keen, 1950 , pl. 7, figs. 4,5 .

Propeamussium (Propeamussium) interradiatum (Gabb). Addicott, 1971 , p. 229, figs. $6,11$.

Pecten (Propeamussium) vacavillensis Palmer, 1923, p. 301, pl. 55, figs. $3,4 a, 4 b, 5$

Original description. - "Shell small, subcircular, equivalve, equilateral, compressed, thin; upper [left] valve, ears equal, moderately large; lower [right] valve, right ear long, deeply and narrowly emarginate. Surface marked by very numerous fine radiating lines, and obscure lines of growth. Internal surface of both valves bearing eight straight, equidistant, large ribs, of variable length among themselves, extending from the beaks to near the middle of the shell, and ending abruptly."

Lectotype.-ANSP 4652 (Stewart, 1930). [Inadvertently cited by Stewart as ANSP 4442.] Holotype of Pecten (Propeamussium) vacavillensis Palmer, UCMP 30596.

Type locality. -Of Propeamussium interradiatum: East of New Idria [Priest Valley quad.. San Benito County], Calif. Kreyenhagen Shale, Eocene and Oligocene; of Pecten (Propeamussium) vacavillensis: UC 3573, Solano County, Calif. Capay Formation, Eocene.

Supplementary description.-Addicott $(1971$, p. 229) notes that whereas the ears and the length of the internal ribs on one of the original hand-drawn illustrations representing a left valve of $P$. interradiatum (Gabb, 1869, pl. 33, fig. 98) indicate reference to Propeamussium (Propeamussium), the other illustration of a portion of the dorsal margin of a right valve (figure 98a) indicates a deep byssal notch and an extremely narrow right anterior ear, suggesting that the figures are of entirely different taxa.

Comparison. - Propeamussium interradiatum (Gabb) differs from P. leohertleini Addicott (1971), described from the Eocene of Alaska, in having a relatively smooth exterior and fewer internal ribs -8 rather than 10 . (Addicott, 1971, p. 227)
"It seems doubtful that Propeamussium stanfordensis [Arnold, 1906] represents young specimens of the well-known Eocene species P. interradiatum (Gabb) as was suggested by Grant and Gale (1931). The shorter, consistently fewer internal ribs -8 rather than 10 or more-and the weaker, much finer concentric sculpture of $P$. interradiatum $* * *$ permit differentiation." (Addicott, 1971, p. 229)

Comments. - The lectotype of $P$. interradiatum, presumably a left valve, does not have the external shell preserved. It bears eight internal ribs; three posterior ribs are straight, the remaining five curve toward the anterior margin. The holotype of Pecten (Propeamussium) vacavillensis is a juvenile specimen $(1.4 \mathrm{~mm}$ high and $1.4 \mathrm{~mm}$ wide), broken subsequent to its original illustration, that was distinguished from $P$. interradiatum by Palmer (1923, p. 301) as follows: " $P$. vacavillensis differs from $P$. interradiatus Gabb in that the internal ribbing occupies only the ventral two-thirds of the shell instead of the dorsal half as indicated in the original figure."

As noted by Stewart (1930, p. 124), on small specimens of $P$. interradiatum the internal ribs reach almost to the ventral shell margin.

Geographic range.-Middle California.

Geologic range.-Eocene.

Occurrence in California. -Eocene: Butano(?) Sandstone (Addicott, 1971), Capay Formation (Palmer, 1923), lower part of Kreyenhagen Shale (Addicott, 1971), and Tejon Formation (Arnold, 1906).

\section{Genus CYCLOPECTEN Verrill, 1897}

Small, thin, not gaping, right valve flexible and upturned at margin in some forms; sculptured with concentric lamellae or nearly smooth, left valve with radial rows of arched scales or pustules; auricles well delimited; cardinal crura single, commonly feebly developed, hinge generally bearing vertical transverse striae; byssal notch large, without a ctenolium.

Geologic range.-Paleocene(?); Miocene through Holocene (table 3).

Habitat. -5 to $2,325 \mathrm{~m}$.

\section{Cyclopecten lompicoensis (Arnold)}

\section{Plate 1, figure 2}

Pecten (Pseudamusium) lompicoensis Arnold, 1906, p. 89, pl. 23, fig. 5; pl. 27, fig. 8.

Original description.- "Adult shell averaging about 11 millimeters in altitude, subcircular, inequivalve, thin, compressed, margins smooth. Right valve ornamented externally by numerous sharp, elevated, equal, equidistant, imbricating, concentric lamellae; hinge line equal to one-half length of disk; ears unequal; anterior nearly twice as long as the posterior, arcuately truncated and sculptured by regular sharp, imbricating, concentric lamellae and 6 or 7 faint

TABLE 3.-Geologic and geographic distribution of the genus Cyclopecten in the eastern Pacific region

$[\mathrm{H}=$ Holocene; $\mathrm{Ple}=$ Pleistocene; $\mathrm{Pl}=\mathrm{Pliocene} ; \mathrm{M}=$ Miocene; $\mathrm{Pa}=$ Paleocene $]$

\begin{tabular}{|c|c|c|c|c|c|c|}
\hline \multirow{2}{*}{ Species } & \multicolumn{3}{|c|}{ California } & \multicolumn{2}{|c|}{$\begin{array}{c}\text { Baja } \\
\text { California }\end{array}$} & \multirow{2}{*}{$\begin{array}{c}\text { Central } \\
\text { and (or) } \\
\text { South } \\
\text { America }\end{array}$} \\
\hline & Northern & Middle & Southern & Norte & Sur & \\
\hline \multirow{2}{*}{\multicolumn{7}{|c|}{$\begin{array}{l}\text { Genus Cyclopecten: } \\
\text { incongruus (Dall) }\end{array}$}} \\
\hline & $\cdots \cdots$ & $\cdots \cdots$. & Pl,Ple & $\mathrm{H}$ & $\cdots \cdots$ & $\cdots \cdot \cdot \cdot$ \\
\hline lompicoensis (A rnold) & $\cdots \cdots$ & $\mathrm{M}$ & & & $\cdots \cdots$ & $\cdots \cdots$ \\
\hline pernomus (Hertlein) & $\cdots \cdots$ & $\cdots \cdots$ & $\mathrm{Pl}$ & $\mathrm{H}$ & $\mathrm{H}$ & $\mathrm{H}$ \\
\hline $\begin{array}{l}\text { Genus Cyclopecten?: } \\
\text { martinezensis (Gabb) }\end{array}$ & & & & … & & \\
\hline 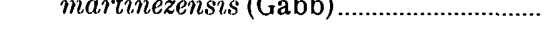 & …. & $\mathrm{Pa}$ & 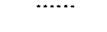 & $\cdots \cdots$ & $\cdots \cdots$ & $\cdots \cdot . \cdot$ \\
\hline
\end{tabular}


radials; posterior ear short, somewhat obliquely truncated and sculptured by concentric lamellae; byssal notch only faintly indicated. Left valve sculptured by concentric lamellae similar to those of the right, and, in addition, having numerous fine radiating striae, which usually become obsolete near the periphery in the adult shell; ears similar to those of the right valve, except that in the specimens examined no radials were noted on the anterior one. Hinge similar to that of $P$. randolphi."

Holotype.-USNM 164931.

Type locality.-Head of Lompico Creek [NW1/4 sec. 24, T. 9 S., R. 2 W., Santa Cruz Quad.], Santa Cruz County, Calif. Monterey Formation, Miocene.

Comparison.-Arnold (1906, p. 89) says that C. lompicoensis can be distinguished from Delectopecten peckhami by its much more prominent and regular concentric lamellae, and well-defined ears.

Comments. - The right posterior auricle of C. lompicoensis is delineated, excluding it from Delectopecten, and no trace of internal ribs can be seen, excluding it from Propeamussium and Parvamussium. The only sculpture preserved is strong, almost equally spaced, concentric ridges on the right valve. The left posterior auricle seems not to be delineated.

I am indebted to T. R. Waller (written commun., 1979) who examined the holotype of this species and said that it "is definitely a member of the Propeamussiidae as evidenced by the presence of a prismatic structure over the entire right valve and lack of a ctenolium. I think that it can best be placed in Cyclopecten for the present."

Geographic range.-Middle California.

Geologic range.-Miocene.

Occurrence in California.-Monterey Formation.

\section{Cyclopecten pernomus (Hertlein)}

\section{Plate 1, figures 3-6}

Pecten (Cyclopecten) rotundatus Dall, 1908, p. 404. Not Pecten rotundus von Hagenow, 1842.

Pecten (Cyclopecten) pernomus Hertlein, new name, 1935, p. 320, pl. 18, figs. 11-13.

Cyclopecten pernomus (Hertlein). Grau, 1959, p. 32-34, pl. 11. Hertlein and Grant, 1972, p. 213-214, pl. 33, figs. 7, 11.

Amusium (Cyclopecten) pernomus Hertlein. Olsson, 1961, p. 168-169, pl. 21 , fig. 6.

Original description. - "Shell very small, thin, white, suborbicular, with subequal ears, both valves nearly equally convex; right valve polished, minutely regularly concentrically striated, which sculpture is barely visible under a hand lens; posterior ear smooth, anterior finely radially threaded, with a narrow but clean-cut byssal sulcus and fasciole; left valve finely sharply radially striated, the anterior ear finely reticulated, the posterior apparently nearly smooth; hinge line short, straight; interior smooth, a pair of small auricular crura present; the hinge line with a minute central pit and two relatively large transversely sharply striated, elongate areas representing a permanent provinculum. Height and length, 3; hinge line, 2.5; diameter, $1.0 \mathrm{~mm}$. A single valve from near the Straits of Magellan, apparently the same species, measures $7 \mathrm{~mm}$. in height." Syntypes.-USNM 110708; two left and one right valve.

Type locality.-Panama Bay, Panama, Albatross Station 2799, in $54 \mathrm{~m}$.

Supplementary description.-“The right valve is slightly smaller than the left. Its anterior auricle has concentric as well as radial striae; its posterior auricle is not 'smooth,' having 7 to 11 fairly prominent radial threads and finer concentric threads. The posterior auricle of the left valve is not 'nearly smooth,' having both fine radial and finer concentric threads. ***" (Grau, 1959, p. 33)
"The ears have a large, impressed, flattened inner surface which is finely vertically grooved or striated along the hinge, these groovings often interlock so well that the valves do not separate easily without breaking the shell." (Olsson, 1961; p. 169)

Comparison.- “Cyclopecten pernomus lacks the distinct posterior flexure which is present on the right valve of $C$. cocosensis Dall. The auricles of $C$. pernomus are much less acutely pointed than those of C. acutus Grau from West Colombia ***" (Hertlein and Grant, 1972 , p. 214)

Comments. - Cyclopecten pernomus is smaller than C. incongruus. The left valve has fine radials, whereas on $C$. incongruus the leftvalve radials are scabrous and more prominent on the posterior half and the shell has strong concentric lamellae. The right valve of $C$. pernomus is smooth; C. incongruus is sculptured by prominent concentric lines.

Geographic range. - Living: Cedros Island, Baja California Norte, Gulf of California, to La Libertad, Ecuador; also Guadalupe Island and Galapagos Islands; fossil: southern California.

Geologic range.-Pliocene through Holocene.

Occurrence in California.-Pliocene: San Diego Formation (Hertlein and Grant, 1972).

Habitat. - Usually on mud bottoms, occasionally sandy mud or sand; sometimes associated with eel grass; 2 to $344 \mathrm{~m}$ (Grau, 1959).

\section{Cyclopecten incongruus (Dall)}

\section{Plate 1, figures 7, 8}

Pseudamusium incongruum Dall, 1916, p. 403.

Cyclopecten incongruus (Dall). Grau, 1959, p. 36, pl. 13.

Original description-"Shell small, white suborbicular, left valve rather flat with short straight hinge line, ears concentrically scaly, sculpture of disk concentric continuous low sharp lamellae, crossed by slightly raised radial lines, conspicuous only at the intersections which form in the middle of the disk square reticulations with a small conspicuous pustule at each intersection; laterally these are more crowded; right valve concave near the margin, closely regularly concentrically lamellose; anterior ear with five radial lines, coarsely lamellose with a shallow notch and serrate margin. Height, 14 ; breadth, 15; diameter, $3 \mathrm{~mm}$."

\section{Holotype.-USNM 207273.}

Type locality. - “*** Station 2986, N.W. of Cerros [sic: Isla Cedros] Island, Lower California." (Grau, 1959, p. 36)

Supplementary description. - "This is the largest eastern Pacific Cyclopecten, none of the other species exceeding $10 \mathrm{~mm}$ in height." (Grau, 1959, p. 36)

Comments.-See C. pernomus.

Geographic range.-Living: Isla Cedros, Baja California Norte; fossil: southern California.

Geologic range.-Pliocene through Holocene. This species may be restricted to the Pleistocene through Holocene, depending upon its stratigraphic position within the Fernando Formation.

Occurrence in California.-Pliocene and Pleistocene: Fernando Formation (Zinsmeister, 1970).

Habitat.-The holotype was collected at $1,250 \mathrm{~m}$ from fine gray sand and broken shell.

\section{Genus CYCLOPECTEN?}

\section{Cyclopecten? martinezensis (Gabb)}

Plate 1, figures 9, 10

Pecten martinezensis Gabb, 1869, p. 198, pl. 33, fig. 96. Stewart 1930, 117-118, pl. 7, fig. 10 
Original description.-"Shell minute, thin, elongate, equivalve, equilateral; sides straight above, below forming with the base a regular curve. Lower valve, right auricle deeply emarginate, narrow; left smaller. Upper valve, right auricle small; left large, margin slightly sinuous. Surface ornamented by fine radiating ribs."

Lectotype. $-\mathrm{MCZ} 15026 \mathrm{a}$.

Type locality.-Martinez [Contra Costa County], Calif. Martinez Formation, Paleocene.

Comments. - On the basis of the lectotype and two remaining specimens in the type lot, this species is small, thin shelled, and has fine radiating ribs or striations. The lectotype is an internal mold that retains no shell. It is presumably a left valve and is moderately inflated for its size. Faint traces of ribs or striations are preserved near the ventral posterior margin. The anterior auricle is small and squarely truncated; the posterior auricle is incomplete but may have been slightly smaller.

One specimen remaining in the type lot, also apparently a left valve, shows traces of fine ribs over the entire surface of the internal mold. The auricles are incomplete, retain patches of the internal shell layer, and are of the same size and proportions as those on the lectotype.

The last remaining specimen in the type lot is an incomplete specimen that shows the interior of the shell. It seems to be a right valve and, if so, the anterior auricle was narrow and perhaps not very long.

None of the specimens in the type lot show internal ribs. Thus the species is presumably neither Pseudamussium nor Parvamussium, and the valves do not show the posterior obliquity of Delectopecten. The fine radial ribs and outline of the auricles suggest Cyclopecten.

Geographic range.-Middle California.

Geologic range.-Paleocene.

Occurrence in California.-Martinez Formation.

\section{Genus PARVAMUSSIUM Sacco, 1897}

Differs from Propeamussium in its usually more rounded shape, lack of lateral gape, presence of well-developed byssal notch, and internal ribs extending to or almost to the ventral margin. Differs from Cyclopecten in possessing internal ribs.

According to T. R. Waller (oral commun., 1979), Parvamussium belongs in the family Propeamussiidae.

Geologic range.-Cretaceous through Holocene (table 4).

\section{Parvamussium mideocenicum (Vokes)}

\section{Plate 1, figure 11}

Propeamussium mideocenicum Vokes, 1939, p. 55-56, pl. 3, figs. 2, 3; not? pl. 3, fig. 4.

Original description. - "Shell small, thin, slightly higher than long; ventral margin evenly rounded, the anterior and posterior margins straight to the umbos; surface of left valve ornamented with
10 to 12 low, rounded ribs separated by flat-bottomed interspaces of varying width, widest on the center of the valve but never less than twice the width of the ribs; both ribs and interspaces marked by faint lines of growth; surface of right valve not seen; ears smooth, subequal, the byssal notch well-defined, small; interior of both valves with 10 to 12 ribs extending from the umbo to the ventral margin and directly opposite the ribbing on the exterior of the valve.

"Propeamussium mideocenicum may be distinguished by the fact that the ribbing on the surface of the left valve is directly opposite that on the interior of the valve, which extends from the umbo to the ventral margin."

Syntypes.-UCMP 15584 and 15586; not? 15585 which may be Parvamussium stanfordensis.

Type locality.-UC 1817. Fresno County, Calif. Cerros Shale Member, Lodo Formation (Keen and Bentson, 1944), Paleocene.

"One of the early Eocene specimens of Propeamussium mideocenicum Vokes, 1939, UCMP 15585 from the Arroyo Hondo Shale Member of the Lodo Formation in the San Joaquin basin, California, might be $P$. stanfordensis. The ears, number and configuration of internal ribs, and size of this syntype are similar to $P$. stanfordensis. The other syntypes (both left valves) are quite distinet; they probably represent an entirely different species than $P$. stanfordensis judging by the occurrence of external ribbing and by the fact that these ribs are much more numerous than on the right valve-12 instead of 9." (Addicott, 1971, p. 229)

Comparison.- " $P$. interradiatum (Gabb) has but 8 internal ribs which extend only half way down the valve from the umbo. *** P. lajollaense (M. A. Hanna) from the La Jolla formation, has about 65 ribs on the exterior of the valve." (Vokes, 1939, p. 56)

Parvamussium leohertleini, from the Eocene of Alaska, differs from $P$. mideocenicum principally in lacking a well-defined byssal notch. The left valve of $P$. mideocenicum can be differentiated from $P$. leohertleini by its prominent, sharp external ribs. Further, but minor, differences are the relatively shorter internal ribs and the prominent, but very fine, growth striae of $P$. leohertleini. (Addicott, 1971, p. 227)

Comments. - The exterior of the left valve bears 12 preserved well-defined, small ribs but may have had originally about 15; the shell is glossy white. The left valve auricles seem to have been equal in size.

Geographic range.-Middle California.

Geologic range.-Paleocene.

Occurrence in California.-Paleocene: Cerros Shale Member, Lodo Formation (Keen and Bentson, 1944).

\section{Parvamussium lajollaense (M. A. Hanna)}

Plate 1, figures 12, 13

Pecten lajollaensis M. A. Hanna, 1927, p. 277, pl. 32, figs. 1, 3-6.

Original description. - "Shells quite small, thin; length and altitude about equal; slightly convex; base evenly rounded; sides nearly

TABLE 4.-Geologic and geographic distribution of the genus Parvamussium in the eastern Pacific region $[\mathrm{H}=$ Holocene; Ple = Pleistocene; $\mathrm{Pl}=$ Pliocene; $\mathrm{M}=$ Miocene: $\mathrm{E}=$ Eocene; $\mathrm{Pa}=$ Paleocene $]$

\begin{tabular}{|c|c|c|c|c|c|c|c|c|c|}
\hline \multirow{2}{*}{ Species } & \multirow[t]{2}{*}{ Alaska } & \multirow{2}{*}{$\begin{array}{c}\text { British } \\
\text { Columbia }\end{array}$} & \multirow[t]{2}{*}{ Washington } & \multirow[t]{2}{*}{ Oregon } & \multicolumn{3}{|c|}{ California } & \multicolumn{2}{|c|}{$\begin{array}{c}\text { Baja } \\
\text { California }\end{array}$} \\
\hline & & & & & Northern & Middle & Southern & Norte & Sur \\
\hline 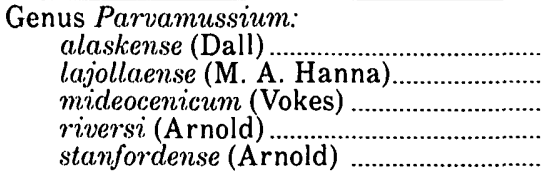 & $\begin{array}{l}\mathrm{H} \\
\cdots \cdots . . \\
\cdots \cdots . \\
\cdots \cdots . \\
\cdots . . .\end{array}$ & $\begin{array}{l}\mathrm{H} \\
\ldots \ldots . \\
\cdots \cdots . . \\
\cdots \cdots . \\
\cdots \cdots .\end{array}$ & $\begin{array}{l}\mathrm{H} \\
\cdots \cdots . . \\
\cdots \cdots . . \\
\cdots \cdots . . \\
\cdots \cdots . .\end{array}$ & $\begin{array}{c}\mathrm{H} \\
\ldots \ldots . \\
\cdots \cdots . . \\
\ldots \ldots . \\
\ldots \ldots .\end{array}$ & $\begin{array}{l}\mathrm{H} \\
\ldots \ldots . \\
\mathrm{Pa} \\
\cdots \cdots . . \\
\cdots . .\end{array}$ & $\underset{\mathrm{E}}{\mathrm{M}, \mathrm{Pl}}$ & $\begin{array}{c}\mathrm{Pl} \text { to } \mathrm{H} \\
\mathrm{E} \\
\ldots \ldots \\
\mathrm{Pl}, \mathrm{Ple}\end{array}$ & $\begin{array}{c}\mathrm{H} \\
\ldots \ldots . \\
\ldots \ldots . \\
\ldots \ldots . \\
\ldots \ldots .\end{array}$ & $\begin{array}{c}\mathrm{H} \\
\cdots \cdots . . \\
\cdots \cdots . . \\
\cdots \cdots . . \\
\cdots \cdots . .\end{array}$ \\
\hline
\end{tabular}


straight to the beaks, forming an angle of about ninety degrees; left valve: hinge line three-fourths the length of the disc; ears sub-equal, the anterior the larger, radially ornamented by fifteen to twenty fine rounded ribs which are crossed by growth lines; disc ornamented by about sixty-five nearly equal sized, fine, rounded linear ribs which are crossed by fine indistinct growth lines; right valve: ears unequal in size, posterior the smaller, anterior much produced, crossed by growth lines but not radial lines; surface of the disc sculptured by fine, prominent, equally spaced, concentric growth lines; radial sculpturing not present; internal ribbing of the right valve consists of ten prominent, narrow, rounded ribs separated by very much wider flat-bottomed interspaces.

"Pecten lajollaensis n. sp. differs from Pecten interradiata Gabb in not having the same sculpturing. The heavy internal ribs of the new species extend to the perifery [periphery] of the shell, rather than only a short way down from the umbones."

Syntypes.-UCMP 31106, 31107, 31108, 31109, 31110.

Type locality.-UC 5062. San Diego County, Calif. Ardath Shale, Eocene.

Comments.-The left valve (UCMP 31108) is sculptured by many (about 65) small, fine, almost equidimensional ribs; on the basis' of type material, this characteristic separates $P$. lajollaense from the other described Tertiary species of Parvamussium. The interior of the right valve (UCMP 31108 ) bears 10 prominent ribs that extend almost to the ventral shell margin.

Geographic range.-Middle to southern California.

Geologic range.-Eocene.

Occurrence in California.-Eocene: Ardath Shale and Muir Sandstone (Weaver, 1953).

\section{Parvamussium stanfordense (Arnold)}

Plate 1, figures 14, 15, 17

Pecten (Propeamussium) stanfordensis Arnold, 1906, p. 91-92, pl. 23, fig. 4.

Propeamussium (Parvamussium) stanfordensis (Arnold). Addicott, 1971 , p. 228-229, figs. 3, 5, 8, 10.

?Propeamussium mideocenicum Vokes, 1939, p. 55-56, pl. 3, fig. 4; not pl. 3, figs. 2,3 .

Original description. - "Shell averaging about 9 millimeters in altitude, subcircular, equivalve, equilateral, thin, only slightly ventricose, and with smooth margins. Right valve with the exterior surface ornamented by numerous fine concentric undulations and in some cases, microscopic radiating striae; interior with 10 to 12 prominent, rounded, equidistant ribs extending from the umbo to or near to the periphery of the disk, those ribs nearest the center of the shell being straight, while those near the sides are somewhat arcuate toward the central rib; hinge line slightly longer than one-half the length of the disk; ears equal in length, and ornamented by the fine concentric undulations; anterior ear with a small byssal notch. Left ${ }^{*}$ valve similar to right, except that its anterior ear lacks the byssal notch."

\section{Holotype.-CAS/SU 12}

Type locality.-Burke [Webb] Ranch, $0.5 \mathrm{~km}$ south [west] of Los Trancos Creek, near Stanford University, San Mateo County, Calif. Butano(?) Sandstone, Eocene (Addicott, 1971).

Supplementary description.-"a virtual topotype $* * *$ has a $* * *$ preserved external surface showing relatively strong, regularly spaced concentric undulations. $* * *$ the anterior ear of the right valve has a rather strong byssal notch that is reflected in the curvature of the growth lines. Moreover, the internal ribs extend almost to the margins of the valves. Accordingly, placement in the subgenus Parvamussium is clearly indicated.
"One of the early Eocene specimens of Propeamussium mideocenicum Vokes, 1939, UCMP 15585 from the Arroyo Hondo Shale Member of the Lodo Formation in the San Joaquin basin, California, might be $P$. stanfordensis. The ears, number and configuration of internal ribs, and size of this syntype are similar to $P$. stanfordensis. The other syntypes (both left valves) are quite distinct; they probably represent an entirely different species than $P$. stanfordensis judging by the occurrence of external ribbing and by the fact that these ribs are much more numerous than on the right valve-12 instead of 9 [sic: 10]." (Addicott, 1971, p. 228-229)

Comparison.-"It seems doubtful that Propeamussium stanfordensis represents young specimens of the well-known Eocene species P. interradiatum (Gabb) as was suggested by Grant and Gale (1931). The shorter, consistently fewer internal ribs -8 rather than 10 or more-and the weaker, much finer concentric sculpture of $P$. interradiatum permit differentiation." (Addicott, 1971, p. 229)

Propeamussium leohertleini, from exposures on Adak Island, is very similar to $P$. stanfordensis (Arnold). It differs, however, in the configuration of the right anterior ear and in minor sculptural detail. (Addicott, 1971, p. 227)

Geographic range.-Middle California; Japan? (Kobayashi, 1926). Geologic range.-Eocene.

"Arnold (1906, p. 92) originally classified the stratigraphic occurrence of this species as middle Miocene, apparently believing the light-colored shale exposure from which it was collected to be part of the Monterey Shale. Consequently, subsequent treatments of Tertiary Propeamussium (Slodkewitsch, 1938; Weaver, 1942) have considered species, and phylogenies, in the context of a Neogene stratigraphic occurrence of this taxon. $* * *$ It was found that the type locality is in an area of upper Eocene rather than middle Miocene rocks, according to recent geologic mapping and related micropaleontologic studies.

"Two of the specimens of Propeamussium stanfordensis figured in this report $* * *$ can be regarded as topotypes. They are from a locality on the north wall of the same drainage from which the holotype was collected by Ralph Arnold, possibly on strike from his locality. They occur with a diverse foraminiferal assemblage of late Eocene Narizian age according to M. C. Israelsky (in written communication to E. H. Pampeyan, April 16, 1963; USGS microfossil locality Mf707). The occurrence is about $45 \mathrm{~m}$ stratigraphically below the base of middle Miocene rocks in a unit mapped by Dibblee (1966) and by Pampeyan (1969) as by Page and Tabor (1967) as unnamed Eocene rocks." (Addicott, 1971, p. 228)

Occurrence in California.-Butano(?) Sandstone and lower part of Kreyenhagen Shale (Addicott, 1971).

\section{Parvamussium riversi (Arnold)}

\section{Plate 1, figures 16, 18}

Pecten (Propeamussium) riversi Arnold, 1906, p. 126-127, pl. 44, figs. $8,9$.

Original description.- "Shell averaging about 14 millimeters in altitude, about as long as high, circular in outline, equilateral, compressed, white, translucent; margins smooth. Right valve much compressed; surface smooth except for numerous very fine, regular, imbricating lamellae; hinge line one-half length of disk; ears distinctly separated from disk by impressed line, subequal in length; the anterior arcuate in front and with about 12 subequal prominent radials and numerous fine, regular, imbricating, incremental lamellae; the posterior slightly obliquely truncated and sculptured similarly to the anterior, except that the radials are nearly obsolete; byssal notch of medium prominence. Interior of disk smooth until an altitude of 15 millimeters is reached, when about 20 to 22 small, 
round, radiating ribs appear and continue to the periphery. Left valve somewhat more convex than the right, and ornamented externally by numerous unequal prominently imbricated ribs, the alternate ones being intercalated between slightly larger ones; whole surface sculptured by fine imbricating lamellae; anterior ear similar to that of the right valve, except that it is more strongly radially ribbed and is less sinuated; posterior ear similar to that of right valve, except that it is more strongly ribbed; interior of left valve similar to that of the right, and having the radial ribs developed only after attaining an altitude of about 15 millimeters."

Holotpye.-CAS/SU 33.

Type locality. - Los Angeles County, Calif. Fernando Formation, Pliocene and Pleistocene.

Comparison. - "This species is very closely allied to P. alaskensis, of which it is undoubtedly the precursor. It differs from the latter in having the external ribs on the left valve more prominently imbricated above, and in having the internal ribs of both valves appearing only after an altitude of about 15 millimeters has been attained." (Arnold, 1906, p. 127)

Comments. - The right valve (holotype) is smooth except for fine concentric lines. The right anterior auricle is broken but was longer than the posterior auricle. The internal ribs are visible only near the ventral shell margin. Parvamussium riversi was synonymized with $P$. alaskense by Grau (1959, p. 18). The differences in the sculpture of the right valves of the holotypes of these two species is such that $P$. riversi is here reinstated. The exterior of the right valve (holotype) of $P$. riversi is smooth; that of $P$. alaskense bears many fine ribs. The interior of the right valve of $P$. riversi shows internal ribs near the ventral margin; on $P$. alaskense the internal ribs are stronger and cover a greater proportion of the shell. It is possible that the variation of $P$. alaskense is sufficient to include $P$. riversi.

Geographic range.-Middle to southern California.

Geologic range.-Miocene to Pleistocene.

Occurrence in California.-Miocene and Pliocene: Purisima Formation (Arnold, 1906); Pliocene and Pleistocene: Fernando, Merced (Arnold, 1906), and San Pedro Formations (Arnold, 1906).

\section{Parvamussium alaskensis (Dall)}

\section{Plate 2, figures 1-7}

Pecten (Pseudamussium?) alaskensis Dall, 1871, p. 155, pl. 16, fig. 4. Dall, 1898, p. 711.

Propeamussium (Parvamussium) alaskense (Dall). Grau, 1959, p. 18-20, pl. 3.

Polynemamussium alaskense (Dall). MacNeil, 1967, p. 6-7, pl. 5, figs. 2-4.

Pecten (Propeamusium) levis Moody, 1916, p. 56-58, pl. 2, figs. 2a-2d. Not Pecten laevis Pennant, 1777.

Pecten culamitus G. D. Hanna, 1924, p. 176, new name for Pecten (Propeamussium) lesis Moody, 1916, not P. leavis Maton and Rackett, 1807.

Original description. - "Shell nearly equilateral, inequivalve, flesh-color with a blush of salmon-color on the umbo of the superior valve. Internally white, the salmon-color showing through the valve. Shell suborbicular, barring the auricles, which are wide and prominent. Lower [right] valve flattened, . $1 \mathrm{in}$. smaller than the upper one; sculpture of fine, close, equal, concentric ridges, sharply defined and separated by narrow non-canaliculated grooves. Valve covered with a fine velvety epidermis, ashy and very finely radiately striate. Surface of the valve, except for the ridges, smooth. Anterior auricle long, prominent, with a deep sinus. Posterior auricle small; both with strong elevated lines of growth, which rise into scales on the eight or nine fine ribs with which the anterior auricle is furnished.
Hinge line straight, smooth. Inside of the valve polished, furnished with twenty-one rounded, radiating ribs, with traces of others intercalated near the margin; nodulous or swollen at the more prominent ridges of growth and at the margin.

"Upper [left] valve similar, inside; anterior auricle shorter, not so deeply sinuated. Valve more convex than the under one, and a little larger. Dorsal areas finely granulate. Umbo smooth; half way toward the margin the striae of increase become more conspicuous, and about thirty-five pseudo-ribs radiate toward the margin. These are formed by the elevation of the concentric lines of growth like ruffles, in such a way that the edge of one fluting of the ruffle overhangs the beginning of the next, and so on. These are very fragile, and when broken away show the nearly smooth surface of the valve underneath, without any true rib at all. Faint grooves are intercalated between the pseudo-ribs toward the margin. Lon. .76, alt. 76, diam. .22 in., width of hinge line $.34 \mathrm{in}$. Angle at the umbones, $100^{\circ} . "$ (alaskensis)

"Shell small, thin, translucent, nearly circular in outline, equilateral, compressed, slightly inequivalve. Right valve is smooth except for numerous very fine incremental lines, which occasionally are enlarged and roughened; traces of submicroscopic radiating striae are to be seen. Hinge line is about five-eighths the width of the shell; ears sharply set off from the disc by equal impressed lines which are nearly straight and slope evenly from the umbone; anterior ear arcuate, coarsely sculptured by about fourteen subequal ridges which radiate from the beak, and by about thirty-five prominent, regular, imbricating lines of growth which curve outward, following the anterior margin; posterior margin makes a right angle with the hinge-line; byssal notch almost obsolete; posterior ear ornamented with a similar number of incremental laminae which are only slightly curved and are nearly vertical, the radiating ridges being indistinct. Interior surface of the valve marked by twenty-two rounding ridges which radiate from the apex but are partially obscured in the upper portions by a callus growth which covers onethird the area of the disc; a single adductor scar appears on the anterior dorsal margin of the callus. Left valve slightly less convex than the right; externally sculptured by fourteen prominent, smooth, rounded ribs which radiate from the apex; in the interspace appear one or sometimes two inter-ribs of varying length, which never reach the beak; anterior ribs and inter-ribs slightly imbricated; incremental lines quite fine and uniform on the posterior threefourths of the surface. Ears of the left valve subequal; both slightly arcuate below the hinge line, the anterior more coarsely sculptured by twelve radiating striae and thirty or more roughened incremental lines which are vertical on the hinge-line and broadly recurved below; beak sharp and straight and slightly raised above the hingeline. Interiorly the valve is sculptured by about twenty distinct, rounded ribs radiating from the umbone, which are independent of the external ornamentation and do not reach the ventral margin; internal ribs slightly obscured, as in the right valve, by a callus growth." (levis)

Holotype.-Location unknown. Thomas R. Waller, Smithsonian Institution, searched the collections at the National Museum of Natural History and did not find any specimen that resembled Dall's (1871, pl. 16, figs. 4a, 4b) original illustrations of Pecten (Propeamusium) levis Moody, UCMP 11084.

Type locality.-Port Etches, western Hinchinbrook Island, Prince William Sound, Alaska, Holocene; of P. levis Moody, UC 3030, Los Angeles County, Calif. Fernando Formation, Pliocene and Pleistocene.

Supplementary description.-"Both the right and left valves of this species have weak internal riblets that become stronger distally, but only the left valve has riblets on the exterior. The number of external riblets is variable, ranging usually from 24 to 30 . Some of 
the riblets tend to become weakly beaded or scabrous toward the margin. The riblets have little relief and tend to merge with the interspaces; usually they are lighter colored than the remainder of the disc. All the ears have weak radial riblets, but such riblets are stronger on the anterior ear of the right valve." (MacNeil, 1967, p. 6)

The count of 21 ribs given by Dall $(1871$, p. 155) is low for the species (T. R. Waller, written commun., 1979).

Comparison.-"This species is easily distinguishable from the Miocene and older species on the Pacific coast by its more numerous internal lirations. The writers tried to distinguish riversi from the living $P$. alaskensis Dall on the basis of the still more numerous internal lirations on the living specimens, until they noticed that Dall's original description calls for only 21 . The form renamed by Hanna is exactly like riversi. P. (Propeamussium) davidsoni Dall, a species living in Alaska, *** has much the same shape; but it has fewer and stronger external ribs on the left valve, and after it is a little more than half grown it develops ribs on the outside of the right valve also." (Grant and Gale, 1931, p. 234)

"Polynemamussium intuscostatum (Yokoyama) (Masuda, 1962b, p. 156), a related species from the early Pliocene to Recent of Japan, is more coarsely sculptured than $P$. alaskense and the riblets are more beaded.

"Pecten (Propeamusium) riversi Arnold *** is closely related to $P$. alaskense; according to Arnold's figures the internal riblets are weaker and more closely restricted to the marginal area, and the external riblets of the left valve are stronger." (MacNeil, 1967, p. 6)

Comments. - Parvamussium calamitus was considered to be conspecific with P. alaskense (Dall) by Grant and Gale (1931, p. 234) and Grau (1959, p. 18) but not by MacNeil (1967, p. 6-7). On the basis of examination of primary type material, the left valve auricles of $P$. calamitus are of almost equal length and height; the anterior left auricle of $P$. alaskense is both markedly longer and higher than the left posterior auricle. The left valve of $P$. alaskense has poorly delineated ribs; the left valve of $P$. calamitus has well-defined, narrow ribs extending almost to the beak and equally strong secondary ribs that appear when the shell has reached a height of about $5 \mathrm{~mm}$. The ribs on the interior of the left valve of $P$. calamitus are fewer in number (about 20 rather than 30 ) and are less prominent than on $P$. alaskense. The auricles on the right valve holotype of $P$. calamitus are broken but seem to have been almost equal; the left posterior auricle is slightly higher than the left anterior auricle. The variability of $P$. alaskense may be sufficient to include $P$. calamitus.

Geographic range.-Living: Japan, Korea; Bering Sea to Baja California Sur; fossil: Japan; Alaska to southern California.

Geologic range.-Pliocene through Holocene.

Occurrence in California.-Pliocene: Lomita Marl Member, San Pedro Formation (Woodring, 1946); Pliocene and Pleistocene: Fernando Formation (J. D. Mount, written commun., 1971) and San Pedro Sand (Arnold, 1906; Woodring, 1946).

Habitat.-Recorded in 18 to $365 \mathrm{~m}$ (Grau, 1959, p. 20).

\section{Family PECTINIDAE}

"Byssate, cemented, or unattached Pectinacea with outer, simpleprismatic calcitic layer on right valve generally present only in early growth stages, rarely absent altogether; crossed-lamellar aragonite restricted to area inside of pallial line or absent. Byssal notch with ctenolium, at least at early growth stage. Mantle curtains bearing guard tentacles." (Waller, 1978, p. 353)

"Shell varying in size, orbicular to oval, valves of some shells equally convex but usually one valve more inflated than other, margins usually, but not invariably closed; umbos central, on either side of which are triangular auricles (ears), anterior one on RV usually with distinct byssal notch or indentation below it; surface smooth or with radial ribs or folds, some species with concentric sculpture of raised lamellae; interior smooth or with fine radial riblets; hinge line straight; external ligament obsolete or nearly so, resilium internal, amphidetic, in triangular pit below umbones; young shells with small taxodont teeth which become obsolete later; cardinal crura or laminae commonly present, diverging from either side of ligamental pit; rounded laminae (auricular crura) present on interior of some shells where auricles join valves; adults monomyarian, with posterior adductor only; free, attached by byssus, or cemented by RV; upper (L) valve, usually more brightly colored ***." (Hertlein, 1969, p. N348)

"The shape and sculpture of the shells of pectens, usually differing in detail on the two valves, are often quite constant, and *** species may often be recognized from fragments. $* * *$ when riblets arise in the interspaces between the ribs they always appear first on the left valve. Dall $(1898$, p. 692,693$)$ pointed out that when ribbing tends to become obsolete, the radial sculpture is retained on the left valve after the right valve has become nearly smooth. Furthermore, that the right anterior ear usually, is the last to lose its radial sculpture.

"An interesting characteristic of the sculpture of these bivalves is that rarely, if ever, do they possess concentric ribbing although some species such as Chlamys (Swiftopecten) swiftii Bernardi and C. condylomatus Dall have concentric thickening and undulations or 'ledging'*** of the shell and others have coarse annular growth lamellae such as are present in the subgenus Camptochlamys Arkell. The geologic range of supraspecific units as well as of species is frequently short. Furthermore, apparently because of the composition and microstructure of the shell (which is made up of irregular foliated layers of calcite with a thin median prismatic layer of aragonite), pectens often occur abundantly as fossils where other mollusks (except some other genera such as Ostrea) are represented only by casts and moulds. From a consideration of the features here enumerated in connection with pectens, it is obvious why this group has furnished some of the most reliable index fossils used in deciphering the age and correlation of strata.

"A striking feature of the Tertiary Pectinidae $* * *$ is the great increase in size during Miocene time. Most specimens from strata of Eocene or Oligocene age do not exceed $50 \mathrm{~mm}$ in diameter. Very large species described from the late Tertiary are: Mizuhopecten kamagai Nagasawa, probably of Pliocene age, in Japan, $280 \mathrm{~mm}$ long; Pecten dregeri von Teppner of Miocene age in Austria, $240 \mathrm{~mm}$ long; Pecten healeyi Arnold in the San Diego Formation, Pliocene, $222 \mathrm{~mm}$ long; and Chlamys (Nodipecten) arnoldi Aguerrevere, of late Miocene or Pliocene age in Venezuela, $218 \mathrm{~mm}$ long. The greatest size reported for a living species is that of Pecten (Patinopecten) caurinus Gould, $288 \mathrm{~mm}$ long and $198 \mathrm{~mm}$ high.

"Some living species of this family especially valuable as food, have received intensive study. An interesting feature of the shell is the presence of concentric rings formed by offsets, or by color changes, during growth, and best observed on the upper valve. These rings *** are a result of a quiescent period of growth during the spawning season. It is generally believed that these rings are formed annually, but this is not always the case because, as pointed out by Gutsell, rings sometimes are present on young shells which have not reached maturity.

"Several thousand species of pectens have been described as fossils. About 350 to 400 species are now living in the seas, the greater number in Indo-Pacific waters." (Hertlein and Grant, 1972, p. 172)

"Pectinid bivalves are perhaps the most useful indices for age determination and correlation of the shallow-water marine Neogene sequences of the marginal eastern North Pacific." (Addicott, 1978, p. 11)

In his discussion of the Family Pectinidae, Hertlein (1969, N348) 
states: "Although many supraspecific units greatly resemble others in shell structure, their close relationship generally has not been proved. The similarities appear to confirm Philippi's theory of iteration of shell form in this group of mollusks. For this reason it seems best to adopt a conservative course in arranging supraspecific units in groups within the Pectinidae. To define such groups as subfamilies or to separate them as families would imply relationships and distinctions based chiefly on supposition only."

As stated in the "Introduction," Hertlein's "groups" are used with some modification herein, but his subgenera are elevated to generic rank.

Geologic range.-Triassic to Holocene.

Habitat. -Some swim freely, others are attached by a byssus; rarely they become cemented and irregular in form as in Hinnites. Coarse, thick-shelled forms live in shallow temperate and tropical waters, but thin-shelled forms usually occur in deep water, up to at least $4,500 \mathrm{~m}$. The largest forms, with the exception of Patinopecten and Placopecten, live in tropical marine water. The shells of species inhabiting temperate water tend to be less convex and the ribs more rounded in the northern part of their range. (Hertlein and Grant, 1972 , p. 172) Pectinids consistently lie with the right valve downward, against the attachment surface, and most exhibit a distinctive overturning reaction when placed upside down. (Waller, 1976, p. 11)

\section{DELECTOPECTEN group}

Delectopecten was placed in the Amusium group by Hertlein. Subsequent study of shell microsculpture by Waller $(1971,1972)$ presents evidence for eliminating that group and placing Amusium in the Pecten group. Delectopecten is here placed in a group of its own.

\section{Genus DELECTOPECTEN Stewart, 1930}

Small, thin, hyaline; posterior auricle on right valve not delineated. Differs from Hyalopecten in that undulations are subdued or lacking, and sculpture commonly develops reticulate pattern' or may be almost lacking.

"Delectopecten differs from Cyclopecten s.l. in the shape of the auricles, the unflexed right valve (except in Cyclopecten greenlandi$c u s)$, the absence of concentric lamellae or ridges on that valve (except in C. vitreus), the always-present ctenolium, and the translucency of all species." (Grau, 1959, p. 39)

Geographic range.-Western North America, Japan, northern Europe, and Australia.

Geologic range.-Eocene through Holocene (table 5).

"Delectopecten is represented on the Pacific coast from the Eocene to the Recent. The following names have been proposed:

\begin{tabular}{|c|c|c|c|}
\hline Name & Type locality & Characters & Remarks \\
\hline $\begin{array}{l}\text { Plagiostoma pedroana } \\
\text { Trask. }\end{array}$ & $\begin{array}{l}\text { San Pedro[east coast of Palos Verdes } \\
\text { Hills], Calif. Cretaceous [Miocene]. }\end{array}$ & $\begin{array}{l}\text { Large: length about } 35 \mathrm{~mm} \text { [apparently exaggerated } \\
\text { by deformation]. Concentric undulations strong. } \\
\text { Right anterior ear sculptured with about } 13 \text { radial } \\
\text { ribs. (Fide Trask.) }\end{array}$ & $\begin{array}{l}\text { Large number of ribs on right anterior ear } \\
\text { needs confirmation. }\end{array}$ \\
\hline $\begin{array}{l}\text { Plagiostoma ammelatus } \\
\text { Trask. }\end{array}$ & 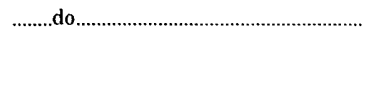 & $\begin{array}{l}\text { Large; length about } 32 \mathrm{~mm} \text { [apparently exaggerated } \\
\text { by deformation]. Concentric undulations strong. } \\
\text { Left anterior ear sculptured with about } 12 \text { radial } \\
\text { ribs. (Fide Trask.) }\end{array}$ & $\begin{array}{l}\text { Considered same as pedroanus. Radial ribs } \\
\text { on left anterior ear suggest that well-pre- } \\
\text { served specimens may show radial ribs on } \\
\text { main part of shell. }\end{array}$ \\
\hline $\begin{array}{l}\text { Plagiostoma truncata } \\
\text { Trask. }\end{array}$ & 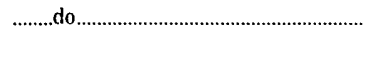 & $\begin{array}{l}\text { Large: length about } 28 \mathrm{~mm} \text { [apparently slightly exag- } \\
\text { gerated by deformation]. Concentric undulations } \\
\text { strong. (Fide Trask.) }\end{array}$ & Considered same as pedroamus. \\
\hline Pecten peckhami Gabb & $\begin{array}{l}\text { Ojai ranch, Santa Barbara [now } \\
\text { Ventura] County, Calif. Bitumi- } \\
\text { nous shale of upper Miocene [Mon- } \\
\text { terey shale of some geologists and } \\
\text { Modelo formation of others]. }\end{array}$ & $\begin{array}{l}\text { Small; length of } 3 \text { specimens in lectotype lot } 12 \text { to } 14.8 \\
\text { mm. Concentric undulations weak. Lectotype sculp- } \\
\text { tured with weak, relatively widely spaced radial } \\
\text { ribs on main part of shell. Right anterior ear sculp- } \\
\text { tured with a few radial ribs ( } 6 \text { or } 7 \text {; fide Arnold). }\end{array}$ & $\begin{array}{l}\text { On many specimens that appear to represent } \\
\text { pechhami radial ribs are not discernible, } \\
\text { except on right anterior ear. Forms resem- } \\
\text { bling peckhami have been recorded from } \\
\text { horizons ranging from Eocene to Miocene. }\end{array}$ \\
\hline $\begin{array}{l}\text { Pecten (Pseudamusitm) nancouner- } \\
\text { ensis Whiteaves. }\end{array}$ & $\begin{array}{l}\text { Forward Inlet, Quatsino Sound, Van- } \\
\text { couver Island; depth } 10 \text { to } 20 \text { fath- } \\
\text { oms. }\end{array}$ & $\begin{array}{l}\text { Small; length } 8.5 \text { to } 10 \mathrm{~mm} \text {. Concentric undulations } \\
\text { weak or absent. Main part of shell sculptured with } \\
\text { weak to strong radial ribs; absent on some speci- } \\
\text { mens. Right anterior ear sculptured with } 5 \text { to } 7 \\
\text { radial ribs. }\end{array}$ & $\begin{array}{l}\text { Radial sculpture very variable in lots assigned } \\
\text { to this form. A pparently ranges from south- } \\
\text { ern Alaska to San Diego in shallow to mod- } \\
\text { erately deep water (12 to } 200 \text { fathoms). }\end{array}$ \\
\hline Pecten roudolphi Dall. & $\begin{array}{l}\text { Off Destruction Island. Wash:; depth } \\
516 \text { fathoms. }\end{array}$ & $\begin{array}{l}\text { Large: length } 28 \text { to } 30.8 \mathrm{~mm} \text {. Concentric undulations } \\
\text { moderately strong or weak. Right anterior ear } \\
\text { sculptured with } 5 \text { to } 8 \text { radial ribs. }\end{array}$ & $\begin{array}{l}\text { A pparently ranges from Bering Sea to Cape } \\
\text { Blanco, Oreg.., in deep water ( } 225 \text { to } 1,064 \\
\text { fathoms). }\end{array}$ \\
\hline $\begin{array}{l}\text { Pecten (pseudamusinm) randolphi } \\
\text { var. tillemookensis A nold. }\end{array}$ & $\begin{array}{l}\text { Off Tillamook Bay, Oreg.: depth } 786 \\
\text { fathoms. }\end{array}$ & $\begin{array}{l}\text { Large: length } 29 \text { to } 32.5 \mathrm{~mm} \text {. Concentric undulations } \\
\text { moderately strong or weak. Type sculptured with } \\
\text { weak radial ribs on main part of shell. In other } \\
\text { specimens this radial sculpture varies from a few } \\
\text { faint ribs to strong ribs covering entire shell. Some } \\
\text { left valves that lack radial sculpture are paired with } \\
\text { faintly sculptured right valves. Right anterior ear } \\
\text { sculptured with } 5 \text { to } 8 \text { radial ribs. }\end{array}$ & $\begin{array}{l}\text { Considered a sculptured variety of randolphi. } \\
\text { as described by Arnold. Radial sculpture } \\
\text { very variable in suites of shells assigned to } \\
\text { this variety. Apparently ranges prom Ber- } \\
\text { ing Sea to San Diego, generally in deep } \\
\text { water ( } 30 \text { to } 1,084 \text { fathoms). }\end{array}$ \\
\hline $\begin{array}{l}\text { Pecten (Pseudamusiom) polyleptus } \\
\text { Dall. }\end{array}$ & $\begin{array}{l}\text { Off Hood Island. Galapagos; depth } \\
300 \text { fathoms. }\end{array}$ & $\begin{array}{l}\text { Small: length } 9.6 \text { to } 10 \mathrm{~mm} \text {. Concentric undulations } \\
\text { weak or absent. Main part of shell sculptured with } \\
\text { weak radial ribs, mainly in form of vaulted scales. } \\
\text { Right anterior ear sculptured with } 4 \text { or } 5 \text { radial ribs. }\end{array}$ & $\begin{array}{l}\text { Represented in two lots from depths of } 300 \\
\text { and } 392 \text { fathoms near Galapagos. Appar- } \\
\text { ently closely allied to H. Helatimosus (Ma- } \\
\text { bille and Rochebrune), a larger form from } \\
\text { southern South America. }\end{array}$ \\
\hline Pecten (Psendomusium) aress Dall. & $\begin{array}{l}\text { Santa Barbara Channel. Calif., off } \\
\text { Santa Cruz Island: depth } 534 \text { fath- } \\
\text { oms. }\end{array}$ & $\begin{array}{l}\text { Moderately large; length } 19.5 \text { to } 23 \mathrm{~mm} \text { (type lot). } \\
\text { Concentric undulations moderately strong or weak. } \\
\text { Main part of shell sculptured with strong radial } \\
\text { ribs. Right anterior ear sculptured with } 5 \text { to } 7 \text { radial } \\
\text { ribs. }\end{array}$ & $\begin{array}{l}\text { Considered a synonym of tillamookensis: } \\
\text { strongly sculptured form. }\end{array}$ \\
\hline $\begin{array}{l}\text { Pecten (Pseudamusium) alterniline- } \\
\text { utus Clark. }\end{array}$ & $\begin{array}{l}\text { Presumably a locality near Walnut } \\
\text { Creek. Contra Costa County. Calif. } \\
\text { (see Clark. table opp. p. 80). San } \\
\text { Ramon sandstone, assigned to Ol- } \\
\text { igocene. }\end{array}$ & $\begin{array}{l}\text { Small; length } 5 \text { to } 5.5 \mathrm{~mm} \text {. [Concentric undulations } \\
\text { apparently weak or absent.] Main part of shell } \\
\text { sculptured with radial ribs. Right anterior ear } \\
\text { sculptured with about } 5 \text { radial ribs. (Fide Clark.) }\end{array}$ & Apparently allied to vancouverensis. \\
\hline $\begin{array}{l}\text { Pecten (Pseudamusimm) zancouseren- } \\
\text { sis sanjumensis Clark and Arnold. }\end{array}$ & $\begin{array}{l}\text { Vancouver Island, British Columbia. } \\
\text { Sooke formation, assigned to } \\
\text { Oligocene. }\end{array}$ & $\begin{array}{l}\text { Small; length } 7 \mathrm{~mm} \text {. Concentric undulations moder- } \\
\text { ately strong. Main part of shell sculptured with } \\
\text { radial ribs. (Fide Clark and Arnold.) }\end{array}$ & Apparently allied to vanconerensis. \\
\hline
\end{tabular}




\begin{tabular}{|c|c|c|c|}
\hline Name & Type locality & Characters & Remarks \\
\hline $\begin{array}{l}\text { Pecten (Pseudamusium) vancouveren- } \\
\text { sis fernandoensis Hertlein. }\end{array}$ & $\begin{array}{l}\text { Ventura River, } 1 / 4 \text { mile south of Tay- } \\
\text { lor well no. } 1 \text { and } 11 \frac{1}{2} \text { miles north of } \\
\text { Ventura, Calif. Fernando, Pliocene } \\
\text { [upper Pliocene]. }\end{array}$ & $\begin{array}{l}\text { Of medium size to moderately large; length } 12.5 \text { to } \\
22.7 \mathrm{~mm} \text {. Concentric undulations moderately strong } \\
\text { to weak: main part of shell sculptured with radial } \\
\text { ribs of varying strength. Right anterior ear sculp- } \\
\text { tured with } 5 \text { to } 7 \text { radial ribs. }\end{array}$ & $\begin{array}{l}\text { A pparently closely allied to tillamookensis. } \\
\text { Pliocenespecimens from Los Angeles Basin } \\
\text { are smaller than tillamookensis, and some } \\
\text { have stronger concentric undulations. }\end{array}$ \\
\hline $\begin{array}{l}\text { Pecten (Pseudamusium) lillisi Hert- } \\
\text { lein. }\end{array}$ & $\begin{array}{l}\text { Crow Creek road, Stanislaus County, } \\
\text { Calif. Kreyenhagen shale, upper } \\
\text { Eocene or lower Oligocene [appar- } \\
\text { ently from part of Kreyenhagen } \\
\text { shale now assigned to Eocene]. }\end{array}$ & $\begin{array}{l}\text { Small; length } 9 \text { to } 15.6 \mathrm{~mm} \text {. Concentric undulations } \\
\text { weak or moderately strong. Main part of shell sculp- } \\
\text { tured with a few or many radial ribs, especially on } \\
\text { right valves. Right anterior ear sculptured with } 4 \text { to } \\
8 \text { radial ribs. }\end{array}$ & $\begin{array}{l}\text { Relations to peckhami, to which this form was } \\
\text { formerly assigned, not determined. Some } \\
\text { specimens have stronger undulations than } \\
\text { peckhami. }\end{array}$ \\
\hline Pecten (Delectopecten) zacae Hertlein. & Gulf of Panama; depth 322 fathoms. & $\begin{array}{l}\text { Moderately large; length } 19 \text { to } 22 \mathrm{~mm} \text {. Concentric } \\
\text { undulations weak. Main part of shell sculptured } \\
\text { with a few or many weak radial ribs. Right anterior } \\
\text { ear sculptured with } 4 \text { to } 6 \text { radial ribs. }\end{array}$ & $\begin{array}{l}\text { Specimens in collection of U.S. National Mu- } \\
\text { seum more obliquely elongate than those of } \\
\text { other recent species of comparable size." }\end{array}$ \\
\hline
\end{tabular}

"The presence or absence of radial ribs on parts of the shell other than the right anterior ear appears to be of doubtful value for specific differentiation. Large suites of specimens agreeing in other characters show gradations from strong sculpture to none. This gradation is well shown in the modern forms (vancouverensis, randolphi, and tillamookensis), in the Oligocene and Miocene forms assigned to peckhami, and in the form from the Eocene part of the Kreyenhagen shale formerly assigned to peckhami and recently named lillisi. The radial ribs vary from strong beaded or scaly ribs covering the entire shell to weak ribs confined to a small part or parts of the shell. Many right valves that elsewhere lack radial ribs, aside from those on the anterior ear, have a few at the anterior margin of the shell. Some left valves that are paired with weakly sculptured right valves lack radial ribs entirely or they are restricted to the anterior ear.

"The size of the shell and the strength of the concentric undulations appear to offer grounds for specific differentiation. The possible value of these characters, however, is undetermined in many of the forms. The outline of the shell may be a characteristic feature in some Recent forms, but many fossil specimens are deformed." (Woodring, 1938, p. 36-38)

\section{Delectopecten lillisi (Hertlein)}

\section{Plate 3, figures 1-3}

Pecten (Pseudamusium) lillisi Hertlein, 1934, p. 5-6, pl. 1, fig. 1; pl. 2 , figs. $2,3$.

Hyalopecten (Delectopecten) lillisi (Hertlein). Woodring, 1938, p. 38. Original description. - "Shell small, of general form of Pecten pedroanus Trask; right valve, the anterior ear well defined, set off from the rest of the shell by a well defined groove, a well developed byssal notch is present; anterior ear ornamented by six or seven riblets, which are crossed by imbricating lines of growth; posterior ear unornamented except by fine lines of growth; the anterior portion of the valve ornamented by about ten fine spinose riblets; the posterior portion of the valve unornamented except by fine lines of growth; entire surface of valve covered by fine submicroscopic camptonectes striations which cross the radiating riblets. Measurements of holotype, altitude $14.1 \mathrm{~mm}$.; length (approximately) $13 \mathrm{~mm}$.; length of hinge line $9.2 \mathrm{~mm} . "$

Holotype.-CAS 6062.

Type locality.-CAS 184. Stanislaus County, Calif. Kreyenhagen Formation, Eocene and Oligocene.

Supplementary description.- "Left valve (paratype), the anterior ear is ornamented by about six to eight fine radial ribs; the surface of the valve is ornamented by fine radiating riblets; entire surface covered by camptonectes striations similar to the right valve." (Hertlein, 1934, p. 6)

"Small; length 9 to $15.6 \mathrm{~mm}$. Concentric undulations weak or moderately strong. Main part of shell sculptured with a few or many radial ribs, especially on right valves. Right anterior ear sculptured with 4 to 8 radial ribs." (Woodring, 1938, p. 38)

"A few right valves have ribs over the entire valve; others have ribs on the greater part of the anterior half of the valve *** Ribs were observed on only one left valve." (Woodring, 1938, p. 40)

Comparison.- "Pecten lillisi may be distinguished from P. pedroanus Trask and other fossil and Recent species of small pectens on the west coast of North America, by the small number of delicate spinose ribs which ornament the anterior portion of the right valve, and by the fine submicroscopic camptonectes striations which cover the surface of the shell." (Hertlein, 1934, p. 6)

"Relations to peckhami, to which this form was formerly assigned, not determined. Some specimens have stronger concentric undulations than peckhami." (Woodring, 1938, p. 38)

Comments.-The radial ribs are longer and more prominent along

TABLE 5.-Geologic and geographic distribution of the genus Delectopecten in the eastern Pacific region

$[\mathrm{H}=$ Holocene; $\mathrm{Ple}=$ Pleistocene; $\mathrm{Pl}=\mathrm{Pliocene} ; \mathrm{M}=\mathrm{Miocene} ; \mathrm{O}=$ Oligocene; $\mathrm{E}=$ Eocene $]$

\begin{tabular}{|c|c|c|c|c|c|c|c|c|c|}
\hline \multirow{2}{*}{ Species } & \multirow[t]{2}{*}{ Alaska } & \multirow{2}{*}{$\begin{array}{c}\text { British } \\
\text { Columbia }\end{array}$} & \multirow[t]{2}{*}{ Washington } & \multirow[t]{2}{*}{ Oregon } & \multicolumn{3}{|c|}{ California } & \multicolumn{2}{|c|}{$\begin{array}{c}\text { Baja } \\
\text { California }\end{array}$} \\
\hline & & & & & Northern & Middle & Southern & Norte & $\frac{\text { Sur }}{10}$ \\
\hline Genus Delectopecten: & & & & & & & & & \\
\hline 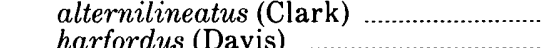 & $\cdots \cdots$. & $\cdots \cdots .$. & $\cdots \ldots .$. & $\cdots \cdots$. & $\cdots \cdots .$. & M? & M? & ........ & ….... \\
\hline lillisi (Hertlein) & ....... & ....... & ....... & ....... & ....... & E.O & 10! & $\ldots . .$. & ....... \\
\hline 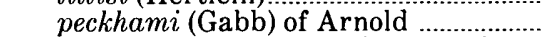 & & & ....... & $\mathbf{M}$ & & $\mathrm{E}$ to $\mathrm{M}$ & $\mathrm{E}$ to $\mathrm{M}$ & ....... & …... \\
\hline randolphi tillamookensis (Arnold)...... & $\mathrm{H}$ & $\mathrm{H}$ & $\mathrm{H}$ & $\mathrm{H}$ & $\mathrm{H}$ & & $\mathrm{Pl}, \mathrm{H}$ & $\mathrm{H}$ & …... \\
\hline $\begin{array}{l}\text { vancouverensis fernandoensis } \\
\text { (Hertlein) }\end{array}$ & ....... & ...... & ...... & $\cdots \cdot$. & ....... & ....... & Pl,Ple & ...... & ...... \\
\hline $\begin{array}{l}\text { vancouverensis vancouverensis } \\
\text { (Whiteaves) }\end{array}$ & $\mathrm{H}$ & $\mathrm{H}$ & $\mathrm{H}$ & $\mathrm{H}$ & $\mathrm{H}$ & $\mathrm{H}$ & $\mathrm{Pl}$ to $\mathrm{H}$ & $\mathrm{H}$ & $\mathrm{H}$ \\
\hline
\end{tabular}


the anterior margin of the left valve but also extend across the disk. The right valve is sculptured anteriorly by slightly nodose, radial ribs that extend to the ventral shell margin.

Geographic range.-Middle California.

Geologic range.-Eocene and Oligocene.

Occurrence in California.-Eocene and Oligocene: Kreyenhagen Formation.

\section{Delectopecten peckhami (Gabb) of Arnold}

\section{Plate 3, figures 4, 5}

Pecten (Pseudamusium) peckhami Gabb. Arnold, 1906, p. 56-57, pl. 3, fig. 8.

Delectopecten peckhami (Gabb) of Arnold. Moore, 1963, p. 67-68, pl. 18, figs. 2, 3; plate 20, figs. 1, 3-5; pl. 21, fig. 2 .

?Pecten peckhami Gabb, 1869 , p. 59-60, pl. 16, figs. 6-8.

?Palliolum (Delectopecten) peckhami (Gabb). Stewart, 1930, p. 119120 , pl. 13 , fig. 4.

?Delectopecten peckhami (Gabb). Watkins, 1974, p. 251-252, fig. 6A.

Original description. - "Shell averaging about 20 millimeters in altitude, subcircular, subequivalve, slightly inequilateral, thin, usually compressed, and with smooth margins. Right valve with the disk showing several small, more or less obsolete, irregular concentric undulations, numerous fine incremental lines and numerous fine obsolete radiating lines; hinge line about two-thirds of the longitude of the disk; anterior ear produced, separated from the body of the shell by a marked groove and a deep, narrow sinus, and prominently sculptured by 6 or 7 radiating ridges and numerous concentric elevated incremental lines; posterior ear not separated by any distinct line from the disk surface and ornamented only by concentric lines and obsolete undulations. Left valve similar to right except that the anterior ear is flat, the swell of the shell commencing with nearly a right angle with the ear-surface; surface of anterior ear usually sculptured only by incremental lines, but occasionally with radiating striae also." (Arnold, 1906, p. 56)

Lectotype.-Arnold's usage based on USNM 164839 is followed here. The lectotype of P. peckhami Gabb, MCZ 15045 (Stewart, 1930), is presumed lost.

Type locality. - Of Arnold's (1906, pl. 3, fig. 8) specimen, USGS 2593. Contra Costa County, Calif. Monterey Shale, Miocene.

Supplementary description. - "As a rule only the molds of casts of this species are found in the shales in which they occur, and for this reason some of the characteristics of sculpture of the species are generally lacking. For example, in a large series of specimens examined, only two or three of the shells showed the radiating sculpture. The disks are generally obliquely distorted and often compressed, but the sculpture on the anterior ear of the right valve is almost always present and is quite characteristic." (Arnold, 1906, p. 56)

"A squeeze of the lectotype of peckhami is available ***. It is a left valve that has a length of about 12 millimeters, weak concentric undulations, and weak, relatively widely spaced radial ribs which are absent in most of the area extending downward from the umbo. These ribs are not well shown on the photograph of the lectotype, the radial lines of which appear to have been added by retouching. The other two specimens in the lectotype lot also are available ***. One-a left valve exposed in interior view - has a length of 13 millimeters; the other-a right valve that lacks the shell aside from small patches of inner layers-has a length of 14.8 millimeters. Both specimens have weak concentric undulations, and neither shows radial ribs, with the exception of traces on the right anterior ear.

" $H$. peckhami seems to be a small species that has weak concentric undulations and weak, relatively widely spaced radial ribs. In many specimens the ribs are apparently absent. They are absent on the specimens from the Monterey group of the San Francisco Bay region figured by Arnold. On some specimens the apparent absence of ribs may be a matter of preservation, as the shell itself is generally not preserved, and preservation in the form of impressions is generally needed to show such weak ribs." (Woodring, 1938, p. 39)

"Delectopecten peckhami (Gabb) of Arnold is thin shelled, small, and possesses very weak to moderately strong concentric undulations. The concentric undulations are most apparent on specimens preserved in shale and subsequently flattened. Specimens collected from limestone and not flattened have barely discernable concentric undulations. The entire surface of the left valve has camptonectes sculpture; most of the specimens of right valves in the collections seem to have smooth shells, but patches of camptonectes sculpture are preserved on a few specimens. A few left valves have radial ribs 0.5 to $1 \mathrm{~mm}$ apart, which apparently disappear near the anterior and posterior margins of the shell. Four right valves were found to possess radial ribs crowded together at the anterior margin. The maximum number of such ribs counted was eight, and they seem to have been slightly spinose." (Moore, 1963, p. 67)

Geographic range.-Japan; Kamchatka and Sakhalin, U.S.S.R.; Oregon to southern California.

Geologic range.-Eocene to Miocene.

Occurrence in California.-Eocene and Oligocene:' Kreyenhagen(?) (Watkins, 1974) and San Lorenzo Formations (Arnold, 1906); Oligocene: Tumey Formation (Atwill, 1935); Miocene: lower Capistrano (White, 1956), Modelo (Hudson and Craig, 1929), Los Laureles Sandstone Member (Hertlein, 1966) and "lower muddy phase," Monterey (Dickinson, 1969), Antelope Shale Member (Weddle, 1965), Monterey, Maricopa Shale of Howard (1935), Puente (Eldridge and Arnold, 1907), and Santa Margarita (Howard, 1935) Formations, Woodhams Member, Monterey Formation (Cummings and others, 1962), Temblor "Horizon" (Loel and Corey, 1932), and Topanga Formation (J. G. Vedder and W. P. Woodring, written commun., 1953).

\section{Delectopecten alternilineatus (Clark)}

\section{Plate 2, figures 8, 9}

Pecten (Pseudomuseum) [sic: Pseudamusium] alternilineatus Clark, 1918 , p. 132-133, pl. 13, figs. 14, 15.

Hyalopecten (Delectopecten) alternilineatus (Clark). Woodring,1938, p. 38.

Original description.- "Shell small, thin, subcircular, compressed, equivalved, nearly equilateral. Apical angle close to 90 . Surface covered by numerous fine, radiating, raised, bifurcated lines, which are nearly obsolete on most of the specimens examined, interspaces between the lines averaging a little wider than the width of the lines. Posterior ear of right valve not separated by a welldefined line from main surface of shell; posterior edge of ear straight, sloping outward; surface smooth on specimens at hand but probably originally radially sculptured, similar to that on the main surface of shell. Anterior ear of right valve very distinct, with a rather deep and acutely angular byssal notch; surface of ear covered by about five subnodose to spinose radiating lines. Ears of left valve similar to those of right except that anteriorly there is no byssal notch."

Holotype.-UCMP 11203.

Type locality.-UC 1131. Contra Costa County, Calif. San Ramon Sandstone, Miocene(?).

Comparison.-"Pecten alternilineatus is about the same size and belongs to the same general type as $P$. vancouverensis Whiteaves, from which it differs in the following respects: The radiating lines on the main surface of the shell are not so numerous nor so closely 
crowded; the ears are larger and the radiating sculpturing is not so coarse; the hinge line is longer in proportion to the width of the shell, and the margins below the ears are less convex than on $P$. vancouverensis.

"Pecten alternilineatus resembles rather closely $P$. peckhami Gabb, a common species in the Lower Miocene of the West Coast, from which it differs as follows: On the left valve the ears are considerably narrower in a dorsal-ventral direction, and in the vicinity of the anterior ear the swell of the main surface of the shell commences as an inclined slope rather than at right angles, as is the case on P. peckhami as described by Gabb; the anterior edge of the anterior ears comes out practically flush with anterior edge of the shell, while on $P$. peckhami this edge is considerably back of the edge of the shell; also on the former the byssal notch is deeper than on the latter." (Clark, 1918, p. 132-133)

Comments. -The right valve of the holotype is smooth except for slightly nodose, radial ribs (about 13) at the anterior dorsal margin. Although described by Clark (1918, p. 132), the right anterior auricle is missing on the holotype. The left valve is smooth except for slightly nodose radial ribs (about 10) that cover the posterior auricle and the depressed area below. The radial ribs on the left valve cover approximately one-half of the area that is ribbed on the right valve. Geographic range.-Middle California.

Geologic range.-Miocene(?).

Occurrence in California.-San Ramon Sandstone.

\section{Delectopecten harfordus (Davis)}

\section{Plate 3, figures 6-9}

Pecten (Camptonectes) harfordus Davis, 1913, p. 456-457, figs. 3, 5, 6. Original description. - "A small thin pecten; form ovate, nearly smooth, and marked with fine almost microscopic groovings which radiate from the umbo and are deflected laterally from a median line on each valve. The shell is marked also by fine concentric lines, every fifth or sixth of which is more distinct. The anterior auricle is large; the anterior edge forms a right angle with the cardinal margin, and rounds sharply into the deep byssal sinus. The left auricle is small and obliquely trunkated [truncated]. The beaks are sharp and stop at the hinge-line."

Syntypes.-CAS/SU 406, 408.

Type locality. -Ten kilometers north of Port Harford [sic: Port San Luis], San Luis Obispo County, Calif. "Jurassic"; [possibly Miocene, teste N. L. Taliaferro in Keen and Bentson (1944). No Delectopecten have been found in valid Franciscan strata in the type area according to B. M. Page (oral commun., 1979).]. Monterey(?) Formation, Miocene.

Comparison. - "This pecten is compared by Stanton to Pecten pedroanus, but the latter differs from these specimens in having stronger radial markings especially on the auricles, and in general outline. It is like $P$. bellistriatus in its sculpture but is smaller; it has finer markings than P. extenuatus Meek." (Davis, 1913, p. 457)

Comments. - A left valve (syntype SU 406) retains small patches of the internal shell layer and shows strong concentric undulations. Two syntypes (SU 408) are right valves. One incomplete specimen (broken off along the ventral margin) bears patches of the internal shell layer and shows the outline of the anterior auricle and a deep byssal sinus. The shell seems to have had concentric undulations. The complete specimen is also poorly preserved and no sculpture of the external shell is preserved.

The paratype (SU 9819) is a double-valved specimen, opened and lying flat on the matrix, but still attached along the hinge margin.
The two valves are poorly preserved but show some strong concentric undulations. The right anterior auricle bears 3 preserved moderately large riblets.

Geographic range.-Southern California.

Geologic range.-Miocene(?).

Occurrence in California.-Monterey(?) Formation.

\section{Delectopecten vancouverensis fernandoensis (Hertlein)}

Plate 3, figure 10

Pecten (Pseudamusium) vancouverensis var. fernandoensis Hertlein, 1925b, p. 43, pl. 4, figs. 6,7 .

Hyalopecten (Delectopecten) fernandoensis (Hertlein). Woodring, 1938 , p. 38.

Original description.-“Shell small, somewhat compressed, pearly. Right valve sculptured by numerous submicroscopic radiating ribs which are crossed by concentric lines forming crosshatched sculpture on the shell, at each intersection a tiny node is developed; the anterior ear is well developed and ornamented by about 5 or 6 radiating ribs crossed by concentric lines of growth, posterior ear ornamented by radiating riblets crossed by concentric lines of growth. Left valve with sculpture similar to that of right, the ears of the left valve are well developed and sculptured similar to that of the right valve. There are about 7 to 9 slight, concentric undulations which are more noticeable on the interior casts of the valves than on the exterior of the valves. Height $16 \mathrm{~mm}$.; length $14 \mathrm{~mm}$.; diameter of left valve approximately $3 \mathrm{~mm}$.; length of hinge line of left valve approximately $10 \mathrm{~mm}$; apical angle of left valve approximately $90^{\circ}$."

Holotype.-CAS/SU 16.

Type locality.-SU 155. Ventura County, Calif. Fernando Formation, Pliocene and Pleistocene.

Supplementary description. - "Of medium size to moderately large; length 12.5 to $22.7 \mathrm{~mm}$. Concentric undulations moderately strong to weak; main part of shell sculptured with radial ribs of varying strength. Right anterior ear sculptured with 5 to 7 radial ribs." (Woodring, 1938, p. 38)

Comparison.--Pecten vancouverensis fernandoensis Hertlein is distinguished from $P$. vancouverensis Whiteaves, by more distinct crosshatched sculpture and usually larger size. $P$. vancouverensis fernandoensis is distinguished from $P$. vancouverensis sanjuanensis Clark, by finer sculpture and larger size in the present species. $P$. vancouverensisfernandoensis differs from $P$. pedroanus Trask, in its characteristic crosshatched sculpture. P. vancouverensis fernandoensis differs from P. randolphi var. tillamookensis Arnold, in that the present species has small nodes developed at the intersection of the crosshatched sculpture, while the variety described by Arnold has finer striae ornamentation on the valves." (Hertlein, 1925b, p. 43)

"The fossils [fernandoensis] from the Los Angeles Basin are considerably smaller than large shells of tillamookensis. Some of the fossils have stronger concentric undulations than Recent shells, but the strength of the undulations is variable in both fossil and Recent specimens." (Woodring, 1938, p. 44)

Comments.-The left posterior auricle of D. v. fernandoensis is larger and higher than the left posterior auricle of D. randolphi tillamookensis. The angle that the left posterior auricle makes where it joins the shell is about 40 on D. v. fernandoensis compared to about 25 on D. r. tillamookensis. Grau (1959, p. 41) considered D. v. fernandoensis to be a valid species.

Geographic range.-Southern California. 
Geologic range.-Pliocene to Pleistocene.

Occurrence in California.-Pliocene and Pleistocene: Fernando Formation

\section{Delectopecten vancouverensis vancouverensis (Whiteaves)}

\section{Plate 3, figures 11, 16}

Pecten (Pseudamusium) vancouverensis Whiteaves, 1893, p. 133, pl. 1. figs. 1, 1a. Arnold, 1906, p. 140, pl. 52, figs. 3, 3a

Hyalopecten vancouverensis (Whiteaves). Woodring, 1946, p. 81, pl. 33 , figs. 2, 3

Cyclopecten (Delectopecten) vancouverensis (Whiteaves). Grau, 1959, p. $40-42$, pl. 15

Original description. - "Shell small, equivalved, compressed lenticular, both valves being equally convex, ovately subcircular in outline apart from the ears and rather oblique; valves extremely thin and fragile, translucent and almost transparent, pale horn color with a slightly yellowish hue. Beaks placed a little behind the midlength; hinge line straight and very long; ears unequal in size, the posterior pair, which are much smaller than the anterior, alike, indistinctly defined and merging gradually and imperceptibly into the general convexity and marginal contour of that side of each valve; anterior ears large, subtriangular, prolonged laterally and longer than high, distinctly defined, that of the left valve somewhat convex in outline above and concave below, that of the right valve with a deep and acutely angular byssal sinus at its base.

"Surface marked by densely crowded and exceedingly minute, irregular and rarely continuous, but on the whole radiating, simple or bifurcating raised lines, also by comparatively large, regularly disposed and distant squamose radii. In the center of each valve the minute and nonsquamose raised lines are essentially parallel to the larger squamose radii, but on the sides the former are disposed obliquely to the latter. The surface of the anterior ear of each valve is minutely cancellated with extremely minute raised lines, which are almost parallel to the hinge line, in addition to the coarser cross lines. The whole sculpture of the exterior of the test is far too minute to be clearly seen without the aid of a microscope or powerful simple lens, but under either of these a few faint concentric lines of growth are also visible."

Holotype.-Location unknown.

Type locality.-Forward Inlet, Quatsino Sound, Vancouver Island, British Columbia, Canada, in $18-37 \mathrm{~m}$.

Supplementary description. - "Radial sculpture very variable in lots assigned to this form." (Woodring, 1938, p. 37)

"Although not mentioned in Whiteaves' very thorough description, a ctenolium of 3 to 6 teeth is present. Many specimens have shallow concentric undulations of the umbonal portion of the disk. On some specimens the squamose sculpture is almost absent and the radii more prominent. Very young shells are frequently nearly smooth." (Grau, 1959, p. 42)

Comparison. -Delectopecten vancouverensis is smaller [ 8.5 to 10.5 $\mathrm{mm}$ ] than D. tillamookensis [ 29 to $32.5 \mathrm{~mm}$ ] and usually has weaker concentric undulations. (Woodring, 1938, p. 37)

"The squarish angle of the posterior auricles and the longer hinge line distinguish this species from the related Cyclopecten randolphi and C. randolphi tillamookensis, the presence of sculpture on the disks also separating it from the former." (Grau, 1959, p. 42)

Delectopecien vancouverensis sanjuanensis (Clark and Arnold, 1923, p. 140), from the Sooke Formation, Vancouver Island, B. C., differs from $D$. v. vancouverensis in having shorter anterior ears and major concentric undulations.
Geographic range.-Living: Bering Sea to southern end of Baja California Sur, and north in the Gulf of California to Isla San Ildefonso Island; fossil: southern California.

Geologic range.-Pliocene through Holocene.

Occurrence in California.-Pliocene: Lomita Marl Member, San Pedro Formation (Woodring, 1946); Pliocene and Pleistocene: Fernando Formation (J. D. Mount, written commun., 1978); Pleistocene: Timms Point Silt Member, San Pedro Formation (Woodring, 1946).

Habitat.-Usually on mud or sand bottoms, occasionally rock, shale or gravel; often attached to calcareous algae; often associated with brachiopods, crinoids, coralline or sponge; 18 to $384 \mathrm{~m}$; rarely less than 90 m. (Grau, 1959, p. 42)

\section{Delectopecten randolphi tillamookensis (Arnold)}

\section{Plate 3, figures 13, 14}

Pecten (Pseudamusium) randolphi Dall var. tillamookensis Arnold, 1906 , p. 139, pl. 48, figs. 3, 3a. Woodring, 1938, p. 37.

Cyclopecten (Delectopecten) randolphi tillamookensis (Arnold). Grau, 1959, p. 45-47, pl. 17 (see for synonymy).

Original description. - "Shell resembling P. randolphi in outline and general characteristics. Disk ornamented by numerous more or less prominent fine, radiating ridges, microscopic radiating striae, and incremental lines of varying prominence. The radiating ridges are narrow and thread-like, and appear to be more prominent anteriorly and near the lines of interrupted growth; the ribs are affected similarly to the disk by the interruptions in growth. The microscopic striae cover the whole surface of the disk and ribs and in a general way radiate from the umbo, but are seldom parallel to the ribs; on the portion of the disk and ear posterior to the umbo the striae are perpendicular to the lines of growth and are thus nearly parallel and not radiating. The right anterior ear has from 6 to 12 prominently imbricated radials."

Holotype.-USNM 150233.

Type locality.-UFSC station 3346, off Tillamook Bay, Oreg. Depth $1,572 \mathrm{~m}$.

Supplementary description:-"Radial sculpture very variable in suites of shells assigned to this variety." (Woodring, 1938, p. 37)

"Disk circular in some specimens, higher than long in others; left valve more convex than right. Small and narrow concentric undulations of disk often present either in umbonal region only or recurring nearly to ventral margin. Radial ridges of disk prominently spinose, continuing over both auricles of left valve and posterior of right; 'incremental lines' actually low concentric ridges covering disk and less prominent than radials; on some specimens both radial and concentric ridges present only at margins. Anterior auricle of right valve with usually 5 to 7 but occasionally as many as 12 imbricated radii; wide fasciole, shallow byssal notch and ctenolium of 4 to 6 teeth. Interior surface of fold of posterior auricle of left valve angulate and ridged." (Grau, 1959, p. 46)

Comparison. - "The subspecies can be distinguished from the typical by the sculpture of the disk, the latter being totally unsculptured except for the anterior auricle of the right valve; the ridge inside of the posterior auricle of the left valve also separates the subspecies." (Grau, 1959, p. 46)

Delectopecten vancouverensis tillamookensis is larger than $D . v$. vancouverensis and usually has stronger concentric undulations. (Woodring, 1938, p. 37)

Geographic range.-Living: Bering Sea to Cedros Island, Bajä California; fossil: southern California.

Geologic range.-Pliocene through Holocene. 
Occurrence in California.-Pliocene: lower Pico Formation (Wissler, 1941); Pliocene and Pleistocene: Fernando Formation (Zinsmeister, 1970).

Habitat.-Usually found on mud bottoms, occasionally on and (or) in sponge; depth 55 to $2,010 \mathrm{~m}$, rarely less than $550 \mathrm{~m}$. (Grau, 1959, p. 47)

\section{Delectopecten pedroanus (Trask), nomen dubium}

Plagiostoma pedroana Trask, 1856, p. 86, pl. 3, fig. 1 [pedrona in text].

Hyalopecten (Delectopecten) pedroanus (Trask). Woodring, 1938, p. 37-39.

Not Pecten (Pseudamusium) pedroanus Trask. Arnold, 1906, p. $90-91$, pl. 28, figs. $4,5$.

Plagiostoma annulatus Trask, 1856, p. 86, pl. 3, fig 2.

Plagiostoma truncata Trask, 1856, p. 86, pl. 3, fig. 3 .

Original description.-"Shell compressed, subtriangular, with eight or nine flatly rounded concentric annulations, which are nearly as distinctly marked on the interior of the valve for about half the height from the ventral margin; beaks acute at the apex, and as high as the line of the auricles; anterior auricle rounded in front, and has a small, thin fold extending from the umbone to the center of its anterior margin, and is covered with about thirteen small, rounded, radiating striae, which converge at the beak; beaks at the anterior third; subacute; anterior margin rounded, and somewhat produced; ventral margin smoothly arched; posterior margin rounded, becoming slightly arcuate toward the dorsum of the shell; posterior auricle angulate and obtusely truncate posteriorly."

Holotype.-Missing and presumed lost.

Type locality.-San Pedro [east coast of Palos Verdes Hills], Los Angeles County, Calif. Trask's specimens evidently came from the lower part of the Valmonte Diatomite or the upper part of the Altamira Shale (Woodring, 1940, p. 39).
Comments. - The holotype of Delectopecten pedroanus has not been found nor have any specimens been found in the type area that are as large as that illustrated by Trask (pl. 3, figs. 1-3) with ribs on the right anterior auricle. Gabb (1869, p. 60) examined Trask's specimens and said they were casts that did not preserve the sculpture. Woodring (1938, p. 39) examined specimens from the Valmonte Diatomite Member, Monterey Shale, near the type locality of $D$. pedroanus, and thought they probably represented $D$. peckhami.

\section{CHLAMYS group}

Both valves convex, left valve usually more so than right valve; with large byssal notch below right anterior ear; sculpture of radial elements fine to coarse, commonly crossed by concentric imbricating lamellae.

Geologic range.-Triassic through Holocene.

\section{Genus CHLAMYS}

Usually higher than long, anterior auricle markedly longer than posterior one; sculpture of numerous, generally grooved or striated and spinose, radial ribs; inner margin commonly with rounded grooved, weak riblets; cardinal crura weak or nearly obsolete.

The characters I have found to be consistently useful in discriminating species of Chlamys are:

(1) The umbonal angle and ratio of length to height-species with a small umbonal angle are higher than long; those with a wide umbonal angle are equidimensional.

(2) The sculpture of the auricles, the extent to which the anterior auricles exceed the posterior auricles in length, and the size of the byssal sinus.

(3) Whether the valves are equilateral or inequilateral, exclusive of the auricles.

(4) Sculpture of the valves. This criterion is useful in separating

TABLE 6.-Geologic and geographic distribution of the genus Chlamys in the eastern Pacific region $[\mathrm{H}=$ Holocene; Ple = Pleistocene; $\mathrm{Pl}=$ Pliocene: $\mathrm{M}=$ Miocene; $\mathrm{O}=$ Oligocene; $\mathrm{E}=$ Eocene; $\mathrm{Pa}=$ Paleocene $]$

\begin{tabular}{|c|c|c|c|c|c|c|c|c|c|}
\hline \multirow{2}{*}{ Species } & \multirow[t]{2}{*}{ Alaska } & \multirow{2}{*}{$\begin{array}{l}\text { British } \\
\text { Columbia }\end{array}$} & \multirow[t]{2}{*}{ Washington } & \multirow[t]{2}{*}{ Oregon } & \multicolumn{3}{|c|}{ California } & \multicolumn{2}{|c|}{$\begin{array}{c}\text { Baja } \\
\text { Califarnia }\end{array}$} \\
\hline & & & & & Northern & Middle & Southern & Norte & $\frac{\text { la }}{\text { Sur }}$ \\
\hline \multicolumn{10}{|l|}{ Genus Chlamys: } \\
\hline anapleus Woodring & ..... & $\cdots \cdots$ & $\cdots .$. & $\cdots . .$. & $\ldots \ldots$ & $\cdots \cdots$ & Pl,Ple & $\cdots \cdots$ & $\cdots \cdots$ \\
\hline bartschi (Arnold)......... & ....... & ….. & ….. & ...... & $\mathrm{Pl}$ & …... & ….. & ...... & ….. \\
\hline branneri (Arnold) ...... & $\cdots \cdots$ & $\cdots \cdots$ & $\cdots \cdots$ & $\cdots \cdots$ & ...... & $\mathrm{O}, \mathrm{M}$ & $\cdots \cdots$ & $\cdots \cdots$ & $\cdots \cdots$ \\
\hline 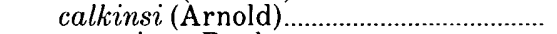 & $\cdots \cdots$ & $\cdots \cdots$ & $\cdots \cdots$ & $\cdots \cdots$ & $\cdots \cdots$ & $\cdots \cdots$ & E & $\cdots \cdots$ & $\cdots . .$. \\
\hline 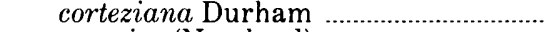 & ...... & ..... & …. & $\cdots \cdots \cdot$ & ….. & ...... & $\mathrm{M} ?, \mathrm{Pl}$ & $\cdots \cdots$ & Pl \\
\hline egregius (Nomland) & $\cdots \cdots$ & $\cdots \cdots$ & $\cdots \cdots$ & $\cdots \cdots$ & $\cdots \cdots$ & $\mathrm{Pl}$ & Pl & $\cdots \cdots$ & ….. \\
\hline hastata ellisi Hertlein and Grant........ & $\cdots \cdots$ & ….... & a.... & $\cdots \cdots .$. & $\cdots \cdots$ & & $\mathrm{Pl}$ & $\cdots \cdots$. & $\cdots \cdots$ \\
\hline $\begin{array}{l}\text { hastata hastata (Sowerby) ..................... } \\
\text { hastata hericius (Gould) }\end{array}$ & $\mathrm{H}$ & $\mathrm{H}$ & $\mathrm{H}$ & $\cdots \cdots$ & $\mathrm{H}$ & $\mathrm{M}$ to $\mathrm{H}$ & $\mathrm{M}$ to $\mathrm{H}$ & $\mathrm{Pl}$ & $\cdots \cdots$ \\
\hline 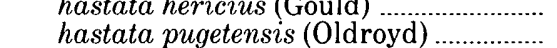 & $\mathrm{H}$ & $\stackrel{\mathrm{H}}{\mathrm{H}}$ & H & $\mathrm{H}$ & H & iv to $\mathrm{H}$ & $\begin{array}{lll}\mathrm{M} \\
\mathrm{Pl}\end{array}$ & $\cdots \cdots . .$. & $\cdots . .$. \\
\hline & ........ & n & ...... & ....... & ..... & $0 . M$ & $\mathrm{OM}$ & ....... & ....... \\
\hline hodgei (Hertlein) & $\ldots \ldots$ & ....... & ...... & ...... & ....... & M & $\mathrm{M}$ & $\ldots \ldots$ & ....... \\
\hline 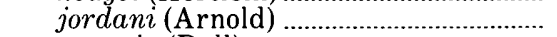 & ...... & ....... & ...... & ...... & PI,Ple & M to Ple & Pl,Ple & ...... & ....... \\
\hline opuntia (Dall) ............. & $\cdots \cdots$ & ...... & ....... & …... & …. & $\mathrm{M}$ to Ple & Pl,Ple & $\mathrm{Pl}$ & $\mathrm{Pl}$ \\
\hline picoensis (Waterfall) ......... & …... & ....... & …... & ....... & $\cdots \cdots$ & ....... & Pl? to Ple & $\cdots \cdots$ & $\cdots \ldots$ \\
\hline proavus (Àrnold) & $\cdots .$. & ..... & $\ldots \ldots$ & ....... & ........ & $\mathrm{Pa} ?$ & $\ldots \ldots$ & $\ldots \ldots$ & $\ldots \ldots$ \\
\hline 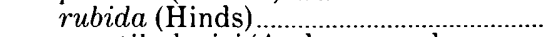 & $\mathrm{Ple}, \mathrm{H}$ & Ple, $\mathrm{H}$ & $\mathrm{H}$ & $\mathrm{H}$ & $\mathrm{H}$ & $\mathrm{M}$ to $\mathrm{H}$ & $\mathrm{M}$ to Ple & $\cdots \cdots$. & $\cdots \cdots$ \\
\hline $\begin{array}{l}\text { sanctiludovici (Anderson and } \\
\text { Martin) }\end{array}$ & & & & $\ldots \ldots$. & & $M$ & & & \\
\hline \multicolumn{10}{|l|}{ sespeensis (Arnold) of Loel } \\
\hline and Corey & $\ldots \ldots$ & $\cdots \cdots$. & $\ldots \ldots$ & $\mathrm{O}, \mathrm{M}$ & $\ldots \ldots$ & ...... & $\mathrm{E}$ to $\mathrm{M}$ & $\cdots \cdots$ & ...... \\
\hline $\begin{array}{l}\text { sespeensis hydei (Arnold) } \\
\text { Genus Chlamys? }\end{array}$ & $\cdots \cdots$ & $\cdots+.$. & $\cdots \cdots$ & & ....... & $\mathrm{O}, \mathrm{M}$ & $\mathrm{O}, \mathrm{M}$ & $\cdots+$. & $\cdots \cdots$ \\
\hline $\begin{array}{l}\text { Genus Chlamys? } \\
\text { mediacostata grewingki (Hertlein) } \ldots . .\end{array}$ & $\ldots . .$. & $\ldots \ldots$. & $\ldots . .$. & $\ldots . .$. & ….... & $\ldots . .$. & & $\mathrm{Pl}$ \\
\hline mediacostata mediacostata & & & & & & & & & \\
\hline . & $\cdots \cdots$ & …. & $\cdots \cdots$ & $\cdots \cdots$ & $\cdots \cdots$ & $\cdots \cdots$ & $\mathrm{M}$ or $\mathrm{Pl}$ & $\cdots \cdots$ & $\mathrm{Pl}$ \\
\hline
\end{tabular}


species that are very different; for example, those with many closely spaced fine ribs from those with wide, heavy ribs. However, the variability of this sculpture within species lots is such that this character is the least reliable. Bifurcation of the ribs seems to be a somewhat helpful distinguishing character as is the spacing of the ribs and interribs.

Geologic range. - Triassic through Holocene (table 6).

Habitat.-Byssus present in some species (Yonge, 1962, p. 116); some capable of swimming; found under rocks and in rock crevices from low tide to $1,540 \mathrm{~m}$ (Abbott, 1974).

"The ecological relationship of the Chlamys and the sponge is very interesting. The flagellate choanocytes lining the chambers of sponges maintain a constant water current through the animal and extract the smallest particles from the current for food. It seems likely that the Chlamys utilizes this current for respiration and excretion, and uses as food the particles that have not already been extracted from the current by the sponge. This constant supply of food may be the reason for the sponge-encrusted Chlamys growing larger than any others. The Chlamys must also receive almost perfect protection when in the sponge, and altogether seems to have a great ecological advantage over unencrusted specimens. It is likely that the sponge obtains initial benefit from the association in using the Chlamys as a substratum to grow on. It is also possible that the sponge is able to utilize part of the lamellibranch's excretory products as food." (Beu, 1965, p. 95)

\section{Chlamys proavus (Arnold)}

\section{Plate 3, figure 15}

Pecten (Chlamys) proavus Arnold, 1906, p. 52-53, pl. 2, figs. 6-8.

Original description. - "Shell averaging about 50 millimeters in altitude, much higher than long, compressed, subequivalve, and equilateral, except for the ears; base regularly rounded; margins smooth; sides straight and forming an acute angle at the umbo. Left valve with numerous more or less unequal, narrow, thread-like, imbricated ribs, between which are occasionally much finer intercalaries; interspaces about as wide as ribs, channeled and flat bottomed; whole surface of disk and ears ornamented by numerous, sharp, imbricating lamellae of growth, which appear more prominently on the anterior portion of the disk; posterior ear short, slightly obliquely truncated, and sculptured by numerous radials and imbricating lamellae; anterior ear unknown, but probably much longer than posterior."

Holotype.-USNM 164930.

Type locality.-SU 2694. San Mateo County, Calif. Locatelli(?) Formation, Paleocene.

Arnold (1906, p. 53) thought that Chlamys proavus came from strata of "Martinez" age; Keen and Bentson (1944, p. 231) considered the type locality to be Oligocene or Miocene. Cummings and others (1962) named the Locatelli Formation, Paleocene, with a type locality in T. 9 S., R. 3 W., not too distant from SU 2694, T. 8 S., R. 3 W. I suggest that Arnold was correct in assigning the small, poorly preserved fauna that occurs with $C$. proavus to the Paleocene.

Supplementary description. - "A fragment of a much larger specimen than the type of $P$. proavus, from the same beds and probably the same species, shows, near the periphery, narrow ridge-like ribs separated by rather wide interspaces in each of which are two or three fine thread-like riblets." (Arnold, 1906, p. 53)

Comparison.- "This species is closely allied to P. traski Gabb, from the Cretaceous of the Pacific coast. It differs from the latter, however, in not having the diagonal microscopic sculpture so characteristic of that species." (Arnold, 1906, p. 53)

Comments.-The holotype is an incomplete left valve retaining only small patches of shell. It is higher than long and seems to have been equilateral. The shell patches have small, rounded, closely spaced ribs bearing strong, concentric ridges. The interspaces are narrower than the ribs on the larger shell patch and some of these spaces have interribs. The left posterior auricle is small and has a few small riblets preserved on it; the left anterior auricle is not preserved.

Geographic range.-Middle California.

Geologic range.-Paleocene(?).

Occurrence in California.-Locatelli(?) Formation.

\section{Chlamys calkinsi (Arnold)}

\section{Plate 3, figure 12}

Pecten (Chlamys) calkinsi Arnold, 1906, p. 51, pl. 2, figs 1, 2.

Original description. - "Shell averaging about 35 millimeters in altitude, subcircular, equivalve or nearly so, equilateral, rather thin, somewhat ventricose, and with only slightly serrate margins. Right valve with the exterior surface ornamented by about 55 small, squarish, slightly imbricated ribs, which show a tendency to become dichotomous near the end in some specimens; interspaces channeled and about one-half as wide as the ribs; hinge line about three-fifths the length of the disk; ears equal in length, flat and with the swell of the disk commencing at right angles to them; anterior ear sculptured by 4 or 5 imbricated radiating ridges; byssal notch distinct; posterior ear sculptured in a similar manner to the anterior. Left valve similar to the right except that in the former the ribs are slightly more rounded and the anterior ear has no notch."

Holotype.-UCMP 12076.

Type locality.-Sisar Valley, Santa Paula quadrangle [S $1 / 2$ sec. 12 , T. 4 N., R. 22 W.], Ventura County, Calif. Coldwater Sandstone, Eocene.

Comparison.- "So far as known this species has no closely allied forms in any of the other California Tertiary formations, and for that reason is admirable as a diagnostic form for the Tejon." (Arnold, 1906, p. 51)

Comments.-The holotype of C. calkinsi, a left valve, is almost equidimensional, and the preserved portions of the auricles are of equal length. The shell bears closely spaced ribs, many' of them $\mathrm{V}$-shaped. The sculpture on the auricles is not preserved. The shell is ventricose near the ventral margin. This species differs from other Chlamys in the seemingly equal auricles and in sculpture.

Geographic range.-Southern California.

Geological range.-Eocene.

Occurrence in California.-Coldwater Sandstone (Keen and Bentson, 1944) and Cozy Dell Shale (Bailey, 1947).

\section{Chlamys branneri (Arnold)}

\section{Plate 4, figure 1}

Pecten (Chlamys) branneri Arnold, 1906, p. 55-56, pl. 3, figs. 9-11. Original description. - "Adult shell averaging about 80 millimeters in altitude, higher than long, equivalve, slightly convex, and equilateral, except for ears; sides only slightly concave above; base regularly rounded below. Right valve with from 20 to 22 prominent, narrow, more or less scaly or spinose ribs, which in the adults are sometimes medially sulcated or dichotomous; interspaces generally much broader than the ribs, channeled and usually containing a spiny or scaly intercalary rib; whole surface sculptured by imbricating incremental lines, often also by microscopic reticulations; hinge line about two-thirds length of disk; anterior ear much produced and sculptured by 6 to 10 imbricated ridges, which are separated by 
equally wide reticulated interspaces; byssal notch profound; posterior ear about three-fifths of anterior, and sculptured similarly. Left valve similar to right."

Holotype.-CAS/SU 358.

Type locality.-Tuff Hill, near Stanford University [hill 357, $3 \mathrm{~km}$ southwest of Stanford University], Santa Clara County, Calif. Unnamed Miocene sandstone of Dibblee (1966).

Supplementary description. - "This species varies considerably in the degree of importance of the minor sculpture, such as reticulation, imbrication, and size of the sulcations and intercalaries. Although unquestionably allied to the Chlamys group, it has larger posterior ears than other species of the group ***." (Arnold, 190, p. 55)

Comparison.-" $P$. branneri resembles $P$. islandicus in size, outline, and general sculpture, but is distinguishable by having only about one-half as many ribs and much larger posterior ears." (Arnold, 1906, p. 55)

Comments. - The holotype is a mold of a left valve with the auricles and about half of the shell preserved. The ribs are narrower than the interspaces which may have a small interrib and which also may have imbricated microsculpture. The left anterior auricle has 12 riblets, slightly spinose, and heavier than the 10 on the posterior auricle which are also slightly spinose. Imbricated microsculpture is preserved on the left anterior auricle.

Geographic range.-Middle California.

Geologic range-Oligocene and Miocene.

Occurrence in California.-Oligocene and Miocene: Temblor Formation (Curran, 1943), Vaqueros Formation (Arnold, 1906; Brabb, 1964); Miocene: unnamed sandstone (Dibblee, 1966).

\section{Chlamys sespeensis (Arnold) of Loel and Corey \\ Plate 4, figures 2, 3}

Pecten (Chlamys) sespeensis Arnold, 1906, p. 69, pl. 8, figs. 2, $2 \mathrm{a}, 3$. Loel and Corey, 1932, p. 196-197, pl. 21, figs. 1-5. Weaver and Kleinpell, 1963, p. 197, pl. 29, figs. 7, 9, 10; pl. 30, figs. 1, 2, 5. Vertipecten sespeensis (Arnold). MacNeil, 1967, p. 38, 40.

Original description.-"Shell averaging about 50 millimeters in altitude, higher than long, inequivalve but both valves equally slightly convex, rather thin, and equilateral, except for ears. Right valve with about 9 pairs of narrow, rounded, nearly smooth ribs, each pair being separated from the adjacent ones by interspaces, which are generally slightly wider than the interspace between the members of the pair; surface sculptured by incremental lines; hinge line about two-thirds length of disk; anterior ear much produced, sculptured by several prominent radials and numerous incremental lines; posterior ear over one-half as long as anterior, and sculptured similarly; byssal notch prominent. Left valve with about nine prominent, narrow, squarish, somewhat convex-topped ribs separated by much broader interspaces, along the bottom of which run one or more thread-like intercalaries of greater or less prominence; ears similar to those of the right valve."

Holotype.-California State Mining Bureau 12480. Missing and presumed lost, fide Keen and Bentson (1944).

Type locality.-Sespe Oil District, Piru quadrangle, Ventura County, Calif. Vaqueros Formation, Oligocene and Miocene.

Supplementary description.-"Individual variation in P. sespeensis is remarkable. In any locality the number of strong ribs may vary from 18 to 29 . The ribs' development is most variable in number, spacing, and strength of intercalary ribs. The valve (which is usually thin) varies considerably in outline and is frequently constricted near periphery." (Loel and Corey, 1932, p. 197)
Comments.-On the basis of a specimen figured by Weaver and Kleinpell (1963, pl. 29, fig. 10; pl. 30, fig. 1) MacNeil (1967, p. 38) considered Chlamys sespeensis to be "very close to the boundary between Chlamys and Vertipecten, morphologically." The hypotypes of Loel and Corey (1932) are typical Chlamys, and sespeensis is here retained in that genus. A few of the left-valve ribs are more prominent than others, but this is true for other Chlamys. The valves are equilateral, and the figured right valve has about 25 low rounded ribs with equal interspaces, some bearing an interrib. The right anterior auricle has six fine riblets and a moderately large byssal sinus. The smaller right posterior auricle is smooth. The left valve figured has 27 rounded to subrounded ribs, some higher than others, separated by slightly wider interspaces bearing 1 or 2 interribs. The left-valve auricles seem to have been smooth.

The valves of Chlamys hodge $i$ are more inequilateral and the left valve much more finely sculptured than $C$. sespeensis. Chlamys branneri has almost square ribs on the left valve and strongly sculptured left anterior auricle, which differentiate it from C. sespeensis.

Geographic range.-Oregon (Durham and others, 1942); Southern California.

Geologic range.-Eocene to Miocene.

Occurrence in California.-Eocene: Coldwater Sandstone (Weaver and Kleinpell, 1963); Oligocene: upper part of Gaviota Formation (Weaver and Kleinpell, 1963); Oligocene and Miocene: Rincon Shale (Avila and Weaver, 1969) and Vaqueros Formation (Kew, 1924; Loel and Corey, 1932; Dibblee, 1950; Squires and Fritsche, 1978).

\section{Chlamys sespeensis hydei (Arnold)}

Plate 4, figures 4, 6

Pecten (Chlamys) sespeensis var. hydei Arnold, 1906, p. 69-70, pl. 5, figs. 3, 3a, 3b. Arnold, 1907b, p. 24, pl. 53, fig. 3.

Original description. - "Shell averaging about 45 millimeters in altitude, much higher than long, subequivalve, slightly convex, and subequilateral, except for ears; anterior sides more concave than posterior; base regularly rounded; umbonal angle comparatively small. Right valve with about 20 subequal, prominent, rounded, somew hat imbricated ribs, which increase gradually in number by division and intercalation as the shell grows; interspaces somewhat narrower than ribs and often containing one or two thread-like intercalaries; ears as in P. hastatus var. hericius except less imbricated, and the posterior relatively larger left valve similar in every respect to right."

\section{Holotype.-CAS/SU 10.}

Type locality.-Lynch's Mountain, Monterey County, Calif. Vaqueros Formation, Oligocene and Miocene.

Supplementary description. - "This variety is characterized by the nearly uniform size of its ribs and interspaces. The shell has a tendency to contract somewhat upon reaching an altitude of about 35 or 40 millimeters." (Arnold, 1906, p. 70)

Comparison. - "P. var. hydei is closely allied to the typical $P$. sespeensis, but may usually be distinguished by its more nearly equal ribs, which are generally more strongly imbricated." (Arnold, 1906, p. 70)

Comments.-The sculpture of the right and left valves of the holotype is the same: rounded ribs with slightly narrower interspaces that may bear an interrib. The shell is high in proportion to length. Chlamys sespeensis hydei differs from C. sespeensis in that it is higher in proportion to length, equilateral, and the valves bear similar sculpture.

Geographic range.-Middle and southern California.

Geologic range.-Oligocene to Miocene. 
Occurrence in California.-Oligocene and Miocene: Vaqueros Formation (Arnold, 1906, 1907b; Arnold and Anderson, 1907; Bailey, 1952; Kew, 1924).

\section{Chlamys hertleini (Loel and Corey)}

Plate 4, figures 7, 8

Pecten (Chlamys) hertleini Loel and Corey, 1932, p. 195-196, pl. 20, figs. $4,6-8$

Chlamys hertleini Loel and Corey. Addicott, 1965, fig. 3e. Addicott, 1967b, fig. 4, B, D.

Original, description. - "Shell medium thin, about as long as high; valves subequal, slightly convex and subequilateral except for ears; anterior sides concave, posterior straight, base regularly rounded umbonal angle 80 degrees. Right valve ornamented by many fine, evenly spaced, minutely noded ribs which number about 60 at the periphery. These ribs are progressively added to outwardly by the strengthening of intercalary ribs, all being of equal strength at the margin; fine incremental lines form the nodes on the ribs and also in the interspaces which are about as wide as ribs. Anterior ear long, ornamented by seven fine riblets, the concentric incremental lines strong forming nodes on ribs and strong lines between ear and margin; byssal notch deep. Left valve similar in all characters save for shallower byssal notch. Height, $4 \mathrm{~m}$.; length, $40 \mathrm{~mm}$.; diameter $10 \mathrm{~mm}$. (both valves)."

Holotype.-UCMP 31725.

Type locality. - UC A316, Santa Barbara County, Calif. Vaqueros Formation, Oligocene and Miocene.

Supplementary description. - "This distinctive Pecten (Chlamys) is different from all others in the Tertiary of the West Coast. On another specimen from the same locality, the posterior ears are seen to be ornamented in the same manner as the posterior [sic: anterior] ears and squarely truncate. Specimens from the Vaqueros of the western Santa Ynez Mountains *** are all small with rib number at the periphery generally less than the type or larger form. The rib number is proportional to the size of the individual." (Loel and Corey, 1932, p. 196)

Comparison. - "Pecten (Chlamys) hertleini, n. sp. differs from $P$. sespeensis Arnold in its distinctively uniform and greater number of ribs-adult specimens of the latter species never have more than about 30 ribs and those are unevenly developed." (Loel and Corey, 1932, p. 196)

Comments. -The holotype is a poorly preserved, double-valved specimen with a small umbonal angle. The right-valve auricles are broken, but the byssal notch is wide. Both valves are similarly sculptured.

Geographic range-Middle and southern California.

Geologic range.-Oligocene to Miocene.

Occurrence in California.-Oligocene: Quail Canyon Sandstone Member, Vaqueros Formation (Loel and Corey, 1932; Vedder, 1973); Oligocene and Miocene: Rincon Shale (Avila and Weaver, 1969), Soda Lake Shale Member, Vaqueros (Vedder, 1973) and Temblor (Page and others, 1951) Formations; Miocene: Jewett Sand (Addicott, 1965 and 1967b), Monterey Formation (Avila and Weaver, 1969), Painted Rock Sandstone Member, Vaqueros Formation (Vedder, 1973), and Skooner Gulch Formation (Addicott, 1967b).

\section{Chlamys hodgei (Hertlein)}

Plate 4, figures 5, 9; plate 5, figure 2

Pecten (Chlamys) hodgei Hertlein, 1925b, p. 42, pl. 4, figs. 1, 2. Stanton, 1966, p. 27, pl. 5, figs. 4, 5.
Chlamys durhami Adegoke, 1969, p. 97-98, pl. 2, fig. 5.

Original description.- "Shell of medium size, higher than long, slightly compressed, equilateral. Right valve ornamented by over 19 radiating ribs which are largely bifid and often have a small riblet on each side of the large ribs, the ribs toward the margins, become finer, interspaces somewhat rounded, showing very fine pitted surfaces, sculptured by a small intercalary riblet, ribs and riblets bearing fine, scattered, sharp, imbricating spines; sides of valve nearly straight, ventral margin regularly rounded; ears unequal, the anterior much larger than the posterior, anterior ear ornamented by about 5 or 6 coarse, radiating riblets which are crossed by concentric lines of growth, byssal notch large; posterior ear small in proportion to the large anterior ear, ornamented by about 9 small, radiating riblets which are crossed by concentric lines of growth. The ornamentation of the left valve consists of alternating large and small ribs but the ribbing is much finer than on the right valve. Height 47 $\mathrm{mm}$.; length $40 \mathrm{~mm}$.; diameter of right valve approximately $8 \mathrm{~mm}$; length of hinge line of right valve $25 \mathrm{~mm}$.; apical angle of right valve approximately $87^{\circ} . "$ (hodgei)

"Shell small, thin, equilateral, gently and evenly convex, slightly higher than long; anterior and posterior dorsal margins moderately long, about half length of shell, subequal and straight, merge into very convex ventral margin with broad angle; umbonal angle about $90^{\circ}$; cardinal area straight and long, about three-fourths length of shell; shell ornamented by about 20-22 dichotomously branching ribs; branching occurs at different levels along individual ribs; rib profile rounded near cardinal area, wide and flat-topped near ventral margin; shell surface sculptured by numerous faint incremental lines of growth; posterior ear short and inconspicuous; anterior ear long, sculptured by 4 or 5 axial riblets and numerous faint lines of growth; byssal notch deep." (durhami)

Holotype.-CAS/SU 20; of Chlamys durhami Adegoke, UCMP 33615 .

Type locality.-SU F-6. Fresno County, Calif. Santa Margarita Formation, Miocene; of Chlamys durhami Adegoke, UC D1099, Kern County, Calif. Santa Margarita Formation, Miocene.

Supplementary description. - "The right valves are ornamented with about 20 bifid ribs; interspaces contain a median riblet, and, in a few instances, one or two tertiary riblets. The left valves bear about 22 flatly rounded ribs; interspaces contain a median riblet one-third to one-fourth as wide as the primary rib and in some interspaces tertiary ribs lie along the sides of the primary ribs. The sculpture of the right valve is variable. On one specimen all the ribs are bifid; on another, only a few are bifid; and on the third, most ribs are bifid but the two parts of the ribs are not equally wide." (Stanton, 1966, p. 27)

Comparison. - Pecten hodgei appears to be closely related to $P$. halimensis Makiyama from the Pliocene of Japan, but it differs in that it has less numerous ribs which are more distinctly bifid, than in the species described by Makiyama. From P.opuntia Dall, P. hodgei differs in having the ribs bifid and arranged in pairs, rather than numerous, closely but irregularly spaced, rounded, and not bifid; the margins of $P$. opuntia are rounded and not straight as in the present species. From P. jordani Arnold, P. hodgei differs in having more numerous, rounder ribs, which on the right valve become bifid much earlier in the growth of the shell. From P. hericius Gould, P. hodgei differs in having less numerous ribs, narrower, less high, and generally finer, and the shell possesses straighter margins in the present species. From $P$. egregius Nomland, $P$. hodge $i$ is distinguished by having more numerous ribs which are differently ornamented in the present species." (Hertlein, 1925b, p. 42)

"Chlamys durhami $[=C$. hodgei $] * * *$ is closely similar in outline and ornamentation to Chlamys jordani Arnold from the upper Pliocene and Pleistocene of San Pedro and Santa Barbara. It may be readily distinguished from the latter by its smaller size, fewer ribs, 
wider interspaces between ribs and the fact that bifurcation of ribs begin much earlier in the new species than in Arnold's species.

"From Chlamys egregius Nomland *** may be distinguished by its less elongate oval outline and its bifurcating ribs." (Adegoke, 1969, p. 97-98)

Comments. -The holotype of Chlamys hodgei is an inequilateral right valve with wide ribs that may bifurcate when the shell is 10 $\mathrm{mm}$ high and that are separated by narrower interspaces that have an interrib. Remnants of spines are present on the ribs near the ventral margin. The right anterior auricle has six riblets; the left anterior auricle about eight, which are finer.

The paratype of Chlamys hodge $i$ is a markedly inequilateral left valve that has much finer ribs than the right valve. The ribs are closely spaced, and the narrow interspaces bear 1 or 2 interribs. The left anterior auricle has 13 riblets of almost equal size.

On the basis of the holotypes, I can find no characters to differentiate Chlamys durhami from Chlamys hodgei. Chlamys durhami is probably a juvenile specimen of $C$. hodge $i$, which was also collected from the Santa Margarita Formation.

Geographic range.-Middle and southern California.

Geologic range.-Miocene.

Occurrence in California.-Castaic (Stanton, 1966) and Santa Margarita Formations.

\section{Chlamys sanctiludovici (Anderson and Martin)}

Plate 5, figures 1, 3

Pecten sancti-ludovici Anderson and Martin, 1914, p. 55, pl. 3, figs. 10a, $10 \mathrm{~b}$.

Not Pecten sancti-ludovici Anderson and Martin. G D. Hanna, 1926a, p. 473 , pl. 22, figs. 1-3.

Original description.- "Shell of moderate size, equivalve, inequilateral, strongly ribbed, moderately inflated; umbones narrow and acute; each valve with nineteen or twenty ribs, rounded on the back and separated by narrow V-shaped interspaces; ribs ornamented by about six riblets forming fasciculi more or less beaded or roughened, not spiny; ears unequal, the anterior being nearly twice the length of the posterior, and on the right valve coarsely ribbed; posterior ear smaller and ornamented with wavy radial threads."

Holotype.-CAS 107.

Type locality. $-0.8 \mathrm{~km}$ above the mouth of Navajoa Creek, San Juan River [NW11/4sec. 16, T. 28 S., R. 16 E., La Panza quadrangle], San Luis Obispo County, Calif. Santa Margarita Formation, Miocene.

Comparison. - "This species differs from Pecten hastatus Sowerby, by having uniform riblets." (Anderson and Martin, 1914)

Comments.-The holotype and paratype have a moderately shallow byssal sinus, nearly equal auricles, and no bifurcated ribs. A delicate scalelike sculpture is preserved on the ribs, which are broadly rounded and covered with fine riblets, as are the interspaces. The right anterior auricle has 5 heavy riblets; the right posterior auricle 11 much finer riblets. In sculpture, $C$. sanctiludovici resembles Aequipecten.

Geographic range.-Middle California.

Geologic range.-Miocene.

Occurrence in California.-Santa Margarita Formation.

\section{Chlamys corteziana Durham}

Plate 5, figure 5

Chlamys corteziana Durham, 1950, p. 64-65, pl. 10, figs. 2, 3, 6 . Pecten sancti-ludovici Anderson and Martin. Hanna, 1926a, p. 473, pl. 22, figs. 1-3; not Pecten sancti-ludoviciAnderson and Martin, 1914.

Original description. - "Shell of medium size, right valve slightly more inflated than left; sculpture discrepant on the two valves; right valve with 17-18 low rounded ribs with interspaces about equal in size, ribs and interspaces each bearing equally spaced finely beaded riblets with an occasional tertiary riblet present; near umbo the primary ribs are higher and nearly square-sided but as shell becomes larger ribs spread out and become low and rounded; anterior ear of right valve with about 12 fine beaded riblets; riblets on posterior ear less distinct than on anterior; left valve with a corresponding number of high, square-sided and noded ribs about two thirds as wide as flat-bottomed interspaces, occasionally a secondary beaded, flat-sided riblet is developed on sides of primary rib."

Holotype.-UCMP 30564.

Type locality.-UC A3579. Baja California Sur. San Marcos Formation, Pliocene.

Comparison.-“This species somewhat resembles Chlamys lowei (Hertlein) living in the Gulf of California but may easily be separated by the large posterior ear and more rounded interspaces on the right valve. Pecten (Chlamys) buchivacoanus F. and H. Hodson and its subspecies from the Miocene of Venezuela is another closely related species, but its left valve has many more secondary and tertiary riblets." (Durham, 1950, p. 64)

Comments. - The holotype is a poorly preserved mold of a right valve that is more inflated than is usual for Chlamys and has 17 subrounded ribs without equal interspaces. The ribs and the interspaces have secondary riblets.

Geographic range.-Southern California to Baja California Sur. Geologic range.-Miocene to Pliocene.

Occurrence in the Californias.-Miocene or Pliocene: Imperial Formation; Pliocene: Gloria (Stump, 1979) and San Marcos Formations and unnamed strata near San Felipe, Baja California Norte.

\section{Chlamys hastata hastata (Sowerby)}

Plate 5, figures 4, 6

P[ecten] hastatus Sowerby, 1842, p. 72, pl. 20, fig. 236.

Pecten (Chlamys) hastatus Sowerby. Arnold, 1906, p. 108-110, pl. 41, fig. 4 ; pl. 42 , figs. $1,1 \mathrm{a}, 2,2 \mathrm{a}$.

Pecten (Pecten) hastatus Sowerby. Grant and Gale, 1931, p. 166-168, pl. 11 , figs. $6 \mathrm{a}, 6 \mathrm{~b}$.

Chlamys (Chlamys) hastata Sowerby. Hertlein and Grant, 1972, p. 188-189, pl. 33, figs. 4-6. Vedder and Moore, 1976, pl. 4, fig. 2. Chlamys hastata (Sowerby). Grau, 1959, p. 84-87, pls. 27, 28.

Pecten (Chlamys) lawsoni Arnold, 1906, p. 117-118, pl. 45, figs. 3, 4.

Original description. - "Oval, inclining to triangular, rather elongated, rough; with very unequal ears, the posterior ones being very small; the upper valve has eight unequal, elevated, angular ribs, with numerous erect, slightly curved sharp spines, and several smaller spinose ribs in the interstices. The lower valve has 22 more nearly equal ribs with more numerous and smaller spines on the angles." (hastata)

"Adult shell averaging about 70 millimeters in altitude, not as long as high, inequivalve, only slightly convex, equilateral, ears unequal; base regularly rounded; sides only slightly concave above; margins somewhat serrate. Right valve with about 18 to 20 subequal, prominent, narrow, round-topped, rugose ridges, separated by somewhat wider interspaces, in each of which runs a single more or less rugose riblet; some of the ribs are occasionally medially. sulcated or dichotomous; surface sculptured by numerous irregular incremental lines, which give the ribs a squamose appearance when they are unworn; ears unequal, the anterior with three or four rather 
prominent rugose radials and numerous incremental lines; the posterior with several less prominent radials, and incremental sculpture; byssal notch rather profound. Left valve with 9 or 10 prominent narrow, round-topped, rugose major ribs, between each two of which there is a single minor rib similar to and almost equaling in prominence the major ribs; a single thread-like intercalary is visible in most of the interspaces; surface sculptured as in the right valve; ears similar to those of right valve except that there is no prominent notch between the anterior one and the disk." (lawsoni)

Holotype.-B.M. (N.H.); of P. lawsoni, lost in San Francisco fire of 1906.

Type locality.-San Diego, Calif., by subsequent designation (Grau, 1959, p. 85), Holocene. Of $P$. lawsoni, USGS 4473, Santa Barbara County, Calif. Careaga Formation (Keen and Bentson, 1944), Pliocene.

Supplementary description. - "Shell averaging about 64 millimeters in altitude, slightly shorter than high, inequivalve, equilateral (except for ears), compressed and with serrate margins; base evenly rounded below; sides slightly concave above. Right valve with 9 pairs of narrow, elevated, spiny ribs, along the sides of which are a pair of smaller spiny riblets; major interspaces much wider than ribs, concave-bottomed and ornamented by 1 or 3 thread-like, spiny, intercalary riblets; whole surface sculptured by microscopic imbricating lines, of which the spines on the ribs and riblets are only modifications; hinge line equal to one-half length of disk; ears unequal, the anterior being about two and one-half times the length of the posterior; anterior ear with 7 or 8 prominently spiny radials and minor riblets, and imbricating incremental lines; byssal notch deep and almost as wide as ear; posterior ear small, and sculptured by fine, spiny radials and imbricating incremental lines. Left valve with about 9 narrow, very prominently spiny ribs; interspaces wide, concave-bottomed, and ornamented by a single prominent, central, imbricated riblet, on each side of which are minor threadlike riblets; whole surface of disk with fine incremental sculpture as in right valve; ears similar to those of right valve except that the anterior one has more ribs and riblets and no byssal notch. Hinge with almost obsolete cardinal crura." (Arnold, 1906, p. 109)

"Valves moderately inflated, left valve with about 10 strong spinose ribs, right valve with nine strong double or paired ribs, paired ribs well spaced, both valves with fine intercalary ribs and fine imbricate sculpture throughout." (McLean, 1978, p. 69)

Comparison. - "Both fossil and Recent shells show perfect gradation between $C$. hastatus proper, characterized by well-differentiated primary ribs that bear well-developed scaly lamellae, and $C$. hericius, which lacks those characters." (Woodring, 1946, p. 80)

"Young specimens of $15 \mathrm{~mm}$ or less in height resemble the young of Hinnites multirugosus (Gale), but those of the latter can be distinguished by the following differences in structure: the disk equilateral (or nearly so), the ribs of the right valve divaricating, the posterior auricles larger and squared, the interspaces of both valves concentrically lamellose." (Grau, 1959, p. 86)

Chlamys hastata pugetensis "is distinguishable from Chlamys hastata and Chlamys hastata hericia by its rib-structure, sculpture of disk, obliquely truncated posterior auricles and internal coloring; juveniles $12 \mathrm{~mm}$ in height or less are only distinguishable by the punctate sculpture of the disk." (Grau, 1959, p. 91)

"Eroded specimens of this species are often difficult to separate from similar specimens of the subspecies $C$. hastata hericius. In general, the major ribs on $C$. hastata are rather sharply defined whereas on $C . h$. hericius these are composed of a fascicule of riblets the whole with a convex outline. The right valve of $C$. hastata is sculptured with 9 or 10 paired, high, steeply sloping ribs, each bearing a row of long spines. There are 1 to 3 thread-like spiny riblets in the interspaces. Very fine, incised groovings are present on the surface in the interspaces between the ribs. On the right valve of C. h. hericius, a generally more northern, larger form, there are three riblets of nearly equal size (although the central one is slightly larger) on each major rib which lend a rounded appearance to the ribs. The ribs on the left valve of $C$. hastata, 9 or 10 in number, are narrower and more steeply sloping than are those of $C$. h. hericius (Hertlein and Grant, 1972, p. 189)

Geographic range.-Living: Bolinas Bay to San Diego, Calif.; fossil: middle California to Baja California Norte.

Geologic range.-Miocene through Holocene.

Occurrence in the Californias.-Miocene: Santa Margarita Formation (Nomland, 1917b; Addicott and Vedder, 1963); Miocene and Pliocene: Etchegoin (Adegoke, 1969), Purisima (Arnold, 1906), and Sisquoc (Woodring, 1950) Formations; Pliocene: Almejas Formation (Minch and others, 1976), Cebada Member, Careaga Sandstone (Woodring, 1950), Foxen Mudstone (Woodring, 1950), Lomita Marl Member, San Pedro Formation (Woodring, 1946), Niguel (J. G. Vedder, written commun., 1978), Ohlson Ranch (Peck, 1960), and San Diego (Hertlein and Grant, 1972) Formations, and unnamed strata on San Clemente Island (Vedder and Moore, 1976); Pliocene and Pleistocene: Fernando (Woodring, 1930), Merced (Arnold, 1906), Pico (W. O. Addicott and J. G. Vedder, written commun., 1968), Santa Barbara (MacNeil, 1967), and Saugus (Kew, 1924) Formations; Pleistocene: upper member, Fernando Formation (Durham and Yerkes, 1964), Timms Point Silt (Woodring, 1946), and unnamed strata on San Nicolas Island (Vedder and Norris, 1963) and at San Diego (Glibert and Van de Poel, 1965).

Habitat. -18 to $90 \mathrm{~m}$ (Hertlein and Grant, 1972, p. 189); on rocky bottoms (McLean, 1978, p. 69); in sand and on shale or corallines, sometimes encased in sponge (Smith and Gordon, 1948).

\section{Chlamys hastata hericius (Gould)}

Plate 5, figures 7, 8

Pecten hericius Gould, 1850, p. 345.

Pecten (Chlamys) hastatus Sowerby var. hericius Gould. Arnold, 1906, p. 110-111, pl. 43, figs. 3, 3a.

Chlamys hastata hericius (Gould). Grau, 1959, p. 87-90, pl. 29.

Chlamys (Chlamys) hastata hericius Gould. Hertlein and Grant, 1972 , p. 189-190, pl. 33, fig. 2 [See for synonymy].

Original description. - "T. rotundato-triangularis, equilateralis, equivalvis; valvis convexis, sub-tumidus: valva superior rosea, lineis exilibus concentricis exasperata, et costis ad 24 angulatis, alternis majoribus et spinis erectis fornicatis insculpta: valva inferior pallidior colore saturatiori zonata, costis sub-equalibus spinifer is armata; natibus acutis, prominentibus; auribus obliquis valde inequalibus radiatim squamoso-striatis; intus porcellana; marginibus crenulatis, rosaceis. Long. $4 \frac{1}{2} ;$; alt. $1 \frac{1}{4}$; lat. $43 / 4$ poll."

Holotype.-USNM 5955.

Type locality.-Strait of Juan de Fuca, Washington, Holocene.

Supplementary description. - "Adult shell averaging about 70 millimeters in altitude, not quite as long as high, both valves compressed, equilateral (except for ears), which are decidedly unequal; margins finely serrate; sides markedly concave above; umbo acute. Right valve with 9 or 10 pairs of spiny fasciculi, the middle rib of each fascicule being the most prominent; interspaces about as wide as the fasciculi, and ornamented by several more or less spiny riblets; spaces between the riblets of the fasciculi and large interspaces channeled and ornamented by fine imbricating incremental lines, but free from any reticulations whatever; hinge line a little over one-half the length of the disk; anterior ear about two and one-half times longer than the posterior, ornamented by imbricating concentric lines, and above the notch by several subequal spiny 
riblets; byssal notch wide and deep; posterior ear small, and ornamented by numerous fine spiny riblets. Left valve with about 9 or 10 elevated fascicule, the middle rib of each fascicule being quite prominently spinose; the spaces between the major fasciculi each occupied by a minor fascicule of more or less scaly riblets; interspaces between riblets channeled and with imbricating incremental

sculpture; ears sculptured as in right valve except that the riblets are smaller and more numerous on the anterior ear. Hinge weakly developed." (Arnold, 1906, p. 110)

Comparison.- "The more extreme variants of typical C. hastata have high, sharp crested ribs with moderately large spinelike scales, whereas the opposite extreme of $C$. hastata hericius has low bundles or fascicles of riblets with all the riblets finely and equally scabrous. Some intermediate specimens might be difficult to assign to either subspecies. If living individuals of these forms do not constitute an entirely continuous series of variation, they come very close to it." (MacNeil, 1967, p. 14-15)

"Chlamys hastata hericius *** differs from typical C. hastata in the generally larger size, less spinose ribs and in that the ribs of the right valve are composed of a fascicule consisting of three nearly equal, spiny riblets, the middle one slightly more prominent, the whole more convex in outline than the corresponding fascicule on $C$. hastata. There is usually a riblet in the middle of each interspace and between this and the major fascicule there are usually two smaller threads and occasionally also a finer pair of intercalaries. The ribs on the left valve also consist of a fascicule of riblets which is more convex than that of $C$. hastata. The surface in the interspaces between the ribs of $C$. h. hericius is usually sculptured with very fine oblique grooves or scratches similar to those on C. hastata. Grau pointed out that the shell of $C$. hastata often is oblique, whereas that of $C$. h. hericius seldom is.

"The form originally described as Pecten islandicus pugetensis I. $\mathrm{S}$. Oldroyd is similar to $C$. h. hericius but it is generally smaller, the interspaces and sometimes the entire valve bears fine honeycomblike sculpture.

"Masuda [1956, p. 249] suggested that Chlamys miyatokoensis Nomura and Hatai $* * *$, which occurs in beds of early Miocene age in Japan, may be an ancestral form of $C$. hastata hericius. The riblets forming the major ribs of the Japanese form are said to be divided into three subequal parts by radial grooves and there are but two or three riblets in the interspaces. Judging from the illustrations given by Masuda, the radial fasciculi appear to be less elevated into raised ribs lending an appearance of nearly equal, spiny, radial riblets over all the right valve. The anterior ears also are smaller than those on the west American form. The medial sulcation giving rise to the paired character of the ribs mentioned by Masuda also is noticeable on some west American specimens $* * *$. Some of the illustrations given by Masuda [1956] bear a decided resemblance to some forms of $C$. $h$. hericius (see especially his plate 35 , figure $9 a$ ) and his suggestion that $C$. miyatokoensis may be an ancestral form of $C$.h. hericius is plausible. The two, however, are apparently distinct forms." (Hertlein and Grant, 1972 , p. 190)

Geographic range. - Living: Port Althorp, Alaska, to Santa Barbara, Calif.; fossil: middle to southern California.

Geologic range.-Miocene through Holocene.

Occurrence in California.-Miocene: San Pablo and Santa Margarita Formations (Arnold, 1906); Miocene and Pliocene: Capistrano (Kern and Wicander, 1974), Etchegoin, and Purisima Formations (Arnold, 1906); Pliocene: Lomita Marl Member, San Pedro Formation (Valentine and Meade, 1961); Pliocene and Pleistocene: Fernando (Moody, 1916; Soper and Grant, 1932), Merced (Arnold, 1906), San Pedro (Arnold, 1906), Santa Bärbara (Waterfall, 1929: as Pico), and Saugus (Kew, 1924) Formations: Pleistocene: unnamed Pleistocene strata at Baldwin Hills (Willett, 1937) and Capistrano Beach (Willett, 1938).
Habitat.- "Chlamys hastata hericius is a generally more northern form, at the present time occurring abundantly in Puget Sound often embedded in sponges. It has been recorded as occurring from Port Althorp, Alaska, south to Newport Bay, California, but we have not seen specimens from southern California." (Hertlein and Grant, 1972, p. 190) From low tide line to $145 \mathrm{~m}$.

\section{Chlamys (Chlamys) hastata ellisi Hertlein and Grant Plate 5, figure 9}

Chlamys (Chlamys) hastata ellisi Hertlein and Grant, 1972, p. 190-191, pl. 3, figs. 2, 3; pl. 34, fig. 6.

Original description. - "Shell characters similar to those of Chlamys hastata but differing in the presence of fine honeycomblike tesselations covering the interspaces and sides of the ribs, but obscured on the tops of the ribs where covered by strong imbricating spinose sculpture. Length, $66 \mathrm{~mm}$; height, $68.5 \mathrm{~mm}$."

Holotype.-LAM 4483.

Type locality.-LAM 305. San Diego County, Calif. San Diego Formation, Pliocene.

Supplementary description. - "The entire surface of left valves is covered with minute tesselations. This sculpture, composed of a layer of minute scaly imbrications, is usually preserved in the interspaces but sometimes covers the ribs as well. Often the scaly honeycomb-like material is mostly gone and the interspaces retain only a pattern of minute reticulation. This type of sculpture $* * *$ is present on $C$. islandica and allied forms. It also occurs on many species in other groups of scallops, including Manupecten, Patinopecten and Swiftopecten. It may be a primitive character. This minute sculpture may easily disappear with erosion and it is quite possible that some fossil specimens lacking perfect preservation in the present as well as in other collections, and referred to Chlamys hastata or C. h. hericius, may represent C. h. ellisi ***."

"It appears that since Pliocene time the members of the Chlamys hastata group bearing honeycomb-like tesselations have been reduced to one subspecies, which is smaller, less numerous, and in general has become restricted to cooler waters." (Hertlein and Grant, 1972, p. 191)

Comparison.- "The only reliable basis for separating C. hastata ellisi*** from C. hastata rests entirely on the presence and recognition of the surficial tesselated sculpture.

"The minute sculpture of the present subspecies is similar to that of the form described as Pecten islandicus pugetensis $* * *$ The ribs of C. hastata pugetensis are more rounded than those of $C$. hastata, those on each valve are nearly equal in size, and the fasciculi are minutely spinose. ${ }^{* * *}$

"Chlamys hastata pugetensis is generally reported to be smaller than C. hastata, C. h. ellisi n. subsp., and C. h. hericius." (Hertlein and Grant, 1972, p. 191)

Geographic distribution.-Southern California.

Geologic range.-Pliocene.

Occurrence in California.-San Diego Formation.

\section{Chlamys egregius (Nomland)}

Plate 6, figure 5

Pecten egregius Nomland, 1917a, p. 231-232, pl. 6, figs. 3, 3a, 3b. Chlamys egregius (Nomland). Peck, 1960, pl. 21, fig. 8. Adegoke, 1969 , p. 98.

Original description. - "Shell equilateral, equivalve, thin, rather compressed; with smooth, regularly rounded base. Dorsal margins long; umbonal angle about 70 degrees. Right valve with about $22-23$ moderately strong, rounded ribs; in each interspace there is one 
small, often invisible, rounded riblet; anterior ear long, arcuate in front, ornamented above byssal notch by about six distinct, radiating ridges and numerous incremental lines; byssal notch well defined; posterior ear very small, sculptured by low radiating ridges and inconspicuous incremental lines. Left valve with about 22 subequal ribs, which are not so prominent as those of the right valve, but with auxiliary riblets more distinct; anterior ear large, with sculpture consisting of faint incremental lines and about.twelve radiating ridges; posterior ear similar to that on the right valve. Dimensions of type, which is a rather small specimen; height, $31 \mathrm{~m}$ width, $24 \mathrm{~mm}$.; width of hinge, $13 \mathrm{~mm} . "$

Holotype-UCMP 11090.

Type locality.-UC 2991. Fresno County, Calif. Upper part of Etchegoin Formation, Pliocene.

Comparison. - "This species differs markedly from Chlamys bartschi (Arnold) with which it was synonymized by Grant and Gale. $C$. egregius has an elongate oval shell ornamented by $22-23$ rounded ribs while $C$. bartschi has a more oval outline and about 40 narrow, threadlike ribs." (Adegoke, 1969, p. 98)

Comments. - The holotype, a right valve, has a small umbonal angle and 22 subrounded scaly ribs with narrower interspaces bearing a secondary rib. The right anterior auricle has 6 ribs and a moderately deep byssal sinus. The valve is equilateral.

Geographic range.-Middle to southern California.

Geologic range.-Pliocene.

Occurrence in California.-Upper part of Etchegoin (Nomland, 1917a), Ohlson Ranch (Peck, 1960), and San Joaquin (Adegoke, 1969) Formations.

\section{Chlamys bartschi (Arnold)}

\section{Plate 6, figure 6}

Pecten (Chlamys) bartschi Arnold. 1906, p. 107-108, pl. 41, fig. 3. Pecten (Pecten) bartschi Arnold. Grant and Gale, 1931, p. 168-169.

Original description.-"Adult shell averaging about 60 millimeters in altitude, somewhat shorter than high, convex, slightly inequilateral; base regularly rounded; margins smooth. Valves with about 40 prominent (more or less unequal) narrow threadlike ribs, ornamented on top by numerous short imbricating spines; interspaces deep, narrow, and channeled; lateral areas rather narrow, perpendicular to disk, and slightly concave. Ears similar to those of $P$. islandicus."

\section{Holotype.-USNM 164841.}

Type locality. - South side of Light-House Point, north of wharf, Crescent City, Del Norte County, Calif. St. George Formation, Pliocene.

Supplementary description. - "Shell of medium size, with the shape and general characters of hastatus except that the byssal ear is somewhat longer and the primary ribs do not have the paired arrangement (if paired, it is because the primary ribs have split, and the ribs are twice as numerous), the primary ribs varying from 20 to 25 in number, with sometimes prominent intercalaries appearing irregularly and increasing the number considerably, secondary riblets on the sides of the primaries sometimes developed, especially in the fewer ribbed varieties, main ribs each with a single row of short, stout prickles.

"Dimensions: Altitude, $50 \mathrm{~mm}$.; length, $45 \mathrm{~mm}$.; length of hinge, $27.5 \mathrm{~mm}$.; convexity of the two valves, $23 \mathrm{~mm}$." (Grant and Gale, 1931, p. 168-169)

Comparison. - "This species, of which only two or three rather poorly preserved specimens are known, is quite closely related to $P$. opuntia, but is readily distinguishable by its much larger size when adult, lack of concentric constriction in the later stages of growth, and relatively shorter disk." (Arnold, 1906, p. 107)
Comments.-The holotype is an incomplete valve; the auricles are not preserved. It looks as though it was equilateral and higher than long.

Geographic range.-Northern California.

Geologic range.-Pliocene.

Occurrence in California.-St. George Formation.

\section{Chlamys jordani (Arnold) \\ Plate 6, figures 3, 7}

Pecten (Chlamys) jordani Arnold, 1903, p. 111, pl. 12, figs. 6, 7. Arnold, 1906, p. 114-115, pl. 44, figs. 1, 1a, 1b.

Pecten jordani Arnold. McLaughlin and Waring, 1914, pl. 1, fig. 49.

Chlamys (Chlamys) rubida jordani (Arnold). MacNeil, 1967, p. 22, pl. 22, fig. 3; pl. 24, fig. 5 .

Chlamys (Chlamys) jordani Arnold. Hertlein and Grant, 1972, p. 191-192, pl. 30, fig. 10; pl. 32, figs. 5, 6, 10, 12, 13 .

Not Pecten jordani Arnold. I. S. Oldroyd, 1924, p. 55-56, pl. 28 , figs. $5,6$.

Not Chlamys islandicus jordani (Arnold). Woodring, 1946, pl. 32, fig. 16.

Not Chlamys rubida jordani (Arnold). Grau, 1959, p. 79-81, pl. 25. Original description. - "Shell of medium size, shape of $P$. hericeus, inequivalve, rather thin; right valve with twenty-five to thirty angular, smooth-topped, imbricated ribs, which become dichotomous after reaching a length of about $30 \mathrm{~mm}$; interspaces deeply channeled and narrower than ribs; anterior ear imperfectly radially ribbed with six ridges, and showing elevated, concentric, incremental lines; posterior ear nearly obsolete, showing four ribs; byssal notch not deep; left valve shows twenty-five to thirty narrow, convex ribs, showing imbrications only slightly; interspaces as large as ribs; after a diameter of about $30 \mathrm{~mm}$ has been reached by the shell, small riblets appear in the widening interspaces; anterior ear shows five narrow, imbricated ridges, with wide interspaces; both valves show a tendency to contract suddenly at the basal margin upon nearing completion of growth; surface of both valves covered with a minute, lattice-like sculpture, which is generally worn off on exposed portions of the shell."

Holotype.-USNM 162522

Type locality.-Deadman Island, San Pedro, Los Angeles County, Calif. San Pedro Formation, Pleistocene.

Supplementary description.-"Typical specimens of Chlamys jordani are quite rare. The type specimen from beds of late Pliocene or early Pleistocene age at San Pedro, California, was described as 45 $\mathrm{mm}$ high, $42 \mathrm{~mm}$ long; the umbonal angle approximately $95^{\circ}$. The valves are sculptured with $25-30$ ribs which become dichotomous after reaching a length of about $30 \mathrm{~mm}$. The ribs on the left valve are rather coarse and a short midrib appears in the interspaces after the valve has reached an altitude of about $30 \mathrm{~mm}$. Both valves tend to contract toward the base.

"One right and one left valve, the larger one $27.3 \mathrm{~mm}$ high, $* * *$ are smaller than the type of $C$.jordani and the ribs become dichotomous following a constriction of the shell when $20 \mathrm{~mm}$ high. One right and two small left valves, the largest one $17.5 \mathrm{~mm}$ high, $* * *$ develop a constriction when $16 \mathrm{~mm}$ high. The ribs and interspaces of all these valves are covered with very fine honeycomb-like reticulate sculpture.

"One right and two left valves *** are typical of $C$. jordani except for their larger size. The right valve is $47 \mathrm{~mm}$ high and has two constrictions in shell growth, one at $30 \mathrm{~mm}$, and one at $42 \mathrm{~mm}$. One left valve $34 \mathrm{~mm}$ high has a constriction at $20 \mathrm{~mm}$, the other is $42 \mathrm{~mm}$ high (incomplete) and is gently contracted at a height of $29 \mathrm{~mm}$. The ribbing on these left valves is dichotomous after the first constriction and, following this, the splitting of the ribs and the development of 
strong riblets in the interspaces result in more numerous finer ribs. Another feature on these left valves is a decided depression on the anterior ear where it joins the disk." (Hertlein and Grant, 1972, p. 192)

Comparison.- "Typical specimens of this species are higher than long and the general appearance is of a more slender shell than that of Chlamys rubida. As mentioned by Arnold, the right valve of $C$. jordani is similar to that of $C$. rubida but the ribs on the left valve are quite different. These reach to a height of about 20 to $30 \mathrm{~mm}$, consist of simple nonfasciculated, moderately coarse ribs covered with fine lattice-like sculpture but with only slight concentric imbrication.

"The smaller apical angle and consequently less elongate, less discoidal shape as well as the constriction followed by splitting of the ribs are characteristic features of $C$. jordani as shown on Arnold's illustrations of the type specimen. These shell characters, in our opinion, differ sufficiently from those of the form described as kincaidi to justify separation of the two." (Hertlein and Grant, 1972, p. 192)

Chlamys jordani may be distinguished from the Miocene Japanese species Chlamys hataii "by the greater number of radial ribs (23 to 25), absence of intercalary threads in the right valve, lack of bifurcation of the radial ribs of the left valve." (Masuda and Akutsu, 1956)

Comments.-The holotype is a double-valved specimen and the valves are equilateral. The right valve has wide, closely spaced ribs that are all bifurcate near the ventral margin; a few bifurcate when the shell reaches a height of about $10 \mathrm{~mm}$. The interspaces are much narrower than the ribs and do not bear interribs; imbricated microsculpture is preserved over the entire shell surface near the ventral margin. The right anterior auricle has five riblets, a rather shallow byssal sinus, and imbricated microsculpture; the left auricle is very small and bears four riblets and imbricated microsculpture. The left-valve ribs are smaller than the right, only a few are slightly bifurcate near the ventral margin, and interribs appear in most of the interspaces near the ventral margin. The left anterior auricle has seven riblets and imbricated microsculpture; the small left posterior auricle, four riblets and imbricated microsculpture.

Geographic range.-Northern to southern California (MacNeil, 1969, p. 22; Hertlein and Grant, 1972, p. 192).

Geologic range.-Miocene through Pleistocene. [Not a Holocene species (MacNeil, 1969, p. 22) as reported by some other authors (Oldroyd, 1924; Woodring, 1946; Grau, 1959).]

Occurrence in California.-Miocene and Pliocene: Purisima Formation (Arnold, 1906); Pliocene: Niguel (J. G. Vedder, written commun., 1978) and San Diego (Hertlein and Grant, 1972) Formations; Pliocene and Pleistocene: Fernando (Arnold, 1907b; Vedder, 1960), Merced (Arnold, 1906), Rio Dell Formation, Wildcat Group (Faustman, 1964), Pico (Kundert, 1952), Santa Barbara (Arnold, 1906), and San Pedro and Saugus(?) (Waterfall, 1929) Formations; Pleistocene: Anchor Silt (Rodda, 1957) and Timms Point Silt Member, San Pedro Formation (McLaughlin and Waring, 1914; A. Clark, 1931).

\section{Chlamys opuntia (Dall)}

\section{Plate 6, figure 2}

Pecten (Chlamys) opuntia Dall, 1898, p. 707, pl. 29, fig. 6. Arnold, 1906, p. 118, pl. 41, fig. 2.

Chlamys (Chlamys) opuntia Dall. Hertlein and Grant, 1972, p. 192-193, pl. 30, figs. 5, 6 [See for synonymy]. Vedder and Moore, 1976, pl. 1, fig. 5 .

Original description. - "Allied to P. hericeus var. navarchus Dall, from which it differs by its smaller and not fasciculated radial ribs, more elongated anterior ear, more densely radially costate posterior ear, small size when adult, and by a tendency to be suddenly contracted at the basal margin on the completion of growth, somewhat as in P. pesfelis. Alt. $35 \mathrm{~mm}$, lat. $32.5 \mathrm{~mm}$."

Holotype.-USNM 107752.

Type locality.-Pacific Beach, San Diego, San Diego County, Calif. San Diego Formation, Pliocene.

Supplementary description.-."Shell averaging about 35 millimeters in altitude, slightly shorter than high, subequivalve, equilateral (except for ears), both valves nearly flat until altitude of about 20 to 25 millimeters is reached, when they grow more convex; contracted at basal margin when adult; sides only slightly concave above. Right valve with 40 to 60 subequal, narrow, imbricated, more or less dichotomous ribs, which are separated by channeled interspaces about equal in width to the ribs; hinge line about two-fifths as long as disk; anterior ear much produced, sculptured by about six prominent, sharply imbricated radials, and imbricating incremental lines; byssal notch quite prominent; posterior ear nearly obsolete, radially and concentrically sculptured; whole surface of disk and ears sometimes microscopically checkered or tessellated. Left valve similar to right." (Arnold, 1906, p. 118)

"The fine, uniform, non-fasciculated radial ribs are quite different from any other west American Pliocene species." (Hertlein and Grant, 1972, p. 193)

Comparison. - "Some authors have considered this species to be a member of the Chlamys islandica group. It somewhat resembles some fine-ribbed variants of that group but the San Diego fossil is easily separable by its finer, even ribbing, slightly smaller umbonal angle, generally smaller size and tendency to constriction toward the ventral margin of adult forms. These features serve to separate it from forms of $C$. rubida and its close relatives.

"The ribbing and the umbonal angle of $C$. opuntia are similar to those features on $C$. hertleini Loel and Corey ***. One decided difference in the two species is in the outline of the posterior ears. The posterior ears on C. opuntia slope obliquely downward from the hinge line whereas those on $C$. hertleini are squarely truncated.

"Chlamys tamurae Masuda and Sawada ***, compared by its authors with $C$. opuntia, differs in that the surface of the left valve (and to a less degree the right valve) is folded forming low, broad corrugations. Furthermore, the illustration *** shows that the major ribs are divided toward the ventral margin of the right valve, a feature only occasionally present on C. opuntia." (Hertlein and Grant, 1972, p. 193)

Comments.-The fine, even ribbing on the shell of $C$. opuntia is distinctive. The holotype is a right valve complete except for a small portion of missing shell at the anterior dorsal edge of the anterior ear. The ribs on the disk have strong, slightly spinose lamellae and imbricated microsculpture. The anterior auricle has 7 lamellose riblets and a moderately wide byssal sinus; the posterior ear has 10 or more fine, lamellose riblets. The shell is equilateral and of about equal length and height.

Geographic range.-Middle California to Baja California Sur. Geologic range.-Miocene to Pleistocene.

Occurrence in the Californias.-Miocene and Pliocene: Purisima Formation (Arnold, 1906); Pliocene: Almejas (Minch and others, 1976), Lomita Marl Member, San Pedro (Woodring, 1946), Niguel (J. G. Vedder, written commun., 1978), and San Diego (Arnold, 1906; Hertlein and Grant, 1972) Formations, unnamed Pliocene strata on San Clemente Island (Vedder and Moore, 1976; Susuki and Stadum, 1978); Pliocene and Pleistocene: Fernando (Arnold, 1907b; Moody, 1916; J. D. Mount, written commun., 1971), Merced (Arnold, 1906), Pico (Winterer and Durham, 1962) and Saugus(?) (Waterfall, 1929) Formations. 


\section{Chlamys hastata pugetensis (Oldroyd)}

Plate 6, figures 1, 9

Pecten islandicus pugetensis I. S. Oldroyd, 1920, p. 136, pl. 4, figs. 5, 6.

Pecten (Pecten) hastatus Sowerby variety pugetensis Oldroyd. Grant and Gale, 1931, p. 168.

Chlamys hastata pugetensis (Oldroyd). Grau, 1959, p. 90-91, pl. 30. Chlamys ("Chlamys") pugetensis (Oldroyd). MacNeil, 1967, p. 15, pl. 22 , figs. 4, 5 .

Chlamys pugetensis (Oldroyd). Roth, 1979, p. 257-260, pl. 2, fig. 9.

Original description. - "Shell much smaller than the typical $C$. islandicus. Sculpture coarser in proportion to the size. Shell more elongate and the ribs spinose. Ribs 17 , with a very fine one in the interspaces. Length, 29; height 31; diameter 11; hinge line, $16 \mathrm{~mm}$." Holotype.-CAS/SU 95 (missing and presumed lost.)

Type locality. - Off San Juan Island, Puget Sound, Wash. Holocene.

Supplementary description. - "Shell rather small, averaging 33 $\mathrm{mm}$ in height; higher than long and moderately convex, right valve more so than left. Hinge $1 / 2$ to $2 / 3$ length of disk. Right valve with 17 to 21 rounded fasciculate ribs, often arranged in pairs; riblets of fasciculi minutely spinose when not worn smooth; interspaces as wide as ribs or wider, with small riblets irregularly disposed; fine punctate sculpture covering disk. Anterior auricle moderately long, with 5 or 6 imbricated riblets, wide fasciole, rounded byssal notch and ctenolium of 5 to 7 teeth; posterior auricle quite small, obliquely truncated, and with 7 or 8 oblique imbricated riblets. Left valve with fasciculated ribs more angulated and usually more profusely spinose; interspaces of varying width and with fine imbricated riblets irregularly disposed; punctate sculpture covering disk as in right valve; anterior auricle large, with shallow byssal sinus, 9 to 11 imbricated riblets, and with small intercalary riblets often present; posterior auricle same as that of right valve." (Grau, 1959, p. 90-91)

"Anterior ears large; anterior ear of right valve may be very long and straight; byssal sinus may be well rounded or angulate. Anterior dorsal margin usually a little longer than posterior dorsal margin. Ribs usually show a weak differentiation into primary, secondary, and even tertiary series. Ribs of right valve are bluntly rounded, but ribs of left valve tend to have a narrow rounded crest; small upright scales may be present. Primary ribs, and some other ribs, tend to become tripartite near the margin by the addition of minor riblets or ridges on the sides. The microsculpture is reticulate or metal lathelike and usually covers all the interspaces." (MacNeil, 1967, p. 15)

"Chlamys pugetensis shows considerable variation from place to place, but the characters of a given population are quite constant. The principal variables in a large lot of $C$. pugetensis *** are the extent to which concentric frilling obscures or interferes with the latticed microsculpture, the predominance on the left valve of certain (usually alternate) major radial ribs over others, and the degree to which major ribs on the right valve tend to fall in pairs. On some specimens the microsculpture appears to cease at or near a growth rest; on others it ceases on one part of the disk but continues outward on other parts as far as the margin." (Roth, 1979, p. 258)

Comparison. - "This subspecies is distinguishable from Chlamys hastata and $C$. hastata hericia by its rib-structure, sculpture of disk, obliquely truncated posterior auricles and internal coloring; juveniles $12 \mathrm{~mm}$ in height or less are only distinguishable by the punctate sculpture of the disk." (Grau, 1959, p. 91)

"Chlamys pugetensis shows a greater tendency toward 'ledging'concentrically disposed breaks-in-slope associated with growth rests-than $C$. hastata or $C$. h. hericius, and the shell is more frequently irregular." (Roth, 1979, p. 258)
Comments. - The valves of the specimen figured (pl. 6, figs. 1,9) are equilateral but the anterior auricles are greatly enlarged in both height and length and the posterior auricles are greatly reduced. The right valve has 20 low rounded ribs covered with scaly, imbricated microsculpture and numerous fine ribs. The interspaces are narrower than the ribs and also have scaly interribs. The right anterior auricle has 7 riblets; the posterior auricle about 9 . The left valve has 21 rounded ribs, every other one slightly higher than the rest, and all bearing secondary ribs and scaly imbricated microsculpture. The left anterior auricle has about 16 riblets with some interspaces bearing a secondary riblet; the posterior auricle has about 10 riblets.

Geographic range.-Living: Sitkalidak Island, off Kodiak Island, Alaska, to Newport Bay, Calif.; fossil: middle and southern California.

Geologic range.-Pliocene to Holocene.

Occurrence in California.-Pliocene and Pleistocene: Fernando Formation (J. D. Mount, written commun., 1971); Pleistocene: unnamed strata near Point Año Nuevo, San Mateo County (MacNeil, 1967).

Habitat. - Low tide to $90 \mathrm{~m}$; on rocks at minus tide, and in rocky, sandy, or muddy bottoms; often associated with algae; occasionally encased in sponge.

\section{Chlamys picoensis (Waterfall) \\ Plate 7, figures 1, 2}

Pecten (Chlamys) islandicus picoensis Waterfall, 1929, p. 83-84, pl. 5, figs. 2,4

Chlamys (Chlamys) picoensis (Waterfall). MacNeil, 1967, p. 28. Pecten (Chlamys) venturaensis Waterfall, 1929, p. 84-85, pl. 6, fig. 4.

Original description. - "Shell subcircular, somewhat longer than high; valve convex, equilateral except for ears; of medium thickness; sides slightly concave above; base evenly rounded; left valve with about 90 (at basal margin) prominent, square, flat-topped, imbricated, radiating ribs which multiply by division and by intercalation; interspaces generally narrower than ribs, channeled, and minutely reticulated; hinge line over half the length of the shell; anterior ear much produced, nearly twice as long as posterior, sculptured with eleven radiating ribs similar to those on disk; byssal notch distinct, rounded; posterior ear with about eight radiating ribs; right valve very similar; judging from the similarity in the two valves of $P$. islandicus."

Holotype.-UCMP 31419; of venturaensis UCMP 31416.

Type locality.-UC 7100. Ventura County, Calif. Upper part of Pico Formation, Pleistocene (may actually be from San Pedro Formation, Pleistocene); of venturaensis, UC 7097, Ventura County, Calif. Upper part of Pico Formation, Pleistocene.

Comparison. - "This differs from the living Pecten islandicus Müller by being relatively longer, and by having a greater apical angle." (Waterfall, 1929, p. 84)

Grau (1959, p. 76) put C. picoensis in synonymy with C. rubida. MacNeil (1967, p. 28) considered C. picoensis to be more closely related to $C$. islandica than to $C$. rubida, and to be more intimately related to the Japanese forms $C$. chinkopensis Masuda and Sawada (1961), from the Pliocene, and C. kinoshitai Kubota (1950), from the Holocene.

Hertlein and Grant (1972, p. 194) said that the radial sculpture on some valves of Chlamys rubida from the San Diego Formation is similar to that of $C$. picoensis.

Comments. - The holotype of C. picoensis is a right valve sculptured with moderately heavy, dichotomous rubs separated by interspaces that are half as wide and in which an interrib may 
appear when the shell has reached a height of about $30 \mathrm{~mm}$. Imbricated microsculpture is preserved in some of the interspaces. The right anterior auricle has four coarse ribs; the right posterior auricle five somewhat finer ribs. The ventral margin is strongly and abruptly turned in towards the body.

The holotype of $C$. venturaensis is a left valve sculptured with rounded ribs narrower than the interspaces and in which an interrib may appear when the shell is about $15 \mathrm{~mm}$ high. Imbricated microsculpture is preserved in many of the interspaces. The left anterior auricle has 9 riblets, the left posterior 7 of about equal size.

Chlamys picoensis is equidimensional with a wide apical angle which distinguishes it from related species. It presumably does not occur in strata older than Pleistocene but is included here because of the doubt concerning the age of the type locality.

Geographic range.-Southern California.

Geologic range.-Pliocene? or Pleistocene.

Occurrence in California.-Pliocene and Pleistocene: San Pedro(?)

Formation (Waterfall, 1929); Pleistocene: upper part of Pico(?) Formation.

\section{Chlamys rubida (Hinds)}

Plate 7, figures 3,5

Pecten rubidus Hinds, 1844, p. 61, pl. 17, fig. 5. Not Pecten rubidus Martyn, 1784, nomenclatorially unavailable. [See Opinion 456 International Commission Zoological Nomenclature.]

Pecten hindsii Carpenter, 1864, p. 606, 645.

Pecten hericeus var. navarchus Dall, 1898, p. 708-709, new name for Pecten rubidus Hinds, 1844.

Pecten (Chlamys) hastatus Sowerby var. hindsii Carpenter. Arnold, 1906, p. 111-112, pl. 43, figs. 1, 2, 2a.

Pecten (Chlamys) rubidus Hinds. Palmer, 1958, p. 69-70, pl. 3, figs. 4-6.

Chlamys rubida (Hinds). Grau, 1959, p. 76-79, pl. 24.

Chlamys (Chlamys) rubida (Hinds). MacNeil, 1967, p. 21-22, pl. 20 figs. 7, 9; pl. 22, figs. 7, 8. Hertlein and Grant, 1972, p. 193-195, pl. 35 , figs. $6,8$.

Original description. - "Testâ subtrigono-orbiculari, inaequaliter duplo-convexâ, inaequiauriculatâ subtenui; valvâ sinistrâ convexâ, costis parvis numerosissimis, serratis, in fasciculos duarum triumve alternatè aggregatis, rufis, interstitiis, pallescentibus; valvâ dextrâ subconvexâ, albidâ, costis majusculis, aggregatis; auriculus sulcatis, posticâ parvâ, obliquâ; intùs albâ." (rubidus)

“'Pecten rubidus, Hds.' Vanc. Is., Lyall. [Hinds's type in Br. Mus. appears the ordinary form, of which $P$. hastatus = hericeus is the highly sculptured var. This shell, which is more allied to Islandicus may stand as $P$. Hindsii.]***

"Pecten (?var.) Hindsii. Broader; ribs close, small, smooth, bifurcating. Passes from hastatus towards Islandicus." (hindsii)

Holotype.-Missing and presumed lost (Palmer, 1958, p. 70); three paratypes are present (MacNeil, 1967, p. 22), in the British Museum of Natural History; of Pecten hindsii, missing and presumed lost.

Type locality._Alaska at a depth of $60 \mathrm{~m}$, Holocene; of Pecten hindsii, Vancouver Island, B.C., Holocene.

Supplementary description. - "The original illustration of Pecten rubidus is that of the exterior of a left valve, the ribs of which are fasciculated and crossed by fine concentric imbrications.

"The right valve of $C$. rubida is sculptured with about 26 radial ribs which are wider than the interspaces, flattish-topped, smooth, and usually dichotomous. The interspaces are narrow, channeled, and sculptured with fine reticulate honeycomb-like tesselations. The left valve is sculptured with narrow, fasciculated ribs which are crossed by fine concentric imbrications, the interspaces are sculp- tured similar to those on the right valve. The ribs on the right valve increase by bifurcation, those on the left, at later stages of growth, by intercalation. The sculpture of this species is quite variable.

"Recent specimens of $C$. rubida are often about $60 \mathrm{~mm}$ high but we have seen fossil specimens $70 \mathrm{~mm}$ high." (Hertlein and Grant, 1972, p. 194)

"Adult specimens averaging 50 millimeters in height and slightly higher than long; left valve more convex than right, and hinge line about half length of disk. Right valve with extremely variable rib structure; 21 to 28 low, smooth, broad and rather flat primary ribs, becoming dichotomous at about 10 to $15 \mathrm{~mm}$ from hinge line and occasionally imbricated near ventral margin; ribs frequently narrower, obscurely fasciculated and almost entirely imbricated. Riblets often develop in interspaces, usually starting at 15 to $20 \mathrm{~mm}$ from hinge margin and occasionally imbricated. Interspaces narrower than ribs and with minute reticulations present in either upper or lower portion or throughout. Anterior auricle large and with 6 or 7 riblets having fine concentric imbrications; byssal notch prominent, and ctenolium of 5 to 7 teeth. Posterior auricle small, with 8 to 11 small spinose riblets; hinge margin tapering gently downward from beak. Left valve also variable in rib structure; primary ribs simple at first, later fasciculated; each fascicle consisting of three (occasionally two) imbricated ridges, often worn smooth at maturity; imbricated secondary rib usually present in center of each interspace, often flanked by two very small rows of spines. Interspaces wider than ribs and minutely reticulated from umbo to center of disk. Anterior auricle large and with moderately deep byssal notch; 10 to 12 small riblets with nearly as many intercalaries, all imbricated. Posterior auricle small, hinge margin tapered as in right valve; 10 to 15 fine imbricated riblets $* * *$ margin delicately fluted." (Grau, 1959, p. 78-79)

Comparison.-"Typical specimens of C. rubida differ from $C$. islandica in the generally smaller size, often less numerous primary ribs, and especially in the smaller posterior ears.

"The shell of C. rubida differs from that of $C$. jordani in the fasciculate rather than simple ribs on the left valve, usually the lack of honeycomb-like tesselation on the tops of the ribs, and usually greater size.

"According to Palmer the type specimens of both P. rubidus and $P$. hindsii cannot be found. Considerable variation in sculpture is revealed in a series of specimens of this species complex and the relationship of the two is not definitely known at the present time. The specimens identified by Carpenter as "Pecten hindsii," illustrated by Palmer, furnish some justification for retaining this form as a subspecies of $C$. rubida and this interpretation of Carpenter's species was proposed by MacNeil (1967). The two forms apparently represent extreme variants in the fine and coarse character of the ribs. The variation in sculpture of the fossils from the San Diego Formation is such that we assign to them the earliest name proposed for this group, at least until the relationship of the variants of this species complex is better known.

"The larger shell and flattish radial ribs on the right valve which are broader than their interspaces are features separating $C$. rubida from C. imanishii Masuda and Sawada *** which was described from beds of Pliocene age in Japan." (Hertlein and Grant, 1972, p. 195)

Geographic range.-Living: Bering Sea to Monterey, Calif.; fossil: Alaska to southern California.

Geologic range.-Miocene through Holocene.

Occurrence in California.-Miocene and Pliocene: Etchegoin (Nomland, 1917a), Purisima (Arnold, 1906), and Towsley (Winterer and Durham, 1962) Formations; Pliocene: Lomita Marl Member, San Pedro Formation (Woodring, 1946), Niguel (J. G. Vedder, written commun., 1978), Ohlson Ranch (Peck, 1960), and San Diego 
(Hertlein and Grant, 1972) Formations, and unnamed strata on San Clemente Island (Vedder and Moore, 1976); Pliocene and Pleistocene: Fernando (Arnold, 1907a; Willett, 1946), Merced (Arnold 1906), Pico (Winterer and Durham, 1962), San Pedro (Woodring, 1946), and Saugus (Kew, 1924) Formations; Pleistocene: Timms Point Silt Member, San Pedro Formation (A. Clark, 1931).

Habitat.-Usually found off rocky shores. Shell usually encased in one of two species of symbiotic sponge: most of ten Ectyodoryx parasitica (Lambe), but occasionally Mycale adherens Lambe. Both species of sponges are said to live only on Chlamys rubida, C. rubida jordani. C. hastata, C. hastata hericia and C. hastata pugetensis, and to be the only species of sponge so restricted. Large barnacles, up to 25 or $30 \mathrm{~mm}$ in altitude, are often attached. Just below low tide to 185 $\mathrm{m}$, possibly deeper. (Grau, 1959; Hertlein and Grant, 1972)

\section{Chlamys anapleus Woodring}

\section{Plate 7, figures 4, 6}

Pecten (Chlamys) hastatus Sowerby var. strategus Dall. Arnold, 1906, p. 113, pl. 44, figs. 2, 2a, 3, 4. Not Pecten hericeus var. strategus Dall, 1898.

Chlamys anapleus Woodring, 1946, p. 81, pl. 34, fig. 15.

Original description. - "The new name Chlamys anapleus *** is proposed for a small Chlamys represented by a valve from the Lomita marl ** *and another from the San Pedro sand ***. It has 10 or 11 wide primary ribs, a weak secondary riblet in most of the interspaces, and is sculptured with microscopic punctuation. The ventral margin of the type is bent, perhaps to form at a later stage a swelling, as in C. parmeleei. On the imperfect Lomita specimen some of the ribs are grooved. This Chlamys also might be considered a form of the C. islandicus group at the opposite extreme from $C$. opuntia in width of ribs. It was identified by Arnold as Pecten (Chlamys) hericeus var. strategus. 'P.' strategus, from Alaska, is considered a synonym of $C$. islandicus beringianus, a wide-ribbed Alaskan variety of $C$. islandicus. The ribs of $C$. anapleus do not enlarge so rapidly as in $C$. islandicus beringianus, and secondary ribs are weak or absent. The Pliocene C. parmeleei and its close Pliocene relative $C$. etchegoini have only half as many primary ribs. C. anapleus is not known to be living."

Holotype.-USNM 498642.

Type locality.-USGS 12530. Los Angeles County, Calif. Basal part of San Pedro Sand, Pliocene.

Comments. - Chlamys anapleus is higher in proportion to length, the ribs are smaller on the disk, the right-valve ribs are not bifurcate, and fewer and weaker secondary ribs are present in the interspaces than in Chlamys behringiana (Middendorf), a species living in Alaska. These two species somewhat resemble Nanaochlamys in sculpture.

Geographic range.-Southern California.

Geologic range.-Pliocene to Pleistocene.

Occurrence in California.-Pliocene: Lomita Marl Member, San Pedro Formation; Pliocene and Pleistocene: San Pedro Sand (Woodring, 1946).

\section{Genus CHLAMYS?}

Chlamys? mediacostata mediacostata (G D. Hanna)

\section{Plate 7, figure 7}

Pecten mediacostatus G D. Hanna, 1926a, p. 472, pl. 22, fig. 6; pl. 24, fig. 2. Mansfield, 1932, p. 46, pl. 16, fig. 2.

Lyropecten mediacostatus (Hanna). Durham, 1950, p. 65, pl. 7, fig. 4. Original description. - "Shell small, altitude a little greater than length, equilateral and equivalve, not noticeably inflated. Surface sculptured with 23 (in the type specimen) ribs which are regularly rounded and are largest in the center of the valve. These ribs are strong at the ventral margin of the shell but are scarcely visible within $18 \mathrm{~mm}$. of the beak; interspaces occupied by riblets, one to each, about one-third the size of the major ribs; in the better preserved specimens there is a fine even concentric sculpture of lirulae looped over the ribs, appearing as though cut with an engraving tool; anterior ear marked with five (in cotype) radiating riblets while the posterior (in the type) is smooth except for fine even concentric sculpture. Measurements of type specimen, a single right, valve, altitude $37.2 \mathrm{~mm}$.; length $30 \mathrm{~mm}$. (slightly compressed longitudinally); thickness $8.5 \mathrm{~mm}$."

Holotype.-CAS 1830.

Type locality.-CAS 681. Imperial County, Calif. Imperial Formation, Miocene or Pliocene.

Comparison.-"There is only one west coast species with which the sculpture of this can be compared, Pecten estrellanus (Conrad) of Miocene and lower Pliocene strata. That species is more inflated, longer than high, and the ribs extend entirely to the beak; moreover, the ribs are squarish and interspaces channeled on each side of the smaller riblet." (G D. Hanna, 1926a, p. 472)

"Pecten interlineatus aidei Harris *** from the Miocene of Venezuela is closely related but may be distinguished by the much heavier interribs in the interspaces." (Durham, 1950, p. 65)

Chlamys mediacostata grewingki Hertlein differs from Chlamys mediacostata mediacostata in having fewer ribs (17 or 18 rather than 23 or 24) and in the smaller apical angle. (Hertlein, 1966a, p. 276)

Comments.-Although the secondary sculpture of a riblet bordered by deep grooves and filling the interspace is similar to Lyropecten, this species is assigned to Chlamys? on the basis of its hinge, outline, and small umbonal angle.

Geographic range.-Southern California to Baja California Sur. Geologic range.-Miocene to Pliocene.

Occurrence in the Californias.-Miocene or Pliocene: Imperial Formation; Pliocene: Boleo (Stump, 1979) and San Marcos Formations (Durham, 1950).

\section{Chlamys? mediacostata grewingki (Hertlein)}

\section{Plate 7, figure 8}

Chlamys mediacostata grewingki Hertlein, 1966, p. 276, 278, fig. 12. Original description. - "Shell, a right valve, higher than long, nearly equilteral, gently convex; with about 17 or 18 low, rounded, radial ribs widest at the middle of the ventral margin and separated by interspaces narrower than the ribs; surfaces of the ribs with traces of concentric imbricating lines of growth which loop upward; each interspace on the ventral half of the shell with a well developed riblet; the ears are imperfectly preserved but the direction of the lines of growth on the posterior ear indicate a nearly square truncated posterior margin, a well developed notch is present under the remnant of the anterior ear. No sculpture is visible on the ears; if originally present, it has been eroded. Dimensions: length $34.2 \mathrm{~mm}$., height $39.6 \mathrm{~mm}$., apical angle $81.5^{\circ}$."

Holotype.-CAS 12812.

Type locality.-CAS 39413. Rancho El Refugio, Baja California Sur. Salada Formation, Pliocene.

Pecten (Lyropecten) tamiamiensis Mansfield (1932, p. 47, pl. 1b, figs. 3,5 ) has the same secondary sculpture as C.? grewingki and has been placed in "Chlamys" (Judith T. Smith, oral commun., 1979).

Comparison. - "The shell of this new subspecies bears a decided resemblance to Pecten mediacostatus Hanna ***. It differs from that 
species in the less numerous ribs (17 or 18 rather than 23 or 24 ) and in the narrower apical angle. All the specimens of $C$. mediacostata in the collections of the California Academy of Sciences, many rather imperfectly preserved, have more numerous ribs than the present specimen." (Hertlein, 1966, p. 276)

Comments.-The holotype is a small (length $35 \mathrm{~mm}$; height 40 $\mathrm{mm}$ ), flat, moderately thick shelled right valve with about half of the anterior auricle missing. The interspaces are almost completely filled by the secondary riblets, but the riblets are separated from the primary ribs by deep grooves. On the basis of the holotype only, this species is assigned to Chlamys?. The secondary sculpture of a riblet filling the interspace distinguishes $C$. ? grewingki from other described Tertiary species of Chlamys described from the western United States, except C.? mediacostata; this sculpture is found on some species of Lyropecten.

Geographic range.-Baja California Sur.

Geologic range.-Pliocene.

Occurrence in Baja California Sur.-Salada Formation.

\section{Genus LEOCHLAMYS MacNeil}

Leochlamys MacNeil, 1967, p. 9-10.

Type species._Chlamys (Leochlamys) tugidakensis MacNeil, Pliocene, Alaska.

Original description. - "Shell of medium to moderately large size, moderately inflated, right valve more inflated than left valve; elongate dorsoventrally. Ears moderately large; recessed, the dorsal slope wider on left valve, anterior ear of right valve elongate and narrow, byssal sinus wide and deep with a moderately strong ctenolium. Ribs strong on both valves, interstitial ribs; present or absent; weakly to very strongly scabrous; many ribs have thick curved spines. Microsculpture reticulate or metal lathelike in juveniles, particularly on left valves, but consisting of fine continuous closely set raised lirations with a fanlike pattern in adults. Provinculum broad and gaping, extending nearly to the end of the ears; crurae moderately strong and weakly inclined. Muscle scars and umbonal callus inconspicuous.

"The most distinguishing characters of Leochlamys are its long anterior ear, its deep, broad byssal notch, and its coarse, usually spiny ribs."

Geologic range.-Jurassic(?); Oligocene through Holocene.

Habitat.-In temperate and cool seas; perhaps some attach to rocks and stones by means of their spines. (MacNeil, 1967, p. 9, 10)

\section{Genus LEOCHLAMYS? \\ Leochlamys? columbiana (Clark and Arnold)}

Plate 8, figure 3

Pecten columbianum Clark and Arnold, 1923, p. 139, pl. 23, figs. 1, 2. Pecten (Chlamys) columbiana Clark and Arnold. Weaver, 1942, p. 84 , pl. 15, fig. 3; pl. 16, fig. 1.

Original description.-"Shell fairly large, height greater than length, dorsal slopes long and straight; apical angle less than 90 degrees, ears prominent, anterior ears about a third longer than posterior. Anterior right ear long and narrow, sculptured by four or five fairly heavy radiating ribs with interspaces slightly less than width of ribs; byssal notch deep and broad and on its dorsal edge are a number of fairly prominent ctenidial teeth, ten of these teeth on type. Posterior ear broad; four heavy radial ribs on posterior ear of type with interspaces somewhat wider than width of ribs with a finer riblet in at least two of interspaces. Main surface of shell sculptured by about 24 bifurcated fairly heavy, round radiating ribs which are slightly less prominent near the dorsal margins and tend to pair, each pair separated by a wider interspace than that separating the individual members of pair; most of these pairs might be described as individual bifurcating ribs, the bifurcation taking place well up toward the beaks; some of the pairs, however, may be traced as distinct ribs up to the beaks. Irregularity of interspacing between pairs is noticeable and some of the individual ribs are bifurcated. Fine interrib in some interspaces. Surface of shell sculptured by fairly heavy concentric lines of growth which produce rather coarse imbrications where they cross ribs. Imbrications probably appeared as spines on uneroded specimens. Left valve unknown. Dimensions of type specimen (smaller of two specimens figured): Height $82.5 \mathrm{~mm}$.; length probably about $75 \mathrm{~mm}$.; length of hinge line about $47 \mathrm{~mm}$. Dimensions of cotype: Height $96 \mathrm{~mm}$.; length about $85 \mathrm{~mm}$."

Holotype.-UCMP 30056 .

Type locality.-SU 130. Vancouver Island, British Columbia. Sooke Formation, Oligocene and Miocene.

Comparison. - Leochlamys? columbiana is very similar to L.? porterensis Weaver but the character of the ribbing is quite different in the details of the bifurcations and spacing; on L.? porterensis the ribs are finer and more numerous along the dorsal margins. The ribs on the ears of L.? porterensis are finer and more numerous, and the concentric lines of growth are finer, the result being a much more finely imbricated surface. (Clark and Arnold, 1923, p. 139)

Comments. - The holotype is a very thick shelled right valve, lacking the anterior auricle and most of the disk. The ribs are large, subrounded, and lamellose. The preserved portions of the valve indicate it was inequilateral. The anterior auricle is missing, but 10 ctenolial teeth are preserved. The right posterior ear has 5 large riblets and 2 small ones.

Geographic range.-British Columbia; southern California.

Geologic range,-Eocene to Miocene.

Occurrence in California.-Eocene and Oligocene: San Emigdio (Eocene and Oligocene) and Pleito (Oligocene) Formations, undifferentiated (Hammond, 1958).

\section{Leochlamys? erici (Wiedey)}

Plate 8, figures 1, 2

Pecten (Chlamys) erici Wiedey, 1928, p. 137-138, pl. 16, fig. 1.

Original description.- "Shell of large size, subovoid in outline, subequivalve and equilateral, moderately inflated, with the right valve apparently the more convex. The anterior dorsal margin is not long and is straight to the extremity, where it is rounded to the basal margin. The latter portion of the shell is evenly and regularly rounded. Posterior dorsal extremity a little more sharply convexly curved than the corresponding anterior portion. Posterior dorsal margin short and nearly straight, or slightly concave in outline. Umbones narrow and very convexly inflated. The sculpturing on the left valve consists of about thirty prominent ribs, which are rounded and closely spaced. They curve irregularly and a few divide near the basal margins of the shell. The ribs exhibit incremental sculpture only near the basal margins of the disk. The right valve appears to have a few less ribs but is similarly sculptured. The anterior ear is small; the posterior ear is the more extended. The umbonal angle is less than 90 degrees. Length, $58 \mathrm{~mm}$;; breadth, $65 \mathrm{~mm}$.; thickness of the attached valves, about $20 \mathrm{~mm} . "$

Holotype.-SDNM 27.

Type locality.-SU 406. Ventura County, Calif. Vaqueros Formation, Oligocene and Miocene.

Comparison.- - Among the fossil Pectens this new species is most closely resembled by $P$. sespeensis, var. hydei Arnold, but the latter is distinctive in possessing much longer anterior and posterior dorsal margins, which form a smaller umbonal angle. The varietal form 
is sculptured by nearly ten less ribs which are more subequal. The characteristic paired ribbing of $P$. sespeensis Arnold, about nine pairs in all, readily serves to distinguish it from the new species, which shows many more individual ribs." (Wiedey, 1928, p. 138)

Comments. -The holotype is an incompletely preserved doublevalved specimen. It may have been equilateral and it is somewhat higher than long. The right valve has coarse, subrounded ribs, some of them bifurcated. The interspaces are narrower than the ribs, and some of them have an interrib.

Geographic range.-Southern California.

Geologic range.-Oligocene to Miocene.

Occurrence in California.-Vaqueros Formation.

\section{Genus NANAOCHLAMYS Hatai and Masuda}

Differs from Swiftopecten in having more numerous, bifid ribs, shorter anterior auricle, and more rounded outline.

Geographic range.-Japan; California.

Geologic range.-Oligocene to Pleistocene.

Comments. - This genus is here reported for the first time, outside of Japan, and is represented by the species Nanaochlamys nutteri. Chlamys islandica behringiana (Middendorf) of Grau (1959, pl. 23, fig. 2) and Chlamys (Chlamys) beringiana (Middendorf). of MacNeil (1967, pl. 23, fig. 3) also bear a marked resemblance to Nanaochlamys, and, to a lesser extent, so does Chlamys anapleus Woodring.

Grant and Gale (1931, p. 174) reported N. nutteri from the Pliocene of Japan, synonymizing Pecten heteroglyptus Yokoyama (1926, p. 304, pl. 33, figs. 1-6).

\section{Nanaochlamys nutteri (Arnold)}

Plate 8, figures 4, 5

Pecten (Chlamys) nutteri Arnold, 1906, p. 67-68, pl. 11, figs. 3, 4, 4 a. Pecten nutteri Arnold. Arnold, 1909, p. 160, pl. 27, figs. 3, 4.

Pecten etchegoini var. nutteri Arnold. Nomland, 1917a, p. 219, pl. 7. figs. 4,$5 ;$ pl. 8 , figs. $2 \mathrm{a}, 2 \mathrm{~b}$.

Pecten (Pallium) swifti Bernard variety nutteri Arnold. Grant and Gale, 1931, p. 174.

Pecten (Swiftopecten) etchegoini Anderson subsp. wattsi Arnold. Faustman, 1964, p. 116, pl. 2, fig. 1; not Pecten (Chlamys) wattsi Arnold, 1906.

Original description. - "Shell averaging about 65 millimeters in altitude, slightly higher than long, inequivalve, equilateral, more or less ventricose, and of ten showing several constrictions or undulations of interrupted growth; margins somewhat coarsely serrate; base regularly rounded; sides straight, and forming an acute angle at the umbo. Right valve with about 8 to 10 , unequal, rather prominent, flat-topped ribs, each of which is channeled by one or more deep, narrow, concave sulcations which divide the primary rib from umbo to margin into two or more generally unequal but evenly convex riblets; interspaces somewhat narrower than the ribs, and containing from 1 to 3 prominent rounded riblets; the riblets become more numerous and the major ribs less prominent anteriorly and posteriorly; the minor sculpture consists of squamose lines of growth, which are more prominent on the ribs, and beautiful microscopic checkered tessellation which is best developed in the major and minor interspaces; hinge line from two-fifths to nearly one-half length of disk; anterior ear prominent and sculptured by 5 or 6 elevated radiating ridges and imbricating concentric lamellae; byssal notch moderately deep; posterior ear rectangularly truncated, a little less than one-half length of anterior, and similarly but less prominently sculptured. Left valve with unequal, rather narrow, convex ribs, the alternate ones being more prominent than those intermediate; extremities of the ribs sometimes ornamented by longitudinal riblets; interspaces of about equal width to the ribs, and ornamented by one or three alternately prominent intercalaries; surface sculptured by imbricating incremental lines; the constrictions, when present, are more pronounced in this valve; ears sculptured similarly to those of the right valve. Hinge with a pair of prominent cardinal crura adjacent to the umbonal pit in the right valve."

Holotype.-CAS/SU 6.

Type locality.-South $0.8 \mathrm{~km}$ of mouth of San Gregorio Creek, Santa Cruz quadrangle, San Mateo County, Calif. Purisima Formation, Pliocene.

Comparison.-"This species is allied to P. parmeleei and P. wattsi but is distinguishable by having a larger number of ribs, which are also narrower and more coarsely radially sculptured. The Miocene forms of $P$. nutteri have more prominent and deeply sulcated ribs on the right valve, are generally more convex and more prominently constricted, and have relatively longer posterior ears than the later forms." (Arnold, 1906, p. 68)

Comments. -The holotype of $N$. nutteri is strongly and crudely sculptured. The ribs preserved on the right valve are deeply and almost evenly bifurcated and some of the interspaces have one or two interribs. The right anterior auricle is broken but seems to have been large, perhaps with only a shallow byssal sinus, and sculptured with moderate ribs. The right posterior auricle is also broken but was perhaps only one-fourth as long as the right anterior auricle. The left valve is more strongly and crudely sculptured than the right valve. The ribs are unevenly and shallowly divided into two or three parts, and no consistent pattern is apparent on the preserved shell. The median rib and the secondmost ribs toward the dorsal and ventral margins are elevated above the others, similar to Vertipecten. Preserved barnacles are attached to the left valve.

Geographic range.-Middle to southern California.

Geologic range.-Miocene to Pleistocene.

Occurrence in California.-Miocene: unnamed strata near Mount Hamilton; Miocene and Pliocene: Etchegoin (Nomland, 1917a; Woodring and others, 1940) and Purisima (Arnold, 1906) Formations; Pliocene: San Joaquin Formation (Adegoke, 1969); Pliocene and Pleistocene: Merced Formation (Arnold, 1906) and Rio Dell Formation, Wildcat Group (Faustman, 1964).

\section{Genus AEQUIPECTEN Fischer, 1886}

Differs from Chlamys in more rounded outline, nearly equal auricles, smaller byssal notch, fewer, usually not bifurcating radial ribs, and flattened, marginally pointed internal riblets near margin; pair of cardinal crura and auricular denticles (or weak auricular crura) present. Argopecten has more highly inflated valves, no secondary radial riblets, and large auricles. Argopecten also has concentric sculpture in looped lamellae and a tendency to oblique growth in adult stage, additional characters that separate it from Aequipecten. Geologic range.-Jurassic(?); Cretaceous through Holocene.

\section{Aequipecten dallasi (Jordan and Hertlein)}

\section{Plate 9, figures 10, 12}

Pecten (Chlamys) dallasi Jordan and Hertlein, 1926, p. 213, pl. 23, figs. 2, 5, 6, 8. Grant and Gale, 1931, p. 169-170.

Chlamys dallasi (Jordan and Hertlein). Durham, 1950, p. 65, pl. 6, fig. 2.

Original description. - "Shell of medium size, moderately thick, in several specimens with strong lines of restricted growth; valves mildly arched, and slightly extended posteriorly; hinge line a little 
over half the total length of the disk. Right valve ornamented by about 15 to 19 almost flat-topped radiating ribs, separated by slightly rounded interspaces almost as wide as the ribs, the summit of the ribs smooth, the sides and interspaces sculptured by fine, sharp, subequal radiating ridges and grooves, the shoulder of each rib on either side marked by a deeper groove; anterior dorsal and posterior dorsal areas of disk smooth; ears unequal, the anterior with a well developed byssal notch and sculpture consisting of about six radiating riblets crossed by concentric lines of growth; posterior ear obliquely truncated behind, and ornamented by four or five radiating riblets between which the interspaces bear fine incised radiating lines. Left valve sculptured much as right; anterior dorsal and posterior dorsal margins of disk sloping more abruptly to base of ears than on right valve; anterior ear indented by a rounded byssal notch and ornamented by five radiating riblets between which are minute sharp radiating grooves; posterior ear obliquely truncated and sculptured much as anterior, the radiating riblets, however, much more subdued and less prominent. Height $42 \mathrm{~mm}$.; length $43 \mathrm{~mm}$. diameter $13 \mathrm{~mm}$.; apical angle approximately $105^{\circ}$."

Holotype.-CAS 1862.

Type locality.-Cañons 1.5 or $3 \mathrm{~km}$ from Punta San Antonio, east coast of Baja California Sur. Salada Formation, Pliocene.

Supplementary description.- "Pecten dallasi is easily recognized by the peculiar minor radiating sculpture superimposed on the major ribs and interspaces. The number of ribs varies considerably, as does the obliquity of the valves." (Jordan and Hertlein, 1926a, p. 214)

Comparison.- - This species resembles somewhat $P$. islandicus var. kincaidi, and $P$. sancti-ludovici, but is distinguished by greater length, shallower ears, shallower byssal notch, and regular ribs with superimposed striations. It approaches closely the typical form of Aequipecten, and should, perhaps, be assigned to that subgenus." (Grant and Gale, 1931, p. 170)

Comments.-The holotype is subrounded in outline and slightly oblique, with nearly equal auricles and no bifurcated ribs. The byssal notch is extremely small. Aequipecten dallasi differs from Chlamys sanctiludovici in being less inflated, in having a more rounded outline, less elongate and more finely sculptured right anterior auricle, and a less elongate left anterior auricle.

Geographic range.-Baja California Sur to Mexico.

Geologic range.-Pliocene.

Occurrence in Baja California Sur.-Carmen (Durham, 1950), Gloria (Stump, 1979), and Salada Formations.

\section{Genus ARGOPECTEN Monterosato, 1889}

Auricles about equal in length, right anterior with distinct byssal notch; concentric sculpture in looped lamellae well developed in interspaces, rarely projecting strongly over radial ribs; tendency to oblique growth in adult stage. Differs from Aequipecten in having more highly and nearly equally inflated valves that usually lack secondary radial riblets and that have larger auricles.

Geologic range.-Miocene through Holocene (table 7).

Habitat.-Living in tropic, subtropic, and warm temperate seas (Hertlein, 1969, p. N357).

For a discussion of Tertiary species of Argopecten in eastern North America, see Waller (1969).

\section{Argopecten diminutivus (Hertlein and Jordan)}

Plate 9, figures 3, 6

Pecten (Plagioctenium) diminutivus Hertlein and Jordan, 1927, p. 623-624.

Pecten (Plagioctenium) calli Hertlein, 1925a, p. 16, pl. 4, figs. 5, 7. Not pl. 4, fig. 6.

Original description. - "Shell.small, right valve fairly flat and ornamented by 16 flattish topped to broadly rounded ribs which are separated by flattish bottomed interspaces which are very slightly narrower than the ribs; right ear well developed with strong byssa

TABLE 7.-Geologic and geographic distribution of the genus Argopecten in the eastern Pacific region

$[\mathrm{H}=$ Holocene; $\mathrm{Ple}=$ Pleistocene; $\mathrm{Pl}=$ Pliocene; $\mathrm{M}=$ Miocene $]$

\begin{tabular}{|c|c|c|c|c|c|}
\hline \multirow{2}{*}{ Species } & \multicolumn{2}{|c|}{ California } & \multicolumn{2}{|c|}{$\begin{array}{c}\text { Baja } \\
\text { California } \\
\end{array}$} & \multirow{2}{*}{$\begin{array}{l}\text { Central } \\
\text { and (or } \\
\text { South } \\
\text { Americ }\end{array}$} \\
\hline & Middle & Southern & Norte & $\overline{\text { Sur }}$ & \\
\hline 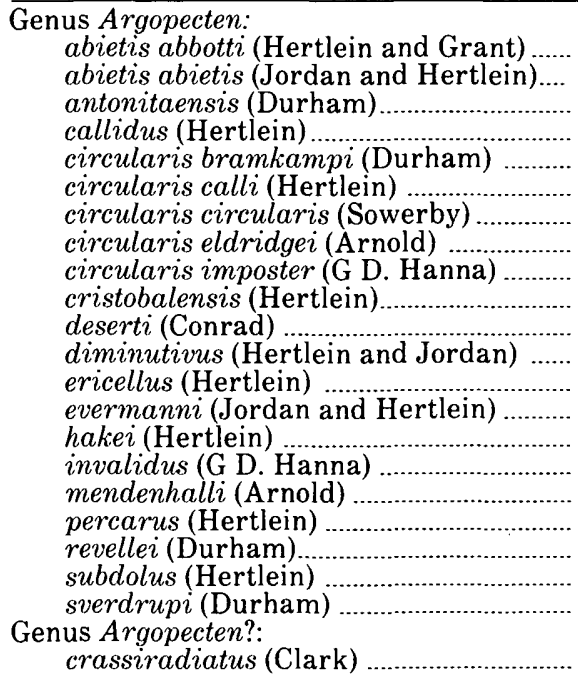 & 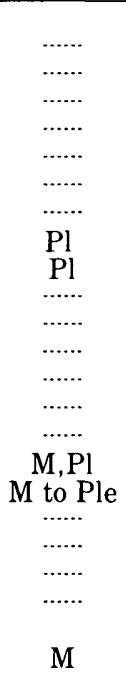 & $\begin{array}{c}\text { Pl,Ple } \\
\ldots \ldots . . \\
\ldots . . \\
\text { Pl,Ple } \\
\text { M or Pl } \\
\ldots \ldots . \\
\text { M to Ple } \\
\text { M,Pl } \\
\text { Pl } \\
\ldots \ldots . \\
\text { M or Pl } \\
\text { M } \\
\text { Pl } \\
\ldots \ldots . \\
\text { Pl } \\
\text { Pl,Ple } \\
\text { M or Pl } \\
\ldots \ldots . . \\
\ldots \ldots . . \\
\text { Pl,Ple } \\
\text { M or Pl }\end{array}$ & $\begin{array}{c}\ldots . . . \\
\ldots \ldots . \\
\mathrm{Pl} \\
\ldots \ldots . \\
\ldots \ldots . \\
\text { Pl to } \mathrm{H} \\
\ldots \ldots . \\
\ldots \ldots . \\
\ldots \ldots . \\
\mathrm{Pl} \\
\ldots \ldots . \\
\ldots \ldots . \\
\mathrm{Pl} \\
\ldots \ldots . \\
\mathrm{Pl} \\
\cdots \ldots . \\
\mathrm{Pl} \\
\cdots \ldots . \\
\mathrm{Pl} \\
\ldots \ldots .\end{array}$ & $\begin{array}{c}\ldots . . \\
\mathrm{Pl} \\
\mathrm{Pl} \\
\mathrm{Pl} \\
\mathrm{Pl} \\
\mathrm{Pl} \\
\mathrm{Pl} \text { to } \mathrm{H} \\
\ldots \ldots . \\
\ldots \ldots . \\
\mathrm{Pl} \\
\mathrm{Pl} \\
\mathrm{M} \\
\cdots \ldots . \\
\ldots \ldots . \\
\mathrm{Pl} \\
\cdots \ldots . \\
\mathrm{Pl} \\
\cdots \ldots . \\
\mathrm{Pl} \\
\cdots \ldots . \\
\mathrm{Pl}\end{array}$ & 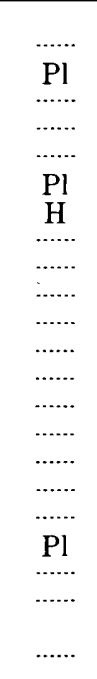 \\
\hline
\end{tabular}


notch. Left valve convex with fairly high and rather sharp umbo, and ornamented by 15 to 16 ribs. Altitude $8 \mathrm{~mm}$.; longitude $8 \mathrm{~mm}$.; thickness $2.1 \mathrm{~mm}$.; apical angle, approximately $98^{\circ}$."

Holotype.-CAS/SU 125.

Type locality.-SU 60. Baja California Sur. Isidro Formation, Miocene.

Supplementary description. - "The $* * *$ Miocene species figured by Hertlein cannot be referred to Pecten calli Hertlein. It is small and may possibly be the young form of some described species, but several specimens have been found, and it seems best to refer to them with a definite name; Pecten (Plagioctenium) diminutivus is proposed.

"The species differs from other west coast Plagiocteniums in its small size and flattish right valve." (Hertlein and Jordan, 1927)

Comments. - The holotype is a very small, moderately heavyshelled, double-valved specimen. The right valve is almost flat; the left valve is moderately inflated, and the left umbo projects above the hinge. The ribs and interspaces on both valves are smooth, with no concentric sculpture.

Geographic range.-Southern California to Baja California Sur. Geologic range.-Miocene.

Occurrence in the Californias.-Temblor "Horizon" (Loel and Corey, 1932) and Isidro Formation (Stump, 1979).

\section{Argopecten mendenhalli (Arnold)}

Plate 9, figures 1, 4

Pecten (Plagioctenium) cerrosensis Gabb var.? mendenhalli Arnold, 1906 , p. $84-85$, pl. 25, figs. 2, 2a, 2 b.

Pecten (Plagioctenium) cerrosensis mendenhalli Arnold. Hertlein, 1925a, p. 16, pl. 1, fig. 5.

Pecten mendenhalli Arnold. G D. Hanna, 1926a, p. 473, pl. 25, figs. 4, 5.

Pecten (Plagioctenium) mendenhalli Arnold. Jordan and Hertlein, 1926b. p. 442

Original description.-"Shell, when adult, averaging about 75 millimeters in altitude. Similar to P. cerrosensis in shape, convexity, and ribbing, but differing from the latter in being much smaller when adult, having fewer ribs (about 19 in the former, while the latter has usually 21 or more), much less prominent incremental lines, and a relatively longer hinge line."

Holotype.USNM 164849.

Type locality.-Santa Rosalia, Baja California Sur. Salada Formation, Pliocene.

Supplementary description. - "A few specimens in the collection appear to belong to this species. They agree with Arnold's figure of the type of $P$. mendenhalli in possessing an unusually long hinge line, valves which are little inflated and are unusually long in proportion to their height and right valves which are evenly rounded at the umbo, and broadly rounded on the ventral margin. They can be distinguished from $P$. invalidis and $P$. callidus by these characters. None of our specimens has quite as broadly rounded ribs as is shown by Arnold's figure of the type of $P$. mendenhalli.

"Examination of many specimens of true $P$. cerrosensis Gabb proves that $P$. mendenhalli is not related to that species, but it is far closer to $P$. invalidus, $P$. callidus, $P$. subdolus, and P. circularis." (Jordan and Hertlein, 1926b, p. 442)

Comparison.-The ribs on Lyropecten cerrosensis are 18 to 20 in number and not 21 or more as on $A$. mendenhalli (Hertlein, 1925a, p. 16).

Comments-The holotype is double valved and slightly inequilateral, with a long hinge. Both valves have low, subrounded ribs separated by slightly narrower interspaces and have looped con- centric lamellae. The finer sculpture of the auricles separates A. mendenhalli from $A$. callidus. The heavier ribs, longer hinge line, and shallower left anterior byssal notch distinguishes $A$. mendenhalli from $A$. subdolus. A. invalidus has wider ribs that are not as rounded as those on $A$. mendenhalli. A. antonitaensis has smaller anterior auricles with a deeper left anterior byssal notch than A. mendenhalli.

Geographic range.-Middle California to Baja California Sur.

Geologic range.-Miocene to Pleistocene.

Occurrence in the Californias.-Miocene or Pliocene: Imperial Formation (G D. Hanna, 1926a; Stump, 1979); Miocene and Pliocene: Purisima Formation (Arnold, 1906); Pliocene: Almejas (Minah and others, 1976), Boleo (Stump, 1979), and Salada (Arnold, 1906) Formations; Pliocene and Pleistocene: Merced Formation (Arnold, 1906).

\section{Argopecten deserti (Conrad)}

Plate 9, figure 2

Pecten deserti Conrad, 1855, p. 15. Conrad, 1857b, pl. 5, fig. 41. Nomland, 1917a, p. 242, pl. 6, figs. 1, 1a, 1b. G D. Hanna, 1926a, p. 470 , pl. 25 , figs. $1-3$.

Pecten (Plagioctenium) deserti Conrad. Arnold, 1906, p. 85, pl. 26 , fig. $3 ;$ not? pl. 26, figs. 1, 2,4 .

Pecten (Lyropecten) deserti Conrad. Mansfield, 1931, p. 46, pl. 17. figs. 3,6 .

Aequipecten deserti (Conrad). Durham, 1950, p. 63, pl. 11, figs. 5, 6 . Chlamys (Argopecten) deserti (Conrad). Hertlein and Grant, 1972, p. 198.

Original description.-"Suborbicular, both valves convex; ribs about 23 , rounded, somewhat flattened toward the base, about as wide as the interstices; [in the lower valve much wider than the interstices,] and the valve more convex than the opposite one; ears equal in the upper valve; left ear of lower valve extended downward and very obliquely striated; cartilage pit profound; a submarginal channel parallel with the upper margin."

Holotype.-USNM 8398.

Type locality.-Carrizo Creek, Colorado Desert [Imperial County], Calif. Imperial Formation, Miocene or Pliocene.

Supplementary description. - "Shell averaging about 32 millimeters in altitude, about as long as high, biconvex, equivalve, subequilateral, and with serrate margins; sides straight and sloping at a steep angle. Right valve with 22 or 23 high, narrow, close-set, smooth, rounded ribs, which sometimes show looped incremental lines on their tops near extremities; interspaces deep, narrow, slightly concave bottomed, and ornamented on the bottom by numerous fine, sharp, straight, incremental lines; hinge liné about three-fourths length of disk; ears subequal; the anterior slightly convex and ornamented by 4 radiating ridges and numerous incremental lines, while the posterior is ornamented by 6 or 7 radials and numerous concentric lines; byssal notch rather small. Left valve similar to the right, except possibly that the ribs are relatively slightly taller. Hinge strong, with a deep resilial pit and a submarginal channel parallel with the upper margin; numerous parallel microscopic lines perpendicular to the hinge line visible in the crural grooves.

"This species is distinguishable from allied forms by its strong hinge, tall, narrow, close-set ridges and straight incremental sculpture in the bottoms of the interspaces." (Grant and Gale, 1931, p. 85)

"Grant and Gale (1931, p. 212) cited the number of ribs on the deserti group 'usually 18 or 19,' and on typical deserti 15 to 19 . Woodring and Stewart (1941, p. 91) stated that $C$. deserti had fewer ribs than $P$. impostor which originally was described as possessing 
21 to 24. It appears obvious that some of the specimens attributed to C. deserti are not referable to it. Judging from the original description given by Conrad, the left valve illustrated by Arnold (1906, pl. 26, fig. 3), the illustrations of Nomland (1917, pl. 6, figs. 1, 1a, 1b), those of Hanna (1926, pl. 25, figs. 1, 2, 3), and of Durham (1950, pl. 11, figs. 5,6) correctly delineate typical specimens of Conrad's species." (Hertlein and Grant, 1972, p. 198)

Comparison.-Argopecten circularis in the San Diego Formation is more elongate than typical $A$. deserti, has fewer ribs, wider submargins that are not sculptured with riblets, and more concave auricles. (Hertlein and Grant, 1972, p. 198)

Geographic range. - Southern California to Baja California Sur. Geologic range.-Miocene(?) to Pliocene.

Occurrence in the Californias.-Miocene or Pliocene: Imperial Formation; Pliocene: Almejas (Minch and others, 1976), Salada (Beal, 1948), and San Marcos (Durham, 1950) Formations.

\section{Argopecten sverdrupi (Durham)}

Plate 9, figure 9

Aequipecten sverdrupi Durham, 1950, p. 64, pl. 8, figs. 2, 5; pl. 9, fig. 7.

Original description. - "Shell of medium size, fairly heavy, resembling $A$. impostor (Hanna) but having only 17 or 18 heavy rounded ribs; obliqueness of valves varying considerably, some specimens being markedly oblique to posterior; ribs rounded, interspaces about half as wide; in one small specimen the younger half of shell, after a heavy constriction representing a marked pause in growth, shows very high ribs on right valve with relatively narrow interspaces, while on left valve the ribs are high but with wide interspaces; anterior ears missing from all six valves at hand; however, the traces of byssal notch present indicate that it was deep and fairly sharply angled, like that of $A$. circularis."

Holotype.-UCMP 15995.

Type locality.-UC A3583. Baja California Sur. Salada Formation, Pliocene.

Supplementary description. - "The 17-18 heavy rounded ribs appear to be characteristic of this species." (Durham, 1950, p. 64)

Comments.-The holotype is a very thick shelled, moderately inflated right valve with a small umbonal angle. It has 17 wide, subrounded ribs and shallow, narrower interspaces. The auricles are broken but the right posterior auricle was very high.

Geographic range.-Southern California to Baja California Sur. Geologic range.-Miocene to Pliocene.

Occurrence in the Californias.-Miocene or Pliocene: Imperial Formation; Pliocene: Salada and San Marcos Formations.

\section{Argopecten circularis circularis (Sowerby)}

Plate 9, figures 7, 8

Pecten tumidus Sowerby, 1835, p. 109. Not Pecten tumidus Turton, 1822.

Pecten circularis Sowerby, 1835, p. 110.

Pecten (Plagioctenium) circularis Sowerby. Arnold, 1906, p. 125126, pl. 43, figs. $3-6$; pl. 44, figs. $6,6 \mathrm{a}, 6$ b, 7. Hertlein, 1935, p. 311-316.

Aequipecten circularis (Sowerby). Durham, 1950, p. 63, pl. 10, figs. $1,5$.

Aequipecten (Plagioctenium) circularis (Sowerby). Olsson, 1961, p. 163, pl. 19, figs. 2, $2 \mathrm{~b}$.

Chlamys (Argopecten) circularis Sowerby. Grau, 1959, p. 97-100, pl. 32. Hertlein and Grant, 1972, p. 197-198, pl. 32, figs. 4, 15, 16.

Argopecten circularis (Sowerby). Waller, 1969, p. 46-48, pl. 5, fig. 12; text figs. 8-10; tables 20, 21.

Pecten (Pecten) compactus Dall, 1898, p. 707, pl. 34, fig. 5.

Original description. - "Pect. testâ suborbiculari, tumida, subaequivalvi, aequilaterali, fusco alboque variâ, auriculis magnis, subaequalibus; costis radiantibus octo-decim interstitiis latioribus, arcuatim striatis; valvâ alterâ sulcis profundioribus: long. 1.5, lat. 0.8, alt. 1.4 poll."

Holotype.-BM(NH) 1950-11-14.18.19.

Type locality.-Guaymas, Mexico. Holocene.

Supplementary description. - "In the smaller valves, there is much variation in the convexity, the width of the interspaces between the ribs and in the height and degree of rounding or flattening of the tops of the ribs. Many of the valves to a height of about $35 \mathrm{~mm}$ are very convex, the ribs are high and flat-topped and rather closely spaced. These closely resemble Arnold's illustration (1906, pl. 44, fig. 7) of the type of Pecten compactus Dall which is now generally placed in the synonymy of $C$. circularis. Other larger ones resemble Arnold's illustration of C. circularis (on his plate 42, fig. 3). Large specimens of C. circularis from the Gulf of California are about $66 \mathrm{~mm}$ long." (Hertlein and Grant, 1972, p. 197-198)

"Mature individuals of moderate size in southern part of range, commonly attaining heights of 40 to $60 \mathrm{~mm}$; of moderate to large size in northern part of range, commonly 50 to $70 \mathrm{~mm}$, a few as high as 95 to $100 \mathrm{~mm}$; equiconvex to right-convex. Outline of disk oblique, with posterior margin extended; disk flanks very steep, commonly turned inward near bases of auricles, and curved in plane perpendicular to commissure and to disk flank. Disk gapes absent or very narrow in southern part of range, narrow to rather wide in northern part.

"Right auricles with dorsal margins dorsal to outer ligament and diverging slightly from outer ligament away from beak; free margins of right auricles forming $90^{\circ}$ or acute angles at junctures with outer ligament. Free margins of posterior auricles moderately to rather deeply sigmoidal in plane of commissure, with central portion of sigmoidal curve forming acute angle with dorsal margins. Right anterior auricle with broadly rounded anterior margin; byssal notch of mature individuals rather deep, with apex pointed, rounded, or truncate; ctenolium generally present except on largest individuals; byssal fasciole planar to strongly arched adjacent to suture with disk.

"Plicae of right valve 18 to 23 in number $* * *$, with external surfaces high and rectangular or subrectangular in cross section proximally, becoming low and subrounded with upper surfaces flattened distally; width generally considerably greater than that of interspaces. Concentric lamellae on both valves generally projecting only in interspaces (although commonly absent from bottoms of interspaces) and on sides of plicae, extending to or slightly over edges of plica crests and commonly demarcating a bald band down crest; trend of lamellae across central region of either valve at heights greater than $30 \mathrm{~mm}$ distally convex across interspaces, sloping rathe: strongly up sides of plicae in proximal direction, and distally concave across crests of plicae; spacing of lamellae close in central region of mature right valve. Disk flanks noncostate or with very faint, incipient costae." (Waller, 1969, p. 46-47)

"Hinge structure strong; cardinal crura very pronounced on right valve and interlocking tightly with left valve; strong transverse striae on crura and provinculum; cardinal margin of right valve well folded over; prominent nodules at base of each auricle on both valves." (Grau, 1959, p. 99)

Comparison.-"Recent adult specimens of $C$. (A.) circularis aequisulcata differ from typical $C$. (A.) circularis in the larger, flatter, and thinner shell as well as in the narrower ribs and less brightly colored shell.

"Some of the fossils from the San Diego formation closely resemble some specimens of the form described as Pecten (Plagioctenium) calli Hertlein $* * *$ from beds of Pliocene age at Bahía. Tórtolo (Turtle 
Bay), Lower California. The record of this form from the San Diego Pliocene, mentioned by E. K. Jordan and Hertlein, is referred by us to juvenile $C$. circularis. Typical specimens of the form C. c. calli possess very highly arched umbos, squarish ribs on the right valve and fine, high ribs on the left valve. There is also a tendency for the valves to develop a length greater in proportion to the height. $* * *$ The valves of $C$. circularis calli are more elongated and the ribs are more numerous and narrower than those of $C$. circularis bramkampi Durham *** described from the Carrizo Creek region in Imperial County, which has about 19 ribs.

"In general appearance and in degree of globosity, some of the smaller specimens from San Diego resemble $C$. eldridgei Arnold *** which was described from beds of late Pliocene age in San Joaquin Valley, California. The fossils from San Diego have thinner shells, which lack constrictions, the ribs are more numerous, often a little more widely spaced and the crenellations along the ventral margin of the interior are less consistently and deeply grooved than those of C. eldridgei. The ribs on some of the left valves of $C$. eldridgei are shallowly medially grooved toward the ventral margin but this feature is lacking on the valves from San Diego.

"The species described as Pecten (Plagioctenium) neahensis by Arnold (1906, p. 87, pl. 15, fig. 2, 2a, 2b) from beds of Miocene age at Neah Bay, Washington, has narrower ribs and a longer hinge line than C. circularis." (Hertlein and Grant, 1972, p. 198)

"A. circularis differs from $A$. gibbus in being more generally right-convex and from both $A$. gibbus and $A$. nucleus in having a more oblique shell with higher and more angular right plicae." (Waller, 1969, p. 47)

Geographic range._Living: Cedros Island, Baja California Norte, to Peru and Galapagos Islands; fossil: southern California to Ecuador.

Geologic range.-Miocene through Holocene.

Occurrence in the Californias.-Miocene and Pliocene: Towsley Formation (Winterer and Durham, 1962); Pliocene: Almejas (Minch and others, 1976), Gloria (Wilson, 1948; Stump, 1979), Infierno (Wilson, 1948: Stump, 1979), Marquer (Durham, 1950), Niguel (J. G. Vedder, written commun., 1978), and San Diego (Hertlein and Grant, 1972) Formations; Pliocene and Pleistocene: Fernando (J. D. Mount, written commun., 1971), Pico (Kundert, 1932), and Saugus (Kew, 1924) Formations; Pleistocene: Palos Verdes Sand (Woodring, 1946).

Habitat. - On rock, gravel, sand, and sandy mud bottoms from 1 to $135 \mathrm{~m}$; associated with kelp, corallines, or gorgonians (Grau, 1959, p. 100).

"Seemingly, a geographic change in the habitat preference of the species [Argopecten circularis sensu lato] may occur, the northern forms $[A$. aequisulcatus] being found more commonly in bays and estuaries than the southern forms, which seem to be more common in open marine waters. (Waller, 1969, p. 47)

\section{Argopecten circularis calli (Hertlein)}

\section{Plate 10, figure 2}

Pecten (Plagioctenium) calli Hertlein, 1925a, p. 16-18, pl. 4, fig. 6. Not pl. 4, figs. 5, 7 [= Argopecten diminutivus Hertlein and Jordan, 1927]. Jordan and Hertlein, 1926b, p. 436-437, pl. 27, fig. 5.

Chlamys (Argopecten) circularis calli (Hertlein). Hertlein and Grant, 1972, p. 198.

Original description. - "Shell small, inequivalve. Right valve slightly arched, ornamented by about 16 or 17 rather high, narrow, rounded, radiating ribs separated by interspaces of about the same width as the ribs; anterior ear with a large byssal notch and sculpture consisting of about five radiating riblets crossed by concentric lines of growth; posterior ear sculptured by radiating riblets crossed by concentric lines of growth. Left valve slightly prolonged posteriorly, much more highly arched than right, and sloping rather abruptly from the umbos, sculptured by about 19 well developed, rather sharp, rounded, radiating ribs separated by interspaces about as wide as the ribs, ribs and interspaces crossed by fine concentric lines; ears slightly concave, the anterior with a small notch and ornamentation consisting of five or six radiating riblets crossed by concentric lines of growth; posterior ear slightly prolonged at the hinge line, sculptured as right. Altitude $24 \mathrm{~mm}$.; longitude $24 \mathrm{~mm}$.; diameter of left valve approximately $7 \mathrm{~mm}$.; apical angle approximately $90^{\circ}$."

Holotype.-CAS/SU 68.

Type locality.-SU 53. First arroyo east of Santiago, Baja California Sur. Salada Formation, Pliocene.

Supplementary description. - "Right valves of this species vary considerably in convexity; usually they are moderately convex, and markedly so at the umbo. The hinge line is about two-thirds as long as the shell. They bear 18-21 ribs, which are rather high and prominent, squarish in early stages of growth and usually square in the adult forms, but in a few individuals later becoming slightly rounded. The ribs are separated by interspaces that are not quite as wide as the ribs and, in unweathered specimens their sides are ornamented by fine concentric lamellae. The posterior ear is well developed, and shows a very faint, broad notch. The ear is ornamented by five or six faint radiating riblets crossed by concentric lines of growth. The anterior ear is well developed, and is cut by a well defined byssal notch; the anterior margin of the ear is rounded, and the surface is ornamented by four to six radiating riblets crossed by incremental lines." (Jordan and Hertlein, 1926b, p. 436-437)

"Typical specimens of the form C. c. calli possess very highly arched umbos, squarish ribs on the right valve and fine, high ribs on the left valve. There is also a tendency for the valves to develop a length greater in proportion to the height. Durham [1950] mentioned this tendency in C. circularis occurring in Pliocene beds in the Gulf of California region." (Hertlein and Grant, 1972, p. 198)

Comparison. - "Pecten calli differs from $P$. andersoni Arnold, in its narrower ribs and more highly arched left valve. From $P$. discus Conrad, and P. raymondi Clark, the present species is distinguished by the differently shaped ribs and less circular outline of the valves. From $P$. deserti Conrad and $P$. impostor Hanna, $P$. calli is distinguished by its high narrow, rounded ribs and only slightly arched right valve. From $P$. santarosanus Böse, $P$. calli is distinguished by the fewer higher ribs and by the presence of a profound rounded notch in the posterior ear of the left valve of the present species, which notch is lacking in $P$. santarosanus." (Hertlein, 1925a, p. 17)

"The valves of $C$. circularis calli are more elongated and the ribs are more numerous and narrower than those of $C$. circularis bramkampi ***." (Hertlein and Grant, 1972, p. 198)

Comments. - The holotype is a small, moderately thick-shelled left valve with narrow, subtriangular ribs that are separated by $\mathrm{U}$-shaped interspaces of equal size that have imbricated concentric lamellae.

Geographic range.-Baja California Sur to Mexico.

Geologic range.-Pliocene.

Occurrence in Baja California Sur.-Pliocene: Salada Formation.

\section{Argopecten circularis bramkampi (Durham)}

\section{Plate 9, figure 5}

Aequipecten circularis subsp. bramkampi Durham, 1950, p. 63, pl. 9, figs. $2,4,8$.

Original description. - "Shell of medium size, resembling $A$. circularis in general outline, but with high, prominent beaks; 19 ribs, 
wide and rounded, interspaces narrow and channeled at bottom; beaks laterally compressed and slightly overhanging hinge line, with ears sharply delimited by an impressed area; anterior ear of right valve with about four radial ribs; byssal notch deep and sharply pointed; posterior ear of right valve with extremely faint and fine radial ribs. Both ears of left valve with 6-8 fine radial ribs."

Holotype-UCMP 30035.

Type locality.-UC A 1268. Imperial County, Calif. Imperial Formation, Miocene or Pliocene.

Comparison.-The high, overhanging, laterally compressed beaks separate $A$. circularis bramkampi from the typical form. (Durham, 1950 , p. 63)

"The valves of $C$. circularis calli are more elongated and the ribs are more numerous and narrower than those of C. circularis bramkampi***." (Hertlein and Grant, 1972)

Comments. - The holotype is a moderately thick-shelled, inequilateral, right valve with a very inflated umbonal area. The ribs are rounded and separated by small, deeply rounded interspaces that have imbricated, concentric lamellae; both the ribs and interspaces are crossed by looped, concentric lamellae near the ventral margin.

Geographic range.-Southern California to Baja California Sur.

Geologic range.-Miocene to Pliocene.

Occurrence in the Californias.-Miocene or Pliocene: Imperial Formation; Pliocene: San Marcos Formation.

\section{Argopecten circularis eldridgei (Arnold)}

\section{Plate 9, figure 11}

Pecten (Plagioctenium) eldridgei Arnold, 1906, p. 87, pl. 25, figs. 3, 3a, 3b, 4, 4a, 4b, 5, 5a, 5b. Howard, 1935, pl. 6, fig. 3.

Pecten (Aequipecten) eldridgei Arnold. Grant and Gale, 1931, p. 214. Aequipecten circularis eldridgei (Arnold). Woodring and others, 1940, p. 53, 54, pl. 24, figs. 10-13.

Original description.-"Shell averaging about 20 millimeters in altitude, nearly as high as long, equivalve, somewhat oblique (the posterior portion being the longer), very thick and heavy, very ventricose, and with serrate margins; base unequally rounded; sides somewhat concave above and sloping at a moderately steep angle. Right valve with 19 or 20 small, rather low but sharply defined, squarish ribs; interspaces about one-half as wide as ribs, channeled, and with flat bottoms; surface of disk ornamented by numerous sharp concentric lines which loop back over the ribs; more or less prominent constrictions, indicating interrupted growth, are common on most specimens; hinge line equal to about three-fourths length of disk; anterior ear slightly longer than posterior, deeply notched, and ornamented by 3 or 4 prominent radiating ridges and numerous imbricating incremental lines; posterior ear rectangularly truncated and ornamented by 8 or 10 radiating ridges and incremental sculpture. Left valve similar to right, except that the ribs are slightly narrower and more rounded; ears similar to those of right valve except that the anterior one is not as deeply notched. Hinge similar to that of $P$. circularis except stronger and with the auricular crura much more highly developed. Adductor impressions very deep."

Holotype.-USNM 164580 (paratypes also so numbered).

Type locality.-McKittrick district (N $1 / 2$ sec. 22, T. 30 S., R. 22 E.), Kern County, Calif. Etchegoin Formation, Miocene and Pliocene.

Comparison. - "This species is similar in many respects to $P$. circularis, but is characterized by its smaller size, greater ventricosity, thicker and heavier shell, deep adductor impressions, and more or less prominent constrictions. It sometimes attains an altitude of 45 millimeters, as shown by fragments collected at the type locality." (Arnold, 1906, p. 87)

Comments.-The holotype is a small, inequilateral left valve with closely spaced, subrounded ribs and shallow interspaces; looped, concentric lamellae cross both the ribs and the interspaces near the ventral margin. The left anterior auricle is deeply notched.

Geographic range.-Middle to southern California.

Geologic range.-Miocene to Pliocene.

Occurrence in California.-Miocene and Pliocene: Etchegoin Formation; Pliocene: Cascajo Conglomerate Member, San Joaquin Formation (Woodring and others, 1940).

\section{Argopecten circularis impostor (G D. Hanna)}

Plate 10, figure 1

Pecten proteus Nomland, 1917a, p. 232, pl. 6, figs. 2, 2a-c. Not Pecten proteus Sowerby, 1847.

Pecten impostor G D. Hanna, 1924, p. 177, new name.

Aequipecten circularis impostor (Hanna). Woodring and others, 1940 , p. 91 , pl. 13, figs. 3, 4, 6-9.

Aequipecten impostor (Hanna). Adegoke, 1969, p. 99, pl. 2, fig. 12.

?Pecten deserti Conrad. Arnold, 1909, p. 76, pl. 26, figs. 1, 2, 4. Not Pecten deserti Conrad, 1855a.

Original description. - "Shell thin, equilateral, equivalve, compressed, with smooth regularly convex margins. Dorsal margins slightly concave; apical angle about 95 degrees. Right valve ornamented externally by $21-24$ wide, moderately high, rounded ribs; on each side of major ribs is usually a faint auxiliary riblet; interspaces between major ribs less than width of ribs; anterior ear slightly longer than posterior, sculptured by about five low radial ridges and indistinct incremental lines; posterior ear ornamented with about seven low, radial ridges and nearly invisible incremental lines. Left valve in general similar to right, but has higher, more strongly rounded, major ribs with narrow interspaces; anterior ear with about seven radiating lines. Dimensions of rather small left valve of type: height, $37 \mathrm{~mm}$.; width, $33 \mathrm{~mm}$.; width of hinge line, $17 \mathrm{~mm}$." Holotype.-UCMP 11089.

Type locality.-UC 2991. Fresno County, Calif. Upper Etchegoin Formation, Pliocene.

Comparison.-"Specimens of this species found in the Coalinga region have heretofore been identified as Pecten deserti Conrad. On comparison of $P$. deserti from the type locality at Carrizo Mountain, San Diego County, with $P$. proteus, n. sp., several marked differences may be observed. In $P$. deserti the ribs are higher, flatter above, with more nearly vertical sides; on the left valve the ribbing continues without interruption from ears over the outer depressed dorsal margins, while in $P$. proteus, n. sp., the corresponding areas have no ribs. The ears of $P$. deserti are larger, more strongly curved, and have less depression where ears join dorsal margins of shell; also the dorsal margins show less marked concavity." (Nomland, 1917a, p. 232)

Argopecten circularis impostor differs from the living California A. circularis Sowerby and its allies in having a smaller thinner shell and smaller ears. Argopecten deserti appears to have not quite so many ribs, and at least some specimens have ribs on the lateral areas; on A. c. impostor the lateral areas are smooth. A. circularis eldridgei is smaller than $A$. circularis impostor and has a thicker shell. (Woodring and others, 1940, p. 91)

Comments.-The holotype is a small, moderately thick-shelled, slightly inequilateral left valve. The left valve ribs are grooved along the edges, and they, and the narrower interspaces, seem to have been covered by imbricated microsculpture.

Geographic range.-Middle and southern California.

Geoiogic range.-Pliocene.

Occurrence in California.-Cascajo Conglomerate Member, San Joaquin and upper part of Etchegoin (Woodring and others, 1940) Formations. 


\section{Argopecten ericellus (Hertlein)}

Plate 12, figure 2

Pecten (Plagioctenium) ericellus Hertlein, 1929, p. 215, pl. 24, figs. 10.11.

Chlamys (Argopecten) ericellus Hertlein. Hertlein and Grant, 1972, p. 199 , pl. 32 , fig. 7 .

Original description.-"Shell small, moderately convex; hinge line straight. Right valve ornamented by about 22 subrounded, fairly low radiating ribs which are separated by narrower interspaces; two tiny midribs are present along the base of the sides of the major ribs; ribs and interspaces crossed by concentric lines of growth; anterior and posterior margins ornamented by concentric lines of growth; ventral margin rounded; ears unequal, the anterior with a well-defined byssal notch, and sculpture of about five or six radiating riblets crossed by incremental lines; the posterior ear sculptured by about four or five radiating riblets crossed by lines of growth, no notch present. Altitude $28 \mathrm{~mm}$.; longitude $29.1 \mathrm{~mm}$; diameter of right valve approximately $7.5 \mathrm{~mm}$.; a pical angle in right valve approximately $94^{\circ} . "$

Holotype.-CAS 2998.

Type locality.-CAS 1132. San Diego County, Calif. San Diego Formation, Pliocene.

Supplementary description. - "The shell of this species is characterized by its narrow, subrounded ribs, narrow interspaces, and by the presence of two tiny riblets, one at the base of each side of most of the major ribs. In some of the interspaces toward the lateral margins only one riblet, or in some cases, none is present." (Hertlein and Grant, 1972, p. 199)

Comparison. - "This form appears to be a member of the Chlamys circularis group. It differs from C. circularis in the smaller posterior ear, more numerous, narrower ribs and interspaces, and in the presence of the riblets in the interspaces toward the ventral margin.

"Grant and Gale (1931, p. 219) stated that this form could be matched by juvenile specimens of Chlamys circularis aequisulcata Carpenter. However, they cited it with question in the synonymy of 'Pecten (Aequipecten) gibbus variety circularis Sowerby.' Comparison of the type specimen of $C$. (A.) ericellus with a series of specimens of $C$. circularis and its subspecies $C$. circularis aequisulcata of comparable size, reveals differences sufficient in our opinion to justify assignment of specific status to $C$. $(A$.) ericellus." (Hertlein and Grant, 1972, p. 199)

Comments.-Imbricated, looped lamellae cross both the ribs and interspaces near the ventral margin, but only the interspaces on the rest of the disk. The right anterior auricle is half again as long as the right posterior auricle.

Geographic range.-Southern California.

Geologic range.-Pliocene.

Occurrence in California.-San Diego Formation.

\section{Argopecten invalidus (G D. Hanna)}

\section{Plate 10, figure 5}

Pecten (Plagioctenium) cooperi Arnold, 1906, p. 124, pl. 49, figs. 2-4. Not Pecten cooperi E. A. Smith, 1903.

Pecten invalidus G D. Hanna, 1924, p. 177, new name.

Chlamys (Argopecten) invalida Hanna. Hertlein and Grant, 1972, p. 200-201, pl. 33, figs. $1,3,8$ (see for synonymy).

Original description. - "Shell averaging about 30 millimeters in altitude, slightly longer than high, both valves moderately convex, disks slightly obliquely produced posteriorly, moderately thick; disk generally characterized by several more or less prominent concentric zones of interrupted growth, which show as color bands even on the fossil shells; sides nearly straight; margins serrate. Right valve with 18 to 20 flat-topped, squarish ribs, which tend to flatten out and become more convex topped in the later stages of growth; interspaces narrower than the ribs, and crossed on the bottom by numerous, fine, sharp, incremental lirulae, which become obsolete on the ribs excepting in the later stages of growth; hinge line somewhat more than one-half length of disk; anterior ear slightly produced and ornamented by 4 or 5 prominent radials and numerous incremental lines; byssal notch deep and sharply defined; posterior ear slightly truncated, and sculptured by obsolete radials and fine incremental lines. Left valve similar to right, except that the ribs are inarrower and the interspaces correspondingly broader. Dimensions: Alt. 30 $\mathrm{mm}$; long. $31 \mathrm{~mm}$; hinge line $17 \mathrm{~mm}$; diameter $12 \mathrm{~mm}$; umbonal angle $95^{\circ} . "$

Holotype.-CAS/SU 8

Type locality.-Pacific Beach, San Diego, San Diego County, Calif. San Diego Formation, Pliocene.

Supplementary description. -"Valves of this species are characterized by their low convexity and by the character of the ribs, 18 to 20 , which are square in the early stages but which widen out and become more convex toward the ventral margin. The interspaces often are ornamented with well developed concentric imbrications.

“*** Two large right valves ***, the larger $47.9 \mathrm{~mm}$ long and 46.8 $\mathrm{mm}$ high, agree with valves of Chlamys invalida except that they are larger and have a greater number of ribs, 21 to 22 . These valves appear to be referable to large gerontic forms of $C$. invalida." (Hertlein and Grant, 1972, p. 201)

Comparison.- "The smaller shell, more rounded outline, fewer ribs which become broader and more rounded toward the ventral margin, occasional concentric zones of interrupted growth, and smaller umbonal angle are features which serve to separate this, species from Chlamys callida.

"The generally smaller more orbicular shell and fewer ribs which become decidedly broader and more convex but not obsolete near the margin are characteristics which serve to separate $C$. invalida from 'Aequipecten' antonitaensis Durham.

"Chlamys (Argopecten) coopericellus Ferreira *** described from strata of early Miocene age in Brazil, was compared by its author with ' $C$. (A.) cooperi (Arnold, 1906)' [= Pecten invalidus Hanna]. A small riblet is present in the interspaces between the ribs of the Brazilian species and in this and in other details it is quite distinct from C. invalida." (Hertlein and Grant, 1972, p. 201)

Comments. - The holotype is a right valve with square to subrounded ribs separated by U-shaped interspaces half as wide as the ribs. The interspaces have imbricated, concentric lamellae; near the ventral margin, looped concentric lamellae also cross the ribs.

Geographic range.-Southern California to Baja California Norte. Geologic range.-Miocene to Pleistocene.

Occurrence in the Californias.-Miocene and Pliocene: Purisima Formation (Arnold, 1906); Pliocene: Almejas (Minch and others, 1976), Niguel (Vedder, 1972), and San Diego (Hertlein and Grant, 1972) Formations; Pliocene and Pleistocene: Fernando (J. D. Mount, written commun., 1971), Merced (Arnold, 1906), and Pico (Grant and Gale, 1931) Formations.

\section{Argopecten subdolus (Hertlein)}

Plate 10, figures 3, 4

Pecten (Plagioctenium) subdolus Hertlein, 1925a, p. 20-21, pl. 5, figs. 2, 4, 7. Jordan and Hertlein, 1926b, p. 443.

Pecten (Aequipecten) purpuratus Lamarck variety subdolus Hertlein. Grant and Gale, 1931, p. 211, pl. 5, fig. 1.

Pecten (Argopecten) subdolus Hertlein. Moore, 1968, p. 50, pl. 23, figs. a, b. 
Chlamys (Argopecten) subdola Hertlein. Hertlein and Grant, 1972, p. 201-202, pl. 30, figs. 7, 8; pl. 35, figs. 2, 5, 9 .

Original description. - "Shell of medium size, the valves moderately convex. Right valve ornamented by about 21 rounded, radiating ribs which become broader toward the ventral margin, the ribs separated by round-bottomed, narrower interspaces, the whole surface ornamented by very fine radial striations and by concentric lines of growth; anterior and posterior margins sculptured only by concentric incremental lines; ventral margin rounded; ears unequal, the anterior with a well defined byssal notch, and sculpture of about six radiating riblets crossed by incremental lines; the posterior also sculptured by about six or seven slight radiating riblets crossed by lines of growth, a very slight notch present. Left valve more arched than right and somewhat one-sided in appearance, ornamented by about 21 rounded, radiating ribs separated by round-bottomed interspaces about as wide as the ribs, the whole surface finely longitudinally striate and crossed by concentric lines of growth; ears slightly concave, the posterior sculptured by very slight radiating riblets and concentric lines of growth, the anterior with a rounded notch, the surface sculptured by a few very slight radiating riblets and by concentric growth lines, the ornamentation indistinct on weathered specimens. Altitude $50 \mathrm{~mm}$.; longitude $50 \mathrm{~mm}$.; diameter approximately $17 \mathrm{~mm}$.; apical angle in each valve approximately $105^{\circ}$."

Holotype.-CAS/SU 51.

Type locality.-SU 115. San Diego County, Calif. San Diego Formation, Pliocene.

Comparison. - "The shell of Chlamys subdola resembles that of $C$. callida, with which it occurs, in outline and in general pattern of sculpture. It differs from the latter species in possessing a thinner shell, in the low rounded ribs, the presence of radial striae on the disk, and weaker sculpture on the ears.

"Specimens of Chlamys subdola closely resemble some individuals of Chlamys impostor Hanna. We have examined a large series of $C$. impostor and it is evident that there is considerable variation in that species with respect to number of ribs (20 to 24), the elevation and degree of roundness of the ribs and in the umbonal angle. The largest specimens usually do not exceed $46 \mathrm{~mm}$ in altitude.

"In comparison to Chlamys impostor, the shell of Chlamys subdola is thinner, it attains a greater size (altitude 50 to $61 \mathrm{~mm}$ ), the ribs, of which there are usually fewer, are flatter and become broader toward the ventral margin, the ears are a little larger, and the ribs on the left valve are finer.

"Grant and Gale (1931, p. 214) considered Chlamys impostor to be a variety of Chlamys deserti Conrad, whereas Woodring and Stewart considered it to be a subspecies of Chlamys circularis Sowerby. Whatever the true relationship may be, there is a striking resemblance between specimens of Chlamys impostor and those of $C$. subdola. However, the differences observed in series of the two lead us, at least for the present, to retain $C$. subdola as a species rather than a subspecies of $C$. impostor.

"'Aequipecten' revellei Durham *** described from strata of Pliocene age on Monserrate Island, in the Gulf of California, bears a resemblance to $C$. subdola, but differs in the more rounded outline and proportionally longer hinge line." (Hertlein and Grant, 1972, p. 202)

Comments.-The holotype is a double-valved specimen, with slightly inequilateral disks; the posterior end is larger than the anterior. The right valve has low, subrounded, radial ribs and shallow interspaces about half as wide. Fine, concentric, looped lamellae cross the interspaces and ribs on the ventral two-thirds of the right disk. The left valve is more inflated than the right, and strong, concentric lamellae cross the interspaces on the dorsal one-third of the disk, and both the ribs and interspaces on the remaining two-thirds.
Geographic range.-Southern California to Baja California Norte. Geologic range.-Pliocene to Pleistocene.

Occurrence in the Californias.-Pliocene: Almejas (Minch and others, 1976), Infierno (Wilson, 1948; Vokes, 1955), and San Diego (Hertlein and Grant, 1972) Formations; Pliocene and Pleistocene: Pico Formation (Grant and Gale, 1931).

\section{Argopecten callidus (Hertlein)}

Plate 10, figures 7, 9

Pecten (Plagioctenium) callidus Hertlein, 1925a, p. 22, pl. 5, figs. 1, 3, 5, 6. Jordan and Hertlein, 1926b, p. 437.

Pecten (Aequipecten) purpuratus Lamarck variety callidus Hertlein. Grant and Gale, 1931, p. 211, pl. 5, fig. 4.

Chlamys (Argopecten) callida Hertlein. Hertlein and Grant, 1972, p. 198-199, pl. 32, figs. 9, 11.

Original description.-"Shell of medium size, the valves moderately arched. Right valve ornamented by about 21 or 22 rather high, flat-topped, radiating ribs separated by narrower interspaces, tops of ribs smooth, but sides and interspaces sculptured by fine, sharp lamellae; anterior and posterior margins sculptured by concentric lines of growth only; ventral margin rounded; ears unequal, the anterior with a large byssal notch and ornamented by about five or six radiating riblets crossed by concentric lines of growth; the posterior sculptured by several radiating riblets. Left valve more convex than right and somewhat one-sided in appearance, with sculpture quite similar to that of right valve except that the interspaces are slightly wider; anterior ear carrying a small, rounded notch and ornamentation consisting of small, radiating riblets and concentric lines of growth; posterior ear sculptured much as the anterior. Altitude $55 \mathrm{~mm}$.; longitude $55 \mathrm{~mm}$.; diameter $19 \mathrm{~mm}$.; apical angle of valves approximately $105^{\circ}$."

Holotype.-CAS/SU 53.

Type locality.-SU 116. Cedros Island, Baja California Norte. Almejas Formation, Pliocene.

Supplementary description.-"The shell of this species is characterized by the gently convex right valve and sculpture consisting of 21 to 22 well developed flat-topped ribs which are separated by narrower interspaces. The left valve is more convex than the right, but is similarly sculptured except that the ribs are narrower and separated by wider interspaces." (Hertlein and Grant, 1972, p. 199)

Comparison.- "The outline and general sculpture of this species is similar to that of Chlamys subdola, but it differs from that species in the much higher flat-topped ribs which retain this character to the ventral margin.

"The greater size, greater number of flat-topped ribs which retain this character to the margin, the lack of interrupted concentric zones of growth and the greater umbonal angle, are features which serve to separate C. callida from C. invalida." (Hertlein and Grant, 1972, p. 199)

Comments. -The holotype is a double-valved specimen, of moderate size, with moderately inflated valves. The posterior portions of the disks are slightly larger than the anterior. The right valve interspaces have imbricated, concentric lamellae; near the ventral margin the ribs and interspaces are crossed by looped concentric lamellae. The left valve has imbricated, concentric lamellae that lap up onto the sides of the ribs but are absent on the tops. Near the ventral margin looped, concentric lamellae cross both the ribs and the interspaces.

Geographic range.-Southern California to Baja California Sur. Geologic range.-Pliocene to Pleistocene.

Occurrence in the Californias.-Pliocene: Almejas (Minch and others, 1976), Gloria (Vokes, 1955), Infierno (Wilson, 1948; Vokes, 
1955), Niguel (J. G. Vedder, written commun., 1978), and San Diego (Hertlein and Grant, 1972) Formations; Pliocene and Pleistocene: Fernando (Hertlein and Grant, 1972) and Pico (Jordan and Hertlein, 1926b) Formations.

\section{Argopecten evermanni (Jordan and Hertlein)}

\section{Plate 13, figure 7}

Pecten (Plagioctenium) evermanni Jordan and Hertlein, 1926b, p. 439-440, pl. 27, fig. 1.

Pecten (Aequipecten) evermanni Jordan and Hertlein. Grant and Gale, 1931, p. 207.

Original description. - "Shell large, thick, moderately inflated. Right valve ornamented by 30 or 31 , flattish topped, equal, radiating ribs, separated by narrow, slightly rounded interspaces crossed by concentric lines of grow th and the sides of ribs fringed by concentric lamellae; anterior ear sculptured by about four radiating ribs, a very prominent thickening at base of ear; posterior ear somewhat similar to anterior in ornamentation, but without any large ridge at base. Length about $125 \mathrm{~mm}$.; height $115 \mathrm{~mm}$.; apical angle $108^{\circ}$."

Holotype.-CAS 2108.

Type locality.-CAS 928. Baja California Norte. Almejas Formation. Pliocene.

Comparison. - "P. evermanni differs from P. hakei Hertlein in possessing more numerous ribs which are flatter and much closer together. From P. purpuratus Lamarck, $P$. evermanni can be distinguished by the much greater number of ribs in the new species." (Jordan and Hertlein, 1926b, p. 440)

Comments. - The holotype is an incomplete, very thick, right valve. The ribs are closely spaced, separated by narrow, deep, Vshaped interspaces, and crossed by looped, concentric lamellae. The auricles are incomplete.

Geographic range.-Baja California Norte.

Geologic range.-Pliocene.

Occurrence in Baja California.-Almejas Formation.

\section{Argopecten percarus (Hertlein)}

Plate 10, figure 6; plate 12, figure 4

Pecten (A equipecten) percarus Hertlein, 1925a, p. 13-14, pl. 2, figs. 2, 5. Jordan and Hertlein, 1926b, p. 435.

Pecten (Aequipecten) purpuratus Lamarck var. percarus Hertlein. Grant and Gale, 1931, p. 210.

Original description. - "Shell moderately large, equilateral, subequivalve. moderately thin, somewhat compressed, the outline round. Right valve ornamented by about 22 moderately strong, rounded ribs, separated by round-bottomed interspaces which are not quite as wide as the ribs; ribs and interspaces sculptured by regular, wavy, incremental lines, and, at irregular intervals, by stronger lines of growth; hinge line about one-half as long as the disk and slightly indented at the beaks; ears unequal, the anterior with a large byssal notch and sculpture consisting of about six or seven radiating riblets, the posterior ear ornamented by about seven radiating riblets, both ears sculptured by incremental lines. Left valve more arched and sharper at umbo than right, and somewhat one-sided in appearance, the disk ornamented by about 25 or 26 rounded, radiating ribs, and also concentrically sculptured much as on right valve; ears ornamented by about six or seven radiating ribs, crossed by concentric incremental lines; ears slightly concave, anterior with a slight byssal notch. Altitude $82 \mathrm{~mm}$.; longitude $91 \mathrm{~mm}$.; diameter approximately $12 \mathrm{~mm}$.; apical angle of valves approximately $118^{\circ} . "$
Holotype.-CAS/SU 42.

Type locality.-SU 48. Baja California Sur. Almejas Formation, Pliocene.

Comparison.- "Pecten percarus is distinguished from other west American Aequipectens by its large size, number of ribs, and its clear concentric incremental lines." (Hertlein, 1925a, p. 14)

Comments. - The holotype is a large, thin-shelled, almost flat, inequilateral right valve. It has 20 low, rounded ribs separated by rounded, somewhat narrower interspaces. Prominent, looped, concentric lamellae cross both the ribs and interspaces. The left-valve paratype is moderately inflated, inequilateral, and has 24 low, subrounded ribs separated by rounded, narrower interspaces. The valve bears concentric, looped, lamellae. In addition to the characters mentioned by Hertlein (1925a, p. 14), this species is distinguished by the almost flat right valve.

Geographic range.-Baja California Peninsula.

Geologic range.-Pliocene.

Occurrence in Baja California.-Almejas Formation (Minch and others, 1976).

\section{Argopecten hakei (Hertlein)}

\section{Plate 11, figure 6}

Pecten (Plagioctenium) hakei Hertlein, 1925a, p. 18-19, pl. 4, figs. 1, 3. Jordan and Hertlein, 1926b, p. 440-441, pl. 31, figs. 1, 2

Pecten (Aequipecten) purpuratus Lamarck variety hakei Hertlein. Grant and Gale, 1931, p. 209, pl. 8, fig. 3 .

Chlamys (Argopecten) hakei Hertlein. Hertlein and Grant, 1972, p. 199-200, pl. 33, fig. 10

Original description. - "Shell moderately arched, coarse and thick, slightly longer than high. Right valve ornamented by about 23 or 24 rounded to slightly flat-topped ribs, separated by narrower, round-bottomed interspaces, both the interspaces and ribs crossed by concentric incremental lines, and, in some cases, by ráther strong lines of growth; anterior ear with a large byssal notch, and sculpture consisting of about five or six radiating riblets, crossed by concentric incremental lines; anterior and posterior margins of valves smooth except for concentric incremental lines; ventral margin rounded; posterior ear ornamented by about eight radiating riblets and by lines of growth, the posterior edge of the ear forming nearly a right angle with the hinge line. Left valve convex, higher at the umbo than the right valve, and ornamented by about 24 or 25 squarish, flattopped, rounded ribs, separated by narrower, round-bottomed interspaces, the whole valve sculptured by concentric lines of growth; ears slightly concave, ornamented by about six or seven radiating riblets. Altitude $90 \mathrm{~mm}$., longitude $95 \mathrm{~mm}$.; diameter of right valve approximately $15 \mathrm{~mm}$.; apical angle of right valve approximately $114^{\circ}$.

Holotype.-CAS/SU 40.

Type locality.-SU 47. Baja California Sur. Almejas Formation, Pliocene.

Supplementary description. - "This species is characterized by its large, thick, coarse valves which are sculptured with 24 to 27 subrounded radial ribs." (Hertlein and Grant, 1972, p. 200)

Comparison. - "The shell of this species can be separated from other somewhat similar west American species of Argopecten by its large size when adult and by the more numerous subrounded radial ribs. In the number of ribs it is exceeded by Chlamys (Argopecten) evermanni $\mathrm{E}$. K. Jordan and Hertlein *** which has 30 to 31 flattish topped ribs separated by very narrow interspaces. Chlamys hakei differs from C. cristobalensis Hertlein in the much wider and less elevated ribs. Chlamys hakei differs from C. purpurata Lamarck now living from Paita, Peru, to Valparaiso, Chile, in the generally 
larger size, larger ears, generally more numerous, rounded ribs which are separated by narrower interspaces. The ribs on the right valve of $C$. purpurata are flat-topped and on both valves the ribs are separated by rather deeply grooved interspaces, those on large left valves often with an interstitial riblet.

"Chlamys hakei can be easily separated from Chlamys (Lyropecten) cerrosensis by the more numerous ribs, lack of coarse hinge teeth, lack of midrib in interspaces and also by the fact that the ears on the left valve slope downward from the margin rather than forming a right angle." (Hertlein and Grant, 1972, p. 200)

Comments. - The right valve holotype is large, heavy-shelled, and has low subrounded radial ribs separated by rather shallow interspaces, half the width of the ribs; both the ribs and the interspaces are crossed by looped concentric lamellae.

Geographic range.-Southern California to Baja California Sur. Geologic range.-Pliocene.

Occurrence in the Californias.-Almejas (Minch and others, 1976) and San Diego (Hertlein and Grant, 1972) Formations.

\section{Argopecten revellei (Durham)}

\author{
Plate 11, figures 1, 3
}

Aequipecten revellei Durham, 1950, p. 63-64, pl. 9, figs. 3, 6, 9. Chlamys revellei Durham. Emerson and Hertlein, 1964, p. 345-346, 349.

Chlamys (Argopecten) revellei Durham. Hertlein, 1966, p. 280, 282, fig. 10.

Original description.-"Shell of medium size [ $57 \mathrm{~mm}$ long, $55 \mathrm{~mm}$ high], equivalved, beaks low, not prominent, very similar to $A$. subdolus (Hertlein); right valve with 22-23 low rounded ribs with very narrow $\mathrm{V}$-shaped interspaces; left valve with corresponding ribs but wider interspaces; anterior ear of right valve with a moderately developed byssal notch and about four fairly wide radial ribs; posterior ear with numerous fine radial ribs, becoming obsolete near hinge line; ears of left valve correspondingly ornamented; hinge line between seven-twelfths and two-thirds the length of the shell, thus separating this species from $A$. subdolus (Hertlein) which has a hinge line only very slightly over half as long as the length of the shell."

Holotype.-UCMP 15510.

Type locality.-UC A3566. Isla Monserrate, Baja California Sur. Salada Formation, Pliocene.

Comparison.-"This species is very similar to the species described as Pecten (Plagioctenium) subdolus Hertlein ***. It differs from that species chiefly in the more circular outline and in that the hinge line (41 $\mathrm{mm}$. long) is longer in proportion to the length of the valves." (Hertlein, 1966, p. 282)

Comments. - The holotype is a moderate-sized, thick-shelled, double valve. The right valve has 22 almost flat ribs separated by narrow grooves, and the surface is sculptured by looped, concentric lamellae. The left valve is inequilateral and has slightly higher ribs, a few subtrigonal, and some grooved along the sides, and narrow interspaces. The left valve has strong, concentric, looped lamellae. The right-valve ribs on $A$. revelle $i$ are wider and fewer in number $(22$ rather than 29) than on A. evermanni. The right valve of $A$. revelle $i$ is much more inflated than is $A$. subdolus, and the left valve has wider and more closely spaced ribs than $A$. subdolus.

Geographic range.-Baja California Sur to Mexico.

Geologic range.-Pliocene.

Occurrence in Baja California.-Carmen (Durham, 1950), Gloria
(Stump, 1979), and Salada Formations.

\section{Argopecten cristobalensis (Hertlein)}

\author{
Plate 13, figure 1
}

Pecten (Plagioctenium) cristobalensis Hertlein, 1925a, p. 19-20, pl. 3 , figs. 1, 2, 5 .

Chlamys (Argopecten) cristobalensis Hertlein. Hertlein and Grant, 1972, p. 200.

Original description. - "Shell large, fairly thick, in several specimens with strong lines of restricted growth; valves moderately arched. Right valve ornamented by about 24 flat-topped, squarish, radiating ribs, separated by flat-bottomed, slightly narrower, interspaces, the whole surface crossed by well defined, wavy, concentric lines of growth; anterior and posterior margins of valve smooth except for concentric incremental sculpture; ventral margin evenly rounded; ears unequal, the anterior ear with a large byssal notch, and ornamented by about five radiating riblets crossed by concentric lines of growth; the posterior ear also bearing about five or six radiating riblets crossed by growth lines. Left valve slightly more convex than right and sculptured much as the latter, the anterior and posterior margins with concentric lines of growth only; ears ornamented by about eight or nine radiating riblets, the anterior ear with a slight notch. Altitude $117 \mathrm{~mm}$; longitude $135 \mathrm{~mm}$.; diameter right valve approximately $17 \mathrm{~mm}$.; apical angle of right valve approximately $100^{\circ}-110^{\circ}$."

Holotype.CAS/SU 36.

Type locality.-SU 49. Baja California Sur. Almejas Formation, Pliocene.

Supplementary description. - " $P$. cristobalensis is easily recognized by its numerous, high, rather narrow, square ribs, separated by deep, square interspaces, and by the presence of unusually strong, sharp concentric lamellae ornamenting the bottoms of the interspaces and the sides of the ribs." (Jordan and Hertlein, 1926b, p. 439)

Comparison.-"Pecten cristobalensis is distinguished from P. cerrosensis mendenhalli Arnold [Lyropecten], by its squarish, more numerous ribs. The greater number of radial, squarish ribs, separated by narrower interspaces, and the less strong development of concentric incremental lines, distinguish the present species from $P$. cerrosensis Gabb proper. P. cristobalensis has a large byssal notch in the anterior ear of the right valve, and the ears are more strongly sculptured by radiating riblets than in $P$. cerrosensis in which the byssal notch is very slight, and, except for lines of growth, the ears are smooth. From $P$. callidus Hertlein, $P$. cristobalensis differs in the more numerous ribs, different ears, and rounder outline. The distinction between the present species and $P$. purpuratus Lamarck is based largely upon the character of the radial ribs and of the anterior ear of the right valve. The ribs of $P$. purpuratus are wider and lower than those of $P$. cristobalensis; and conversely, the interspaces are narrower in $P$. purpuratus; furthermore the ribs of the latter species expand much more rapidly toward the ventral margin than do those of $P$. cristobalensis. The lateral serrations on the radial ribs, so strongly developed in Lamarck's species, are very slight in the present form. The presence of three very strong ribs on anterior ear of right valve of $P$. purpuratus with only a vestige of a fourth, rather than five less strong riblets as in $P$. cristobalensis, is also an evident and apparently constant difference." (Hertlein, 1925a, p. 20)

"Chlamys hakei differs from C. cristobalensis *** in the much wider and less elevated ribs." (Hertlein and Grant, 1972, p. 200)

Comments.-The holotype is a moderately large, thick-shelled, 
right valve that has heavy, square ribs and square interspaces that are half as wide. Looped, concentric lamellae cross the ribs and interspaces on the ventral half of the disk.

Geographic range.-Isla Cedros to Bahia Tortugas, Baja California Peninsula.

Geologic range.-Pliocene.

Occurrence in Baja California.-Almejas Formation (Minch and others, 1976).

\section{Argopecten abietis abietis (Jordan and Hertlein)}

\section{Plate 11, figure 2; plate 12, figure 3}

Pecten (Plagioctenium) abietis Jordan and Hertlein, 1926a, p. 214215 , pl. 23, figs. $1,3,7$.

Aequipecten abietis (Jordan and Hertlein). Durham, 1950, p. 62, pl. 10, figs. 4, 7; pl. 11, fig. 4.

Chlamys (Argopecten) abietis E. K. Jordan and Hertlein. Emerson and Hertlein, 1964, p. 349, 354, figs. 4a-e. Hertlein, 1966, p. 278 , 280, fig. 15.

Original description.- - "Shell averaging about 45 millimeters in altitude, about as long as high, fairly thick and solid, somewhat produced posteriorly. Right valve ornamented by 19-21 subtriangular ribs, in adults becoming flattened toward the margin, separated by sharp, narrow-bottomed interspaces, the sides of the ribs and interspaces decorated by sharp, close-set fringing lamellae; hinge line about two-thirds the length of disk; ears about equal in length, rather large, the anterior ear ornamented by about four rather faint radial ribs crossed by concentric lines of growth, the byssal notch well defined; posterior ear faintly radially and concentrically sculptured. Left valve with the ribs more pronouncedly triangular in cross-section, the sides densely fringed with lamellae; ears similar to those of right valve, but the byssal notch on anterior ear less developed; hinge strong; cardinal crura well developed. Altitude $45 \mathrm{~mm}$.; longitude $46 \mathrm{~mm}$.; diameter of left valve about 32 mm.: apical angle about $100^{\circ}$."

Holotype.-CAS 2079.

Type locality.-CAS 937. Isla Maria Madre, Mexico. Unnamed Pliocene strata.

Supplementary description. - "The radial ribs of this species are triangular to subtriangular in cross-section, especially in the early stage of growth. These are separated by narrow interspaces and the sides of the ribs and the interspaces are covered with a dense fringe of concentric lamellae." (Hertlein, 1966, p. 280)

"In some well-preserved specimens $* * *$ the byssal notch is extremely shallow, in others it is of the normal type. Two individuals $* * *$ have much higher ribs than the average. $* * *$ many small specimens have the $\mathrm{V}$-shaped ribs flat-topped, but on the larger individuals these ribs grade into those of the typical form." (Durham, 1950, p. 62)

Comparison. - "This species is closely related to $P$. circularis, but is distinguishable by the character of the ribbing. The ribs of $P$. abietis are wide at the base, and are triangular or subtriangular in cross-section. The interspaces are very narrow, and the sides of the ribs and interspaces are covered by a dense fringe of concentric lamellae. The ribs of $P$. circularis are distinctly rounder and much narrower in cross section, and the interspaces are much wider." (Jordan and Hertlein, 1926a, p. 214)

"The byssal notch varies somewhat in depth but is never so deep as in the living Pecten purpuratus or Pecten circularis; further, the anterior ear is not so produced in proportion to its width as in those two species. The ribs normally have a low V-shaped profile, thus differing from the two aforementioned living forms in which the sides of the ribs are nearly vertical.

"A few specimens *** are very close to Pecten mendenhalli Arnold, but the rest are more typical of $A$. abietis. It is possible that additional collecting at Santa Rosalia (type locality for P. mendenhalli) may show that the two species are the same." (Durham, 1950, p. 62) Argopecten abietis abbotti differs from $A$. abbotti "in the deeper notch under the right anterior ear, in the more widely spaced ribs and by the more flattened character of the ribs toward the ventral margin of the left valve." (Hertlein and Grant, 1972, p. 196-197)

Comments.-The holotype is a thick-shelled left valve with 19 triangular ribs separated by narrow, shallow interspaces bearing looped, concentric lamellae. The right-valve paratype, figured herein, is thick shelled and has 19 subrounded ribs with narrow, shallow interspaces. Looped, concentric lamellae can be seen on the ribs and interspaces near the ventral margin.

Geographic range.-Baja California Sur to Isla Maria Madre, Mexico.

Geologic range.-Pliocene.

Waller (196, p. 55) notes that his Argopecten species $a$, from the Miocene in Florida, is similar to A. abietis and says that: "Because faunal interchange between the Atlantic-Caribbean and Pacific is generally accepted during the Miocene and Pliocene, Argopecten species $a$ may be conspecific with a Pacific form."

Occurrence in Baja California.-Carmen (Durham, 1950), Gloria (Stump, 1979), Infierno (Stump, 1979), Marquer, and San Marcos Formations (Durham, 1950).

\section{Argopecten antonitaensis (Durham)}

Plate 11, figures 4, 5

Aequipecten antonitaensis Durham, 1950, p. 62, pl. 9, figs. 1, 5 . Original description.-"Shell small, resembling $A$. percarus (Hertlein); moderately convex, nearly equivalved; ornamented by 22 moderately high, rounded ribs with nearly vertical sides; on right valve interspaces about half as wide as ribs, on left valve equal in width to ribs; radial ribs crossed by fine concentric growth lines; extreme lateral margins smooth; hinge line 0.6 length of shell; ears unequal, elongate, anterior slightly longer than posterior; a large byssal notch in right valve; anterior ear of left valve decidedly alate; posterior ears slightly drawn out; anterior ear with about 7 radial ribs, posterior ear with about $8 . "$

Holotype.-CAS 5957.

Type locality.-CAS 795. Baja California Sur. Carmen Formation, Pliocene.

Supplementary description. - "The long narrow anterior ear with that of the left valve being drawn out is very characteristic." (Durham, 1950, p. 62)

Comparison. - "The ears [of $A$. antonitaensis] suggest $A$. percarus (Hertlein) but are longer in proportion to length of shell. It is also similar to some specimens of $A$. impostor (Hanna) but may be separated by the more produced posterior ears of the present species." (Durham, 1950, p. 62)

Comments. - The holotype is a rather small, inequilateral, doublevalved specimen with a moderately thick shell. The right valve has imbricated, concentric lamellae on both the ribs and interspaces and looped concentric lamellae near the ventral margin; the left valve is sculptured like the right. The left anterior auricle is long and deeply notched.

Geographic range.-Baja California Sur.

Geologic range.-Pliocene.

Occurrence in Baja California.-Carmen Formation. 


\section{Argopecten abietis abbotti (Hertlein and Grant)}

\section{Plate 12, figures 1,5}

Chlamys (Argopecten) abietis abbotti Hertlein and Grant, 1972, p. 196-197, pl. 34, fig. 5; pl. 36, figs. $1,6$.

Original description.-"Shell large, thick, both valves highly convex, somewhat elongated posteriorly; hinge line long, a little over two thirds the length of the valves. Right valve with 21 radial ribs which are high, narrowly flat-topped and steeply sloping until the valve is about $70 \mathrm{~mm}$ high, then becoming lower and broadly rounded; the sides of the ribs and the interspaces are ornamented with close-set fringing lamellae; anterior ear sculptured with 4 or 5 fine radial riblets, a well developed byssal notch present; posterior ear faintly radially striated and with lines of growth which reveal a shallow sinuation. Left valve with a ribbing similar to that of the right except that the ribs are narrower and more triangular, the anterior ear with a shallower notch and with faint traces of fine riblets. Inner margin of valves scalloped by the corresponding ribs and interspaces on the exterior. Dimensions: length $129.0 \mathrm{~mm}$, height $118.0 \mathrm{~mm}$, convexity (both valves together), $64.0 \mathrm{~mm}$, length of hinge line $88.0 \mathrm{~mm}$."

Holotype.-SDNM 04334.

Type locality.-From cut in exposure at Frontier Housing Project, Loma Portal, San Diego, San Diego County, Calif. San Diego Formation, Pliocene.

Comparison. - "The shell characters of this new subspecies appear to be intermediate between those of Chlamys (Argopecten) abietis E. K. Jordan and Hertlein *** and those of $C$. (A.) aequisulcata Carpenter $* * *$. This new subspecies differs from $C$. (A.) abietis in the deeper notch under the right anterior ear, in the more widely spaced ribs and by the more flattened character of the ribs toward the ventral margin of the left valve. It differs from $C$. (A.) circularis aequisulcata in the larger, thicker shell, longer hinge line, more triangular shape of the ribs in the early stages of growth but which become rounded and flattened toward the ventral margin on the right valve, and also in the more highly convex left valve with narrower interspaces between the ribs.

"The rotund appearance of large specimens of this new subspecies lends a general resemblance to $C$. (A.) hakei Hertlein but it may be separated from that species by the fewer ribs (21 or 22 rather than 24 to 27) which are triangular until the shell is about $70 \mathrm{~mm}$ high and then become broader and flatter toward the ventral margin." (Hertlein and Grant, 1972, p. 196-197)

Geographic range.-Southern California:

Geologic range.-Pliocene to Pleistocene.

Occurrence in California.-Pliocene: San Diego Formation; Pleistocene: Las Posas Formation (Hertlein and Grant, 1972).

\section{Genus ARGOPECTEN? \\ Argopecten? crassiradiatus (Clark)}

\section{Plate 10, figure 8}

Pecten (Plagioctenium?) crassiradiatus Clark, 1915, p. 450, pl. 47, fig. 7.

Original description. - "Shell medium in size; fairly heavy; apical angle about $98^{\circ}$; height about equal to the length; dorsal edges nearly straight. Hinge plate over half the length of the shell. Right valve sculptured by sixteen heavy, broadly rounded, radiating ribs, which become somewhat narrower near the margins; interspaces very narrow and deep. Dorsal margins rather strongly depressed, the depressed area being narrow and without ribs. Anterior ear longer than posterior, deeply notched with anterior edge gently convex, sculptured by four fairly heavy radiating ribs. Left valve unknown."

Holotype.-UCMP 11584.

Type locality.-UC 367. Contra Costa County, Calif. [Locality description not available.] Cierbo Sandstone, Miocene.

Comments. - The holotype is a thick-shelled, incomplete, slightly inflated right valve with 14 wide, smooth, closely spaced radial ribs, separated by very narrow, deep interspaces. The right anterior auricle bears 4 riblets; the right posterior auricle is missing. The ribs on $A . ?$ crassiradiatus are more closely spaced than on $A$. cristobalensis, higher and more closely spaced than on $A$. hakei, and higher than on $A$. evermanni.

Geographic range.-Known only from the type locality, middle California.

Geologic range.-Miocene.

Occurrence in California.-Cierbo Sandstone.

\section{Genus ANTIPECTEN Cossmann, 1914}

Right valve nearly flat, left valve convex; auricles very large, hinge line oblique.

Differs from Aequipecten in the obliquity of the hinge line, larger auricles, and in the unequal size of the ribs of the left valve. Differs from Leptopecten in having a thick shell, higher ribs, and secondary riblets on both the ribs and interspaces of the left valve and on the ribs of the right valve. Differs from Pacipecten in having higher posterior auricles and secondary riblets on the ribs and interspaces of the left valve and on the ribs of the right valve. Differs from Fortipecten in having an oblique hinge line and in that the umbo of the right valve does not overhang the left valve.

Geographic range.-France; Baja California Sur?

Geologic range.-Miocene; Pliocene(?).

\section{Genus ANTIPECTEN?}

\section{Antipecten? praevalidus (Jordan and Hertlein)}

Plate 13, figures 2, 4, 5

Pecten (Leptopecten) praevalidus Jordan and Hertlein, 1926b, p. $435-436$, pl. 29 , figs. $2,3$.

Pecten (Aequipecten) praevalidus Jordan and Hertlein. Grant and Gale, 1931, p. 206.

Original description. - "Shell of moderate size, somewhat inflated, elongated posteriorly giving an oblique outline, the hinge line fourfifths the length of the shell. Right valve nearly flat, ornamented by about 13 or 14 flat-topped radiating ribs which are often longitudinally sculptured by one or two slight sulci; ribs separated by interspaces about as wide as the ribs, the bottoms of some of the interspaces lightly, longitudinally striate; anterior ear large, cut by a large byssal notch, and ornamented by four or five radiating ribs crossed by concentric lines of growth; left ear larger than right, sloping acutely from hinge line to posterior margin of shell, ornamented by six to nine unequal radiating riblets. Left valve somewhat more arched than right, ornamented by 15 or 16 moderately rounded radiating ribs some of which show a fairly well defined medial sulcus; interspaces as wide as ribs; both ribs and interspaces finely longitudinally striate, and crossed by concentric lines of growth; ears much as those of right valve, and similarly ornamented, except that the anterior ear of the left, carries six or seven radiating riblets between which are intercalated minute raised lines. Length $50 \mathrm{~mm}$.; height $48 \mathrm{~mm}$.; diameter approximately $15 \mathrm{~mm}$.; length of hinge line approximately $40 \mathrm{~mm}$.; apical angle $103^{\circ}$."

Holotype.-CAS 2101. 
Type locality.-CAS 945. Baja California Sur. Almejas Formation, Pliocene.

Supplementary description.- "The large size, the flattish right valve, the flat-topped ribs of the right valve and the striations of the ribs of both valves characterize this large Leptopecten. Some specimens attain a length of about $70 \mathrm{~mm}$., and a height of about $60 \mathrm{~mm}$. or more." (Jordan and Hertlein, 1926b, p. 436)

Comparison. - "Like typical Pecten latiauratus Conrad but about twice as large and with distinct radial striation on the ribs and interspaces; ears as in tumbezensis." (Grant and Gale, 1931, p. 206)

Comments. - Antipecten? praevalidus does not resemble any of the other pectinids described from the eastern Pacific. It resembles Aequipecten only in the secondary sculpture of riblets on the ribs and interspaces of the left valve and on the ribs of the right valve. It resembles Leptopecten only in the obliquity of the shell and the high posterior auricles. It has a moderately thick shell like Pacipecten but is more oblique and bears secondary riblets. It differs from Antipecten in having a straight hinge line that is shorter, but in other characters it is surprisingly similar. Hertlein and Grant (1972, p. 203) noted the "remarkable" resemblance of this species to Chlamys sacyi Cossmann and Peyrot, the type species of Antipecten from the Miocene of France. I have placed A.? praevalidus tentatively in Antipecten to call attention to its similarity to that genus and to its uniqueness.

Geographic range.-Baja California Sur.

Geologic range.-Pliocene.

Occurrence in Baja California-Almejas (Minch and others, 1976) and Gloria (Stump, 1979) Formations.

\section{Genus LEPTOPECTEN Verrill, 1897}

Small, thin, very oblique, only slightly convex, ribs narrow with wider interspaces; cardinal crura small, hinge plate crossed by fine transverse grooves. Pacipecten is more equilateral in form and has a thicker shell than Leptopecten.

Geographic range.-North and South America.

Geologic range.-Miocene through Holocene (table 8).

\section{Leptopecten bellilamellatus (Arnold)}

Plate 13, figures 3, 6

Pecten (Chlamys) bellilamellatus Arnold, 1906, p. 108, pl. 41, figs. 6 , 6a, 7, 7a.

Pecten (Aequipecten) bellilamellatus Arnold. Grant and Gale, 1931, p. 205.

Chlamys (Leptopecten) bellilamellata Arnold. Hertlein and Grant, 1972 , p. 203, pl. 32, figs. $1,2,8$.

Original description. - "Shell averaging about 18 millimeters in altitude, about as long as high, equivalve, both valves moderately convex, inequilateral; sides nearly straight; margins not serrate.
Right valve with 15 or 16 prominent narrow, sharply convex-topped ribs with sloping sides; interspaces much wider than ribs, with narrow, flat bottoms; surface sculptured by numerous, regular, equidistant, thin, concentric, imbricating lamellae, which cut squarely across the bottoms of the interspaces, curve convexly toward the umbo on the sides of the ribs, and loop gracefully downward away from the umbo on the tops; hinge line equal to the length of the disk; ears equal in length; anterior ear convexly truncated, separated from the disk by a deep, sharply defined, byssal notch, and sculptured by fine, regular, incremental lamellae and five or six subequal radials; posterior ear acutely pointed, radially striate, and with incremental sculpture similar to but not quite as prominent as that of the anterior. Left valve similar to right; anterior ear more prominently sculptured, both radially and concentrically, than the posterior."

\section{Holotype.-CAS/SU 35.}

Type locality.-Pacific Beach, San Diego, San Diego County, Calif. San Diego Formation, Pliocene.

Comparison.-The small size, long hinge line, narrow, sharply topped ribs, and beautifully curved incremental lamellae are characters which separate $L$. bellilamellatus from $L$. latiaurata and $L$. delosi (Arnold). (Arnold, 1906, p. 108)

Comments. The holotype is a very small, thin-shelled, doublevalved specimen. The hinge line is almost as long as the valve. The entire surface of the right-valve disk bears imbricated, concentric lamellae. The lamellae are at right angles to the ribs in the bottom of the interspaces, loop up toward the dorsal margin on the sides of the ribs, and then loop down toward the ventral margin on the tops of the ribs. A ctenolium is exposed along the junction of the right auricle and the disk. The left valve ribs are identical to those on the right valve, but the microsculpture is barely visible.

Geographic range.-Middle California to Baja California Sur.

Geologic range.-Miocene to Pleistocene.

Occurrence in the Californias.-Miocene and Pliocene: Purisima Formation (Arnold, 1906); Pliocene: Almejas (Minch and others, 1976) and San Diego (Hertlein and Grant, 1972) Formations; Pliocene and Pleistocene: Merced Formation (Arnold, 1906).

\section{Leptopecten latiauratus (Conrad)}

\section{Plate 15, figures 7, 9}

Pecten latiauratus Conrad, 1837, p. 238, pl. 18, fig. 9.

Leptopecten latiauratus (Conrad). Woodring, 1946, p. 81. Clark, 1971, p. 269-272, figs. 0369, 0372, 0373, 0380, 0459.

Chlamys (Leptopecten) latiaurata (Conrad). Grau, 1959, p. 107-110, pl. 35 , fig. 1.

Not? Chlamys (Leptopecten) latiaurata Conrad. Hertlein and Grant, 1972, p. 203-204, pl. 35, figs. 1,3 .

Original description.-"Shell inequilateral, thin, compressed; ribs fourteen, flattened on the back, slightly sulcated; interstices

TABLE 8.-Geologic and geographic distribution of the genus Leptopecten in the eastern

Pacific region

$[\mathrm{H}=$ Holocene: $\mathrm{P}] \mathrm{e}=$ Pleistocene: $\mathrm{Pl}=$ Pliocene: $\mathrm{M}=$ Miocene $]$

\begin{tabular}{|c|c|c|c|c|c|}
\hline \multirow{2}{*}{ Species } & \multicolumn{3}{|c|}{ California } & \multicolumn{2}{|c|}{$\begin{array}{c}\text { Baja } \\
\text { California }\end{array}$} \\
\hline & Northern & Middle & Southern & Norte & Sur \\
\hline 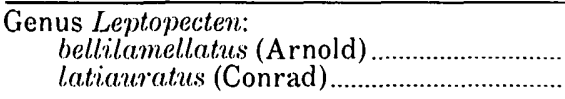 & $\ldots \ldots$. & $\begin{array}{l}\mathrm{M} \text { to } \mathrm{Ple} \\
\mathrm{M} \text { to } \mathrm{H}\end{array}$ & $\begin{array}{c}\mathrm{Pl} \\
\mathrm{Pl} \text { to } \mathrm{H}\end{array}$ & $\cdots$ & $\begin{array}{c}\mathrm{Pl} \\
\mathrm{Pl} \text { to } \mathrm{H}\end{array}$ \\
\hline
\end{tabular}


transversely striated; ears very wide, unequal, both acutely angulated at the extremity; colour reddish brown and white, variegated or spotted."

Syntypes.-BM (NH) 55.3.14.53 and 61.5.20.89 (Keen, 1966).

Type locality.- "Inhabits below the efflux of the tide near Sta. Diego and Sta. Barbara." The type locality has been cited as "San Diego, California" by some authors, such as Grant and Gale (1931, p. 203) and Grau (1959, p. 109), but none formally designated.

Supplementary description.-" P. latiauritus is found living attached to kelp, those specimens inhabiting the deeper, quieter waters being less strongly sculptured than those which are subjected to a more strenuous existence nearer the shore." (Arnold, 1906, p. 116)

"Shell rather thin, slightly oblique and moderately convex; equilateral or nearly so; adult specimens averaging $20 \mathrm{~mm}$ in height and length. Hinge line almost always longer than disk in juvenile stage; in adult stage infrequently longer, usually slightly shorter. Both valves with 12 to 16 rounded ribs (actually corrugations of disk), rather flat on top and occasionally with a central groove; interspaces about same width as ribs and in some specimens having one or two low radial ridges; concentric lamellae covering disk, quite profuse in juvenile stage but less prominent in adult. Anterior auricles longer than posterior, former projecting beyond margin of disk, latter seldom reaching to margin; anterior auricle of right valve having 4 to 7 imbricated riblets, other auricles having 4 to 8 riblets and fine concentric lamellae. Reverse surfaces of interspaces flat and angulated." (Grau, 1959, p. 109)

"A series of specimens reveals that the number of ribs may vary from 12 to 16 . Some of these may be faintly medially sulcated. A faint intercalary riblet may be present in the interspaces especially on large specimens." (Hertlein and Grant, 1972, p. 204)

Comparison.- "Chlamys (Leptopecten) latiaurata differs from $C$. (L.) monotimeris Conrad in the squarish ribs rather than rounded undulations of the shell." (Hertlein and Grant, 1972, p. 204)

"This species differs from its subspecies monotimeris in having a thicker shell, longer hinge line, acutely pointed auricles, less pronounced obliquity, higher and narrower ribs, and concentric lamellae on the disks." (Grau, 1959, p. 110)

"The variety $L$. latiauratus cerritensis ('fragilis'), based on material from the Palos Verdes sand, has fewer and wider ribs than $L$. latiauritus proper. The variety L. latiauratus delosi, based on material from the San Pedro sand, has strong concentric lamellae." (Woodring, 1946, p. 81)

Comments. - The specimen figured by Hertlein and Grant (1972, pl. 35, figs. 1, 3) as Chlamys (Leptopecten) latiaurata is similar to
Pacipecten tumbezensis. It differs from L. latiaurata in not being oblique and in having a shorter right anterior auricle and smaller right posterior auricle than is common for L. latiaurata.

Geographic range.-Living: Point Reyes, Calif., to Cabo San Lucas, Baja California Sur and Guadalupe Island; fossil: middle California to Baja California Sur.

Geologic range.-Miocene through Holocene.

Occurrence in the Californias.-Miocene and Pliocene: Purisima Formation (Arnold, 1906); Pliocene: Almejas Formation (Minch and others, 1976), Lomita Marl Member, San Pedro Formation (Woodring, 1946), and unnamed Pliocene strata of northern Santa Clara County (Addicott, 1969); Pliocene and Pleistocene: Fernando (Woodring, 1931; Kennedy, 1975) and Merced (Arnold, 1906) Formations; Pleistocene: Timms Point Silt Member, San Pedro Formation (Woodring, 1946), and unnamed strata of Baja California Norte (Valentine, 1957).

Habitat. - "Found attached to rocks or pilings in shallow water; in deeper water on rock, shale, gravel or sand bottoms, often attached to calcareous algae." (Grau, 1959, p. 110)

"Leptopecten *** latiaurata, commonly known as 'kelp-pecten,' occurs at many places along the coast of southern California attached by its byssus to vegetable growths, pilings, or rocks. It occurs in shallow water but it has been taken at a depth of 229 meters. $* * *$ It reaches maturity in about 9 to 12 months and in that period of time attains a length of about $32 \mathrm{~mm}$.

"Formerly it flourished in the still, warm waters of Mission Bay, San Diego Co., where it lived attached to Zostera." (Hertlein and Grant, 1972, p. 204)

Clark (1971, p. 271-272) says that "there seems to be little doubt that environmental factors can have a profound influence on the morphological characteristics of the shell of a bivalved mollusk" and that, although far from definitive, his observations "strongly suggest that the difference in temperature is the major cause of the differences in morphology" between L. latiauratus and L. monotimeris.

\section{Genus PACIPECTEN Olsson, 1961}

Shell with rounded, flat-topped, or triangular ribs; interspaces as wide or wider. Auricles large, posterior ones spreading, the right anterior long and narrow with a deep byssal notch bordered by a few ctenolial teeth. Differs from Leptopecten in its more equilateral form, longer anterior auricle with deeper byssal notch, and heavier shell.

Geographic range.-Eastern Pacific.

Geologic range.-Miocene through Holocene (table 9).

TABLE 9.-Geologic and geographic distribution of the genus Pacipecten in the eastern Pacific region $[\mathrm{H}=$ Holocene; $\mathrm{P}]=$ Pliocene; $\mathrm{M}=$ Miocene; $\mathrm{O}=$ Oligocene $]$

\begin{tabular}{|c|c|c|c|c|c|c|}
\hline \multirow{2}{*}{ Species } & \multicolumn{3}{|c|}{ California } & \multicolumn{2}{|c|}{$\begin{array}{c}\text { Baja } \\
\text { California }\end{array}$} & \multirow{2}{*}{$\begin{array}{l}\text { Central } \\
\text { and (or) } \\
\text { South } \\
\text { America }\end{array}$} \\
\hline & Northern & Middle & Southern & Norte & Sur & \\
\hline \multicolumn{7}{|l|}{ Genus Pacipecten: } \\
\hline andersoni andersoni (Arnold) & ....... & $\mathrm{M}$ & M & M & M & ...... \\
\hline $\begin{array}{l}\text { andersoni barkerianus (Arnold) } \\
\text { andersoni subandersoni..... }\end{array}$ & ...... & $\mathrm{O}, \mathrm{M}$ & $\mathrm{O}, \mathrm{M}$ & & & ...... \\
\hline (Loel and Corey) & ...... & $\cdots \cdots$ & $\mathrm{O}, \mathrm{M}$ & $\cdots \cdots$ & M & $\cdots \ldots$ \\
\hline bilineatus (Clark) & $\cdots \cdots$ & M & & $\cdots \cdots$. & & ...... \\
\hline 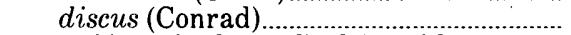 & M & $\mathbf{M}$ & M & $\cdots \cdots$ & $\cdots \cdots$ & $\cdots \cdots$ \\
\hline pabloensis (Conrad) of Arnold .................... & $\cdots \cdots$ & $\mathrm{M}$ & M & $\cdots \cdots$ & $\cdots \cdots$. & $\cdots \cdots$ \\
\hline 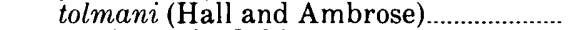 & ….. & M & …... & …- & …... & ...... \\
\hline 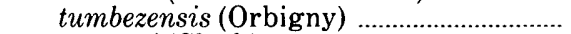 & $\cdots \cdots$ & ...... & ...... & ....... & $\mathrm{Pl}$ to $\mathrm{H}$ & $\mathrm{H}$ \\
\hline weaveri (Clark) & & M & ….. & $\cdots \cdots \cdot$ & & $\cdots \cdots \cdot$ \\
\hline
\end{tabular}




\section{Pacipecten andersoni subandersoni (Loel and Corey)}

Plate 14, figure 6

Pecten (Plagioctenium) andersoni Arnold subandersoni Loel and Corey, 1932, p. 202, pl. 21, figs. 7, 8 .

Aequipecten andersoni (Arnold) subandersoni (Loel and Corey). Adegoke, 1969, p. 98, pl. 1, fig. 11.

Original description. - "Pectens of the phylum of $P$. andersoni Arnold which have been collected from many localities in the Vaqueros horizon have consistently fewer ribs than the typical form which has 17, and fewer than those from all collections examined from the Temblor horizon. Rarely is a specimen found in the Vaqueros with 16 ribs; the average number on hundreds counted is 15 , many having but 14 well defined ribs. Some individuals from the Temblor horizon have 16 ribs. Since there is an apparent stratigraphic significance in the rib number in $P$. andersoni it is thought that this Vaqueros form (including variants in outline and rib character as in the case of $P$. andersoni Arnold) should be given a subspecific or varietal designation. It should be noted that the type of $P$. andersoni Arnold (1906) was found in sandstones a few feet below the Monterey shale of Santa Cruz County, according to Arnold, and is therefore Temblor in age, in accord with the Temblor faunule associated."

Holotype.-UCMP 31741.

Type locality.-UC A572. San Luis Obispo County, Calif. Vaqueros Formation, Oligocene and Miocene.

Comments. - Pacipecten andersoni subandersoni can only be differentiated from $P$. andersoni by the number of ribs: $P$. andersoni usually has 17 and $P$. a. subandersoni usually has 15 .

Geographic range.-Southern California to Baja California Sur. Geologic range.-Oligocene to Miocene.

Occurrence in California.-Oligocene and Miocene: Temblor (Adegoke, 1969) and Vaqueros Formations; Miocene: Isidro (Stump, 1979) and Tierra Redonda (Durham, 1970) Formations.

\section{Pacipecten andersoni barkerianus (Arnold)}

Plate 20, figures 2, 5

Pecten (Plagioctenium) andersoni var. barkerianus Arnold, 1906, $\mathrm{p}$. 83-84, pl. 26, fig. 9.

Chlamys barkeriana (Arnold). Schenck and Keen, 1940, pl. 39, fig. 5 .

Original description. - "Shell averaging about 40 millimeters in altitude, somewhat longer than high, equilateral, somewhat ventricose, and with serrate margins; base regularly rounded; sides nearly straight, sloping at a moderately low angle. Left valve with 17 rather narrow, prominent rounded ribs, each with a rounded, thread-like riblet running longitudinally along its top; at more or less regular intervals small obsolete spines protrude from the riblet; interspaces wider than the ribs, with sloping sides, and flat bottoms; whole surface of disk crossed by very fine incremental lines; hinge line longer than one-half length of disks; ears subequal, rectangularly truncated, and sculptured by radiating ridges and incremental lines."

Holotype.-Missing and presumed destroyed in the San Francisco fire of 1906.

Type locality.-Barker's Ranch [N1/2, T. 29 S., R. 29 E.], Kern County, Calif. Temblor Formation, Oligocene and Miocene.

Supplementary description. - "This variety *** is characterized by the thread-like riblet along each primary rib on the left valve * * *" (Arnold, 1906, p. 84)

Geographic range.-Middle and southern California.
Geologic range.-Oligocene to Miocene.

Occurrence in California.-Oligocene and Miocene: Temblor Formation; Miocene: Modelo Formation (Hudson and Craig, 1929) and Olcese Sand (Schenck and Keen, 1940).

\section{Pacipecten andersoni andersoni (Arnold) \\ Plate 14, figure 1}

Pecten (Plagioctenium) andersoni Arnold, 1906, p. 82-83, pl. 26, figs. 5, 5a, 6, 7, 8, 8a. Loel and Corey, 1932, pl. 21, fig. 6 .

Pecten (Aequipecten) andersoni Arnold. Grant and Gale, 1931, p. 202-203, pl. 4, figs. 4, 5 .

Pecten andersoni Arnold. Hanna and Hertlein, 1943, fig. 63-1 and 63-2.

Aequipecten andersoni (Arnold). Stewart, 1946, pl. 17, figs. 1-3. Woodring, 1946, p. 27, pl. 28, fig. 11. Adegoke, 1969, p. 98, pl. 1, fig. 13; pl. 2, fig. 2 .

Leptopecten andersoni (Arnold). Addicott, 1972, pl. 3, figs. 11, 20. Original description. - "Shell averaging about 35 millimeters in altitude, generally somewhat longer than high, both valves convex more or less inequivalve and inequilateral; margins smooth; base regularly rounded; sides concave above. Right valve with 14 to 18 prominent rounded ribs, separated by flat-bottomed interspaces, which are generally of about equal width to, but sometimes narrower than, the ribs; surface sculptured by numerous, sharp, imbricating, incremental lines, and sometimes, at irregular intervals, by more or less prominent lines of interrupted growth; hinge line more than one-half length of disk; ears subequal; anterior ear with 3 or 4 sharp radials and numerous fine concentric lines; byssal notch quite pronounced; posterior ear sculptured similarly to anterior, and truncated nearly rectangularly. Left valve more convex than the right, sculptured similarly and with similar ears, except that the notch in the anterior is not so pronounced."

Holotype.-USNM 164932.

Type locality. - Zayante Creek, Santa Cruz County, Calif. Monterey(?) Formation, Miocene.

Supplementary description. - "characterized by subcircular flat valves with about 16 to 18 rounded ribs and relatively wide, flatbottomed interspaces." (Adegoke, 1969, p. 98)

Comparison.-"Large specimens of $P$. andersoni very closely resemble some specimens of $P$. discus but differ from the latter in the fewer number (14 to 18 ) of their ribs, $P$. discus having 18 to 21 .

"A prominent characteristic of this species is that the left is decidedly the more convex of the two valves. In this respect it is similar to $P$. latiauritus and varieties. In fact, the young of $P$. andersoni is almost indistinguishable, in some instances, from small specimens of $P$. latiauritus var. monotimeris. The young of $P$. andersoni are equilateral, are relatively more convex, and have more prominent ribs than the adult forms." (Arnold, 1906, p. 82)

Pacipecten andersoni andersoni consistently has fewer ribs (14 to 18) than P. discus (17 to 20). (Vedder and Moore, 1976)

Geographic range.-Middle California to Baja California Sur.

Geologic range.-Miocene. "restricted in stratigraphic occurrence to the 'Temblor' Stage of the California molluscan sequence, a unit that is of latest early Miocene and middle Miocene age in terms of European series-epoch terminology." (W. O. Addicott, written commun., 1978)

Occurrence in the Californias.-Altamira Shale Member, Monterey Shale (Woodring, 1946), Branch Canyon Sandstone (Vedder, 1968), Buttonbed Sandstone Member, Temblor (Addicott, 1972), Chamisal (Bowen, 1966), Gould Shale Member, Monterey (Addicott, 
1972), Hames Member, Monterey (Addicott and others, 1978), Isidro (Stump, 1979), Los Tularcitos Member, Chamisal (Hertlein in Bowen, 1966), McLure Shale Member, Monterey (Adegoke, 1969), Media Shale Member, Temblor (Anderson and Land, 1969), Modelo (Hudson and Craig, 1929), and Moreno (Page and others, 1951) Formations, Olcese Sand (Addicott, 1965), Round Mountain Silt (Addicott, 1965), Saltos Shale Member, Monterey (Vedder, 1973; Addicott and others, 1978), San Pablo (Arnold, 1906), Tierra Redonda (Durham, 1970), Topanga (Vedder and Woodring, written commun., 1953), Tortugas (Minch and others, 1976), and Twisselman Sandstone Member, Monterey (Addicott, 1972) Formations, and unnamed Miocene sandstone of Dibblee, 1966 (Arnold, 1906). [This subspecies does not occur in the Vaqueros Formation, and citations to that effect are in error.]

\section{Pacipecten tolmani (Hall and Ambrose)}

Plate 14, figure 2

Pecten tolmani Hall and Ambrose, 1916, p. 82. Trask, 1922, pl. 3, figs. 1, 3. Wiedey, 1929, p. 23, pl. 1, fig. 2. Hall, 1958, p. 51, pl. 2, fig. 1. "Pecten" tolmani Hall and Ambrose. Schenck and Keen, 1950, pl. 44, figs. 5, 6

Original description. - "Both valves convex, left more convex of two, inequilateral, base regularly rounded; margins smooth. Right valve with 16 to 18 prominent rounded ribs, separated by rounded interspaces, narrower than the ribs; ribs on left valve more prominent and irregularly spaced; surface sculptured by numerous, fine, imbricating, regular lines of growth; hinge line less than one-half length of disk; ears subequal; anterior ear of other specimens show 5 or 6 sharp radial lines emanating from beak, crossed by fine, faint, concentric lines; sculpture of posterior ear less distinct but truncated at right angles."

Holotype.-CAS/SU 23.

Type locality.-[Mouth of Welch Creek, Sunol], Pleasanton quadrangle, Alameda County, Calif. Briones Sandstone, Miocene.

Comparison.-“This species resembles an enlarged $P$. andersoni but $* * *$ is much larger than $P$. andersoni, the hinge (proportional to size) much shorter, and the umbonal angle much larger.

"It is possible this form is a descendant of $P$. andersoni, of Monterey times. The young are very similar to $P$. andersoni, and it is not certain that the forms classified as $P$. andersoni in the Briones are not the young of P. tolmani." (Hall and Ambrose, 1916, p. 82)

Comments.-The holotype is a large (for the genus), moderately inflated left valve. The umbonal angle is small, the umbo inflated, and the beak higher than the hinge line. Although the umbonal angle is small and the line of attachment of the auricles to the disk steeply concave, the shell then flares outward toward the anterior and posterior margins in a line subparallel to the hinge, and in this character resembles $P$. weaveri. The ribs on $P$. tolmani are subrounded, not prominent, and are separated by wider interspaces at the ventral margin. The anteriormost and posteriormost margins of the shell bear only faint traces of ribs. The valve seems to have been inequilateral with the anterior portion larger than the posterior.

The left valve holotype of $P$. tolmani is twice as large as the left valve syntype of $P$. weaveri and has 17 low rounded ribs. Pacipecten weaver $i$ has 14 ribs on the left valve syntype and these ribs are higher and more ridgelike than those on $P$. tolmani. In addition, $P$. weaveri does not have the slightly sculptured areas at the anterior and posterior margins. Pacipecten weaveri has fine concentric lamellae on the left valve that may be bunched together giving a roughness to the ribs; $P$. tolmani has an almost smooth left valve with barely perceptible concentric lines.

Geographic range.-Middle California.
Geologic range.-Miocene.

Occurrence in California.-Briones (Hall, 1958) and Cierbo (Huey, 1948) Sandstones.

\section{Pacipecten weaveri (Clark)}

Plate 15, figures 4, 5

Pecten (Patinopecten) weaveri Clark, 1915, p. 454-455, pl. 45, figs. 1, 2.

"Pecten" weaveri Clark. Schenck and Keen, 1950, pl. 42, fig. 2.

Original description. - "Shell discoidal, broader than high, equilateral, nearly equivalved; apical angle about $90^{\circ}$, dorsal edges gently concave; hinge line about half the length of the shell. Right valve sculptured by about fourteen low, broad-topped, squarish ribs, the interspaces between which are flat-bottomed and about as wide as the tops of the ribs. Surface concentrically sculptured by rather coarse, somewhat irregular incremental lines. Anterior ear slightly longer than posterior, deeply notched, sculptured by three medium coarse, radiating ribs. Posterior ear marked by two or three faint radiating riblets. Left valve sculptured by fourteen fairly prominent, rounded, radiating ribs with interspaces about equal to the width of the ribs; the ribs next to the dorsal edges are not so prominent as the others. Surface also covered by fine, sharp, incremental lines. Anterior and posterior ears each marked by three medium fine, radiating riblets; anterior edge of anterior ear slightly notched."

Syntypes.-UCMP 11575, 11576.

Type locality.-UC 407. Contra Costa County, Calif. Cierbo Sandstone, Miocene.

Supplementary description. - "The differences in the sculpturing on the two valves is quite noticeable; the left valve, with fairly prominent rounded ribs and the sharp incremental lines, contrasts quite strongly with the right valve, with its low, squarish ribs and coarser incremental lines." (Clark, 1915, p. 455)

Comments.-The right valve syntype is inequilateral with the posterior side of the disk larger than the anterior. The umbonal angle is small, but at a distance about $5 \mathrm{~mm}$ below the hinge line the anterior portion of the shell margin turns abruptly outward toward the anterior; the posterior margin is less concave, with a more even slope. The right anterior auricle is long and narrow and has three strong riblets; the right posterior auricle is low and has two fine riblets. The right valve has 14 ribs that are subrounded and rather flat near the ventral margin but subtrigonal on the rest of the shell. Bunched concentric threads form irregular bumps on the ribs.

The left valve syntype is like the right valve in outline. It has 13 prominent ribs with strong concentric lamellae in the interspaces and also on the ribs near the ventral margin. The concentric lamellae are bunched to form irregular bumps on the ribs at random intervals, mostly near the ventral margin. The left anterior auricle has three riblets, the left posterior two. [See P. tolmani for comparison with that species.]

Geographic range.-Middle California.

Geologic range.-Miocene.

Occurrence in California. -Cierbo and Neroly (Hall, 1960) Sandstones.

\section{Pacipecten discus (Conrad)}

Plate 14, figures 3-5; 7-9

Pecten discus Conrad, 1857c, p. 190-191, pl. 3, fig. 1. [Reprinted in Dall, 1909, p. 181.] 
Pecten (Plagioctenium) discus Conrad. Arnold, 1906, p. 86-87, pl. 27, figs. 1, 1a, 2-4.

Pecten (Aequipecten) discus Conrad. Grant and Gale, 1931, p. 200201, pl. 4, fig. 7.

Leptopecten discus (Conrad). Vedder and Moore, 1976, p. 121, pl. 1, figs. 4, 8, 11. Addicott and others, 1978, pl. 4, fig. 18.

Chlamys discus (Conrad). Stanton, 1966, p. 27.

Aequipecten discus (Conrad). Squires and Fritsche, 1978, p. 21, pl. 4, fig. 7.

Pecten (Pecten) raymondi Clark, 1915, p. 450-452, pl. 46, figs. 1, 2; pl. 47 , figs. 1,2

Aequipecten raymondi (Clark). Adegoke, 1969, p. 99, pl. 2, figs. 7, 10, 11.

Pecten (Pecten) cierboensis Clark, 1915, p. 449, pl. 47, fig. 6 .

Pecten (Pecten) raymondi brionianus Trask, 1922, p. 148-149, pl. 1, figs. $2,3$.

Pecten raymondi brionianus Trask. Hall, 1958, p. 51, pl. 3, fig. 1.

Aequipecten raymondi (Clark) brionianus (Trask). Adegoke, 1969, p. 99, pl. 2, fig. 1.

Pecten (Pecten) andersoni gonicostatus Trask, 1922, p. 149, pl. 1, fig. 5.

Original description. - "Suborbicular, slightly oblique, profoundly compressed or discoidal, thin; ribs about 17 , rather distant, not very prominent, narrow, subtriangular, slender, and more distant toward the lateral margins; ears very unequal, rather small."

Holotype-USNM 13335; of $P$. raymondi, UCMP 11581; of $P$. brionianus, UCMP 12368; of $P$. cierboensis, UCMP 11585; of $P$. gonicostatus, UCMP 12370.

Type locality.-Between La Purisima and Santa Ynez [T. 7 N., R 32 W.. SB. Santa Barbara County], Calif. Monterey(?) Formation, Miocene. Of P. raymondi, UC 1492, Contra Costa County, Calif., San Pablo Group, Miocene; of P. brionianus. UC 3532, Alameda County, Calif., Briones Sandstone, Miocene; of $P$. cierboensis, UC 14, Contra Costa County, Calif., Briones Sandstone, Miocene; of P. gonicostatus, UC 1176. Contra Costa County, Calif., Briones Sandstone, Miocene.

Supplementary description. - "Leptopecten discus (Conrad) is a small, moderately thin-shelled species. $* * *$ The right valve $* * *$ bears 17 to 19 ribs that are rounded on the umbonal disk and flattened at the ventral margin; the interspaces are flat and slightly narrower than the ribs. The right valve is almost flat with an inflation of about $3 \mathrm{~mm}$ on the disk. The left valve $* * *$ bears 18 to 20 sharply rounded ribs; the interspaces are slightly rounded and somewhat wider than the ribs. The left valve is more inflated than the right valve, with a maximum inflation of 4 to $5 \mathrm{~mm}$. The right anterior ear is narrow and bears 4 strong riblets; the byssal notch is narrow and deep. The right posterior ear bears as many as four very weak riblets, usually difficult to discern without magnification. The left anterior ear bears 5 to 7 riblets, the left posterior ear 3 to 5 ; these riblets are of moderate strength on both ears. The umbonal angle is about $120^{\circ}$.

"The type specimen of $L$. discus *** is an internal mold of a left valve showing the internal ribbing, which reflects the character of the external ribs ***. The valve is very flat with less than $5 \mathrm{~mm}$ inflation and the umbonal angle is $130^{\circ}$. The valve bears 16 prominent ribs, 1 weak posterior rib, and 2 or 3 weak anterior ribs. Eighteen ribs, almost as wide as the interspaces, can be counted at the beak. The specimen is $53 \mathrm{~mm}$ long and $47 \mathrm{~mm}$ high; the hinge is $20.5 \mathrm{~mm}$ long. A small ( $20 \mathrm{~mm}$ wide) external mold on the slab containing the type specimen bears 18 ribs, one bifurcated (W. $O$. Addicott, written commun., 1969)." (Vedder and Moore, 1976, p. 121)

"Shell averaging about 50 millimeters in altitude, about as long as high, equivalve, equilateral, thin, rather compressed, and with smooth margins; umbonal angle large, averaging about $108^{\circ}$; sides somewhat concave above. Right valve with 17 to 20 moderately strong, rounded ribs, separated by rather flat interspaces about equal in width to the ribs; surface sculptured by regular, elevated, wavy, incremental lines and, at irregular intervals, generally by more or less prominent lines of interrupted growth; hinge line about one-half length of disk; ears unequal, the anterior showing several strong radials, while on the posterior the radials are obsolete; both ears sculptured by fine concentric lines. Left valve similar to right; ears more or less distinctly radially ridged and obliquely truncated.

"This species, of which the type is a poor specimen, being preserved as a cast in indurated clay, is characterized by its moderately strong, convex ribs, compressed disk, and strikingly unequal ears on the right valve. Specimens of $P$. discus having the shell material preserved always show moderately high, convex ribs; the internal casts (in which form the species is generally found) have the ribs more or less squarish, and low. The specimens having the fewest number of ribs have the widest lateral areas or submargins. The type does not show the radial sculpture found in most cases on the ears of the left valve." (Arnold, 1906, p. 86)

Comparison. - "P. discus is closely allied to P. pabloensis but has the constant difference of larger size when adult and stronger rounded ribs instead of weak squarish ones." (Arnold, 1906, p. 86)

"Shells referable to C. raymondi have been found in this study but appear to be part of a gradational series encompassing both $C$. raymond $i$ and $C$. discus and grouped most closely around the typical C. discus." (Stanton, 1966, p. 27)

"Leptopecten andersoni (Arnold), a species similar to $L$. discus, consistently has fewer ribs (14 to 18). Leptopecten pabloensis (Conrad) has a thinner shell; the ribs become obsolete at the ventral margins $* * *$, and the byssal notch on the right anterior ear is twice as wide as the byssal notch on L. discus." (Vedder and Moore, 1976, p. 121)

Geographic range.-Northern (Roth, 1979) to southern California.

Geologic range.-Miocene.

"Leptopecten discus is restricted to the 'Margaritan' Stage of the California molluscan sequence, a unit that is the time equivalent of the Mohnian benthic foraminiferal stage." (Warren O. Addicott, written commun., 1979)

Occurrence in California.-Branch Canyon Sandstone (Vedder, 1973), Briones Sandstone (Trask, 1922; Weaver, 1953; Hall, 1958), Castaic Formation (Stanton, 1966), Cierbo Sandstone (Weaver, 1949), McLure Shale Member, Monterey Formation (Adegoke, 1969), Modelo Formation (Oakeshott, 1958), Neroly Sandstone (Hall, 1960), Santa Margarita (Arnold, 1906; Vedder, 1973; Addicott and others, 1978; Squires and Fritsche, 1978), upper part of Temblor (Adegoke, 1969), and Wimer (Roth, 1979) Formations, and unnamed Miocene strata on San Clemente Island (Vedder and Moore, 1976).

\section{Pacipecten pabloensis (Conrad) of Arnold}

Plate 15, figures 1, 3

Pecten pabloensis Conrad, 1857b, p. 71, pl. 3, fig. 14. Hertlein, 1951 , p. 190 , fig. 2 , no. 14 .

Pecten (Plagioctenium) pabloensis Conrad. Arnold, 1906, p. 88-89, pl. 27, figs. 5-7.

Pecten (Chlamys) pabloensis Conrad. Clark, 1915, p. 452-453, pl. 47, fig. 8 , pl. 48 , fig. 2.

Pecten (Aequipecten) pabloensis Conrad. Grant and Gale, 1931, p. 199-200.

Leptopecten pabloensis (Conrad). Vedder and Moore, 1976, pl. 1, figs. $1,2$.

Original description.-“Orbicular, compressed, thin, concentri- 
cally wrinkled; ribs $18-20$, slender; little prominent, with an intermediate radiating line." (Conrad, 1857b)

"Shell averaging about 35 millimeters in altitude, about as high as long, equivalve, equilateral, thin, only slightly ventricose, and with smooth margins; sides sloping at a low angle and quite prominently concave above. Right valve with 18 to 20 square, flat-topped, radiating ribs, which are narrower and less distinct laterally and become more feeble as the periphery of the disk is approached; interspaces about as wide as the ribs, flat bottomed and often separated from the principal ribs by impressed lines which give the interspaces the appearance of bearing intercalary riblets; whole surface of disk sculptured by fine concentric lines and, in some instances, more or less prominent lines showing interrupted growth; hinge line somewhat longer than one-half length of disk; anterior ear slightly longer than posterior, deeply notched, and ornamented by 4 or 5 coarse radiating ridges and sharp, raised incremental lines; posterior ear slightly concave behind, and covered by numerous incremental lines and several obsolete radiating ribs. Left valve similar to the right except that in some cases the ribs are slightly more rounded above, and the looped or wavy concentric lines are more conspicuous; ears similar to those of the right valve except that the anterior one lacks the deep byssal notch. Hinge as in P. circularis except that the cardinal crura are very faint, while the auricular crura are quite prominent." (Arnold, 1906)

Holotype.-Missing and presumed lost; hypotypes of Arnold (1906, pl. 27, figs. 5-7), CAS/SU 302 and 302a, 302b.

Type locality.-San Pablo Bay [Contra Costa County], Calif. San Pablo Group, Miocene; of Arnold (1906, p. 88-89), the same.

Supplementary description.- "The prominence of the ribs seems to be the most variable factor in this species. As a rule the ribs are sharp and well defined until the shell attains an altitude of 10 or 15 millimeters, when they broaden out and become low, those near the sides almost losing their identity in some specimens. One specimen examined retained the elevated and sharply defined ribs up to an altitude of over 25 millimeters ***." (Arnold, 1906, p. 89)

"The most interesting character of $P$. pabloensis is its possession of strong Amusium-like internal lirae, which are stronger than the external ribbing, and which cause on internal casts the two lines of bilineatus." (Grant and Gale, 1931, p. 200)

Comparison.- "This species appears to be a degenerate offshoot of $P$. discus, with which it occurs and with which it intergrades. The humped-up form may have been caused by the influx of more or less fresh water, and this suggestion is strengthened by the fact that pabloensis sometimes occurs very abundantly all by itself in beds two or three feet thick." (Grant and Gale, 1931, p. 199)

Pacipecten pabloensis has a thinner shell, the ribs become obsolete at the ventral margins, and the byssal notch on the right anterior ear is twice as wide as on P. discus. (Vedder and Moore, 1976, p. 121)

Comments. - The right valve figured by Arnold (1906, pl. 27, figs. $6,6 a)$ is moderately inflated and has 19 ribs that are narrow and subrounded and prominent until the shell reaches a height of about $10 \mathrm{~mm}$ at which point they begin to broaden and become flat. At the ventral margin the ribs are broad and flat and demarcated by a deep, incised groove on both sides. Three barely perceptible interribs appear near the ventral anterior margin. The right anterior auricle has five slightly nodose riblets; the right posterior auricle has six faint riblets. The anterior dorsal margin is concave; the posterior is almost straight.

The left valve figured by Arnold (1906, pl. 27, figs. 5, 5a) is almost flat and has 23 very-narrow ribs separated by interspaces up to four times as wide, which commonly have an interrib near the ventral margin. The left anterior auricle has seven riblets crossed by concentric lamellae which produce small nodes where bunched on the riblets. The left posterior auricle has six riblets sculptured as they are on the left anterior auricle.

Pacipecten pabloensis resembles $P$. bilineatus (Clark) in sculpture but can be distinguished by the outline of the shell. In Pacipecten bilineatus the shell flares outward at an angle slightly subparallel to the hinge on both the anterior and posterior sides; on P. pabloensis the posterior margin slopes evenly toward the ventral edge.

Geographic range.-Middle to southern California.

Geologic range.-Miocene.

Occurrence in California.-Briones Sandstone (Weaver, 1953), Cierbo Sandstone (Clark, 1915; Hall, 1960), Modelo Formation (Hudson and Craig, 1929), Neroly Sandstone (Hall, 1960), and San Pablo Formation (Hertlein, 1951).

\section{Pacipecten bilineatus (Clark)}

Plate 15, figure 6

Pecten (Plagioctenium) bilineatus Clark, 1915, p. 448-449, pl. 64 figs. 3, 4.

Original description. - "Shell thin, medium in size, equivalved and equilateral, usually longer than high. Dorsal edges gently concave, the anterior dorsal edge usually being shorter than the posterior; ventral edge quite strongly and regularly arcuate. Apical angle averaging about $102^{\circ}$. Hinge plate about half as long as the length of the shell. Both valves gently convex and similarly sculptured by 18 to 20 low, flat-topped, radiating ribs with interspaces little wider than the tops of the ribs. In each interspace and almost filling it there is a low, broad, flat-topped interrib. On some specimens these broad interribs become almost as prominent as the ribs themselves; this is more especially noticeable near the dorsal edges, where the ribbing becomes finer. Anterior ear of right valve notched, bearing three to four fine, radiating riblets; posterior edge of posterior ear slightly oblique, bearing very faint, almost obsolete, radiating riblets. Ears of left valve similar to those of the right valve, except that the anterior ear is not notched."

Holotype.-UCMP 11579.

Type locality.-UC 1632. Contra Costa County, Calif. Cierbo Sandstone, Miocene.

Comparison. - "P. bilineatus differs from P. pabloensis Conrad in that the ribs are wider and not so far apart, they do not show the tendency to split as in the other species, the interrib is much broader. The concentric sculpturing is different, on P. pabloensis Conrad it is distinctly imbricated, the species belonging to the same subgenus as Pecten hastatus Sowerby - that is, Chlamys; on P. bilineatus it is not imbricated.

" $P$. bilineatus resembles $P$. raymond $i$ in the number and width of the ribs, in the width of the interspaces, and in general outline; it differs from that species in the following respects: it has a thinner shell, the ribs are not so prominent; on $P$. raymondi there is no interrib; the two valves of the latter are unequal, the right valve being flat and the left valve convex, thus belonging to the subgenus Pecten; the valves of $P$. bilineatus are both convex * * *" (Clark, 1915, p. 449)

Comments. - In Pacipecten bilineatus the shell flares outward at an angle slightly subparallel to the hinge on both the anterior and posterior sides; on $P$. pabloensis the posterior margin slopes evenly toward the ventral edge.

Geographic range.-Middle California.

Geologic range.-Miocene.

Occurrence in California.-Briones (Weaver, 1953) and Cierbo Sandstones. 
TABLE 10.-Geologic and geographic distribution of the genus Lyropecten

$[\mathrm{PI}=$ Pliocene; $\mathrm{M}=$ Miocene; $\mathrm{O}=$ Oligocene $]$

\begin{tabular}{|c|c|c|c|c|}
\hline \multirow{2}{*}{ Species } & \multicolumn{2}{|c|}{ California } & \multicolumn{2}{|c|}{$\begin{array}{c}\text { Baja } \\
\text { California }\end{array}$} \\
\hline & Middle & Southern & Norte & Sur \\
\hline \multirow{9}{*}{ 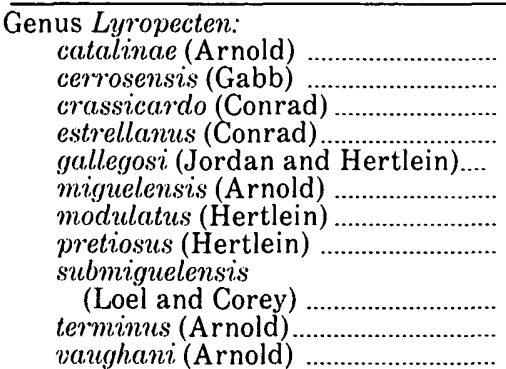 } & & & ....... & $\ldots \ldots$ \\
\hline & $\mathrm{M}, \mathrm{Pl}$ & $\mathrm{M}, \mathrm{Pl}$ & $\mathrm{Pl}$ & $\mathrm{Pl}$ \\
\hline & $\mathrm{M}$ & $\mathrm{M}$ & $\cdots \cdots$ & $\cdots$ \\
\hline & & & $\mathrm{Pl}$ & …... \\
\hline & $0, M$ & O,M & ….... & \\
\hline & $\cdots \cdots$ & M & $\ldots \ldots$ & $\mathrm{M}$ \\
\hline & O.M & $0 \mathrm{M}$ & ....... & ....... \\
\hline & & M,Pl & ....... & ....... \\
\hline & $\ldots \ldots$. & $0, M$ & $\ldots \ldots$. & ....... \\
\hline
\end{tabular}

\section{Pacipecten tumbezensis (Orbigny)}

Plate 15, figures 2, 8

Pecten tumbezensis Orbigny, 1846, p. 663.

Pecten (Aequipecten) tumbezensis d'Orbigny. Grant and Gale, 1931, p. 206.

Pecten (Pacipecten) tumbezensis (d'Orbigny). Olsson, 1961, p. 164, pl. 21, figs. 2-2c.

Chlamys (Leptopecten) tumbezensis (d'Orbigny). Grau, 1959, p. 118120 , pl. 40.

Original description. - "Pect. testâ suborbiculari, depressiusculâ, subaequivalvi, aequilaterali, auriculis inaequalibus, dextrâ majusculâ; valvarum alterâ radiatim costatâ, pallescente seu albâ, costis quatuordecim majoribus, rotundatis, laevibus, alterâ radiatim costatâ, costis quindecim acutioribus, fuscis, punctulis caerulescentibus aspersis, interstitiis tenuissimè transversim striatis, pallescentibus; long. 1.4 , lat. 0.5 , alt. 1.3 poll."

Holotype.-Location unknown. Not found at BM (NH) (Keen, 1966, p. 6).

Type locality.-Tumbez, Peru. Holocene.

Supplementary description. - "Shell small or of medium size, seldom above $35 \mathrm{~mm}$. in height, subequivalve. Ribs number from 13 to 15; those of the right valve are nearly square in section between deeply grooved interspaces; those of the left valve narrowly triangular between wider interspaces. Surface is nearly smooth except for minute concentrics and still finer radial striae. *** Anterior right ear with a deep, byssal notch." (Olsson, 1961, p. 164-165)

"Shell of moderate size, adult specimens averaging $32 \mathrm{~mm}$ in height. Both valves moderately convex; left one slightly shallower and often depressed between umbo and ventral margin. Beak closer to anterior of shell, resulting in anterior auricles and submargins of shorter length than posterior. Right valve with 14 or 15 rounded ribs and interspaces of same width; interspaces having fine concentric lamellae in juvenile stage, smooth when adult; anterior auricle with 4 strong ridges covered with prominent concentric lamellae; posterior auricle with 4 to 6 ridges crossed by fine lamellae; byssal notch small and ctenolium having 3 or 4 teeth. Left valve with 14 or 15 usually rounded but occasionally triangular ribs; interspaces slightly wider and usually smooth, but occasionally having fine concentric lamellae." (Grau, 1959, p. 119-120)

Geographic range.-Living: Gulf of California to Peru; fossil: Baja California Sur.
Geologic range.-Pliocene through Holocene.

Occurrence in Baja California Sur.-Pliocene: Infierno (Stump, 1979) and Salada (Hertlein, 1966) Formations.

Habitat.-Just below low tide level to $130 \mathrm{~m}$, usually in mud, occasionally in sandy mud or sand. (Grau, 1959, p. 120)

\section{Genus LYROPECTEN Conrad, 1862}

"Shell large, thick, valves usually nearly equally inflated, sometimes undulated in the vicinity of the umbos, sometimes strongly constricted at various stages of growth; ears nearly equal in size, a byssal notch present under right anterior ear; ribs large and undivided; entire shell covered with radial striae and fine concentric imbrications; hinge with large coarse cardinal crura or teeth." (Hertlein and Grant, 1972, p. 208, 209)

Geographic range.-Eastern Pacific.

Geologic range.-Oligocene(?); Miocene to Pliocene (table 10).

Habitat.-Perhaps subtropical (Hertlein and Grant, 1972).

"Lyropecten appears on the Pacific coast in the lower Miocene (Vaqueros formation), and the large shells of this genus are used by field geologists as a readily recognized aid in distinguishing the late Tertiary from the early Tertiary. There are large Pectens in the late Eocene and Oligocene of the Pacific coast (ynezianus Arnold, porterensis Weaver), but they belong to an endemic genus, Vertipecten, which became extinct in the Miocene and is not directly related to Lyropecten *** The Pacific coast Lyropecten has been considered a migrant from the West Indies and Central America, or from the Atlantic coast through Central America, but Lyropecten proper has not certainly been recognized in the West Indian and Central American Miocene." (Woodring, 1938, p. 35)

\section{Lyropecten miguelensis (Arnold) \\ Plate 16, figures 1, 2, 4}

Pecten (Lyropecten) miguelensis Arnold, 1906, p. 79-80, pl. 22, figs. 1, 1a, 1b; pl. 23, fig. 1. Hertlein, 1928, p. 151, pl. 24, fig. 1. Loel and Corey, 1932, p. 199-200, pl. 29, figs. 2, 3; pl. 30, fig. 2.

Original description. - "Shell averaging about 110 millimeters in altitude, about as long as high, inequivalve, subequilateral, rather thin, and with margins more or less serrate; base rounded; sides slightly concave above, the posterior being slightly longer than the anterior. Right valve more convex than the left, with 17 or 18 promi- 
nent rounded ribs, each sculptured by several ( 10 or 11 at extremity of ribs in type) distinct radiating raised riblets and numerous sharp, minutely wavy, incremental lines; interspaces narrower than ribs, and containing by a prominent radial auxiliary rib, which is ornamented by the incremental sculpture, and toward the periphery of the disk, by two or more radiating riblets as in the large ribs; hinge line somewhat longer than one-half the length of the disk; anterior ear arcuate in front, with small byssal notch, and sculptured by 5 or 6 prominent, rounded, radiating ridges and numerous sharp, concentric lines; posterior ear with 10 or 11 radiating riblets and fine incremental sculpture. Left valve less ventricose than the right, but otherwise similar to it, except that the ribs are slightly narrower and the interspaces relatively broader; ears similar to those of the right valve except that the anterior one lacks the byssal notch."

Holotype.-UCMP 12079.

Type locality.-San Miguel Island, Calif. Vaqueros Formation, Oligocene and Miocene.

Comparison.- "This species is distinguishable from P. estrellanus and others of the same group by its larger size, inequality of valves (which are more or less inequilateral), and radially striate surface from umbo to periphery. It sometimes shows the constrictions common to P. estrellanus." (Arnold, 1906, p. 80)

"This form is intermediate in general characters between Pecten magnificus variety crassicardo and $P$. estrellanus, having 17 or 18 prominent rounded ribs which are wider than the interspaces, both the ribs and the interspaces being ornamented by longitudinal striae as on crassicardo, and having a prominent mid-rib as on estrellanus. The left valve of the type is depressed behind the umbones, but this feature is probably not a characteristic of the species. P. miguelensis is distinguished from crassicardo by the wider ribs and narrower interspaces on the right valve and by the mid-rib. From estrellanus it is distinguished by stronger striation, higher, rounder ribs, and larger size." (Grant and Gale, 1931, p. 178)

Lyropecten miguelensis does not have the feather-like microsculpture that distinguishes L. estrellanus.

Geographic range.-Middle to southern California.

Geologic range.-Oligocene to Miocene.

Occurrence in California.-Oligocene and Miocene: Rincon Shale (Avila and Weaver, 1969), Soda Lake Shale Member, Vaqueros Formation (Vedder, 1973), and Vaqueros Formation (Repenning and Vedder, 1961; Eaton, 1965; Addicott, 1968; Avila and Weaver, 1969; Bereskin and Edwards, 1969); Miocene: Carneros Sandstone Member, Temblor Formation (Addicott, 1972), Painted Rock Sandstone Member, Vaqueros (Vedder, 1973), Saltos Shale Member, Monterey (Vedder, 1973), and Tierra Redonda (Durham, 1968) Formations.

\section{Lyropecten submiguelensis (Loel and Corey) Plate 16, figures 3, 5; plate 17 , figure 1}

Pecten (Lyropecten) miguelensis (Arnold) submiguelensis, n. var. Loel and Corey, 1932, p. 200, pl. 29, fig. 1; pl. 30, fig. 1; pl. 31, figs. 1a, $1 \mathrm{~b}, 1 \mathrm{c}$.

Original description. - "Shell medium in size, similar to type of $P$. miguelensis Arnold in characters of shape, except in being nearly equivalve; valves fairly thin, ornamented alike by 15 low, flattish ribs with rounded sides, each with seven or eight riblets; interspaces slightly concave, with four or five riblets; anterior ears with eight or nine riblets ( $P$. miguelensis has fewer). Height, $69 \mathrm{~mm}$.; length, 72 mm.; diameter (both valves), $34 \mathrm{~mm}$."

Holotype.-UCMP 31737.

Type locality.-UC A311. Santa Barbara County, Calif. Vaqueros Formation, Oligocene and Miocene.
Comparison.-"This variety is similar in all characters to $P$. miguelensis Arnold (1906) save for the constant comparative thinness of shell and valves and the lack (or faint development) of the intercalary ribs which is accompanied by lower height of the major ribs. Owing to this lower height of the main ribs there appear to be one or two fewer ribs. The valves are more nearly equal in convexity than in the type form of the species." (Loel and Corey, 1932, p. 200)

In a series of specimens of $L$. condylomatus from the type San Fernando Formation, Tamaulipas, Mexico, some are $70 \mathrm{~mm}$ high, considerably larger than the holotype, nearly devoid of nodes, and resemble some specimens of L. miguelensis submiguelensis of similar size. (Hertlein and Grant, 1972, p. 209)

Geographic range.-Middle to southern California.

Geologic range.-Oligocene to Miocene.

Occurrence in California.-Oligocene and Miocene: Rincon Shale (Avila and Weaver, 1969) and Vaqueros Formation (Kleinpell and Weaver, 1963).

\section{Lyropecten vaughani (Arnold)}

\section{Plate 17, figures 2-4}

Pecten (Lyropecten) vaughani Arnold, 1906, p. 81-82, pl. 23, figs. 3 , 3a, 3b. Loel and Corey, 1932, p. 201-202, pl. 21, fig. 9.

Pecten (Lyropecten) nodosus (Linnaeus) variety vaughani Arnold. Grant and Gale, 1931, p. 180-181.

Lyropecten crassicardo vaughani (Arnold). Addicott, 1972, p. 9, pl. 2, fig. 6.

Original description. - "Shell averaging about 40 millimeters in altitude, slightly longer than high, inequivalve, equilateral, convex, and showing constrictions with consequent undulations on the right valve and nodose ribs on the left; base regularly rounded; sides nearly straight above; margins smooth. Right valve with 12 prominent convex ribs separated by concave-bottomed interspaces somewhat narrower than the ribs; surface of ribs and interspaces sculptured by numerous fine, imbricated, threadlike, radial lines, between which are fine imbricating concentric lirae, the lines multiplying by intercalation toward the periphery of the disk; hinge line about five-eighths length of disk; ears unequal, the anterior much elongated, rather narrow, and ornamented by 4 very prominent, rounded, sharply imbricated radials and numerous fine imbricating incremental lirae; byssal notch deep; posterior ear about one-half length of anterior, somewhat concave behind, and ornamented by about 6 radial and numerous fine incremental lirae. Left valve similar to right, but with narrower, sharper ribs and correspondingly broader interspaces; the second, fourth, seventh, tenth, and twelfth ribs from the posterior end are more prominent than the others, and are subnodose at the lines of undulation of the disk; anterior ear similar to that of the right valve but with 2 or 3 more radials, which are less prominent; posterior ear like that of right."

Holotype.-CAS/SU 9 [Probably a late juvenile form according to Judith T. Smith (written commun., 1979)].

Type locality.-Ojai Valley, Ventura County, Calif. Vaqueros Formation, Oligocene and Miocene.

Comparison.-Though allied to L. magnolia and L. crassicardo, $L$. vaughani is distinguishable by its small size, obviously unequal ears, long and strongly radially sculptured right anterior ear, deep byssal notch, undulating disk, and finely striated, concave-bottomed interspaces. This form seems to combine the number of ribs of L. magnolia (L. magnolia generally has one to three less), with the sculpture of L. crassicardo var. hamiltoni, the undulations of L. crassicardo, and the long, strongly sculptured, right anterior ear of the typical Chlamys. It appears to be a connecting link between the typical Chlamys and Lyropecten. (Arnold, 1906, p. 82) 
Geographic range.-Southern California.

Geologic range.-Oligocene to Miocene.

Occurrence in California.-Oligocene and Miocene: Vaqueros Formation (Arnold, 1906; Loel and Corey, 1932); Miocene: Carneros Sandstone Member, Temblor Formation (Addicott, 1972).

\section{Lyropecten pretiosus (Hertlein)}

\section{Plate 17, figures 5, 8}

Pecten (Lyropecten) pretiosus Hertlein, 1925a, p. 12-13, pl. 2, fig. 6; pl. 3, fig. 4. Grant and Gale, 1931, p. 185.

Original description. - "Shell small. Right valve moderately arched, and ornamented by about 17 or 18 rounded, radiating ribs, separated by somewhat narrower interspaces; ribs and interspaces sculptured by fine, radiating lines and crossed by fine, concentric lines of growth; anterior and posterior margins turning down abruptly, and smooth except for incremental striae; ventral margin rounded and turned down abruptly; anterior ear with a distinct byssal notch, and a slight groove also present between ear and margin of shell; about five radiating riblets crossed by incremental lines ornament the ear; posterior ear sculptured by about six or seven radiating riblets, crossed by incremental striae, the ear sloping downward and slightly posteriorly from the hinge line. Left valve ornamented by about 14 or 15 radiating ribs, the whole surface with sculpture similar to that of right valve; ears sculptured much as on right valve. Altitude $27 \mathrm{~mm}$.; longitude $29 \mathrm{~mm}$.; diameter of right valve approximately $10 \mathrm{~mm}$.; apical angle of right valve approximately $87^{\circ} . "$

Holotype-CAS/SU 38. [Juvenile right valve (Judith T. Smith, written commun., 1979).]

Type locality.-SU 59. Baja California Sur, Isidro Formation, Miocene.

Comparison. - "The characteristic shape, sculpture, and shape of ears distinguish this beautiful little Pecten from other species." (Hertlein, 1925a, p. 13)

"This species appears to be closely related to $P$. condylomatus Dall but can not be definitely assigned to that species. It differs from specimens of the latter ***in smaller size, the right valve is higher at the umbo and the ribs are lower, evenly rounded and ornamented by numerous fine striae." (Hertlein and Jordan, 1927, p. 624)

Geographic range.-Southern California to Baja California Sur. Geologic range.-Miocene.

Occurrence in the Californias.-Temblor "Horizon" (Loel and Corey, 1932) and Isidro Formation (Beal, 1948).

\section{Lyropecten crassicardo (Conrad)}

Plate 17, figures 6, 7; plate 18, figures 1-3, 5; plate 21, figure 3; plate 28, figure 1

Pallium crassicardo Conrad, 1857a, p. 313 [reprinted in Dall, 1909, p. 173].

Pecten (Lyropecten) crassicardo Conrad. Arnold, 1906, p. 71, pl. 16, figs. 1, 1a; pl. 17, figs. 1, 1a, 1b; pl. 18, figs. 1, 2, 2a. Arnold, 1907a, pl. 44, fig. 1. Hanna and Hertlein, 1941, fig. 63-8.

Pecten crassicardo Conrad. Clark, 1915, pl. 45, fig. 3.

Pecten (Lyropecten) crassicardo Conrad nov. var.? Clark, 1915, pl. 46, fig. 3.

Pecten (Lyropecten) magnificus Sowerby variety crassicardo (Conrad). Grant and Gale, 1931, p. 183-184, pl. 9, figs. 4, 5.

Lyropecten crassicardo (Conrad). Addicott, 1965, fig. 3b. Vedder and Moore, 1976, p. 121, pl. 2, figs. 1, 7, 10.

Pecten (Lyropecten) crassicardo Conrad var. hamiltoni Arnold, 1906, p. 73-74, pl. 11, figs. 5,6 .
Pecten (Lyropecten) magnificus Sowerby variety hamiltoni Arnold. Grant and Gale, 1931, p. 184-185.

Pecten (Pallium) holwayi Clark, 1915, p. 454, pl. 47, fig. 5.

Pecten crassicardo biformatis Nomland, 1917b, p. 307, pl. 18, figs. 1 , 1a, 1b; pl. 19, fig. 4.

Pecten crassicardo nomlandi Hertlein, 1931, p. 369, new name. Not Pecten biformatus Bittner, 1899.

Lyropecten crassicardo (Conrad) nomlandi (Hertlein). Adegoke, 1969 , p. $100-101$, pl. 2 , fig. 8.

Pecten (Lyropecten) ricei Trask, 1922, p. 148, pl. 2, figs. 1-2.

Pecten (Lyropecten) vickeryi Trask, 1922, p. 148, pl. 4, fig. 1.

Swiftopecten adekunbiana Adegoke, 1969, p. 104, pl. 6, figs. 3, 5.

Original description.-"Obtusely ovate or suborbicular, thick; lower valve ventricose; ribs 15-16, elevated, back rounded, sides flattened, disks radiato-striate, 9 or 10 on the ribs, intervals of ribs concave, umbo or whole disk at wide intervals having a tendency to be humped and nodose; upper valve convex or slightly ventricose; ears large, equal; hinge thick, with prominent, acute, oblique teeth; fosset profound; muscular impression very large. Height 5 inches." (crassicardo)

"Adult shell averaging about 60 millimeters in altitude, subequivalve, equilateral, convex; sides concave above; margins smooth. Right valve with 15 to 17 prominent convex-topped ribs, separated by interspaces narrower than the ribs; surface of ribs and interspaces sculptured by rather coarse radiating lines and imbricating incremental lamellae; anterior ear longer than the posterior, and with 4 prominent, finely imbricated radials; byssal notch rather deep; posterior ear rectangularly truncated, and with radial and concentric sculpture. Left valve similar to right, except with slightly wider interspaces. The disk of this variety is generally contracted after reaching an altitude of 40 millimeters or more." (hamiltoni)

"Shell large, equilateral; posterior, anterior, and ventral margins strongly depressed; surface of shell with a marked step-like depression, indicating a former depressed ventral margin, situated not quite one third the distance from the ventral edge to the beak. Surface sculptured by three heavy rounding ribs; these ribs are very prominent between the step-like depression and the ventral depressed margin, but very faint and almost disappearing between the step and the beak. Surface also sculptured by fine, regular, radial striae or riblets, which cover both the interspaces and the ribs, and by fine imbricate concentric lines. Shell feebly lirate internally, the lirations being most prominent on the depressed area along the ventral edge. Adductor muscle scar prominent." (holwayi)

"Shell equilateral, equivalve, thin, rather compressed; with more or less serrate, regularly convex, basal margins. Right valve with about fifteen high, squarish, rather narrow ribs; interspaces considerably wider than ribs, both being ornamented by numerous fine radiating lines; surface sculptured by fine, almost invisible, imbricate lines; the larger specimens frequently show abrupt constrictions or undulations at later stages of growth. Anterior ear ornamented with incremental growth lines and about six radiating ridges; posterior ear smaller but otherwise similar to anterior. Left valve with about fifteen-seventeen high squarish ribs. These are wider than the interspaces or than the ribs of the other valve, ornamented with fine incremental lines; byssal notch well developed. Dimensions of type: Height, $92 \mathrm{~mm}$.; length, $114 \mathrm{~mm}$.; length of hinge line, about $65 \mathrm{~mm}$.; umbonal angle, 110 degrees." (nomlandi)

"Shell medium in size; about as long as high, equilateral; apical angle about $89^{\circ}$; anterior and posterior dorsal margins strongly depressed; surface of left valve with fourteen low flat topped to broadly rounded ribs; interspaces flat, about equal in width to ribs, and possessing from three to four, almost invariably three, small riblets, which have a tendency to become bifurcated near the ventral margin." (ricei) 
"Shell large, slightly more wide than high; ears about one-half the width of the shell; dorsal margins strongly depressed and quite long, being about three-fourths the height of the shell; surface with sixteen prominent ribs; every third rib being higher and more strongly developed than the others; interspaces about as wide as ribs; both ribs and interspaces ornamented with numerous fine riblets; ears with five to six small ribs." (vickeryi)

"Shell medium sized, thin, subcircular, length approximately equal to height; ornamented by 5 very prominent major ribs separated by very wide interspaces; major ribs prominently elevated at each of the numerous concentric constrictions in ventral half of shell; between each adjacent pair of major ribs are 2 minor ribs of approximately same diameter as major ribs but less prominently elevated; minor ribs and interspaces ornamented by numerous fine radial riblets; major ribs generally less ornate than minor ribs; anterior ear longer and more prominent than posterior ear; both ears ornamented by fine radial riblets." (adekunbiana)

Holotype.-Missing and presumed lost. ANSP 30745a is herewith designated the lectotype. It is one of three specimens labelled by Gabb as having been given to him by Conrad. Of hamiltoni USNM 164845; of holwayi UCMP 11580; of nomlandi UCMP 11308; of ricei UCMP 12364; of vickeryi CAS/SU 26; of adekunbiana UCMP 36639

Type locality.-Monterey County, Calif. Subsequent field work restricts the locality to the La Panza Quadrangle, where L. crassicardo is abundant in the Santa Margarita Formation, Miocene (Judith T. Smith, oral commun., 1979). Of hamiltoni, Alum Rock Canyon [San Jose Quad.], Santa Clara County, Calif., Briones Sandstone, Miocene; of holwayi, UC 1632, Contra Costa County, Calif., Cierbo Sandstone, Miocene; of nomlandi, UC 3029, Kern County, Calif., Santa Margarita Formation, Miocene; of ricei, UC 3535 , Alameda County, Calif., Briones Sandstone, Miocene; of vickeryi, vicinity of McGuire Peaks, Pleasanton Quad., Alameda County, Calif., Briones Sandstone, Miocene; of adekunbiana, UC D1088, Fresno County, Calif., Santa Margarita Formation, Miocene.

Supplementary description.- "Adult, shell averaging about 130 millimeters in altitude, about as long as high, inequivalve, convex, equilateral (except for ears), thick, and generally prominently and abruptly constricted or undulated one or more times near the umbo and sometimes at later stages of growth; sides nearly straight; base regularly rounded; margins smooth. Right valve with 14 to 17 prominent, perpendicular-sided, convex-topped ribs, which are separated by more or less deeply channeled, flat-topped, convex-bottomed interspaces somewhat narrower than the ribs; whole surface of ribs and interspaces sculptured by numerous radial striae and fine, $\mathrm{mi}$ nutely wavy, imbricating, concentric lines; hinge line about foursevenths length of disk; anterior ear somewhat produced, subarcuate laterally and sculptured by about 5 prominent radial ridges and numerous fine imbricating incremental lines; posterior ear about three-fourths length of anterior, sculptured similarly, but slightly less prominently, and rectangularly truncated. Left valve similar to right, except that the ribs are narrower, and the interspaces correspondingly broader; ears similar to posterior one of right valve. Hinge with a deep resilial pit, on each side of which are several prominent lateral crura or teeth.

"The tops of the ribs sometimes overhang the interspaces and also sometimes appear smooth. Great variation is shown in regard to the number, abruptness, and prominence of the constrictions on the disk. One or two are generally present near the umbo in most specimens, and some show as many as six or seven at different periods of growth. The specimens of this species from Orange County are generally freer from constrictions and the disks are usually more compressed than in the forms from central California; otherwise the former are normal types." (Arnold, 1906, p. 72)

"Lyropecten crassicardo (Conrad) in collections from Lemon Tank Reservoir [unnamed Miocene strata on San Clemente Island] ranges from $26 \mathrm{~mm}$ wide and $26 \mathrm{~mm}$ high $* * *$ to $160 \mathrm{~mm}$ wide and about $145 \mathrm{~mm}$ high ***. The right valve bears 12 to 13 primary ribs ***, the left valve 12 to $14 * * *$. Of nine right valves, one has 12 ribs, the remaining eight 13; of six left valves, one has 12 ribs, four 13 ribs, and one 14 ribs. Judith T. Smith (oral commun., 1975) has found 15 ribs on the right valve and 14 ribs on the left valve to be more common on L. crassicardo elsewhere in the Californias.

"The anterior ear is longer than the posterior ear on both valves. The left posterior ear is truncated at a right angle to the hinge; the left anterior ear is enlarged just below the hinge. The right anterior ear bears 5 to 6 riblets, the right posterior ear 8 to 12; the left posterior ear bears 8 to 12 riblets, the left anterior, 7 to 10 . The first 2 or 3 riblets below the hinge on the ears are usually largest. On both right and left valves of large specimens, additional riblets are present near the margins of the posterior ears but do not cross them.

"Fine striations and lyrae are present on the entire surface of both right and left valves of $L$. crassicardo, these striations are of equal strength on the specimens from San Clemente Island." (Vedder and Moore, 1976, p. 121-122)

Comparison.-" $P$. crassicardo is characterized by its comparatively few ribs, which, with the interspaces, are more or less prominently striated. It is distinguishable from $* * * P$. magnolia, with which it is often confused, by its more numerous and much narrower ribs, relatively shorter hinge line, more prominently striate ears, and its tendency to become constricted; distinguishable from $P$. estrellanus, with which it is often associated, by its fewer and rather finely striate ribs and lack of a major intercalary riblet (the bottoms of the interspaces of $P$. crassicardo being striate rather than containing a riblet). Some of the lateral ribs and interspaces, and the surface near the periphery of the disk in adults of $P$. estrellanus generally show sculpture similar to that characteristic of $P$. crassicardo." (Arnold, 1906, p. 72)

"On most left valves of L. crassicardo, the middle rib and the third rib from the middle toward both the anterior and posterior margins are elevated above the other ribs. On left valves of Lyropecten cerrosensis (Gabb), three ribs rather than two are present between the elevated ribs. This feature, when preserved serves to separate $L$. cerrosensis from L. crassicardo (Judith T. Smith, oral commun., 1975)." (Vedder and Moore, 1976, p. 121-122)

According to Judith T. Smith (written commun., 1979) L. crassicardo has 14 to 15 ribs whereas L. estrellanus has 16 to 17 . The juvenile valves of $L$. estrellanus are commonly more convex than those of $L$. crassicardo, which are flat. $L$. crassicardo may have elongate incipient nodes; $L$. estrellanus does not. Left valves of $L$. crassicardo commonly have the central rib raised and the third next rib toward both the anterior and posterior margins.

Comments.-Arnold (1906, pl. 18, fig. 1) figured a specimen (ANSP 30745) which he considered to be the holotype of $L$. crassicardo. That specimen is a left valve with the auricles missing and on the shell is written "Pres. by Dr. Wilson." For two reasons I believe this specimen is not the holotype: (1) The auricles are missing and they were described by Conrad; (2) Conrad (1856, p. 313) cites A. S. Taylor as the collector, and this specimen was presented by $\mathrm{Dr}$. Wilson. The specimen is one of three labelled by Gabb as "dupl. types-Given me by Mr. Conrad." I have selected as the lectotype the best preserved specimen of the three, and it is not the one figured by Arnold.

The lectotype is a left valve with the anterior auricle missing and only a portion of the posterior auricle preserved. It has 16 square, slightly undercut ribs and both the ribs and the slightly narrower to as wide interspaces have fine riblets. At two-thirds the distance from the beak to the ventral margin the shell is constricted, producing a marked ledge; near the ventral margin is another less pronounced ledge.

The holotype of Swiftopecten adekunbiana Adegoke (1969, p. 104) 
is a fragment of a much larger left valve of $L$. crassicardo. The holotype of Pecten holwayi Clark (1915, p. 454) is a worn left valve with no auricles preserved, but it is ledged and has raised ribs in the same position as L. crassicardo. (Judith T. Smith, written commun., 1979)

Geographic range.-Middle to southern California. [The records of L. crassicardo in Baja California are in error and the species represented is probably L. submiguelensis (Judith T. Smith, written commun., 1979).]

Geologic range.-Miocene.

Occurrence in California.-Branch Canyon Sandstone (Vedder, 1973), Briones Sandstone (Weaver, 1953), Buttonbed Sandstone Member, Temblor Formation (Addicott, 1972), Castaic Formation (Stanton, 1966), Cierbo Sandstone (Eaton and others, 1941), Cold Creek Member, Gould Shale Member, Monterey Formation (Addicott, 1972), Topanga Formation (Takeo Susuki, written commun., 1978), McLure Shale Member, Monterey (Adegoke, 1969), "middle sandy phase," Monterey (Dickinson, 1969), Modelo(?) (Kew, 1924), Neroly Sandstone (Eaton and others, 1941), Obispo (Hall and others, 1966), Saltos Shale Member, Monterey (Vedder, 1973), San Onofre Breccia (Bereskin and Edwards, 1969), San Pablo (Arnold, 1906; Clark, 1915), and Santa Margarita (Arnold, 1906; Addicott, 1965; Adegoke, 1969; Dickinson, 1969) Formations; unnamed Miocene strata on San Clemente Island (Vedder and Moore, 1976).

\section{Lyropecten catalinae (Arnold) Plate 18, figures 4, 6}

Pecten (Lyjropecten) estrellanus Conrad var. catalinae Arnold, 1906 , p. 76-77, pl. 20, figs. 3, 3a, 4. Grant and Gale, 1931, p. 186.

Original description. - Shell averaging about 65 millimeters in altitude, considerably longer than high, equivalve, equilateral, of medium thickness, only slightly ventricose, and with margins more or less serrate; base evenly rounded; sides only slightly concave above. Right valve with 19 or 20 square, flat-topped ribs, all of which are sculptured by incremental lines and the 3 or 4 outer ribs on each side by more or less prominent radial lines; interspaces narrower than ribs and ornamented by a prominent squarish riblet; hinge line over one-half length of disk; anterior ear arcuate in front, with ratheir small byssal notch, and ornamented by concentric lines and 5 or 6 rather prominent radiating ridges; posterior ear with concave end and ornamented by numerous fine radiating ridges and incremental lines. Left valve similar to right except that the ears are both like the posterior one of the right valve and the interspaces are relatively a little wider."

Holotype.-CAS/SU 30.

Type locality. - Near Isthmus, Santa Catalina Island, Los Angeles County, Calif. San Onofre(?) Breccia, Miocene. [Subsequent field work and comparison of holotype matrix with that of other specimens suggests that the type locality is near the saddle on the north side of Mt. Banning (Judith T. Smith, written commun., 1979).]

Supplementary description. - "According to the figure, the type of catclince from Santa Catalina Island has a strong midrib filling the interspaces, as in estrellanus s.s. Material from the Pliocene at Temescal Canyon mentioned by Arnold as representing catalinae is not recognized in the National Museum collection. This record is probably an error, as catalinae is not mentioned in Arnold's later lists from this locality." (Woodring. 1938, p. 34)

Comparison.- "This species is similar in general characteristics to the typical $P$. estrellanus, but differs from it in being much flatter, having a relatively much longer hinge, and, on the average, more ribs. The characteristic constriction of $P$. estrellanus is also lacking in this variety, so far as known." (Arnold, 1906, p. 77)

Geographicrange.-Middle and southern California. According to
Judith T. Smith (written commun., 1979) L. catalinae is restricted to Catalina Island and the Ventura Basin and probably is restricted to the Miocene.

Geologic range.-Miocene.

Occurrence in California.-Miocene: Modelo Formation (Judith

T. Smith, written commun., 1979) and San Onofre Breccia.

\section{Lyropecten estrellanus (Conrad)}

Plate 19, figure 2

Pallium estrellanum Conrad, 1857a, p. 313. Conrad, 1857b, p. 71, pl. 3, fig. 15.

Pecten (Lyropecten) estrellanus Conrad. Arnold, 1906, p. 74-76, pl. 19, figs. 1, 1a; pl. 20, figs. 1, 2, 2a; pl. 21, figs. 1, 1a, 1b, 2, 2a, 2b. Grant and Gale, 1931, p. 185-186, pl. 8, fig. 4. G D. Hanna and Hertlein, 1941, fig. 63-7.

Lyropecten estrellanus (Conrad). Woodring, 1938, p. 33-34. Addicott, 1972, pl. 4, fig. 1. Addicott and others, 1978, pl. 1, fig. 4; pl. 4, fig. 11.

Lyropecten volaeformis Conrad, 1862, p. 291. New name for Pallium estrellanum Conrad, $1857 \mathrm{~b}$, pl. 3 , fig. $15=L$. estrellanus fide Arnold, 1906, p. 74.

Original description. - "Suborbicular; lower valve ventricose, slightly undulated; ribs 17 , broad, little prominent, convex, with an intermediate linear rib, from which the larger ribs are separated by an impressed line; upper valve convex, somewhat undulated, ribs flattened and the intermediate small ribs with a longitudinal impressed line on the lower part of the valve. Height $2 \frac{1}{2}$ inches."

Lectotype.-USNM 13317 (Woodring, 1938; neoholotype, TuckerRowland, 1938).

Type locality.-Estrella Valley [San Luis Obispo County], Calif. Santa Margarita Formation, Miocene.

Supplementary description.-"Shell averaging about 90 millimeters in altitude, somewhat longer than high; equivalve, equilateral, of medium thickness, generally quite ventricose, and with margins more or less serrate; base evenly rounded; sides sloping, slightly concave above. Right valve with 16 to 20 prominent, squarish ribs separated by channeled interspaces which are narrower than the ribs; interspaces each with one sharply outlined, squarish riblet in the middle; surface sculptured by fine raised incremental lirulae which loop back over the ribs and riblets, and, on the anterior and posterior portions of the disk, by radiating striae, which increase in number as the periphery of the disk is approached; hinge line straight and nearly equal to one-half length of disk; ears equal; anterior ear arcuate in front and ornamented above byssal area by three or four radiating ridges and numerous incremental nines; byssal notch sharply defined; byssal area with incremental sculpture only; posterior ear with slightly concave end and ornamented by 5 or 6 radiating ridges and more or less prominent incremental lines. Left valve with the ribs narrower and having more sloping sides and rounded tops than those of the right; interspaces wider; auxiliary riblets inclined to be dichotomous near the ends in the more mature specimens; the looping incremental lirulae and the secondary radiating lines apparently more highly developed in this valve than in the right; ears similar to the posterior ear of the right valve.

"This is a most variable species in size, shape, and sculpture, the above description applying to the most common form. One peculiar characteristic sometimes shown by this species is a contraction or interruption in the growth at different stages. ${ }^{* *}$ Up to the first interruption the sculpture is generally simple and quite constant, but afterwards it (especially the radial) becomes more complex, the riblets in the interspaces becoming dichotomous and the radiating lines becoming more numerous and prominent.

"The variety of this species described as Lyropecten volaeformis by 
Conrad is the extremely convex type. Conrad thought that the valves were unequal in the very convex shell, but in all the specimens of this sort examined by the writer, both valves show an equal amount of convexity. $* * *$

"Specimens of this species from Catalina Island show more ribs (right valves, 19 to 21) than the average, and also appear to be slightly inequivalve, the left valve being the more ventricose. The characteristic interruption and constriction took place on most of the Catalina specimens at an altitude of about 55 millimeters.

"A specimen of this species from San Benito County *** is very convex, and shows beautiful equal, equidistant, looped lamellae over the surface of the valve. The intercalary riblets on this specimen are sharply defined." (Arnold, 1906, p. 75)

In the type lot of L. estrellanus "the lectotype and two others, on which the number of ribs is discernible, have 17 ribs; the interspaces are occupied by a strong midrib, which is split toward the margin, and the two branches may be flanked by a riblet. The anterior ear of a right valve has four relatively strong ribs." (Woodring, 1938, p. 33)

"Arnold's figured right valve from the Santa Margarita sandstone of the Coalinga region (1909, pl. 10, fig. 3$)^{* * *}$ is strongly inflated; is sculptured with 17 ribs; has a strong midrib that is not split toward the margin but in some interspaces is not stronger than riblets added near the margin; and has four relatively strong ribs on both ears. Strongly marked 'resting stages,' possibly induced by unfavorable conditions, produce humps in the profile." (Woodring, 1938, p. 34)

Comparison. - "This species is distinguished from P. miguelensis by its lower, smoother, squarer ribs. From crassicardo it can also be told by its mid-rib." (Grant and Gale, 1931, p. 185)

"In some interspaces one secondary rib is stronger than others, but it does not completely fill the interspace as in the smaller Miocene $L$. estrellanus. Lyropecten terminus, from the Pliocene of the Salinas Valley, is smaller than $L$. cerrosensis and has a relatively strong secondary rib. It evidently is more closely related to L. estrellanus than is $L$. cerrosensis, which may be descended from the Miocene $L$. crassicardo." (Woodring, 1950, p. 85)

Lyropecten estrellanus can be distinguished from L. miguelensis by its feather-like microsculpture.

Geographic range.-Middle to southern California.

Geologic range.-Miocene to Pliocene.

Occurrence in California.-Miocene: Branch Canyon Sandstone (Vedder, 1973), Buttonbed Sandstone Member, Temblor (Addicott, 1972), Castaic (Stanton, 1966), Cierbo Sandstone (Hall, 1960), Cold Creek Member, Topanga (Takeo Susuki, written commun., 1978), McLure Shale Member, Temblor (Adegoke, 1969), Media Shale Member, Temblor (Anderson and Land, 1969), Modelo (Oakeshott, 1958), and Monterey (Arnold, 1906; Mandra, 1963) Formations, Neroly Sandstone (Eaton and others, 1941; Hall, 1960), Pancho Rico (Addicott and others, 1978), and Santa Margarita (Arnold, 1906; Durham and Addicott, 1964; Adegoke, 1967; Durham, 1968; Vedder, 1973) Formations, Topanga Group (Takeo Susuki, written commun., 1978), and Tranquillon Volcanics (Dibblee, 1950); Miocene and Pliocene: Towsley (Kern, 1973) and Etchegoin (Arnold, 1906; Adegoke, 1960) Formations; Pliocene: Morales Formation (Hill and others, 1958).

\section{Lyropecten terminus (Arnold) Plate 19, figures 1, 5}

Pecten (Lyropecten) estrellanus Conrad var. terminus Arnold, 1906, p. 77, pl. 23, figs. 2, 2a. Grant and Gale, 1931, p. 186.

Lyropecten terminus (Arnold). Addicott, 1974, pl. 1, fig. 5.

Original description.-"Shell averaging about 70 millimeters in . altitude, somewhat longer than high, ventricose, subequivalve, equilateral; margins coarsely serrate. Right valve with about 15 prominent, squarish ribs, separated by narrower channeled interspaces, in each of which runs a prominent intercalary; surface of ribs and interspaces obsoletely radially striate; hinge line more than one-half length of disk; ears subequal, the anterior strongly radially ribbed, the posterior with finer sculpture; byssal notch deep and rather narrow. Left valve similar to right, except that the ribs are relatively narrower."

Holotype-UCMP 11662.

Type locality.-Monterey County, Calif. Pancho Rico Formation, Pliocene. Subsequent work by Durham and Addicott (1965) suggests that the type locality is in terraces on east side of Salinas Valley or in tributary canyons to the valley between King City and San Lucas (Judith T. Smith, written commun., 1979).

Comparison.-Lyropecten terminus is distinguishable from $L$. estrellanus by its fewer and broader ribs, relatively longer hinge line, and finer obsolete radial striation; and from L. catalinae by its fewer ribs and greater convexity. (Arnold, 1906, p. 77)

"This species is probably a direct descendant of Lyropecten estrellanus (Conrad). It is distinguished from the latter by the usually fewer ribs with numerous radial striations, and the vertical sides of the primary ribs. In L. estrellanus the ribs are slightly more numerous and have a uniformly rounded profile." (Adegoke, 1969, p. 101)

Lyropecten cerrosensis has more numerous ribs (17 to 19) that are usually more rounded than those on $L$. terminus which has but 15 flat-topped ribs. (Hertlein and Grant, 1972, p. 211)

Geographic range.-Southern California.

Geologic range.-Miocene to Pliocene.

Occurrence in California.-Miocene: Pancho Rico Formation (Addicott, 1974); Miocene and Pliocene: Etchegoin Formation (Arnold, 1906; Adegoke, 1969; Addicott, 1972). [According to Judith T. Smith (written commun., 1979) L. terminus is restricted to the Pliocene, and the records of Arnold (1906) in the San Pablo and Santa Margarita Formations are in error.]

\section{Lyropecten gallegosi (Jordan and Hertlein) Plate 19, figure 3}

Pecten (Lyropecten) gallegosi Jordan and Hertlein, 1926, p. 434-435, pl. 29, fig. 1.

Original description. - "Shell large, and of the same general outline as $P$. cerrosensis Gabb, but flatter. Right valve ornamented by 21 to 23 , narrow, square, flat-topped and often T-rail shaped radiating ribs; interspaces flat-bottomed, with a well defined midrib, their bottoms and walls also finely, radially striate; ribs and interspaces crossed by concentric lines of growth; anterior dorsal and posterior dorsal margins of the valve bearing several sharp, radiating riblets; anterior ear large, with a well defined byssal notch, the ear ornamented by six to eight strong, radiating riblets which are crossed by lines of growth; posterior ear smaller than anterior, and sloping obliquely, posteriorly and downward from posterior termination of hinge line to edge of disk, the ear sculptured by 10 to 12 sharp, strong, radiating riblets crossed by growth lines. Height $125 \mathrm{~mm}$.; length $138 \mathrm{~mm}$.; apical angle $116^{\circ}$. Left valve more highly arched than right, and similarly sculptured; at intervals every fifth rib is slightly raised, as is the case on occasional specimens of $P$. cerrosensis Gabb."

Holotype.-CAS 2096.

Type locality.-CAS 946. Baja California Norte, Almejas Formation, Pliocene.

Comparison.- -It is recognized that intergradation may ultimately be proved with $P$. cerrosensis Gabb, which itself is rather 
variable, but the type and paratypes of $P$. gallegosi present such striking characters as to merit a separate designation. From $P$. cerrosensis, the present form is distinguished mainly by having a much flatter shell, and by a greater intensity of sculpture. The slightly greater number of ribs, which are in nowise rounded, the sharp riblets on the anterior dorsal and posterior dorsal margins of the shell, and the strong sculpture on the ears are distinguishing characters. From P. hakei Hertlein, P. gallegosidiffers in having the strong hinge teeth characteristic of a Lyropecten, in the presence of a midrib between the major radial ribs, and in other less important particulars." (Jordan and Hertlein, 1926b, p. 434-435)

"The strong midrib indicates that Pecten (Lyropecten) gallegosi Jordan and Hertlein, from Cedros Island, where it is associated with cerrosensis, is allied to estrellanus." (Woodring, 1938, p. 34)

Lyropecten gallegosi has more rectangular ribs and stronger radial microsculpture than L. cerrosensis (Judith T. Smith, written commun., 1979).

Geographic range.-Baja California Norte.

Geologic range.-Pliocene.

Occurrence in Baja California.-Almejas Formation (Minch and others. 1976)

\section{Lyropecten modulatus (Hertlein)}

\section{Plate 19, figure 4}

Pecten (Lyropecten) modulatus Hertlein. 1925a, p. 11-12, pl. 3, fig. 6. Pecten subnodosus Sowerby. G D. Hanna, 1926a, p. 474, pl. 25, fig. 6. Not Pecten subnodosus Sowerby, 1835.

Not Liyropecten modulatus (Hertlein). Durham, 1950, p. 65, pl. 11,

fig. 7. [= Nodipecten subnodosus (Sowerby).]

Original description. - "Shell moderately convex, fairly heavy, showing slight areas of constricted growth. Right valve ornamented by about 14 longitudinally sculptured radiating ribs, which are rounded in the earlier part of the shell, but which, toward the ventral margin, show a tendency to become flattened; interspaces of varying width but all narrower than the ribs, all containing a small midrib; anterior and posterior margins of shell ornamented by fine longitudinal riblets; ears unequal, the anterior ear large. with large byssal notch and sculpture consisting of about seven well defined radial riblets and concentric growth lines, the left ear small in comparison with the large right, its posterior edge sloping down almost vertically to the margin of shell, the surface of the ear ornamented by about eight or more radiating riblets over which are superimposed fine longitudinal and concentric lines. Altitude $58 \mathrm{~mm}$.; longitude 60 $\mathrm{mm}$.; diameter of right valve approximately $14 \mathrm{~mm}$.; apical angle, right valve approximately $92^{\circ}$."

Holotype.-CA.S/SU 39.

Type locality.-SU 43. Baja California Sur. Almejas Formation, Pliocene.

Supplementary description.-The left valve has 10 to 11 ribs, 3 of which are nodose and separated by 2 lesser ribs; the right-valve ribs have no nodes (Judith T. Smith, written commun., 1979).

Comparison. - "Pecten modulatus bears some resemblance to $P$. vaughani Arnold, but is much larger and also has sculptured margins and prominent midriblets in the interspaces, while in $P$. vaughani the interspaces bear fine striae only." (Hertlein, 1925a, p. 12)

Geographic range.-Southern California to Baja California Sur. Geologic range.-Miocene to Pliocene.

Occurrence in the Californias.-Miocene or Pliocene: Imperial Formation (Judith T. Smith, written commun., 1979); Pliocene: Almejas (Minch and others, 1976), Salada, and San Marcos (Durham, 1950) Formations.

\section{Lyropecten cerrosensis (Gabb)}

Plate 20, figures 1, 3, 4; plate 21, figure 1

Pecten cerrosensis Gabb, 1866, p. 32. Gabb, 1869, pl. 9, figs. 55, 55a. Pecten (Plagioctenium) cerrosensis Gabb. Hertlein, 1925a, p. 15-16, pl. 6, fig. 1 .

Pecten (Lyropecten) cerrosensis Gabb. Jordan and Hertlein, 1926b, $\mathrm{p}$. $432-433$, pl. 32 , fig. 4 . Moore, 1968 , p. 44, pl. 20, figs. a, b.

Pecten (Lyropecten) estrellanus (Conrad) var. cerrosensis Gabb. Grant and Gale, 1931, p. 187, pl. 8, figs. 1a, 1b, 2a, 2b; pl. 9, fig. 2.

Lyropecten cerrosensis (Gabb). Woodring, 1938, p. 32-34, pl. 7, figs. 1, 2. Woodring, 1950, p. 85, pl. 21, fig. 1 .

Chlamys (Lyropecten) cerrosensis Gabb. Hertlein and Grant, 1972, p. 209-211, pl. 34, figs. 1-4; pl. 36, fig. 7.

Pecten (Lyropecten) ashleyi Arnold, 1906, p. 122-123, pl. 47, figs. 1, 1a; pl. 48, fig. 1.

Not Pecten (Plagioctenium) cerrosensis Gabb. Arnold, 1906, p. 123-124, pl. 44, fig. 5; pl. 49, figs. 1, 1a, 1b. [= Argopecten.]

Original description.- -Shell equivalve, subcircular, broader than long, convex; beaks small; sides sloping concavely above, rounded below; ears small, subequal, roughened and irregular, sinus very small. Surface marked by eighteen or twenty flat ribs, with flat or slightly concave interspaces; margins undulated, the ends of the ribs being deeply emarginated, and the interspaces being prolonged into tongue-like processes." (cerrosensis)

"Adult shell averaging about 150 millimeters in altitude, much longer than high, subequivalve, convex, inequilateral, the posterior portion of the disk being obliquely produced; sides concave above. Right valve with about 18 or 19 prominent, rather squarish, flattopped (convex-topped near umbo) ribs which are more or less prominently sculptured by numerous thread-like, somewhat imbricated, radial ridges; interspaces narrower than ribs, channeled and ornamented by an intercalary riblet and, in the later stages of growth, by several imbricated radial lines; hinge line about one-half length of disk; anterior ear somewhat produced, prominently notched and sculptured by numerous imbricating incremental lines and several more or less prominent unequal radials; posterior ear slightly shorter than anterior, and similarly sculptured except with more, but less conspicuous, radials. Left valve slightly more convex than right and similar to it except that the ribs are slightly narrower and more convex, and the interspaces are correspondingly wider and generally have the bottom entirely sculptured with subequal radial lines, with the prominent intercalary lacking; ears subequal, rectangularly truncated and sculptured in a similar manner to the posterior ear of the right valve." (ashleyi)

Holotype.-UCMP 32669 (formerly UCMP 1091); of L. ashleyi, UCMP 12082.

Type locality.-Isla Cedros, Baja California Norte. Almejas Formation, Pliocene; of $L$. ashleyi, same locality. [Subsequent collecting by Frank Kilmer restricts the type locality to the beach cliffs below Cedros Village and the canyons just south of it (Judith T. Smith, written commun., 1979).]

Supplementary description. - "Fragments of an exceptionally large valve from San Diego $* * *$ have a riblet stronger than the others in the interspaces some distance from the margin of the valve, in the middle of the interspaces or a short distance from the middle. Hertlein's figure of the type of cerrosensis shows a riblet slightly stronger than others in interspaces on the middle of the right valve about halfway between the umbo and lower margin ***." (Woodring, 1938, p. 33)

"The entire shell is radially striated with fine threads as are other 
species of Lyropecten. The interspaces bear four or five striations or threads of which the central one is stronger than the others and forms a midrib." (Hertlein and Grant, 1972, p. 210)

Some left valves, especially juvenile or young adult parts, have the central rib and the fourth anterior and posterior lateral ribs raised (Judith T. Smith, written commun., 1979).

Comparison.-" L. cerrosensis is larger than L. estrellanus, estrellanus catalinae, and estrellanus terminus but is not much larger than *** gallegosi; it also lacks the strong midrib of estrellanus and its allies, those on the young shell figured by Jordan and Hertlein being weaker than in estrellanus. It is almost as large as the Miocene L. crassicardo (Conrad), ${ }^{* *}$ but $* * *$ the ears are sculptured with fewer riblets. On some specimens of crassicardo a riblet in some of the interspaces is stronger than the others." (Woodring, 1938, p. 34)

"In some interspaces one secondary rib is stronger than others, but it does not completely fill the interspace as in the smaller Miocene $L$. estrellanus. Lyropecten terminus, from the Pliocene of the Salinas Valley, is smaller than $L$. cerrosensis and has a relatively strong secondary rib." (Woodring, 1950, p. 85)

"The general characters of the shell of the present species closely resemble those of $C$. (L.) estrellanus $* * *$. A midrib is present in the interspaces between the ribs of $C$. (L.) cerrosensis as it is in $C$. (L.) estrellanus and its subspecies. However, the midrib is usually decidedly finer than it is on the shells of the $C$. (L.) estrellanus group. Some young specimens of $C$. $(L$. $)$ cerrosensis have a well developed midrib and in this respect closely resemble some specimens of $C$. $(L$.) estrellanus. Compared to typical $C$. (L.) estrellanus Conrad $* * *$ the valves of $C$. (L.) cerrosensis are less inflated, generally larger, more elongated posteriorly, the midrib in the interspaces is usually smaller and not split at the margin, there are more numerous riblets on the ears and often there are more and coarser radial threads and riblets on the posterior submargin. Chlamys (L.) cerrosensis has more numerous ribs which are usually more rounded than those on $C$. (L.) estrellanus terminus Arnold which has but 15 flat-topped ribs. The valves of $C .(L$.$) cerrosensis are more convex and the midribs are$ usually finer than are those of $C$. (L.) estrellanus catalinae Arnold. Chlamys (L.) gallegosi E. K. Jordan and Hertlein bears a close resemblance to $C$. $(L$.) cerrosensis but the former species has flatter, squarer, and much more closely spaced ribs, the riblet in the interspaces is much coarser and the radial threads on the shell are generally coarser.

"In general outline and sculpture C.cerrosensis bears a similarity to $C$. (L.) crassicardo Conrad but differs in possessing a midrib in the interspaces between the major ribs, in the usually greater number of ribs, 17 to 19 or 20 in comparison to 14 to 17 , also in lacking constrictions which often are present on the shell of Conrad's species." (Hertlein and Grant, 1972, p. 210-211)

Comments. - The largest specimen known is $190 \mathrm{~mm}$ long and 175 $\mathrm{mm}$ high (Moore, 1968, p. 44, pl. 20, figs. a, b).

Geographic range.-Southern California to Baja California Sur.

Geologic range.-Miocene and Pliocene. This species is the last known Lyropecten to have lived in California seas (Woodring, 1950, p. 85).

Occurrence in the Californias.-Miocene: Pancho Rico Formation (Durham and Addicott, 1965); Miocene and Pliocene: Etchegoin Formation (Smith, 1912); Pliocene: Almejas Formation (Arnold 1906; Minch and others, 1976), Cebada Member, Careaga Sandstone (Woodring, 1950), lower member, Fernando Formation (Durham and Yerkes, 1964), Foxen Mudstone (Woodring, 1950), Niguel (Vedder, 1960), lower part of Pico (Kew, 1924; Winterer and Durham, 1962), Salada (Beal, 1948), and San Diego (Hertlein and Grant, 1972) Formations; Pliocene: Gragg and Squire Members, Pismo Formation (Hall, 1973).

\section{Genus MACROCHLAMIS Sacco, 1897}

Differs from Lyropecten in that the left valve is usually more convex than the right valve (but this character is variable), the byssal notch shallower, and the cardinal crura weaker.

Geographic range.-Eurasia, western Atlantic, and eastern Pacific.

Geologic range.-Oligocene to Pliocene.

\section{Macrochlamis magnolia (Conrad)}

Plate 21, figures 4, 5

Pecten magnolia Conrad, 1857c, p. 191, pl. 1, fig. 2.

Pecten (Lyropecten) magnolia Conrad. Arnold, 1906, p. 77-79, pl. 24, figs. 1, 2; pl. 25, fig. 1. Loel and Corey, 1932, p. 198-199, pl. 25, figs. $1-4$; pl. 26 , figs. $1 \mathrm{a}, 1 \mathrm{~b}$; pl. 27 , figs. 1 , 2 ; pl. 28 , fig. 1 .

Lyropecten magnolia (Conrad). Addicott, 1965, fig. 3, i. J. T. Smith, 1975 , pl. 1, figs. $3-5,7$.

Pecten (Lyropecten) vaughani emigdioensis Wagner and Schilling, 1923 , p. 253 , pl. 45 , fig. 2 .

Macrochlamis magnolia (Conrad). Addicott, 1972, pl. 2, fig. 8.

Original description. - "Suborbicular, ribs 11, very large, prominent, convex-depressed on the back, laterally angulated, longitudinally rugoso-striate. Locality, Santa Ynez Mountains, S. B. C." (magnolia)

"Shell small; equilateral; convex; slightly longer than high; base regularly rounded, dorsal margins slightly concave; left valve with 10 prominent ribs, rail-shaped and flat to rounded on top; interspaces nearly equal to ribs in width; bottoms rounded; surface of ribs and interspaces covered with very fine radial striae; incremental lines not prominent; anterior ear sculptured by 5 distinct riblets; byssal notch shallow; posterior ear (imperfect type) ornamented by 1 rounded and 3 sharp ribs. Dimensions: length, $23 \mathrm{~mm}$; height, 21 $\mathrm{mm}$.; convexity of left valve, $5.5 \mathrm{~mm}$." (emigdioensis)

Type.-Lectotype USNM 13325 (Keen and Bentson, 1944); holotype of M. emigdioensis, UCMP 11417.

Type locality.-Santa Inez [Ynez] Mountains [T. 5 N., R. 30 W., S.B., Santa Barbara County], Calif. Vaqueros Formation, Oligocene and Miocene. Of $M$. emigdioensis: UC 3224, Kern County, Calif., Vaqueros Formation, Oligocene and Miocene.

Supplementary description. - "Shell averaging about $150 \mathrm{mil}-$ limeters in altitude, slightly longer than high, subequivalve, equilateral, rather thick, somewhat ventricose, and with smooth margins; base regularly rounded; sides sloping above, and slightly concave. Right valve slightly more convex than left, with about 9 to 11 broad, flat-topped, equal, equidistant ribs; interspaces slightly narrower than ribs and flat-bottomed; whole surface of ribs and interspaces covered by imbricated radiating riblets (about 10 on each rib) and fine, concentric incremental lines; hinge line about two-thirds the length of the disk; anterior ear slightly longer than the posterior, with arcuate end and fine concentric incremental sculpture, but obsolete radiating ridges; posterior ear with no radial sculpture whatever; byssal notch relatively small. Left valve quite similar to right but with narrower, more rounded ribs; sculpture of radiating riblets and fine wavy incremental lines; interspaces broader than in right valve; ears almost identical to those of right." (Arnold, 1906, p. 78)

"The umbone of the right valve is commonly higher and more convex than that of the left, projecting above the hinge line.

"In one zone of the type region ***, Pecten magnolia Conrad has develcped 10 to 12 ribs in a large percentage of individuals. A count of all specimens in the collections and in the field gives an average 
TABLE 11.-Geologic and geographic distribution of the genus Nodipecten

$[\mathrm{H}=$ Holocene; $\mathrm{Ple}=$ Pleistocene: $\mathrm{Pl}=$ Pliocene; $\mathrm{M}=$ Miocene $]$

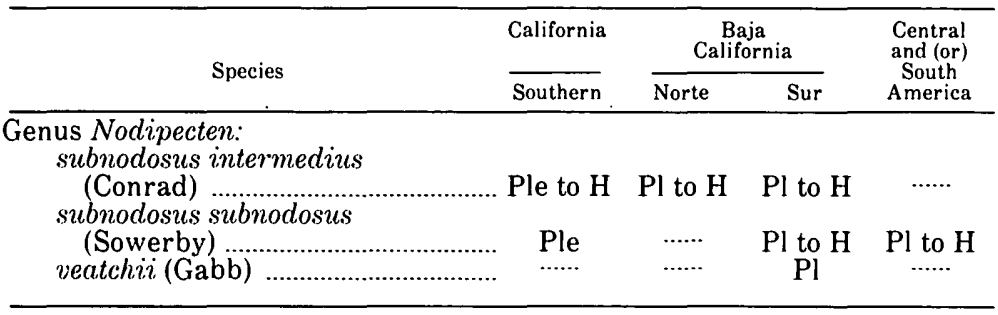

rib number of 9 and a range of 6 to 13." (Loel and Corey, 1932, p. 198)

Comparison. - P. magnolia is somewhat closely allied to P. crassicardo***. It is distinguishable from the latter by its fewer ( 9 to 11 , instead of 14 to 17), broader, more square-cut and more coarsely radially sculptured ribs, and the obsolete radial sculpture on its ears." (Arnold, 1906, p. 78)

Comments. - Pecten (Lyropecten) vaughani emigdioensis is a juvenile specimen of M. magnolia.(Judith T. Smith, oral commun., 1978).

Geographic range.-Middle to southern California.

Geologic range.-Oligocene and Miocene.

Occurrence in California.-Oligocene: Agua Sandstone Member, Temblor (Dibblee, 1973) and Quail Canyon Sandstone Member, Vaqueros (Dibblee, 1973) Formations; Oligocene and Miocene: Mindego Basalt (Cummings and others, 1962), Rincon Shale (Bailey, 1952). Soda Lake Shale Member, Vaqueros (Vedder, 1973; Squires and Fritsche, 1978), Temblor (Nilsen and others, 1973), and Vaqueros (Arnold, 1906; Kew, 1924; Loel and Corey, 1932; Dibblee, 1950; Repenning and Vedder, 1961; Addicott, 1968) Formations; Miocene: Painted Rock Sandstone Member, Vaqueros Formation (Vedder, 1973), Pyramid Hill Sand Member. Jewett Sand (Addicott, 1974), and Tranquillon Volcanics (Dibblee, 1950).

\section{Genus NODIPECTEN Dall, 1989}

Ctenolium well developed; imbricated surface layer in some species very marked. Differs from Lyropecten in that ribs are intermittently nodose (hollow nodes) and posterior auricle is smaller than anterior.

Geographic range.-Western Atlantic; eastern Pacific.

Geologic range.-Miocene through Holocene (table 11).

\section{Nodipecten subnodosus subnodosus (Sowerby)}

\section{Plate 6, figures 4, 8}

Pecten submodosus Sowerby, 1835, p. 109.

Pecten (Nodipecten) subnodosus Sowerby. Arnold, 1906, in part, p. 128-129, pl. 52, fig. 1; not pl. 53, figs. 1, 1 a.

Pecten (Lyropecten) subnodosus Sowerby. Hertlein, 1935, p. 317-318. Lyyropecten subnodosus (Sowerby). Durham, 1950, p. 65, pl. 11, fig. 1. Nodipecten subnodosus (Sowerby). Grau, 1959, p. 128-132, pl. 43.

Not Pecten subnodosus Sowerby. G D. Hanna, 1926a, p. 474, pl. 25, fig. 6 [= Lyropecten modulatus Hertlein].

Original description. - "Pect. testâ subqequivalvi, aequilaterali, auriculus inaequalibus; striis radiantibus numerosissimis, radiisque decem, crassis, rotundatis, alternatim nodoso-vesicularibus vel subnodosis; intùs plerumque purpureo signatâ; long. 5.25, lat. 2.75, alt. 5. poll."

\section{Holotype.-In BM (NH).}

Type locality.-Isla La Plata, Ecuador. Holocene.

Supplementary description. - "Shell large and thick, averaging $130 \mathrm{~mm}$ in height when adult, and usually longer than high; left valve usually more concave than right; hinge line from almost half to slightly more than half length of disk. Right valve often concentrically undulated; 10 ribs (occasionally 11), those next to submargins being almost obsolete; ribs rounded and with 7 to 15 thin radial ridges; interspaces with 5 to 8 ridges of same size; fine concentric imbricating lamellae between all ridges. Anterior auricle short for size of disk, of varying height, and concentrically lamellose; from 8 to 12 radiating riblets, those next to disk being much smaller; byssal notch rather shallow and either rounded or angled; ctenolium of 5 to 10 teeth in young shells, later only 3 or 4 obscurely present. Posterior auricle shorter, also lamellose, and with 10 to 18 radial riblets. Left valve often concentrically undulated; usually 9 but occasionally 10 ribs, those next to submargin being almost obsolete; ribs rounded and having 8 to 16 thin radial ridges; central rib and alternate one or two either side often having hollow nodules, with degree of prominence varying in individuals; interspaces with 6 to 8 radial ridges; entire disk profusely covered with fine imbricating lamellae which is nearly always worn off tops of ribs on mature specimens. Anterior auricle concentrically lamellose and with 10 to 15 radial ridges of varying size; byssal sinus shallow. Posterior auricle same as that of right valve. Hinge line with strong diagonal crura adjoining resilial pit. ${ }^{* * *}$ heavy white callus covering umbonal area, surrounding muscle scar, and reaching to from one-thirds to two-thirds of distance to ventral margin.

"Specimens from western Lower California and the Gulf of California to southern West Mexico are usually larger at maturity $* * *$ with 10 ribs on the right valve and 9 on the left, while those from central West Mexico (overlapping the above) to Peru are usually smaller $* * *$ with 11 ribs on the right valve and 10 on the left. Conrad's Pecten intermedius was based on the northern 'form'; he commented, 'It differs from subnodosus *** in having much finer striae, numbering nearly double as many between each rib.' The finer striae are actually found only on occasional specimens, and the features of the northern 'form' mentioned above would not be of specific or infraspecific significance even if they were constant." (Grau, 1959, p. 130-131)

"Both valves are similar, not strongly convex. Most specimens of the typical form have 10 ribs in the left valve and 11 ribs in the right, counting the deep furrows around the ventral margin. The ribs are as wide as their intervals, both covered with a series of close-set, coarse, slightly scabrous radial cords; there are usually a scattering of small or coarse, sometimes hollow nodes or humplike swellings along the summit of the ribs, best developed on the left valve. ${ }^{* * *}$ Ears unequal in size, the anterior larger and longer, that of the right valve with a deep notch." (Olsson, 1961, p. 161) 
Comparison.-"Grant and Gale (1931, p. 179-182) united this species with Pecten nodosus (Linnaeus). However, the two may easily be separated by the fewer interribs (usually 3 or 4) of that species compared to 6 or 8 on Sowerby's species. Further, L. subnodosus is usually more inflated. A large specimen *** has much less than the normal degree of inflation but still retains the greater number of interribs. Many of the specimens $* * *$ are similarly less inflated, a condition that has not been noted in any of the recent specimens." (Durham, 1950, p. 65) See also comparison below in section on Nodipecten subnodosus intermedius.

Geographic range.-Living: Isla Tres Marias to Peru; fossil: southern California to Oaxaca, Mexico.

Geologic range.-Pliocene to Holocene.

Occurrence in the Californias. - Pliocene: unnamed strata on Isla Cerralvus; Pleistocene: Palos Verdes Sand (Woodring, 1946). The record in the Imperial Formation (G D. Hanna, 1926a) is in error; the species is Lyropecten modulatus (Judith T. Smith, written commun., 1979).

Habitat.-From low tide to $110 \mathrm{~m}$. Found in shallow depressions in sand at low tide; in deeper water on rock, sand or mud bottoms, associated with red algae, nullipores, corraline and coral; vermetids, bryozoans and barnacles often commensal.

\section{Nodipecten subnodosus intermedius (Conrad)}

Plate 22, figure 1; plate 23, figure 5

Lyropecten intermedius Conrad, 1867, p. 7.

Pecten (Nodipecten) subnodosus Sowerby. Arnold, 1903, p. 108. Not Pecten subnodosus Sowerby, 1835.

Pecten (Nodipecten) subnodosus Sowerby. Arnold, 1906, in part, p. 128-129, pl. 53, fig. 1, not pl. 52, fig. 1.

Pecten subnodosus Sowerby. Jordan, 1924, p. 148.

Pecten (Lyropecten) subnodosus Sowerby. Jordan and Hertlein, 1926b, p. 418. Hanna and Hertlein, 1927, p. 141.

Pecten (Lyropecten) nodosus (Linnaeus) variety intermedius (Conrad). Grant and Gale, 1931, p. 181-182.

Original description. - "Rounded-oval, ventricose; ribs 9-10 nodose, as wide as the interstices; with numerous closely scaled striae covering the whole surface, and numbering about ten between each rib. Purple, within purple, with a large white central deposit of callus."

Holotype.-The holotype is missing and presumed lost.

Type locality.-Cabo San Lucas, Baja California Sur.

Comparison.-Right valves of Holocene specimens of Nodipecten subnodosus intermedius differ from $N$. subnodosus subnodosus in having the ribs evenly distributed; right valves of $N$. subnodosus subnodosus have ribs grouped in $\mathbf{5}$ about a wider central space. Holocene specimens of Nodipecten nodosus nodosus have more bulbous or flared nodes, sometimes on all ribs of both right and left valves, and a slightly coarser, striate, lyrate microsculpture than $N$. subnodosus intermedius (Judith T. Smith, written commun., 1980).

Geographic range. - Living: Santa Catalina Island, Calif., to Baja California Sur and in Golfo de California; fossil: Baja California Norte to Mexico.

Geologic range.-Pliocene through Holocene.

Occurrence in the Californias.-Pliocene: Almejas (Minch and others, 1976), Carmen (Durham, 1950), Infierno(?) (McFall, 1968), Marquer (Durham, 1950), and San Marcos (Durham, 1950) Formations; Pleistocene: unnamed strata at San Pedro and San Diego, Isla de Cedros, and Golfo de California.

\section{Nodipecten veatchii (Gabb)}

Plate 22, figure 4; plate 23, figure 2

Pecten veatchii Gabb, 1869, p. 32, pl. 10, fig. 56 .

Pecten (Nodipecten) veatchii Gabb. Arnold, 1906, p. 106-107, pl. 40, figs. 1, 1a.

Pecten (Lyropecten) veatchii Gabb. Jordan and Hertlein, 1926b, p. 418.

Pecten (Lyropecten) nodosus (Linnaeus) variety veatchii Gabb. Grant and Gale, 1931, p. 182

Original description. - "Shell large, equivalve, a very little broader than long; base regularly rounded; sides sloping above, with a slight concavity; ears unequal; sinus in the right ear of the lower valve moderately deep; surface of ears covered by small radiating ribs and fine imbricating lines of growth; surface of valves ornamented by about 8 broad, flat, subnodose ribs, arranged in pairs, and a few small linear ribs on the side; besides the ribs, the whole surface is covered by small radiating lines, and crossed by very irregular lines of growth, and very fine imbricating concentric lines."

Holotype-UCMP 12078

Type locality.-Isla de Cedros, Baja California Norte. Almejas Formation, Pliocene.

Supplementary description.-"Shell averaging about 130 millimeters in altitude $* * *$ subequivalve, equilateral, of medium thickness, somewhat ventricose, and with margins finely serrate $* * *$. Right valve slightly less ventricose than left, $* * *$ [and] the whole surface is covered by several more or less prominent concentric undulations and numerous fine, squarish, imbricated, raised riblets; hinge line a little more than one-half the length of the disk; anterior ear about one and two-thirds length of posterior, ornamented by about 12 radiating riblets and numerous fine, sharp, imbricating, incremental lines; byssal notch about one-fourth length of ear in depth; posterior ear much smaller than anterior, but sculptured in a similar manner. Left valve with about 7 broad, flat, round-cornered ridges of unequal size, which are separated by interspaces of unequal width, there being 3 or 5 prominent ribs, between each pair of which is a smaller one; the surface of this valve is sculptured similarly to that of the right, except that the concentric undulations on the ribs become more or less prominent nodes toward the apex of the shell; ears similar to those of the right valve, except that the anterior one has a simple arcuate end and no notch." (Arnold, 1906, p. 106-107)

Comparison. - "This species is quite similar to and is no doubt the precursor of $P$. subnodosus, from which it differs by attaining a larger size and having fewer and broader ribs. Like the living form, it is quite variable as regards the number and rugosity of its ribs." (Arnold, 1906, p. 107)

Geographic range.-Baja California Sur. [According to Judith T. Smith (written commun., 1979) N. veatchii does not occur north of Baja California, and the records of Arnold (1906) and Smith (1912) are in error.]

Geologic range.-Pliocene.

Occurrence in Baja California.-Almejas Formation (Minch and others, 1976).

\section{Genus SWIFTOPECTEN Hertlein, 1936}

Higher than long, nearly equivalve, auricles nearly equal and with well-developed byssal notch and ctenolium in adult; four, five, or more folded radial ribs (paired in some shells), thickened where 
TABLE 12.-Geologic and geographic distribution of the genus Swiftopecten

$[\mathrm{Ple}=$ Pleistocene; $\mathrm{Pl}=$ Pliocene; $\mathrm{M}=$ Miocene $]$

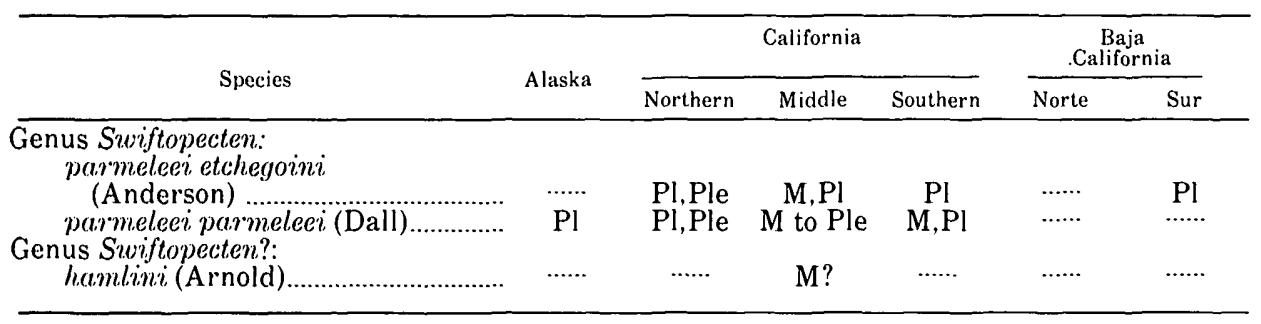

crossed by concentric undulations, commonly with nodes at intersections on left valve, entire surface with coarse radial striae and microscopic tesselations; hinge with strong cardinal crura, one on each side of ligamental pit.

Manupecten has radial ribs rather than folds and no constricted radial ribs on the left valve.

Geographic range.-Japan and eastern Pacific.

Geologic range.-Miocene through Holocene (table 12)

Habitat. - In 1 to $145 \mathrm{~m}$.

\section{Swiftopecten parmeleei parmeleei (Dall)}

\section{Plate 23, figures 1, 3, 4}

Pecten (Chlamys) parmeleei Dall, 1898, p. 708, pl. 37, figs. 14, 14a. Arnold, 1906, p. 119, pl. 41, figs. 1, 1a; not? 5, 5a [= S. swiftii fide Masuda, 1972].

Chlamys parmeleei (Dall). Woodring, 1950, p. 83, pl. 16, fig. 20

Chlamys (Swiftopecten) parmeleei-Dall. Hertlein and Grant, 1972, p. 206-208, pl. 31, fig. 5; pl. 37, figs. 1-10; text fig. 10 (see for synonymy)

Pecten (Chlamys) wattsi Arnold, 1906, p. 120, pl. 11, figs. 1, 1 a.

Original description. - "This species is close to P. Swiftii Bernhardi [sic: Bernardi] of Japan (J. de Conchyl., vii., plates 1 and 2, 1858) but smaller, and differs by the smooth top surface of the ribs, which in $P$. Swiftii are more or less striated or coarsely threaded, and by the not alternated radial riblets on the right posterior ear; also, especially, by the profuse coalescent microscopically checkered squamation, which makes a complete external coating to the valve. Alt. 45 , lat. $38 \mathrm{~mm} . "$ (Dall, 1898)

"Shell averaging about 65 millimeters in altitude, slightly higher than long, equilateral, of medium thickness, decidedly ventricose, and with margins slightly finely serrate; base regularly rounded; sides sloping above, with slight concavity. Left valve with 5 high, rather narrow, rounded, almost smooth ribs, which are made prominently nodose by several very pronounced concentric undulations, or constrictions; interspaces much wider than ribs and each ornamented by about 5 small, subequal, rounded, imbricated riblets; whole surface of disk with a profuse, coalescent, microscopically checkered squamation; hinge line about two-fifths length of disk; anterior ear with arcuate end, and with surface sculptured by about 5 prominent imbricated riblets and several concentric undulations: posterior ear obsolete. Right valve about equal to left in convexity, with broad, flat-topped ribs and narrower interspaces, both being longitudinally sculptured by subequal riblets; ears similar to left; byssal notch not prominent; surface sculpture microscopic; constrictions less pronounced than in left valves." (wattsi)

Holotype-USNM 154479; of $P$. wattsi missing and presumed destroyed in San Francisco fire of 1906; lectotype CAS 5945 (G D.
Hanna and Hertlein, 1941, p. 176, fig. 65-18).

Type locality.-San Diego [San Diego County], Calif. San Diego Formation, Pliocene; of S. wattsi, USGS 4712, Fresno County, Calif., Etchegoin Formation, Miocene and Pliocene.

Supplementary description. - "A fine series **'* collected *** from near the Mexican boundary [San Diego Formation, Pliocene] *** of various sizes, from 4 to $79 \mathrm{~mm}$ high ***. Some attain a height of $32 \mathrm{~mm}$ with only a trace of undulation of the shell. Some have three, others as many as five, constrictions in the shell. These undulations where they cross the ribs, lend a nodose appearance to the ribs.

"The ribs are large, convex and consist of folds in the shell, those of the right valve corresponding to the interspaces of the left. There are four broad ribs on the right valve and often in addition a narrow, minor one near the anterior and posterior margins. The ribs on this valve are separated by narrower interspaces than those on the left. There are five on the left valve which is more convex than the right. The ribs and interspaces of both valves are sculptured with nearly equal, coarse, radial threads. The anterior ears are much larger than the posterior ones and are sculptured with 5 to 9 riblets, those on the left posterior ear are fine and nearly equal in size." (Hertlein and Grant, 1972, p. 207)

"Parmelee $i$ is characterized by its small shell which is contorted posteriorly in the young stage but tends to become rounded with growth ***." (Masuda, 1972, p. 401)

Comparison. - "The dorsal (umbonal) part of the shell of , large specimens of $C$. parmelee $i$ is more inflated than that of $C$. swiftii and is more strongly set off from the ears ***. C. parmelee $i$ has concentric swellings, whereas C. parmeleei etchegoini lacks the swellings." (Woodring, 1950, p. 83)

"Parmeleei differs from the closely related Swiftopecten swiftii in having smaller shell which tends to become rounded with growth and somewhat larger apical angle." (Masuda, 1972)

"A comparison of large specimens of Chlamys (Swiftopecten) parmeleei with $C$. (S.) swiftii from Japan reveals that on C. (S.) parmelee $i$ and its subspecies the left posterior ear is generally sculptured with finer more nearly equal riblets. The radial ribs on both valves of the Japanese species tend to bifurcate toward the ventral margin whereas those on $C$. (S.) parmeleei only rarely show this feature. Furthermore the west American forms do not reach the size of $C$. (S.) swiftii which attains a height of at least $108 \mathrm{~mm}$." (Hertlein and Grant, 1972, p. 208)

Geographic range.-Alaska; middle to southern California.

Geologic range.-Miocene(?); Pliocene; Pleistocene(?).

Occurrence in California.-Miocene: Castaic Formation (Stanton, 1966); Miocene and Pliocene: Capistrano (Kern and Wicander, 1974), Etchegoin (Arnold, 1906; Woodring and others, 1940), Purisima (Arnold, 1906), and Tahana Member, Purisima (Cummings and others, 1962; Durham and Morgan, 1978) Formations; Pliocene: 
Cebada Member, Careaga Sandstone (Woodring, 1950), lower member, Fernando (Durham and Yerkes, 1964), Niguel (Vedder, 1960), Pico (Addicott and Vedder, written commun., 1968), San Diego (Hertlein and Grant, 1972), San Joaquin (Woodring and others, 1940) Formations; Pliocene and Pleistocene: Merced Formation (Arnold, 1906) and Wildcat Group (Arnold, 1906).

\section{Swiftopecten parmeleei etchegoini (Anderson)}

\section{Plate 22, figures 2, 3}

Pecten etchegoini Anderson, 1905, p. 198, pl. 18, figs. 92, 93. Hanna and Hertlein, 1943, p. 172, fig. 63, 1-2.

Pecten (Pallium) swiftii Bernard variety etchegoini Anderson. Grant and Gale, 1931, p. 173-174, pl. 1, figs. 3a, 3b.

Swiftopecten etchegoini (Anderson). Adegoke, 1969, p. 104-105.

Chlamys etchegoini (Anderson). Woodring, Stewart, and Bramlette, 1940, pl. 13, fig. 5; pl. 32, fig. 1 .

Chlamys (Swiftopecten) parmeleei etchegoini (Anderson). Hertlein and Grant, 1972, p. 208.

Pecten (Chlamys) wattsi var. morani Arnold, 1906, p. 121-122, pl. 10, figs. 3-6.

Original description.-."Shell rather large, thick, and ovate in outline; ears nearly equal, costate; ribs strong and grouped in sets of 3 or 4 , forming radial undulations in the shell, seen both within and without; margin of valve fluted within. The grouping of the ribs is a variable feature of the shell. In some specimens the depressions are wider, in others narrower than in the one figured. Concentric lines are usually visible on the shell." (Anderson, 1905)

"Adult shell averaging about 65 millimeters in altitude, much shorter than high, inequivalve, equilateral, moderately convex, and with slightly serrate margins. Right valve less convex than the left, ornamented by 4 very broad, prominent, flat-topped ridges, each of which carries from 5 to 7 strong, squarish, elevated, subequidistant riblets; interspaces narrow and rather deep, each ornamented by 1 or 2 squarish riblets; hinge line about one-third length of disk; anterior ear much more prominent than the posterior, regularly arcuate-ended and sculptured by 5 or 6 radials; byssal notch only slightly developed; posterior ear very short, obliquely truncated and radially striate. Left valve more convex than right, and usually more or less undulated by constrictions; disk with 5 subequal, narrow, ridge-like ribs, separated by wide interspaces, in each of which are from 2 to 5 subequal, prominent, squarish riblets; whole surface ornamented by a superimposed tessellation, which is usually worn off in the adult shells; ears similar to those of the right valve, there being nearly as pronounced a byssal notch in the anterior ear of the left valve as in the anterior one of the right." (Arnold, 1906)

Holotype.-CAS 55. Of S. morani, USNM 164929.

Type locality.-Kreyenhagen Ranch on Zapata [Zapato] Chino Creek [Mt. Diablo Range, Fresno County], Calif. Upper part of Etchegoin Formation, Pliocene. Of $S$. morani, Mr. Moran's place, Priest Valley [SW $1 / 4$ sec. 14, T. 20 S., R. 12 E., Monterey County], Calif. Etchegoin Formation, Miocene and Pliocene.

Comparison._-"This species can be distinguished from S. nutteri (Arnold), S. wattsi (Arnold), and S. parmeleei Dall by the absence of concentric swellings and the tendency for the major ribs to bifurcate at an earlier age than in the other species." (Adegoke, 1969, p. 105)

Chlamys parmeleei parmeleei has concentric swellings whereas $C$. parmeleei etchegoini does not. (Woodring, 1950, p. 83)

Geographic range.-Northern California to Baja California Sur. Geologic range.-Miocene to Pleistocene.

Occurrence in the Californias.-Miocene and Pliocene: Etchegoin Formation (Anderson, 1905; Arnold, 1906; Woodring and others, 1940); Pliocene: Almejas Formation (Hertlein and Grant, 1972),
Cantil Costero (Hertlein and Allison, 1959), Careaga Sandstone (Woodring, 1950), Foxen Mudstone (Woodring, 1950), San Diego (Hertlein and Allison, 1959), and San Joaquin (Woodring and others, 1940; Adegoke, 1969) Formations; Pliocene and Pleistocene: Rio Dell Formation (Faustman, 1964).

\section{Genus SWIFTOPECTEN?}

\section{Swiftopecten? hamlini (Arnold)}

Plate 24, figure 5

Pecten (Chlamys) hamlini Arnold, 1906, p. 67, pl. 11, fig. 2.

Pecten (Pallium) hamlini Arnold. Grant and Gale, 1931, p. 171.

Chlamys (Swiftopecten?) hamlini (Arnold). Hertlein and Grant, 1972, p. 205.

Original description. - "Type somewhat distorted but originally about 60 millimeters in altitude, and probably somewhat shorter than high; moderately convex; base evenly rounded; sides nearly straight. Right valve with 4 broad, squarish ribs, each ornamented above by about 5 prominent imbricated radiating ridges, and separated by relatively narrow interspaces; hinge line more than one-half length of disk; anterior ear much longer than posterior and ornamented by several imbricated radiating ridges; byssal notch quite prominent; posterior ear short and radially ridged."

Holotype.-USNM 164844.

Type locality.-USGS 3851. Monterey County, Calif. Santa Margarita(?) Formation, Miocene.

Supplementary description. - "A specimen, which is probably a left valve of $P$. hamlini, was found associated with Pecten branneri in the lower Miocene at Tuff Hill, near Stanford University, Santa Clara County. This specimen has three widely separated, narrow, ridge-like ribs, and the interspaces are ornamented by a number of rather coarse radiating riblets; altitude 31 millimeters." (Arnold, 1906, p. 67)

"The type, a right valve, is *** a distorted specimen. It possesses 4 broad ribs each of which are radially grooved forming 5 radiating ridges. This rare species may be related to the Swiftopecten group or it may be referable to some other group with radially grooved ribs ** * The relationship, if any, of $P$. hamlini with other Californian species is not known at the present time." (Hertlein and Grant, 1972)

Comparison.- "This species is closely allied to P. wattsi, but is distinguishable from the latter species by its relatively broader (?) disk and longer hinge line. The characteristics of sculpture are approximately the same in the two species." (Arnold, 1906, p. 67)

"The original specimen of this species is very poor and badly distorted. Specimens in the collection at Stanford University show that it is a form of the $P$. swiftii type, distinguishable from the variety parmeleei of that species not by its shape but by its fewer, coarser secondary ribs." (Grant and Gale, 1931, p. 171)

Comments.-Judith T. Smith (oral commun., 1979) examined the holotype and felt that this species could be a distorted Lyropecten.

Geographic range.-Middle California.

Geologic range.-Miocene(?).

Occurrence in California.-Santa Margarita(?) Formation (Keen and Bentson, 1944).

\section{Genus VERTIPECTEN Grant and Gale, 1931}

Left valve usually strongly convex, right valve nearly flat; right anterior auricle narrow and elongate with large byssal notch as wide as auricle; hinge practically smooth with shallow ligament pit. Differs from Athlopecten in that ribs of left valve are not paired and about every third one is elevated. Differs from Patinopecten in that 
TABLE 13.-Geologic and geographic distribution of the genus Vertipecten

[ $\mathrm{M}=$ Miocene; $\mathrm{O}=$ Oligocene; $\mathrm{E}=$ Eocene $]$

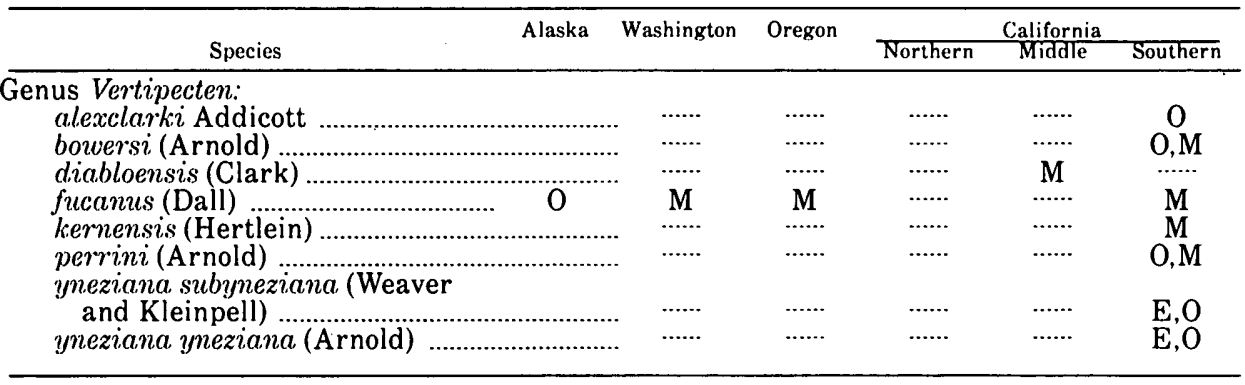

both the right and left valves have imbricated microsculpture. Patinopecten has this sculpture only on the left valve. This microsculpture is most commonly found on the right valve of Vertipecten at the posterior edge of the disk and on the posterior ear.

Geographic range.-Western North America and Japan.

Geologic range.-Oligocene to Miocene (table 13).

\section{Vertipecten yneziana yneziana (Arnold)}

Plate 25, figures 2, 3

Pecten (Chlamys) (?) yneziana Arnold, 1907b, p. 8-9 [separate pagination], pl. 51, figs. $6 \mathrm{a}, 6 \mathrm{~b} ;$ not pl. 50 , fig. 4 .

Pecten (Vertipecten) ynezianus Arnold. Grant and Gale, 1931, p. 191.

Pecten (Vertipecten) yneziana yneziana Arnold. Weaver and Kleinpell, 1963, p. 198, pl. 30, figs. 6, 7; pl. 31, figs. 1, 4.

Vertipecten yneziana (Arnold). J. T. Smith, 1975, pl. 1, fig. 6.

Original description.- "Shell averaging 60 to 70 millimeters in altitude; slightly higher than long, moderately convex, practically equivalve and equilateral, rather thin; base regularly rounded; dorsal margins concave; margins somewhat serrate. Surface of disk ornamented by from 30 to 45 irregular, inequidistant rounded, more or less imbricated ribs; in some instances the ribs occur quite regularly, every alternate one being prominent, with lesser ones (appearing as intercalaries) between; in others the ribs are irregularly disposed, although there is a tendency for the alternate ones to be larger and sometimes dichotomous. Ears radially striate in addition to incremental imbricating sculpture; anterior ear of right valve with deep byssal notch and well isolated byssal area."

Holotype.-USNM 165313a.

Type locality.-USGS 4507. Santa Barbara County, Calif. Gaviota Formation, Eocene and Oligocene. [According to Wilson (1954, p. 147) the type locality is in the middle member of Dibblee (1950, pl.1).]

Comparison. - "The imperfect fragments which furnish the characters described above represent a species apparently allied to $P$. perrini Arnold, although it is smaller and has more numerous and less imbricate ribs than the latter." (Arnold, 1907b, p. 426)

"Pecten yneziana * * can usually be distinguished [from sespeensis] by the greater umbonal angle ( $c a .75^{\circ}$ for $P$. sespeensis vs. $c a$. $110^{\circ}$ for $P$. yneziana, though with extreme variation) and by the greater number and prominence of the bifurcation of the ribs, especially near the margins of the disc." (Weaver and Kleinpell, 1963, p. 198)

Geographic range.-Southern California.

Geologic range.-Eocene to Oligocene.

Occurrence in Califormia. - Eocene and Oligocene: Gaviota (Dibblee, 1950; Weaver and Kleinpell, 1963; J. T. Smith, 1975) and Sacate and Gaviota Formations, undifferentiated (Weaver and
Kleinpell, 1963); Oligocene: Alegria Formation (Dibblee, 1950; Smith, 1975).

Vertipecten yneziana subyneziana (Weaver and Kleinpell) Plate 24, figure 3

Pecten (Vertipecten) yneziana subyneziana Weaver and Kleinpell, 1963 , p. 198, pl. 31, figs. $2,3,7$.

Original description. - "This form is all but indistinguishable from $P$. yneziana yneziana except for its much smaller size. Young forms of $P$. yneziana yneziana are not available for comparison. However, where known to date, the two morphological varieties seem to occupy separate stratigraphic intervals in the column."

Holotype.-CAS/SU 9265.

Type locality.-UC B6940. Santa Barbara County, Calif. Cold water Sandstone, Eocene.

Supplementary description.-"With this previously undescribed subspecies the very phylogenetic radicle of the subgenus Vertipecten, as described by Grant and Gale (1931, pp. 188-189), is now recognized. In fact, one faces the problem of whether to classify this 'connecting link' with its immediate ancestors of Chlamys, as its small size alone would seem to dictate, or with its larger and more robust descendants of Vertipecten, from which it is all but indistinguishable except for the very small size." (Weaver and Kleinpell, 1963, p. 198)

Geographic range.-Southern California.

Geologic range.-Eocene to Oligocene.

Occurrence in California. - Eocene: Coldwater Sandstone; Eocene and Oligocene: Sacate and Gaviota Formations undifferentiated (Weaver and Kleinpell, 1963).

\section{Vertipecten alexclarki Addicott}

Plate 24, figures 1, 2, 4

Vertipecten alexclarki Addicott, 1973, p. 26-27, pl. 1, figs. 9, 10, 13; pl. 2, figs. $1,3,5,8,9$; pl. 3, figs. 1. 4. Smith, 1975, pl. 1, fig. 7 . Original description. - "Moderately large, reaching as much as $115 \mathrm{~mm}$ in height, higher than long. Apical angle narrow, averaging about $70^{\circ}$. Right valve relatively flat; has 20 to 30 or more flattopped, scaly ribs that tend to be dichotomous in the central portion of the disk but more irregular in development toward the sides. Scales are fine and closely spaced near the beak but become coarser and more widely spaced toward base. Secondary riblets usually developed in the interspaces between the paired ribs. Anterior auricle long, set off by deep byssal notch. Auricle sculptured by five strong ribs bearing heavy flanges. Left valve convex and has rather 
uniform sculpture of primary, secondary, and tertiary rounded ribs bearing strong, rather widely spaced flanges toward the base. Medial primary and two lateral primaries that tend to divide the disk into quadrants are somewhat stronger than other primary ribs."

Lectotype.-USNM 646531.

Type locality.-USGS M3281. Kern County, Calif. Wygal Sandstone Member, Temblor Formation, Oligocene.

Supplementary description.- "This species is assigned to Vertipecten because of the distinct inequality of the valves, the right valve being relatively flat and the left being moderately convex $* * *$, and because of the relatively greater strength of the central and two lateral primary ribs on the left valve, the three of which tend to divide the valve into quadrants. In sculptural detail and in the size of the right anterior ear, the species resembles Chlamys.

"The right valve of Vertipecten alexclarki $* * *$ is characterized by narrow, flat-topped ribs that are highly irregular in their development, whereas the left valve has a more or less orderly development of rounded primary, secondary, and tertiary ribs. The ribs of both valves are scaly." (Addicott, 1973, p. 26)

Comparison.- "This species seems to be a lineal antecedent of the early and middle Miocene species Vertipecten perrini (Arnold). The Miocene species differs, however, by having fewer, much coarser ribs on the right valve that also tend to be smooth and generally are not dichotomous. The medial portion of the right valve of $V$. perrini also has a depression coinciding with an interspace and reflecting a relatively much more strongly raised medial rib on the left valve.

"The sculpture of the right valve of Chlamys branneri $* * *$ is similar to that on the Vertipecten alexclarki.***Although the type material of $C$. branneri is poorly preserved, it is an equivalved species and, therefore, is properly assigned to Chlamys and not to the subsequently proposed genus Vertipecten, which is characterized by a relatively flat right valve and a convex left valve $* * *$. Other differences are the similar sculpture of both valves of $C$. branneri, the lack of an accentuated medial rib on the left valve, and the greater number of radial ribs on the auricles of this species -6 to 10 rather than 5. It is possible that specimen, or specimens, identified by Arnold (1906, p. 56) as C. branneri from the lower part of what is now mapped as Vaqueros Sandstone $* * *$ on Twobar Creek in the Santa Cruz Mountains, may represent $V$.alexclarkin. sp. The material is from rocks of approximately the same age. C. branneri, on the other hand, is from unnamed rocks of middle Miocene age from Coyote Hills near the Stanford University campus * * *" (Addicott, 1973, p. 26)

Geographic range.-Southern California.

Geologic range.-Oligocene.

Occurrence in California.-Wygal Sandstone Member, Temblor Formation.

\section{Vertipecten bowersi (Arnold)}

Plate 24, figure 6; plate 25, figure 1

Pecten (Lyropecten) bowersi Arnold, 1906, p. 70-71, pl. 12, figs. 1, 2; pl. 13, figs. 1, 1a. Loel and Corey, 1932, p. 198, pl. 22, fig. 1

Pecten (Vertipecten) bowersi Arnold. Hanna and Hertlein, 1943, p. 176, fig. 64-20.

Original description.-"Shell averaging about 150 millimeters in altitude and length, inequivalve, equilateral, rather thick, ventricose, and with smooth margins; base regularly rounded; sides sloping, the anterior ones slightly concave upward. Right valve considerably less ventricose than left, the surface of the disk being almost flat until an altitude of 50 or 60 millimeters is reached, when it begins to be more or less convex; surface ornamented with about 18 subequal, prominent, rounded ribs, which, with the interspaces, are obsoletely radiately striate and crossed by fine wavy incremental lines; the ribs tend to become smaller toward the sides of the disk, there being a varying number of riblets near the sides in different specimens; interspaces subequal, round bottomed, about as wide as the ribs, and sometimes containing an auxiliary riblet; hinge line about three-fifths length of shell; ears about equal in length, anterior ear divided into two nearly equal parts by a line radiating from the apex, the part above the dividing line being ornamented by 3 or 4 radiating ribs and concentric lines while the lower part (byssal area) is ornamented by imbricating incremental lines which are convex toward the apex; byssal notch wide and of medium depth; posterior ear rectangularly truncated, radiately ribbed, and crossed by concentric incremental lines. Left valve prominently and evenly ventricose; sculptured the same as the right valve except that most of the interspaces contain an auxiliary riblet; anterior ear arcuate ended, radiately ribbed, and with concentric incremental sculpture; posterior ear as in right valve."

\section{Holotype.-UCMP 12075}

Type locality.-Santa Inez [Ynez] Canyon [Santa Ynez Quad.] Santa Barbara County, Calif. Topanga(?) Formation, Miocene.

Supplementary description.- "This species is distinguishable by its large size, almost smooth rounded ribs, and the greater convexity of the left valve. The flat surface of the right valve near the apex is also a very noticeable characteristic." (Arnold, 1906, p. 71)

Comparison.-Lyropecten bowersi "is distinguishable from $P$. perrini Arnold (1906) by its fewer and more rounded ribs, and the usual convexity and similarity of both valves-unlike $P$. perrini." (Loel and Corey, 1932, p. 198)

Lyropecten bowersi has simple microsculpture and the interspaces bear one riblet, features that distinguish it from L. perrini (Judith $\mathrm{T}$. Smith, written commun., 1979).

Geographic range.-Southern California.

Geologic range.-Oligocene to Miocene.

Occurrence in California.-Oligocene and Miocene: Vaqueros Formation (Arnold, 1907b); Miocene: upper part of Topanga Canyon Formation (Judith T. Smith, written commun., 1980), Painted Rock Sandstone Member, Vaqueros Formation (Judith T. Smith, written commun., 1980), and Saltos Shale Member, Monterey Formation (Judith T. Smith, written commun., 1980).

\section{Vertipecten perrini (Arnold) \\ Plate 25, figures 4-6}

Pecten (Lyropecten) perrini Arnold, 1906, p. 80-81, pl. 14, figs. 1, 1a pl. 15, fig. 1. Loel and Corey, 1932, p. 202, pl. 23, fig. 1; pl. 24, fig. 1.

Pecten (Vertipecten) nevadanus Conrad var. perrini Conrad. Grant and Gale, 1931, p. 190.

Vertipecten perrini (Arnold). Addicott, 1974, pl. 1, figs. 3, 4; J. T. Smith, 1975, pl. 1, figs. 4, 5 .

Original description. - "Shell averaging about 150 millimeters in altitude, somewhat longer than high, inequivalve, equilateral, of medium thickness, ventricose, and with smooth margins; base regularly rounded; sides sloping and decidedly concave above. Right valve nearly flat, with about 23 unequal, narrow, more or less rounded, and often prominently imbricated, radiating ribs, which are sometimes dichotomous; interspaces unequal, narrow, and occasionally ornamented by a small auxiliary riblet; surface sculptured by fine incremental lamellae which are much more prominent in some specimens than in others; hinge line about one-half length of 
disk; ears about equal in length; anterior ear wide, ornamented by concentric incremental sculpture; byssal notch wide and deep; posterior ear ornamented by several prominent, more or less imbricated radiating ridges, and concentric sculpture. Left valve quite prominently ventricose, otherwise similar to the right, except that the ribs seem to vary even more in relative size and spacing; anterior ear lacking notch, otherwise ears similar to those of the right valve." Holotype.-CAS/SU 13.

Type locality.-Between Morro and Toro Creeks [W1/4 sec. 4, T. 29 S., R. 11 E.], San Luis Obispo County, Calif. Vaqueros Formation, Oligocene and Miocene.

Supplementary description. - "This is a most variable species, there being no two specimens sculptured in exactly the same manner in a series of over fifty specimens examined. The convexity of the valves is almost constant, the variable factors being the number and relative importance of the intercalary ribs, and the prominence of the incremental sculpture." (Arnold, 1906, p. 80)

Comparison. - Vertipecten perrini is like V.nevadanus of authors [now called V.kernensis] "but with the ribs smaller, more flattened, and more numerous, multiplying by irregular bifurcation on the right valve and by irregular accentuation of the intercalaries on the left; also with more minor radial riblets than is usual in the typical variety." (Grant and Gale, 1931, p. 190)

"This large form, sometimes difficult to differentiate from Pecten. bowersi Arnold, is perhaps the most variable species of the Lyropectens. In some specimens the more convex valve is almost identical to that of $P$. bowersi. The characteristically flatter $P$. perrini has a possible *** ancestral form *** which was described by Arnold as $P$. inezana. The two forms are almost, if not, identical. $P$. perrini is distinct from other similar species in its usual flatness of the right valve and irregular scaly ribbing." (Loel and Corey, 1932, p. 201)

Geographic range.-Southern California.

Geologic range.-Oligocene to Miocene.

Occurvence in California.-Oligocene: Agua Sandstone Member, Temblor Formation (Addicott, 1972); Oligocene and Miocene: Temblor (Loel and Corey, 1932; Dickinson, 1963) and Vaqueros (Arnold, 1906; Hoots, 1930; Loel and Corey, 1932) Formations; Miocene: Pyramid Hill Sand Member, Jewett Sand (Addicott, 1974).

\section{Vertipecten fucanus (Dall)}

Plate 26, figures 3, 4; plate 27, figure 1

Pecten (Chlamys) fucanus Dall, 1898, p. 704, pl. 26, fig. 7. Arnold, 1906, p. 66-67, pl. 10, figs. 1, 2, 2 a.

Pecten (Vertipecten) nevadanus Conrad var. fucanus Dall. Grant and Gale, 1931, p. 190, [not? pl. 7, figs. 1a, 1b].

Vertipecten fucanus (Dall). Moore, 1963, p. 66-67, pl. 19, figs. 1, 2; pl. 20, fig. 8; pl. 21, figs. 1, 3; pl. 22, figs. 1, 4. Addicott, 1976a, p. 29, pl. 4, figs. 1, 2, 5, 7, 10, 12. Addicott, 1976b, pl. 1, fig. 1 .

Vertipecten cf. propatulus (Conrad). Stewart, 1946, pl. 17, fig. 4.

Pecten (Patinopecten) propatulus Conrad. Arnold, 1906, pl. 9, figs. 1 , 1a, 2, 2a [not pl. 7, fig. 1]. Not Pecten propatulus Conrad, 1849. Original description. - "This is a rather large species of the type of $P$. Hindsii var. strategus, both valves moderately convex and with a fine subsidiary surface tessellation; sixteen squarish ribs, of which the median one in the left valve is stronger than the rest and surmounted by prominent imbricated scales; the others are simply radially striated, as are the interspaces, which carry a mesial elevated thread; the submargins are radially threaded, as are the subequal ears, which also bear marked concentric lamellae; the resilial pit is of moderate size and the cardinal edge is deeply grooved parallel to and just below the margin; the interior reflects the external ribbing. Alt. 85 , lat. 80 , convexity of left valve $16 \mathrm{~mm}$."
Holotype.-USNM 107790.

Type locality.-USGS 2464. Clallam County, Wash. Clallam Formation, Miocene.

Supplementary description._-Adult shell averaging nearly 100 millimeters in altitude, about as long as high, inequivalve (the left being the more convex), equilateral, moderately thin, and with nearly smooth margins. Right valve with from 14 to 17 more or less unequal, prominent, rather squarish, radiately striate ribs, between which (especially the anterior and posterior ones) are occasionally intercalated small riblets; interspaces unequal and averaging somewhat narrower than the ribs; whole surface of disk sculptured by rather prominent lines of growth and a fine subsidiary tessellation; hinge line longer than one-half length of disk; ears equal in length; the anterior rather narrow and sculptured by 4 prominent radials and fine, imbricating, incremental lamellae; the posterior rectangularly truncated and sculptured by more, but less prominent radials and fine concentric lamellae; byssal notch profound. Left valve usually having 15 or 16 unequal, prominent, convex-topped ribs, the median one generally being stronger than the rest, with the second or third one from it on each side only a little less prominent; the prominent ribs, especially the median one, is generally surmounted by elevated imbricating scales; the other ribs are simply radially striated, as are the interspaces, which often carry one or more elevated riblets; the submargins are radially threaded, as are the subequal ears, which are rectangularly truncated, and also bear marked concentric lamellae ***." (Arnold, 1906, p. 66)

"The median rib on the left valve of Vertipecten fucanus is always elevated above the others; the fourth rib on either side may also be elevated, but to a lesser degree, and in some places the second rib on the anterior and posterior side of the median rib is elevated. The ribs on the left valve are usually strong, narrow, and rounded, and the median rib is less rounded than the others. An imbricated, lamellar microsculpture is often preserved on the left valve and is usually particularly apparent on the elevated median rib. *** This microsculpture may be seen also on some places on the left valve ears of $V$. fucanus. There is usually one interrib in each interspace on the left valve, but there may be as many as 2 or 3 . On the right valve of $V$. fucanus there are about 15 or 16 slightly rounded flat-topped finely striated ribs in some places with a median groove. The interspaces seem to be smooth, without any interribs." (Moore, 1963, p. 66)

"Specimens in the collections average about $80-90 \mathrm{~mm}$ in greatest diameter. These averages are misleading because the relatively small specimens are easiest to collect: In the field, most specimens exceed 100 in maximum diameter, and there are several specimens in the stratigraphic collections that are as large as $110-120 \mathrm{~mm}$. The right valves have 17 or 18 somewhat irregular flat-topped ribs. This valve also has a reticulate, or honeycombed, microsculpture that covers both the ribs and interspaces. There are usually 15 or 16 crested ribs on the left valves; the medial rib is much stronger than any of the others and most are scaly or imbricated. Both valves have fine, irregular lateral ribs." (Addicott, 1976a, p. 29-30)

Comparison. - "V. fucanus may be closely related to $V$. nevadanus (Conrad). On the basis of a comparison of the type and topotype specimens of $V$. fucanus with specimens of $V$. nevadanus possibly from near the type locality, they are considered separate species. The right valve of $V$. nevadanus is usually much more highly sculptured and has numerous interribs. The left valve of $V$. nevadanus seems to have more ribs and more interribs than $V$. fucanus." (Moore, 1963, p. 66)

"The ears of $V$.fucanus ***are relatively much larger than those of $P$. propatulus. Specifically, the length of the ears on specimens of $V$. fucanus is considerably more than half the width of the valves whereas on $P$. propatulus the ears are less than half the width of the valves. A second difference is the initially flat or slightly concave 
profile of right valves of $V$. fucanus during early growth stages. This profile contrasts with the regularly convex profile of $P$. propatulus. In adult specimens of $V$. fucanus, the initially flat profile of $V$. fucanus usually develops into a gently convex profile similar to that of $P$. propatulus. Finally, the ribbing in right valves of $V$. fucanus is much more irregular than on P. propatulus, especially in the lateral areas. Many specimens of $V$. fucanus have one or more irregular ribs in the medial part of the disk and most specimens have a widening and deepening of the medial interrib corresponding to the strongly raised opposing rib of the left valve." (Addicott, 1976a, p. 29)

Geographic range.-Washington to southern California.

Geologic range.-Miocene.

"Vertipecten fucanus seems to be a very useful species in biostratigraphic correlation of Miocene formations in the Pacific Northwest States. Its restricted stratigraphic occurrence in the Nye Mudstone of western Oregon and the Jewett Sand of central California is indicative of provincial early Miocene age." (Addicott, 1976a, p. 30)

Occurrence in California.-Jewett Sand (Addicott, 1976a).

\section{Vertipecten diabloensis (Clark)}

Plate 21, figure 2; plate 39, figure 4

Pecten gabbi Clark, 1918, p. 131, pl. 15, figs. 1, 2. Not Pecten gabbi Dall, 1898.

Pecten diabloensis Clark in G D. Hanna, 1924, p. 176, new name.

Original description.-"Shell fairly large, heavy, equivalved; right valve flat; left valve convex. Apical angle about $100^{\circ}$; dorsal edges very nearly straight; ventral edge rather strongly convex. Left valve sculptured by about nineteen prominent and variable, rounded radiating ribs; on the type specimen, a left valve, seven of these ribs are heavier than the others; one radiating from the beak down to the middle of the ventral edge, three of the other ribs being anterior and three posterior to this; in each interspace between these major ribs is a less prominent and narrower rib, and in the interspaces between this narrower rib and the major ribs on each side of it is a still less prominent and more narrow rib; besides this, in some of the interspaces, there is a fourth set of ribs still less prominent than the others. The valve originally had strong and beautiful imbricated sculpturing, which does not show on the type specimen but is seen on some of the external casts. Ears large and heavy. One specimen of a cast of the anterior ear shows eight or nine radiating ribs; the ones next the dorsal margin being much finer than the others; surface of ear strongly imbricated. Right valve flat, sculptured by nineteen or twenty fairly heavy, rather broadly rounded, radiating, somewhat variable ribs; as on the left valve there is a tendency for some of the ribs to be heavier than the others, but this difference is not so great nor is the distribution of the heavy ribs so regular; apparently there were no riblets in the interspaces. Surface of right valve sculptured by imbricated incremental lines, which are coarser than on the left valve. Sculpturing of ears of right valve not preserved."

Holotype-UCMP 11138.

Type locality.-UC 1311. Contra Costa County, Calif. San Ramon Sandstone, Miocene.

Comparison.- "P. perrini is a very variable species, the sculpturing being more irregular than on $P$. gabbi $[=P$. diabloensis $]$; it has about the same number of ribs, and on some specimens certain of the ribs stand out more prominently than others, as is the case with $P$. gabbi. The imbricated concentric sculpturing appears to be much stronger on the former, is more irregular, and the inter-ribbing and striations are heavier." (Clark, 1918, p. 131)

Geographic range.-Middle California.

Geologic range.-Miocene(?).

Occurrence in California.-San Ramon Sandstone.

\section{Vertipecten nevadanus (Conrad), nomen dubium}

Pecten nevadanus Conrad, 1855a, p. 19, pl. 8, fig. 77.

Original description.-“Ovate, flat or slightly concave; ribs 17 ? large, flattened on the back; interstices strongly wrinkled transversely."

Holotype.-Missing and presumed lost.

Type locality.-Ocoyo Creek [Pozo Creek, NE $1 \frac{1}{4}$ sec. 12, T. 28 S., R. 28 E., Kern County], Calif.

Neotype.-CAS/SU 431 (Grant and Gale, 1931).

Neotype locality.-Uncertain; McKittrick district or Santa Monica Mountains, Calif. Miocene(?).

Comments.-According to the International Code of Zoological Nomenclature (Article 75), for a neotype to be validly designated it must come "as nearly as practicable from the original type-locality, and where relevant, from the same geological horizon ***." Grant and Gale (1931, p. 190) in describing the locality for their neotype say that it is "reported to have come from the lower Miocene of the McKittrick district, but ** may have come from the Santa Monica Mountains." The imprecision of the locality data for the neotype invalidates the designation and Pecten nevadanus Conrad may be considered a nomen dubium.

According to Judith T. Smith (oral commun., 1979) Vertipecten nevadanus has been confused with Vertipecten bowersi for many years. In addition, the holotype is missing, the original illustration poor, and no good material is available for either a lectotype or a neotype. She therefore feels that the specific name should no longer be used.

Vertipecten nevadanus of authors is now called Vertipecten kernensis (Hertlein).

\section{Vertipecten kernensis (Hertlein)}

Plate 28, figure 6

Pecten (Patinopecten) kernensis Hertlein, 1925b, p. 40, pl. 4, fig. 3. Schenck and Keen, 1940, pl. 28, figs. 1-3.

Vertipecten nevadanus (Conrad) of authors; not Pecten nevadanus Conrad, 1855.

Pecten catilliformis Conrad, 1855a, p. 20. Conrad, 1857b, pl. 9, fig. 83.

Original description.-"Shell large, slightly arched, moderately thick. Right valve ornamented by about 22 to 24 fairly high, flattish topped, round edged, radiating ribs of unequal size, separated by slightly rounded interspaces which are narrower than the ribs, many of the interspaces sculptured by a tiny midrib, whole surface ornamented by fine concentric lines of growth; anterior ear large, bearing a large byssal notch, ear ornamented by about 4 or 5 radiating riblets crossed by concentric lines of growth; posterior ear ornamented by about 6 radiating riblets crossed by concentric lines of growth. Height approximately $93 \mathrm{~mm}$.; length approximately $93 \mathrm{~mm}$.; length of hinge line $57 \mathrm{~mm}$.; apical angle approximately $100^{\circ}$."

Holotype.-CAS/SU 128; of catilliformis, described from drawings, no type extant (Arnold, 1906, p. 141).

Type locality.-SU 150. Kern County, Calif. Jewett Sand, Miocene. Comparison.-"Pecten kernensis differs from P. propatulus Conrad, and $P$. oregonensis Howe, in the more numerous, unequal ribs, and less numerous, coarser ribs on the posterior ear of the present species. From P. caurinus Gould, P. kernensis is distinguished by the narrower ribs and strongly sculptured ears." (Hertlein, 1925b, p. 40)

Vertipecten kernensis has a wider byssal notch, smaller right posterior auricle with larger riblets, and more closely spaced ribs on the right valve than $V$. fucanus. 
Geographic range.-Southern California.

Geologic range.-Oligocene to Miocene. [This species is an index fossil of the middle "Vaqueros" megafaunal stage (Judith T. Smith, written commun., 1980).]

Occurrence in Califormia.-Oligocene: upper part of the Pleito Formation (Judith T. Smith, written commun., 1980); Oligocene and Miocene: Vaqueros Formation (Loel and Corey, 1932; Judith T. Smith, written commun., 1980); Miocene: Carneros Sandstone Member, Temblor Formation (Judith T. Smith, written commun., 1980), Freeman Silt (Schenck and Keen, 1950; Addicott, 1956), lower part of Jewett Sand (Addicott, 1956), Olcese Sand (Addicott, 1956), and Topanga Formation (Takeo Susuki, written commun., 1978).

\section{Genus HINNITES De France, 1821}

Free in early stages similar to Chlamys, but later cemented by right valve which becomes irregular.

Geologic range.-Eocene to Holocene.

Habitat. - Warm-temperate to tropic.

Hertlein (1969) placed Hinnites in the Hinnites group. Hinnites is here placed in the Chlamys group because of recent studies by Waller (Thomas R. Waller, written commun., 1979) that show that the cementing habit is polyphyletic and that living "Hinnites" pusio shows a geographic cline ranging from uncemented typical Chlamys to cemented typical Hinnites.

\section{Hinnites benedicti Adegoke}

\section{Plate 26, figure 2}

Hinnites benedicti Adegoke, 1969, p. 103-104, pl. 3, figs. 3, 5 .

Original description. - "Shell medium sized, thin, similar to Hinnites multirugosus crassiplicatus (Gale); outline oblong-oval, much higher than long; ornamented by over 40 low, rounded, subequally prominent ribs; frequently 1 riblet in each interspace; ribs only. slightly spinose, become more prominent, more irregular and more spinose toward ventral margin; anterior ear longer than posterior ear; byssal notch deep."

Holotype-UCMP 36638.

Type locality. -UC D702. Fresno County, Calif. Santa Margarita Formation, Miocene.

Comparison. - "This species may be readily distinguished from Hinnites multirugosus crassiplicatus (Gale) [= Hinnites giganteus], which occurs in the same beds, by the more elongate and oval outline and the more numerous but less prominent radial ribs. The 'Chlamys stage' lasts longer $(28-34 \mathrm{~mm})$ in the new species than it does in crassiplicatus. Additionally, the ribs are remarkably uniform and are only slightly spinose." (Adegoke, 1969, p. 104)

Comments. -A slight shell irregularity can be seen on the holotype at about $35 \mathrm{~mm}$, the maximum size given by Adegoke (1969, p. 104) for the Chlamys stage.

Geographic range.-Middle California.

Geologic range.-Miocene.

Occurrence in California.-Santa Margarita Formation.

\section{Hinnites giganteus (Gray)}

Plate 26, figures 1, 5; plate 27, figures 2-4

Lima gigantea Gray, 1825, p. 139.

Pecten (Hinnites) giganteus (Gray). Arnold, 1903, p. 115. Arnold, 1906, p. 93 , pl. 29 , figs. $1,2,2$ a.

Hinnites giganteus (Gray). Oldroyd, 1924, p. 63, pl. 25, figs. 1a, 1 b. Hertlein and Grant, 1972, p. 211-212, pl. 41, fig. 16. Roth and
Coan, 1978, p. 297. Addicott and Galehouse, 1973, fig. 30. Addicott and others, 1978, pl. 4, fig. 19.

Pecten (Chlamys) multirugosus Gale, 1928, p. 92-93.

Pecten (Pecten) multirugosus (Gale). Grant and Gale, 1931, p. 159 , pl. 11 , figs. $5 \mathrm{a}, 5 \mathrm{~b}$.

Hinnites multirugosus (Gale). Fitch, 1953, p. 41, fig. 7. Grau, 1959, p. 134-137.

Hinnita poulsoni Conrad, 1834, p. 182, pl. 14. Not Pecten poulsoni Morton, 1834.

Hinnites crassa Conrad, 1857 c, p. 190, pl. 2, figs. 1, 2. Hertlein and Grant, 1972, p. 212.

Pecten (Chlamys) multirugosus variety crassiplicatus Gale, 1928, p. 93, new name for Hinnites crassa Conrad, 1857c.

Pecten (Pecten) multirugosus variety crassiplicatus Gale. Grant and Gale, 1931, p. 160-161.

Hinnites multirugosus var. crassiplicatus (Gale). Stanton, 1966, pl. 5, fig. 6.

Hinnites multirugosus subsp. crassiplicatus (Gale). Adegoke, 1969, p. 103 , pl. 3 , figs. $1,2$.

Original description. - "Testa crassa, ponderosa, subauriculata. Albido-rosea, irregulariter radiata costata striata; intus alba, rufo maculata. Lat. 15-4, long. 18-4 unc." (giganteus)

"Pecten multirugosus is virtually a new name for the common Pliocene to Recent West Coast species formerly known as Pecten (Hinnites) giganteus (Gray); but in order to avoid any questions about the location or identity of the original types, the species is described as new and a new type is cited. The type is a Recent specimen from San Diego and is now No. 5 in the type collection of the San Diego Society of Natural History. There are also two paratypes (Nos. 2978 and 2979) at the California Academy of Sciences, and another in the Oldroyd Collection at Stanford University." (multirugosus)

"Ovate or subovate, thick, irregular, with large, rounded, unequal, radiating, irregular ribs, squamose, and with foliated spines on the lower part of the valves or near the base; intervals of the ribs with three or four squamose, prominent lines; hinge profoundly thickened; fosset profoundly excavated, angular; muscular impression very large." (crassa)

Holotype.-In BM (NH); of H. multirugosus, SDNM 5; of H. crassa, USNM 13336 (also lectotype of Keen and Bentson, 1944).

Type locality.-None originally cited; of $H$. multirugosus, San Diego, Calif., Holocene; of H. crassa, Salinas Valley [T. 29 S., R. 13 E., San Luis Obispo County], Calif. Santa Margarita Formation, Miocene.

“*** Gray's (1825) name gigantea was available when proposed and has remained available throughout its nomenclatural history. Gale's (1928) rejection of it was invalid because he did not contend that the two species-group taxa, 'Lima' gigantea Gray and Plagiostoma giganteum Sowerby, were congeneric. Pecten (Chlamys) multirugosus Gale, 1928, is therefore a junior synonym of Hinnites giganteus (Gray, 1825), and the latter is the valid name for the Pacific Coast rock scallop." (Roth and Coan, 1978, p. 297)

Supplementary description.- - Shell large, heavy, and irregular in outline when adult; averaging 105 to $150 \mathrm{~mm}$ in height, occasionally much larger; ratio of height to length variable, but almost always higher than long.

"Juvenile form (up to from 20 to $30 \mathrm{~mm}$ in height): identical with Chlamys; slightly higher than long; valves of nearly equal convexity; hinge line from $2 / 3$ to $3 / 4$ length of disk. Right valve with numerous low and finely imbricated ribs, which become dichotomous early and appear to be paired, particularly near ventral margin; specimens up to about $15 \mathrm{~mm}$ in height have distinct intercostal concentric lamellae, which disappear soon thereafter. Anterior auricle long, often produced as far as anterior margin of disk; 6 to 11 concentrically lamellated radial riblets; deep byssal notch and ctenolium of 5 teeth. 
Posterior auricle $1 / 3$ to $1 / 2$ length of anterior and with faint, oblique, imbricated radial riblets. Left valve with 10 or 11 ribs, moderately to prominently spinose; between them 3 to 5 imbricated riblets, with either center one of three or second and fourth of five slightly larger. Anterior auricle large, with 12 to 20 imbricated radial riblets of irregular size; byssal sinus usually shallow; posterior auricle same as that of right valve. $* * *$

"Adult form: large, heavy and irregular; juvenile Chlamys stage preserved intact on each valve, succeeding growth being much heavier and coarser. Shell attached by right valve to rock (or other foreign object), by means of shell substance secreted by outer lobe of mantle of that valve; moderately to greatly distorted (both laterally and horizontally) as result of conformation to surface of fixed object and, in many cases, restriction of space in which to grow. Right valve quite convex, with adult ribs (below Chlamys stage) straight or irregularly waved and moderately to heavily imbricated; ribs actually low ridges on outer surface of valve, no trace of them being visible from interior. Auricles usually have margins obliterated by surrounding shell deposit; no ctenolium. Left valve flattish and usually slightly smaller than right; structure of ribs and auricles same as on right valve. Hinge line straight when growth of shell not hampered; when growth is restricted (as in narrow rock crevices), new hinge lines are formed successively lower so valves can continue to open; in such cases hinge line tapers downward on each side of ligament, more so posteriorly. ${ }^{* * *}$

"In the juvenile stage this species is quite constant. Adolescent and adult specimens vary greatly in convexity and outline, but are easily recognizable. ***" (Grau, 1959, p. 136-137)

"This species attains a large size in northern waters. $* * * a$ specimen from the San Juan Islands in Puget Sound *** was 222 $\mathrm{mm}^{* * *}$ long, $168 \mathrm{~mm} * * *$ wide, and near the byssal plug the valve was $64 \mathrm{~mm}^{* * *}$ thick. The lower valve weighed 3 pounds and 1 ounce. $* * *$ A huge specimen $230 \mathrm{~mm}$ long, was reported $* * *$ from Santa Cruz Island, California. ***"

"Attachment to the substratum takes place when the shell is between 2.2 and $4.2 \mathrm{~cm}$ high." (Hertlein and Grant, 1972, p. 212)

Comparison.- "Young specimens of [Chlamys hastata] $15 \mathrm{~mm}$ or less in height resemble the young of Hinnites multirugosus (Gale) [= $H$. giganteus], but those of the latter can be distinguished by the following differences in structure: the disk equilateral (or nearly so), the ribs of the right valve divaricating, the posterior auricles larger and squared, the interspaces of both valves concentrically lamellose." (Grau, 1959, p. 86)

Geographic range.-Living: Aleutian Islands, Alaska to Baja California Sur; fossil: northern California to Baja California Sur.

Geologic range. - Miocene through Holocene.

Occurrence in the Californias.-Miocene: Branch Canyon Sandstone (Vedder, 1973), Castaic (Stanton, 1966), Monterey (Arnold, 1906), Painted Rock Member, Vaqueros (Vedder, 1973), Pancho Rico (Durham and Addicott, 1965), San Pablo (Arnold, 1906), and Santa Margarita (Nomland, 1917b; Adegoke, 1969; Addicott and others, 1978) Formations, and unnamed strata on San Clemente Island (Vedder and Moore, 1976); Miocene and Pliocene: Capistrano (Kern and Wicander, 1974), Etchegoin (Nomland, 1917a), and Purisima (Arnold, 1906) Formations; Pliocene: Niguel (J. G. Vedder, written commun., 1978), San Diego (Hertlein and Grant, 1972), and Salada (Beal, 1948) Formations, and unnamed strata on San Clemente Island (Vedder and Moore, 1976); Pliocene and Pleistocene: Fernando (Moody, 1916; Zinsmeister, 1970), Merced (Arnold, 1906), Paso Robles (Addicott and Galehouse, 1973), Pico (Addicott and Vedder, 1963), San Pedro (Arnold, 1906), and Saugus (Kew, 1924) Formations; Pleistocene: Timms Point Silt (A. Clark, 1931), and unnamed Pleistocene strata on San Nicolas Island, Calif., and in Baja California Norte (Valentine, 1957).
Habitat.-"Free-swimming juveniles often found on gravel bottoms; byssal attachment to a fixed object occurs when shell is anywhere from 15 to $25 \mathrm{~mm}$. high, cementation beginning soon thereafter; one or more of the following are often commensal on the left valve of adult specimens: hydroids, barnacles, bryozoa, boring sponges." (Grau, 1959, p. 137)

"*** In sheltered waters from high tide to a depth of 55 meters. In northern waters it lives close to shore and in shallower water." (Hertlein and Grant, 1972, p. 222)

\section{PECTEN group}

Right valve decidedly convex, left valve gently convex, flat, or concave; auricles nearly equal; radial ribs usually fairly broad; hinge with cardinal crura or almost lacking armature.

Geologic range.-Eocene through Holocene.

\section{PECTEN subgroup}

Byssal notch very shallow.

Geologic range.-Eocene through Holocene.

\section{Genus AMUSIUM Röding, 1798}

Fairly large, thin, valves slightly convex and gaping along margins below auricles; trace of byssal notch present; internal lirae commonly in pairs; hinge with pair of short ridges diverging from shallow ligamental pit and extending toward margins; auricular crura present.

Geologic range.-Miocene to Holocene.

Habitat.-In temperate seas but most abundant in tropic and subtropic water.

"The type species of Amusium, A. pleuronectes, strongly resembles true Pecten in shell microsculpture. The internal ribs of $A$ musium are the result of crenulations of the foliated calcite layer, as are the external costae and deep radial plicae of Pecten, Chlamys, and other Pectinidae." (Waller, 1971, p. 6)

Based on study of shell microsculpture by Waller $(1971,1972)$, Amusium is here placed in the Pecten subgroup.

\section{Amusium lompocensis (Arnold)}

$$
\text { Plate 2, figures 10, } 11
$$

Pecten (Amusium) lompocensis Arnold, 1906, p. 92-93, pl. 28, figs. 1-3.

Amusium lompocensis (Arnold). Addicott, 1974, pl. 1, fig. 2.

Pecten (Amussiopecten) lompocensis Arnold. Susuki and Stadum, 1978, p. 11-12, figs. 12-17.

Original description. - "Adult shell averaging about 100 millimeters in altitude, somewhat longer than high, compressed, subequivalve, equilateral, and thin; base regularly rounded; sides straight, or nearly so; margins smooth. Right valve with external surface smooth except for very fine and numerous concentric and nearly obsolete radiating striae; internal surface sculptured by about fourteen pairs of rather prominent rounded radiating lirae, the members of each pair being separated by flat spaces usually of about two-thirds the width of the major interspaces (in one case the spaces between the members of each pair were as wide as the interspaces); hinge line about two-fifths the length of the disk; ears subequal, obliquely truncated, and finely concentrically sculptured; anterior with a faint suggestion of a byssal notch; ctenolium absent. Left valve similar in all respects to the right except that the anterior 
ear has a straight, rather than an arcuate end."

Holotype.CAS 81.

Type locality. - Six kilometers south of Lompoc, Santa Barbara County, Calif. Tranquillon(?) Formation, Miocene.

Comparison.- "This very unique species, of which there are no closely allied forms in the Tertiary or living faunas of the west coast, so far as known, is somewhat analogous to $P$. (Amusium) mortoni Ravenel of the Miocene and Pliocene of eastern America. It is distinguishable from the latter species, however, by the smaller number, greater prominence, and more regular arrangement of the internal ribs. $P$. lompocensis is included in $A$ musium because it appears to show stronger affinities for this than for any other group." (Arnold, 1906, p. 92)

Amussiopecten vanvlecki has been confused with Amusium lompocensis. Amussiopecten vanvlecki may be distinguished from $A$. lompocensis by its prominent, flat, wide ribs. $A$. lompocensis lacks radial surface ribs. Both species are usually found preserved as casts, but even so their ribbing is different in that $A$. vanvlecki has raised rib molds whereas in $A$. lompocensis only the interior riblets are represented by grooves in the cast. (Loel and Corey, 1932, p. 195)

"On the right valve of $P$. (A.) lompocensis, the external radial ribs are poorly defined and the ribs are paired internally. On the left valve, the external ribs are better developed and the internal ribs are not paired but equally spaced with the interspaces. In $P$. (A.) vamilecki, the external ribs on both valves are better developed but internally, the paired ribs occur on the left valve and they are equally spaced in the right valve." (Susuki and Stadum, 1978, p. 12)

Comments. - The holotype of $A$. lompocensis was broken after it was originally illustrated, perhaps as a result of the San Francisco fire in 1906, and now consists of the posterior half of the left valve. No shell remains on the specimen but the paired internal lirae are clearly visible and are more closely spaced near the posterior margin.

Geographic range.-Middle to southern California.

Geologic range.-Miocene.

Occurrence in California.-Miocene: Branch Canyon Sandstone (Hill and others, 1958; Vedder, 1973), Monterey Shale (Kleinpell and Weaver, 1963), Obispo Formation (Hall and others, 1966), San Onofre Breccia (Addicott, 1974), Temblor "Horizon" (Loel and Corey, 1932), and Tierra Redonda (Durham, 1970) Formations, Tranquillon Volcanics (Dibblee, 1950); unnamed Miocene strata north of Bald Mountain in Santa Barbara County (Vedder and others, 1967), and unnamed Miocene strata, San Clemente Island (Susuki and Stadum, 1978).

\section{Genus PECTEN Müller, 1776}

Radial ribs well developed, usually flat topped, commonly radially striated or grooved; concavity present in many shells on left valve umbonal area.

Geologic range.-Eocene through Holocene (table 14).
Habitat.-In warm temperate and tropical seas from 10 to $1,845 \mathrm{~m}$ (Hertlein and Grant, 1972).

\section{Subgenus PECTEN}

\section{Pecten (Pecten) aletes Hertlein}

Plate 28, figures 3, 4

Pecten (Pecten) aletes Hertlein, 1925a, p. 8, pl. 2, figs. 1, 4. Hertlein, 1966 , p. 268

Pecten (Janira) humphreysii Conrad variety aletes Hertlein. Grant and Gale, 1931, p. 222.

Original description. - "Shell of medium size. Right valve moderately convex, ornamented by about 11 rather broad, flat-topped radiating ribs, which anteriorly and posteriorly decrease in size, each rib with one to four narrow, slight, radial sulcations; interspaces flat-bottomed, narrower than the ribs, occasionally bearing a tiny radiating riblet, the whole surface of valve sculptured by fine, close, concentric striae; ears subequal, marked by growth lines, but lacking all radial sculpture. Left valve slightly concave, with a pronounced depression toward the beak; about nine flat-topped radial ribs, separated by interspaces about as wide as the ribs, the ribs and interspaces both covered by fine, sharp, concentric sculpture; ears subequal, and somewhat concave, ornamented only by fine incremental lines. Altitude $62 \mathrm{~mm}$; longitude $65 \mathrm{~mm}$.; diameter of right valve approximately $13 \mathrm{~mm}$; apical angle of right valve approximately $100^{\circ} . "$

Holotype.-CAS/SU 44

Type locality.-SU 50. Baja California Sur, Salada Formation, Pliocene.

Comparison. - "Pecten aletes differs from P. bellus Conrad in the smaller number of ribs, which are finely sulcate. It differs from $P$. laqueatus Sowerby, from Japan, to which it is most closely related, in the fewer ribs; also in that the ears on the right valve of the present species appear to be straighter and not quite as arcuate as those of $P$. laqueatus." (Hertlein, 1925a, p. 8)

Comments. - Pecten aletes has fewer wider ribs than other eastern Pacific Tertiary species. The right valve holoty pe has seven primary ribs that are wide, flat, slightly undercut, and separated by interspaces slightly narrower than the ribs at the ventral margin. Three secondary ribs are present on the anterior end of the shell and two on the posterior end. Some of the ribs have radial riblets and grooves, and the entire shell surface has slightly imbricated, concentric sculpture. The portion of the anterior auricle exposed has no riblets; the posterior auricle is missing. The left valve paratype has seven wide, flat ribs separated by slightly wider interspaces. A secondary rib appears in some of the interspaces near the ventral margin. The entire shell has imbricated, concentric lamellae. The posterior auricle has one small riblet; the anterior auricle none.

The ribs on $P$. aletes are fewer in number, broader, and flatter than on $P$. bellus.

TABLE 14.-Geologic and geographic distribution of the genus Pecten (Pecten)

$[\mathrm{Ple}=$ Pleistocene; $\mathrm{Pl}=$ Pliocene; $\mathrm{M}=$ Miocene $]$

\begin{tabular}{|c|c|c|c|c|}
\hline \multirow{2}{*}{ Species } & \multicolumn{2}{|c|}{ California } & \multicolumn{2}{|c|}{$\begin{array}{c}\text { Baja } \\
\text { California }\end{array}$} \\
\hline & Middle & Southern & $\frac{\text { Norte }}{\text { Note }}$ & Sur \\
\hline 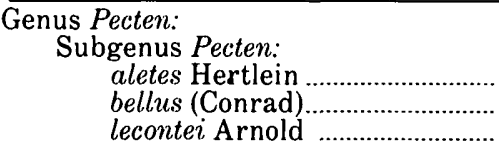 & $\begin{array}{c}\mathrm{M} \text { to } \mathrm{Ple} \\
\mathrm{M}, \mathrm{Pl}\end{array}$ & $\mathrm{Pl}, \mathrm{Ple}$ & $\begin{array}{l}\ldots \ldots . \\
\mathrm{Pl} \\
\mathrm{Pl}\end{array}$ & $\begin{array}{c}\mathrm{Pl} \\
\mathrm{Pl} \\
\ldots \ldots\end{array}$ \\
\hline
\end{tabular}


Geographic range.-Baja California Sur.

Geologic range.-Pliocene.

Occurrence in Baja California.-Salada Formation (Beal, 1948).

\section{Pecten (Pecten) lecontei Arnold}

\section{Plate 28, figures 2, 5}

Pecten (Pecten) lecontei Arnold, 1906, p. 98, pl. 33, figs. 4, 4a, 4b.

Original description. - "Shell averaging about 60 millimeters in altitude, longer than high, plano-convex, equilateral, and with smooth margins; base evenly rounded; sides concave above. Right valve convex, and ornamented by about 18 prominent round-topped, perpendicular-sided, smoothish ribs, separated by interspaces, which are narrower than the ribs and have nearly flat bottoms; surface sculptured by fine wavy incremental lines, which are generally worn off from the tops of the ribs; hinge less than one-half the length of the disk; ears somewhat convex; the anterior with 2 or 3 broad, nearly obsolete, radiating ridges, imbricating incremental lines, and a rather small byssal notch; the posterior rectangularly truncated, and with fine incremental sculpture. Left valve flat or slightly concave, ornamented by about 17 prominent rounded ribs, which are separated by interspaces about equal in width to the ribs; surface sculptured by numerous fine, sharp, regular, raised, incremental lines; ears concave, rectangularly truncated, and covered by fine sharp incremental lines."

Holotype.-CAS/SU 4.

Type locality.-Isla Cedros, Baja California Norte. Almejas Formation, Pliocene.

Comparison.- "This species is distinguishable from $P$. diegensis, $P$. bellus, $P$. stearnsii and other members of this group by the number and convexity of the ribs on the right valve. The left valves of $P$. lecontei and $P$. diegensis are somewhat similar, although the former has fewer ribs and is generally slightly more concave." (Arnold, 1906, p. 98)

"Pecten (Pecten) leconte ${ }^{*} * *$ is quite distinct from P. bellus and its variants. The ribs, about 18 on the right valve and 17 on the left, are round-topped. Those on the right valve usually quite smooth, separated by flat-bottomed interspaces which are narrower than the ribs. The left valve is usually slightly concave and the rounded ribs are quite different from the high usually flat-topped ribs of $P$. bellus." (Hertlein and Grant, 1972, p. 177)

Comments. - The holotype is a double-valved specimen and has imbricated concentric lamellae on the left valve.

Geographic range.-Middle California to Baja California Norte. Geologic range.-Miocene to Pliocene.

Occurrence in the Californias.-Miocene and Pliocene: Purisima Formation (Arnold, 1906); Pliocene: Almejas Formation (Minch and others, 1976).

\section{Pecten (Pecten) bellus (Conrad)}

Plate 29, figures 1.4

Janira bella Conrad, 1857a, p. 312 [reprinted in Dall, 1909, p. 173] Conrad, 1857b, p. 71, pl. 3, fig. 16.

Pecten (Pecten) bellus (Conrad). Arnold, 1903, p. 103-104, pl. 21, figs. 1, 2. Arnold, 1906, p. 95-96, pl. 31, figs. 1, 1a. Jordan and Hertlein, 1925b, p. 430-431, pl. 32, fig. 2; pl. 33, figs. 1, 2; pl. 34, figs. 2-4. Jordan and Hertlein, 1926b, p. 430-431. Hertlein and Grant, 1972, p. 174-177, pl. 30, figs. 1, 2, 3, 4, 9; pl. 32, fig. 14; text fig. 7.

Pecten hemphillii Dall, 1878, p. 15. Woodring, 1950, p. 82-83, pl. 16 , figs. 15, 16; pl. 21, fig. 8 .
Pecten (Pecten) hemphillii Dall. Dall, 1898, p. 706. Arnold, 1903, p. 105-106. Arnold, 1906, p. 97, pl. 33, figs. 3, 3a, 3b.

Pecten (Janira) bellus (Conrad) variety hemphillii Dall. Grant and Gale, 1931, p. 226, pl. 3, figs. 1a, 1b. Durham, 1950, p. 60, pl. 7, figs. 3,5 .

Pecten (Pecten) auburyi Arnold, 1906, p. 94, pl. 33, figs. 2, 2a; pl. 34, figs. 2, 2a.

Original description.-_"Subtriangular; inferior valve convex, ribs 14 or 15 , square, about as wide as the intervening spaces, very prominent, some of them with one or two longitudinal obsolete lines; disk finely wrinkled concentrically; upper valve flattened, deeply depressed toward the apex; ribs rather narrower than those of the opposite valve, obscurely bicarinated above, disk ornamented with close, fine, squamose, concentric wrinkles. Length 4 inches, height 3 $3 / 4$ inches." (bellus)

"This species has a strong general resemblance to the last, and is best described by comparison with it. P. Hemphillii is smaller, with sixteen ribs, as against twenty-six in a $P$. Stearnsii of the same size, with which throughout it will be compared; the lateral niargins of the ears are perpendicular and straight, instead of outwardly rounded; the hinge-line is perfectly straight, not slightly concave; the ribs on the lower valve are flattened above, with symptoms of a groove on the top surface, instead of beautifully roundly vaulted; the interspaces are of course wider; the raised concentric lamellae toward the periphery become long, coarse, and very crowded; on the lower valve, the shell is more vaulted, with hardly any traces of the raised lamellae, and with larger, rude, hardly flattened, radiating ribs, which show no trace of grooving or riblets; the ears and byssal notch are smaller and more coarsely sculptured. Height, $56 \mathrm{~mm}$; breadth, $63 \mathrm{~mm}$; breadth of hinge-line, $28 \mathrm{~mm}$; thickness, $15 \mathrm{~mm}$." (hemphillii)

"Adult shell averaging about 60 millimeters in altitude, somewhat longer than high, inequivalve, plano-convex, equilateral, and with smooth margins. Right valve convex and ornamented by about 16 or 17 prominent, rather narrow, convex-topped ribs; interspaces slightly narrower than the ribs, and with concave bottoms; whole surface sculptured by prominent, fine, sharp, subequal incremental lines; hinge line less than one-half length of disk; ears subequal and convex; anterior ear with two or three obsolete radiating ridges, prominent concentric sculpture, and small byssal notch; posterior ear with concentric sculpture only. Left valve flat or slightly concave, ornamented by 16 or 17 prominent, narrow, convex-topped ribs, which are separated by deep, almost flat-bottomed interspaces slightly wider than the ribs; whole surface sculptured by prominent, fine, sharp, equal, concentric lines; ears slightly concave, rectangularly truncated, and sculptured by fine, sharp, concentric lines." (auburyi)

Neotype.-ANSP 960 (Stewart, 1930); holotype of P. hemphillii USNM 7943; neotype of $P$. auburyi CAS 87 (Keen and Bentson, 1944).

Type locality.-Santa Barbara, Santa Barbara County, Calif. Santa Barbara Formation, Pliocene and Pleistocene; of $P$. hemphillii San Diego, San Diego County, Calif., San Diego Formation, Pliocene; of P. auburyi Puente Hills, Los Angeles County, Calif., Pico(?) Formation, Pliocene and Pleistocene.

Supplementary description. - "Shell large, thin, inequivalve, elegantly, radiately ribbed. Left (upper) valve slightly convex, the point of greatest convexity being generally about one-fourth the distance from the apex toward the ventral margin; between this point of greatest convexity and the apex there is a deeply depressed area, the depression generally not affecting the two outer ribs on each side, which inclose the depression on the sides; surface of left valve ornamented by 13 or 14 prominent, flat-topped, sometimes faintly bicarinated, radiating ribs, which have flat, sloping sides; 
these ribs become broader, less elevated, and less sharply angulated near the periphery in the adult; interspaces slightly wider than the tops of the ribs, with slightly rounded bottoms; whole surface of left disk covered with fine, sharp, concentric, regular lamellae; ears rather small, subequal, slightly concave, finely concentrically lamellated, separated from the disk by an impressed line. Right (lower) valve prominently convex, the point of greatest convexity being about one-third the distance from the apex to the ventral margin of the disk; the umbo in this valve curves sharply and meets the plane of the ears at an angle of about 90 degrees; surface of right valve ornamented by 14 or 15 prominent, nearly flat-topped, square, radiating ribs, some of them with one or two longitudinal obsolete lines; the ribs become somewhat less elevated and the sides more sloping as the periphery is approached in the adult; surface of right disk ornamented with close, fine, squamose, concentric wrinkles; ears subequal, arched, covered with crowded, elevated lamellae; byssal notch small." (Arnold, 1906, p. 95-96)

"We have examined over 600 specimens, the greater number single valves, varying in size from $8 \mathrm{~mm}$ to $78.8 \mathrm{~mm}$ high. The number of ribs vary from 12 to 18 but the average is about 15 . The ribs on the ventral portion of large forms tend to become broad, flat-topped, the sides slope rather steeply to the interspaces. The ribs on smaller specimens are higher, narrower and more rounded. The tops of ribs on large specimens sometimes bear one or more faint longitudinal grooves. The ribbing on the interior of valves, which is well defined on the right valve, extends to the umbonal area, on the left valve to the muscle impression. Low flanges are present on the ribs near the ventral margin of large valves. There are usually two pairs of rather weakly developed cardinal crura but these are not prominent. Auricular crura are well developed on the left valve but less pronounced on the right valve." (Hertlein and Grant, 1972, p. 176)

Comparison.-"Pecten (Pecten) lecontei Arnold described from Cedros Island, Lower California, is quite distinct from P. bellus and its variants. The ribs, about 18 on the right valve and 17 on the left, are round-topped. Those on the right valve usually quite smooth, separated by flat-bottomed interspaces which are narrower than the ribs. The left valve is usually slightly concave and the rounded ribs are quite different from the high usually flat-topped ribs of $P$. bellus.

"Pecten (Pecten) slevini Dall and Ochsner described from strata of Pliocene age on the Galapagos Islands differs from P. bellus and its variants by the narrower, rounded ribs on the right valve which are separated by wider interspaces and by the wider apical angle. ***

"The shell of Pecten bellus bears a general resemblance to that of $P$. albicans Schröter and to $P$. excavatus Anton, which have fewer ribs. but close relationship with these Japanese species has not been demonstrated." (Hertlein and Grant, 1972, p. 177)

"Collections of $P$. (P.) hemphilli from the San Diego Formation, Pacific Beach, California, and of $P$. $(P$.) bellus from the Santa Barbara Formation, Santa Barbara, California, have been examined and no consistently useful characters have been found for separating specimens of these two forms that are of similar size. The only consistent difference is that $P$. $(P$.) bellus from Santa Barbara usually reaches a greater maximum size than the form that has been called $P$. $(P$.) hemphilli from Pacific Beach. This is in agreement with the findings of Hertlein and Grant $(1972$, p. 176-177), who examined more than 600 specimens of $P$. $(P$.) hemphilli from the San Diego Formation and placed that species in synonymy with $P$. $(P$. bellus." (Vedder and Moore, 1976, p. 124)

Comments. - The neotype is a double-valved specimen. The right valve has 16 ribs that are flat-topped, unequal in size, and separated by interspaces ranging in width from half as wide to wider than the ribs. Secondary ribs are in some of the subrounded interspaces. The right anterior auricle has a narrow, shallow byssal notch and one riblet; the right posterior auricle has no riblets. The left valve has 14 ribs subrounded at the anterior and posterior ends of the shell but flat topped on the rest of the shell. One rib is split close to the umbo. The interspaces are wider than the ribs and do not have secondary riblets. The entire shell has imbricated, concentric lamellae, and the auricles have no riblets.

Geographic range.-Middle California to Baja.California Sur. Geologic range.-Miocene to Pleistocene.

Occurrence in the Californias.-Miocene and Pliocene: Purisima Formation (Arnold, 1906); Pliocene: Almejas (Minch and others, 1976), Carmen (Durham, 1950), Cebada and Graciosa Members, Careaga Sandstone (Woodring, 1950), Niguel (Vedder, 1960), Salada (Beal, 1948), and San Diego (Arnold, 1906; Hertlein and Grant, 1972) Formations, unnamed Pliocene on San Clemente Island (Vedder and Moore, 1976; Susuki and Stadum, 1978); Pliocene and Pleistocene: Fernando (Arnold, 1907a; Moody, 1916; Soper and Grant, 1932; Zinsmeister, 1970), Merced (Arnold, 1906), Pico (Waterfall, 1929; Winterer and Durham, 1962), Potato Harbor (Weaver and Meyer, 1969), and Saugus (Kew, 1924) Formations; Pleistocene: Lindavista Formation (Kennedy, 1973).

\section{Pecten (Pecten) slevini Dall and Ochsner}

Pecten (Pecten) slevini Dall and Ochsner, 1928, p. 118, pl. 3, fig. 9; pl. 4, fig. 4. Hertlein and Grant, 1972, p. 177.

Comments.-Pecten slevini was described from Pliocene strata on the Galapagos Islands. The specimen illustrated by Grant and Gale (1931, p. 227, pl. 2, fig. 3) as P. slevini, from the Pliocene of Los Angeles County, was incorrectly identified. It is probably a distorted specimen of $P$. bellus (Hertlein and Grant, 1972, p. 177). Therefore, $P$. slevini does not occur in the Californias and is not illustrated in this report.

\section{Genus AMUSSIOPECTEN Sacco, 1897}

Differs from Flabellipecten in its nearly obsolescent radial ribs with correspondingly stronger internal radial riblets similar to Amusium; cardinal margin of hinge commonly more angulated with high angulated auricles.

Geologic range.-Oligocene to Miocene.

\section{Amussiopecten vanvlecki (Arnold)}

Plate 29, figure 5; plate 30, figure 1

Pecten (Pecten) vanvlecki Arnold, 1907b, p. 428, pl. 53, figs. 1, 2. Loel and Corey, 1932, p. 195, pl. 20, figs. 3, 5 .

A mussiopecten vanvlecki (Arnold). Masuda, 1971b, p. 210-21'1, pl. 25 , figs. 1a, 1b, 2-4. Addicott, 1974, pl. 2, fig. 2

Original description. - "Shell averaging about $70 \mathrm{~mm}$. in altitude, length and height about equal, outline circular; both valves convex, the right slightly more so than the left, equilateral, thin; base regularly rounded; sides only very slightly concave above; margins smooth. Right valve somewhat convex, the region of greatest convexity being just below the beak; surface ornamented with 13 or 14 rather prominent ribs, these being quite rounded in the younger stages of growth, but gradually becoming flatter and lower toward the periphery; interspaces rounded near umbos, but shallower and flatter below; equal, fine, sharp, raised incremental lines, separated by interspaces as wide as the lines, cover the surface of the disk and ears; hinge line longer than half length of disk; ears subequal, anterior with a shallow byssal notch; posterior rectangularly truncated. Left valve slightly less convex than right, flat to concave immediately below umbo; ribs regularly rounded throughout entire 
length, becoming flatter and sometimes almost obsolute toward the periphery; minute sculpture as in right valve; ears flat, the anterior one showing two or three faint radial riblets. Interior of both valves reflecting the external ribbing very prominently."

Holotype.-USNM 165305.

Type locality.-USGS 4478. Santa Barbara County, Calif. Vaqueros Formation, Oligocene and Miocene.

Supplementary description. - "Shell slightly inflated, subequivalve, though right valve a little more convex than slightly inflated left valve which is sometimes nearly flat in younger stage but tends to become slightly inflated with growth; radial ribs of right valve flatly round-topped, more or less squarish in profile, rather distinctly separated from their interspaces and varying in number from about 13 to $18^{* * *}$. Hinge with simple cardinal crura with a distinct provinculum and distinct cardinal crura terminating distally in an oblong denticle. Paired internal ribs well developed near ventral margin." (Masuda, 1971b, p. 210)

Comparison.-"Pecten vanvlecki has frequently been confused with Pecten (Amusium) lompocensis Arnold (1906), described from the Temblor Miocene in Southern California, as already pointed out by Loel and Corey (1932), but the former is easily distinguishable from the latter by its rather thick shell, squarish, low, flatly roundtopped radial ribs tending to become obsolete towards the ventral and lateral margins, paired internal ribs developed at lower part and larger and angulated auricles. $* * *$ However, because of the state of preservation sometimes the two can not be distinguished from one another." (Masuda, 1971b, p. 210-211)

Comments.-Flabellipecten? hawleyi was placed in synonymy with A. vanvlecki as an immature form by Masuda (1971b, p. 210-211). The left valve holotype of $F$.? hawleyi is almost flat and has 18 narrow, round ribs separated by slightly wider interspaces. Both auricles are smooth, but the rest of the shell bears imbricated, concentric lamellae. The left valve paratype of $A$. vanvleck $i$ is somewhat convex and has 13 ribs; the anterior auricle has three faint riblets. I believe that $F$.? hawleyi is not an immature form of $A$. vanvlecki and concur with Hertlein and Grant (1972, p. 178) in tentatively assigning it to Flabellipecten.

Geographic range.-Southern California to Baja California Sur. Geologic range.-Oligocene and Miocene.

Occurrence in the Californias.-Oligocene and Miocene: Soda Lake Shale Member, Vaqueros (Vedder, 1973) and Vaqueros (Arnold, 1907b; Loel and Corey, 1932; Dibblee, 1950; Avila and Weaver, 1969) Formations; Miocene: Branch Canyon Sandstone (Vedder, 1968), Buttonbed Sandstone Member, Temblor Formation (Addicott, 1972), Isidro (Stump, 1979), Obispo Formation (Hall, 1973), Painted Rock Sandstone Member, Vaqueros Formation. (Vedder, 1973), and Saltos Shale Member, Monterey Shale (Vedder, 1973).

\section{Genus EUVOLA Dall, 1898}

Valves smooth except for radial grooves which are more prominent on umbonal portion; interior with narrow, rounded riblets corresponding to exterior radial sculpture.
Geographic range.-West Atlantic, Caribbean, southern California, and Baja California Sur.

Geologic range.-Miocene through Holocene (table 15).

\section{Euvola keepi (Arnold)}

Plate 30, figures 5, 6

Pecten (Pecten) keepi Arnold, 1906, p. 60-61, pl. 5, fig. 1; pl. 6, figs. 1, 1a.

Pecten keepi Arnold. G D. Hanna, 1926a, p. 471.

Pecten (Janira) keepi Arnold. Grant and Gale, 1931, p. 229.

Pecten (Euvola) keepi Arnold. Durham, 1950, p. 61, pl. 6, figs. 5, 6.

Original description.-"Shell averaging about 75 millimeters in altitude, longer than high, plano-convex, equilateral, and with smooth margins; sides concave above; lateral area very broad. Right valve ventricose and ornamented by about 20 low, broad, rounded ribs, separated by shallow interspaces in which are low, broad intercalaries; the sulcation on the interior of the valve corresponding to the intercalary is often quite prominent; whole surface sculptured by inconspicuous incremental lines; hinge line more than one-half length of disk; ears equal, somewhat convex, rather obliquely truncated and turned up slightly at the corners; sculpture of ears consists of fine incremental lines; byssal notch rather small. Left valve flat, with a slight tendency toward concavity near the umbo, with broad lateral areas and with 18 or 19 low, rather flat-topped ribs; interspaces somewhat wider than the ribs; surface sculptured by fine incremental lines; ears concave, obliquely truncated and sculptured by more or less irregular concentric lines."

Holotype.-CAS/SU 5.

Type locality.-Carrizo Creek district [N $1 / 2$ sec. 14, T. 15 S., R. 8 E., S.B.], San Diego County, Calif. Imperial Formation, Miocene or Pliocene.

Comparison.- "The ears of the left valve are more concave and more definitely set off than on $P$. refugioensis Hertlein; further, the apical angle is greater." (Durham, 1950, p. 61).

Comments.-The holotype is a double-valved specimen. The right valve is strongly convex and seems to have been inequilateral, with the posterior end the largest. This valve has about 17 very low, flat, almost obsolete wide ribs with narrow, slightly rounded interspaces. The auricles are smooth and strongly convex. The left valve is flat except near the umbos and ventral margin where it is concave. It has 15 narrow flat ribs separated by slightly wider interspaces, a few of which have one or two secondary riblets. The auricles are smooth and markedly concave. The right valve of E. refugioensis is smooth except on the umbo which has narrow, somewhat rounded, closely spaced ribs. The rest of the shell shows barely perceptible obsolete ribs a few of which can be seen and felt as slight protuberances on the shell. The auricles are only slightly convex. The left valve of $E$. refugioensis has almost obsolete ribs which are wider and not as strongly demarcated as on E. keepi. The auricles are smooth and only slightly concave. All of these characters serve to distinguish $E$. keepi from E. refugioensis, and I do not concur with Grant and Gale (1931, p. 229) that the species are the same.

TABLE 15.-Geologic and geographic distribution of the genus Euvola

$[\mathrm{PI}=$ Pliocene; $\mathrm{M}=$ Miocene $]$

\begin{tabular}{|c|c|c|c|}
\hline \multirow{2}{*}{ Species } & \multirow{2}{*}{$\frac{\text { California }}{\text { Southern }}$} & \multicolumn{2}{|c|}{$\begin{array}{c}\text { Baja } \\
\text { California } \\
\end{array}$} \\
\hline & & Norte & Sur \\
\hline 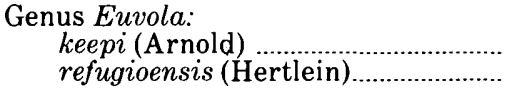 & $\mathrm{M}$ or $\mathrm{Pl}$ & $\cdots \cdots$ & $\begin{array}{c}\text { M,Pl } \\
\text { Pl }\end{array}$ \\
\hline
\end{tabular}


Geographic range.-Southern California to Baja California Sur, and Santa Rosalia, Mexico.

Geologic range.-Miocene(?) to Pliocene

Occurrence in the Californias.-Miocene: Isidro Formation (Stump, 1979); Miocene or Pliocene: Imperial Formation (Arnold, 1906; G D. Hanna, 1926a); Pliocene: Salada (Beal, 1948) and San Marcos (Durham, 1950) Formations.

\section{Euvola refugioensis (Hertlein)}

Plate 30, figures 2-4

Pecten (Pecten) refugioensis Hertlein, 1925a, p. 7, pl. 1, fig. 2; pl. 5, fig. 9.

Pecten (Euvola) refugioensis Hertlein. Durham, 1950, p. 61, pl. 6, fig. 3. Hertlein, 1966 , p. 274 , figs. $16,17$.

Original description. - "Shell of medium size. Right valve practically smooth, ornamented, however, by fine concentric lines of growth, and close to the beaks also by fine, faint, radiating ribs which, however, disappear at the umbo; ventral margin smooth; interior of the shell ornamented by about 19 dichotomous ribs; ears about equal and concentrically sculptured; a slight groove showing where the ears meet the margins of the shell; a slight byssal notch present on the anterior ear. Left valve fairly smooth, ornamented interiorly much as right, a depressed area which is lower than the margins extends from the beaks to about one-half the height of the shell; ears slightly concave, ornamented by concentric lines of growth. Altitude $56 \mathrm{~mm}$; longitude $57 \mathrm{~mm}$.; diameter of right valve approximately $14 \mathrm{~mm}$.; apical angle of right valve approximately $97^{\circ} . "$

Holotype.-CAS/SU 49.

Type locality.-SU 50. Baja California Sur. Salada Formation, Pliocene.

Supplementary description. - "The largest *** left valve *** is 88 $\mathrm{mm}$. high and $95 \mathrm{~mm}$. long (slightly imperfect on one end). The smallest is a left valve $29 \mathrm{~mm}$. high and $27.6 \mathrm{~mm}$. long. The largest right valve *** is a fragment $75 \mathrm{~mm}$. high." (Hertlein, 1966, p. 274)

Comparison. - "The shell of this species differs from that of Pecten (Euvola) keepi Arnold usually in the lack of radial ribbing on the ventral half of the valves or if ribbing is present it is much more weakly developed." (Hertlein, 1966, p. 274)

Comments.-See E. keepi for the description of the right-valve holotype of E. refugioensis, the left-valve paratype, and comparison of the two species.

Geographic range.-Baja California Sur.

Geologic range.-Pliocene.

Occurrence in Baja California.-Carmen (Durham, 1950) and Salada (Beal, 1948) Formations.

\section{Genus FLABELLIPECTEN Sacco, 1897}

Differs from Pecten (Pecten) in the less highly arched right valve, greater apical angle, and more numerous and usually lower radial ribs. The character of the umbonal area (Hertlein, 1969, p. N369) does not differentiate Flabellipecten from Pecten (Pecten), because some species of Flabellipecten also have a depression there.

Geographic range.-Eurasia, southeastern and western United States, and Panama.

Geologic range.-Miocene through Holocene (table 16).

\section{Flabellipecten carrizoensis (Arnold)}

Plate 31, figures 4, 6

Pecten (Pecten) carrizoensis Arnold, 1906, p. 59-60, pl. 4, figs. 1, 1a, 1b, 2, 3, and 3a. Durham, 1950, p. 61, pl. 8, figs. 1, 3 .

Pecten carrizoensis Arnold. G D. Hanna, 1926a, p. 470.

Pecten (Janira) stearnsii variety carrizoensis Arnold. Grant and Gale, 1931, p. 224.

Original description.-"Shell averaging about 42 millimeters in altitude, longer than high, inequivalve, plano-convex, equilateral, and with smooth margins; base evenly rounded; sides concave above. Right valve convex, ornamented by about 18 or 19 prominent, square, flat-topped medially sulcated ribs; interspaces channeled and slightly narrower than ribs; whole surface sculptured by fine, regular, concentric incremental lines; hinge line less than one-half length of disk; ears subequal, convex, and ornamented by concentric lines. Left valve flat or slightly concave, ornamented by about 17 prominent, equal, equidistant, narrow, convex-topped ribs, which are separated by flat-bottomed interspaces much wider than the ribs; surface sculptured by numerous fine, regular, wavy, concentric lines; ears concave and sculptured by concentric lines."

Holotype.-CAS/SU 11.

Type locality.-Head of Garnet Canyon [N1/2 sec. 13, T. 15 S., R. 8 E., S.B.], San Diego County, Calif. Imperial Formation, Miocene or Pliocene.

Supplementary description. - Flabellipecten carrizoensis differs from the type species of Flabellipecten in the fairly high, medially sulcated ribs, but it is believed to be allied to $P$. diegensis and should be included in the same supraspecific taxonomic category. (Hertlein and Grant, 1972, p. 178)

Comparison. - "This species belongs to the group of which $P$. diegensis is the living member. $P$. carrizoensis, $P$. stearnsii, and $P$. diegensis taken in chronologic order as above may rëpresent a genetic series. The three species are alike in most respects: They are all plano-convex, have squarish, more or less sulcated or longitudi-

TABLE 16.-Geologic and geographic distribution of the genus Flabellipecten

$[\mathrm{H}=$ Holocene: $\mathrm{Ple}=$ Pleistocene: $\mathrm{Pl}=$ Pliocene; $\mathrm{M}=$ Miocene; $\mathrm{O}=$ Oligocene $]$

\begin{tabular}{|c|c|c|c|c|c|c|}
\hline \multirow{2}{*}{ Species } & \multicolumn{3}{|c|}{ California } & \multicolumn{2}{|c|}{$\begin{array}{c}\text { Baja } \\
\text { California }\end{array}$} & \multirow{2}{*}{$\begin{array}{l}\text { Central } \\
\text { and (or) } \\
\text { South } \\
\text { America }\end{array}$} \\
\hline & Northern & Middle & Southern. & Norte & Sur & \\
\hline \multicolumn{7}{|l|}{ Genus Flabellipecten: } \\
\hline 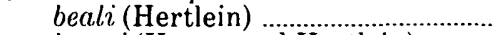 & $\cdots \cdots$ & …... & $\cdots \cdots$ & $\cdots \cdots$ & $\mathrm{Pl}$ & $\cdots \cdots$ \\
\hline boesei (Hanna and Hertlein). & $\cdots \cdots$ & $\cdots \cdots$ & $\cdots \cdots$ & $\cdots \cdots$ & $\mathrm{Pl}$ & $\cdots \cdots$ \\
\hline 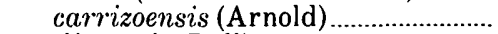 & $\cdots \cdots$ & $\cdots \cdots$ & $\mathrm{M}$ or $\mathrm{Pl}$ & & $\mathrm{Pl}$ & $\cdots \cdots$ \\
\hline 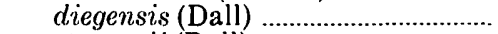 & $\mathrm{H}$ & & Pl to $\mathrm{H}$ & Ple & $\cdots \cdots$ & $\ldots \ldots$ \\
\hline \multirow{2}{*}{\multicolumn{7}{|c|}{ Genus Flabellipecten?: }} \\
\hline & & & & & & \\
\hline hawleyi (Hertlein) ............................ & $\cdots \cdots$ & $\ldots \ldots$. & O,M & $\cdots \cdots$ & $\cdots \cdots$ & $\cdots \cdots$ \\
\hline 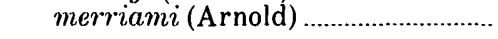 & $\ldots \ldots$ & $\mathrm{M}, \mathrm{Pl}$ & Pl,Ple & & $\cdots \cdots$ & $\cdots \cdots$ \\
\hline
\end{tabular}


nally ridged ribs, convex ears on the right valve, and rather narrow, rounded ribs and concave ears on the left.

" $P$. carrizoensis differs from the other two members of the group in the smaller number and less prominence of its ribs and in its relatively much shallower and narrower interspaces." (Arnold, 1906 , p. 60)

“Pecten (Pecten) lecontei Arnold from Cedros Island is very similar except that the left valve is usually entirely concave instead of first concave and then convex as in P. carrizoensis." (Durham, 1950, p. 61)

Comments. - The holotype is a small, incomplete, double-valved specimen. The right valve has 18 flat-topped ribs, some of which are grooved, and interspaces as wide as the ribs. The auricles are missing. The left valve has 16 rounded ribs separated by slightly wider interspaces and retains small patches of imbricated, concentric microsculpture on a few ribs. The umbonal area is depressed. The anterior auricle seems to have been smooth and the posterior auricle to have two riblets.

Geographic range.-Southern California to Baja California Sur. Geologic range.-Miocene(?) to Pliocene.

Occurrence in the Californias.-Miocene or Pliocene: Imperial Formation (G D. Hanna, 1926a); Pliocene: Boleo (Stump, 1979), Salada (Beal, 1948) and San Marcos (Durham,1950) Formations.

\section{Flabellipecten bosei (Hanna and Hertlein)}

Plate 32, figures 1, 2

Pecten (Pecten) bösei Hanna and Hertlein, 1927, p. 153-154, pl. 5, figs. 2, 3. Durham, 1950, p. 60, pl. 7, fig. 1.

Original description. - "Shell fairly large; right valve convex, ornamented by about 24 to 25 rather low, flattish-topped ribs which seldom show sulcation; interspaces narrower than ribs, flattish but slightly rounded at edges; ribs and interspaces crossed by fine concentric incremental lines; ears fairly large, subequal; anterior shows a faint byssal notch, above which the anterior ear slopes to hinge line forming an oblique angle; this ear possesses a fold near base; posterior ear slopes fairly abruptly to shell; ears set off from shell by sharp line and both ears ornamented by fine incremental lines of growth. Left valve slightly convex, ornamented by about 24 to 25 radiating, rounded ribs and interspaces, crossed by fine concentric incremental lines; ears slope from hinge line obliquely toward margin of shell. Length of right valve $74 \mathrm{~mm}$.; height $66 \mathrm{~mm}$.; apical angle, approximately $100^{\circ}$; hinge length, $28 \mathrm{~mm}$."

Syntypes.-CAS 2215 and 2216.

Type locality.-CAS 795. Baja California Sur. Salada Formation, Pliocene.

Comparison.- "This species differs from $P$. stearnsii Dall and $P$. diegensis Dall in possessing much lower ribs and these are usually broader and seldom show sulcation." (Hanna and Hertlein, 1927, p. 154)

"This species may be distinguished from $P$. bakeri by the right valve being much more convex than the left which is but slightly convex, and by the nondevelopment of the secondary riblets on the primaries of the left valve when the specimen is over $60 \mathrm{~mm}$ high." (Durham, 1950, p. 60)

Comments. - The left valve syntype (CAS 2216) is depressed in the umbonal area.

Geographic range.-Baja California Sur.

Geologic range.-Pliocene.

Occurrence in Baja California Sur.-Gloria (Stump, 1979), Infierno (Stump, 1979) and Salada (Beal, 1948) Formations and unnamed Pliocene strata on Carmen and Monserrate Islands.

\section{Flabellipecten stearnsii (Dall)}

Plate 31, figures 7, 8

Janira florida Hinds. Dall, 1874, p. 297. Not Pecten floridus Hinds, $1844=$ Pecten diegensis Dall, 1898.

Pecten stearnsii Dall, 1878, p. 11, 14. Woodring, 1946, p. 80, pl. 30 , figs. 9,11 ; pl. 32 , figs. 14,15 .

Pecten (Pecten) stearnsii Dall, 1898, p. 706, pl. 26, fig. 5. Arnold, 1903, p. 106, pl. 12, fig. 3. Arnold, 1906, p. 100, pl. 32, figs. 1, 1 a. Moore, 1968, p. 48, pl. 22, figs. a, b.

Pecten (Janira) stearnsii variety stearnsii Dall. Grant and Gale, 1931, p. 223, pl. 3, figs. 2a, 2 b.

Pecten (Flabellipecten) stearnsii Dall. Hertlein and Grant, 1972, p. 178-180, pl. 29, figs. 2, 4; pl. 35, fig. 10; text fig. 8.

Original description. - "Shell moderately large, thin, regular; elegantly radiately ribbed. Upper valve flattened or even a little concave, with about twenty-four regularly rounded, vaulted, even ribs, separated by slightly wider channeled interspaces; the whole surface covered with fine, sharp, concentric, regular lamellae, a little looped backward over the top of the ribs, but showing no appearance of reticulation anywhere; ears small, nearly symmetrical, covered with more elevated, crowded, concentric lamellae, especially near the margins; hinge-margin straight, or even a little concave toward the umbo; peripheral margins of the valves strongly and regularly crenulated and interlocking; interior regularly deeply grooved, to correspond with the external ribs; lower valve slightly convex, with about twenty-six regular even ribs, separated by channelled interspaces some what narrower than the ribs; the top surface of each rib is flattened with a broad, shallow groove in the middle, with one or two faint riblets on each side of the groove; the whole surface is covered with concentric lamellae, like those of the upper valve, but less sharp, and about twice as crowded. Ears subequal, arched, covered with crowded, elevated lamellae; byssal notch very small. Height of shell, $90 \mathrm{~mm}$; breadth, $100 \mathrm{~mm}$; breadth of hingeline, $34 \mathrm{~mm}$; thickness, $15 \mathrm{~mm}$."

Holotype.-USNM 7942.

Type locality.-Well at San Diego, San Diego County, Calif. San Diego Formation, Pliocene.

Supplementary description.-Flabellipecten stearnsii differs from the type species of Flabellipecten in the fairly high, medially sulcated ribs but is believed to be allied to $P$. diegensis and should be included in the same supraspecific taxonomic category. (Hertlein and Grant, 1972, p. 178)

Comparison.-"Pecten stearnsii is an extinct species and, as mentioned by Dall and by Arnold, it is the precursor of $P$. diegensis Dall, a Recent species which occurs at the present time in waters off San Diego.

"Pecten stearnsii differs from the Recent species in the greater number of ribs, 23 to 26 on the right valve and about 24 on the left valve in comparison to 19-21 on the right valve of $P$. diegensis and 20-21 on the left one. Furthermore, the hinge line of $P$. stearnsii is shorter, the ribs are usually more deeply medially sulcated and the interspaces between the ribs are narrower than those of $P$. diegensis. Woodring, Bramlette, and Kew (1946, p. 80) called attention to the fact that near the margin of the interior of the right valve of Pecten diegensis a flange occurs along each edge of the projection corresponding to the interspace on the exterior. Similar flanges appear to be lacking or but slightly developed near the anterior and posterior ends of the right valve of $P$. stearnsii.

"The two forms are very similar but in our opinion the differences are sufficient to justify recognition of each as a separate species.

"Pecten sericeus Hinds, a Recent species originally described from 
Panama, differs from $P$. stearnsii and $P$. diegensis in that the ribs, especially toward the ventral margin on adult right valves, often develop a low, median, tricarinate ridge.

"Three fossil forms of Pliocene age in the Gulf of California region are closely allied to $P$. stearnsii.

"Pecten carrizoensis Arnold *** has fewer (18 or 19 on right, 17 on the left valve) and less prominent ribs, which are separated by narrower interspaces than those on $P$. stearnsii.

"Pecten beali Hertlein *** differs from $P$. stearnsii in that the ears of the right valve bear radial riblets and in that a fine radial riblet occurs in each interspace between the radial ribs on the left valve. ${ }^{* *}$

"Pecten bösei Hanna and Hertlein *** differs from P. stearnsii in possessing lower, nonsulcated, often almost smooth ribs. Specimens from Pliocene beds in the Gulf of California region referred to $P$. stearnsii by Hanna and Hertlein (1927) are not typical of that species, but are more nearly allied to $P$. bösei." (Hertlein and Grant, 1972, p. 179-180)

Geographic range.-Middle California to Islas Tres Marias, Mexico.

Geologic range.-Miocene to Pleistocene.

Occurrence in the Californias.-Miocene and Pliocene: Purisima Formation (Arnold, 1906); Pliocene: Almejas Formation (Minch and others, 1976), Lomita Marl Member, San Pedro Formation (Woodring, 1946), Niguel (J. G. Vedder, written commun., 1978) and San Diego (Arnold, 1906; Hertlein and Grant, 1972) Formations; Pliocene and Pleistocene: Fernando (Eldridge and Arnold, 1907) and Merced (Arnold, 1906) Formations; Pleistocene: Timms Point Silt Member, San Pedro Formation (A. Clark, 1931; Woodring, 1946).

\section{Flabellipecten beali (Hertlein)}

\section{Plate 31, figures 3, 5}

Pecten (Pecten) beali Hertlein, 1925a, p. 10-11, pl. 2, fig. 3; pl. 5, fig. 8. Original description. - "Shell inequivalve, plano-convex, equilateral, the ventral margin evenly rounded. Right valve convex, ornamented by about 23 or 24 prominent, square, flat-topped, strongly medially sulcate radial ribs, with in some cases, fainter radial grooves superimposed; interspaces flat-bottomed and slightly narrower than the ribs, the whole surface sculptured by fine, regular, concentric lines; posterior ear sculptured by about four radial riblets, and by fine incremental lines. Left valve flat or slightly concave, ornamented by about 21 radiating ribs separated by flatbottomed interspaces, each of which bears a single small intercalated riblet, the ribs and interspaces crossed by fine concentric lines; a somewhat depressed area is found just below the beak; margins of shell somewhat concave, bearing four or five radiating ribs and fine concentric imbricating lines; ears somewhat concave, ornamented by three or four radiating riblets and by fine concentric lines of growth. Altitude $55 \mathrm{~mm}$.; longitude $56 \mathrm{~mm}$.; diameter of right valve approximately $10 \mathrm{~mm}$.; apical angle of right valve approximately $114^{\circ} . "$

Holotype.-CAS/SU 55

Type locality.-SU 64. Baja California Sur, Salada Formation, Pliocene.

Comparison. - "Pecten beali appears to be related to P. carrizoensis Arnold, but is larger, and the ribs are more numerous and more deeply sulcate. On the left valve the radial interspaces are ornamented by small midribs which are lacking in Arnold's species.. $P$. carrizoensis also is longer in proportion to the height than $P$. beuli." (Hertlein, 1925a, p. 11)

"Pecten beali*** differs from $P$. stearnsii in that the ears of the right valve bear radial riblets and in that a fine radial riblet occurs in each interspace between the radial ribs on the left valve." (Hertlein and Grant, 1972, p. 180)

Flabellipecten beali differs from the type species of Flabellipecten in the fairly high, medially sulcated ribs but is believed to be allied to $P$. diegensis and should be included in the same supraspecific category. (Hertlein and Grant, 1972, p. 178)

Geographic range.-Baja California Sur.

Geologic range.-Pliocene.

Occurrence in Baja California.-Salada Formation.

\section{Flabellipecten diegensis (Dall)}

Plate 31, figure 2; plate 32, figure 4

Pecten floridus Hinds, 1845, p. 60, pl. 17, figs. 6, 6a. Not Ostrea florida Gmelin, 1791.

Pecten (Pecten) diegensis Dall, 1898, p. 710, new name. Arnold, 1903, p. 106, pl. 12, fig. 5. Arnold, 1906, p. 127, pl. 51, figs. 1, 1a, 1b. Oldroyd, 1924, p. 51-52, pl. 29, fig. 5; pl. 41, fig. 3. Grau, 1959, p. $143-145$, pls. 52,53 .

Pecten (Janira) stearnsii Dall variety diegensis Dall. Grant and Gale, 1931, p. 223-224, pl. 3, fig. 4.

Original description.-“Testâ orbiculari, plano-subconvexâ, aequiauriculatâ; valvâ sinistrâ planulatâ, propê medium subelevatâ, rufescente sparsim albo maculatâ, costis viginti-duo ad latera compressis, supernè rotundatis cum interstitiis laminis minimis epidermidis transversim striatis; valvâ dextrâ subconvexâ, pallescente, costis quadratis, mediô sulco impressis; auriculis aequalibus, rectis, laevibus, epidermide indutis; intùs albâ, versus auriculas et margines saturatè fuscâ."

Holotype.-BM (NH) 79.2.26.241 (1 specimen, probably holotype fide Keen, 1966a).

Type locality.-San Diego, San Diego County, Calif. Holocene. (Depth $10 \mathrm{~m}$. )

Supplementary description.-"Shell averaging about 60 millimeters in altitude, longer than high, inequivalve, plano-convex, or nearly so, equilateral and with smooth margins; base evenly rounded; sides slightly concave above. Right valve somewhat convex (more pronounced near the umbo), and ornamented by about 22 or 23 prominent T-rail-shaped ribs, flattened, and generally longitudinally ridged or sulcated on top, which overhang deep, narrow, flatbottomed interspaces; whole surface sculptured by numerous fine, sharp, incremental lines; hinge line slightly less than one-half length of disk; ears equal, slightly convex, rectangularly truncated, sculptured by fine, sharp, incremental lines; anterior ear with small byssal notch. Left valve flat or nearly so, generally concave near apex, ornamented by 21 or 22 prominent, narrow convex-topped ribs, which are separated by concave-bottomed interspaces about equal in width to the ribs; whole surface prominently sculptured by numerous regular, fine, sharp, concentric, raised lines; ears concave, convexly truncated, and ornamented by the same concentric sculpture as the disk." (Arnold, 1906, p. 128)

"The average adult specimen is $90 \mathrm{~mm}$ in height, $110 \mathrm{in}$ length and 20 in diameter. ${ }^{* * *}$ Although Arnold said the right valve has 22 or 23 ribs and the left 21 or 22 , such specimens must be quite uncommon; all that the author has ever seen had 18 to 21 on the right valve and 17 to 20 on the left." (Grau, 1959, p. 144)

Comparison. - "Although closely related to Pecten sericeus Hinds, this species is quite distinct and differs in the following respects: less orbicular (length considerably greater than height); ribs of right valve always squarish, flat-topped, and often longitudinally ridged; ribs of left valve wider and rounded; interspaces of both valves narrower (especially left); auricular margins perpendicular (or 
nearly so) rather than oblique; hinge line relatively longer; concentric lamellae on disks and auricles only half as numerous." (Grau, 1959 , p. 144)

"Pecten stearnsii differs from the Recent species [F. diegensis] in the greater number of ribs, 23 to 26 on the right valve and about 24 on the left valve in comparison to 19-21 on the right valve of $P$. diegensis and 20-21 on the left one. Furthermore, the hinge line of $P$. stearnsii is shorter, the ribs are usually more deeply medially sulcated and the interspaces between the ribs are narrower than those of $P$. diegensis. Woodring, Bramlette, and Kew $(1946$, p. 80) called attention to the fact that near the margin of the interior of the right valve of Pecten diegensis a flange occurs along each edge of the projection corresponding to the interspace on the exterior. Similar flanges appear to be lacking or but slightly developed near the anterior and posterior ends of the right valve of $P$. stearnsii.

"The two forms are very similar but in our opinion the differences are sufficient to justify recognition of each as a separate species." (Hertlein and Grant, 1972, p. 180)

Geographic range.-Living: Northern California to Guadelupe Island, Mexico; fossil: southern California to Baja California Norte. Geologic range.-Pliocene(?); Pleistocene through Holocene.

Occurrence in the Californias.-Pliocene and Pleistocene: Santa Barbara Formation (Pico Formation of Waterfall, 1929); Pleistocene: unnamed strata of southern California (Kanakoff and Emerson, 1959) and Baja California Norte (Valentine, 1957).

Habitat. -10 to $365 \mathrm{~m}$.

"Usually found on $* * *$ the following varieties of bottom: shale, rock, gravel, gray sand, green sand, mud; associated with coralline, nullipores, kelp, sponge. $* * *$ The commensal gastropod Capulus californicus Dall is often attached to the anterior side of the umbo of the right valve." (Grau, 1959, p. 144, 145)

\section{Genus FLABELLIPECTEN? Flabellipecten? hawleyi (Hertlein) Plate 31, figure 1}

Pecten (Pecten) hawleyi Hertlein, 1925b, p. 40, pl. 4, figs. 4, 5. Loel and Corey, 1932, p. 194, pl. 20, figs. 1, 2.

Original description. - "Shell small, moderately thick, inequivalve. Right valve moderately convex, the point of greatest convexity being about one-third the distance from the apex to the ventral margin of the disk, the umbos gently rounded to the plane of the ears; surface ornamented by 17 to 18 prominent, sharply rounded ribs with nearly flat interspaces, toward the posterior extremity the ribs become flattened, and broader, and the interspaces broader proportionately; toward the periphery of the disk the ribs become somewhat less elevated and the sides of the ribs are more sloping to the flattened interspaces, in addition the surface of the right valve is ornamented by closely spaced, very fine, concentric lines, which are most prominent near the periphery of the disk; ears ornamented by concentric lines of growth, the anterior with a small byssal notch. Left valve slightly convex, slightly depressed near the anterior and posterior dorsal margins, ornamented by 16 to 17 very narrow, round ribs which expand but slightly towards the periphery of the disk, and are separated by interspaces wider than the ribs, the surface also sculptured by numerous fine, concentric growth lines which are more prominent than those on the right valve; ears crossed by very fine lines of growth. Height $32 \mathrm{~mm}$.; length $34 \mathrm{~mm}$.; apical angle of left valve approximately $125^{\circ}$."

Holotype-CAS/SU 19.

Type locality.-SU 860. Santa Barbara County, Calif. Vaqueros Formation, Oligocene and Miocene.
Comparison.-“Pecten hawleyi Hertlein resembles $P$. sanctaecruzensis Arnold, but the present species is smaller, has a greater number of ribs, and has more prominent concentric sculpture on both valves than $P$. sanctaecruzensis." (Hertlein, 1925b, p. 40)

Comments.-For a description of the left valve holotype of $F$.? hawleyi and comparison see Amussiopecten vanvlecki.

Geographic range.-Southern California.

Geologic range.-Oligocene to Miocene.

Occurrence in California.-Oligocene and Miocene: Vaqueros Formation (Hertlein, 1925b; Loel and Corey, 1932).

\section{Flabellipecten? merriami (Arnold)}

Plate 32, figure 5; plate 33, figure 1

Pecten (Pecten) merriami Arnold, 1906, p. 99, pl. 30, figs. 1, 1a, 2. Pecten (?Patinopecten) merriami Arnold. Hertlein and Grant, 1972, p. 185-186.

Original description. - "Shell averaging about 115 millimeters in altitude, longer than high, inequivalve, equilateral, of medium thickness, and with smooth margins; base evenly rounded; sides straight or only slightly concave above, sloping at a rather low angle. Right valve decidedly ventricose, with 18 or 19 subequal, strong, square ribs, some of which show faint medial sulcations near their extremities; interspaces flat-bottomed and somewhat narrower than ribs; whole surface of disk sculptured by more or less prominent lines of growth; hinge line more than one-half length of shell; ears about equal in length; anterior ear with faint byssal notch, obsolete radiating ridges and fine incremental sculpture; posterior ear rectangularly truncated, and with faint radial and fine concentric sculpture. Left valve flat to concave, with a more or less prominent bulge just below the umbo, as in $P$. bellus; ribs prominent and rounded, relatively flatter and broader as the periphery of the disk is approached; interspaces about as wide as the ribs, round-bottomed, and some of them showing a faint intercalary riblet; surface sculptured by fine, sharp, looped, concentric lines; ears ornamented by 5 or 6 rather prominent radiating ridges and numerous fine concentric lines."

\section{Holotype.-UCMP 12086.}

Type locality.-From light-colored shale under the conglomerate on San Felician Creek, near Piru, Ventura County, Calif. Pico Formation, Pliocene and Pleistocene.

Comparison.- " $P$. merriami is distinguishable from $P$. bellus, to which it is allied, by its much larger size when adult, more numerous ribs (18 to 19 in the former, 14 to 15 in the latter), relatively longer hinge line (the hinge line of the former being about 60 per cent of the length of the disk, while that of the latter is only about 45 per cent), and the radial ridging of the ears." (Arnold, 1906, p. 99)

Comments. - The holotype is a large, incomplete, double-valved specimen with the umbonal areas and auricles of both valves missing. The right valve has about 18 square ribs, a few of them grooved, and interspaces slightly narrower than the ribs. The right valve is convex, more so than would be expected for Patinopecten. The left valve has about 15 rounded ribs separated by interspaces of about equal width. The umbonal area is missing, but the shell is slightly convex below it, then flattens out, and is markedly concave at the v̀entral margin.

The paratype illustrated by Arnold (1906, pl. 30, fig. 2), which is missing and presumed lost (Keen and Bentson, 1944, p. 90), was a large specimen with a wide apical angle, long hinge, and two riblets on the anterior auricle and about three on the posterior auricle.

Geographic range.-Southern California.

Geologic range.-Miocene to Pleistocene. 
TABLE 17.-Geologic and geographic distribution of the genus Oppenheimopecten $[\mathrm{H}=$ Holocene; $\mathrm{Ple}=$ Pleistocene; $\mathrm{PI}=$ Pliocene; $\mathrm{M}=$ Miocene; $\mathrm{O}=$ Oligocene $]$

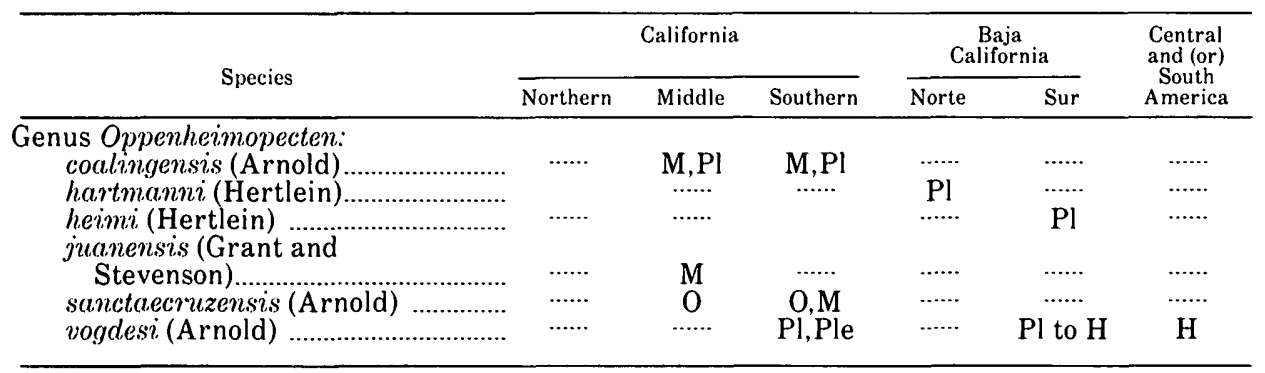

Occurrence in California.-Miocene and Pliocene: Purisima Formation; Pliocene and Pleistocene: Pico Formation (Keen and Bentson, 1944).

\section{Genus OPPENHEIMOPECTEN von Teppner, 1922}

Right valve very strongly convex; beak strongly incurved and overhanging that of left valve; ribs rounded to subrectangular, auricles squarely terminated. Left valve flat to concave, ribs low and wide but narrower than interspaces.

Geographic range.-Living in Indo-Pacific, Australia, Japan, Hawaii, and eastern Pacific.

Geologic range.-Oligocene through Holocene (table 17).

Habitat.-In shallow tropical and subtropical seas.

\section{Oppenheimopecten sanctaecruzensis (Arnold)}

Plate 32, figure 3; plate 33, figure 2

Pecten (Pecten) sanctaecruzensis Arnold, 1906, p. 54-55, pl. 3, figs. 12, 13. Addicott, 1973, p. 24-25, pl. 2, figs. 4, 7.

Pecten (Pecten) dickersoni Wagner and Schilling, 1923, p. 253, pl. 45, fig. 1.

Original description.- "Shell averaging about 50 millimeters in altitude, slightly longer than high, planoconvex, equilateral, rather thin; base regularly rounded; sides only slightly concave above; margins smooth. Right valve quite convex and ornamented with about 12 prominent, perpendicular-sided, slightly convex-topped ribs, separated by flat-bottomed, channeled interspaces about equal in width to the ribs; surface sculptured by small, almost imperceptible, obsolete, radiating striations and numerous fine sharp concentric lines; hinge line considerably longer than one half length of disk; ears subequal; anterior with shallow byssal notch and fine, sharp concentric lines; posterior similarly sculptured, but rectangularly truncated. Left valve flat, with slight concavity near umbo; lateral areas rather prominent; ribs squarish, with slightly convex tops narrower than those of the right valve and with proportionally wider inter[s]paces; ears subequal, rectangularly truncated, and with surface sculptured by numerous fine, sharp incremental lines." (Arnold, 1906)

"Small in size; convex; equilateral; dorsal margins slightly concave; base evenly rounded; on the type specimen there are 14 ribs on the right valve; ribs rail-shaped being somewhat larger on top than near the base; tops of ribs slightly rounded; wider than interspaces; bottom of interspaces flat; each rib sculptured by a faint groove running down the center but nearly obsolete on some; hinge line at least two-thirds the length of the disc; anterior and posterior ears fairly large, ornamented by about five fairly coarse and irregular ribs; left valve unknown, probably flat. Dimensions: length, $19 \mathrm{~mm}$.; height, $19 \mathrm{~mm}$.; convexity of right valve, $8 \mathrm{~mm}$." (Wagner and Schilling, 1923)

Holotype.CAS/SU 360; of P. dickersoni, UCMP 11416.

Type locality.-SU 111. Santa Cruz County, Calif. Vaqueros Formation, Oligocene and Miocene; of $P$. dickersoni, UC 3231, Kern County, Calif., Pleito Formation (Addicott, 1973, p. 25), Oligocene.

Supplementary description. - "Right valves of the pectinid range from about 45 to $85 \mathrm{~mm}$ (millimeters) in length. They have 12 or 13 strong ribs which have gently rounded upper surfaces and vertical sides. The interspaces are deep, relatively flat bottomed, and somewhat narrower than the ribs. On two of the larger specimens, there is a suggestion of fine radial sculpture on a few of the ribs.

"Two left valves *** are relatively flat. The interior of the better preserved valve is characterized by strong cardinal crura that extend almost to the ligamental pit. Each valve has 12 prominent radial ribs that are much sharper than those of the right valve and that are separated by relatively wide interspaces. These valves measure about 48 and $73 \mathrm{~mm}$ long." (Addicott, 1973, p. 25)

Comparison.- "This species is allied to $P$. bellus and may be its precursor, as it is very similar to the latter in most respects. $P$. sanctaecruzensis may be distinguished from $P$. bellus by its fewer ribs (11 instead of 14) and relatively smaller size when adult." (Arnold, 1906, p. 54-55)

Study of several topotypes indicates that the pattern and number of ribs on $P$. dickersoni are identical to $P$. sanctaecruzensis. (Addicott, 1973, p. 25)

Comments.-The auricles on the left-valve holotype are deeply concave.

Geographic range.-Middle to southern California.

Geologic range.-Oligocene to Miocene: Possibly early Zemorrian of Kleinpell (Addicott, 1973, p. 25). According to Burchfiel (1964, p. 405) O. sanctaecruzensis "is, as far as known, limited to the Zemorrian Stage, and can be used as an index fossil to the Vaqueros Sandstone."

Occurrence in California.-Oligocene: Pleito (Addicott, 1973) and Wygal Sandstone Member, Temblor (Addicott, 1973) Formations; Oligocene and Miocene: Vaqueros Formation (Keen and Bentson, 1944).

\section{Oppenheimopecten juanensis (Grant and Stevenson)}

\section{Plate 33, figure 5}

Pecten (Pecten) juanensis Grant and Stevenson, 1948, p. 804-805, pl. 124, figs. 1-4.

Pecten (Oppenheimopecten) juanensis Grant and Stevenson. Hertlein and Grant, 1972, p. 180, 182.

Original description. - "Shell of moderate size; right valve highly ventricose; left valve flattish (none well preserved); right valve 
sculptured with 18 to 21 rounded ribs which are less convex near their medial portions though not flat, with evenly rounded interspaces which are somew hat narrower than the ribs; no interribs nor radial striations present on type material; ears of right valve about equal in length, smooth, with occasional subdued growth lines; byssal notch under right anterior ear slightly developed; hinge apparently similar or identical to that of Pecten coalingaensis. Dimensions of type: Height, $21 / 8$ inches (54 mm.); width, $21 / 4$ inches $(57 \mathrm{~mm}$.); ventricosity of right valve, $15 / 16$ inch $(24 \mathrm{~mm}$.); length of hinge, $13 / 32$ inch $(27 \mathrm{~mm}$.)."

Holotype.-UCLA 10441.

Type locality.-UCLA 435. San Luis Obispo County, Calif. Neroly Sandstone, Miocene.

Comparison.-"This new species differs from Pecten coalingaensis Arnold of the upper Pliocene in its lack of ribs on the ears of the right valve, in its lower, broader, less convex ribs with narrower interspaces, and in its greater ventricosity. Both species appear to have the same average number of ribs, which is about 20 on the right valve.

"From Pecten vogdesi Arnold, the new Miocene species differs in its smaller size, less ventricosity and smooth ears. P. vogdesi has 3 or 4 strong ribs on the right anterior ear with more, slightly less prominent ribs on the posterior ear. Both ears of the new Miocene species are smooth.

"The similarities between the new species and $P$. coalingaensis Arnold $* * *$ is greater than the similarities between the new species and Pecten bellus Conrad $* * *$. We believe that $P$. juanensis, $P$. coalingaensis and $P$. vogdesi are genetically related and form a clan to which $P$. bellus is only related as a possible off-shoot from the upper Miocene species here described, or from an earlier common ancestor $* * *$ the apical angle of the umbones $* * *$ in the new species is about 90 degrees, but in $P$. vogdesi is about 95 to 100 degrees. *** Pecten heimi Hertlein ${ }^{*} * *$ has but weakly sculptured ears. In general appearances it closely resembles the new Miocene species which, however, has unsculptured ears. Possibly the relationship of the new species is closer to P. heimi than to P. vogdesi." (Grant and Stevenson, 1948, p. 805)

The apical angle of $O$. juanensis is about $90^{\circ}$ rather than $95^{\circ}$ to $100^{\circ}$ as in P. vogdesi. (Hertlein and Grant, 1972, p. 182)

Geographic range.-Middle California.

Geologic range.-Miocene.

Occurrence in California.-Neroly Sandstone.

\section{Oppenheimopecten coalingaensis (Arnold)}

\section{Plate 33, figure 3}

Pecten coalingaensis Arnold in Anderson, 1905, p. 197, pl. 18, figs. 94-98. Arnold, 1909, p. 158, pl. 26, figs. 1, 2. Stewart, 1940, p. 90-91, pl. 13, figs. $1,2,17,18$; pl. 16, fig. 4 . Woodring, 1946 , p. 80 . G D. Hanna and Hertlein, 1941, fig. 65-10. Grant and Stevenson, 1948, pl. 124, figs. 5, 6 .

Pecten (Pecten) coalingaensis Arnold, 1906, p. 97, pl. 4, figs. 4, 4a, 5. Adegoke, 1969, p. 96-97, pl. 1, figs. 1, 14.

Pecten (Janira) bellus (Conrad) variety coalingaensis Arnold in Anderson. Grant and Gale, 1931, p. 227, pl. 2, fig. 2.

Pecten (Oppenheimopecten) coalingaensis Arnold. Hertlein and Grant, 1972, p. 180.

Original description. - "Shell about 45 millimeters in altitude, longer than high, plano-convex, or nearly so, equilateral, and with smooth margins. Right valve ventricose and ornamented by about 20 ribs which have narrow, somewhat convex tops, and sides which slope at angles of about $45^{\circ}$; interspaces quite deeply impressed, channeled, and flat bottomed; surface sculptured by fine incremen- tal lines; hinge line slightly longer than one-half length of disk; ears equal, convex, and ornamented by 2 or 3 obsolete radiating ridges and numerous fine incremental lines. Left valve flat, with 19 prominent convex ribs, a surface sculpture of fine regular incremental lines, and concave ears which are slightly obliquely truncated."

Lectotype.-CAS/SU 7 is here designated the lectotype. The specific name coalingaensis was first used by Arnold in Anderson (1905, p. 197, pl. 18, figs. 94-98), and the specimens illustrated in that paper would therefore be the primary types. The specimens, however, are missing from the California Academy of Sciences and presumed lost. In 1906 (p. 97, pl. 4, figs. 4, 4a) Arnold described coalingaensis as a "new species," illustrated a right and a left valve and called the right valve the "type" and the left valve the cotype. The left valve is missing and presumed lost in the San Francisco fire of 1906. The right valve illustrated by Arnold (1906, pl. 4, figs. 4, 4a) is the specimen selected as the lectotype.

Type locality.-Coalinga [sec. 36, T. 20 S., R. 14 E.], Kreyenhagen Ranch on Zapata [Zapato] Chino Creek [Fresno County], Calif. Etchegoin Formation, Pliocene.

Supplementary description.-On 150 valves of this species the number of ribs ranges from 15 to 23 ; three-fourths of the inflated valves have 19 to 21 ribs, and three-fourths of the flatter valves have 18 to 20 ribs." (Stewart, 1940 , p. 90-91)

Comparison. - "The nearest living relative of $P$. coalingaensis is $P$. cataractes Dall $[=O$. vogdesi $]$, from the Gulf of California. The living species may be distinguished from $P$. coalingaensis by the presence of secondary radials in the interspaces on the flatter valve. All of 150 valves of $P$. coalingaensis lack secondary radials except 5 , which have a radial in one or two interspaces, but only 1 of 29 left valves of $P$. cataractes lack the radials, and that valve is small (height, 22 millimeters). $P$. coalingaensis and its allies may be distinguished from $P$. bellus Conrad *** and its allies, by the greater number of ribs, the greater inflation of the inflated valve, and the shorter internal channels-corresponding to the external ribs-on the flatter valve. The cross section of the ribs of the inflated valve also differ in the two groups: $P$. bellus has square-topped ribs, whereas $P$. coalingaensis has round-topped ribs." (Stewart, 1940, p. 91)

Oppenheimopecten coalingaensis is distinguished from $O$. vogdesi by the lack of secondary riblets on the left valve. (Woodring, 1946, p. 80)

Comments.-The lectotype is a slightly distorted right valve with 20 ridgelike to subrounded ribs separated by deep, slightly narrower interspaces.

Geographic range.-Middle to southern California.

Geologic range.-Miocene and Pliocene.

Occurrence in California.-Miocene and Pliocene: Etchegoin (Arnold, 1906; G D. Hanna and Hertlein, 1943) and Purisima (Arnold, 1906) Formations; Pliocene: San Joaquin Formation (Stewart, 1940; Adegoke, 1969).

\section{Oppenheimopecten hartmanni (Hertlein)}

\section{Plate 33, figure 4}

Pecten (Pecten) hartmanni Hertlein, 1925a, p. 8-9, pl. 1, figs. 4, 6. Pecten (Janira) hartmanni Hertlein. Grant and Gale, 1931, p. 229.

Pecten (Oppenheimopecten) hartmanni Hertlein. Hertlein and Grant, 1972 , p. 180.

Original description.-"Right valve excessively arched, ornamented by about 16 or 17 rounded radiating ribs which become flattened toward the ventral margin of the shell; anterior and posterior margins highly arcuate, smooth except for faint lines of growth; ears somewhat convex and turned up slightly at the ends, the anterior sculptured by about four poorly defined radiating riblets which 
are crossed by concentric incremental lines, and cut by a slight byssal notch; left ear with a few faint radial riblets and slight concentric striae. Altitude $75 \mathrm{~mm}$.; longitude $65 \mathrm{~mm}$.; diameter of right valve approximately $30 \mathrm{~mm}$; apical angle of right valve approximately $88^{\circ} . "$

Holotype.-CAS/SU 48.

Type locality. -SU 54. Baja California Norte. Almejas Formation, Pliocene.

Comparison. - "Pecten hartmanni differs from P. hemphilli Dall in possessing a more highly arched right valve and in the shape of the ears, which in the present species are somewhat more concave. It differs from $P$. cataractes Dall in having fewer ribs, and in that the margins of the shell descend abruptly rather than expanding laterally, as in the case in Dall's species, and also in P. vogdesi Arnold." (Hertlein, 1925a, p. 9)

Comments. - The holotype is a thick-shelled right valve with 17 ribs that enlarge rapidly, are wide and almost flat at the ventral margin, and are separated by very narrow interspaces.

Geographic range.-Baja California Norte.

Geologic range.-Pliocene.

Occurrence in Baja California.-Almejas Formation (Mina, 1956).

\section{Oppenheimopecten heimi (Hertlein)}

\section{Plate 33, figure 6}

Pecten (Pecten) heimi Hertlein, 1925a, p. 9-10, pl. 1, fig. 3; pl. 3, fig. 3. Pecten (Oppenheimopecten) heimi Hertlein. Hertlein and Grant, 1972 , p. 182

Original description. - "Shell concavo-convex, equilateral, inequivalve. Right valve highly arched, and ornamented by about 20 or 21 rounded, radiating ribs which become flattened toward ventral margin, these separated by round-bottomed interspaces about onehalf as wide as the ribs; ribs and interspaces crossed by concentric incremental lines of growth; ventral margin of shell rounded; ears somewhat convex; a distinct groove on right ear close to margin of shell, and byssal notch also present; anterior margin of right ear somewhat convex; ear ornamented by about four or five radiating riblets and by concentric incremental lines. Left valve slightly concave and ornamented by about 17 or 18 radiating ribs which are separated by round-bottomed interspaces, the ribs and interspaces crossed by fine concentric incremental lines; a depressed area present just below the beaks; anterior and posterior margins of valve flattened, higher than the depressed inner area near beak, sloping abruptly to ears; ears concave and sculptured by fine incremental lines only. Altitude $75 \mathrm{~mm}$.; longitude $85 \mathrm{~mm}$.; diameter of right valve approximately $25 \mathrm{~mm}$.; apical angle of right valve approximately $97^{\circ} . "$

Holotype.-CAS/SU 46.

Type locality.-SU 65. Southern part of Arroyo San Gregorio, Baja California Sur. Salada Formation. Pliocene.

Comparison. - "Pecten heimi differs from P. hemphillii Dall in the number of ribs, which is greater in the $P$. heimi, and in the ears which are smooth, and more convex in the present species than in $P$. hemphillii. From $P$. coalingensis Arnold and $P$. auburyi Arnold it is distinguished by its larger size and the more rounded shape of its ribs; from $P$. vogdesi Arnold, by the fact that the shell in $P$. heimi does not flatten out at the ventral margin as does $P$. vogdesi, and $P$. heimi has a greater number of ribs than Arnold's species. $P$. heimi differs from $P$. hartmanni Hertlein, in being longer in proportion to the altitude, less inflated, and in possessing differently shaped ears. From $P$. aztecus Böse, $P$. heimi is distinguished by the fewer, more rounded, broader ribs, in the present species; furthermore, $P$. heimi is larger and apparently more convex." (Hertlein, 1925a, p. 10)

The auricles of the type specimen of $O$. heimi, a right valve, are weakly sculptured, and the auricles of the left valve are smooth, whereas the auricles of $O$. vogdesi have well-defined riblets. (Hertlein and Grant, 1972, p. 182)

Comments. - The holotype is a thick-shelled right valve with 20 ribs that are moderately large and flat at the ventral margin and are separated by narrow interspaces of different widths. The umbonal area of the right valve of $O$. juanensis is more inflated than on $O$. heimi, and $O$. juanensis has smooth auricles. The right valve of $O$. keep $i$ is less inflated, and the ribs are wider and lower than on $O$. heimi. The right valve of $O$. hartmanni is much more inflated than $O$. heimi, and the ribs are wider and more closely spaced. The right valve of $O$. vogdesi is less inflated than $O$. heimi, and the byssal notch is wider.

Geographic range.-Baja California Sur.

Geologic range.-Pliocene.

Occurrence in Baja California.-Salada Formation.

\section{Oppenheimopecten vogdesi (Arnold)}

\section{Plate 34, figure 5}

Pecten dentatus Sowerby, 1835, p. 109. Not Pecten dentatus J. Sowerby, 1829.

Pecten (Pecten) dentatus Sowerby. Arnold, 1903, p. 104, pl. 12, figs. 1, 1a.

Pecten (Euvola) cataractes Dall, 1914, p. 121, new name for Pecten dentatus G. B. Sowerby, not Pecten dentatus J. Sowerby.

Pecten (Pecten) vogdesi Arnold, 1906, p. 100-101, pl. 33, figs. 1, 1a; pl. 34, fig. 1. Hertlein, 1935, p. 304-305. Olsson, 1961, p. 158, pl. 20, figs. $4-4 \mathrm{~b}$.

Pecten (Oppenheimopecten) vogdesi Arnold. Grau, 1959, p. 149-152, pl. 55. Hertlein and Grant, 1972, p. 181-182, pl. 29, figs. 1, 3, 5, 6 .

Original description. - "Shell similar to P. excavatus, except averaging larger and with the following differences: Right valve, somewhat less convex, has 19 or 20 broader, flatter ribs, which are separated by relatively broader interspaces that occasionally show faint intercalary riblets or faint longitudinal striations. Left valve with fewer ribs than $P$. excavatus, and having no intercalary riblets, or faint ones, which become obsolete near the periphery of the disk; ears slightly less concave than in P. excavatus."

Holotype.-CAS/SU 4.

Type locality.-San Pedro, Los Angeles County, Calif. Upper part of San Pedro Formation, Pleistocene.

Supplementary description. - "Shell inequivalve and longer than high; average fully adult specimen about $110 \mathrm{~mm}$ high and $100 \mathrm{~mm}$ long; left valve smaller than right and recessed into latter, at ventral margin to depth of 6 to $8 \mathrm{~mm}$, hinge line slightly more than half length of disk. Right valve deeply convex; umbo strongly inflated and projecting above hinge margin (starting to do so when shell reaches height of from 35 to $44 \mathrm{~mm}$ ); hinge recurved at maturity, with contact surfaces of cardinal crura at right angle to left valve; 19 to 21 rounded ribs, strongly produced ventrally and resulting in prominently dentate margin; interspaces about half as wide as ribs; surface of disk covered by very minute growth striae which become stronger near ventral margin. Interior of disk with deep grooves near ventral margin, resulting from external ribs; reverse surfaces of interspaces flat and ridged. Anterior auricle very slightly longer than posterior; strong convex fold 2 or $3 \mathrm{~mm}$ above disk; upper portion of auricle flat, angled at about $45^{\circ}$ from perpendicular, finely concentrically lamellose and with 4 or 5 riblets; byssal notch shallow and ctenolium absent after shell reaches height of 40 to 45 $\mathrm{mm}$. Posterior auricle convex and with 6 to 11 faint riblets covered 
by fine concentric lamellae. Left valve shallowly concave; 18 to 20 rather flat ribs, with 4 or 5 small riblets next to submargins; ribs having one to three grooves near ventral margin; interspaces slightly wider than ribs, having a low central riblet and being finely concentrically lamellose. Interior of disk grooved near ventral margin as result of external ribs, grooves becoming shallower toward umbonal area; reverse surfaces of interspaces flattened and ridged; low rounded ridge parallel to submargin at base of each auricle and terminating in small white knob at lower end; cardinal crura prominent and with contact surfaces at right angle to disk. Both auricles concave, concentrically lamellose, and often slightly longer than those of right valve; 2 or 3 prominent riblets adjoining hinge margin, with occasionally 2 or 3 indistinct riblets below them." (Grau, 1959, p. 151)

"Shell large (altitude 70 to $100 \mathrm{~mm}$.), slightly longer than high, inequivalve, the right valve being convex, its umbone projecting above the hinge line, the left valve concave, equilateral, and with more or less serrate margins. Ribs in the right valve about 20; these are wide, low and rounded, broader than high, separated by narrower interspaces, their surface smooth except for incremental lines which loop across them. Ribs in the left valve about 19; these are narrow, squarish, flat-topped, about equal in width to their interspaces, sometimes longitudinally sulcated or ridged, interspaces flat-bottomed, usually with a well-developed mid-rib, the surface sculptured by numerous fine, sharp concentric lines, more marked in the interspaces. Ears subequal, the right anterior with a byssal notch." (Olsson, 1961, p. 158)

"The observable shell characters of the Pliocene $P$. vogdes $i$ do not differ from Recent specimens. On some left valves the interspaces lack a radial riblet but on others it is present. This feature varies in both fossil and Recent specimens. The hinge of juvenile specimens has but one pair of crura but adults have two pairs." (Hertlein and Grant, 1972, p. 181-182)

Comparison.-“Pecten (Pecten) heimi Hertlein *** is a similar species but that it is identical to $P$. vogdesi, as believed by Grant and Gale, is open to question. The ears of the type specimen are weakly sculptured and the ears of the left valve are smooth, whereas the ears of Recent $P$. vogdesi are ornamented with well defined riblets.

"Pecten (Pecten) juanensis Grant and Stephenson *** has smooth ears and the apical angle is about $90^{\circ}$ rather than $95^{\circ}$ to $100^{\circ}$ in $P$. vogdesi. Grant and Stephenson suggested that $P$.juanensis might be the precursor of $P$. coalingaënsis Arnold in Anderson and P. vogdesi.

"Pecten (Oppenheimopecten) hancocki $\mathrm{Grau}$, a Recent species from Cocos Island, has only 16 to 17 ribs and the right valve is much less convex than that of $P$. vogdesi and it differs in other details.

"In general appearance $P$. vogdesi bears a general resemblance to some members of the $P$. benedictus group and especially the $P$. aduncus group in the Miocene of the Mediterranean region but there are differences in the shape of the ribs and in other details." (Hertlein and Grant, 1972, p. 182)

Geographic range.-Living: Baja California Sur to Gulf of California and to Peru; fossil: southern California to Mexico.

Geologic range.-Pliocene through Holocene.

Occurrence in the Californias.-Pliocene: Gloria (Stump, 1979), Infierno (Stump, 1979), San Diego (Hertlein and Grant, 1972), and San Marcos (Durham, 1950) Formations: Pliocene and Pleistocene: Palos Verdes Sand (Woodring and others, 1946) and San Pedro Formation (Arnold, 1906).

Habitat.-4 to $420 \mathrm{~m}$; usually in sand, sandy mud, or mud; associated with coral or sponge. (Grau, 1959, p. 152)

\section{PATINOPECTEN subgroup}

Byssal notch deep, cardinal crura weak.

\section{Genus PATINOPECTEN Dall, 1898}

Large, round, gently convex valves, left valve nearly flat; radial ribs sulcate in some species.

Yabepecten (Masuda, 1963) has a shallower byssal notch in right valve and more numerous, rounded radial ribs.

Mizuhopecten (Masuda, 1963) was questionably placed in synonymy with Patinopecten by Hertlein (1969). Mizuhopecten (type: Pecten yessoensis Jay) has imbricated microsculpture on both valves (pl. 40, fig. 3); Patinopecten has this sculpture only on the left valve (pl. 41, fig. 5; pl. 43, fig. 2). I do not know at this time how meaningful microsculpture is in the pectinids, but the fact that its preservation is usually fortuitous makes it an unreliable character for differentiating fossil species.

Geographic range.-North and northeastern Pacific.

Geologic range.-Oligocene through Holocene (table 18).

Habitat.-Patinopecten caurinus (Gould), the only Patinopecten now living in the eastern Pacific, is found from Alaska to northern California at depths of 15 to $275 \mathrm{~m}$. It is taken in considerable numbers by flatfish trawlers at depths of 58 to $88 \mathrm{~m}$ in California. In British Columbia its maximum population density occurs at about $35 \mathrm{~m}$, on a mixed sand and mud bottom. In the natural habitat the species has been observed lying in small depressions that are presumed to be a result of current scour around the shell. It is byssally attached to a size of about 3 to $4 \mathrm{~cm}$ in shell diameter and has a ctenolium during its young stage.

Masuda (1962, p. 213) reported that the shells of Patinopecten yessoensis (Jay), of Japan, are rather large in size in calm seas, with the convexity of the right valve low and the left valve rather inflated, whereas those living in less calm water have thick shells with a more

TABLE 18.-Geologic and geographic distribution of the genus Patinopecten

$[\mathrm{H}=$ Holocene; $\mathrm{Ple}=$ Pleistocene; $\mathrm{Pl}=\mathrm{Pliocene} ; \mathrm{M}=\mathrm{Miocene} ; \mathrm{O}=$ Oligocene $]$

\begin{tabular}{|c|c|c|c|c|c|c|c|c|c|}
\hline \multirow{2}{*}{ Species } & \multirow[t]{2}{*}{ Alaska } & \multirow{2}{*}{$\begin{array}{l}\text { British } \\
\text { Columbia }\end{array}$} & \multirow[t]{2}{*}{ Washington } & \multirow[t]{2}{*}{ Oregon } & \multicolumn{3}{|c|}{ California } & \multicolumn{2}{|c|}{$\begin{array}{c}\text { Baja } \\
\text { California }\end{array}$} \\
\hline & & & & & Northern & Middle & Southern & Norte & Sur \\
\hline Genus Patinopecten: & - & - & - & - & - & M & - & - & - \\
\hline caurinus (Gould) .............. & $\mathrm{H}$ & $\mathrm{H}$ & $\mathrm{H}$ & $\mathrm{H}$ & $\mathrm{Pl}$ to $\mathrm{H}$ & $\mathrm{Pl}, \mathrm{Ple}$ & Ple & - & - \\
\hline haywardensis (Lutz) ….......................... & - & - & - & - & $\overline{D 1}$ & $M$ & - & $\bar{n}$ & $\bar{n}$ \\
\hline healeyi (Arnold) .................................... & - & - & - & - & PI & $\begin{array}{l}\text { M? to } \\
\text { Ple? }\end{array}$ & $\begin{array}{l}\text { M? to } \\
\text { Ple? }\end{array}$ & PI & $\mathrm{P} !$ \\
\hline $\begin{array}{l}\text { lohri (Hertlein) } \\
\text { propatulus (Conrad) }\end{array}$ & - & - & $\overline{\mathrm{M}}$ & $\overline{\mathrm{M}}$ & - & $\underset{\mathbf{M}}{\mathrm{M}, \mathrm{Pl}}$ & $\begin{array}{l}\text { M,Pl } \\
\text { O,M }\end{array}$ & - & - \\
\hline
\end{tabular}


convex right valve and a nearly flat left valve.

The predators of $P$. caurinus are Octopus and the large sun-star Pycnopodia; juveniles are attacked by crabs.

Golikov and Scarlato (1970) note that $P$. yessoensis in the Sea of Japan "inhabits mainly depths of 0.5 to $25 \mathrm{~m}$ on the sand and siltsand bottom (often with stone and shell admixtures). In summer time, when surface water layers warm to $15^{\circ}-20^{\circ} \mathrm{C}$, the scallops are found at depths of 0.5 to $12 \mathrm{~m}$ and are most abundant in a depth ranging from 1.5 to $4 \mathrm{~m}$; their young settle at the same depths on the fronds of seaweed. In autumn, before the first frosts, the molluses leave the shallow inshore waters and move to depths of 3 to $25 \mathrm{~m}$, being most abundant at 6 to $8 \mathrm{~m}$. By this time, their quantity considerably decreases, due mainly to elimination of the young. In winter, their activity is greatly reduced and they accumulate at 3.5 to $6.5 \mathrm{~m}$ depths. Their number decreases still more at the beginning of spring due to a general rise in the death-rate ***. When spring approaches and the surface layers of the water warm to $6^{\circ}-8^{\circ} \mathrm{C}$, the molluses become active and spread to depths from 0.5 to 8 or $9 \mathrm{~m}$, being found usually at depths of 3 to $7 \mathrm{~m}$. Because of the prespawning aggregations of mature individuals in the most favourable plots their population density somewhat increases at this time."

\section{Patinopecten propatulus (Conrad)}

Plate 34, figures 1, 4, 6; plate 35, figures 1,2

Pecten propatulus Conrad, 1849 , p. 726 , atlas pl. 18, figs. 13 , 13a. Meek, 1864, p. 26. Conrad, 1865, p. 154.

Pecten (Patinopecten) propatulus Conrad. Dall, 1898, p. 699. Arnold, 1906, p. 64-75, pl. 7, fig. 1 [not pl. 9, figs. 1, 1a, 2, 2a = Vertipecten fucanus (Dall)]. Dall, 1909, p. 112, pl. 16, fig. 1 [not pl. 15, figs. 1, 1a, 2, 2a = Vertipecten fucamus (Dall)]. Grant and Gale, 1931, p. 192-193, pl. 22, fig. 5. Weaver, 1942, p. 91, pl. 19, fig. 6, pl. 20 , fig. 2.

Vertipecten cf. V. propatulus (Conrad). Stewart, 1946, pl. 17, fig. 4. Patinopecten propatulus (Conrad). Moore, 1963, p. 64-65, pl. 16, figs. 1-4; pl. 17, figs. 2-5, 7.

Original description. - "Large, subequivalve, suborbicular, compressed; costae about 17 , rounded, narrow, interstices much wider than the ribs; ears unequal."

Lectotype.-USNM 3504 (Moore, 1963)

Type locality. - Astoria [Columbia County], Oreg. Astoria Formation, Miocene.

Supplementary description. - "Patinopecten propatulus is of moderate size and the valves are slightly and equally inflated. There are 16 to 22 flat-topped to slightly rounded or flattened finely striated ribs on the right valves and 15 to 18 evenly rounded or ridgelike ribs on the left valves. The right anterior ear has a moderately deep byssal sinus and the surface of the ear above the sinus is ribbed; the right posterior and left valve ears are finely ribbed. The right and left anterior ears are folded. Well-preserved left valves show the surface to be sculptured by an imbricated lamellar microsculpture

***: this sculpture may also be present on the left valve ears; it has not been found on right valves.

"The lectotype is an internal mold of both valves and only fragments of the innermost shell layer remain. The specimen was contained in a concretion and apparently only the right valve was exposed when Conrad described the species; the specimen was removed from the concretion at some later date, and both valves are now exposed. There are 16 flat-topped to slightly rounded ribs on the right valve and the interspaces are flat to slightly rounded and wider than the ribs. The left valve has probably more than 13 rounded ribs and the interspaces are slightly rounded and wider than the ribs.
The lectotype is approximately $10.3 \mathrm{~cm}$ high and $10.2 \mathrm{~cm}$ wide (broken along margins).

"The number and configuration of the ribs and interspaces on both valves of Patinopecten propatulus is variable. The right valve has 16 to 22 ribs; 19 ribs are most common. The interspaces may be narrow, less than a third the width of the rib, or more commonly as wide or somewhat wider than the rib. Both the ribs and the interspaces are usually flat, but they may be slightly rounded. The ribs are often square but may be moderately undercut, and show fine radial striations on well-preserved specimens. There is occasionally an interrib in some of the interspaces especially near the anterior and posterior margins of the shell. There may also be as many as five threadlike ribs on the anterior or posterior margin of the shell; these fine ribs were not included in the rib counts.

"The anterior ear on the right valve has a moderately deep byssal sinus covering more than a third of the total area of the ear and 3 to perhaps more than 5 imbricated ribs on the upper part of the ear The posterior right ear has 5 to 10 ribs usually about half as wide as those on the anterior ear. These ribs may be of equal width and may alternate with very fine threadlike ribs.

"The left valve has 15 to 18 ribs which are usually evenly rounded, but which may rise abruptly to a narrow ridge or may be flat-topped. Both types of ribs may be present on the same specimen. The interspaces may be flat, slightly rounded, or moderately round and may contain a fine interrib. The interribs when present are usually centered in the interspace but may be crowded close to the posterior side of the rib. Flangelike lamellae are present near the dorsal end of the first few posterior ribs on two left valves $* * *$.

"The left anterior ear has 5 to 8 or more ribs, similar in size to those on the posterior ear of the right valve, and it usually has fine threadlike interribs. On all but immature specimens, the posterior ear is depressed medially. The left posterior ear is sculptured by 6 to 8 ribs, similar in weight to those on the anterior ear but without the fine interribs that are often present on the anterior ear.

"An imbricated lammelar microsculpture may be present on the left valve of $P$. propatulus $* * *$. This microsculpture is on a thin now chalky shell layer that flakes off leaving no trace of the presence of the microsculpture and the remaining shell seems to be perfectly preserved." (Moore, 1963, p. 64-65)

Comparison. - "P. propatulus is allied to P. caurinus (Gould) of the Recent, which has been collected from sedimentary rocks as old as Pliocene $*^{* *}$ in age. Recent specimens of $P$. caurinus reach a much larger maximum size than $P$. propatulus. The ribs on the right valve of $P$. caurinus tend to disappear near the margins on large specimens, and the ribs on both ears of the right valve are poorly developed, being barely discernible on some specimens. The ribs on the left valves of $P$. caurinus are usually flat topped whereas on $P$. propatulus this is rare, although they may be rounded similar to those of $P$. propatulus. The ribs on the left valve also tend to disappear along the margins of large specimens of $P$. caurinus. The ribs on the ears of the left valve of $P$. caurinus tend to be finer than those on $P$. propatulus. Interribs are less frequently present on both the right and left valves of $P$. caurinus. The umbonal angle on $P$. propatulus is narrower than on $P$. caurinus, $P$. propatulus averaging about $100^{\circ}$ and $P$. caurinus averaging about $125^{\circ} . "$ (Moore, 1963 , p. 65)

Patinopecten healeyi has more ribs (mostly more than 20) than $P$. propatulus, and Patinopecten lohri has stronger intercalaries and deeper interspaces than P. propatulus. (Arnold, 1906, p. 65)

"Poorly preserved specimens of $P$. propatulus, or specimens of only the right valve, are difficult to separate from Vertipecten fuca. nus (Dall). The shell of $P$. propatulus is usually thinner; the ribs on the right valve are often flatter; and the byssal sinus somewhat more shallow. Ribs on the right valve of $V$. fucanus may be split, whereas 
they commonly are not on $P$. propatulus and may be more conspicuous, narrower, and more closely and irregularly spaced; and in some specimens unevenly split, with one part half the width of the other." (Moore, 1963, p. 65)

Comments. - Patinopecten haywardensis has a wider apical angle, wider byssal notch, and narrower ribs with wider interspaces than P. propatulus. Patinopecten calaverasensis has the ribs more closely spaced, not as evenly distributed by width, and has wider riblets than $P$. propatulus.

Geographic range.-Washington to southern California.

Geologic range.-Oligocene to Miocene.

Occurrence in California.-Oligocene and Miocene: Temblor Formation (Adegoke, 1969); Miocene: Briones Sandstone (Crittenden, 1951) and Monterey Formation (Hall, 1973).

\section{Patinopecten haywardensis (Lutz) \\ Plate 35, figure 4; plate 36, figure 1}

Pecten (Patinopecten) haywardensis Lutz, 1951, p. 386-387, p. 17, figs. 9, 10.

Original description.- "Shell of large size, suborbicular, compressed, equivalve; apical angle about 115 degrees for specimen 60 $\mathrm{mm}$. high, about 130 degrees if measurements taken tangential to dorsal slope of specimen $120 \mathrm{~mm}$. high; dorsal slope slightly concave; hinge margin less than half width of shell; right valve with 17 or 18 square, flat-topped, radiating ribs, some with slight medial sulcus; interribs as wide or slightly wider than ribs, square, with vertical side walls, some with medial interriblets; entire surface ornamented with numerous fine growth lines; anterior ear longer than posterior ear, nearly flat, ventral half slightly convex, dorsal half covered with from 5 to 6 well-defined radiating riblets crossed by numerous growth lines; byssal notch slightly less deep than in $P$. caurinus, deeper than in P. propatulus; posterior ear slightly and evenly concave, ornamented by 7 or 8 radiating riblets, posterior edge sloping at about 110 degrees from hinge margin; left valve with about 17 V-shaped ribs; anterior ear like $P$. caurinus, possibly with more concave ventral half of anterior edge; posterior ear slightly and evenly convex. (Left valve notations from internal cast.)"

Holotype.-UCMP 34133.

Type locality.-UC A-4566. Alameda County, Calif. Sobrante Sandstone, Miocene.

Comparison.- "This species may be distinguished from P. cauri$n u s$ by its much better developed riblets on the right posterior ear, a greater angle between the hinge margin and the posterior edge of the posterior ear, and also by its more squarely shaped ribs and interspaces which have vertical side walls, its slightly less deep byssal notch, a shorter hinge line in proportion to the width of the shell, and a greater number of ribs. (Grant and Gale, 1931, p. 195, have given the rib count of more than 25 Recent and Pliocene specimens of $P$. caurinus in the collections of Stanford University as between 16 and 20. Mr. E. J. Wilson and the author counted the ribs of the Recent specimens in the Stanford stratigraphic collection and found them to have not less than 20 and as many as 23.) $P$. haywardensis may be distinguished from $P$. propatulus by its larger apical angle, greater width of the hinge line in proportion to the width of the shell $(P$. propatulus has a hinge line proportionally much smaller than that of $P$. caurinus), a deeper byssal notch, and a greater number of riblets on the anterior ear. The ribs of $P$. propatulus are much higher than those of either $P$. caurinus or $P$. haywardensis, especially in the intermediate growth stage." (Lutz, 1951, p. 386-387)

Comments.-The holotype and paratype of $P$. haywardensis are molds from which the figured latex impressions were made. Patinopecten haywardensis may be distinguished by the narrow, high, square, widely spaced ribs on the right valve; none of the ribs are sulcated.

Geographic range.-Middle California.

Geologic range.-Miocene.

Occurrence in California.-Sobrante Sandstone.

\section{Patinopecten calaverasensis (Hall)}

Plate 35, figures 5, 6

Pecten (Patinopecten) haywardensis calaverasensis Hall, 1958, p. 51-52, pl. 2, fig. 2; pl. 3, fig. 4; pl. 4, fig. 3.

Original description. - "Shell of moderate to large size; right valve convex, with 20 or 21 flat-topped ribs; ribs approximately twice as wide as interribs; bifurcating ribs common; small riblets common; left valve slightly flatter than right valve; growth lines well developed on left valve; bifurcating ribs not as frequent as on left valve; byssal notch well-developed; anterior ear longer than posterior ear and slightly convex; riblets on anterior ear crossed by growth lines; posterior ear nearly flat, with no well-defined riblets and with welldefined growth lines."

Holotype.-CAS/SU 8442.

Type locality.-SU 3252. Contra Costa County, Calif. Oursan Sandstone, Miocene.

Comparison. - "This subspecies may be distinguished from Pecten haywardensis Lutz by its greater number of ribs. Lutz $(1951$, p. 386) gives the rib count of $P$. haywardensis as 17. P. haywardensis calaverasensis has 20 or 21 ribs. The related $P$. propatulus has 15 or 16 ribs." (Hall, 1958, p. 52)

Comments.-Patinopecten propatulus has 16-22 ribs on the right valve, 19 being most common. The right valve of $P$. calaverasensis has 20 or 21 ribs, and this feature does not distinguish it from $P$. propatulus. The right-valve ribs of $P$. calaverasensis are mostly lower, wider, and more closely spaced than on P. propatulus. In addition, the interribs are wider than on $P$. propatulus, and the right posterior auricle is longer and much higher than the right anterior auricle; on $P$. propatulus the auricles are equal in length, and the right posterior auricle only slightly higher than the right anterior auricle. The right-valve ribs of $P$. calaverasensis are unevenly distributed by width and in this character somewhat resemble a specimen from the Astoria Formation, Oregon, identified as Vertipecten? cf. V. fucanus (Moore, 1963, pl. 21, fig. 4).

On the underside of the holotype a portion of a left valve, presumably the same species, is preserved. The shell has narrow ribs that rapidly widen toward the ventral margin, interspaces as wide or wider each bearing a fine riblet, and preserved patches of imbricated microsculpture. The left valve was apparently almost flat.

Geographic range.-Middle California.

Geologic range.-Miocene.

Occurrence in California.-Sobrante Sandstone.

\section{Patinopecten lohri (Hertlein)}

Plate 34, figure 2; plate 36, figures 2, 3

Pecten (Patinopecten) oweni Arnold, 1906, p. 63-64, pl. 8, figs. 1, 1a, 1b. Not Pecten oveni De Gregorio, 1884.

Pecten (Patinopecten) lohri Hertlein, 1928, p. 93, new name. G D. Hanna and Hertlein, 1943, fig. 65-1.

Pecten (Patinopecten) healeyi Arnold variety lohri Hertlein. Grant and Gale, 1931, p. 197-198, pl. 6, figs. 1a, 1b.

Patinopecten lohri (Hertlein). Woodring, Stewart, and Richards, 1940 , pl. 32 , figs. $2-5$. Woodring, 1950 , p. 83-84, p. 7, figs. 7, 9. Adegoke, 1969, p. 103, pl. 2, figs. 6, 7. Addicott, 1974, pl. 2, fig. 4. 
Addicott and others, 1978, p. 82, text fig. Moore, 1979, p. 6-7, pl. 13 , figs. $3,4,6$

Original description. - "Shell averaging about 85 millimeters in altitude, slightly longer than high, inequivalve, equilateral, and with more or less serrate margins; base regularly rounded; sides somewhat concave above. Right valve much more convex than the left, with 15 of 16 subequal, strong, elevated, squarish ribs, which become more or less deeply medially sulcated after about 40 or 50 millimeters in length; interspaces about as wide as ribs, channeled and ornamented with more or less prominent rounded intercalary riblets; whole surface of disk sculptured by fine lines of growth hinge line considerably longer than length of disk; anterior ear slightly longer than posterior, obsoletely radially ribbed, and with sharp incremental sculpture; byssal notch quite prominent and equal in width to about one-third width of ear; posterior ear rectangularly truncated and with prominent incremental, but nearly obsolete, radial sculpture. Left valve less ventricose than right; ribs quite high, narrow, and rounded; interspaces much wider than ribs, with round bottoms, and each ornamented by a prominent rounded intercalary rib; surface sculptured by numerous sharp, regular, concentric lines; ears slightly truncated and sculptured as those of right valve. Hinge as in P. caurinus."

Holotype-UCMP 12081.

Type locality.-Foxin's Ranch [W1/2 sec. 28, T. 9 N., R. 32 W.], Santa Barbara County, Calif. Tinaquaic Sandstone Member, Sisquoc Formation (Woodring, 1950, p. 83-84), Pliocene.

Comparison.-Patinopecten lohri may be distinguished from $P$. healeyi by its smaller size, greater convexity, fewer and stronger ribs. more prominent intercalary riblets on the right valve, and relatively much longer hinge line." (Arnold, 1906, p. 63)

"The ribs on large left valves of $P$. lohr $i$ are wide and divided, whereas on $P$. healeyi they are narrow and not divided, or on some very large left valves are moderately wide and faintly divided by one or more shallow grooves. Right valves of $P$. lohri generally have a strong secondary rib in the space between the primary ribs, whereas on right valves of $P$. healeyi secondary ribs are absent or, if present generally are weak. Some right valves of $P$. lohri, however, lack secondary ribs or have weak secondaries. Left valves of both species have secondaries. Owing to the presence of divided ribs on both valves of $P$. lohri, right and left valves are difficult to distinguish unless the ears are preserved, whereas right and left valves of $P$. healeyi are readily differentiated." (Woodring, 1950, p. 83)

The right valve of the holotype of $P$. lohr $r$ is more inflated than is typical for $P$. healeyi; the primary ribs are higher, dichotomous at an earlier stage, fewer in number, and therefore more widely spaced. Each interspace bears a wide secondary rib that first appears when the shell has reached a height of about $30 \mathrm{~mm}$. The primary ribs are deeply dichotomous, the first division of a rib taking place when the shell is about $15 \mathrm{~mm}$ in height, the last at about $55 \mathrm{~mm}$. At the ventral margin of the holotye, which is about $90 \mathrm{~mm}$ in height, the primary ribs, except two at each of the margins of the shell, are dichotomous. and two near the posterior margin are completely divided. Both sides of the split ribs are more rounded than on $P$. healeyi. A narrow unsculptured band is present along the posterior margin of the shell. The right anterior auricle is poorly preserved but seems to be sculptured by subdued riblets and to have a byssal notch similar to $P$. healeyi. The posterior auricle bears a shallow groove bordered by low ridges; this feature is discernible on about two-thirds of the auricule but seems to disappear before reaching the posterior edge. The right anterior auricle is broken at the margin but was possibly not as high as the left anterior auricle. The right valve is noticeably inequilateral, and the anterior margin, excluding the auricle, forms an angle of about $40^{\circ}$ with the hinge; the posterior margin forms an angle of about $25^{\circ}$.
The left valve of the holotype of $P$. lohri bears fewer primary ribs than $P$. healeyi, and these ribs are therefore more widely spaced. The ribs are also higher, especially on the younger portion of the shell, than is common for $P$. healeyi. Each interspace has a strong secondary rib, and three of the interspaces closest to the posterior margin bear two secondary ribs. The shell is worn, but traces of concentric lamellar sculpture, similar to that seen on some $P$. healeyi are visible under magnification. A few of the primary ribs near the central portion of the shell have subdued shell protuberances that seem not to be primary structures but rather to be related to a time of breakage and subsequent repair of the shell. The left.valve is strongly inequilateral; the posterior shell margin, excluding the ear, forms an angle of $25^{\circ}$ with the hinge, the anterior margin, $40^{\circ}$. The ears are markedly inequilateral, the posterior being about $26 \mathrm{~mm}$ long and $13 \mathrm{~mm}$ high and the anterior about $30 \mathrm{~mm}$ long and $22 \mathrm{~mm}$ high. A similar inequilaterality is seen on large specimens of $P$. healeyi (Moore, 1979, pl. 8, figs. 1, 13, 4, 6).

Geographic range.-Middle to soùthern California.

Geologic range.-Miocene to Pliocene.

Occurrence in California.-Miocene: Pancho Rico (Durham and Addicott, 1964; Addicott and others, 1978) and San Pablo (Arnold, 1906) Formations; Miocene and Pliocene: Edna Member, Pismo (Hall, 1973), Etchegoin (Arnold, 1906; Woodring and others, 1940; Durham and Wolfe, 1958; Adegoke, 1969; Bertholf, 1962; Anderson and Land, 1969; Addicott, 1974) and Towsley (Kern, 1973) Formations; Pliocene: Pomponio Mudstone and San Gregorio Sandstone Members, Purisima Formation (Cummings and others, 1962) and Tinaquiac Sandstone Member, Sisquoc Formation (Woodring, 1950).

\section{Patinopecten healeyi (Arnold)}

Plate 34, figure 3; plate 35, figure 3; plate 36, figure 4; plate 37, figure 3; plate 38, figures 2-5 plate 39 , figure 1 ; plate 40 , figure 5; plate 41 , figure 2; plate 42 , figures 1-3

Pecten expansus Dall, 1878, p. 14. Not Pecten expansus Smith, 1847 , p. 413,419 , pl. 18 , fig. 21 .

Pecten (Patinopecten) expansus Dall, 1898, p. 706, p. 26, fig. 1 . Arnold, 1903, p. 108.

Pecten (Patinopecten) healeyi Arnold, 1906, p. 103, p. 36, figs. 1, 1a; pl. 37, figs. 1, 1a, 2. Arnold and Anderson, 1907, p. 154, pl. 26, figs. 1, 2. Grant and Gale, 1931, p. 196, pl. 6, figs. 2a, 2b. Hertlein and Grant, 1972, p. 183-185, pl. 31, figs. 1, 4, 6, 7; pl. 33, fig. 9; pl. 36, figs. 8, 9; text fig. 9. Susuki and Stadum, 1978, figs. 20, 21.

Patinopecten healeyi (Arnold). Woodring, 1950, p. 19, fig. 9; pl. 21, fig. 9. Vedder and Moore, 1976, p. 122, pl. 3, figs. 2-6, 9, Moore, 1979 , p. $2-7$, pls. $1-15$.

Pecten (Patinopecten) healeyi Arnold sanclementensis Susuki and Stadum, 1978, p. 10-11, figs. 18,10

Original description. - "Shell averaging 130 millimeters in altitude, length about equal to height, inequivalve (the right slightly more ventricose than the left), equilateral, and with smooth margins; base evenly rounded; sides only slightly concave above. Right valve somewhat ventricose, and ornamented by 18 to 21 strong. squarish, subequal primary ribs, which become more or less dichotomous, and sometimes trichotomous, after 30 or 40 millimeters in length; medial sulcus of rib more or less deep, in some cases being as deep as the interspaces near the ends, thus completely dividing the primary rib; interspaces subequal, much narrower than the ribs, quite deeply channeled, and often ornamented by a small, rounded intercalary riblet; whole surface crossed by numerous fine lines of growth; hinge line less than one-half length of disk; anterior ear only slightly longer than left, arcuate in front, and ornamented by several obsolete radial ridges and numerous sharp incremental lines; byssal 
notch quite prominent; posterior ear slightly obliquely truncated, and ornamented by sharp incremental lines and sometimes by obsolete radiating ridges. Left valve much compressed; ribs narrow and rounded, more or less sharply toward the top (there being in some cases a narrow, slightly raised line along the top); interspaces wide, and each ornamented by a more or less prominent, rounded, intercalary riblet; whole surface striated concentrically by fine, sharp, wavy lines; ears obliquely truncated and sculptured similarly to those of the right valve." (healeyi)

"Distinguishable by the much finer and greater number of closely and equally spaced ribs on the left valve; ribs narrow, flat, interspaces shallow and narrow on right valve; right valve gently but evenly convex; left valve slightly convex with anterior and posterior margins flat to somewhat concave; poorly developed ribbing on umbonal area of both valves." (sanclementensis)

Holotype.-USNM 148012; of P. sanclementensis, syntypes UCLA $38790,38791$.

Type locality.-San Diego, San Diego County, Calif. San Diego Formation, Pliocene; of $P$. sanclementensis, unnamed Pliocene strata, San Clemente Island, California.

Supplementary description.-Patinopecten healeyi is easily recognized by the flat-topped medially sulcated radial ribs on the right valve. Juvenile specimens are smooth in the early stage, but radial undulations of the anterior margin usually begin to form after the shell has attained a height of 3 to $5 \mathrm{~mm}$. Some specimens remain smooth up to a height of $23 \mathrm{~mm}$. The ribs on the right valve, especially those toward the anterior and posterior margins, begin to develop a slight medial sulcus after the shell has attained a height of $10 \mathrm{~mm}$, but such sulcations on the medial ribs are well developed only after a height of 30 to $40 \mathrm{~mm}$ has been attained. Occasionally the ribs on large specimens may bear two sulcations which thus divide the major ribs into three small riblets, but such forms, so far as known, have no taxonomic significance. (Hertlein and Grant, 1972, p. 185)

Although intercalaries may be present in the right-valve interspaces, they are not common, and a narrow unsculptured band may be present at the anterior and posterior margins of the right valve that is usually wider at the posterior side.

A smooth form of $P$. healeyi, described as Pecten (Patinopecten) healeyi Arnold sanclementensis Susuki and Stadum, tends to be relatively thin-shelled and has been found only in unnamed Pliocene strata on San Clemente Island, southern California (Vedder and Moore, 1967, p. 122, pl. 3, figs. 2-6, 8; Susuki and Stadum, 1978, p. $10-12$, figs. 18, 19). A fragment of a large right valve shows the disk to be smooth to about $30 \mathrm{~mm}$, at which point strong dichotomous ribs appear with very narrow interspaces. An incomplete right valve that is almost $100 \mathrm{~mm}$ high has the disk smooth in the midportion of the shell to about $40 \mathrm{~mm}$, with the rest of the shell sculptured by very low, closely spaced dichotomous and trichotomous ribs. A large, incomplete, worn right valve, that was originally more than $145 \mathrm{~mm}$ long, has a smooth disk to $55 \mathrm{~mm}$ and shows subdued dichotomous ribs near the posterior margin; the largest specimen obtained was about $160 \mathrm{~mm}$ high, with the hinge about $75 \mathrm{~mm}$ long. A,small complete right valve that is $50 \mathrm{~mm}$ high is essentially smooth, although traces of the same rib pattern seen on the other right valves from San Clemente Island are visible in low-angle reflected light. These smooth right valves also have a wide unsculptured band at both the anterior and posterior margins.

Three right valves from the San Diego Formation at Pacific Beach, Calif. (CAS 105, 547), have a smooth disk to $20 \mathrm{~mm}$ and the ribs somewhat subdued for an additional interval of about $10 \mathrm{~mm}$, and one right valve has closely spaced low ribs that are not dichotomous on the midportion of the shell.

Woodring (in Woodring and Bramlette, 1950, p. 84) noted that the interspaces on many right valves of $P$. healeyi from the Santa Maria district are much narrower than the interspaces on right valves of $P$. healeyi from the San Diego Formation and that the right valves are more inflated. A few specimens from collections now available from the San Diego Formation show this same sculpture and valve inflation, as do some from the Niguel Formation of Pliocene age in the San Juan Capistrano quadrangle (USGS M2096, M2098).

In one collection from the Fernando Formation (Pliocene), in the Newport Beach quadrangle, right valves with dichotomous and trichotomous ribs, right valves with narrow subdued ribs, and right valves with smooth disks to about $50 \mathrm{~mm}$ followed by low subdued ribs occur together. In another collection from the same area (USGS M5040) fragments show right valves of the smooth form, some with very closely spaced dichotomous ribs, and others with very closely spaced dichotomous and trichotomous ribs. On some specimens of right valves from this locality there is no unsculptured band at the posterior shell margin.

The right valve of $P$. healeyi may extend as much as $10 \mathrm{~mm}$ beyond the left valve along the entire distal margin of the disk. A similar discrepancy between valves has been noted on Patinopecten caurinus (Gould), the Holocene genotype of Patinopecten, which has also been collected from sedimentary rocks as old as Pliocene in age (Grau, 1959, p. 147; Moore, 1963, p. 63)

Although the typical left-valve sculpture has been described as primary ribs with interspaces always bearing a secondary rib, it is common to find specimens that have a few smooth interspaces without a secondary rib, and even specimens with no secondary ribs are occasionally found. The left valve may bear 17 to 21 primary ribs; 18 is the most common number. The umbonal angle, measured on the disk between ears, is between $110^{\circ}$ and $120^{\circ}$, with $115^{\circ}$ being the most common; a $120^{\circ}$ umbonal angle is found on inequilateral specimens with a very enlarged anterior ear.

The left-valve sculpture of specimens of $P$. healey $i$ from the San Diego Formation ranges from narrow rounded ribs with wide interspaces that each bear a fine intercalary riblet to left valves with wide square ribs that may bear a fine rib along the top and that may have some interspaces that do not bear an intercalary. The squareribbed forms usually begin with a sculpture of narrow rounded ribs that become flat when the shell reaches a height of about $60 \mathrm{~mm}$. On some square-ribbed forms the intercalaries are fine and rounded, but on others, although the intercalaries are rounded, they are much wider. On some left valves the ribs tend to become obsolete near the ventral margin, a feature also seen on P. caurinus (Moore, 1963, p. $65)$. Some left valves are noticeably thinner than others that bear the same primary rib pattern.

Four left valves were collected from unnamed Pliocene strata on San Clemente Island with right valves of the smooth form. Although no articulated specimens were found, it is assumed that these left valves represent the smooth form. They have unusually fine, narrow ribs, a bit more closely spaced than is common, with some of the intercalaries as strong as the primary ribs (Moore, 1979, p. 5, fig. 3; Susuki and Stadum, 1978, fig. 19). One of these left valves is about $160 \mathrm{~mm}$ high.

On some left valves the shell curves upward along the ventral margin away from the soft parts, probably in response to pressure from the larger right valve. This extension of the left valve is usually exceptionally thin, with obsolete ribs, rarely preserved, and may be more common than its preservation indicates.

If the right-valve primary ribs are strongly dichotomous, in essence producing another interspace, the usual left-valve response is to produce a strong secondary rib about equal in size to that of the space produced by the dichotomy. On these left valves the primary ribs will also be larger than average and square rather than rounded. If the right-valve disk is smooth followed by low primary ribs that are only shallowly dichotomous, the left valve will usually respond with small rounded primaries and with secondaries of 
almost equal size. On articulated specimens one can usually predict the sculpture of either valve by simply examining the opposing valve.

The left anterior auricle is larger than the right anterior auricle on large specimens. The byssal notch is convexly folded and elevated above the rest of the auricle, a feature also noted on P. caurinus, and the left anterior auricle is concavely folded toward the right anterior auricle opposite the byssal notch thus bringing the auricles closer together. The fold on the left anterior auricle usually becomes more pronounced as the shell grows larger so that on very large specimens the byssal opening is almost closed and presumably not functional for byssal attachment.

The left-valve anterior auricle of $P$. healeyi may be higher as well as longer than the posterior auricle. Marked enlargement of the left anterior auricle is usually characteristic of large specimens, but it is sometimes seen on juvenile shells. The enlargement is usually coincident with the increased flexure of the auricle and the resultant closing of the byssal gap.

The resilial pit on the right valve is bordered on each side by a narrow, sharp projecting ridge. The resilial pit on left valves may be bordered by a ridge that is followed by a groove and a second shorter ridge or may be bordered by only one ridge.

Small patches of an imbricated microsculpture, similar to that found on many different pectinids such as Vertipecten (Moore, 1963 , p. 63) and Chlamys (Verrill, 1897, p. 73), and on some, if not all species referred to Yabepecten by Masuda (1963, p. 22, fig. 4), are preserved on some left valves of $P$. healeyi, and one juvenile specimen shows the entire surface to be so sculptured (pl. 40, fig. 5). Both the right ( pl. 40, fig. 3) and the left valves of Patinopecten yessoensis bear this microsculpture.

One well-preserved juvenile left valve of $P$. healeyi was found that had the imbricated microsculpture well preserved and was also small enough to be mounted without destruction for the scanning electron microscope. The specimen was scanned from the dorsal to the ventral margin in the center of the disk between the same two ribs, and the progressive development of the microsculpture can be seen (Moore, 1979, p. 11, figs. 1-3; pl. 12, figs. 1-3).

Comparison. - "The ribs on large left valves of $P$. lohri are wide and divided, whereas on $P$. healey $i$ they are narrow and not divided, or on some very large left valves are moderately wide and faintly divided by one or more shallow grooves. Right valves of $P$. lohri generally have a strong secondary rib in the space between the primary ribs, whereas on right valves of $P$. healeyi secondary ribs are absent or, if present generally are weak. Some right valves of $P$. lohri, however, lack secondary ribs or have weak secondaries. Left valves of both species have secondaries. Owing to the presence of divided ribs on both valves of $P$. loh $v i$, right and left valves are difficult to distinguish unless the ears are preserved, whereas right and left valves of P.healeyi are readily differentiated." (Woodring, 1950, p. 83)

The right valve of the holotype of $P$. lohri is more inflated than is usual for $P$. healeyi; the primary ribs are higher, dichotomous at an earlier stage, fewer in number (14), and therefore more widely spaced.

The left valve of the holotype of $P$. lohri bears fewer (12) primary ribs than $P$. healeyi, and these ribs are therefore more widely spaced. The ribs are also higher, especially on the younger portion of the shell, than is common for $P$. healeyi.

Yabepecten tokunagai (Yokoyama) differs from P. healeyi in rightvalve sculpture, having low, rounded, closely spaced ribs. In addition, an imbricated microsculpture is present on the right valve (Masuda, 1963, pl. 12, fig. 4), and this sculpture has been found only on left valves of $P$. healeyi.

The marked consistent dichotomy of the right-valve ribs separates $P$. healeyi from other Patinopecten, with the exception of P. lohri, which has already been discussed. Although several species such as Patinopecten oregonensis (Howe), Patinopecten coosensis (Dall), and Patinopecten oregonensis cancellosus Moore may have a few dichotomous ribs at the anterior and posterior margins of the right valve, none bear low, flat dichotomous ribs over the entire shell surface. (Moore, 1979, p. 7)

"Yabepecten condoni (Hertlein) (Hertlein, 1925, p. 41, pl. 4, figs. 8, 9; Masuda and Addicott, 1970, p. 153-156, figs. 1, 3-9) has a large smooth area on the umbonal disk and therefore somew hat resembles the smooth form of $P$. healey $i^{* *}$. Y. condoni differs by having a deeper byssal notch than the smooth form of $P$. healeyi and radial ribs that are less distinct and rarely divided." (Vedder and Moore, 1976, p. 122)

"Pecten healeyi is quite distinct from P. propatulus and differs in the more numerous and more deeply sulcated ribs on the right valve, finer ribs on the left valve and smaller byssal fasciole beneath the right anterior ear." (Hertlein and Grant, 1972, p. 185)

Geographic range.-Northern California to Baja California Sur. Geologic range.-Miocene(?) to Pleistocene(?).

Occurrence in the Californias.-Miocene and Pliocene: Capistrano (Kern and Wicander, 1974), Etchegoin (Nomland, 1917a; Barbat and Galloway, 1935), and Purisima (Arnold, 1906) Formations, and Tahana Member, Purisima Formation (Cummings and others, 1962; Kern, 1973; Durham and Morgan, 1978); Pliocene: Almejas Formation (Minch and others, 1976), Falor Formation (Moore, 1979), Foxen Mudstone (Woodring, 1950), Cebada and Graciosa Members, Careaga Sandstone (Woodring, 1950), Niguel (Vedder, 1960), San Diego (Arnold, 1906; Hertlein and Grant, 1972) and San Joaquin (Stanton and Dodd, 1976) Formations, and unnamed Pliocene strata, San Clemente Island (Vedder and Moore, 1976; Susuki and Stadum, 1978); Pliocene and Pleistocene: Fernando (Arnold, 1907a; Moody, 1916; Soper and Grant, 1932; Vedder, 1972), Merced (Moore, 1979), Pico (Winterer and Durham, 1962), and Saugus (W. O. Addicott, written commun., 1978) Formations: Pleistocene(?): basal Las Posas Formation (Hall and Redin, 1967).

Habitat. - "This species lived in warm water unlike its northern relative Pecten caurinus Gould ***" (Hertlein and Grant, 1972, p. $185)$.

\section{Patinopecten caurinus (Gould)}

Plate 38, figure 1; plate 39, figure 5

Pecten caurinus Gould, 1850, p. 345.

Pecten (Patinopecten) caurinus Gould. Arnold, 1906, p. 101-103, pl. 38, figs. 1, 1a, 1b; pl. 39, figs. 1, 2. Grant and Gale, 1931, p. 195-196, pl. 6, fig. 4. Grau, 1959, p. 145-148, pl. 54 (see for synonymy).

Patinopecten caurinus (Gould). Woodring, 1946, p. 81, pl. 32, fig. 17; pl. 33, fig. 1. Addicott, 1974, pl. 1, fig. 6 .

Patinopecten (Patinopecten) caurinus (Gould). Roth, 1979, p. 248252 , pl. 2, figs. 1, 2, 8; pl. 3, figs. $5,9$.

Pecten heermannii Conrad, 1855 b, p. 267.

Pecten meekii Conrad, 1857a, p. 313.

Original description. - "T. trigono-orbicularis, haud crassa, inequivalvis, sub-equilateralis; valva superior convexiuscula, rubra, striis concentricis tenuibus insculpta, costis humilibus rotundatis vel interdum subduplicatis ad 20 ornatis; valva inferior convexa, alba, versus marginem rubricans, radiis ad 22 elevatis, quadratis, longitrorsum striatis; natibus rosaceis compressis; auribus transversis, sub-equalibus, radiatim striatis: intus lactea, rosaceo fimbriata. Long. $2 \frac{3}{4}$; lat $2 \frac{1}{4}$; alt. 1 poll [ $68.8 \mathrm{~mm}, 56.3 \mathrm{~mm}, 25 \mathrm{~mm}$ ]."

Holotype.-USNM 5954; of heermannii ANSP 14446; of meekii USNM 13333. 
Type locality.-Puget Sound, Wash. Holocene; of heermannii, unknown; of meekii, San Rafael Hills [T. 8 N., R. 29 W., Santa Barbara County]; of merriami, San Felician Creek, near Piru [Santa Susana quadrangle], Ventura County, Pico Formation, Pliocene and Pleistocene.

Supplementary description.-"Shell averaging about 150 millimeters in altitude, slightly longer than high, valves much compressed (the right generally slightly more convex than the left), equilateral, and with smooth margins; sides straight or only slightly concave above. Right valve with 20 to 25 strong, flat-topped squarish ribs, which, in some well-preserved specimens, show faint obsolete radial striae; interspaces flat-bottomed and about equal in width to the ribs; whole surface of disk sculptured by fine incremental lines; hinge line less than one-half length of disk; anterior ear only very slightly longer than posterior, ornamented with fine, sharp, incremental lines, but generally having no radial sculpture whatever; byssal notch prominent; posterior ear rectangular behind, and with sculpture similar to anterior. Left valve slightly less ventricose than right, with narrow rounded ribs and wide concave-bottomed interspaces; surface ornamented by fine, regular, raised, wavy, concentric lines, and sometimes more or less tesselated; ears obliquely truncated and sculptured with sharp incremental lines and sometimes by obsolete radiating ridges." (Arnold, 1906, p. 102)

"Specimens of this species show considerable variation in the ratio of the width of the ribs to the width of the interspaces; this seems to be especially true in the Scotia area, although this may be a result of the large number of specimens collected. The writer feels that these differences reflect the normal variation within the species.". (Faustman, 1964, p. 116)

"Shell large, average adult specimens measuring $150 \mathrm{~mm}$ in altitude, slightly oblique, inequivalve and compressed; auricles nearly equal. Right valve larger than left and having 18 to 22 squarish flat-topped ribs which occasionally show faint radial striae and/or longitudinal ridges; interspaces flattish and becoming wider toward ventral margin; fine concentric growth lines covering disk. Posterior auricle flat, with perpendicular margin and strong incremental lines; anterior auricle rather narrow, with faint (often obsolescent) radial ridges, sharp incremental lines and a prominent convex fold next to the disk; byssal notch moderately deep and no ctenolium. Left valve smaller than right and slightly less convex; 18 to 22 low and gently-rounded ribs; fine concentric lamellae covering disk. Posterior auricle having strong incremental lines and sometimes faintly ridged; anterior auricle having an oblique margin, a prominent concave fold and strong incremental lines.

"The holotype was a young shell. In 1918 W. J. Eyerdam dredged a specimen outside of Wrangell Narrows, Alaska, having some of the ventral margin broken off but still measuring $288 \mathrm{~mm}$ in length and $198 \mathrm{~mm}$ in height, the largest so far recorded." (Grau, 1959, p. 147)

Comparison.-“The Japanese subspecies Pecten caurinus yessoensis (Jay) differs from P. caurinus in the following respects: right valve considerably more convex, auricles higher and longer, byssal notch much less pronounced ***" (Grau, 1959, p. 147)

The marked consistent dichotomy of the right-valve ribs separates P. healeyi from P. caurinus. (Moore, 1979, p. 7)

Geographic range.-Living: Off Sand Point, Shumagin Islands, Alaska, to Point Sur, Calif.; fossil: northern to southern California. Geologic range.-Miocene through Holocene.

Occurrence in California.-Miocene and Pliocene: Purisima Formation (Arnold, 1906); Pliocene: Lomita Marl Member, San Pedro Formation (Woodring, 1946), and Ohlson Ranch Formation (Peck, 1960); Pliocene and Pleistocene: Fernando (Arnold, 1906; Moody, 1916; Soper and Grant, 1932; Vedder, 1972), Merced (Arnold, 1906), and Pico (Grant and Gale, 1931) Formations, Rio Dell Formation, Wildcat Group (Faustman, 1964), San Pedro Sand (Woodring, 1946), Santa Barbara Formation (Waterfall, 1929);
Pleistocene: Anchor Silt Member, San Pedro Formation (Rodda, 1957) and Timms Point Silt Member, San Pedro Formation (A. Clark, 1931; Woodring, 1946).

Habitat.-Patinopecten caurinus lives at depths of 15 to $275 \mathrm{~m}$ and in British Columbia its maximum population density occurs at about $35 \mathrm{~m}$ on a mixed sand and mud bottom ( $\mathrm{F}$. R. Bernard, written commun., 1976). In more southern waters the greatest density is between 55 and $85 \mathrm{~m}$ (Fitch, 1953, p. 44). In the natural habitat the species has been observed lying in small depressions that are presumed to be a result of current scour around the shell. P. caurinus is byssally attached to a size of about 3 to $4 \mathrm{~cm}$ in shell diameter (F. R. Bernard, written commun., 1976) and has a ctenolium during its younger stage. The predators of $P$. caurinus are Octopus and the large sun star Pycnopodia; juveniles are attacked by crabs (F. R. Bernard, written commun., 1976). (Moore, 1979, p. 10-11)

\section{Genus LEOPECTEN Masuda, 1971a}

Genotype-Pecten (Patinopecten) bakeri Hanna and Hertlein, 1927. Pliocene, Baja California Sur.

Original description.-."Shell large, gently inflated, of medium thickness, longer than high, equilateral, subequivalve, right valve a little more inflated than left valve which is nearly flat in younger stage but tends to become inflated with growth; right valve with distinct, perpendicular sided, flatly round-topped radial ribs which are sculptured with sometimes faint, fine radial threads, fine intercalary threads and fine, rugose incremental lines; left valve with distinct but low, narrow radial ribs usually sculptured with a few faint, fine radial threads, a few fine intercalary threads, and raised, regularly spaced, rugose, fine incremental lines; auricles large; right anterior auricle angulated at end, with very wide and shallow byssal notch; hinge with very simple, low, fine cardinal crura with fine provinculum and wide and shallow resilial pit; auricular crura well developed, terminating distally in a distinct oblong denticle at each extremity; interior surface with distinct paired internal ribs at lower part."

Supplementary description.-Leopecten "resembles Patinopecten externally but Patinopecten lacks paired internal ribs and has a well developed byssal notch below the right anterior auricle. Amussiopecten $* * *$ is distinguishable from Leopecten by its radial ribs which tend to become obsolete towards the ventral and lateral margins, lack of radial threads on the surface of the radial ribs and no intercalary threads in the interspaces between the radial ribs. $* * *$ Flabellipecten $* * *$ is distinguishable from the present one [Leopecten] by its rather more inflated right valve, plano-convex left valve, rather small auricles and more distinct and complicated cardinal crura." (Masuda, 1971a, p. 171)

Geographic range.-Baja California Sur.

Geologic range.-Pliocene (table 19).

Habitat.-Considered from the stand point of the associated fauna, Leopecten may have been a tropical or subtropical genus (Masuda, 1971a, p. 171).

TABLE 19.-Geologic and geographic distribution of the genus Leopecten

$[\mathrm{PI}=$ Pliocene $]$

\begin{tabular}{|c|c|c|}
\hline \multirow[t]{2}{*}{ Species } & \multicolumn{2}{|c|}{ Baja Celifornia } \\
\hline & Norte & Sur \\
\hline 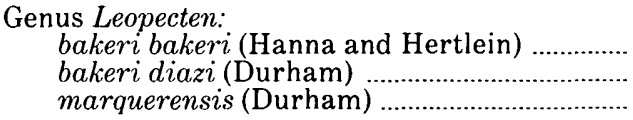 & $\begin{array}{l}\ldots . . . \\
\cdots \cdots \\
\cdots \cdots . . \\
\cdots \cdots . .\end{array}$ & $\begin{array}{l}\mathrm{Pl} \\
\mathrm{Pl} \\
\mathrm{Pl}\end{array}$ \\
\hline
\end{tabular}




\section{Leopecten bakeri bakeri (Hanna and Hertlein)}

\section{Plate 40, figure 4}

Pecten (Patinopecten) bakeri Hanna and Hertlein, 1927, p. 153, pl. 5, fig. 1.

Pecten (Janira) stearnsii var. bakeri Hanna and Hertlein. Grant and Gale, 1931, p. 224-225, in part; not pl. 4, figs. 1a, 1 b.

Patinopecten bakeri (Hanna and Hertlein). Durham, 1950, p. 66, pl. 12, fig. 1; pl. 13, fig. 7 .

Leopecten bakeri (Hanna and Hertlein). Masuda, 1971a, p. 171-172, pl. 20, figs. 1, 2. Addicott, 1974, pl. 2, fig. 1.

Original description. - "Left valve, large, subcircular, moderately convex, moderately thick; about 23 to 25 radiating square sided ribs separated by interspaces a little wider than the ribs, each rib ornamented with three small riblets, one on each shoulder and a middle riblet which is a little higher than the two other riblets; interspaces ornamented by three small riblets, the middle one usually slightly more prominent than the other two; ribs and interspaces both covered by fine, fairly sharp concentric lines of growth; ears subequal, set off from beak by sharp squarish shoulders, ornamented by about eight or nine radiating riblets which are crossed by concentric incremental lines. Length approximately $150 \mathrm{~mm}$.; height approximately $132 \mathrm{~mm}$.; apical angle approximately $123^{\circ}$."

Holotype.-CAS 1865.

Type locality.-CAS 794. Baja California Sur. San Marcos Formation (Masuda, 1971a), Pliocene.

Supplementary description. - "Shell large, longer than high, equilateral, nearly equivalve but right valve a little more convex than left; surface with distinct radial ribs and raised, regularly spaced, distinct incremental lines; right valve with about 23 rather low, flat-topped, square sided radial ribs which are broader than their interspaces and with a few faint, fine radial threads on their surface near ventral margin; radial threads on surface of radial ribs appear at about middle part of shell and tend to become somewhat distinct towards ventral margin; interspaces between radial ribs with an intercalary thread, appearing at about middle part of disc and tending to become distinct towards ventral margin, also with secondary intercalary threads near ventral margin; auricles rather large, with a very shallow byssal notch below anterior one, provided with rather distinct concentric lines and rarely with a few faint, fine radial threads; interior surface provided with paired internal ribs that are distinct near ventral margin; hinge with very low, simple, fine cardinal crura, wide and shallow resilial pit with very fine, flat, internal ridges which diverge downward, and auricular crura which terminate distally in a distinct, oblong denticle at each extremity." (Masuda, 1971a, p. 172)

Comparison.- "This species may easily be distinguished from Pecten healeyi Arnold by the less prominent ribs and by the greater apical angle. It is obviously of the same stocks as $P$. caurinus Gould, rather than the P. stearnsii Dall stock to which Grant and Gale assigned it. Their figured specimen appears to be $P$. bakieri subsp. diazi n. subsp. P. baker i may be separated from the subspecies diazi by having the interspaces and ribs of the right valve of approximately the same width." (Durham, 1950, p. 66)

Geographic range.-Baja California Sur.

Geologic range.-Pliocene.

Occurrence in Baja California.-Gloria (Stump, 1979), Infierno (Stump, 1979), and San Marcos (Masuda, 197la) Formations.

\section{Leopecten bakeri diazi (Durham)}

Plate 39, figure 2; plate 40, figure 2

Patinopecten bakeri diazi Durham, 1950, p. 66, pl. 12, fig. 2; pl. 13 , fig. 4.
Leopecten bakeridiazi(Durham). Masuda, 1971a, p. 172-173, pl. 20. figs. $3,4$.

Pecten (Janira) stearnsii Dall var. bakeri Hanna and Hertlein. Grant and Gale, 1931, in part, pl. 4, figs. 1a, 1b.

Original description. - "At a number of localities Patinopectens of the $P$. bakeri stock may be separated from the typical form by the partial or complete obsolescence of the anterior and posterior areas of fine ribbing and by the squarer sides of the major ribs of the left valve. On the same valve, the secondary riblets on the primary ribs are commonly entirely absent or very feeble, and the tertiary intercalaries in the interspaces are missing. In the central areas of the right valve the primary ribs are $1 \frac{1}{4}-1 \frac{1}{2}$ times as wide as the interspaces, whereas in the typical form they are approximately of equal width."

Holotype.-UCMP 15968.

Type locality.-UC A3566. Baja California Sur. Carmen Formation, Pliocene.

Supplementary description. - "This subspecies is characterized by its large, compressed, subequivalved shell which is longer than high, right valve with squarish, distinct radial ribs with very faint, fine threads on surface of radial ribs near ventral and lateral margins, an intercalary thread between radial ribs in adult specimens, and raised, rugose, regularly spaced incremental lines; somewhat angulated auricles with a wide, shallow byssal notch below anterior auricle. It is sculptured with fine concentric lines and several faint, fine radial threads; the left valve having somewhat square sided radial ribs in younger stage, with three fine radial threads, and an intercalary thread in interspaces between radial ribs, crossed by raised, rugose, regularly spaced, fine incremental lines; simple cardinal crura; shallow resilial pit; and paired internal ribs and distinct auricular crura which terminate distally in an oblong denticle at each extremity." (Masuda, 1971a, p. 172-173)

Comparison.-"Leopecten bakeri (Hanna and Hertlein) differs from the present subspecies in having the right valve with many fine radial threads at lateral margins and the left valve with perpendicular sided major radial ribs, distinct radial threads on surface of radial ribs and tertiary intercalary threads in interspaces between radial ribs." (Masuda, 1971a, p. 172-173)

Geographic range.-Baja California Sur.

Geologic range.-Pliocene.

Occurrence in Baja California.-Carmen Formation.

\section{Leopecten marquerensis (Durham)}

Plate 39, figure 3; plate 40, figure 1

Patinopecten marquerensis Durham, 1950, p. 67, pl. 14, figs. 1, 2. Leopecten marquerensis (Durham, 1950). Masuda, 1971a, p. 173-174, pl. 21, figs. $1,2$.

Original description. - "Shell large; in general outline, ornamentation, and size very similar to $P$. bakeri. Right valve with about 20 prominent primary ribs, $1 \frac{1}{2}$ times as wide as the interspaces. Anterior and posterior to these are several finer ribs. Interspaces without intercalaries. Left valve with an equivalent number of low inverted $V$-shaped primary ribs, with three secondary riblets, one on each side and one at apex of $V$. Interspaces with a single intercalary riblet. On an unworn specimen the posterior margin has an area of fine ribbing similar to that on typical P. bakeri."

Holotype-UCMP 15475.

Type locality.-UC A3518. Baja California Sur. Marquer Formation, Pliocene.

Supplementary description. - "This species is characterized by its subequivalved shell, in which the right valve is a little more inflated than the left valve; with a very wide and shallow byssal notch below the right anterior auricle; several fine radial threads on the auricles 
TABLE 20.-Geologic and geographic distribution of the genus Lituyapecten

[Ple = Pleistocene: $\mathrm{Pl}=$ Pliocene; $\mathrm{M}=$ Miocene $]$

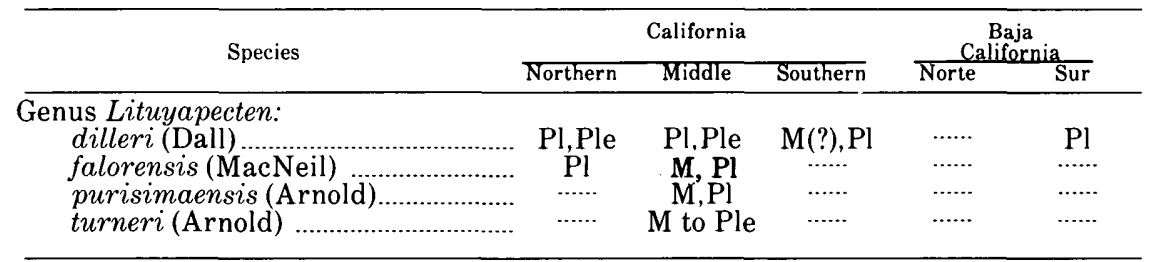

of the left valve but those of the right valve with only concentric lines; radial ribs on right valve without radial threads on their surface." (Masuda, 1971a, p. 173)

Comparison. - "The inverted V-shaped ribs with three secondaries on the left valve together with the absence of any intercalaries on the right valve, and the central primary ribs of the right valve being half again as wide as the interspaces separates this species from $P$. bakeri and its subspecies diazi." (Durham, 1950, p. 67)

"This species differs from the other species of Leopecten in having no radial threads on the surface of the radial ribs and in the interspaces between the radial ribs of the right valve." (Masuda, 1971a, p. 173)

Geographic range.-Baja California Sur.

Geologic range.-Pliocene.

Occurrence in Baja California.-Marquer Formation.

\section{Genus LITUYAPECTEN MacNeil, 1961}

Differs from Patinopecten in having one to several rows of frill-like flanges on the rounded to flat-topped ribs of the left valve. Geographic range.-Alaska to Baja California Sur. Geologic range.-Oligocene to Pliocene (table 20).

\section{Lituyapecten falorensis (MacNeil)}

Plate 41, figures 1, 5

Pecten oregonensis Howe var. Manning and Ogle, 1950, p. 23-24, pls. 6, 7 .

Patinopecten (Lituyapecten) falorensis MacNeil, 1961, p. 234-235 pl. 38 , figs. 1,3 ; pl. 44 , figs. 2,4 ; pl. 45 , figs. 2 , 4 ; pl. 46 , figs. $1-4$. Original description.- "Shell moderately large; suborbicular to weakly extended posteriorly; valves moderately inflated; right valve slightly more inflated than left valve; shell moderately thin. Posterior dorsal margin moderately concave, and anterior margin nearly straight; left valve with low but sharp steplike submarginal slopes, and right valve slopes less sharp because of inflation of ears. Dorsal margin of ears straight. Ears sculptured by radial riblets with moderately strong beads, about seven riblets on posterior ear of left valve; posterior ears longer and with stronger radial riblets than anterior ears; no denticles along byssal sinus; dorsal margin of left ear of left valve with a weak swelling or fold. Ribs 21 to 23 . Right valve of ten having a split rib, one segment having no counterpart on left valve; right valve ribs broad with undercut sides, interspaces narrow and deep; bottoms flattened; central ribs flattened or rounded on top; terminal ribs with a median sulcus which at the margin may be nearly as deep and wide as the primary interspaces. Left valve ribs moderately broad with a row of short flanges or denticles along each side; central area depressed and troughlike; three terminal ribs on each side narrow and with a single row of short flanges on their crest; interspaces round-bottomed and narrower than the ribs on some specimens, wider on others, no interstitial riblets on any specimens observed. Juvenile microsculpture unknown."

Holotype.-UCMP 34172.

Type locality.-UC A4233. Humboldt County, Calif. Falor Formation, Pliocene.

Comparison.- "The specimen figured by Manning and Ogle refigured here and made the holotype of the species, is the only specimen of a yakatagensis-like Lituyapecten figured previously other than the type of yakatagensis itself. Its relationship to yakatagensis was not recognized and instead, it was identified tentatively as a variety of $P$. oregonensis Howe, a species described from the Empire formation of western Oregon. $* * *$ it is very difficult to identify right valves, even on specimens whose left valves are very dissimilar.

"There are two specimens in the Manning and Ogle collection besides the holotype. They are smaller than the type, but they appear to have narrower ribs than the corresponding stage on the type. In this respect they approach some of the typical specimens of $P$. purisimaensis. The left valves of these two specimens have narrow but definitely flat-topped ribs with denticulate margins ***. Typical $P$. (L.) purisimaensis on the other hand, has narrow rounded ribs over most of its disk with two or three of the central ribs slightly wider and having a weak concavity along the crest. $* * *$ The Purisima formation also contains a form that has wide ribs on the right valve and broad, flat-topped ribs with marginal denticles on the left valve ***, and that compares favorably with the type of falorensis.

"Although it is difficult to say how many species are involved here and, if they are distinct, just what the varietal range of each species is, it is fairly certain that purisimaensis and falorensis are very closely related. $P$. (L.) yakatagensis is a highly variable species if all the specimens here referred to it are really conspecific. The same range of variation has not been noted in lituyaensis, but possibly all variants of that species have not been found. If approximately the same range of variation could be demonstrated for lituyaensis, a strong case for considering falorensis as a variety or, at most, a subspecies of purisimaensis could be made. To state the problem another way, it is not known whether purisimaensis and falorensis represent divergent stocks of common but not too distant ancestry or whether the three species, yakatagensis, lituyaensis, and purisimaensis (including falorensis) are linear elements of one very variable stock, no parts of it having been clearly set off by geographical isolation. If the latter were so, all the variants existing at any particular instant of time belonged to one species, whereas the mean of variation shifted sufficiently through time to make at least three distinct species recognizable." (MacNeil, 1961, p. 234)

Geographic range.-Northern to middle California.

Geologic range.-Miocene to Pliocene.

Occurrence in California.-Miocene and Pliocene: Purisima 
Formation (MacNeil, 1961), and Tahana Member, Purisima Formation (Durham and Morgan, 1978); Pliocene: Falor Formation (MacNeil, 1961).

\section{Lituyapecten purisimaensis (Arnold)}

\section{Plate 41, figures 3, 4}

Pecten. (Patinopecten) purisimaensis Arnold, 1906, p. 105, pl. 34, fig. 3; pl. 35, figs. 1, 1a. Grant and Gale, 1931, p. 194, pl. 6, fig. 3. MacNeil, 1961, p. 233, pl. 44, figs. 1,3 .

Patinopecten (Lituyapecten) purisimaensis (Arnold). Peck, 1960, pl. 21 , fig. 14.

Original description.- - Shell averaging about 125 millimeters in altitude, length same as height, valves both equally well compressed, equilateral, and with the margins smooth; base regularly rounded; sides relatively short, straight, sloping at a moderate angle. Right valve with about 24 prominent, T-rail-shaped ribs, flattened and sometimes faintly dichotomous above, overhanging deep, channeled, flat-bottomed interspaces, which are about equal in width to the ribs; whole surface of disk with incremental sculpture, which develops into prominent scales on the sides of the ribs; hinge line equal to about two-fifths length of disk; anterior ear only slightly longer than posterior, sculptured by about three prominent radiating ridges and numerous imbricating incremental lines; byssal notch prominent, but not deep, being equal in width to one-half width of ear; posterior ear obliquely truncated, and ornamented by about three prominent radiating ribs and imbricating incremental lines. Left valve with narrow, rather sharp, concave-sided ribs and wide concavebottomed interspaces; surface with fine incremental sculpture; ears obliquely truncated and sculptured similar to those of right, except that the radiating ridges are finer and more numerous."

Holotype.-CAS/SU 3.

Type locality. - North of mouth of Pescadero Creek [Santa Cruz quadrangle, San Mateo County], Calif. Purisima Formation, Pliocene.

Supplementary description. - "The typical form of the species has rather narrow ribs on its right valve, and most of the ribs have short marginal denticles or flares recalling those on the terminal ribs of $P$. (L.) lituyaensis. *** The left valve has narrow ribs with wide, round-bottomed interspaces. Two or three of the central ribs are slightly wider with a weak concavity along the crest, but most of the ribs are narrowly rounded on top and bear a single row of denticles or narrow flanges along their crest. They are broken or worn on most specimens observed, and even on the fairly well preserved specimen figured here, only their base is preserved." (MacNeil, 1961, p. 233)

Comparison. - "Patinopecten turneri A rnold from the Pliocene of the Tomales Bay region, California, was regarded by Grant and Gale *** as a synonym of purisimaensis. If Grant and Gale were influenced by an error in Arnold's statements about his figured specimens they did not say so. Arnold figured three specimens, two of them as right valves and one as a left valve; however, all three of Arnold's specimens are left valves. This gave him an erroneous concept of his supposed new species and made it appear to be very different from purisimaensis. Actually purisimaensis and turneri are closely related, but some good specimens of turneri $* * *$ show a well-defined sulcus on the right valve ribs that is not found in purisimaensis. These species should probably be kept separate.

"Patinopecten (L.) purisimaensis is related to $P$. (L.) dilleri (Dall), ** *. $P$. (L.) dilleri usually has coarse flanges on both valves, those of the right valve being either single and crossing the ribs $* * *$, or divided and along the margins of the ribs $* * *$. The left valve has strong single flanges ***. It is doubtful if dilleri should be regarded as a variety of coosensis as was done by Grant and Gale ***. In view of the Alaskan forms now known, it seems more likely that dilleri and coosensis stem from different early Miocene forms; dilleri from poulcreekensis, and coosensis from an early variant of yakatagensis.

"In spite of its apparent close relation to dilleri, purisimaensis appears to be more closely related to falorensis ***. In fact, it is difficult to say from the known specimens whether two species are represented in the Purisima formation, purisimaensis and falorensis, or whether all the specimens in question should be regarded as belonging to one greatly variable species. For the time being they are treated as two species although it may later be found preferable to treat falorensis as a subspecies of purisimaensis. (MacNeil, 1961 , .p. 233)

Geographic range.-Middle California

Geologic range.-Miocene to Pliocene.

Occurrence in California.-Miocene and Pliocene: Purisima (Arnold, 1906), and Tahana Member, Purisima (Cummings and others, 1962; Durham and Morgan, 1978) Formation; Pliocene: Ohlson Ranch Formation (Peck, 1960).

\section{Lituyapecten turneri (Arnold)}

\section{Plate 37, figures 1, 2}

Pecten (Patinopecten) turneri Arnold, 1906, p. 106, pl. 34, fig. 4; pl. 35 , figs. 2,3 .

Patinopecten turneri (Arnold). Peck, 1960, pl. 21, figs. 15, 16. Original description.-"Shell averaging about 70 to 80 millimeters in altitude, length same as height, both valves equally compressed, equilateral, and with smooth margins; base regularly rounded; sides nearly straight and sloping at a rather low angle. Right valve with eighteen to twenty-two high, narrow, flat-topped, concave-sided ribs, which, in most cases, show a distinct medial sulcus after reaching a length of 30 or 35 millimeters; interspaces much wider than ribs, round bottomed and sometimes ornamented near the end by a faint intercalary riblet; whole surface of disk finely concentrically striated; hinge line slightly longer than one-half length of disk; ears equal, rectangularly truncated; anterior ear sculptured by four or five prominent radiating ridges and numerous fine incremental lines; byssal notch shallow but distinct; posterior ear with sculpture similar to anterior. Left valve with narrow rounded ribs, which are separated by round-bottomed and concavesided interspaces much wider than the ribs; surface sculptured by fine, distinct, wavy, concentric lines; ears as in right valve, except lacking byssal notch. Hinge as in P. caurinus."

Holotype.-CAS/SU 430.

Type locality.-Arroyo San Antonio, Tomales Bay, Marin County, Calif. Merced Formation (Keen and Bentson, 1944), Pliocene and Pleistocene.

Comparison. - "Patinopecten turneri Arnold *** was regarded by Grant and Gale ***as a synonym of purisimaensis. If Grant and Gale were influenced by an error in Arnold's statements about his figured specimens they did not say so. Arnold figured three specimens, two of them as right valves and one as a left valve; however, all three of Arnold's specimens are left valves. This gave him an erroneous concept of his supposed new species and made it appear to be very different from purisimaensis. Actually purisimaensis and turneri are closely related, but some good specimens of turneri $* * *$ show a well-defined sulcus on the right valve ribs that is not found in purisimaensis. These species should probably be kept separate." (MacNeil, 1961, p. 233)

Geographic range.-Middle California.

Geologic range.-Miocene to Pleistocene. 
Occurrence in California.-Miocene and Pliocene: Purisima (Arnold, 1906), and Tahana Member, Purisima (Durham and Morgan, 1978) Formation; Pliocene and Pleistocene: Merced Formation (Dickerson, 1922; Keen and Bentson, 1944).

\section{Lituyapecten dilleri (Dall)}

\section{Plate 42, figure 4}

Pecten (Lyropecten) dilleri Dall, 1901, p. 117-118.

Pecten (Patinopecten) dilleri Dall. Arnold, 1906, p. 62, pl. 5, fig. 2. Hertlein and Jordan, 1927, p. 431-432, pl. 30, fig. 1.

Pecten (Patinopecten) coosensis Shumard variety dilleri Dall. Grant and Gale, 1931, p. 193-194.

Patinopecten dilleri (Dall). Woodring, 1950, p. 84-85, pl. 11, figs. 1, 9. Pecten (Lituyapecten) dilleri Dall. MacNeil, 1961, p. 233, 235-236.

Hertlein and Grant, 1972, p. 186-187, pl. 35, figs. 4, 7.

Original description. - "Shell large, averaging about 190 millime-

ters in altitude, rather compressed, nearly orbicular with a relatively short, straight, hinge line, dorsally rectangular, nearly smooth, subequal ears, the posterior with 3 small riblets; a wellmarked though shallow byssal fold; and moderately thick valves. The right valve is somewhat more convex and strongly sculptured, bearing 29 to 30 high, narrow, T-rail shaped ribs, flattened above, overhanging narrower, deep, nearly smooth channels; and with marked concentric imbrication, feeble on top of the ribs but articularly scaly at their sides. The sculpture of the left valve is less pronounced, hidden in the matrix, but apparently similar."

Lectotype.-USNM 164846, which Arnold (1906, pl. 5, fig. 2) illustrated as a cotype, is here designated the lectotype.

Type locality.-Eel River, Humboldt County, Calif. Rio Dell Formation, Pliocene and Pleistocene.

Supplementary description.- "The left valve of $P$. dilleri is large, subcircular in outline, and slightly arched. The anterior ear is rather sharply truncated at the anterior margin, and is ornamented by about six to eight radiating ribs which are crossed by concentric lines of growth and are roughened by raised scaly imbrications. The posterior ear slopes slightly from the posterior dorsal margin to the base; it bears about six radiating ribs and is otherwise sculptured similar to the anterior ear.

"The left valve bears about 27 or 28 slightly rounded, high, prominent radiating ribs separated by interspaces that are a little wider than the ribs. The tops of the ribs are ornamented by strong, raised scaly concentric imbrications; the sides of the ribs and the interspaces are marked only by faint traces of rather widely spaced concentric lamellae." (Hertlein and Jordan, 1927, p. 431-432)

"There seems to be little doubt that dilleri is a Lituyapecten. It is a highly variable species if all the specimens that have been referred to it are really conspecific. Among pectens of its own age, it appears to be most closely related to $P$. (L.) purisimaensis as numerous writers have claimed. However it has characters which link it unmistakably with both $P$. (L.) poulcreekensis and poulcreekensis var. ${ }^{* * *}$, both early Miocene forms. Its relation to purisimaensis may be, therefore, one of parallelism rather than of direct intergradation, purisimaensis merely representing the varietal extreme of the purisimaensis-falorensis stock that perpetuated more of the characters that both it and the dilleri stock inherited from a common early Miocene ancestor." (MacNeil, 1961, p. 235-236)

"One well preserved specimen found in the San Diego Formation is present in the collections of the University of California at Los Angeles. The record of Pecten dilleri from San Diego by Woodring was based upon this specimen. It is $88.7 \mathrm{~mm}$ long, $88.6 \mathrm{~mm}$ high (anterior margin slightly defective), convexity (both valves together), $17 \mathrm{~mm}$. There are 27 radial ribs of which two nearest the anterior margin on the right valve are medially grooved. The riblets on the anterior ears are fine but well defined, those on the posterior ears only faintly indicated. Scaly concentric lamellae are only faintly noticeable on the right valve but on the left valve these are well developed. $* * *$

"On some specimens of this species from other formations, concentric lamellae may cross the ribs or only flanges may be present along the margins of the ribs on the right valve. On well preserved left valves, strong, elevated, concentric lamellae cross the ribs, or are occasionally interrupted and alternating, as shown on the illustrations of a left valve from northern Lower California by $\mathrm{E}$. K. Jordan and Hertlein (1926, pl. 30, fig. 1)."(Hertlein and Grant, 1972, p. 186)

Comparison.- "P. dilleri Dall is distinguished from P. purisimaensis Arnold and from $P$. coosensis Shumard by having a larger number of ribs which, in the left valve of Dall's species, are fairly large, slightly rounded, and more distant than in the others. The great prominence of the raised scaly imbrications on the ribs is also characteristic of $P$. dilleri." (Hertlein and Jordan, 1927, p. 432)

"Patinopecten (L.) purisimaensis is related to $P$. (L.) dilleri (Dall) ***.P. (L.) dilleri usually has coarse flanges on both valves, those of the right valve being either single and crossing the ribs ***, or divided and along the margins of the ribs $* * *$. The left valve has strong single flanges." (MacNeil, 1961, p. 233)

"Pecten (Lituyapecten) purisimaensis Arnold ***, is characterized by fewer (22 to 24 ), usually broader ribs on the right valve and narrower, sharper ribs with correspondingly wider interspaces on the left valve.

"Fossils cited as 'P. dilleri variety' by Woodring (1950, pl. 9, figs. 6-8), from the Sisquoc Formation in the Santa Maria district are characterized by the presence of riblets in the interspaces on the left valve and by minute riblets crossed by very fine lamellae in the interspaces on the right valve.

"Pecten (Lituyapecten) coosensis Shumard bears a resemblance to $P$. (L.) dilleri in the slightly developed flanges on the ribs and in that the ribs bear one or more medial grooves toward the ventral margin, ***" (Hertlein and Grant, 1972, p. 187)

Geographic range.-Northern California to Baja California Sur. Geologic range.-Miocene(?) to Pleistocene. Patinopecten dilleri characterizes the Moclipsian Molluscan Stage of Addicott (1976b) and affords a basis for correlation between strata in southern California and Baja California.

Occurrence in the Californias.-Miocene or Pliocene: Imperial Formation (Mount, 1974); Pliocene: Almejas (Minch and others, 1976), Cebada Member, Careaga (Woodring, 1950), and Fernando (Durham and Yerkes, 1964; Vedder, 1972; Kern and Wicander, 1974) Formations, Foxen Mudstone (Woodring, 1950), Niguel (Vedder, 1960) and San Diego (Hertlein and Grant, 1972) Formations; Pliocene and Pleistocene: Merced (Faustman, 1964) and Rio Dell (Faustman, 1964) Formations.

\section{FOSSIL LOCALITIES}

[Corrections and information not in the original description are in brackets; feet and miles are converted to the metric system; formations are cited as emended by later workers, where pertinent]

California Academy of Sciences:

CAS 681. Alverson Canyon, near source, Coyote Mountain, Imperial County, Calif. Imperial Formation.

CAS 794. "Cuesta Blanca" on Arroyo de Arca $24 \mathrm{~km}$ north of Loreto, Baja California Sur. San Marcos Formation.

CAS 795. Punta San Antonita, Baja California Sur. Collected along a canyon about $0.8 \mathrm{~km}$ inland and which empties near point. Carmen Formation.

CAS 928. Bernstein's abalone camp, Isla Cedros, Baja California 
Norte. Almejas Formation.

CAS 937. Arroyo Hondo, Isla Maria Madre, Mexico. Unnamed Pliocene strata.

CAS 945. Southeast of Bahia Tortola, Baja California Sur. Almejas Formation.

CAS 946. [East coast of] Isla Cedros, Baja California Norte. [The section north of Gran Cañon, about $15 \mathrm{~km}$ north of Pueblo Cedros, former site of Bernstein's Abalone Camp.] Almejas Formation.

CAS 1132. Pacific Beach, San Diego, San Diego County, Calif. San Diego Formation.

CAS 1874. From SE cor. sec. 35, T. 6 S., R. 7 E., M.D.M., Stanislaus County, Calif.; on the north side of Crow Creek road. Kreyenhagen Shale.

CAS 27625. SE cor. sec. 31, T. 28 S., R. 20 E., Carneros Creek quad. Wygal Sandstone Member, Temblor Formation.

CAS 39413. Along the trail about $200 \mathrm{~m}$ to the southeast from CAS loc. 39412, southeast of the ranch house, Rancho El Refugio, Baja California Sur. Salada Formation.

Los Angeles Natural History Museum:

LAM $305.730 \mathrm{~m}$ east and $310 \mathrm{~m}$ south of $\mathrm{NW}$ cor. sec. 8, T. $19 \mathrm{~S}$., R. 2 W., S.B.M. (San Ysidro quad., 1943 ed.) [San Diego County], California. San Diego Formation.

Stanford University [These collections are now all in the California Academy of Sciences]:

SU 43. Mesa west of Mesa de las Auras, Laguna Scammon quad.. Baia California Sur. Salada Formation.

SU 47. Bahía Tórtola, Baja California Sur. Salada Formation

SU 48. Mouth of large arroyo northwest of Mesa de Elephant Laguna Scammon quad., Baja California Sur. Salada Formation.

SU 49. Slopes of Salada, $4.5 \mathrm{~km}$ southeast of Bahía Tórtola, uppermost beds, Bahia San Cristobal quad., Baja California Sur. Salada Formation.

SU 50. Rancho Refugio, north of San José del Cabo, Baja California Sur.

SU 53. First arroyo east of Santiago, Baja California Sur. Salada Formation.

SU 54. Arroyo Mesquital, above the yellow silts which are well exposed in this arroyo. Baja California Norte, Almejas Formation.

SU 59. Turritella bed above Laguna San Gregorio, $190 \mathrm{~m}$ north of Bahla de Magdalena, Baja California Sur, on the trail from Arroyo Mesquital to La Purisima. Isidro Formation.

SU 60. West side of Mesa de Elephant, Laguna Scammon quad. Baja California Sur. Isidro Formation.

SU 64. Pebbly sandstone near Comondú-Salada contact, arroyo near La Palma, Baja California Sur. Salada Formation.

SU 65. Southern part of Arroyo San Gregorio, Baja California Sur. Salada Formation.

SU 111. Two Bar Creek, $0.4 \mathrm{~km}$ above junction with San Lorenzo River, Santa Cruz County, Calif., about $185 \mathrm{~m}$ above base. Vaqueros Formation.

SU 115. Pacific Beach, San Diego, San Diego County, Calif. San Diego Formation.

SU 116. Isla Cedros, Baja California Norte. Salada Formation.

SU 130. Sea cliffs at mouth of Fossil Creek, $3 \mathrm{~km}$ west of Sherringham Point, Jordan River, Vancouver Island, B.C. Sooke Formation.

SU 150. Pyramid Hill, $5 \mathrm{~km}$ northwest of mouth of Kern River Canyon, Caliente quad. [sec. 10, T. 28 S., R. 29 E.], Kern County, Calif. Jewett Sand.

SU 155. Drill core, depth $850 \mathrm{~m}, 1,300 \mathrm{~m}$ northwest of Signal Hill, $150 \mathrm{~m}$ east of Orange Avenue, $230 \mathrm{~m}$ north of Willow
Street, Long Beach [Los Angeles County], Calif. Fernando Formation.

SU 406. From the west end of South Mountain where it is truncated by the Santa Clara River, in a grayish-green, firmly indurated sandstone, but a few meters above the river bed, $3 \mathrm{~km}$ southwest of Santa Paula, Ventura County, Calif. Vaqueros Formation.

SU 860. Santa Inez [Ynez] Mountains, Santa Barbara County, Calif. Vaqueros Formation.

SU 2694. Between headwaters of San Lorenzo River and Pescadero Creek [off old dirt road running 180 to $275 \mathrm{~m}$ west of new highway, between Saratoga Point and Boulder Creek, SE $1 / 4$ sec. 23, T. 8 S., R. 3 W., just west of Santa Cruz County line, Santa Cruz quad., San Mateo County], Calif. Locatelli(?) Formation

SU 3252. 100 millimeters east, 412 millimeters south, of northwest corner as measured on 1953 edition, La Costa Valley quad., Alameda County, Calif. Briones Sandstone.

SU. F-6. Coalinga region, sec. 20, T. 19 S., R. 15 E. [Fresno County], California. Santa Margarita Formation.

University of California at Berkeley:

UC 14. In valley north of Sobrante Ridge, on west fork of Bear Creek, $0.8 \mathrm{~km}$ from source, long $122^{\circ} 12^{\prime} 35^{\prime \prime} \mathrm{W}$., lat $37^{\circ} 55^{\prime} 58^{\prime \prime}$ N. [Concord quad.], Contra Costa County, Calif. Briones Sandstone.

UC 367. Locality description not available.

UC 407. [On San Pablo Bay, near north mouth of tunnel on first point southwest of Selby Station, Napa quad., Contra Costa County] California. Cierbo Sandstone.

UC 1176. [N $1 / 2$ sec. 19, T. 2 N., R. 3 W.] Carquinez quad., Contra Costa County, Calif. Briones Sandstone.

UC 1311. $2.5 \mathrm{~km}$ southeast of Muir Station, long $122^{\circ} 6^{\prime} 8^{\prime \prime} \mathrm{W}$, lat $37^{\circ} 58^{\prime} 14^{\prime \prime}$ N., Contra Costa County, Calif. San Ramon Sandstone.

UC 1492. [South side of Mount Diablo, SE $1 / 4 \mathrm{SW}^{1 / 4} \mathrm{sec} .14, \mathrm{~T} .1 \mathrm{~S}$. ., R. 1 W.] Mount Diablo quad., Contra Costa County, Calif. San Pablo Group.

UC 1632. On bay shore just west of town of Rodeo, a little south of Lone Tree Point, Napa quad., Contra Costa County, Calif. Cierbo Sandstone.

UC 1817. Opposite the place where Urruttia Canyon enters Salt Creek, $30 \mathrm{~m}$ up fourth small draw from west end of ridge, $\mathrm{SW}^{1 / 4} \mathrm{NW}^{1 / 4}$ sec. 15 , T. 18 S., R. 14 E., Coalinga quad. [Fresno County], California. Cerros Shale Member, Lodo Formation.

UC 2991. [Near Zapato Creek] on top of ridge south of road near center SE $1 / 4$ sec. 17, T. 22 S., R. 16 E, [Coalinga quad., Fresno County], California. Upper part of Etchegoin Formation.

UC 3029. Tejon Hills, Caliente quad., sec. 13, T. 32 S., R. 29 E., Kern County, Calif. Santa Margarita Formation.

UC 3030. Fourth and Broadway, Los Angeles [Los Angeles County], Calif. Fernando Formation.

UC 3224 [not 3234]. East of Rock Springs, near Bee Spring Ridge, in SW cor. NW $1 / 4$ sec. 28, T. 10 N., R. 21 W., S.B. [Mount Pinos quad., Kern County], California. Vaqueros Formation.

UC 3231. West side of Salt Creek, near SW cor. sec. 21, T. 10 N., R. 20 W., S.B., Kern County, Calif. Pleito Formation.

UC 3532. [N1/2sec. 4, T. 4 S., R. 1 E.] Pleasanton quad., Alameda County, Calif. Briones Sandstone.

UC 3535. [NE $1 / 4$ sec. 32, T. 4 N., R. 1 E.] Pleasanton quad., Alameda County, Calif. Briones Sandstone.

UC 7100. Northwest cor. sec. 3, T. 3 N., R. 21 W., Ventura County, Calif. San Pedro(?) Formation.

UC A311. In canyon east of pass between two high peaks on crest of island, Santa Rosa Island, Calif. Vaqueros Formation. 
UC A316. Along bluffs on south side of Santa Ynez River about $1.5 \mathrm{~km}$ west of bridge on steep spur southwest of the "HG" ranch house [Lompoc quad., Santa Barbara County], California. Vaqueros Formation.

UC A572. [Corner of San Luis Obispo, Cayucos, and Adelaida quads., T. 28 S., R. 11 E.] San Luis Obispo County, Calif. Vaqueros Formation.

UC A1268. Upper part of basal sandstone and conglomerate series on northwest side of Carrizo Mountain. S. $5^{\circ} 30^{\prime} \mathrm{E}$. of Carrizo Station. Oyster reef on ridge running west from east side of meander of stream in badland area. Imperial County, Calif. Imperial Formation.

UC A3518. Marquer Bay, Carmen Island. In cliff facing bay, just south of northern arroyo. About $45 \mathrm{~m}$ above sea level (aneroid barometer reading). Same bed as at loc. A3513 [yellow calcareous sands], and about $6 \mathrm{~m}$ below a coral-reef horizon. Marquer Formation.

UC A 3566. From Pecten bed in calcareous "sandstone" overlying algal sandstone which is in fault contact with breccia, on east side of southern tip of Isla Monserrate, Baja California Sur. Salada Formation.

UC A3583. Bahía Santa Inez, Baja California Sur. From sandstones outcropping on a beach west of Punta Santa Inez and unconformably overlain by Pleistocene terrace. Salada Formation.

UC A4233. Bank of Boulder Creek from $90 \mathrm{~m}$ south to $180 \mathrm{~m}$ north of bridge near "Beckstine Ranch" (Wiggins Ranch), in about a 5-m stratigraphic interval, about $16 \mathrm{~km}$ southeast of Blue Lake, Humboldt County, Calif. Falor Formation.

UC A4566. Approximately $25 \mathrm{~mm}$ due west of top of the capital "E" of Eden Creek on the 800-ft contour line, Hayward quad., $0.6 \mathrm{~km}$ north of junction of Hollis Creek and Eden Creek, $25 \mathrm{~m}$ below the base of the Claremont Chert, Alameda County, Calif. Sobrante Sandstone.

UC B6940. Along Camino Cielo near Sacate-"Coldwater" contact, San Rafael Mountain quad., grid coordinates: 11138501273370, Santa Barbara County, Calif. Coldwater Sandstone.

UC D702. From approximately 2-m-thick oyster bed about 1 to $1.5 \mathrm{~m}$ above locality D701 [sec. 15, T. 19 S., R. 15 E., $740 \mathrm{~m}$ north, $770 \mathrm{~m}$ west], Domengine Ranch quad., Kern County, Calif. Santa Margarita Formation.

UC D1088. Sec. 28, T. 19 S., R. 15 E., 1,105 m north, $105 \mathrm{~m}$ east, Coalinga quad. From oyster-pecten bed of the Santa Margarita Formation outcropping on hill slope about $35 \mathrm{~m}$ north of Standard Oil well 184 . Fossil bed is about $10 \mathrm{~m}$ stratigraphically below the unconformity at the base of the marine Etchegoin Formation, Kern County, Calif. Santa Margarita Formation.

UC D1099. Along road cut between Shell oil wells 155-15 and 254-15 from very well sorted, fine-grained, buff to brown, silty sandstone over $5 \mathrm{~m}$ thick; sec. 15 , T. 19 S., R. 15 E., $760 \mathrm{~m}$ north, $750 \mathrm{~m}$ west, Domengine Ranch quad., Kern County, Calif.

University of California at Los Angeles:

UCLA 435. East side of valley of San Juan Creek, elevation approximately $2,700 \mathrm{~m}$, in west middle half of sec. 32 , T. $28 \mathrm{~S}$., R. 16 E., M.D.B.M., San Luis Obispo County, Calif. Neroly Formation.

U.S. Geological Survey, Washington, D.C., register:

USGS 2464. Forty kilometers eastward from Cape Flattery, on the south shore of Fuca [Juan de Fuca] Strait, Wash. Clallam Formation.

USGS 3851. Head of Slacks Canyon [Priest Valley quad., sec. 8, T. 22 S., R. 13 E.], Monterey County, Calif. Santa Margarita Formation.
USGS 4478. South of Santa Ynez $3 \mathrm{~km}$, on knoll just east of mouth of Ballard Canyon, west end of Santa Ynez Range [Lompoc quad.], Santa Barbara County, Calif. Vaqueros Formation.

USGS 4507. Just above the San Julian ranch house, about $16 \mathrm{~km}$ southeast of Lompoc [Lompoc quad.], Santa Barbara County, Calif. Gaviota Formation.

USGS 4712. East of Zapato Creek [1.2 km east of B.M. 922], SW $1 / 4 \mathrm{SE} 1 / 4$ sec. 8 , T. 22 S., R. 16 E. [Coalinga quad., Fresno County], California. Etchegoin Formation.

USGS 12530. Deadman Island, east side. (Same as CIT loc. 130, now inaccessible.) Los Angeles County, Calif. Basal part of San Pedro Sand.

U.S. Geological Survey, Menlo Park, Calif., register:

USGS M3772. On southeast side of ridge paralleling Media Agua Creek about $60 \mathrm{~m}$ above dirt road, $315 \mathrm{~m}$ south, $60 \mathrm{~m}$ east of NW cor. sec. 23, T. 28 S., R. 19 E., Las Yeguas Ranch $7 \frac{1}{2}$ ' quad., Kern County, Calif. Wygal Sandstone Member, Temblor Formation.

USGS M3281. On south side of hill 2259 just below summit, $2,000 \mathrm{ft} \mathrm{N} ., 1,000 \mathrm{ft} \mathrm{W}$. of SE cor. sec. 22, T. 28 S., R. 19 E., Las Yeguas Ranch 71/2' quad., Kern County, Calif. Wygal Sandstone Member, Temblor Formation.

\section{GEOLOGIC FORMATIONS CITED FOR OCCURRENCE OF PELECYPODS}

\section{Family Propeamussiidae and Family Pectinidae}

Name
California:

Age

Agua Sandstone Member,

Temblor Formation

Alegria Formation

Altamira Shale Member.

Monterey Shale

Anchor Silt Member',

San Pedro Formation

Antelope Shale Member,

Monterey Formation .............................. Miocene.

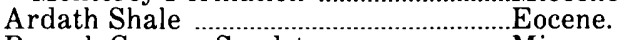

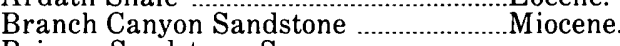

Briones Sandstone, San

Pablo Group ............................................. Miocene.

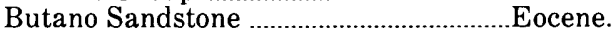

Buttonbed Sandstone

Member, Temblor Formation ............ Miocene.

Capay Formation...................................... Eocene.

Capistrano Formation ............................. Miocene and Pliocene.

Careaga Sandstone ..................................Pliocene.

Carneros Sandstone Member,

Temblor Formation ............................ Miocene.

Cascajo Conglomerate Member,

San Joaquin Formation ........................Pliocene.

Castaic Formation ${ }^{1}$.................................... Miocene.

Cebada Member, Careaga

Sand or Sandstone...................................Pliocene.

Cerros Shale Member,

Lodo Formation ...................................Paleocene.

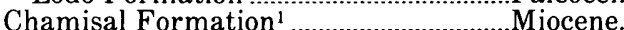

Cierbo Sandstone, San

Pablo Group

Cold Creek Member, Topanga

Canyon Formation

Coldwater Sandstone and

Coldwater Sandstone Member, ${ }^{1}$

Tejon Formation

Cozy Dell Shale and Cozy Dell

Shale Member, ${ }^{1}$ Tejon Formation ....Eocene.

Edna Member, Pismo Formation .......... Miocene and Pliocene. 'Stratigraphic nomenclature used is that of the references cited in the text and does not
necessarily accord with that of the U.S. Geological Survey. 
Etchegoin Formation

Falor Formation

Miocene and Pliocene.

Fernando Formation.

Pliocene.

ocene and

Foxen Mudstone .........................................Pliocene.

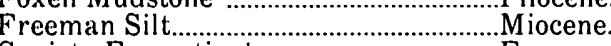

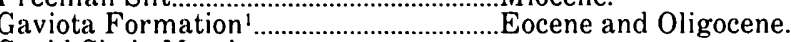

Gould Shale Member,

Monterey Formation ............................ Miocene.

Graciosa Member, Careaga

Sand or Sandstone.

Pliocene.

Gragg Member, Pismo Formation ........Pliocene.

Hames Member,

Monterey Formation ............................ Miocene.

Imperial Formation .......................................... Miocene or Pliocene.

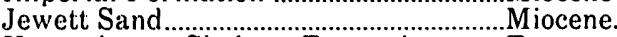

Kreyenhagen Shale or Formation .........Eocene and Oligocene.

Las Posas Formation' '..............................Pleistocene.

Lindavista Formation ................................Pleistocene.

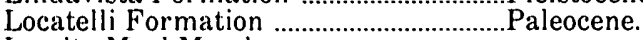

Lomita Marl Member.

San Pedro Formation $\quad$ Pliocene.

Los Laureles Sandstone Member, ${ }^{1}$

Monterey Formation .............................. Miocene.

Los Tularcitos Member,'

Chamisal Formation................................ Miocene.

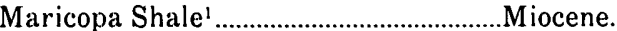

Martinez Formation _...................

McLure Shale Member,

Monterey Formation '.............................Miocene.

Media Shale Member.

Temblor Formation …...................... Miocene.

Merced Formation ..................................... Pliocene and

Pleistocene.

Mindego Basalt Oligocene and Miocene.

Modelo Formation Miocene.

Monterey Formation, Shale.

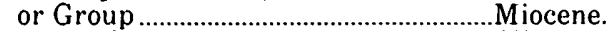

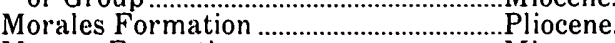

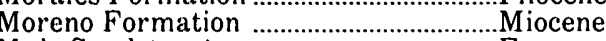

Muir Sandstone' Eocene.

Neroly Sandstone.

San Pablo Group ....................................... Miocene.

Niguel Formation ................................................. Pliocene

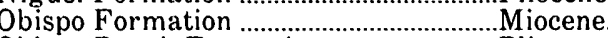

Ohlson Ranch Formation' '......................... Pliocene.

Olcese Sand Miocene.

Oursan Sandstone. Monterey Group.... Miocene.

Painted Rock Sandstone Member,

Vaqueros Formation

Palos Verdes Sand

Pancho Rico Formation.

Paso Robles Formation

Pico Formation

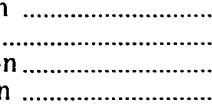

Miocene.

Pleistocene.

Miocene.

cene, Pliocene, and Pleistocene.

Pleito Formation ... Ple and Pleistocene.

Pomponio Mudstone M
Purisima Formation Oligocene.

Potato Harbor Formation

Puente Formation

Miocene.

Pullen Formation, Wildcat Group ...... Pliocene.

Purisima Formation ................................... Miocene and Pliocene.

Pyramid Hill Sand Member,

Jewett Sand

Quail Canyon Sandstone Member.

Vaqueros Formation

Miocene.

Raqueros For

Oligocene.

Rio Dell Formation.

Wildcat Group

..Oligocene and Miocene.

Round Mountain Silt

Sacate Formation' ${ }^{1}$

St. George Formation.

Saltos Shale Member,

Monterey Formation ......................... Miocene.

San Diego Formation .................................... Pliocene.

San Emigdio Formation ............................Eocene and Oligocene.

San Gregorio Sandstone Member.

Purisima Formation

San Joaquin Formation.
San Lorenzo Formation .............................. Eocene and Oligocene.

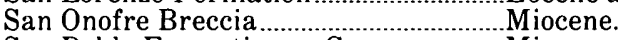

San Pablo Formation or Group _............ Miocene.

San Pedro Formation or Sand ................Pliocene and

San Ramon Sandstone .............................. Miocene(?).

Santa Barbara Formation ........................... Pliocene and

Pleistocene.

Santa Cruz Mudstone................................. Miocene.

Santa Margarita Formation .................... Miocene

Saugus Formation........................................Pliocene and

Pleistocene.

Sisquoc Formation

Skooner Gulch Formation ……..................... Miocene.

Sobrante Sandstone ……………………........ Miocene.

Soda Lake Shale Member,

Vaqueros Formation .......................... Oligocene and Miocene.

Squire Member, Pismo Formation ......Pliocene.

Tahana Member,

Purisima Formation

Temblor Formation

Tierra Redonda Formation

Timms Point Silt Member,

San Pedro Formation...

Tinaquaic Sandstone Member.

Sisquoc Formation ............................... Pliocene.

Topanga Group . Miocene.

Topanga Canyon Formation,

Topanga Group ...................................... Miocene.

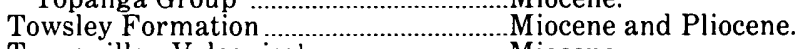

Tranquillon Volcanics ${ }^{1}$..................................... Miocene.

Tumey Formation ${ }^{1}$........................... Oligocene.

Twisselman Sandstone Member,

Monterey Formation ............................Miocene.

Valmonte Diatomite Member,

Monterey Shale

Miocene.

Oligocene and Miocene.

Wildcat Group ............. Pliocene and

Wimer Formation ${ }^{1}$................................. Miocene.

Woodhams Member, ${ }^{1}$ Monterey

Formation

Wygal Sandstone Member,

Temblor Formation.

Baja California peninsula:

Pliocene.

Pliocene.

Cantil Costero Formation ........................Pliocene.

Carmen Formation ......................................Pliocene.

Gloria Formation.........................................Pliocene.

Infierno Formation .................................Pliocene.

Isidro Formation

Marquer Formation ...................................Pliocene.

Salada Formation .........................................Pliocene.

San Marcos Formation .............................Pliocene.

Tepetate Formation ..............................Paleocene and Eocene.

Tortugas Formation Miocene.

Oregon:

Astoria Formation ...................................... Miocene.

Empire Formation ....................................... Miocene

Washington:

Clallam Formation

Gries Ranch Formation

Lincoln Creek Formation .......................... Eocene to Miocene.

Sooke Formation

\section{REFERENCES CITED}

Abbott, R. T., 1974, American Seashells [2d ed.]: New York, Van Nostrand Reinhold, 663 p., 24 pls.

Addicott, W. O., 1956, Miocene stratigraphy northeast of Bakersfield, California: University of California (Berkeley), Ph.D. dissertation.

1965, Miocene macrofossils of the southeastern San Joaquin Valley, California: U.S. Geological Survey Professional Paper 525-C, p. C101-C109, 4 figs.

1967, Age of the Skooner Gulch Formation, Mendocino 
County, California: U.S. Geological Survey Bulletin 1254-C, p. C1-C11, 4 figs.

1968, Mid-Tertiary zoogeographic and paleographic discontinuities across the San Andreas fault, California, in Dickinson, W. R., and Grantz, Arthur, eds., Proceedings of conference on geologic problems of San Andreas fault system: Stanford University Publications, University Series, Geological Science, v. 11, p. 144-165.

1969, Late Pliocene mollusks from San Francisco Peninsula, California, and their paleogeographic significance: California Academy of Sciences Proceedings, ser. 4, v. 37, no. 3, p. 57-93, 4 pls., 3 figs., 4 tables.

1971, Some Paleogene mud pectens of the genus Propeamussium from Alaska and California: The Veliger, v. 13, no. 3, p. 226-230, 13 figs.

1972, Provincial middle and late Tertiary molluscan stages, Temblor Range, California, in Pacific Coast Miocene Biostratigraphic Symposium: Pacific Section Society of Economic Paleontologists and Mineralogists, Bakersfield, California, 1972, Proceedings, 26 p., 4 pls., 3 figs., 5 tables.

1973 . Oligocene molluscan biostratigraphy and paleontology of the lower part of the type Temblor Formation, California: U.S. Geological Survey Professional Paper 791, 48 p., 9 pls., 5 figs., 1 table.

1974, Giant pectinids of the eastern North Pacific margin: significance in Neogene zoogeography and chronostratigraphy: Journal of Paleontology, v. 48, no. 1, p. 180-194, 2 pls., 7 figs.

1976a, Molluscan paleontology of the lower Miocene Clallam Formation, northwestern Washington: U.S. Geological Survey Professional Paper 976, 44 p., 9 pls., 10 figs., 7 tables.

$1976 \mathrm{~b}$, Neogene molluscan stages of Oregon and Washington, in Neogene Symposium: Pacific Section Society of Economic Paleontologists and Mineralogists meeting, San Francisco, California, p. 95-115, 5 pls., 6 figs., 1 table.

1978 , Pectinids as biochronologic indices in the Neogene of the eastern north Pacific: Proceedings of the Second Working Group Meeting, Biostratigraphic Datum-Planes of the Pacific Neogene, IGCP Project 114, Bandung, May 30-June 1, 1977, Indonesia Geological Research and Development Centre, Special Publ. no. 1.

Addicott, W. O., and Galehouse, J. S., 1973, Pliocene marine fossils in the Paso Robles Formation, California: U.S. Geological Survey Journal of Research, v. 1, no. 5, p. 509-514, 4 figs.

Addicott, W. O., Poore, R. Z., Barron, J. A., Gower, H. D., and McDougall, Kristin, 1978, Neogene biostratigraphy of the Indian Creek-Shell Creek area, northern La Panza Range, California, in Addicott, W. O., ed., Neogene biostratigraphy of selected areas in the California Coast Ranges; U.S. Geological Survey Open-File Report 78-446, p. 49-82, 4 pls., 12 figs.

Addicott, W. O., and Vedder, J. G., 1963, Paleotemperature inferences from late Miocene mollusks in the San Luis ObispoBakersfield area, California: U.S. Geological Survey Professional Paper 475-C, p. C63-C68.

Adegoke, O. S., 1967, California late Miocene records of Swiftopecten Hertlein, 1935 (Pelecypoda: Pectinidae): The Veliger, v. 9, no. 3, p. 337-339, pl. 47.

1969 , Stratigraphy and paleontology of the marine Neogene formations of the Coalinga region, California: University of California Publications in Geological Sciences, v. 80, 241 p., 13 pls.

Anderson, D. N., and Land, P. E., 1969, Cymric oil field, California: California Oil Fields, v. 55, no. 1, p. 5-21.

Anderson, F. M., 1905, A stratigraphic study in the Mount Diablo
Range of California: California Academy of Sciences Proceedings, ser. 3, v. 2, no. 2, p. 155-248, pls. 13-35.

Anderson, F. M., 1905, A stratigrapnic study in the Mount Diablo Range of California: California Academy of Sciences Proceedings, ser. 3 , v. 2, no. 2, p. 197, pl. 18.

Anderson, F. M., and Martin, Bruce, 1914, Neocene record in the Temblor Basin, California, and Neocene deposits of the San Juan District, San Luis Obispo County: California Academy of Sciences Proceedings, ser. 4, v. 4, p. 15-112, pls. 1-10.

Arnold, Ralph, 1903, The paleontology and stratigraphy of the marine Pliocene and Pleistocene of San Pedro, California: California Academy of Sciences Memoirs, v. 3, 419 p., 37 pls.

1906, The Tertiary and Quaternary pectens of California: U.S. Geological Survey Professional Paper 47, 264 p., 53 pls., 2 figs.

1907a, New and characteristic species of fossil mollusks from the oil-bearing Tertiary formations of southern California: U.S. National Museum Proceedings, v. 32, no. 1545, p. 525-546, pls. 38-51.

$1907 \mathrm{~b}$, New and characteristic species of fossil mollusks from the oil-bearing Tertiary formations of Santa Barbara County, California: Smithsonian Miscellaneous Collections, v. 50, no. 4, p. $419-447$, pls. $50-58$.

1909, Paleontology of the Coalinga district, Fresno and Kings Counties, California: U.S. Geological Survey Bulletin 396, 173 p., pls. 1-30 [January, 1910].

Arnold, Ralph, and Anderson, Robert, 1907, Geology and oil resources of the Santa Maria oil district, Santa Barbara County, California: U.S. Geological Survey Bulletin 322, 161 p., 26 pls.

Atwill, E. R., 1935, Oligocene Tumey Formation of California: American Association of Petroleum Geologists Bulletin, v. 19, no. 8, p. 1192-1204.

Avila, F. A., and Weaver, D. W., 1969, Mid-Tertiary stratigraphy, Santa Rosa Island [California], in Weaver, D. W., ed., Geology of the Northern Channel Islands: American Association of Petroleum Geologists and Society of Economic Paleontologists and Mineralogists, Pacific Sections, Special Publication, p. 48-67.

Bailey, T. L., 1947, Origin and migration of oil into Sespe red beds, California: A merican Association of Petroleum Geologists Bulletin, v. 31, no. 11, p. 1913-1935, 4 figs.

1952, Summerland area, in Redwine, L. E., chairman, Cenozoic correlation section paralleling north and south margins [of the] western Ventura basin from Point Conception to Ventura and Channel Islands, California: American Association of Petroleum Geologists, Subcommittee on the Cenozoic of the Geologic Names and Correlations Committee, 2 sheets.

Barbat, W. F., and Galloway, John, 1934, San Joaquin Clay, California: American Association of Petroleum Geologists Bulletin, v. 18, no. 4, p. 476-499.

Beal, C. H., 1948, Reconnaissance of the geology and oil possibilities of Baja California, Mexico: Geological Society of America Memoir 31, 138 p., 11 pls.

Bereskin, S. R., and Edwards, L. N., 1969, Mid-Tertiary stratigraphy, southwestern Santa Cruz Island [California], in Weaver, D. W., ed., Geology of the northern Channel Islands: American Association of Petroleum Geologists and Society of Economic Paleontologists and Mineralogists, Pacific Sections, Special Publication, p. 68-79.

Bernard, F. R., 1978, New bivalve molluscs, subclass Pteriomorphia, from the northeastern Pacific: Venus, v. 37, no. 2, p. 61-75, 18 text figs.

Bertholf, H. W., 1962, Northeast area of McKittrick oil field [California]: California Oil Fields, v. 48, no. 1, p. 63-68.

Beu, A. G., 1965, Ecologic variation of Chlamys dieffenbachi (Reeve) 
(Mollusca, Lamellibrachiata): Royal Society of New Zealand Transactions, Zoology, v. 7, no. 5, p. 93-96, 1 pl.

Bowen, O. E., 1966, Stratigraphy, structure, and oil possibilities in Monterey and Salinas quadrangles, California, in.Symposium ** * of Papers: American Association of Petroleum Geologists, Pacific Section, 40th Ann. Meeting, Bakersfield, Calif., 1965, p. 48-67.

Brabb, E. E., 1964, Subdivision of San Lorenzo Formation (EoceneOligocene) west-central California: American Association of Petroleum Geologists Bulletin, v. 48, no. 5, p. 670-679, 2 figs.

Burch, J. Q., ed., 1944, Distributional list of the West American marine Mollusca from San Diego, California, to the Polar Sea: Southern California Conchological Club Minutes, No. 33, p. 7-14 (mimeographed).

Burchfiel, B. C., 1964, Stratigraphic reassignment of four species in the lower Miocene rocks of the Bear Creek area, Santa Cruz County, California: Journal of Paleontology, v. 38, no. 2, p. 401-405, 2 figs.

Carpenter, P.P., 1864, Supplementary report on the present state of our knowledge with regard to the Mollusca of the West Coast of North America: British Association for the Advancement of Science Report 1863, p. 517-686 [1864].

Clark, Alex, 1931, The cool-water Timms Point Pleistocene horizon at San Pedro, California: San Diego Society of Natural History Transactions, v. 7, no. 4, p. 25-42.

Clark, B. L., 1915, Fauna of the San Pablo Group of middle California: University of California Publications Department of Geology Bulletin, v. 8, no. 22 , p. 385,572 , pls. 42-71.

1918, The San Lorenzo Series of middle California: University of California Publications Department of Geology Bulletin, v. 11, no. 2, p. 45-234, pls. 3-24, 4 text figs.

Clark, B. L., and Arnold, Ralph, 1923, Fauna of the Sooke Formation, Vancouver Island, with a description of a new coral by $T$. Wayland Vaughan: University of California Publications, Department of Geological Sciences Bulletin, v. 14, no. 5, p. 123-234, pls. 15-42.

Clark, G. R., 1971, The influence of water temperature on the morphology of Leptopecten latiauratus (Conrad, 1937): The Veliger, v. 13 , no. 3 , p. $269-272,1$ pl.

Conrad, T. A., 1834, Description of a new species of Hinnita: Academy of Natural Sciences Journal, v. 7, p. 182-183, pl. 14.

1837, Descriptions of new marine shells from upper California, collected by Thomas Nuttall, Esq.: Philadelphia Academy of Natural Sciences Journal, v. 7, p. 227-268, pls. 17-20.

1849, Fossils from northwestern America, in Dana, J. D., U.S. Explor. Exped.*** *, 1838-1842, under the command of Charles Wilkes: Geology, v. 10, app. p. 723-728, atlas, pls. 17-21.

1855a, Report of Mr. T. A. Conrad on the fossil shells collected in California by W. P. Blake, geologist of the expedition under the command of Lt. R. S. Williamson, U.S. Topographical Engineers, 1853, in app. to Preliminary Geological Report of W. P. Blake: U.S. Session, House of Representatives Document No. 129, p. 5-20. [Reprinted in Dall, 1909.]

1855b, Description of eighteen new Cretaceous and Tertiary fossils: Philadelphia Academy of Natural Sciences Proceedings, v. 7 , p. 265-268.

1857a, Descriptions of three new genera; twenty-three new species middle Tertiary fossils from California, and one from Texas: Philadelphia Academy of Natural Sciences Proceedings, v. 8, p. 312-316. [Reprinted in Dall, 1909, p. 173-175.]

1857b. Description of the Tertiary fossils collected on the survey [Williamson's survey], in Reports of explorations and surveys $*^{* *}$ railroad ${ }^{* *}$ from the Mississippi River to the Pacific Ocean: U.S. 33d Congress, 2d Session, Senate Executive
Document No. 78 and House of Representatives Executive Document No. 91, v. 6, pt. 2, p. 69-73, pls. 2-5. [Reprinted in Dall, 1909, p. 176-179.]

$1857 \mathrm{c}$, Report on the paleontology of the Survey [Parke's survey], in Reports of explorations and surveys *** railroad *** from the Mississippi River to the Pacific Ocean: U.S. 33d Congress, 2d Session, Senate Executive Document No. 78 and House of Representatives Executive Document No. 91, v. 7, pt. 2, p. 189-196, pls. 1-10. [Reprinted in Dall, 1909, p. 180-185.]

1862 , Descriptions of new genera, subgenera, and species of Tertiary and Recent shells: Philadelphia Academy of Natural Sciences Proceedings, v. 14, no. 6, p. 284-291.

1865, Catalogue of the older Eocene shells of Oregon: American Journal of Conchology, v. 1, p. 150-154.

1867. Paleontological miscellanies: American Journal of Conchology, v. 3, p. 5-7.

Crittenden, M. D., Jr., 1951, Geology of the San Jose-Mount Hamilton area, California: California Division of Mines Bulletin 157, 74 p., 11 pls., 14 figs.

Cummings, J. C., Touring, R. M., and Brabb, E. E., 1962, Geology of the northern Santa Cruz Mountains, California, in Bowen, 0. E., Jr., ed., Geologic guide to the gas and oil fields of northern California: California Division of Mines Bulletin 181, p. 179-220.

Curran, J. F., 1943, Eocene stratigraphy of the Chico Martinez Creek area, Kern County, California: American Association of Petroleum Geologists Bulletin, v. 27, no. 10, p. 1361-1386.

Dall, W. H., 1871, Descriptions of sixty new forms of mollusks from the west coast of North America and the North Pacific Ocean, with notes on others already described: American Journal of Conchology, v. 7 , pt. 2, p. 93-160, pls. 13-16.

1874 , Notes on some Tertiary fossils from the California coast, with a list of the species obtained from a well at San Diego, California, with descriptions of two new species: California Academy of Sciences Proceedings, v. 5, p. 296-299.

1878, Fossil mollusks from the later Tertiaries of California:

U.S. National Museum Proceedings, v. 1, no. 8, p. 10-16.

1898 , Contributions to the Tertiary fauna of Florida, with especial reference to the Miocene silex beds of Tampa and the Pliocene beds of the Caloosahatchie River: Wagner Free Institute of Science of Philadelphia Transactions, v. 3, pt. 4, p. 571-947, pls. 23-25.

1901, A new Lyropecten: Nautilus, v. 14, no. 10, p. 117-118.

1908 , Reports on the dredging operations of the west coast of Central America to the Galapagos, to the west coast of Mexico, and in the Gulf of California *** expedition to the eastern tropical Pacific *** by the *** Albatross *** reports on the Mollusca and Brachiopoda: Harvard Museum of Comparative Zoology Bulletin 43, p. 205-487, 22 pls.

1909. Contributions to the Tertiary paleontology of the Pacific Coast. I. The Miocene of Astoria and Coos Bay, Oregon: U.S. Geological Survey Professional Paper 59, 278 p., 23 pls.

1914, Notes on some West American pectens: Nautilus, v. 27, no. 11, p. 121-122.

1916, Diagnoses of new species of marine bivalve mollusks from the northwest coast of America in the United States National Museum: U.S. National Museum Proceedings, v. 52, no. 2183, p. $393-417$.

Dall, W. H., and Ochsner, W. H., 1928, Tertiary and Pleistocene Mollusca from the Galapagos Islands: California Academy of Sciences Proceedings, ser. 4, v. 17, no. 4, p. 89-139, pls. 2-7, 5 text figs.

Davis, C. H., 1913, New species from the Santa Lucia Mountains, California, with a discussion of the Jurassic age of the Slate's Springs: Journal of Geology, v. 21, no. 5, p. 453-458, figs. 1-7. 
Dibblee, T. W., Jr., 1950, Geology of southwestern Santa Barbara County, California; Point Arguello, Lompoc, Point Conception, Los Olivos, and Gaviota quadrangles: California Division of Mines Bulletin 150, $95 \mathrm{p}$.

1966, Geology of the Palo Alto quadrangle, Santa Clara and San Mateo Counties, California: California Division of Mines Map Sheet 8.

1973, Stratigraphy of the southern Coast Ranges near the San Andreas fault from Cholame to Maricopa, California: U.S. Geological Survey Professional Paper 764, 45 p.

Dickerson, R. E., 1914, Fauna of the Martinez Eocene of California: University of California Publications Department of Geology Bulletin, v. 8, no. 6, p. 61-180, pls. 6-18.

1922, Tertiary and Quaternary history of the Petaluma, Point Reyes, and Santa Rosa quadrangles [California]: California Academy of Sciences Proceedings, ser. 4, v. 11, no. 19, p. 527-601.

Dickinson, W. R., 1963, Tertiary stratigraphic sequence of the Hancock Ranch area, Monterey and Kings Counties, California, in Guidebook to the geology of the Salinas Valley and the San Andreas fault: American Association of Petroleum GeologistsSociety of Economic Paleontologists and Mineralogists, Pacific Section, Annual Field Trip, 1963, p. 47-53.

1969, Miocene stratigraphic sequence on upper Sespe Creek and Pine Mountain [California], in Dickinson, W. R., chm., Society of Economic Paleontologists and Mineralogists, Pacific Coast Section, 1969 Field Trip [Guidebook], upper Sespe Creek: p. 49-55.

Durham, D. L., 1968, Geology of the Tierra Redonda Mountain and Bradley quadrangles, Monterey and San Luis Obispo Counties, California: U.S. Geological Survey Bulletin 1255, 60 p.

1970, Geology of the Sycamore Flat and Paraiso Springs quadrangles, Monterey County, California: U.S. Geological Survey Bulletin 1285, $34 \mathrm{p}$.

Durham, D. L., and Addicott, W. O., 1964, Upper Miocene and Pliocene marine stratigraphy in southern Salinas Valley, California: U.S. Geological Survey Bulletin 1194-E, p. E1-E7.

1965, Pancho Rico Formation, Salinas Valley, California: U.S. Geological Survey Professional Paper 524-A, p. A1-A22, 5 pls.

Durham, D. L., and Yerkes, R. F., 1964, Geology and oil resources of the eastern Puente Hills area, southern California: U.S. Geological Survey Professional Paper 420-B, p. B1-B62.

Durham, J. W., 1950, Megascopic paleontology and marine stratigraphy, in 1940 E. W. Scripps Cruise to the Gulf of California, pt. II: Geological Society of America Memoir 43, p. 1-216, 48 pls.

Durham, J. W., Harper, Herbert, and Wilder, Beverly, 1942, Lower Miocene in the Willamette Valley, Oregon: Geological Society of America Bulletin, v. 53, p. 1817.

Durham, J. W., and Morgan, S. R., 1978, New sand dollars (Echinoidea) of the genera Merriamaster and Dendraster from Purisima Formation, California: California Academy of Sciences Proceedings, ser. 4, v. 41, no. 11, p. 297-305, 5 figs.

Durham, J. W., and Wolfe, J. A., 1958, Joint occurrence of Dendraster and Scutellaster [Anorthoscutum] [Abs.]: Geological Society of America Bulletin, v. 69, no. 12, pt. 2, p. 1682-1683.

Eaton, J. E., Grant, U.S., 4th, and Allen, H. B., 1941, Miocene of Caliente Range and environs, California: American Association of Petroleum Geologists Bulletin, v. 25, no. 2, p. 193-262, 9 pls.

Eldridge, G. H., and Arnold, Ralph, 1907, The Santa Clara Valley, Puente Hills, and Los Angeles oil districts, southern California: U.S. Geological Survey Bulletin 309, 266 p., pls. 25-41.

Emerson, W. K., and Hertlein, L. G., 1964, Invertebrate megafossils of the Belvedere Expedition to the Gulf of California: San Diego
Society of Natural History Transactions, v. 13, no. 17, p. 333-368.

Faustman, W. F., 1964, Paleontology of the Wildcat Group at Scotia and Centerville Beach, California: University of California Publications in Geological Sciences, v. 41, no. 2, p. 97-160, 3 pls. 7 figs.

Fitch, J. E., 1953, Common marine bivalves of California: California Department of Fish and Game, Fish Bulletin 90, 102 p., 63 figs.

Gabb, W. M., 1866-1869, Tertiary invertebrate fossils: California Geological Survey, Paleontology, v. 2, Cretaceous and Tertiary fossils, sec. 1, pt. 1, p. 1-38, 1866; sec. 1, pt. 2, p. 39-63, 1869, pls. $1-34$.

Gale, H. R. , 1928, West Coast species of Hinnites [California]: San Diego Society of Natural History Transactions, v. 5, no. 9, p. 91-94.

Glibert, Maxime, and Van de Poel, Luc, 1965, Les Bivalvia fossiles du Cénozoīque etranger des collections de l'Institute Royal des Sciences Naturelles de Belgique: Institute Royal des Sciences Naturelles de Belgique Mémoire, Ser. 10, part 81, p. 1966.

Golikov, A. N., and Scarlato, O. A., 1970, Abundance, dynamics and production properties of populations of edible bivalves Mizuhopecten yessoensis and Spisula sachalinensis related to the problem of organization of controllable submarine farms at the western shores of the Sea of Japan: Helgoländer wiss. Meeresunters., v. 20, p. $498-513$, 14 figs.

Gould, A. A., 1850, [On the shells collected by the United States Exploring Expedition]: Boston Society of Natural History Proceedings, v. 3 , p. $343-348$

Grant, U. S., 4th, and Gale, H. R., 1931, Catalogue of the marine Pliocene and Pleistocene Mollusca of California and adjacent regions: San Diego Society of Natural History Memoir, v. 1, 1036 p., 32 pls., 15 figs., 3 tables.

Grant, U. S., and Stevenson, R. E., 1948, A new Pecten from the upper Miocene of California: Journal of Paleontology, v. 22, no. 6. p. 804-805, pl. 124.

Grau, Gilbert, 1959, Pectinidae of the Eastern Pacific: Alan Hancock Pacific Expedition, v. 23, p. 1-308, pls. 1-57.

Gray, J. E., 1825, A list and description of some species of shells not taken notice of by Lamarck: Annuals of Philosophy, new ser., v. 9, p. 134-140, 1 text fig.

Hall, C. A., Jr., 1958, Geology and paleontology of the Pleasanton area, Alameda and Contra Costa Counties, California: University of California Publications in Geological Sciences, v. 34, no. 1 , p. 1-90, pls. 1-12, 2 figs., 5 maps.

1960, Displaced Miocene molluscan provinces along the San Andreas fault, California: California University Publications in Geological Sciences, v. 34, no. 6, p. 281-308.

1973, Geologic map of the Morro Bay South and Port San Luis Quadrangles, San Luis Obispo County, California: U.S. Geological Survey Miscellaneous Field Studies Map MF-511.

Hall, C. A., Turner, D. L., and Surdam, R. C., 1966, Potassium-argon age of the Obispo Formation with Pecten lompocensis Arnold, southern Coast Ranges, California: Geological Society of America Bulletin, v. 77, p. 443-446, 1 fig.

Hall, E. A., and Redin, T., 1967, Big Mountain oil field, Ventura County, California, Stratigraphic section, in Geology of the Big Mountain oil field and the nearby area, including notes on the trip from Piru to Big Mountain, Ventura County, California: American Association of Petroleum Geologists, Pacific Section, Spring Field Trip, Morning Section, $6 \mathrm{p}$.

Hall, E. B., and Ambrose, A. W., 1916, Descriptions of new species from the Cretaceous and Tertiary of the Tesla, Pleasanton, San Jose, and Mt. Hamilton quadrangles, California: Nautilus, v. 30, no. 6 , p. $68-71$, no. 7 , p. $77-82$. 
Hammond, P. E., 1958, Geology of the lower Santiago Creek area San Emigdio Mountains, Kern County, California: University of California, Los Angeles, Master of Arts thesis.

Hanna, G D., 1924, Rectifications of nomenclature: California Academy of Sciences Proceedings, ser. 4, v. 13, no. 10, p. 151-156.

1926a, Paleontology of Coyote Mountain, Imperial County, California: California Academy of Sciences Proceedings, ser. 4, v. 14 , no. 18 , p. $427-503$, text fig. 1 , pls. $20-29$.

1926b, Expedition to the Revillagigedo Islands, Mexico, in 1925: California Academy of Sciences Proceedings, v. 15, no. 1, p. $1-113$.

Hanna, G D., and Hertlein, L. G., 1927, Expedition of the California Academy of Sciences to the Gulf of California in 1921; Geology and Paleontology: California Academy of Sciences Proceedings, ser. 4 , v. 16 , no. 6 , no. $137-156$.

1943, Characteristic fossils of California: California Division of Mines Bulletin 118, p. 165-182, figs. 62-65.

Hanna, M. A., 1927, An Eocene invertebrate fauna from the La Jolla quadrangle, California: University of California Publications Department of Geological Sciences Bulletin, v. 16, no. 8, p. 247-398, pls. 24-57.

Hertlein, L. G., 1925a, Pectens from the Tertiary of Lower California: California Academy of Sciences, ser. 4, v. 14, no.1, p. 1-35, pls. 1-6.

1925b, New species of marine fossil Mollusca from western North America: Southern California Academy of Sciences Bulletin, v. 24, pt. 2, p. 39-46, pls. 3-4.

1928. Preliminary report on the paleontology of the Channel Islands, California: Journal of Paleontology, v. 2, no. 2, p. 142-157, pls. 22-25.

1929, A new Pecten from the San Diego Pliocene: California Academy of Sciences Proceedings, ser. 4, v. 18, no. 5, p. 215, pl. 24.

1931. Changes of nomenclature of some Recent and fossil Pectinidae from Japan, Porto Rico, South America, New Zealand, and California: Journal of Paleontology, v. 5, no. 4 p. $367-369$.

1934, New oysters and a new Pecten from the Tertiary of California: Southern California Academy of Sciences Bulletin v. 33 , pt. 1, p. $1-5$, pls. 1,2 .

1935. The Recent Pectinidae, no. 25, in The Templeton Crocker Expedition of the California Academy of Sciences, 1932: California Academy of Sciences Proceedings, ser. 4, v. 21 no. 25 , p. $301-328$, pls. $18-19$.

1951. Invertebrate fossils and fossil localities in the San Francisco Bay area, in Geologic Guidebook of the San Francisco Bay Counties [California]: California Division of Mines Bulletin 154 , p. $187-192$.

1966, Pliocene fossils from Rancho El Refugio, Baja California, and Cerralvo Island, Mexico: California Academy of Sciences Proceedings, ser. 4, v. 30, no. 14, p. 265-284, figs. 1-17.

1969, Family Pectinidae Rafinesque, 1815, in Moore, R. C., ed., Treatise on invertebrate paleontology: Geological Society of A merica and University of Kansas, pt. N, Mollusca, v. 1 and 2, $952 \mathrm{p}$. , illus.

Hertlein, L. G., and Allison, E. C., 1959, Pliocene marine deposits in northwest Baja California, Mexico, with the description of a new species of Acanthina (Gastropoda): California Academy of Sciences Bulletin, v. 58, pt. 1, p. 17-26, 8 pls.

Hertlein, L. G., and Grant, U. S., 4th, 1972, The geology and paleontology of the marine Pliocene of San Diego, California (Paleontology: Pelecypoda): San Diego Society of Natural History Memoir 2, pt. 2B, 409 p., pls. 28-57.
Hertlein, L. G., and Jordan, E. K., 1927, Paleontology of the Miocene of Lower California: California Academy of Sciences Proceedings, ser. 4, v. 16 , no. 19 , p. $605-647$, pls. $17-21$.

Hill, M. L., Carlson, A., and Dibblee, T. W., Jr., 1958, Stratigraphy of Cuyama Valley-Caliente Range area, California: American Association of Petroleum Geologists Bulletin, v. 42, no. 12, p. 2973-3000.

Hinds, R. B., 1844-1845, The zoology of the voyage of H.M.S. Sulphur under the command of Captain Sir Edward Belcher *** during the years 1836-42. Mollusca: London, Smith, Elder and Co., 4 tomes, pt. 1, no. 6,24 p., pt. 2, no. 7, p. $25-48,1844$; pt. 3 , no. 8 , p. $49-72,1845,21$ pls. [1845].

Hoots, H. W., 1930, Geology and oil resources along the southern border of San Joaquin Valley, California: U.S. Geological Survey Bulletin 812-D, p. D243-D332.

Howard, P. J., 1935, Report on Buena Vista Hills, a portion of the Midway-Sunset oil field [California]: California Oil Fields, v. 20, no. 4 , p. 5-22, 7 pls.

Hudson, F. S., and Craig, E. K., 1929, Geologic age of the Modelo Formation, California: American Association of Petroleum Geologists Bulletin, v. 13, no. 5, p. 509-518.

Huey, A. S., 1948, Geology of the Telsa quadrangle, California: California Division of Mines Bulletin 140, $75 \mathrm{p}$.

Jordan, E. K., 1924, Quaternary and Recent molluscan faunas of the west coast of Lower California: Southern California Academy of Sciences Bulletin, v. 23, no. 5, p. 145-156.

Jordan, E. K., and Hertlein, L. G., 1926a, A Pliocene fauna from Maria Madre Island, in Expedition to the Revillagigedo Islands, Mexico, in 1925: California Academy of Sciences Proceedings, ser. 4, v. 15, p. 209-217, pl. 23.

$1926 \mathrm{~b}$, Contribution to the geology and paleontology of the Tertiary of Cedros Island adjacent parts of Lower California: California Academy of Sciences Proceedings, ser. 4, v. 15, no. 14 , p. 409-464, pls. 27-34.

Kanakoff, G. P.; and Emerson, W. K., 1959, Late Pleistocene invertebrates of the Newport Bay area, California: Los Angeles County Museum Contributions in Science no. 31, 47 p., 5 figs.

Keen, A. M., 1966, West American mollusk types in the British Museum (Natural History). II Species described by R. B. Hinds: The Veliger, v. 8, no. 4, p. $265-275$, pls. $46,47,6$ text figs. 1971, Sea shells of tropical West America [2d ed.]: Stanfórd, Calif., Stanford University Press, 1,064 p., 3,305 figs.

Keen, A. M., and Bentson, Herdis, 1944, Check list of California Tertiary marine Mollusca: Geological Society of America Special Paper 56, 280 p., 4 figs., 2 tables.

Kennedy, G. L., 1973, A marine invertebrate faunule from the Lindavista Formation, San Diego, California: San Diego Society of Natural History Transactions, v. 17, no. 10, p. 119-127, 3 figs.

1975, Paleontologic record of areas adjacent to the Los Angeles and Long Beach. Harbors, Los Angeles County, California: Allan Hancock Expedition, Marine Studies of San Pedro Bay, California, pt. 9, paleontology.

Kern, J. P., 1973, Early Pliocene marine climate and environment of the eastern Ventura basin, southern California: University of California Publications in Geological Sciences, v. 96, 117 p., 27 figs.

Kern, J. P., and Wicander, E. R., 1974, Origin of a bathymetrically displaced marine invertebrate fauna in the upper part of the Capistrano Formation (lower Pliocene), southern California: Journal of Paleontology, v. 48, no. 3, p. 495-505, 4 text figs.

Kew, W. S. W., 1924, Geology and oil resources of a part of Los Angeles and Ventura Counties, California: U.S. Geological Survey Bulletin 753, $202 \mathrm{p}$.

Kleinpell, R. M., and Weaver, D. W., 1963, Oligocene biostratig- 
raphy of the Santa Barbara embayment, California: University of California Publications in Geological Sciences, v. 43, 250 p., 38 pls.

Kubota, Kaoru, 1950, Fossil Pectinidae of the Setana series; explanation of Cenozoic fossils from northern Japan, 9: Shinseidai-noKenkyu (Cenozoic Research), no. 6, p. 12-18, pls. 8, 9. [In Japanese].

Kundert, C. J., 1952, Geology of the Whittier-La Habra area, Los Angeles County, California: California Division of Mines Special Report 18, $22 \mathrm{p}$.

Loel, Wayne, and Corey, W. H., 1932, The Vaqueros Formation, lower Miocene of California: I. Paleontology: University of California Publications Department of Geological Sciences Bulletin, v. 22 , no. 3, p. 31-410, pls. 4-65, 2 maps.

Lutz, G. C., 1951, The Sobrante Sandstone: University of California Publications Department of Geological Sciences Bulletin, v. 28, no. 13 , p. $367-406$, pls. $15-18,3$ text figs.

McFall, C. C., 1968, Reconnaissance geology of the Conception Bay Area, Baja California, Mexico: Stanford University Publication, Geological Sciences, v. 10, no. 5, 25 p., 3 pls., 3 figs., 1 table.

McLaughlin, R. P., and Waring, C. A., 1914, Petroleum industry of California: California Mining Bureau Bull. 69, 519 p., atlas.

McLean, James, 1978, Marine shells of southern California: Los Angeles County Museum of Natural History, Science Series 24, revised edition, 104 p., 54 figs.

MacNeil, F. S., 1961, Lituyapecten (new subgenus of Patinopecten) from Alaska and California: U.S. Geological Survey Professional Paper 354-J, p. J225-J237, pls. 35-46.

1967, Cenozoic pectinids of Alaska, Iceland, and other northern regions: U.S. Geological Survey Professional Paper 553, 57 p., 25 pls.

Mandra, Y. T., 1963, Buttle Diatomite, a new member of the Monterey Formation, Salinas Valley, California, in Guidebook to the geology of Salinas Valley and the San Andreas fault: American Association of Petroleum Geologists, Society of Economic Paleontologists and Mineralogists, Pacific Sections, Annual Field Trip, 1963, p. 104-105.

Mansfield, W. C., 1931, Pliocene fossils from limestone in southern Florida, in Shorter contributions to general geology, 1931: U.S. Geological Survey Professional Paper 170-D, p. D43-D56, pls. 14-18.

Masuda, Kôichirô, 1956, On the Miocene Pectinidae from the environs of Sendai; part 9, on Pecten (Chlamys) miyatokoensis Nomura and Hatai: Palaeontological Society of Japan Transactions and Proceedings, new ser., no. 24, p. 247-250, pl. 35.

1962, Tertiary Pectinidae of Japan: Tohoku University Science Reports, ser. 2, v. 33, no. 2, 238 p., 27 pls.

1963, The so-called Patinopecten of Japan: Palaeontological Society of Japan Transactions and Proceedings, new ser., v. 52, p. $145-153$, pls. $22,23$.

1971a, On some Patinopecten from North America: Palaeontological Society of Japan Transactions and Proceedings, new ser., no. 83, p. 166-178, pls. 19-21.

1971b, Amussiopecten from North America and northern South America: Palaeontological Society of Japan Transactions and Proceedings, new ser., no. 84, p. 205-224, pls. 25, 26.

1972, Swiftopecten of the northern Pacific: Palaeontological Society of Japan Transactions and Proceedings, new ser., no. 87, p. $395-408$, pls. 48,49 .

Masuda, Kôichirô, and Akutsu, Jun, 1956, A new fossil Chlamys from the environs of Utsunomiya City, Japan: Palaeontological Society of Japan Transactions and Proceedings, new series, no. 21, p. 129-132.

Masuda, Kôichirô, and Sawada, Yoshio, 1961, Some new Tertiary pectinids from southwestern Hokkaido, Japan: Japanese Journal of Geology and Geography, v. 32, no. 1, p. 19-29, pl. 4.

Meek, F. B., 1864, Check list of the invertebrate fossils of North America; Miocene: Smithsonian Miscellaneous Collection, v. 7, no. $183,32 \mathrm{p}$.

Mina, Federico, 1956, Geologia de la Parte Sur de la Peninsula de Baja California: International Geological Congress, 20th, Mexico City, Mexico, 1956, Excursion A-7, 79 p., [5 maps, 1 table].

Minch, J. C., Gastil, Gordon, Fink, William, Robinson, John, and James, A. H., 1976, Geology of the Vizcaino Peninsula, in Howell, D. G., ed., Aspects of the geologic history of the California continental borderland: American Association of Petroleum Geologists, Pacific Sec., Misc., Pub. 24, p. 136-195, 5 text figs.

Moody, C. L., 1916, Fauna of the Fernando of Los Angeles: University of California Publications Department of Geology Bulletin, v. 10 , no. 4 , p. $39-62$, pls. 1-2.

Moore, E. J., 1963, Miocene marine mollusks from the Astoria Formation in Oregon: U.S. Geological Survey Professional Paper 419, 109 p., 32 pls., 9 figs., 3 tables [1964].

1968, Fossil mollusks of San Diego County [California]: San Diego Society of Natural History Occasional Paper 15, 76 p., 34 pls.

1979, Sculptural variation of the Pliocene pelecypod Patinopecten healeyi (Arnold): U.S. Geological Survey Professional Paper 1003, 15 p., 15 pls.

Moore, R. C., ed., 1969, Treatise on invertebrate paleontology: Geological Society of American and University of Kansas, pt. N, Mollusca, v. 1 and 2, 952 p., illus.

Mount, J. D., 1974, Molluscan evidence for the age of the Imperial Formation, southern California [abs.]: Southern California Academy of Sciences, Annual Meeting, May 3 and 4, p. 29.

Müller, O. F., 1776, Zoologiae Danicae Prodromus, seu Animalium Daniae et Novegiae Indigenarum, characteres, nomina, et synonyma imprimis popularium: Haviniae, v. $32,282 \mathrm{p}$.

Nilsen, T. H., Dibblee, T. W., Addicott, W. O., 1973, Lower and middle Tertiary stratigraphic units of the San Emigdio and western Tehachapi Mountains, California: U.S. Geological Survey Bulletin 1372-H, 22 p., 3 figs.

Nomland, J. O., 1917a, The Etchegoin Pliocene of middle California: University of California Publications, Department of Geology Bulletin, v. 10, no. 14, p. 191-254, pls. 6-12, 2 text figs.

$1917 \mathrm{~b}$, Fauna of the Santa Margarita beds in the North Coalinga region of California: University of California Publications, Department of Geology Bulletin, v. 10, no. 18, p. 293-326, pls. 14-20.

Oakeshott, G. B., 1958, Geology and mineralogy deposits of San Fernando quadrangle, Los Angeles County, California: California Division of Mines Bulletin 172, $147 \mathrm{p}$.

Oldroyd, I. S., 1920, New species of West Coast shells: Nautilus, v. 33, p. 135-136.

1924, The marine shells of the West Coast of North America: Stanford University Publications Department of Geological Sciences, v. 1, no. 1, 247 p., 57 pls. [1925].

Olsson, A. A., 1961, Mollusks of the tropical eastern Pacific: Ithaca, N.Y., Paleontological Research Institute, 547 p., 86 pls.

Orbigny, Alcide d', 1834-47, Voyage dans l'Amerique Meridionale, $* * *$ Mollusques: Paris, v. 5, pt. 3, 758 p.; atlas 85 pls.

Page, B. M., Marks, J. G., and Walker, G. W., 1951, Stratigraphy and structure of mountains northeast of Santa Barbara, California: American Association of Petroleum Geologists Bulletin, v. 35, no. 8, p. 1727-1780.

Palmer, D. B. K., 1923, A fauna from the middle Eocene shales near Vacaville, California: University of California Publications Department of Geological Sciences Bulletin, v. 14, no. 8, p. 
289-318, figs. 52-57.

1958, Type specimens of marine Mollusca described by P. P. Carpenter from the West Coast: Geological Society of America Memoir 76, 376 p., 35 pls., 2 tables.

Peck, J. H., Jr., 1960, Paleontology and correlation of the Ohlson Ranch Formation [California]: University of California Publications in Geological Sciences, v. 36, no. 4, p. 233-242, pl. 21.

Repenning, C. A., and Vedder, J. G., 1961, Continental vertebrates and their stratigraphic correlation with marine mollusks, eastern Caliente Range, California, in Geological Survey research, 1961: U.S. Geological Survey Professional Paper 424-C, p. C235-C239.

Rodda, P. U., 1957, Paleontology and stratigraphy of some marine Pleistocene deposits in northwest Los Angeles Basin. California: American Association of Petroleum Geologists Bulletin, v. 41, no. 11, p. 2475-2492, 12 figs.

Roth, Barry, 1979, Late Neogene of northern California and southern Oregon: University of California, Berkeley, Ph.D. dissertation, 800 p., 6 pls.

Roth, Barry, and Coan, E. V., 1978, Nomenclature notes on Hinnites giganteus (Gray): The Veliger, v. 20, no. 3, p. 297.

Sakamoto, Kenji, 1973, Techniques for photographing modern mollusks: The Veliger, v. 16, no. 2, p. 140-142, 1 pl.

Schenck, H. G., and Keen, A. M., 1940, California fossils for the field geologist (preliminary edition): Stanford, California, privately printed, $86 \mathrm{p} ., 56 \mathrm{pls}$.

1950, California fossils for the field geologist: Stanford, California, Stanford University Press, 88 p., $56 \mathrm{pls}$.

Slodkewitsch, W. S., 1938, Tertiary Pelecypoda from the Far East, v. 10, pt. 2: Union of Soviet Socialist Republic Academy of Sciences, Paleontological Institute, Paleontology of USSR, v. 10, pt. 3, fasc. 19,275 p., 106 pls.

Smith, A. G., and Gordon, Mackenzie, Jr., 1948, The marine mollusks and brachiopods of Monterey Bay, California: California Academy of Sciences Proceedings, ser. 4, v. 26, no. 8, p. 147-2े45, pls. $3,4,4$ figs.

Smith, J. P., 1912, Geologic range of Miocene invertebrate fossils of California: California Academy of Sciences Proceedings, ser. 4, v. 3 , no. 8 , p. 161-182.

1916. The geologic formations of California, with reconnaissance geologic map: California State Mining Bureau Bulletin $72,47 \mathrm{p}$.

Smith, J. T., 1975, Age, correlation, and possible Tethyan affinities of mollusks from the Lodo Formation of Fresno County, California, in Weaver, D. W., Hornaday, G. R., and Tipton, Ann, eds., Paleogene symposium and selected technical papers, Conference on future energy horizons of the Pacific Coast: American Association of Petroleum Geologists, Society of Economic Paleontologists and Mineralogists, and Society of Economic Geologists, Ann. Mtg., Pacific Secs., Long Beach, Calif., p. 464-483, 2 pls., 3 figs., 3 tables.

Soper, E. K., and Grant, U. S., 4th, 1932, Geology and paleontology of a portion of Los Angeles, California: Geological Society of America Bulletin, v. 43, no. 12, p. 1041-1068, 7 figs.

Sowerby, G. B. (first of name), 1835, Characters of and observations on new genera and species of Mollusca and Conchifera collected by Mr. Cuming: Zoological Society of London Proceedings, 1835, pt 3., p. 4-7, 21-23, 41-47, 49-51, 84-85, 93-96, 109-110.

Sowerby, G. B., Jr. (second of name), [1842] 1847-1887, Thesaurus conchyliorum or monographs of genera of shells, edited by G. B. Sowerby, Jr., completed by G. B. Sowerby [third of name]: London, v. 1-5.

Squires, R. L., and Fritsche, A. E., 1978, Miocene macrofauna along Sespe Creek, Ventura County, California, in Fritsche, A. E., ed.,
Depositional environments of Tertiary rocks along Sespe Creek, Ventura County, California: Pacific Coast Paleogeography Field Guide 3, Pacific Section, Society of Economic Paleontologists and Mineralogists, Los Angeles, California.

Stanley, S. M., 1970, Relation of shell form to life habits of the Bivalvia (Mollusca): Geological Society of America Memoir 125, 296 p., 40 pls., 7 tables.

Stanton, R. J., Jr., 1966, Megafauna of the upper Miocene Castaic Formation, Los Angeles County, California: Journal of Paleontology, v. 40 , no. 1 , p. $21-40,3$ pls.

Stanton, R. J., Jr., and Dodd, J. R., 1976, Pliocene biostratigraphy and depositional environments of the Jacalitos Canyon area, California, in Fritsche, A. E., Best, H. T., Jr., and Wornardt, W. W., The Neogene Symposium: Society of Economic Paleontologists and Mineralogists Pacific Section, Annual Meeting, p. 85-94, 5 figs., 2 tables.

Stewart, R. B., 1930, Gabb's California Cretaceous and Tertiary type Lamellibranchs: Philadelphia Academy of Natural Sciences Special Publication 3, 314 p., 17 pls.

1946, Geology of Reef Ridge, Coalinga district, California, in Shorter Contributions to General Gealogy : U.S. Geological Survey Professional Paper 205-C, p. 81-115, pls. 9-17.

Stump, T. E., 1979, The evolutionary biography of west Mexican Pectinidae (Mollusca: Bivalvia): University of California (Davis), Ph.D. dissertation, 520 p., 19 pls.

Susuki, Takeo, and Stadum, C. J., 1978, A Neogene section, northeastern San Clemente Island, California: Los Angeles County Natural History Museum, Contributions in Science, no. 299, 24 p., 29 figs.

Trask, J. B., 1856, Description of three new species of the genus, Plagiostoma from the Cretaceous rocks of Los Angeles: California Academy of Sciences Proceedings, v. 1, p. 86, pl. 3.

Trask, P. D., 1922, The Briones Formation of middle California: University of California Publications, Department of Geological Sciences Bulletin, v. 13, no. 5, p. 133-174, pls. 1-8.

Tucker-Rowland, H. I., 1938, The Atlantic and Gulf Coast Pectinidae of the United States: Musee royal d'Histoire Naturelle de Belgique Memoire, ser. 2, fasc. 13, 76 p., 6 pls.

Turton, William, 1822, Conchylia dithyra insularum Britannicarum. The bivalve shells of the British Islands: London, M. A. Nuttali, 4 tomes; reprint, 1848,279 p., 20 pls.

Valentine, J. W., 1957, Late Pleistocene faunas from the northwestern coast of Baja California, Mexico: San Diego Society of Natural History Transactions, v. 12 , no. 16 , p. 289-308, figs. 1-6.

Valentine, J. W., and Meade, R. F., 1961, Californian Pleistocene paleotemperatures: University of California Publioations in Geological Sciences, v. 40, no. 1, p. 1-46, 4 text figs.

Vedder, J. G., 1960, Previously unreported Pliocene mollusca from the southeastern Los Angeles Basin [California], in Short papers in the Geological Sciences: U.S. Geological Survey Professional Paper 400-B, p. B326-B328.

1968, Geologic map of Fox Mountain quadrangle, Santa Barbara County, California: U.S. Geological Survey Miscellaneous Geologic Investigations Map I-547.

1972, Review of stratigraphic names and megafaunal correlation of Pliocene rocks along the southeast margin of the Los Angeles basin, California, in Stinemeyer, E. H., ed., Pacific Coast Miocene Biostratigraphic Symposium: Society of Economic Paleontologists and Mineralogists, Pacific Section, 47th Annual Meeting, March 9-10, 1972, Proceedings, 364 p., illus.

1973, Geologic framework and correlation of Miocene rocks in the Caliente Range, in Sedimentary facies changes in Tertiary rocks-California Transverse and southern Coast Ranges: American Association of Petroleum Geologists, Society of Eco- 
nomic Paleontologists and Mineralogists, and Society of Economic Geologists, Pacific Sections, Annual Meeting, 1973, Society of Economic Paleontologists and Mineralogists Trip 2.

Vedder, J. G., Gower, H. D., Clifton, H. E., and Durham, D. L., 1967, Reconnaissance geologic map of the central San Rafael Mountains and vicinity, Santa Barbara County, California: U.S. Geological Survey Miscellaneous Geologic Investigations Map I-487, scale $1: 48,000$.

Vedder, J. G., and Moore, E. J., 1976, Paleoenvironmental implications of fossiliferous Miocene and Pliocene strata on San Clemente Island, California, in Howell, D. G., ed., Aspects of the geologic history of the California Continental Borderland: American Association of Petroleum Geologists, Pacific Section, Miscellaneous Publication 24, p. 107-135, 4 pls., 9 figs., 1 table.

Vedder, J. G., and Norris, R. M., 1963, Geology of San Nicholas Island, California: U.S. Geological Survey Professional Paper 369,65 p., 5 pls., 19 figs., 9 tables.

Verrill, A. E., 1897, A study of the Pectinidae with a revision of the genera and subgenera: Connecticut Academy of Sciences Transactions, v. 10, pt. 1, p. 41-96, pls. 16-21.

Vokes, H. E., 1939, Molluscan faunas of the Domengine and Arroyo Hondo Formations of the California Eocene: New York Academy of Sciences Annals, v. 38, p. 1-246, pls. 1-22.

1955 , in Wilson, I. F., Geology and mineral deposits of the Boleo Copper District, Baja California, Mexico: U.S. Geological Survey Professional Paper 273, 134 p., 11 pls., 38 figs., 33 tables.

Wagner, C. M., and Schilling, K. H., 1923, The San Lorenzo Group of the San Emigdio region, California: University of California Publications, Department of Geological Sciences Bulletin, v. 14, no. 6, p. 235-276, pls. $43-50$.

Waller, T. R., 1969, The evolution of the Argopecten gibbus stock (Mollusca: Bivalvia), with emphasis on the Tertiary and Quaternary species of eastern North America: Paleontological Society Memoir 3 (Journal of Paleontology, v. 43, no. 5, supplement), 125 p., 8 pls., 9 figs., 43 tables.

1971, The glass scallop Propeamussium, a living relict of the past: American Malacological Union Annual Report for 1970, p. 5-7.

1972, The functional significance of some shell microsculptures in the Pectinacea (Mollusca: Bivalvia): International Geologic Congress, Montreal, Section 7, Paleontology, p. 48-56.

1976, The behavior and tentacle morphology of Pteriomorphian bivalves: a motion-picture story: American Malacological Union Bulletin, Inc. for 1975, p. 7-13, 2 figs

1978, Morphology, morphoclines and a new classification of the Pteriomorpha (Mollusca: Bivalvia): Philosophical Transactions of the Royal Society of London, Bulletin 284, p. 345-365, 2 figs., 2 tbls.

Waterfall, L. N., 1929, A contribution to the paleontology of the Fernando Group, Ventura County, California: University of California Publications, Department of Geological Sciences Bulletin, v. 18, no. 3, p. 71-92, pls. 5, 6 .

Watkins, Rodney, 1974, Paleobiology of an offshore molluscan fauna from the California Oligocene: Palaeogeography, Palaeoclimatology, Palaeoecology, v. 15, p. 245-266.

Weaver, C. E., 1942, Paleontology of the marine Tertiary formations of Oregon and Washington: University of Washington [Seattle] Publications in Geology, v. 5, pt. 1, p. 1-274; pt. 3, p. 563-790, 104 pls.

1949, Geology of the Coast Ranges immediately north of the San Francisco Bay region, California: Geological Society of America Memoir 35, 242 p.

1953, Eocene and Paleocene deposits at Martinez, California:
University of Washington [Seattle] Publications in Geology, v. 7, 102 p., pls. 1,2 .

Weaver, D. W., and Kleinpell, R. M., 1963, Mollusca from the Turritella variata Zone, in Kleinpell, R. M., and Weaver, D. W., Oligocene biostratigraphy of the Santa Barbara Embayment, California: University of California Publications in Geological Sciences, v. 43 , pt. 2, p. 81-161, pls. 18-38.

Weaver, D. W., and Meyer, G. L., 1969, Stratigraphy of northeastern Santa Cruz Island [California], in Weaver, D. W., ed., Geology of the northern Channel Islands: American Association of Petroleum Geologists and Society of Economic Paleontologists and Mineralogists, Pacific Sections, Special Publication, p. 95-104.

Weddle, J. R., 1965, Northeast area of McKittrick oil field [California]: California Oil Fields, v. 52, no. 2, p. 5-20.

White, W. R., 1956, Pliocene and Miocene Foraminifera from the Capistrano Formation, Orange County, California: Journal of Paleontology, v. 30, no. 2, p. 237-260.

Whiteaves, J. F., 1893, Notes on some marine invertebrata from the coast of British Columbia: Ottawa Naturalist, v. 7, p. 133-137, 1 $\mathrm{pl}$.

Wiedey, L. W., 1928, Notes on the Vaqueros and Temblor Formations of the California Miocene with descriptions of new species: San Diego Society of Natural History Transactions, v. 5, no. 10 , p. 95-182, pls. 9-21.

Willett, George, 1937, An upper Pleistocene fauna from the Bald win Hills, Los Angeles County, California: San Diego Society of Natural History Transactions, v. 8, no. 30, p. 379-406, pls. 25, 26.

1938, Report on Pleistocene molluscan fauna at Capistrano Beach, Orange County, California: Southern California Academy of Sciences Bulletin, v. 36, pt. 3, p. 105-107.

1946. Additional notes on the Pliocene molluscan fauna of Los Angeles city [California]: Southern California Academy of Sciences Bulletin, v. 45, pt. 1, p. 28-32.

Wilson, E. J., 1954, Foraminifera from the Gaviota Formation east of Gaviota Creek, California: University of California Publications in Geological Sciences, v. 30, no. 2, p. 103-170.

Wilson, I. F., 1948, Buried topography, initial structures, and sedimentation in Santa Rosalia area, Baja California, Mexico: American Association of Petroleum Geologists Bulletin, v. 32, no. 9, p. 1762-1807, 3 tbls.

Winterer, E. L., and Durham, D. L., 1962, Geology of southeastern Ventura basin, Los Angeles County, California: U.S. Geological Survey Professional Paper 334-H, p. H275-H366, pls. 44-49, figs. $49-68,11$ tables.

Wissler, S. G., 1941, Stratigraphic formations of the producing zones of the Los Angeles Basin oil fields [California]: California Division of Mines Bulletin 118, p. 209-234, pl. 5, figs. 81-91.

Woodring, W. P., 1930, Pliocene deposits of Simi Valley, California: California Academy of Sciences Proceedings, ser. 4, v. 19, no. 6, p. $57-64$.

1931, in Hoots, H. W., Geology of the eastern part of the Santa Monica Mountains, Los Angeles County, California: U.S. Geological Survey Professional Paper 165-C, p. C83-C134, pls. 18-33.

1938, Lower Pliocene mollusks and echinoids from the Los Angeles basin, California and their inferred environment: U.S. Geological Survey Professional Paper 190, 67 p., 9 pls.

1946, in Woodring, W. P., Bramlette, M. N., and Kew, W. S. W., Geology and paleontology of Palos Verdes Hills, California: U.S. Geological Survey Professional Paper 207, 145 p., 37 pls. 1950 , in Woodring, W. P., and Bramlette, M. N., Geology and paleontology of the Santa Maria district, California: U.S. Geological Survey Professional Paper 222, 185 p., 23 pls., 9 figs. 
Woodring, W. P., Stewart, Ralph, and Richards, R. W., 1940, Geology of the Kettleman Hills oil field, California: U.S. Geological Survey Professional Paper 195, 170 p., 57 pls., 15 figs. [1941]. Yokoyama, Matajiro, 1926, Fossil shells from Sado: Imperial University of Tokyo, Journal of the Faculty of Science, ser. 2, v. 1, pt. 8 , p. $249-312$, pls. $32-37$.

Yonge, C. M., 1962, On the primitive significance of the byssus in the bivalvia and its effects in evolution: Marine Biological Associa- tion of the United Kingdom Journal, v. 42, p. 113-125, 6 text figs. Yonge, C. M., and Thompson, T. E., 1976, Living marine mollusks: William Collins Sons and Co., London, 188 p., 16 pls., 162 figs. Zinsmeister, W. J., 1970, A late Pliocene macrofossil fauna of Newport Beach, Orange County, California: Southern California Academy of Sciences Bulletin, v. 69, no. 3 and 4, p. 121-125 [1971]. 



\section{INDEX}

[Italic page numbers indicate major references]

\section{A}

abbotti, Argopecten, 41

Argopocten abietis, 32, 41, 42; pl. 12

Chlamys (Argopecten)abietis, 42

Abbreviations, 6

abiotis, Aoquipocten, 41

Argopocten, 41

abietis, 32,41 ; pls. 11, 12

Chlamys (Argopecten) 41, 42

Pecton, 41

(Plagioctonium) 41

abiotis abbotti, Argopecten. 32. 41.42; pl. 12 abbotti, Chlamys (Argopecten), 42 abiotis, Argopecten, 32,41; pls. 11, 12 Acknowledgments, $\sigma$

"cutus, Cyclopecten, 8

adekunbiana, Swiftopecten, 51, 52; pl. 21

adheren.s, Mycale, 29

adnencus, Pecten, 78

Acquipccten, 2, 22, $31,32,39,42,43$

abietis, 41

andersoni, 45

subundersoni, 45

antonitacnsis, 37, 41

circularis, 34,35

bramkampi, 35

oldridgei, 36

imposter, 36

dallasi, $s 1 ;$ pl. 9

deserti, 33

discus, 47

impostor, 36, 41

percarus, 41

raymondi, 47

brionianus, 47

rovelloi, 38,40

svordmepi. 34

(Plagioctonium) circularis, 34

(Aoquipocten) andersoni, Pecten, 45 bollilamellatus, Pecten, 43

discus, Pecten, 47

cldridyai, Pecton, 36

cvormeanni, Pecten, 39

gibbus circularis, Pecten, 37

pablognsis, Pecten, 47

percarus, Pecten, 39

pracvalidus, Pocten, 42

purpuratus callidus, Pecten, 38

hakci, Pocten, 39

percarus, Pecten, 39

subdolus, Pecten, 37

tumbezensis, Pecten, 49

aequisulcata, Chlamys (Argopecten), 42

Chlamys (Argopecten) circularis, 34, 42 circularis, 37

acquisulcatus, Argopecten, 35

Agua Sundstone Member, Temblor Formation $57,63,90$

aidei, Pecten interlineatus, 29

alaskcnse, Parvamussium, 9, 11; pl. 2

Polynomamussium, 11, 12

Propeamussium (Parvamussium), 11

alaskensis, Parvamussium, pl. 2

Pocton, 11, 12

(Pseudamussium?), 11

albicans, Pecten, 69

Alegria Formation, 61, 90

aletes, Pocten, 67

Peiten (Janira) humphreysii, 67 (Pecten), 67; pl. 28

alexclarki, Vertipecten, $61 ;$ pl. 24
Almejas Formation, 23, 26, 33, 34, 35, 37, 38, 39, $40,41,43,44,54,55,56,58,60,68,69$, $73,77,83,88,89,91$; pls. $10,11,12,13$, $19,20,21,22,23,28,33$

Altamira Shale, 18

Altamira Shale Member, Monterey Shale, 45, 90 alternilineatus, Delectopecten, 14, 15; pl. 2

Hyalopecten (Delectopecten), 15

Pecten, 15, 16

(Pseudamusium), 13

(Pseudomuseum), 15

Amusium, 2, 48, 66, 69

group, 13

lompocensis, 66,67 ; pl. 2

pleuronectes, 66

(Cyclopecten) pernomus, 8

(A musium) lompocensis, Pecten, 66, 67, 70

mortoni, Pecten, 67

Amussiopecten, $2,69,84$

vanvlecki, 67, 9, 74; pls. 29, 30

anapleus, Chlamys, 18, 29, 31; pl. 7

Anchor Silt Member, San Pedro Formation, 26, 84,90

andersoni, Aequipecten, 45

Leptopecten, 45,47

Pacipecten andersoni, 44, 45 ; pl. 14

Pecten, 35, 45, 46

(Aequipecten), 45

(Plagioctenium), 45

andersoni, Pacipecten, 44,$45 ;$ pl. 14

barkerianus, Pacipecten, 44, 45; pl. 20

Pecten (Plagioctenium), 45 gonicostatus, Pecten (Pecten), 47

subandersoni, Aequipecten, 45

Pacipecten, 44, $45 ; \mathrm{pl} .14$

Pecten (Plagioctenium), 45

annulatus, Plagiostoma, 13, 18

Antelope Shale Member, Monterey Formation, 15,90

Antipecten, 42,43

Antipecten?, 2, 42

praevalidus, $42 ; \mathrm{pl} .13$

antonitaensis, Aequipecten, 37, 41

Argopecten, 32, 33, 41; pl. 11

arces, Pecten (Pseudamusium), 13

Ardath Shale, 10, 90; pl. 1

Argopecten, 2, 31, 82, 39, 55

abbotti, 41

abietis, 41

abbotti, 32, 41, 42; pl. 12

abietis, 32,41 ; pls. 11, 12

aequisulcatus, 35

antonitaensis, 32, 33, 41; pl. 11

callidus, $32,33, s 8$; pl. 10

circularis, $34,35,36$

bramkampi, 32,$35 ;$ pl. 9

calli, 32,35 ; pl. 10

circularis, 32,$34 ; \mathrm{pl} .9$

eldridgei, $32, s 6 ;$ pl. 9

imposter, $32, s 6$; pl. 10

sensu lato, 35

cristobalensis, $32,40,42 ;$ pl. 13

deserti, $32, s s, 36 ;$ pl. 9

diminutivus, 32,$35 ; \mathrm{pl} .9$

ericellus, 32,37 ; pl. 12

evermanni, $32,39,40,42 ; \mathrm{pl}, 13$

geographic distribution, 32

geologic distribution, 32

gibbus, 35

imposter, 34 vanvlecki, Pecten, 67

(Amussiopecten) lompocensis, Pecten, 66, 67

hakei, $32,89,42 ; \mathrm{pl} .11$
Argopecten-continued

invalidus, $32,33,87 ;$ pl. 10

mendenhalli, 32,89 ; pl. 9

nucleus, 35

percarus, $32,39,41 ;$ pls. 10,12

revellei, 32,$40 ;$ pl. 11

subdolus, $32,33, s 7,40 ;$ pl. 10

sverdrupi, $32, s 4 ; \mathrm{pl} .9$

species $a, 41$

(Argopecten) abietis, Chlamys, 41, 42

abietis abbotti, Chlamys, 42

aequisulcata, Chlamys, 34, 42

calli, Chlamys, 35

circularis, Chlamys, 34

aequisulcata, Chlamys, 34, 42

calli, Chlamys, 35

cooperi, Chlamys, 37

coopericellus, Chlamys, 37

cristobalensis, Chlamys, 40

deserti, Chlamys, 33

ericellus, Chlamys, 37

evermanni, Chlamys, 39

hakei, Chlamys, 39, 42

invalida, Chlamys, 3 ?

revellei, Chlamys, 40

subdola, Chlamys, 38

subdolus, Pecten, 37

Argopecten?, 42

crassiradiatus, 32,$42 ; \mathrm{pl} .10$

arnoldi, Chlamys (Nodipecten), 12

Arroyo Hondo Shale Member, Lodo Formation, 9 10

ashleyi, Lyropecten, 55 ; pls. 20, 21

Pecten, 55

(Lyropecten), 55

Astoria Formation, 79, ' 1 ; pls. $3,27,34,35$

Athlopecten, 60

auburyi, Pecten, 68, 77

Pecten (Pecten), 68

aztecus, Pecten, 77

bakeri, Leopecten, 85

Leopecten bakeri, 84,854 pl. 40

Patinopecten, 85, 86

Pecten, 72, 85

(Janira) stearnsii, 85

(Patinopecten), 84, 85

bakeri, Leopecten, 84,$85 ; \mathrm{pl} .40$

diazi, Leopecten, 84,85 ; pls. 39,40

Patinopecten, 85, 86

Pecten, 85

barkeriana, Chlamys, 45

barkerianus, Pacipecten andersoni, 44, 45; pl. 20

Pecten (Plagioctenium) andersoni, 45

bartschi, Chlamys, 18, 25; pl. 6

Pecten (Chlamys), 25 (Pecten), 25

beali, Flabellipecten, $71,7 s ;$ pl. 31

Pecten, 73

(Pecten), 73

behringiana, Chlamys, 29

Chlamys (Chlamys), 31 islandica, 31

bella, Janira, 68

bellilamellata, Chlamys (Leptopecten), 43

bellilamellatus, Leptopecten, $43 ; \mathrm{pl} .13$

Pecten (Aequipecten), 43 (Chlamys), 43

bellistriatus, Pecten, 16

bellus, Pecten, 67, 68, 69, 74, 75, 76 
bellus-continued

Pecten (Pecten), 67, 68; pl. 29 coalingaensis, Pecten (Janira), 76 hemphillii, Pecten (Janira), 68

benedicti, Hinnites, $65 ; \mathrm{pl} .26$

benedictus, Pecten, 78

beriangiana, Chlamys (Chlamys), 31 beringianus, Chlamys islandicus, 29

biformatis, Pecten crassicardo, 51

biformatus, Pecten, 51

bilineatus, Pacipecten, 44, 48; pl. 15 Pecten, 48 (Plagioctenium), 48

boesei, Flabellipecten, 71

Boleo Formation, 29, 33, 72, 91 bosei, Flabellipecten, 72 ; pl. 32 bösei, Pecten, 73

Pecten (Pecten), 72

bowersi, Lyropecten, 62

Pecten, 63

(Lyropecten), 62

(Vertipecten), 6

Vertipecten, 61, 62, 64; pls. 24, 25

bramkampi, Aequipecten circularis, 35

Argopecten circularis, 32,$35 ;$ pl. 9

Chlamys circularis, 35,36

Branch Canyon Sandstone, 45, 47, 53, 54, 66, 67 , 70,90

branneri, Chlamys, 18, 19, 62; pl. 4

Pecten, 20, 60

(Chlamys), 19

Briones Sandstone, 46, 47, 48, 52, 53, 80, 89; pls. $14,17,18$

San Pablo Group, 90

brionianus, Aequipecten raymondi, 47

Pacipecten, pl. 14

Pecten, 47

(Pecten) raymondi, 47

raymondi, 47

buchivacoanus, Pecten (Chlamys), 22

Butano Sandstone, 7, 10, 90; pl.

Buttonbed Sandstone Member, Temblor Formation, 45, 53, 54, 70, 90

calamitus, Parvamussium, 12; pl. 2 Pecten, 11

calaverasensis, Patinopecten, 78,$80 ;$ pl. 35 Pecten haywardensis, 80 (Patinopecten) haywardensis, 80 californicus, Capulus, 74 calkinsi, Chlamys, 18, 19; pl. 3

Pecten (Chlamys), 19

calli, Argopecten circularis, 32,$35 ; \mathrm{pl} .10$

Chlamys (Argopecten) circularis, 35 circularis, 35,36

Pecten, 33, 35

(Plagioctenium), 32, 34, 35

callida, Chlamys, 37, 38

Chlamys (Argopecten), 38

callidus, Argopecten, $32,33,38 ;$ pl. 10

Pecten, 33, 40

(Aequipecten) purpuratus, 38

(Plagioctenium), 38

Camptochlamys, 12

(Camptonectes) harfordus, Pecten, 16

cancellosus, Patinopecten oregonensis, 83

Cantil Costero Formation, 60, 91

Capay Formation, 7, 90

Capistrano Formation, 15, 24, 59, 66, 83, 90

Capulus californicus, 74

Careaga Formation, 23

Cebada Member, 88

Careaga Sand, Cebada Member, 90

Graciosa Member, 91
Careaga Sandstone, 60,90

Cebada Member, 23, 56, 60, 69, 83, 90

Graciosa Member, 69, 83, 91

Carmen Formation, 32, 40, 41, 58, 69, 71, 85, 88, 91; pls. $11,39,40$

Carneros Sandstone Member, Temblor Formation, 50, 51, 65, 90

carrizoensis, Flabellipecten, $71 ; \mathrm{pl} .31$

Pecten, 71, 72, 73

(Janira) stearnsii, 7

(Pecten), 71

Cascajo jconglomerate Member, San Joaquin Formation, 36, 90

Castaic Formation, 22, 47, 53, 54, 59, 66, 90

catalinae, Chlamys (Lyropecten) estrellanus; 56

Lyropecten, $49,53,54 ;$ pl. 18 estrellanus, 56

Pecten, 53

(Lyropecten) estrellanus, 53

cataractes, Pecten, 76, 77

Pecten (Euvola), 77

catilliformis, Pecten, 64

caurinus, Patinopecten, $78,79,82,83$; pls. 38,39

Patinopecten (Patinopecten), 83

Pecten, 64, 80, 81, 83, 84, 85, 87 (Patinopecten), 12, 83

yessoensis,.Pecten, 84

Cebada Member, Careaga Formation, 88

Careaga Sand, 90

Careaga Sandstone, 23, 56, 60, 69, 83, 90

cerritensis fragilis, Leptopecten latiauratus, 44

Cerros Shale Member, Lodo Formation, 9, 89, 90; pl. 1

cerrosensis, Chlamys, 56

Chlamys (Lyropecten), 40, 55, 56

Lyropecten, 33, 49, 52, 54, 55; pls. 20,21

Pecten, 33, 40, 54, 55

(Lyropecten), 55

estrellanus, 55

(Plagioctenium), 55

mendenhalli, Pecten, 40

Pecten (Plagioctenium), 33

Chamisal Formation, 45, 90

Los Tularcitos Member, 46, 91

chinkopensis, Chlamys, 27

Chlamys, 2, 18, 30, 31, 48, 50, 61, 62, 65, 66, 83

anapleus, 18, 29, 31; pl. 7

barkeriana, 45

bartschi, 18, 25; pl. 6

behringiana, 29

branneri, $18,19,62 ; \mathrm{pl} .4$

calkinsi, 18,$19 ; \mathrm{pl} .3$

callida $, 37,38$

cerrosensis, 6

chinkopensis, 27

circularis, .34, 35, 37, 38

aequisulcata, 37

bramkampi, 35, 36

calli, 35,36

group, 37

condylomatus, 12

corteziana, 18, 22; pl. 5

crassiplicatus, 65

cristobalensis, 39,40

dallasi, 31

deserti, 33, 34, 38

group, 33

discus, 47

durhami, 21, 22; pl. 5

egregius, 18, 22, 24; pl. 6

eldridge $i, 3$

etchegoini, 29, 60

geographic distribution, 18

geologic distribution, 18

group, 18,65

hakei, 39, 40

hastata, 22, 23, 24, 27, 29, 66
Chlamys-continued

hastata-continued

ellisi, 18, 24

group, 24

hastata, 18, 22; pl. 5

hericia, $23,27,29$

hericius, $18,23,27 ; \mathrm{pl} .5$

pugetensis, 18, 23, 24, 27, 29; pl. 6

hastatus, 23

hataii, 26

hericius, 23

hertleini, 18, 21, 26; pl. 4

hodgei, $18,20,21 ;$ pls. 4,5

imanishii, 28

impostor, 38

invalida, 37,38

islandica, 24, 27, 28

behringiana, 31

group, 26

islandicus, 2

beringianus, 29

group, 29

jordani, 25

jordani, 18, 21, 25, 28; pl. 6

kincaidi, 26

kinoshitai, 27

lowei, 22

mediacostata, 30

grewingki, 29

mediacostata, 2

miyatokoensis, 24

opuntia, 18,26, 29; pl. 6

parmeleei, 29, 59

etchegoini, 59, 60

parmeleei, 60

picoensis, 18,27 ; pl. 7

proavus; 18,$19 ; \mathrm{pl} .3$

pugetensis, 27

purpurata, 39, 40

raymondi, 47

revellei, 40

rubida, 18, 26, 27, 28; pl. 7 jordani, 25, 29

sacyi, 43

sanctiludovici, 18, $\$ 2,32 ; \mathrm{pl} .5$

sespeensis, 18,$20 ; \mathrm{pl} .4$ hyde i, 18, 20; pl. 4

subdola, 38

swiftii, 59

tamurae, 2

venturaensis, 27, 28; pl. 7

(Argopecten) abietis, 41, 42 abietis abbotti, 42

aequisulcata, 42

callida, 38

circularis, 34

aequisulcata, 34, 42

calli, 35

cooperi, 37

coopericellus, 37

cristobalensis, 40

deserti, 33

ericellus, 37

evermanni, 39

hakei, 39, 42

invalida, 37

revellei, 40

subdola, 38

(Chlamys) beringiana, 31

hastata, 22

ellisi, $24 ; \mathrm{pl}, 5$

hericius, 23

jordani, 25

opuntia, 26

picoensis, 27

pugetensis, 27

rubida, 28

jordani, 25 
Chlamys-continued

(Leochlomys) tugidakensis, 30

(Leptopecten.) bellilamellata, 43 latiaurata, 43, 44 monotimaris, 44 tumbezensis, 49

(Lyropecten) corrosensis, 40, 55, 50 crassicardo, 56 ostrollamus, 56 catalimas, 50 gallegosi, 56

(Nodipoctert) armoldi, 12

(Swiftopecton) parmelosi, 59 parmoleci etchogoini, 60 swiftii, 12,59

(Swiftopecten?) hamlini, 60

Chlamys?, 18,20

yrowinghi, 29, 30

modiacostatat, 30

growinghi, 18,$29 ;$ p1. 7 mediacostata, 18, $29 ; \mathrm{pl} .7$

(Chlamys), Pocten, 21

bartschi, Pucten., 25

bohringiana, Chlamys, 31

bollilamellatus, Pecten, 43

boringiana, Chlamys, 31

brannori, Peotom, 19

buchivacoanus, Pocten, 22

calkinsi, Pocten, 19

columbianu, Pecten, 30

dullasi, Pecten, 31

orici, Pocten, 38

fucanus, Pectom, 63

hamlini, Pecton, 60

hastata, Chlamys, 22 ollisi, Chlamys, 24; pl. 5 horicins, Chlomys, 23

hastatus, Pocten, 22

hericous, Pecten, 23 hindsii, Pecten, 28 strutogus, Pocton, 29

horiceus strotegus, Pocten, 29

hortloini, Peoten, 21

hodgei, Pecton, 21

islundicus picoonsis, Pecten, 27

jordani, Chlamys, 25

Pecten, 25

lawami, Pacton, 2

maltimugosus, Pocten, 65 crassiplicatus, Pecten, 65

nuttori, Poeten, 31

opuntia, Chlamys, 20

Pocten, 26

pabloonsis, Pocten, 47

parmeleci, Pocten, 59

pieoonsis, Chlamys, 27

proavus, Pecten, 19

pugetensis, Chlamys, 27

mebida, Chlamyn, 28

jordani, Chlamys, 25

rubidus, Pacton, 28

sespeensis, Pocton, 20

hycloi, Pocten, 20

vonturaousis, Pocton, 27

wattsi, Pocton, 31, 59

morani, Pocton, 60

yneziana, Pecten, 61

Cierbo Sundstone, 42, 46, 47, 48, 52, 53, 54, 89; pls. $10,15,28$

Sun Pablo Group, 90

ciorboonsis, Pacipecten, pl. 14

Pecton, 47

(Pecton), 47

circularis, Aoquipocton, 34, 35

Aoquipocten (Plagioctonium), 34

Argopecton, 34, 35, 36

circularis, 32,$84 ; \mathrm{pl} .9$ circularis-continued

Chlamys, 34, 35, 37, 38

(Argopecten), 34

Pecten, 33, 34, 36, 41

(Aequipecten) gibbus, 37

(Plagioctenium), 34

aequisulcata, Chlamys, 37

Chlamys (Argopecten), 34, 42

bramkampi, Aequipecten, 35

Argopecten, 32, $35 ;$ pl. 9

Chlamys, 35,36

calli, Argopecten, 32,$85 ;$ pl. 10

Chlamys, 35, 36

(Argopecten), 35

circularis, Argopecten, 32,$84 ; \mathrm{pl} .9$

eldridgei, Aequipecten, 36

Argopecten, 32,$86 ;$ pl. 9

group, Chlamys, 37

imposter, Aequipecten, 36

Argopecten, 32,86 ; pl. 10

sensu lato, Argopecten, 35

Clallam Formation, 63, 90, 91; pl. 26

coalingaensis, Oppenheimopecten, $76 ; \mathrm{pl} .33$

Pecten, 76, 78

(Janira) bèllus, 76

(Oppenheimopecten), 76

(Pecten), 76

coalingaërssis, Pecten, 78

coalingensis, Oppenheimopecten, 75 Pecten, 77

cocosensis, Cyclopecten, 8

Cold Creek Member, Monterey Formation, 53

Topanga Canyon Formation, 90

Topanga Formation, 54

Coldwater Sandstone, 19, 20, 61, 90; pls. 3, 24

Coldwater Sandstone Member, Tejon Formation, 90

columbiana, Leochlamys?, so; pl. 8

Pecten (Chlamys), 30

columbianum, Pecten, 30

compactus, Pecten, 34

Pecten (Pecten), 34

condoni, Yabepecten, 83

condylomatus, Chlamys, 12

Lyropecten, 50

Pecten, 51

cooperi, Chlamys (Argopecten), 37

Pecten, 37

(Plagioctenium), 37

coopericellus, Chlamys (Argopecten), 37

coosensis, Patinopecten, 83

Pecten, 87, 88

(Lituyapecten), 88

dilleri, Pecten (Patinopecten), 88

corteziana, Chlamys, 18, 22; pl. 5

Cozy Dell Shale, 19, 90

Cozy Dell Shale Member, Tejon Formation, 90

crassa, Hinnites, 65; pls. 26, 27

crassicardium, Pallium, 51

crassicardo, Chlamys (Lyropecten), 56

Lyropecten, $49,50,51,54,56 ;$ pls. 17, 18, 21, 28

Pallium, 51

Pecten, 50, 51, 52, 57

(Lyropecten), 51

magnificus, 51

magnificus, 5

biformatis, Pecten, 51

hamiltoni, Lyropecten, 50

Pecten (Lyropecten), 51

nomlandi, Lyropecten, 51

Pecten, 51

vaughani, Lyropecten, 50

crassiplicatus, Chlamys, 65

Hinnites multirugosus, 65

Pecten (Chlamys) nultirugosus, 65

(Pecten) multirugosus, 65

crassiradiatus, Argopecten?, 32,$42 ;$ pl. 10 crassiradiatus - continued

Pecten (Plagioctenium?), 42

cristobalensis, Argopecten, $32,40,42 ; \mathrm{pl} .13$

Chlamys, 39, 40

(Argopecten), 40

Pecten, 40

(Plagioctenium), 40

Cyclopecten, 2, 6, 7, 8, 9, 13

acutus, 8

cocosensis, 8

geographic distribution, 7

geologic distribution, 7

greenlandicus, 13

incongruus, 7,$8 ; \mathrm{pl} .1$

lompicoensis, 7,$8 ; \mathrm{pl} .1$

pernomus, 7,8 ; pl. 1

randolphi, 17

tillamookensis, 17

vitreus, 13

(Delectopecten) randolphi tillamookensis, 17 vancouverensis, 17

(Cyclopecten) pernomus, Amusium, 8

pernomus, Pecten, 8

rotundatus, Pecten, 8

Cyclopecten?, 7,8

martinezensis, 7,$8 ;$ pl. 1

D

dallasi, Aequipecten, $s 1 ;$ pl. 9

Chlamys, 31

Pecten, 31

(Chlamys), 31

davidsoni, Pecten (Propeamussium), 12

Delectopecten, 2, 6, 8, 9,13,14, 16

alternilineatus, 14,$15 ; \mathrm{pl} .2$

geographic distribution, 14

geologic distribution, 14

group, 13

harfordus, 14, 16; pl. 3

lillisi, $14 ; \mathrm{pl} .3$

peckhami , 8, 14,15, 18; pl. 3

pedroanus, 18

randolphi tillamookensis, 14, 16, 17; pl. 3

tillamookensis, 17

vancouverensis, 17

fernandoensis, 14,16 ; pl. 3

sanjuanensis, 17

tillamookensis, 17

vancouverensis, 14,17 ; pl. 3

(Delectopecten) alternilineatus, Hyalopecten, 15

fernandoensis, Hyalopecten, 16

lillisi, Hyalopecten, 14

peckhami, Palliolum, 15

pedroanus, Hyalopecten, 18

randolphi tillamookensis, Cyclopecten, 17 .

vancouverensis, Cyclopecten, 17

zacae, Pecten, 14

delosi, Leptopecten, 43

dentatus, Pecten, 77

Pecten (Pecten), 77

deserti, Aequipecten, 33

Argopecten, 32, 89,36 ; pl. 9

Chlamys, 33, 34, 38

(Argopecten), 33

Pecten, 33, 35, 36

(Lyropecten), 33

(Plagioctenium), 33

group, Chlamys, 33

diabloensis, Pecten, 64

Vertipecten, 61,$64 ;$ pls. 21,39

diazi, Leopecten bakeri, 84, 85 ; pls. 39,40

Patinopecten bakeri, 85, 86

Pecten bakeri, 85

dickersoni, Pecten, 75

Pecten (Pecten), 75 
diegensis, Flabellipecten, 71, 78 ; pls. 31,32

Pecten, 68, 71, 72, 73, 74

(Janira) stearnsii, 73

(Pecten), 73

dilleri, Lituyapecten, 86,88 ; pl. 42

Patinopecten, 88

(Lituyapecten), 87, 88

Pecten, 87, 88

(Lituyapecten), 88

(Lyropecten), 88

(Patinopecten), 88

coosensis, 88

diminutivus, Argopecten, 82,$35 ; \mathrm{pl}, 9$

Pecten (Plagioctenium), 32, 33

discus, Aequipecten, 47

Chlamys, 47

Leptopecten, 47

Pacipecten, 44, 46, 48; pl. 14

Pecten, 35, 45, 46, 48

(Aequipecten), 47

(Plagioctenium), 47

dregeri, Pecten, 12

durhami, Chlamys, 21, 22; pl. 5

Ectyodoryx parasitica, 29

Edna Member, Pismo Formation, 81, 90

egregius, Chlamys, 18, 22, 24; pl. 6 Pecten, 21, 24

eldridgei, Aequipecten circularis, 36 Argopecten circularis, 32,$36 ; \mathrm{pl} .9$ Chlamys, 35

Pecten (Aequipecten), 36 (Plagioctenium), 36

ellisi, Chlamys (Chlamys) hastata, 24; pl. 5 Chlamys hastata, 18, 24

emigdioensis, Macrochlamis, 56; pl. 21 Pecten, 56

(Lyropecten) vaughani, 56, 57

Empire Formation, 86, 91

ericellus, Argopecten, 32,$87 ;$ pl. 12 Chlamys (Argopecten), 37 Pecten (Plagioctenium), 37

erici, Leochlamys?, $30 ; \mathrm{pl} .8$

Pecten (Chlamys), 30

estrellanum, Pallium, 53

estrellanus, Chlamys (Lyropecten), 56 Lyropecten, 49, 50, 52, 5s, 56; pl. 19 Pecten, 29, 50, 52, 53, 55

(Lyropecten), 53

catalinae, Chlamys (Lyropecten), 5

Lyropecten, 56

Pecten (Lyropecten), 53

cerrosensis, Pecten (Lyropecten), 55

terminus, Lyropecten, 56 Pecten (Lyropecten), 54

Etchegoin Formation, 23, 24, 25, 28, 31, 36, 54, 56 $59,60,66,76,81,83,89,90,91 ;$ pls. 6,9 $10,22,23,33$

tchegoini, Chlamys, 29,60

Chlamys parmeleei, 59,60 (Swiftopecten) parmeleei, 60

Pecten, 60

(Pallium) swiftii, 60

Swiftopecten, 60

parmeleei, 59,$60 ;$ pl. 22

nutteri, Pecten, 31

wattsi, Pecten (Swiftopecten), 31

Euvola, 2.70

keepi, 70,$71 ; \mathrm{pl}, 30$

geographic distribution, 70

geologic distribution, 70

refugioensis, 70,$71 ; \mathrm{pl} .30$

Euvola) cataractes, Pecten, 77

keepi, Pecten, 70, 71
(Euvola)-continued

refugioensis, Pecten, 71

evermanni, Argopecten, $32,89,40,42 ;$ pl. 13

Chlamys (Argopecten), 39

Pecten, 39

(Aequipecten), 39

(Plagioctenium), 39

excavatus, Pecten, 69,77

expansus, Pecten, 81

Pecten (Patinopecten), 81

extenuatus, Pecten, 16

\section{$\mathbf{F}$}

Falor Formation, 83, 86, 87, 90, 91; pl. 41 falorensis, Lituyapecten, $86 ; \mathrm{pl} .41$

Patinopecten (Lituyapecten), 86

Pecten, 87

Fernando Formation, 8, 11, 12, 16, 17, 18, 23, 24 $26,27,29,35,37,39,44,56,60,66,69$, $73,82,83,84,88,89,91$; pls. $1,2,3$

fernandoensis, Delectopecten vancouverensis, 14 , $16 ; \mathrm{pl} .3$

Hyalopecten (Delectopecten), 16

Pecten, 16

(Pseudamusium) vancouverensis, 14, 16 vancouverensis, 16

Flabellipecten, 2, 69, 70, 71, 84

beali, 71,73 ; pl. 31

boesei, 71

bosei, 72 ; pl. 32

carrizoensis, $71 ; \mathrm{pl}, 31$

diegensis, 71,73 ; pls. 31,32

geographic distribution, 7

geologic distribution, 71

stearnsii, 71, 72; pl. 31

Flabellipecten?,74

hawleyi, 70,71,74; pl. 31

merriami, 71,74 ; pls. 32,3

(Flabellipecten) stearnsii, Pecten, 72; pl. 31

florida, Janira, 72

floridus, Pecten, 72, 73

Fortipecten, 42

Fossil localities, 8

Foxen Mudstone, 23, 56, 60, 83, 88, 91

fragilis, Leptopecten latiauratus cerritensis, 44

Freeman Silt, 65, 91

fucanus, Pecten (Chlamys), 63

Pecten (Vertipecten) nevadanus, 63

Vertipecten, $61,68,64,79,80$; pls. 26,27

gabbi, Pecten, 64

gallegosi, Chlamys (Lyropecten), 56

Lyropecten, $49,54,56 ;$ pl. 19

Pecten, 55

(Lyropecten), 54, 55

Gaviota Formation, 20, 61, 90, 91; pl. 25

gelatinosus, Hyalopecten, 13

Geographic distribution, Argopecten, 32

Chlamys, 18

Cyclopecten, 7

Delectopecten, 14

Euvola, 70

Flabellipecten, 71

Leopecten, 84

Leptopecten, 43

Lituyapecten, 86

Lyropecten, 49

Nodipecten, 57

Oppenheimopecten, 75

Pacipecten, 44

Parvamussium, 9

Patinopecten, 78
Geographic distribution-continued

Pecten (Pecten), 67

Pectinidae, 2

Propeamussiidae, 2

Swiftopecten, 59

Vertipecten, 61

Geologic distribution, Argopecten, 32

Chlamys, 18

Cyclopecten, 7

Delectopecten, 14

Euvola, 70

Flabellipecten, 71

Leopecten, 84

Leptopecten, 43

Lituyapecten, 86

Lyropecten, 49

Nodipecten, 57

Oppenheimopecten, 75

Pacipecten, 44

Parvamussium, 9

Patinopecten, 78

Pecten (Pecten), 67

Pectinidae, 2

Propeamussiidae, 2

Swiftopecten, 59

Vertipecten, 61

Geologic formations containing pelecypods, 90

gibbus, Argopecten, 35

circularis, Pecten (Aequipecten), 37

gigantea, Lima, 65

giganteum, Plagiostoma, 65

giganteus, Hinnites, 65,66 ; pls. 26, 27

Pecten (Hinnites), 65

Gloria Formation, 22, 35, 38, 40, 41, 43, 72, 78, 85,

gonicostatus, Pacipecten, pl. 14

Pecten, 47

(Pecten) andersoni, 47

Gould Shale Member, Monterey Formation, 45, 53,91

Graciosa Member, Careaga Sand, 91

Careaga Sandstone, 69, 83, 91

Gragg Member, Pismo Formation, 56, 91

greenlandicus, Cyclopecten, 12

grewingki, Chlamys mediacostata, 29

Chlamys?, 29, 30

mediacostata, 18,$29 ; \mathrm{pl} .7$

Gries Ranch Formation, 91

hakei, Argopecten, 32, s9, 41, 42; pl. 11

Chlamys, 39, 40

(Argopecten), 39, 42

Pecten, 39, 55

(Aequipecten) purpuratus, 39

(Plagioctenium), 39

halimensis, Pecten, 21

Hames Member, Monterey Formation, 46, 91

hamiltoni, Lyropecten, pl. 18

Lyropecten crassicardo, 50

Pecten, 52

(Lyropecten) crassicardo, 51

magnificus, 51

hamlini, Chlamys (Swiftopecten?), 60

Pecten, 60

(Chlamys), 60

(Pallium) 60

Swiftopecten?, 59,$60 ; \mathrm{pl}, 24$

hancocki, Pecten (Oppenheimopecten), 78

harfordus, Delectopecten, 14,16 ; pl. 3

Pecten (Camptonectes), 16

Oppenheimopecten, 75, 76; pl. 33

Pecten, 77

(Janira), 76

(Oppenheimopecten), 76

(Pecten), 76 
hartmanni, Oppenheimopecten, 75,76 ; pl. 33

Pecten, 77

(Janira), 76

(Oppenheimopecten), 76

(Pecton), 76

hastata, Chlamys, 22, 23, 24, 27, 29, 66

Chlamys (Chlamys), 22

hastata, 18, 22; pl. 5

ellisi, Chlamys, 18, 24

Chlamys (Chlamys), $24 ;$ pl. 5

group, Chlamys, 24

hastata, Chlamys, 18, 22; pl. 5

horicia, Chlamys, 23, 27, 29

hericius, Chlamys, 18, 2s, 27; pl. 5 Chlamys (Chlamys), 23 Pecten, 20

pugetensis, Chlamys, 18, 23, 24, 27, 29; pl. 6 hastatus, Chlamys, 23

Pocten, 22, 25, 28, 48 (Chlamys), 22 (Pecton), 22

horicius, Pecten, 20 Pocton (Chlamys), 23

hindsii, Pecton (Chlamys), 28

pugetensis, Pecten. (Pecten), 27

strategus, Pecten (Chlamys), 29

hataii, Chlamys, 26

hawleyi, Flabollipecten?, 70, 71, $74 ; \mathrm{pl}, 31$ Pocten, 74 (Pacten), 74

hayvardousis, Patinopocten, 78, 80 ; pls. 35,36

Pocten, 80

(Patinopecten), 80

calaverasensis, Pecten, 80

Pecten (Patinopecten), 80

healeyi, Patinopecten, 78, 79, $81,82,84$; pls. 34,35 $36,37,38,39,40,41,42$

Pocten, 12, 82, 83, 85 (Patinopocten), 81

lohri, Pocten (Patinopecten), 80

sanclementensis, Pecten (Patinopecten), 81

hoormannii, Pecten, 83, 84

hoimi, Opponhoimopecten, 75, 77; pl. 33

Pocton, 76, 77

(Oppenhaimopecten), 77

(Pocton), 77, 78

homphilli, Pecton, 77

Pocten (Pocten), 69

hemphillii, Pocten, 68; pl. 29

Pocton (Janira) bellus, 68 (Pecton), 68

Homphillii, Pecton, 68

horicans, Pecton, 28

navarchus, Pecton, 26, 28

strategus, Pecten, 29

Pecten (Chlamys), 29

hericia, Chlamys hastata, 23, 27, 29

horicius, Chlamys, 23

Chlamys (Chlamys) hastata, 23 hastata, 18, 2s, 27; pl. 5

Pecten, 21, 23 (Chlamys) hastatus, 23 hastatus, 20

Hertlein, L. G., cited, 1

Hertlein, L. G., quoted, 12,13

hortloini, Chlamys, 18, 21, 26; pl. 4

Pecten (Chlamys), 21

hotoroglyptus, Pocten, 31

hindsii, Pecten, 28

Pocten (Chlamys) hastatus, 28

Hinnita poulsoni, 65

Hinnites, 2, 13, 65

benedicti, $65 ; \mathrm{pl} .20$

crassa, 65; pls. 26, 27

giganteus, 65,66 ; pls. 26,27

group, 65
Hinnites-continued

multirugosus, 23, 65, 66

crassiplicatus, 65

pusio, 65

(Hinnites) giganteus, Pecten, 65

hodgei, Chlamys, 18, 20, 21; pls. 4, 5

Pecten, 21

$$
\text { (Chlamys), } 21
$$

holwayi, Pecten, 51, 52, 53; pl. 28

Pecten (Pallium), 51

humphreysii aletes, Pecten (Janira), 67

Hyalopecten, 13

gelatinosus, 13

peckhami, 15

vancouverensis, 17

(Delectopecten) alternilineatus, 15

fernandoensis, 16

lillisi, 14

pedroanus, 18

hydei, Chlamys sespeensis, 18, 20; pl. 4

Pecten, 20

(Chlamys) sespeensis, 20

sespeensis, 30

$$
\text { I, J, K }
$$

imanishii, Chlamys, 28

Imperial Formation, 22, 29, 33, 34, 36, 55, 58, 70 $71,72,88,90,91 ;$ pls. $7,9,30,31$

impostor, Aequipecten, 36, 41

Aequipecten circularis, 36

Argopecten, 34 circularis, 32,36 ; pl. 10

Chlamys, 38

Pecten, 33, 35, 36

incongruum, Pseudamusium, 8

incongruus, Cyclopecten, 7,8 ; pl. 1

inezana, Pecten, 63

Infierno Formation, 35, 38, 41, 49, 58, 72, 78, 85, 91

interlineatus aidei, Pecten, 29

intermedius, Lyropecten, 58

Nodipecten subnodosus, 57, 58; pls. 22, 23

Pecten, 57

(Lyropecten) nodosus, 58

interradiata, Pecten, 10

interradiatum, Propeamussium, 7, 9, 10; pl. 1 Propeamussium (Propeamussium), 7

interradiatus, Pecten, 7

Pecten (Propeamussium), 7

Introduction, 1

intuscostatum, Polynemamussium, 12

invalida, Chlamys, 37, 38

Chlamys (Argopecten), 37

invalidus, Argopecten, 32, 33, s7; pl, 10

Pecten, 33, 37

Isidro Formation, 33, 45, 46, 51, 70, 71, 89, 91; pls 9,17

islandica, Chlamys, 24, 27, 28

behringiana, Chlamys, 31

group, Chlamys, 26

islandicus, Chlamys, 29

Pecten, 20, 27, 28

beringianus, Chlamys, 29

group, Chlamys, 29

jordani, Chlamys, 25

kincaidi, Pecten, 32

picoensis, Pecten (Chlamys), 27

pugetensis, Pecten, 24, 27

Janira bella, 68

florida, 72

(Janira) bellus coalingaensis, Pecten, 76

bellus hemphillii, Pecten, 68

hartmanni, Pecten, 76

humphreysii aletes, Pecten, 67

keepi, Pecten, 70
(Janira)-continued

stearnsii bakeri, Pecten, 85 carrizoensis, Pecten, 71

diegensis, Pecten, 73 stearnsii, Pecten, 72

Jewett Sand, 21, 64, 65, 89, 91

Pyramid Hill Sand Member, 57, 63, 91

jordani, Chlamys, 18, 21, 25, 28; pl. 6

Chlamys (Chlamys), 25

(Chlamys) rubida, 25

islandicus, 25

rubida, 25, 29

Pecten, 21, 25 (Chlamys), 25

juanensis, Oppenheimopecten, $75,76,77$; pl. 33

Pecten, 76, 78

(Oppenheimopecten), 75

(Pecten), 75, 78

kamagai, Mizuhopecten, 1

keepi, Euvola, 70, 71; pl. 30

Oppenheimopecten, 77

Pecten, 70

(Euvola), 70, 71

(Janira), 70

(Pecten), 70

kernensis, Pecten, 64

Pecten (Patinopecten), 64

Vertipecten, $61,63,64 ; \mathrm{pl} .28$

kincaidi, Chlamys, 26

Pecten islandicus, 32

kinoshitai, Chlamys, 27

Kreyenhagen Formation, 14, 15, 91; pl 3

Kreyenhagen Shale, $7,10,14,89,91$; pl.

L

La Jolla Formation, 9

laevis, Pecten, 11

ajollaense, Parvamussium, 9 ; pl. 1

Propeamussium, 9

lajolluensis, Pecten, 9, 10

laqueatus, Pecten, 67

Las Posas Formation, 42, 83, 91

latiaurata, Chlamys (Leptopecten), 43, 44 Leptopecten, 43, 44

latiauratus, Leptopecten, 48 ; pl. 15 Pecten, 43

cerritensis fragilis, Leptopecten, 44

latiauritus, Pecten, 44, 45 monotimeris, Pecten, 45

lawsoni, Pecten, 23

Pecten (Chlamys), 22

leavis, Pecten, 11

lecontei, Pecten, 68

Pecten (Pecten), 67, 68, 69, 72; pl. 28

Leochlamys, $s 0$

Leochlamys?, 2, 30

columbiana, $30 ; \mathrm{pl} .8$

erici, $s 0 ; \mathrm{pl} .8$

porterensis, 30

(Leochlamys) tugidakensis, Chlamys, 30

leohertleini, Parvamussium, 9

Propeamussium, 7, 10

Leopecten, 2, 84

bakeri, 85

bakeri, 84,$85 ;$ pl. 40

diazi, 84,85 ; pls. 39,40

geographic distribution, 84

geologic distribution, 84

marquerensis, 84,85 ; pls. 39,40

Leptopecten, $2,42,49$

andersoni, 45, 47

bellilamellatus, $43 ; \mathrm{pl} .13$

delosi, 43

discus, 47

geographic distribution, 43 
Leptopecten-continued geologic distribution, 43 latiaurata, 43, 44

latiauratus, $43 ;$ pl. 15 cerritensis fragilis, 44 monotimeris, 44 pabloensis, 47

(Leptopecten) bellilamellata, Chlamys, 43 latiaurata, Chlamys, 43, 44 monotimeris, Chlamys, 44 praevalidus, Pecten, 42 tumbezensis, Chlamys, 49

levis, Pecten, 11

Pecten (Propeamusium), 11

lillisi, Delectopecten, $14 ; \mathrm{pl} 3$

Hyalopecten (Delectopecten), 14

Pecten, 14

(Pseudamusium), 14

Lima gigantea, 65

Lincoln Creek Formation, 91

Lindavista Formation, 69, 91

lituyaensis, Pecten, 86 Pecter (Lituyapecten), 87

Lituyapecten, 2, 86

dilleri, 86,$88 ;$ pl. 42

falorensis, 86 ; pl. 41

geographic distribution, 86

geologic distribution, 86

purisimaensis, 86,87 ; pl. 41 turneri, 86,$87 ; \mathrm{pl}, 37$

(Lituyapecten) coosensis, Pecten, 88 dilleri, Patinopecten, 87, 88 Pecten, 88

falorensis, Patinopecten, 86

lituyaensis, Pecten, 87

poulcreekensis, Pecten, 88

purisimaensis, Patinopecten, 87,88 Pecten, 86,88

purisimaensis-falorensis stock, Pecten, 88 yakatagensis, Pecten, 86

Locatelli Formation, 19, 89, 91; pl. 3

Lodo Formation, Arroyo Hondo Shale Member, 9 10

Cerros Shale Member, $9,89,90 ;$ pl. 1

lohri, Patinopecten, $78,79,80,83 ;$ pls. 34,36 Pecten (Patinopecten), 80 (Patinopecten) healeyi, 80

Lomita Marl Member, San Pedro Formation, 12 $17,23,24,26,28,29,44,73,84,9$

lompicoensis, Cyclopecten, 7,8 ; pl.

Pecten (Pseudamusium),

lompocensis, Amusium, 66,$67 ; \mathrm{pl} .2$ Pecten, 67

(Amusium), 66, 67, 70

(Amussiopecten), 66, 67

Los Laureles Sandstone Member, Monterey Formation, 15, 91

Los Tularcitos Member, Chamisal Formation, 46

lowei, Chlamys, 22

Lyropecten, 2, 6, 29, 30, 40, 49, 50, 55, 56, 57

ashleyi, 55; pls. 20,21

bowersi, 62

catalinae, $49,53,54 ; \mathrm{pl} .18$

cerrosensis, $33,49,52,54,55 ;$ pls. 20,21

condylomatus, 50

crassicardo, $49,50,51,54,56 ;$ pls. 17, 18, 21,28 hamiltoni, 50

nomlandi, 51

vaughani, 50

estrellanus, $49,50,52,53,56 ;$ pl. 19

catalinae, 56

terminus, 56

gallegosi $49,54,56$; pl. 19

geographic distribution, 49

geologic distribution, 49

hamiltoni, pl. 18
Lyropecten-continued

intermedius, 58

magnolia, 50, 56

mediacostatus, 29

miguelensis, $49,50,54$; pl. 16

submiguelensis, 50

modulatus , 49, 55, 57, 58; pl. 19

nomlandi, pl. 17

pretiosus, 49,51 ; pl. 17

ricei, pl. 18

submiguelensis, 49, 50, 53; pls. 16, 17

subnodosus, 57,58

terminus, $49,54,56$; pl. 19

vaughani, 49,$50 ; \mathrm{pl} .17$

vickeryi, pl. 17

volaeformis, 53

(Lyropecten) ashleyi, Pecten, 55

bowersi, Pecten, 62

cerrosensis, Chlamiys, 40, 55, 56 Pecten, 55

crassicardo, Chlamys, 56

Pecten, 51

hamiltoni, Pecten, 51

deserti, Pecten, 33

dilleri, Pecten, 88

estrellanus, Chlamys, 56

Pecten, 53

catalinae, Chlamys, 56

$$
\text { Pecten, } 53
$$

cerrosensis, Pecten, 55

terminus, Pecten, 54

gallegosi, Chlamys, 56

Pecten, 54, 55

magnificus crassicardo, Pecten, 51

hamiltoni, Pecten, 51

magnolia, Pecten, 56

miguelensis, Pecten, 49 ubmiguelensis, Pecten, 50

modulatus, Pecten, 55

nodosus intermedius, Pecten, 58

vaughani, Pecten, 50

veatchii, Pecten, 58

perrini, Pecten, 62

pretiosus, Pecten, 51

ricei, Pecten, 51

subnodosus, Pecten, 57, 58

tamiamiensis, Pecten, 29

vaughani, Pecten, 50

emigdioensis, Pecten, 56, 57

veatchii, Pecten, 58

vickeryi, Pecten, 51

M

Macrochlamis, 6,56

emigdioensis, 56 ; pl. 21

magnolia, $56 ;$ pl. 2

Macrochlamys,

mognificus crassicardo, Pecten, 50

crassicardo, Pecten (Lyropecten), 51

hamiltoni, Pecten (Lyropecten), 51

magnolia, Lyropecten, 50, 56

Macrochlamis, $56 ; \mathrm{pl}, 21$

Pecten, 52, 56, 57 (Lyropecten), 56

Manupecten, 24, 59

Margaritan Stage, 47

Maricopa Shale, 15, 91

Marquer Formation, 35, 41, 58, 85, 86, 90, 91; pls. $9,39,40$

marquerensis, Leopecten, 84,$85 ;$ pls. 39,40 Patinopecten, 85

Martinez age strata, 19

Martinez Formation, 9, 91; pl. 1

martinezensis, Cyclopecten?, $7, \delta$; pl. 1 Pecten, 8
McLure Shale Member, Monterey Formation, 46 , $47,53,91$

Temblor Formation, 54

Media Shale Member, Temblor Formation, 46, 54 ,

mediacostata, Chlamys, 30

Chlamys mediacostata, 29

Chlamys?, 30

mediacostata, 18,$29 ; \mathrm{pl} .7$

grewingki, Chlamys, 29

Chlamys?, 18,$29 ; \mathrm{pl} .7$

mediacostata, Chlamys, 29

Chlamys?, 18, 29 ; pl. 7

mediacostatuis, Lyropecten, 29

Pecten, 29

meekii, Pecten, 83, 84

mendenhalli, Argopecten, $32, s s ;$ pl. 9

Pecten, 33, 41

cerrosensis, 40

(Plagioctenium), 33 cerrosensis, 33

Merced Formation, 11, 23, 24, 26, 29, 31, 33, 37, 43, $44,60,66,69,73,83,84,87,88,91 ; \mathrm{pl} .37$ merriami, Flabellipecten?, 71,74; pls. 32, 33

Pecten, 74, 84

(?Patinopecten), 74

(Pecten), 74

mideocenicum, Parvamussium, $9 ; \mathrm{pl} .1$

Propeamussium, 9, 10

miguelensis, Lyropecten, $49,50,54 ; \mathrm{pl}, 16$

Pecten, 50,54 (Lyropecten), 49

submiguelensis, Lyropecten, 50

Pecten (Lyropecten), 50

Mindego Basalt, 57, 91

miyatokoensis, Chlamys, 24

Mizuhopecten, 78

kamagai, 12

Moclipsian molluscan stage, 88

Modelo Formation, 13, 15, 45, 46, 47, 48, 53, 54, 91

modulatus, Lyropecten, 49, 55, 57, 58; pl. 19

Pecten, 55

(Lyropecten), 55

Mohnian benthic foraminiferal stage, 47

Molluscan stage, Moclipsian, 88

monotimeris, Chlamys (Leptopecten), 44 Leptopecten, 44

Pecten latiauritus, 45

Monterey Formation, 8, 15, 16, 21, 45, 47, 53, 54, $66,80,91$; pls. $1,3,14,28$

Antelope Shale Member, 15, 90

Cold Creek Member, 53

Gould Shale Member, 45, 53, 91

Hames Member, 46, 91

Los Laureles Sandstone Member, 15, 91

McLure Shale Member, 46, 47, 53, 91

Saltos Shale Member, 46, 50, 53, 62, 91

Twisselman Sandstone Member, 46, 91 Woodhams Member, 15, 91

Monterey Group, 91 Oursan sandstone, 91

Monterey Shale, 10, 13, 15, 45, 67, 91; pl. 3

Altamira Shale Member, 45, 90

Saltos Shale Member, 70

Valmonte Diatomite Member, 18, 91

Morales Formation, 54, 91

morani, Pecten (Chlamys) wattsi, 60 Swiftopecten, $60 ; \mathrm{pl} .22$

Moreno Formation, 46, 91

mortoni, Pecten (Amusium), 67

Muir Sandstone, 10,91

multirugosus, Hinnites, 23, 65, 66

Pecten, 65

(Chlamys), 65

(Pecten), 65

crassiplicatus, Hinnites, 65

Pecten (Chlamys), 65 


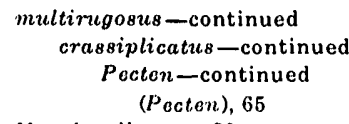

Mycalo adhorens, 29

N

Nanuochlamys, 2, 29, 31 nutteri, $81 ;$ pl. 8

Havarchus, Pocton hericeus, 26, 28

noahonsis, Pecten (Plagioctenium), 35

Neroly Formation, 90 .

Neroly Sundstone, $46,47,48,53,54,76 ;$ pl. 33 San Pablo Group, 91

nevadanus, Pecten, 64

Vertipecton, 63,64

fucanus, Pecten (Vortipccten), 63

perrini, Pecten (Vertipecten), 62

Niguel Formation, 23, 26, 28, 35, 37, 39, 56, 60, 66 $69,73,82,83,88,91$

Nodipocten, 2, 6, 57

geographic distribution, 57

geologic distribution, 57

nodosus nodosus, 58

subnodosus, 55, 57

subnodosus intermedius, 57,58 ; pls. 22,23 subruodosus, $57 ; \mathrm{pl} .6$

voatchii, 57,$58 ;$ pls. 22,23

(Nodipocten) arnoldi, Chlamys, 12 subnodosus, Pecten, 57, 58 voutchii, Pocton, 58

nodosus, Nodipecton nodosus, 58

Pecton, 58

intormodius, Pecten (Lyropocten), 58

nodosus, Nodipocten, 58

vaughani, Pocten (Lyropecten), 50

voatchii, Pocton (Luropecten), 58

nomlandi, Lyropecten, pl. 17

Lyropecten crassicardo, 51

Pocten, 51, 52

crassicardo, 51

nuclous, Argopecton, 35

vutteri, Nancochlamys, $\$ 1 ; \mathrm{pl}, 8$

Pocten, 31

(Chlamys), 31

otchegoini, 31

(Pallium) swifti, 31

Swiftopecton, 60

Nyc Mudstone, 64

Obispo Formation, 53, 67, 70, 91

\section{Octopus, 79, 84}

Ohlson Ranch Formation, 23, 25, 28, 84, 87, 91

Olcese Sand, 45, 46, 65, 91

Opponheimopecten, 2, 75

coalingaensis, $76 ; \mathrm{pl} 33$

coulingensis, 75

geographic distribution, 75

geologic distribution, 75

hartmanni, 75, 76 ; pl. 33

hoimi, 75, 77; pl. 33

juanonsis, $75,76,77$; pl. 33

koopi, 77

sanctaecruzensis, 75 ; pls. 32,33

vogdesi, $75,76,77 ; \mathrm{pl} .34$

(Opponhoimopocten) coalingaensis, Pecten, 76

hancocki, Pecton, 78

hartmanni, Pecton, 76

hoimi, Pecten, 77

juanonsis, Pecten, 75

vogdesi, Pecten, 77

opuntia, Chlamys, 18, 26, 29; pl. 6

Chlamys (Chlamys), 26

Pecten, 21, 25 opuntia-continued

Pecten-continued

(Chlamys), 26

oregonensis, Patinopecten, 83

Pecten, 64, 86

cancellosus, Patinopecten, 83

Ostrea, 12

Oursan Sandstone, 80 ; pl. 35 Monterey Group, 91

oveni, Pecten, 80

Pecten (Patinopecten), 80

Oyster reef, 90

Oyster-pecten bed, 90

\section{$\mathrm{P}$}

pabloensis, Leptopecten, 47

Pacipecten, 44, 47 ; pl. 15

Pecten, 47, 48

(Aequipecten), 47

(Chlamys), 47

(Plagioctenium), 47

Pacipecten, 2, 42, 43, 44

andersoni andersoni, 44, $45 ; \mathrm{pl} .14$

barkerianus, 44, 45 ; pl. 20

subandersoni, 44,$45 ;$ pl. 14

bilineatus, 44,$48 ; \mathrm{pl} .15$

brionianus, pl. 14

cierboensis, pl. 14

discus, 44, 46, 48; pl. 14

geographic distribution, 44

geologic distribution, 44

gonicostatus, pl. 14

pabloensis, 44,$47 ;$ pl. 15

raymondi, pl. 14

tolmani, 44, 46; pl. 14

tumbezensis, 44,$49 ;$ pl. 15

weaveri, 44,$46 ; \mathrm{pl} .15$

(Pacipecten) tumbezensis, Pecten, 49

Painted Rock Member, Vaqueros Formation, 66

Painted Rock Sandstone Member, Vaqueros Formation, 21, 50, 57, 62, 70, 91

Palliolum (Delectopecten) peckhami, 15

Pallium crassicardium, 51

crassicardo, 51

estrellanum, 53

(Pallium) hamlini, Pecten, 60

holwayi, Pecten, 51

swifti nutteri, Pecten, 31

swiftii etchegoini, Pecten, 60

Palos Verdes Sand, 35, 58, 78, 91

Pancho Rico Formation, 54, 56, 66, 81, 91; pl. 19

parasitica, Ectyodoryx, 29

parmeleei, Chlamys, 29,59

Chlamys parmeleei, 60 (Swiftopecten), 59

Pecten, 31, 60

(Chlamys), 59

Swiftopecten, 60 parmeleei, $59 ;$ pl. 23

etchegoini, Chlamys, 59, 60 Chlamys (Swiftopecten), 60 Swiftopecten, 59,$60 ; \mathrm{pl} .22$

parmeleei, Chlamys, 60

Swiftopecten, $59 ; \mathrm{pl} .23$

Parvamussium, 2, 8, 9, 10

alaskense, 9,$11 ;$ pl. 2

alaskensis, pl. 2

calamitus, 12 ; pl. 2

geographic distribution,

geologic distribution, 9

lajollaense, $9 ; \mathrm{pl} .1$

leohertleini, 9

mideocenicum, $9 ; \mathrm{pl} .1$

riversi, 9,$10 ; \mathrm{pl}$.

stanfordense, 9,$10 ; \mathrm{pl}$.

stanfordensis, 9
(Parvamussium) alaskense, Propeamussium, 11

tanfordensis, Propeamussium, 10

Paso Robles Formation, 66, 91

Patinopecten, $2,13,24,60,61,74,78,84,86$ bakeri, 85,86

diazi, 85,86

calaverasensis, 78,$80 ; \mathrm{pl} .35$

caurinus, $78,79,82,88$; pls. 38,39

coosensis, 83

dilleri, 88

geographic distribution, 78

geologic distribution, 78

haywardensis, 78,80 ; pls. 35,36

healeyi, $78,79,81,82,84$; pls. $34,35,36,37,38$ $39,40,41,42$

lohri, $78,79,80,83 ;$ pls. 34,36

marquerensis, 85

oregonensis, 83

cancellosus, 83

propatulus, $78,79,80$; pls. $26,34,35$

purisamaensis, 87

subgroup, 78

turneri, 87

yessoensis, $78,79,83 ; \mathrm{pl}, 40$

(Lituyapecten) dilleri, 87, 88

falorensis, 86

purisimaensis, 87,88

(Patinopecten) caurinus, 83

(Patinopecten) bakeri, Pecten, 84, 85

caurinus, Patinopecten, 83

Pecten, 12, 83

coosensis dilleri, Pecten, 88

dilleri, Pecten, 88

expansus, Pecten, 81

haywardensis, Pecten, 80 calaverasensis, Pecten, 80

healeyi, Pecten, 81

lohri, Pecten, 80

sanclementensis, Pecten, 81, 82

kernensis, Pecten, 64

lohri, Pecten, 80

oweni, Pecten, 80

propatulus, Pecten, 63, 79

purisimaensis, Pecten, 87

turneri, Pecten, 87

weaveri, Pecten, 46

(?Patinopecten) merriami, Pecten, 74

peckhami, Delectopecten, $8,15,18$; pl. 3

Hyalopecten, 15

Palliolum (Delectopecten), 15

Pecten, 13, 14, 15, 16 (Pseudamusium), 14, 15

Pecten, 2, 30, 48, 49, 51, 67

abietis, 41

aduncus, 78

alaskensis, 11, 12

albicans, 69

aletes, 67

alternilineatus, 15, 16

andersoni, 35, 45, 46

ashleyi, 55, 68, 77

auburyi, 68, 77

aztecus, 77

bakeri, 72,85

diazi, 85

beali, 73

bed, 90

bellistriatus, 16

bellus, $67,68,69,74,75,76,78$

benedictus, 78

biformatus, 51

bilineatus, 48

bösei, 73

bowersi, 63

branneri, 20, 60

brionianus, 47

calamitus, 11 


\section{B108}

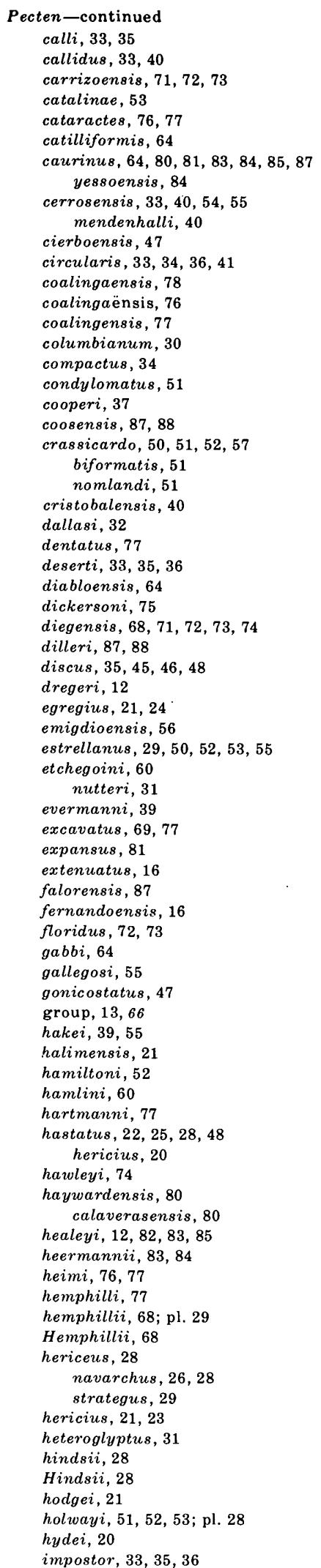

PALEONTOLOGY OF CALIFORNIA AND BAJA CALIFORNIA

Pecten-continued

inezana, 63

interlineatus aidei, 29

intermedius, 57

interradiata, 10

interradiatus, 7

invalidus, 33, 37

islandicus, 20, 27, 28

kincaidi, 32

pugetensis, 24, 27

jordani, 21, 25

juanensis, 76, 78

keepi, 70

kernensis, 64

laevis, 11

lajollaensis, 9, 10

laqueatus, 67

latiauratus, 43

latiauritus, 44, 45 monotimeris, 45

lawsoni, 23

leavis, 11

lecontei, 68

levis, 11

lillisi, 14

lituyaensis, 86

lompocensis, 67

magnificus crassicardo, 50

magnolia, 52, 56, 57

martinezensis, 8

mediacostatus, 29

meekii, 83, 84

mendenhalli, 33, 41

merriami, 74,84

miguelensis, 50, 54

modulatus, 55

multirugosus, 65

nevadanus, 64

nodosus, 58

nomlandi, 51,52

nutteri, 31

opuntia, 21, 25

oregonensis, 64,86

oweni, 80

pabloensis, 47,48

parmeleei, 31,60

peckhami, 13, 14, 15, 16

pedroanus, 14, 16

percarus, 39

perrini, $62,63,64$

pesfelis, 26

poulcreekensis, 87

proavus, 19

propatulus, 63, 64, 79, 80, 83

proteus, 36

purisimaensis, 86, 87, 88

purpuratus, 39, 40, 41

randolphi, 8, 13, 14, 17

randolphi tillamookensis, 16

raymondi, $35,47,48$

brionianus, 47

refugioensis, 70

ricei, 51,52

riversi, 12

rotundus, 8

rubidus, 28

sanclementensis, 82

sanctaecruzensis, 74,75

sancti-ludovici, 22,32

santarosanus, 35

sericeus, 72,73

sespeensis, 20, 21, 31, 61

hydei, 30

slevini, 69

stearnsii, $68,71,72,73,74,85$

Stearnsii, 68

strategus, 29
Pecten-continued

subdolus, 33

subgroup, 66

subnodosus, $55,57,58$

swiftii, 59, 60

tillamookensis, 13, 14, 16

tolmani, 46

traski, 19

tumbezensis, 43, 49

tumidus, 34

vacavillensis, 7

vancouverensis , $13,14,15,16$

fernandoensis, 16

sanjuanensis, 16

vanvlecki, 70

veatchii, 58

vickeryi, 52

vogdesi, 76, 77, 78

wattsi, 31, 59, 60

weaveri, 46

yakatagensis, 86, 87

yessoensis, 78

yneziana, 61

$$
\text { yneziana, } 61
$$

(Aequipecten) andersoni, 45

bellilamellatus, 43

discus, 47

eldridgei, 36

evermanni, 39

gibbus circularis, 37

pabloensis, 47

percarus, 39

praevalidus, 42

purpuratus callidus, 38

hakei, 39

percarus, 39

subdolus, 37

tumbezensis, 49

(Amusium) lompocensis, 66, 67, 70 mortoni, 67.

vanvlecki, 67

(Amussiopecten) lompocensis, 66, 67

(Argopecten) subdolus, 37

(Camptonectes) harfordus, 16

(Chlamys), 21

bartschi, 25

bellilamellatus, 43

branneri, 19

buchivacoanus, 22

calkinsi, 19

columbiana, 30

dallasi, 31

erici, 30

fucanus, 63

hamlini, 60

hastatus, 22

hericius, 23

hindsii, 28

strategus, 29

hericeus strategus, 29

hertleini, 21

hodgei, 21

islandicus picoensis, 27

jordani, 25

lawsoni, 22

multirugosus, 65

crassiplicatus, 65

nutteri, 31

opuntia, 26

pabloensis; 47

parmeleei, 59

proavus, 19

rubidus, 28

sespeensis, 20

hydei, 20

venturaensis, 27

wattsi, 31,59 


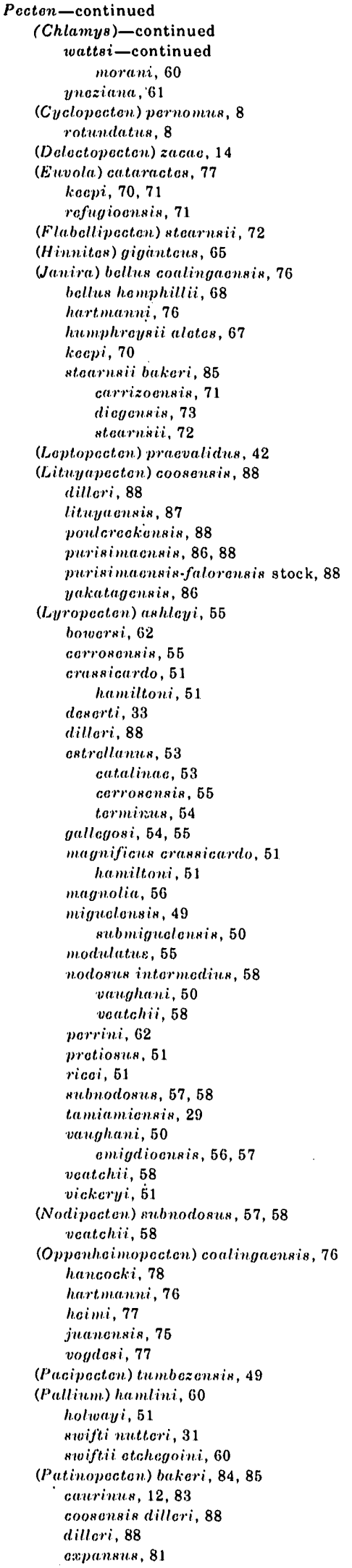

Pecten-continued

(Patinopecten)-continued

haywardensis, 80

calaverasensis, 80

healeyi, 81

lohri, 80

sanclementensis, 81,82

kernensis, 64

lohri, 80

oveni, 80

propatulus, 63,79

purisimaensis, 87

turneri, 87

weaveri, 46

(?Patinopecten) merriami, 74

(Pecten), 67, 71

aletes, $67 ;$ pl. 28

andersoni gonicostatus, 47

auburyi, 68

bartschi, 25

beali, 73

bellus, 67,68 ; pl. 29

bösei, 73

carrizoensis, 71

cierboensis, 47

coalingaensis, 76

compactus, 34

dentatus, 77

dickersoni, 75

diegensis, 73

geographic distribution, 67

geologic distribution, 67

hartmanni, 76

hastatus, 22

pugetensis, 27

havoleyi, 74

heimi, 77, 78

hemphilli, 69

hemphillii, 68

juanensis, 75,78

keepi, 70

lecontei, $67,68,69,72 ;$ pl. 28

merriami, 7

multirugosus, 65

crassiplicatus, 65

raymondi, 47

brionianus, 47

refugioensis, 71

sanctaecruzensis, 75

slevini, 69

stearnsii, 72

vanvlecki, 69

vogdesi, 77

(Plagioctenium) abietis, 41

andersoni, 45

barterianus, 45

subandersoni, 45

bilineatus, 48

calli, $32,34,35$

callidus, 38

cerrosensis, 55

$$
\text { mendenhalli, } 33
$$

circularis, 34

cooperi, 37

cristobalensis, 40

deserti, 33

diminutivus, 32, 33

discus, 47

eldridgei, 36

ericellus, 37

evermanni, 39

hakei, 39

mendenhalli, 33

neahensis, 35

pabloensis, 47

subdolus, 37, 40

(Plagioctenium?) crassiradiatus, 42

(Propeamusium) levis, 11 riversi, 12
Pecten-contined

(Propeamussium) davidsoni, 12 interradiatus, 7

riversi, 10

stanfordensis, 10

vacavillensis, 7

(Pseudamusium) alternilineatus, 13

arces, 13

illisi, 14

lompicoensis, 7

peckhami, 14, 15

pedroanus, 18

polyleptus, 13

randolphi tillamookensis, 13, 17

vancouverensis, 13,17

fernandoensis, 14, 16

sanjuanensis, 13

(Pseudamussium?) alaskensis, 11

(Pseudomuseum) alternilineatus, 15

(Swiftopecten) etchegoini wattsi, 31

(Vertipecten) bower $s i, 62$ nevadanus fucanus, 63 perrini, 62

yneziana subynezianbl, 61 yneziana, 61

ynezianus, 61

(Pecten), Pecten, 67, 71

aletes, Pecten, $67 ; \mathrm{pl} .28$

andersoni gonicostatus, Pecten, 47

auburyi, Pecten, 68

bartschi, Pecten, 25

beali, Pecten, 73

bellus, Pecten, 67, 68 ; pl. 29

bösei, Pecten, 72

carrizoensis, Pceten, 71

cierboensis, Pecten, 47

coalingaensis, Pecten, 76

compactus, Pecten, 34

dentatus, Pecten, 77

dickersoni, Pecten, 75

diegensis, Pecten, 73

hartmanni, Pecten, 76

hastatus, Pecten, 22 pugetensis, Pecten, 27

hawleyi, Pecten, 74

heimi, Pecten, 77, 78

hemphilli, Pecten, 69

hemphillii, Pecten, 68

juanensis, Pecten, 75, 78

kespi, Pecten, 70

lecontei, Pecten, $67,68,69,72 ;$ pl. 28

merriami, Pecten, 74

multirugosus, Pecten, 65

crassiplicatus, Pecten, 65

raymondi, Pecten, 47

brionianus, Pecten, 47

refugioensis, Pecten, 71

sanctaecruzensis, Pecten, 75

slevini, Pecten, 69

stearnsii, Pecten, 72

vanvlecki, Pecten, 69

vogdesi, Pecten, 77

Pectinacea, 6, 12

Pectinidae, 1, 2, 6, 12, 66, 90

geographic distribution, 2

geologic distribution, 2

pedroana, Plagiostoma, 13, 18

pedroanus, Delectopecten, 18

Hyalopecten (Delectopecten), 18

Pecten, 14, 16

(Pseudamusium), 18

Plagiostoma, 13

pedrona, Plagiostoma, 18

Pelecypods, occurrence in geologic formations, 90 systematics, 0

percarus, Aequipecten, 41

Argopecten, 32,$39 ;$ pls. 10,12

Pecten, 39 


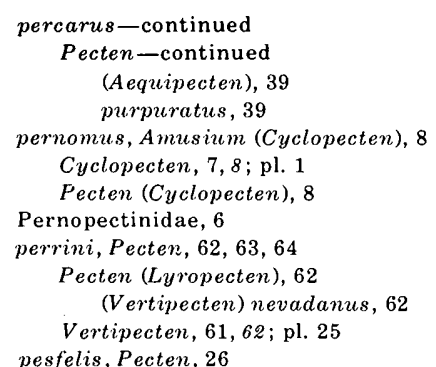

pesfelis, Pecten, 26

Pico Formation, 18, 23, 24, 26, 27, 28, 29, 35, 37, $38,39,56,60,66,68,69,74,75,83,84$, $91 ;$ pls. $7,32,33$

picoensis, Chlamys, 18, 27; pl. 7

Chlamys (Chlamys), 27

Pecten (Chlamys) islandicus, 27

Pismo Formation, Edna Member, 81, 90

Gragg Member, 56, 91

Squire Member, 56, 91

Placopecten, 13

Plagioctenium, 33

(Plagioctenium) abietis, Pecten, 41

andersoni, Pecten, 45 barkerianus, Pecten, 45 subandersoni, Pecten, 45

bilineatus, Pecten, 48

calli, Pectien, $32,34,35$

callidus, Pecten, 38

cerrosensis, Pecten, 55 mendenhalli, Pecten, 33

circularis, Aequipecten, 34 Pecten, 34

cooperi, Pecten, 37

cristobalensis, Pecten, 40

deserti, Pecten, 33

diminutivus, Pecten, 32,33

discus, Pecten, 47

eldridgei, Pecten, 36

ericellus, Pecten, 37

evermanni, Pecten, 39

hakei, Pecten, 39

mendenhalli, Pecten, 33

neahensis, Pecten, 35

pabloensis, Pecten, 47

subdolus, Pecten, 37, 40

(Plagioctenium?) crassiradiatus, Pecten, 42

Plagiostoma annulatus, 13,18

giganteum, 65

pedroana, 13,18

pedroanus, 13

truncata, 13, 18

Pleito Formation, 30, 65, 75, 89, 91; pl. 32

pleuronectes, Amusium, 66

polyleptus, Pecten (Pseudamusium), 13

Polynemamussium alaskense, 11,12 intuscostatum, 12

Pomponio Mudstone Member, Purisima Formation, 81, 91

porterensis, Leochlamys?, 30

Vertipecten, 49

Potato Harbor Formation, 69, 91

poulcreekensis, Pecten, 87

Pecten (Lituyapecten), 88

poulsoni, Hinnita, 65

praevalidus, Antipecten?, 42; pl. 13

Pecten (Aequipecten), 42 (Leptopecten), 42

pretiosus, Lyropecten, 49,51 ; pl. 17

Pecten (Lyropecten), 51

proavus, Chlamys, 18, 19 ; pl. 3

Pecten, 19 (Chlamys), 19

Procedures, 1

propatulus, Patinopecten, 78, 79,80 ; pls. 26, 34, 35

Pecten, 63, 64, 79, 80, 83 propatulus - continued

Pecten-continued

$$
\text { (Patinopecten), 63, } 79
$$

Vertipecten, 63,79

(Propeumusium) levis, Pecten, 11 riversi, Pecten, 12

Propeamussiidae, 1, 2, 6, 8, 9, 90

geographic distribution, 2 geologic distribution, 2

Propeamussium, 2, 6, 7, 8, 9, 10

interradiatum, $7,9,10$; pl. 1

lajollaense, 9

leohertleini, 7,10

mideocenicum, $9,10^{\prime}$

stanfordensis, 7, 9, 10

(Parvamussium) alaskense, 11

stanfordensis, 10

(Propeamussium), 7

interradiatum, 7

(Propeamussium), Propeamussium, 7 davidsoni, Pecten, 12

interradiatum, Propeamussium, 7 .

interradiatus, Pecten, 7

riversi, Pecten, 10

stanfordensis, Pecten, 10

vacavillensis, Pecten, 7

proteus, Pecten, 36

Pseudamussium, 9

incongruum, 8

(Pseudamusium) alternilineatus, Pecten, 13

arces, Pecten, 13

lillisi, Pecten, 14

lompicoensis, Pecten, 7

peckhami, Pecten, 14, 15

pedroanus, Pecten, 18

polyleptus, Pecten, 13

randolphi tillamookensis, Pecten, 13, 17

vancouverensis, Pecten, 13,17

fernandoensis, Pecten, 14, 16 sanjuanensis, Pecten, 13

(Pseudamussium?) alaskensis, Pecten, 11

(Pseudomuseum) alternilineatus, Pecten, 15

Puente Formation, 15, 91

pugetensis, Chlamys, 27

Chlamys (Chlamys), 27 hastata , 18, 23, 24, 27, 29; pl. 6

Pecten islandicus, 24, 27 (Pecten) hastatus, 27

Pullen Formation, Wildcat Group, 91

Purisima Formation, 11, 23, 24, 26, 28, 31, 33, 37, $43,44,59,66,68,69,73,75,76,83,84$, $86,87,88,91$; pls. 8,41

Pomponio Mudstone Member, 81,91

San Gregorio Sandstone Member, 81, 91

Tahana Member, 59, 83, 87, 88, 91

purisimaensis, Lituyapecten, 86,$87 ;$ pl. 41

Patinopecten, 87

(Lituyapecten), 87, 88

Pecten, 86, 87, 88

(Lituyapecten), 86, 88

(Patinopecten), 87

purisimaensis-falorensis stock, Pecten (Lituyapecten), 88

Purpose and scope, 1

purpurata, Chlamys, 39, 40

purpuratus, Pecten, 39, 40, 41

callidus, Pecten (Aequipecten), 38

hakei, Pecten (Aequipecten), 39

percarus, Pecten (Aequipecten), 39

subdolus, Pecten (Aequipecten), 37

pusio, Hinnites, 65

Pycnopodia, 79, 84

Pyramid Hill Sand Member, Jewett Sand, 57, 63, 91
$\mathrm{Q}, \mathrm{R}$

Quail Canyon Sandstone Member, Vaqueros Formation, 21, 57, 91

randolphi, Cyclopecten, 17

Pecten, 8, 13, 14, 17

tillamookensis, Cyclopecten, 17

Cyclopecten (Delectopecten), 17

Delectopecten, $14,16,17 ; \mathrm{pl} .3$

Pecten, 16

(Pseudamusium), 13, 17

raymondi, Aequipecten, 47

Chlamys, 47

Pacipecten, pl. 14

Pecten, 35, 47, 48 (Pecten), 47

brionianus, Aequipecten, 47

Pecten, 47 (Pecten), 47

References cited, 91

refugioensis, Euvola, 70, 71 ; pl. 30

Pecten, 70

(Euvola, 71

(Pecten), 71

revellei, Aequipecten, 38,40

Argopecten, 32,40; pl. 11

Chlamys, 40 (Argopecten), 40

ricei, Lyropecten, pl. 18

Pecten, 51, 52 (Lyropecten), 51

Rincon Shale, 20,21, 50, 57, 91

Rio Dell Formation, 60, 88; pl. 42 Wildcat Group, 26, 31, 84, 91 riversi, Parvamussium, 9,$10 ; \mathrm{pl} .1$

Pecten, 12

(Propeamusium), 12

(Propeamussium), 10

rotundatus, Pecten (Cyclopecten), 8

rotundus, Pecten, 8

Round Mountain Silt, 46, 91

rubida, Chlamys, 18, 26, 27, 28; pl. 7

Chlamys (Chlamys), 28

jordani, Chlamys, 25, 29 Chlamys (Chlamys), 25

rubidus, Pecten, 28

Pecten (Chlamys), 28

Sacate Formation, 61, 91

sacyi, Chlamys, 43

St. George Formation, 25, 91; pl, 6

Salada Formation, $29,30,32,33,34,35,40,49,55$ $56,66,67,68,69,71,72,73,77,89,90$ 91 ; pls. $7,9,10,11,28,30,31,32,33$

Saltos Shale Member, Monterey Formation, 46, $50,53,62,9$

Monterey Shale, 70

San Diego Formation, 8, 23, 24, 26, 27, 28, 34, 35, $37,38,39,40,42,43,56,59,60,66,68$ $69,72,73,78,82,83,88,89,91 ;$ pls. 5,6 , $10,12,13,23,29,31,34,35,36,37,38$ $39,40,42$

San Emigdio Formation, 30, 91

San Fernando Formation, 50

San Gregorio Sandstone Member, Purisima Formation, 81, 91

San Joaquin Formation, 25, 31, 60, 76, 83, 91

Cascajo Conglomerate Member, 36, 90

San Lorenzo Formation, 15, 91

San Marcos Formation, 22, 29, 34, 36, 41, 55, 58 , $71,72,78,85,88,91 ;$ pls. 5,40

San Onofre Breccia, 53, 67, 91; pl. 18

San Pablo Formation, 24, 46, 48, 53, 54, 66, 81, 91; pl. 15

San Pablo Group, 47, 48, 89, 91; pl. 14

Briones Sandstone, 90 
San Pablo Group-continued

Cierbo Sundstone, 90

Neroly Sundstone, 91

San Pedro Formation, 11, 24, 25, 26, 27, 28, 29, 44, (66, 77, 78, 89, 91; pls. 6, 7, 34

Anchor Silt Member, 26, 84, 90

Lomita Marl Member, 12, 17, 23, 24, 26, 28, 29 $44,73,84,91$

Timms Point Silt Member, 17, 26, 29, 44, 73, 84,9

Sun Pedro Sund, 12, 29, 84, 90, 91; pl. 7

San Ramon Sandstone, 13, 15, 16, 64, 89, 91; pls. 2 , 21,39

namelomentensis, Pecten, 82

Pectem (Putinopecten) henleyi, 81, 82

senctuocruzensis, Oppenheimopecten, 75 ; pls. 32 , 33

Pocten, 74, 75

(Pectem), 75

sunctiludovici, Chlamys, 18, 2Q, 31; pl. 5

sancti-hudovici, Pactem, 22, 31

sanjuchonsis, Dolectopecten vancouverens is 17

Pocton (Pscudamusium) vancouverensis, 13 vancouverousis, 16

Santa Burbara Formation, 23, 24, 26, 68, 73, 84, $91 ;$ pl. 29

Suntu Cruz Mudstone, 9

Santa Margarita Formation, 15, 21, 22, 23, 24, 47, $52,53,54,60,65,66,89,90,91 ;$ pls. 4,5 , $17,18,19,21,24,26,27$

Suntu Murgurita Sandstone, 54

santarosanus, Pocten, 35

Saugus Formation, 23, 24, 26, 29, 35, 66, 69, 83, 91 sericous, Pocton, 72, 73

sos'poonенін, Chlamys, 18, 20; pl. 4

Pocton, 20, 21, 31, 61 (Chlamys), 20

Vortipectem, 20

hydloi, Chlamys, 18,80; pl. 4

$$
\text { Pacton, } 30
$$$$
\text { (Chlamys), } 20
$$

Sisquoc Formution, 23, 88, 91

Tinaquaic Sundstone Member, 81,91 ; pls. 34,

Skooner Gulch Formation, 21, 91

slovini, Pecton, 69

Pocton (Pocton), 69

Sobrante Sundstone, $80,90,91$; pls. 35, 36

Soda Lake Shale Member, Temblor Formation, 21

Vuqueros Formation, 21, 50, 57, 70, 91

Sooke Formation, 13, 17, 30, 89, 91; pl. 8

Squire Member, Pismo Formation, 56, 91

stanfordonso, Parvamussium, 9, 10; pl. 1

stanfordensis, Paruamassizm, 9

Pocten (Propoumusaizum), 10

Propocumussium, 7, 9, 10

(Parvamassium), 10

steurnsii, Flabellipecten, 71, 72; pl, 31

Pocten, 68, 71, 72, 73, 74, 85

(Flabellipocton), 72

(Unira) stearnsii, 72

(Pocton), 72

bakeri, Pocten (Janira), 85

Gurrizocusis, Pocten (Janira), 71

diogonsis, Pecten (Janira), 73

stoarnsii, Pecton (Janira), 72

Stcurnsii, Pocten, 68

stratogues, Pecton, 29

Pecton (Chlamys) hastatus, 29

(Chlamys) hericeus, 29

hericens, 29

subandorsoni, Aoquipecten andersoni, 45

Pacipecten andersoni, 44, 45; pl. 14

Pocton (Plagioctenium) andersoni, 45

subdola, Chlamys, 38

Chlamys (Argopocton), 38

subdolus, Argopecten, 32, 33, s7, 40; pl. 10 subdolus - continued

Pecten, 33

(Aequipecten) purpuratus, 37

(Argopectein), 37

(Plagioctenium), 37, 40

submiguelensis, Lyropecten, $49,50,53 ;$ pls. 16,17

Lyropecten miguelensis, 50

Pecten (Lyropecten) miguelensis, 50

subnodosus, Lyropecten, 57, 58

Nodipecten, 55, 57

subnodosus, $57 ;$ pl. 6

Pecten, 55, 57, 58

(Lyropecten), 57, 58

(Nodipecten, 57, 58

intermedius, Nodipecten, 57,58 ; pls. 22,23

subnodosus, Nodipecten, 57; pl. 6

subyneziana, Pecten (Vertipecten) yneziana, 61

Vertipecten yneziana, $61 ; \mathrm{pl} .24$

sverdrupi, Aequipecten, 34

Argopecten, 32, $84 ; \mathrm{pl} .9$

swifti nutteri, Pecten (Pallium), 31

swiftii, Chlamys, 59

Chlamys (Swiftopecten), 12, 59

Pecten, 59, 60

Swiftopecten, 59

etchegoini, Pecten (Pallium), 60

Swiftopecten, 2, 24, 31, 58

adekunbiana, 51, 52; pl. 21

etchegoini, 60

geographic distribution, 59

geologic distribution, 59

group, 60

morani, $60 ;$ pl. 22

nutteri, 60

parmeleei, 60

etchegoini, 59,$60 ;$ pl. 22

parmeleei, $59 ;$ pl. 23

swiftii, 59

vattsi, $60 ;$ pl. 23

(Swiftopecten) etchegoini wattsi, Pecten, 31 parmeleei, Chlamys, 59

parmeleei etchegoini, Chlamys, 60

swiftii, Chlamys, 12, 59

Swiftopecten?, 60

hamlini, 59,60; pl. 24

(Sviftopecten?) hamlini, Chlamys, 60

Systematics, pelecypods, 6

Tahana Member, Purisima Formation, 59, 83, 87 , 88,91

tamiamiensis, Pecten (Lyropecten), 29

tamurae, Chlamys, 26

Tejon Formation, 7

Coldwater Sandstone Member, 90

Cozy Dell Shale Member, 90

Temblor faunule, 45

Temblor Formation, 20, 21, 45, 47, 57, 63, 80, 91 Agua Sandstone Member, 57, 63, 90

Buttonbed Sandstone Member, 45, 53, 54, 70,

Carneros Sandstone Member, 50, 51, 65, 90

McLure Shale Member, 54

Media Shale Member, 46, 54, 91

Soda Lake Shale Member, 21

Wygal Sandstone Member, 62, 75, 89, 90, 91; pl. 24

Temblor horizon, $15,33,45,51,67$

Temblor Stage, 45

Tepetate Formation, 91

terminus, Lyropecten, $49,54,56$; pl. 19

Lyropecten estrellanus, 56

Pecten (Lyropecten) estrellanus, 54

Tierra Redonda Formation, 45, 46, 50, 67, 91 tillamookensis, Cyclopecten (Delectopecten) randolphi, 17

Cyclopecten randolphi, 17

Delectopecten, 17 randolphi, 14, 16, 17; pl. 3 vancouverensis, 17

Pecten, 13, 14, 16 (Pseudamusium) randolphi, 13, 17 randolphi, 16

Timms Point Silt Member, 23, 66

San Pedro Formation, 17, 26, 29, 44, 73, 84, 91

Tinaquaic Sandstone Member, Sisquoc Formation, 81, 91; pls. 34, 36

tokunagai, Yabepecten, 83

tolmani, Pacipecten, 44, 46; pl. 14 Pecten, 46

Topanga Canyon Formation, 62 Cold Creek Member, 90, 91

Topanga Formation, 15, 46, 53, 62, 65; pls. 24, 25 Cold Creek Member, 54

Topanga Group, 54, 91

Topanga Canyon Formation, 91

Tortugas Formation, 46, 91

Towsley Formation, 28, 35, 54, 81, 91

Tranquillon Formation, 67; pl. 2

Tranquillon Volcanics, 54, 57, 67, 91

traski, Pecten, 19

truncata, Plagiostoma, 13, 18

tugidakensis, Chlamys (Leochlamys), 30

tumbezensis, Chlamys (Leptopecten), 49

Pacipecten, 44,49; pl. 15

Pecten, 43, 49

(Aequipecten), 49

(Pacipecten), 49

Tumey Formation, 15, 91

tumidus, Pecten, 34

turneri, Lituyapecten, 86,$87 ; \mathrm{pl}, 37$

Patinopecten, 87

Pecten (Patinopecten), 87

Turritella bed, 89

Twisselman Sandstone Member, Monterey Formation, 46, 91

vacavillensis, Pecten, 7

Pecten (Propeamussium), 7

Valmonte Diatomite, 18

Valmonte Diatomite Member, Monterey Shale, 18,91

vancouverensis, Cyclopecten (Delectopecten), 17

Delectopecten, 17 vancouverensis, 14,$17 ;$ pl. 3

Hyalopecten, 17

Pecten, 13, 14, 15, 16 (Pseudamusium) 13, 17

fernandoensis, Delectopecten, 14,$16 ;$ pl. 3 Pecten, 16

(Pseudamusium), 14, 16

sanjuanensis, Delectopecten, 17

Pecten, 16

(Pseudamusium), 13

tillamookensis, Delectopecten, 17

vancouverensis, Delectopecten, 14,$17 ; \mathrm{pl} 3$

vanvlecki, Amussiopecten, 67,$69 ; 74 ;$ pls. 29,30

Pecten, 70

(Amusium), 67

(Pecten), 69

Vaqueros Formation, 20,21, 30, 31, 45, 46, 49, 50 $51,56,57,62,63,65,70,74,75,89,90$ 91 ; pls. $4,8,14,16,17,21,25,29,30,31$. 33

Painted Rock Sandstone Member, 21, 50, 57 $62,66,70,91$

Quail Canyon Sandstone Member, 21, 57, 91

Soda Lake Shale Member, 21, 50, 57, 70, 91 
Vaqueros horizon, 45

Vaqueros megafaunal-stage, 65

Vaqueros Sandstone, 75

vaughani, Lyropecten, 49,50 ; pl. 17

Lyropecten crassicardo, 50

Pecten (Lyropecten), 50

(Lyropecten) nodosus, 50

emigdioensis, Pecten (Lyropecten), 56, 57 veatchii, Nodipecten, 57,58 ; pls. 22,23

Pecten, 58

(Lyropecten), 58 nodosus, 58

(Nodipecten), 58

venturaensis, Chlamys, 27, 28; pl. 7

Pecten (Chlamys), 27

Vertipecten, 2,$6 ; 20,31,49,60,83$

alexclarki, $61 ;$ pl. 24

bowersi, $61,62,64$; pls. 24,25

diabloensis, 61,$64 ;$ pls. 21,39

fucanus, $61,63,64,79,80$; pls. 26,27

geographic distribution, 61

geologic distribution, 61

kernensis, $61,63,64 ;$ pl. 28

nevadanus, 63,64

perrini, 61, 62; pl. 25

porterensis, 49

propatulus, 63,79

sespeensis, 20

yneziana, 61

subyneziana, $61 ; \mathrm{pl} .24$

yneziana, $61 ; \mathrm{pl} .25$

ynezianus, 49
(Vertipecten) bowersi, Pecten, 62 nevadanus fucanus, Pecten, 63 perrini, Pecten, 62

yneziana subyneziana, Pecten, 61

yneziana, Pecten, 61

ynezianus, Pecten, 61

vickeryi, Lyropecten, pl. 17

Pecten, 52

(Lyropecten), 51

vitreus, Cyclopecten, 13

vogdesi, Oppenheimopecten, $75,76,77 ; \mathrm{pl}, 34$

Pecten, 76, 77, 78

(Oppenheimopecten), 77

(Pecten), 77

volaeformis, Lyropecten, 53

\section{$\mathrm{W}, \mathrm{Y}, \mathrm{Z}$}

wattsi, Pecten, $31,59,60$

Pecten (Chlamys), 31, 59

(Swiftopecten) etchegoini, 31

Swiftopecten, $60 ;$ pl. 23

morani, Pecten (Chlamys), 60

weaveri, Pacipecten, 44,$46 ;$ pl. 15

Pecten, 46

(Patinopecten), 46
Wildcat Group, 60,$91 ; \mathrm{pl} .23$

Pullen Formation, 91

Rio Dell Formation, 26, 31, 84, 91

Wimer Formation, 47, 91

Woodhams Member, Monterey Formation, 15, 91

Wygal Sandstone Member, Temblor Formation, $62,75,89,90 ; 91 ;$ pl. 24

Yabepecten, 78, 83

condoni, 83

tokunagai, 83

yakatagensis, Pecten, 86,87

Pecten (Lituyapecten), 86

yessoensis, Patinopecten, 78, 79, 83; pl. 40

Pecten, 78

$$
\text { caurinus, } 84
$$

neziana, Pecten, 61

Pecten (Chlamys), 61 (Vertipecten) yneziana, 61 yneziana, 61

Vertipecten, 61 yneziana, $61 ; \mathrm{pl} .25$

subyneziana, Pecten (Vertipecten), 61 Vertipectien, 61 ; pl. 24

yneziana, Pecten, 61

Pecten (Vertipecten), 61 Vertipecten, $61 ;$ pl. 25

ynezianus, Pecten (Vertipecten), 61

Vertipecten, 49

zacae, Pecten (Delectopecten), 14

Zemorrian Stage, 75

Zostera, 44 


\section{PLATES $1-42$}

[Contact photographs of the plates in this report are available, at cost, from the U.S. Geological Survey Photographic Library, Federal Center, Denver, Colorado 80225] 


\section{PLATE 1}

FIgUREs 1. Propeamussium interradiatum (Gabb) (p. B7)

Lectotype ANSP $4652(\times 2.0)$. Length $18 \mathrm{~mm}$, height $19 \mathrm{~mm}$. Kreyenhagen

Shale, Eocene and Oligocene.

2. Cyclopecten lompicoensis (Arnold) (p. B7).

Holotype USNM $164931(\times 3.0)$. Height about $13 \mathrm{~mm}$. Monterey Formation, Miocene.

3-6. Cyclopecten pernomus (Hertlein) (p. B8).

Syntypes USNM $110708(\times 10.0)$. Panama Bay, Panama, Holocene.

3. Exterior of right valve. Height $3.5 \mathrm{~mm}$.

4. Interior of right valve illustrated in figure 3 .

5. Exterior of left valve. Height $2.8 \mathrm{~mm}$.

6. Exterior of left valve. Height $3.0 \mathrm{~mm}$.

7, 8. Cyclopecten incongruus (Dall) (p. B8).

Holotype USNM $207273(\times 2.0)$. Length $15 \mathrm{~mm}$, height $14 \mathrm{~mm}$. Isla Cedros, Baja California Norte, Holocene.

9, 10. Cyclopecten? martinezensis (Gabb) (p. B8).

Martinez Formation, Paleocene.

9. Lectotype MCZ 15026a (×4.0). Height $9 \mathrm{~mm}$.

10. Paratype MCZ 15026 ( $\times 4.0)$. Height $6 \mathrm{~mm}$.

11. Parvamussium mideocenicum (Vokes) (p. B9).

Syntype UCMP $15584(\times 4.0)$. Height $8 \mathrm{~mm}$. Cerros Shale Member, Lodo

Formation, Paleocene.

12, 13. Parvamussium lajollaense (M. A. Hanna) (p. B9).

Ardath Shale, Eocene.

12. Syntype UCMP $31108(\times 4.0)$. Height $3.8 \mathrm{~mm}$

13. Syntype UCMP $31106(\times 4.0)$. Height $3.8 \mathrm{~mm}$.

14, 15, 17. Parvamussium stanfordense (Arnold) (p. B10).

14. Topotype USNM 646446 ( $\times 3.0)$ (Addicott, 1971, fig. 5). Left valve (top). Length $8 \mathrm{~mm}$, height $7.8 \mathrm{~mm}$. USGS locality M1492.

15. Syntype UCMP $15585(\times 4.0)$ of Parvamussium mideocenicum $($ Vokes $)=$ Parvamussium stanfordense (Arnold)? Height $6.2 \mathrm{~mm}$. Cerros Shale Member, Lodo Formation, Paleocene.

17. Holotype CAS/SU $12(\times 4.0)$. Length $7.2 \mathrm{~mm}$, height $7.8 \mathrm{~mm}$. Butano(?)

Sandstone, Eocene.

16, 18. Parvamussium riversi (Arnold) (p. B10).

Holotype CAS/SU $33(\times 3.0)$. Length $17 \mathrm{~mm}$, height $17 \mathrm{~mm}$. Fernando

Formation, Pliocene and Pleistocene. 

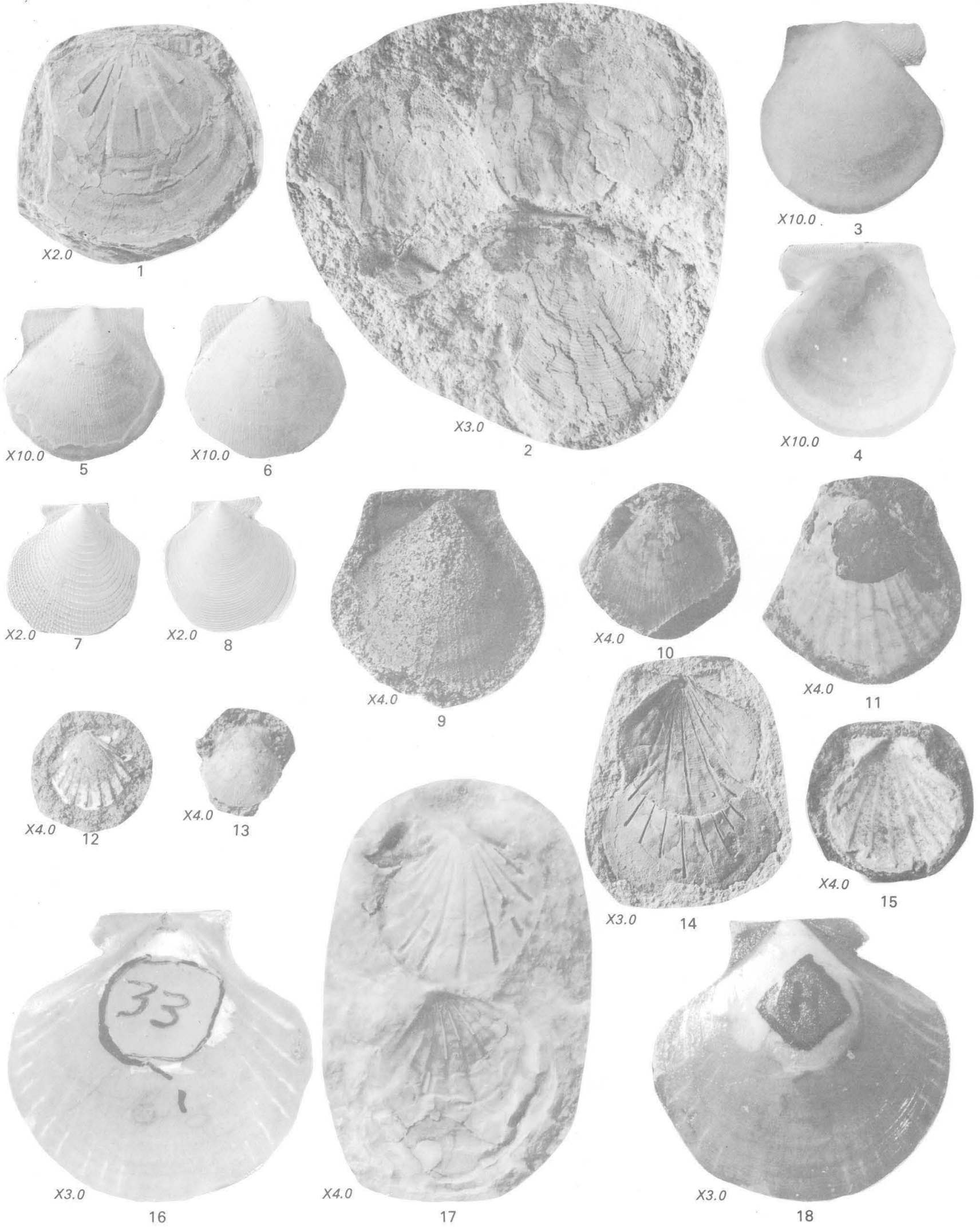

PROPEAMUSSIUM, CYCLOPECTEN, PARVAMUSSIUM 


\section{PLATE 2}

Figures 1-7. Parvamussium alaskensis (Dall) (p. (B11).

1. Holotype of Parvamussium calamitus (G D. Hanna), UCMP 11084 ( $x$ 3.0). Length $15 \mathrm{~mm}$, height $16 \mathrm{~mm}$. Fernando Formation, Pliocene and Pleistocene.

2, 3. Paratype of Parvamussium calamitus (G D. Hanna), UCMP 11779 ( $x$ 3.0). Length $15 \mathrm{~mm}$, height $14 \mathrm{~mm}$, hinge $9 \mathrm{~mm}$. Fernando Formation, Pliocene and Pleistocene.

4, 5. Hypotype USNM $149604(\times 2.0)$ (Arnold, 1906, pl. 53, figs. 2, 2a). Height $22 \mathrm{~mm}$ (right valve); height $25 \mathrm{~mm}$ (left valve). Pribilof Islands, Bering Sea. Holocene, $145 \mathrm{~m}$.

6, 7. Hypotype USNM $62343(\times 2.0)$. Length $18 \mathrm{~mm}$, height $18 \mathrm{~mm}$, hinge 6 $\mathrm{mm}$. Port Etches, Alaska. Holocene.

8, 9. Delectopecten alternilineatus (Clark) (p. B15).

Holotype UCMP $11203(\times 4.0)$. Length $5 \mathrm{~mm}$, height $6 \mathrm{~mm}$, hinge $3 \mathrm{~mm}$. San Ramon Sandstone, Miocene(?).

10, 11. Amusium lompocensis (Arnold)!(p. B66):

10. Holotype CAS 81 . Height $105 \mathrm{~mm}$. Tranquillon(?) Formation, Miocene.

11. Paratype USNM 164852 (copied from Arnold, 1906, pl. 28, fig. 2). 

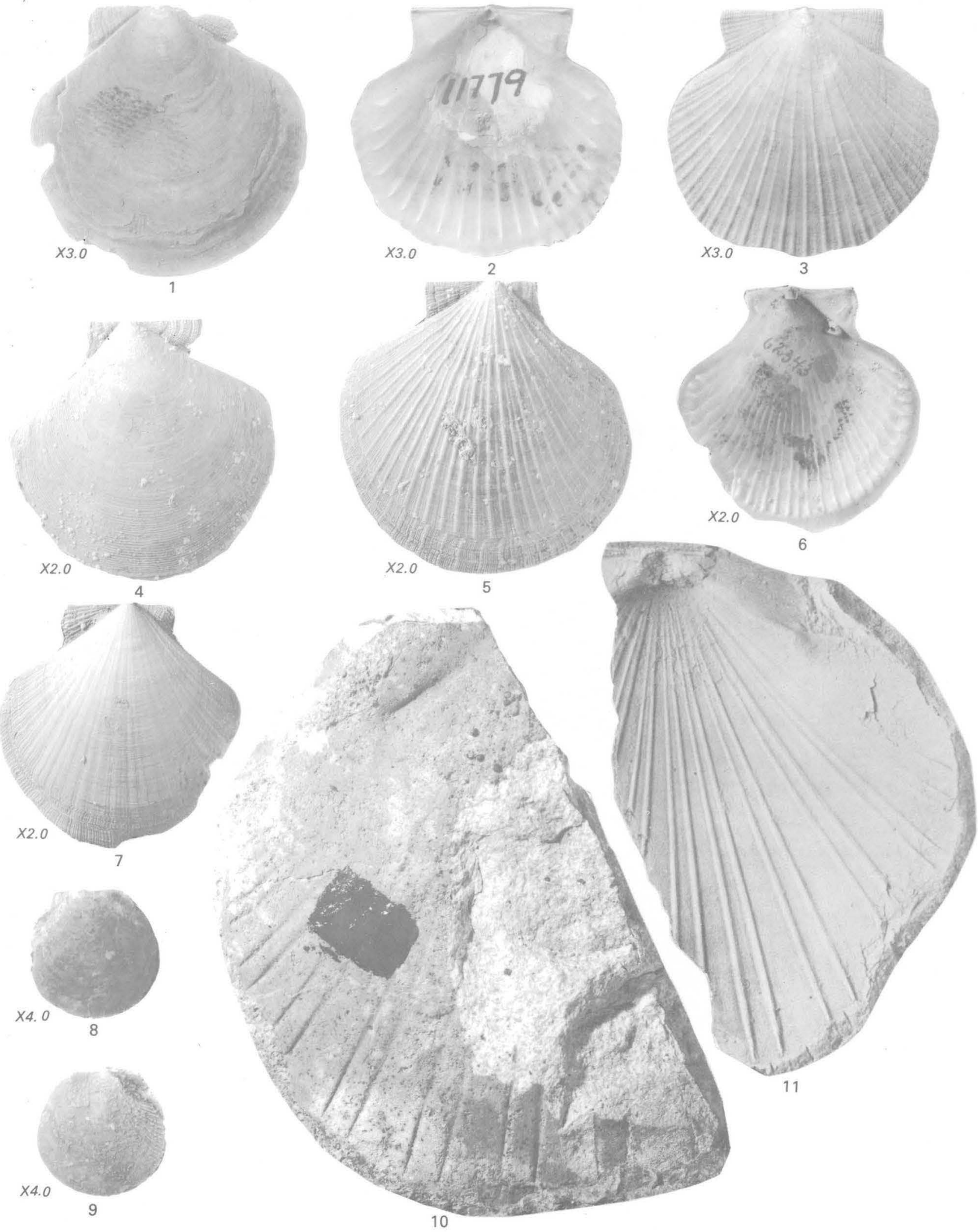

PARVAMUSSIUM, DELECTOPECTEN, AMUSIUM 


\section{PLATE 3}

Figures

1-3. Delectopecten lillisi (Hertlein) (p. B14).

Kreyenhagen Formation, Eocene and Oligocene.

1, 3. Holotype CAS $6062(\times 3.0)$. Length $13 \mathrm{~mm}$, height $13 \mathrm{~mm}$, hinge $8 \mathrm{~mm}$.

2. Paratype CAS $6063(\times 3.0)$. Hingre $10 \mathrm{~mm}$.

4, 5. Delectopecten peckhami (Gabb) of Arnold (p. B15).

4. Hypotype USNM $563246(\times 4.0)$ (Moore, 1963, pl. 20, fig. .3). Astoria Formation, Miocene, Oregon.

5. Hypotype USNM $164839(\times 1.5)$ (Arnold, 1906, pl. 3, fig. 28; Moore, 1963, pl. 21, fig. 2). Monterey Shale, Miocene.

6-9. Delectopecten harfordus (Davis) (p. B16).

Monterey(?) Formation, Miocene(?).

6. Syntype CAS/SU $406(\times 2.0)$. Length $15 \mathrm{~mm}$, height $13 \mathrm{~mm}$, hinge $11 \mathrm{~mm}$.

7, 9. Syntype CAS/SU $408(\times 2.0)$.

7. Hinge $9 \mathrm{~mm}$.

9. Length $14 \mathrm{~mm}$, height $19 \mathrm{~mm}$, hinge $10 \mathrm{~mm}$.

8. Paratype CAS $9819(\times 2.0)$

10. Delectopecten vancouverensis fernandoensis (Hertlein)(p. B16).

Holotype CAS/SU $16(\times 3.0)$. Length $14 \mathrm{~mm}$, height $15 \mathrm{~mm}$, hinge $10 \mathrm{~mm}$. Fernando Formation, Pliocene and Pleistocene.

11, 16. Delectopecten vancouverensis vancouverensis (Whiteaves) (p. B17).

Hypotype USNM $126643(\times 8.0)$. Departure Bay, Vancouver Island, B.C. Holocene, $35 \mathrm{~m}$. Length $6 \mathrm{~mm}$, height $6 \mathrm{~mm}$, hinge $5 \mathrm{~mm}$.

12. Chlamys calkinsi (Arnold) (p. B19).

Holotype UCMP $12076(\times 1.5)$. Height $45 \mathrm{~mm}$. Coldwater Sandstone, Eocene.

13, 14. Delectopecten randolphi tillamookensis (Arnold) (p. B17)

Holotype USNM 150233 (Arnold, 1906, pl. 48, figs. 3, 3a). Height $30 \mathrm{~mm}$. Tillamook Bay, Oreg. Holocene, $1,437 \mathrm{~m}$.

15. Chlamys proavus (Arnold) (p. B19).

Holotype USNM 164930. Height $38 \mathrm{~mm}$. Locatelli(?) Formation, Paleocene. 
GEOLOGICAL SURVEY
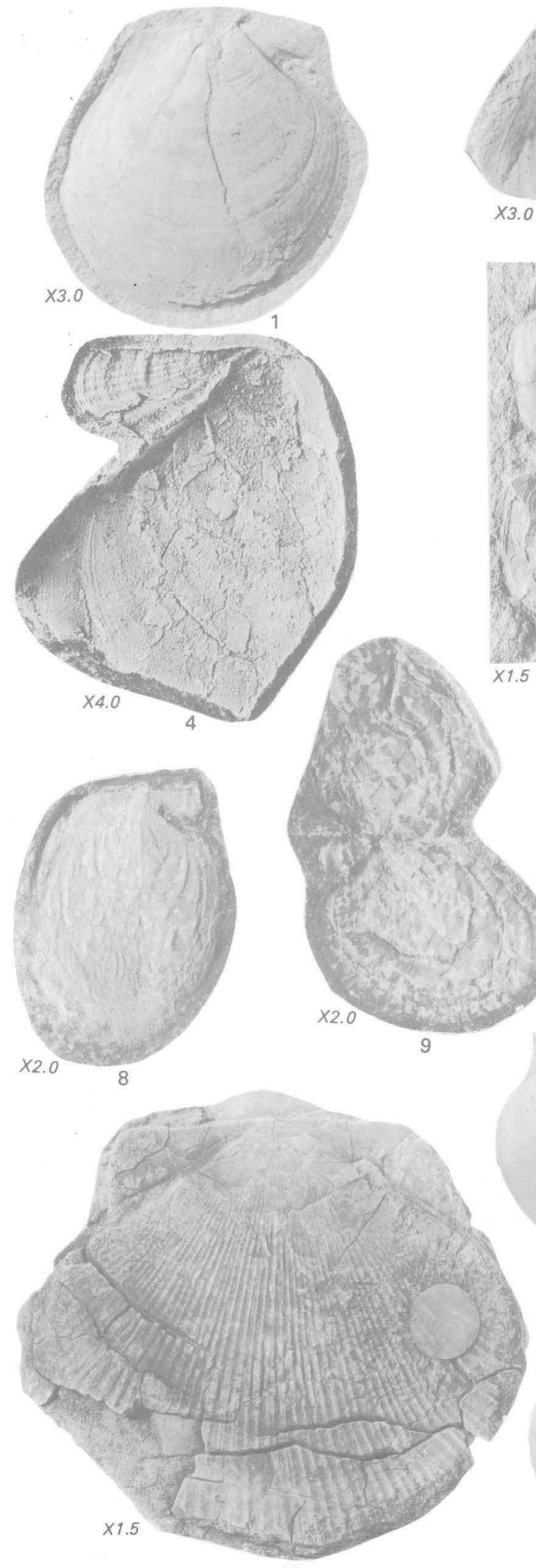

$\times 1.5$
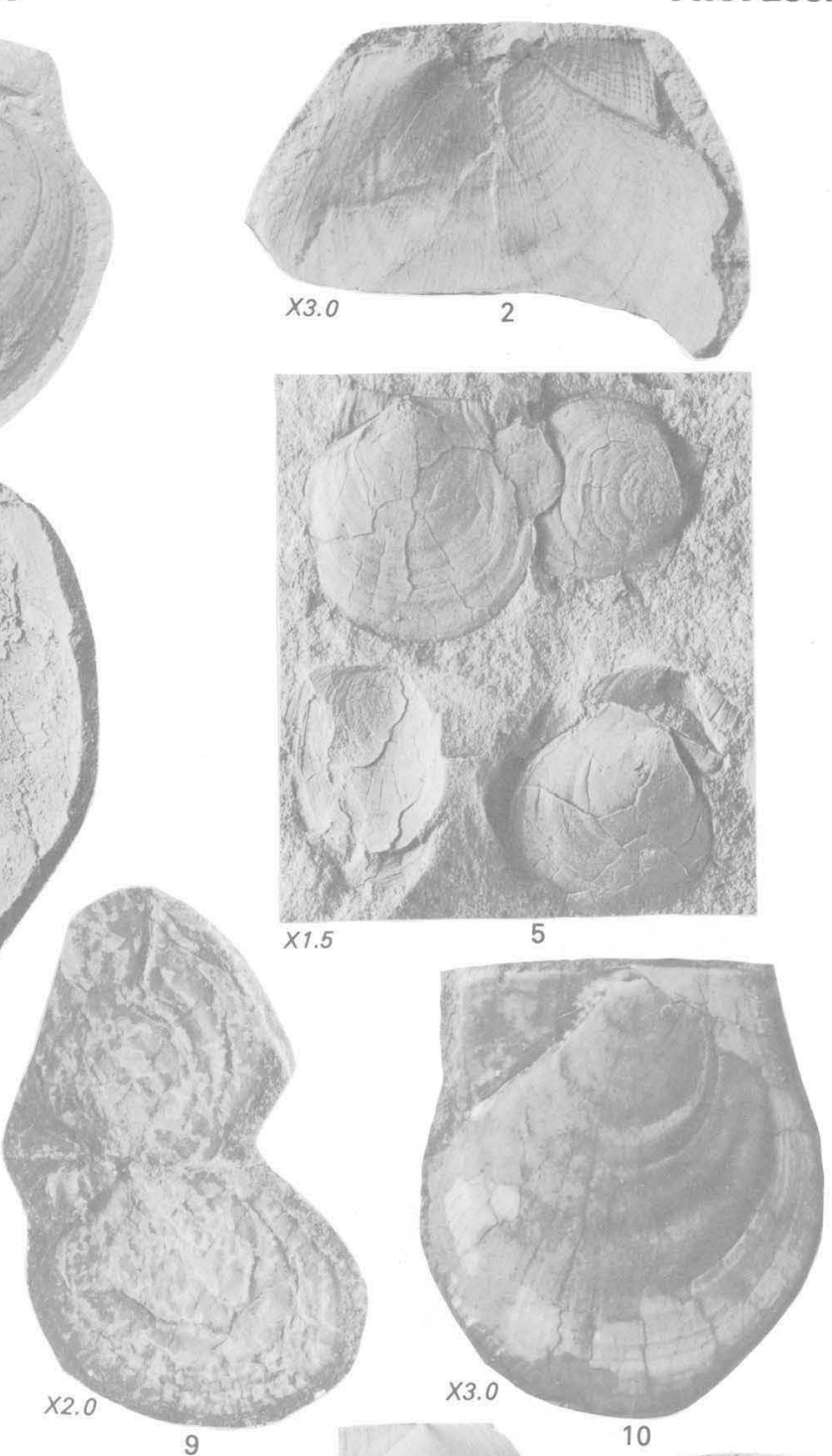

12
PROFESSIONAL PAPER 1228-B PLATE 3
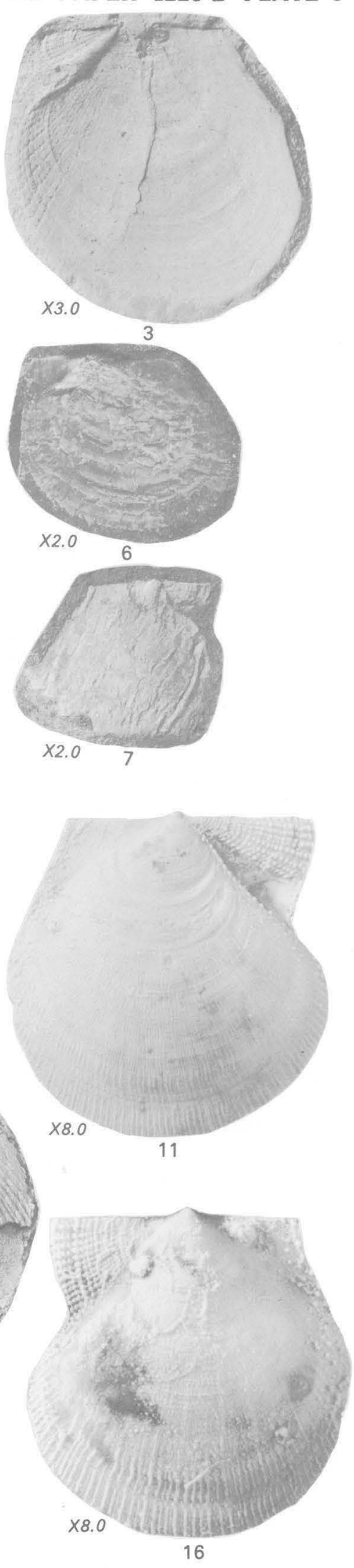

DELECTOPECTEN, CHLAMYS 


\section{PLATE 4}

1. Chlamys branneri (Arnold) (p. B19).

Holotype CAS/SU 358 ( $\times 1.5)$. Photograph is of clay impression made from mold of holotype. Hinge $31 \mathrm{~mm}$. Unnamed Miocene sandstone of Dibblee (1966), near Stanford University, California.

2, 3. Chlamys sespeensis (Arnold) of Loel and Corey (p. B20).

Vaqueros Formation, Oligocene and Miocene.

2. Hypotype UCMP 31721 (Loel and Corey, 1932, pl. 21, fig. 5) Hinge $25 \mathrm{~mm}$. Vaqueros Formation, Oligocene and Miocene.

3. Hypotype UCMP 31722 (Loel and Corey, 1932, pl. 21, fig. 4). Length $39 \mathrm{~mm}$, height $47 \mathrm{~mm}$, hinge $24 \mathrm{~mm}$.

4, 6. Chlamys sespeensis hydei (Arnold) (p. B20).

Holotype CAS/SU $10(\times 1.5)$. Length $40 \mathrm{~mm}$, height $46 \mathrm{~mm}$. Vaqueros Formation, Oligocene and Miocene.

5, 9. Chlamys hodgei (Hertlein) (p. B21).

Santa Margarita Formation, Miocene.

5. Holotype CAS/SU $20(\times 1.5)$. Length $40 \mathrm{~mm}$, height $45 \mathrm{~mm}$, hinge $25 \mathrm{~mm}$.

9. Paratype CAS/SU $21(\times 2.0)$. Length $24 \mathrm{~mm}$, height $32 \mathrm{~mm}$, hinge $15 \mathrm{~mm}$.

7, 8. Chlamys hertleini (Loel and Corey) (p. B21).

Holotype UCMP $31725(\times 1.5)$. Length $40 \mathrm{~mm}$, height $46 \mathrm{~mm}$. Vaqueros Formation, Oligocene and Miocene. 
GEOLOGICAL SURVEY
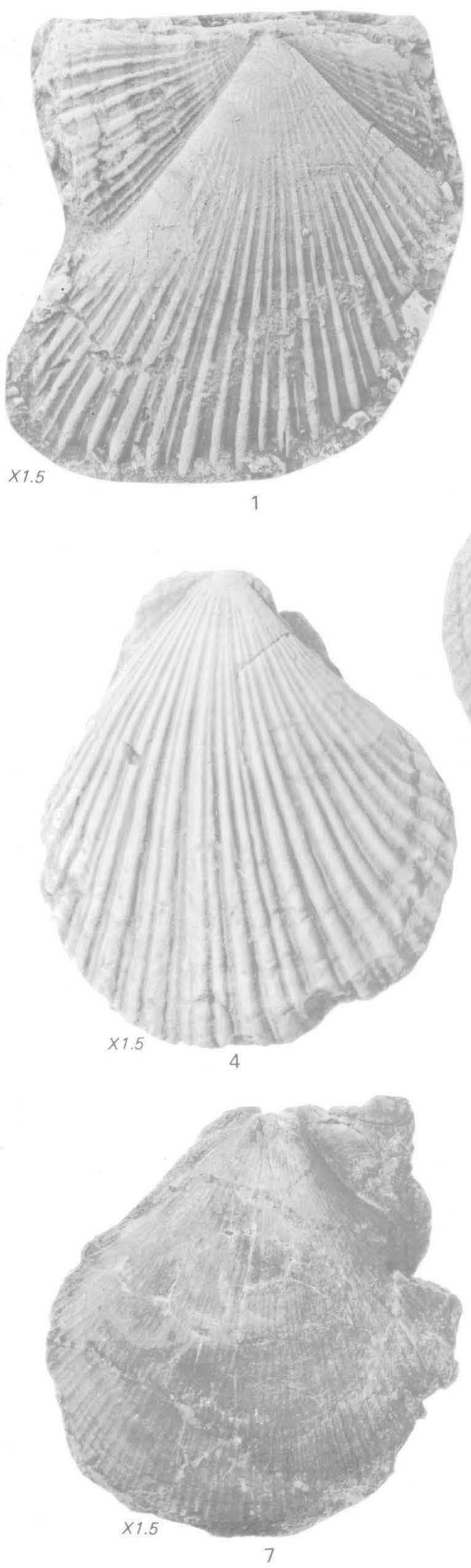

PROFESSIONAL PAPER 1228-B PLATE 4
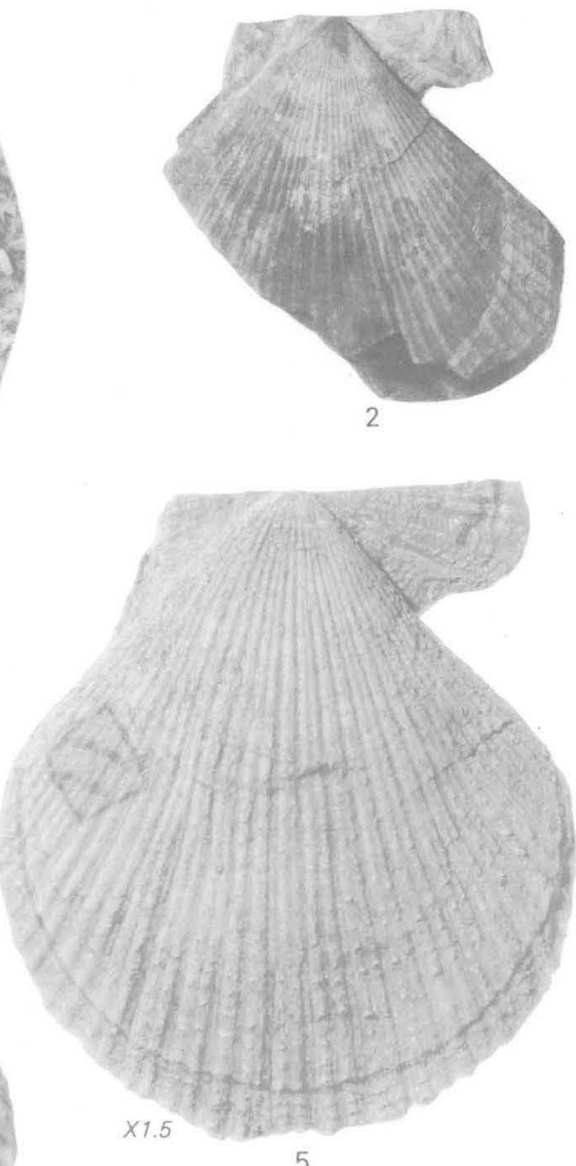

5
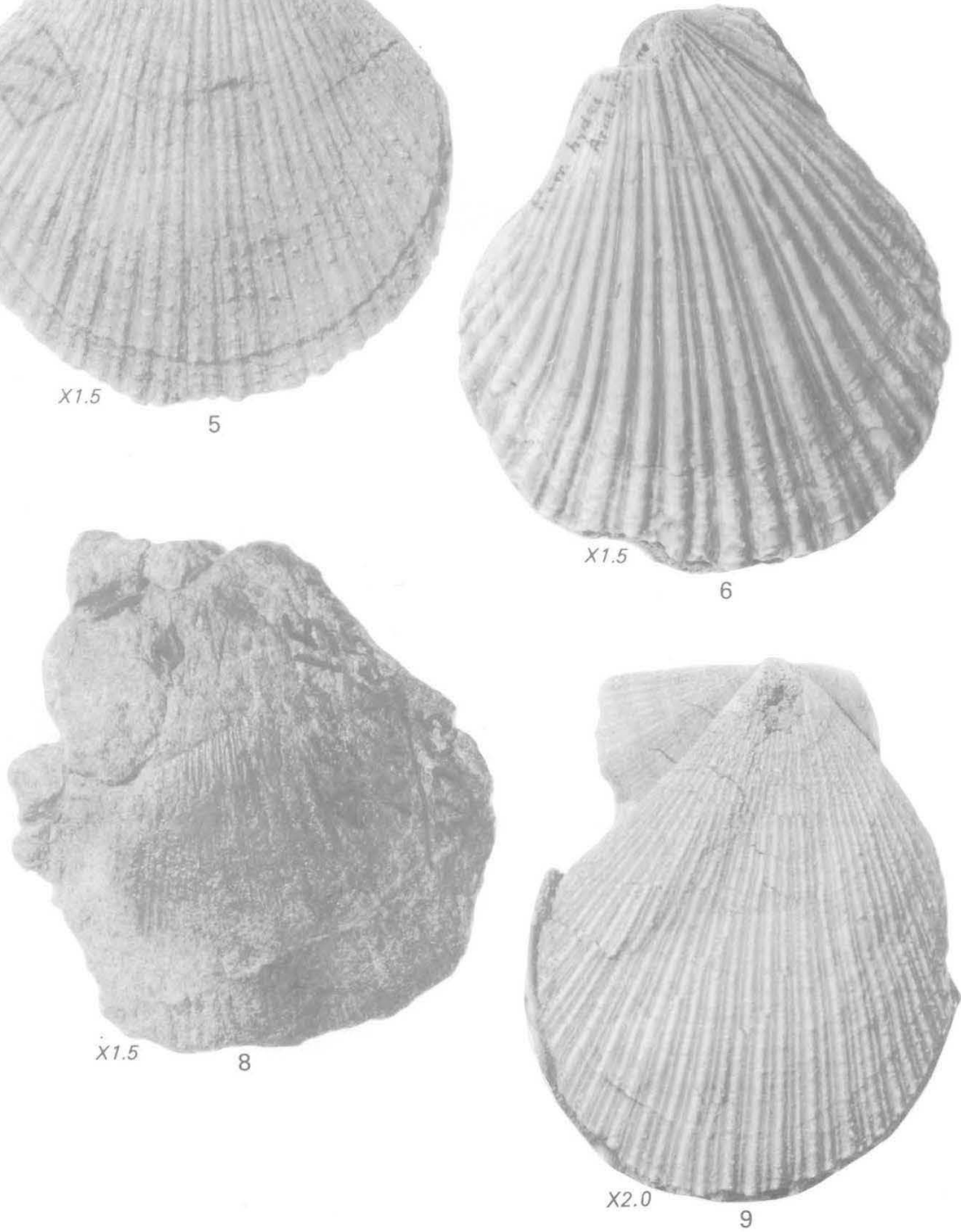

CHLAMYS 


\section{PLATE 5}

1, 3. Chlamys sanctiludovici (Anderson and Martin) (p. B22).

Santa Margarita Formation, Miocene.

1. Holotype CAS $107(\times 1.5)$. Length $36 \mathrm{~mm}$, height $40 \mathrm{~mm}$, hinge $25 \mathrm{~mm}$.

3. Paratype CAS $108(\times 1.5)$. Length $40 \mathrm{~mm}$, height $42 \mathrm{~mm}$.

2. Chlamys hodgei (Hertlein) (p. B21).

Holotype of Chlamys durhami Adegoke, UCMP $36615(\times 2.0)$. Length $30 \mathrm{~mm}$, height $36 \mathrm{~mm}$, hinge $21 \mathrm{~mm}$ (estimated). Santa Margarita Formation, Miocene.

4, 6. Chlamys hastata hastata (Sowerby) (p. B22).

Copy of Arnold (1906, pl. 42, figs. 1, 1a). Height $64 \mathrm{~mm}$. Monterey Bay, Calif. Holocene.

5. Chlamys corteziana Durham (p. B22).

Holotype UCMP $30564(\times 2.0)$. Photograph is of latex impression of holotype mold. San Marcos Formation, Pliocene.

7, 8. Chlamys hastata hericius (Gould) (p. B23).

Holotype USNM 5955. Length $60 \mathrm{~mm}$, height $66 \mathrm{~mm}$, hinge $28 \mathrm{~mm}$. Strait of Juan de Fuca, Wash. Holocene.

9. Chlamys (Chlamys) hastata ellisi Hertlein and Grant (p. B24).

Holotype LAM 4483. Length $66 \mathrm{~mm}$, height $69 \mathrm{~mm}$. San Diego Formation, Pliocene. (Photograph courtesy of Barry Roth, California Academy of Sciences.) 

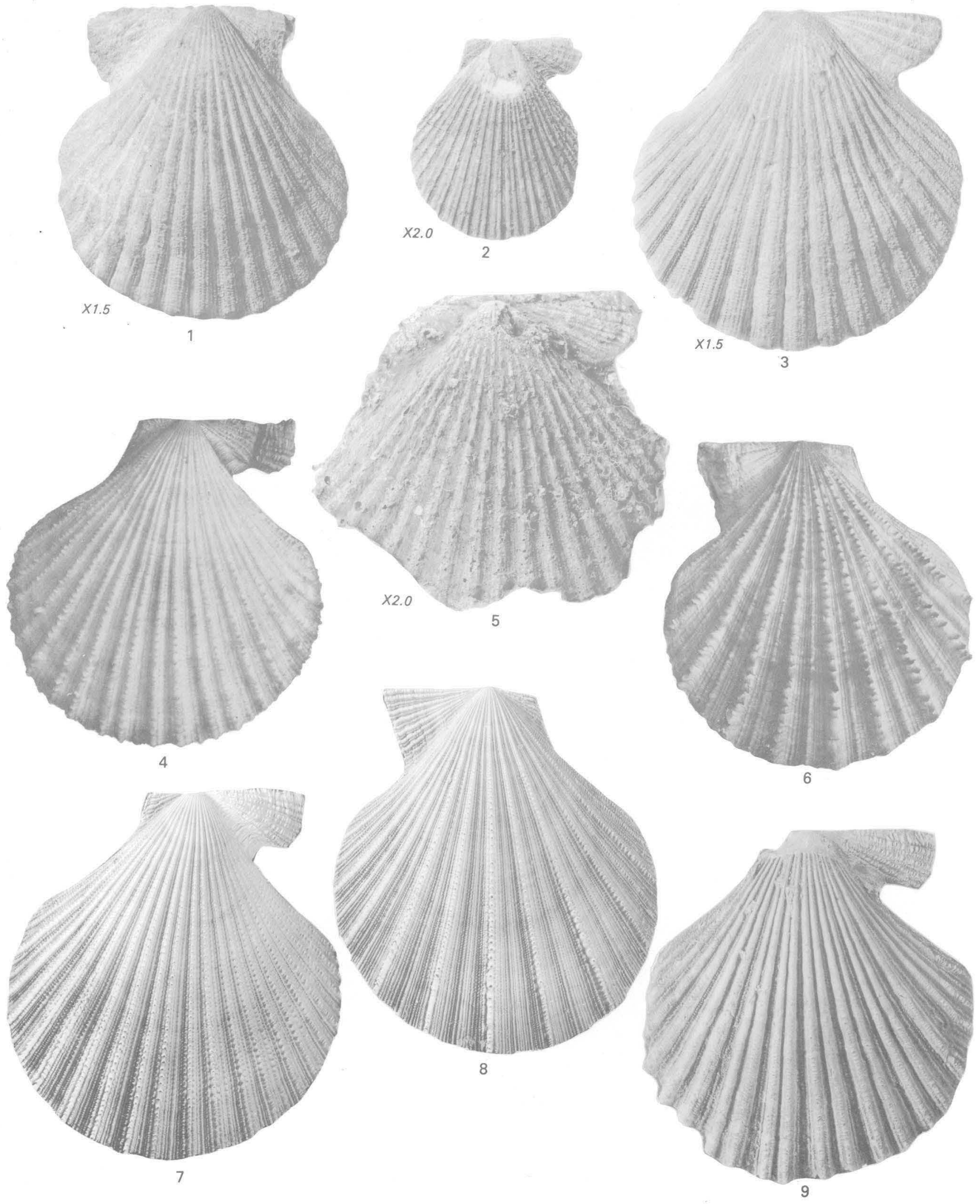

CHLAMYS 


\section{PLATE 6}

1, 9. Chlamys hastata pugetensis (Oldroyd) (p. B27).

"Virtual paratype" CAS 12390 (× 1.5). Length $38 \mathrm{~mm}$, height $43 \mathrm{~mm}$, hinge $24 \mathrm{~mm}$. Puget Sound, Wash., Holocene.

2. Chlamys opuntia (Dall) (p. B26).

Holotype USNM 107752. Length $33 \mathrm{~mm}$, height $35 \mathrm{~mm}$. San Diego Formation, Pliocene.

3, 7. Chlamys jordani (Arnold) (p. B25).

Holotype USNM 162522. Length $43 \mathrm{~mm}$, height $47 \mathrm{~mm}$, hinge $18 \mathrm{~mm}$. San Pedro Formation, Pleistocene.

4, $8 . \quad$ Nodipecten subnodosus subnodosus (Sowerby) (p. B57).

Hypotype SDNM 78669. Length $93 \mathrm{~mm}$, height 85. San Juan del Sur, Nicaragua, Holocene.

5. Chlamys egregius (Nomland) (p. B24).

Holotype UCMP $11090(\times 2.0)$. Length $24 \mathrm{~mm}$, height $31 \mathrm{~mm}$, hinge $13 \mathrm{~mm}$ (estimated). Upper part of Etchegoin Formation, Pliocene.

6. Chlamys bartschi (Arnold) (p. B25)

Holotype USNM 164841. Length $50 \mathrm{~mm}$. St. George Formation, Pliocene. 
GEOLOGICAL SURंVEY

PROFESSIONAL PAPER 1228-B PLATE 6
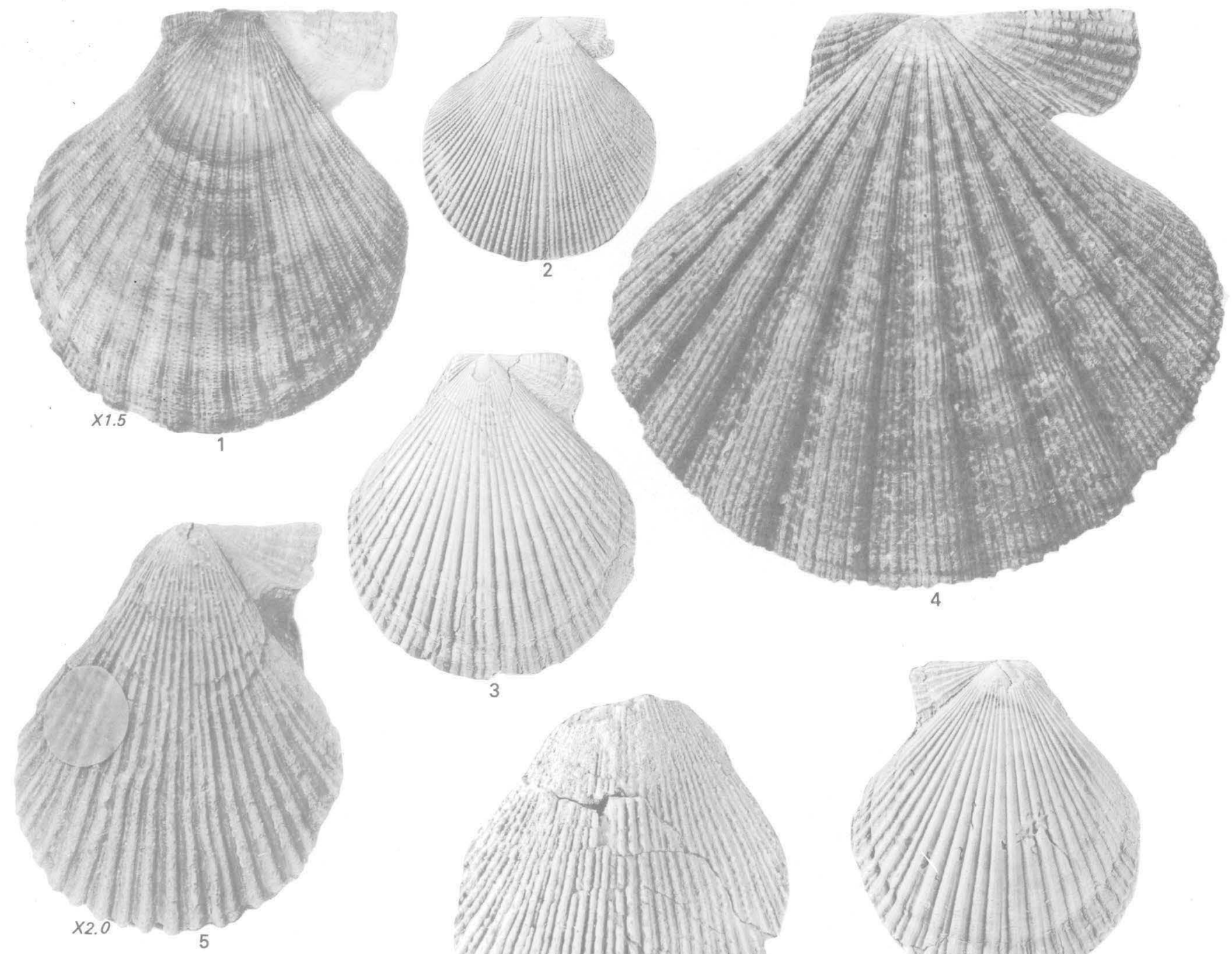

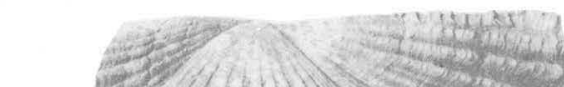
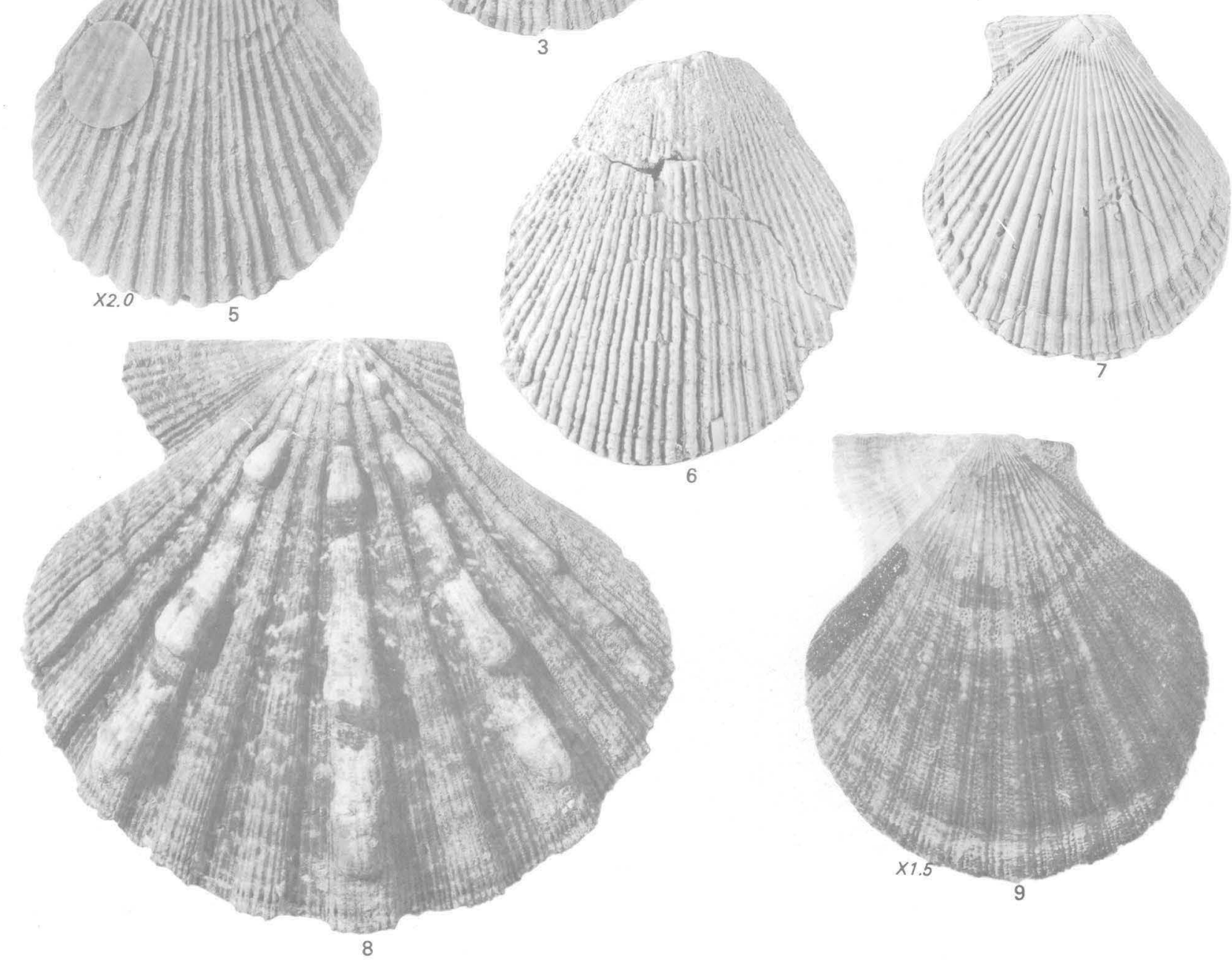

CHLAMYS, NODIPECTEN 


\section{PLATE 7}

Figures

1-2. Chlamys picoensis (Waterfall) (p. B27).

Upper part of Pico or San Pedro Formation, Pleistocene.

1. Holotype UCMP 31419 . Length $68 \mathrm{~mm}$, height $69 \mathrm{~mm}$, hinge $30 \mathrm{~mm}$.

2. Holotype of Chlamys venturaensis (Waterfall), UCMP 31416. Length $68 \mathrm{~mm}$, height $68 \mathrm{~mm}$, hinge $32 \mathrm{~mm}$.

3, 5. Chlamys rubida (Hinds) (p. B28).

Hypotype USNM 150220 (MacNeil 1967, pl. 20, figs. 7, 9). Length $50 \mathrm{~mm}$, height $55 \mathrm{~mm}$. South side of Alaska Peninsula, Holocene.

4, 6. Chlamys anapleus Woodring (p. B29).

4. Holotype USNM $498642(\times 2.0)$. Length $23 \mathrm{~mm}$, height 20 . Basal part of San Pedro Sand, Pleistocene.

6. Hypotype copied from Arnold (1906, pl. 44, fig. 4) (× 3.0). Height $21 \mathrm{~mm}$. San Pedro Formation, Pleistocene.

7. Chlamys? mediacostata mediacostata (G D. Hanna) (p. B29).

Holotype CAS 1830 . Length $30 \mathrm{~mm}$, height $37 \mathrm{~mm}$. Imperial Formation, Miocene or Pliocene.

8. Chlamys? mediacostata grewingki (Hertlein) (p. B29).

Holotype CAS $12812(\times 1.5)$. Length $34 \mathrm{~mm}$, height $40 \mathrm{~mm}$. Salada Formation, Pliocene. 


\section{GEOLOGICAL SURVEY}

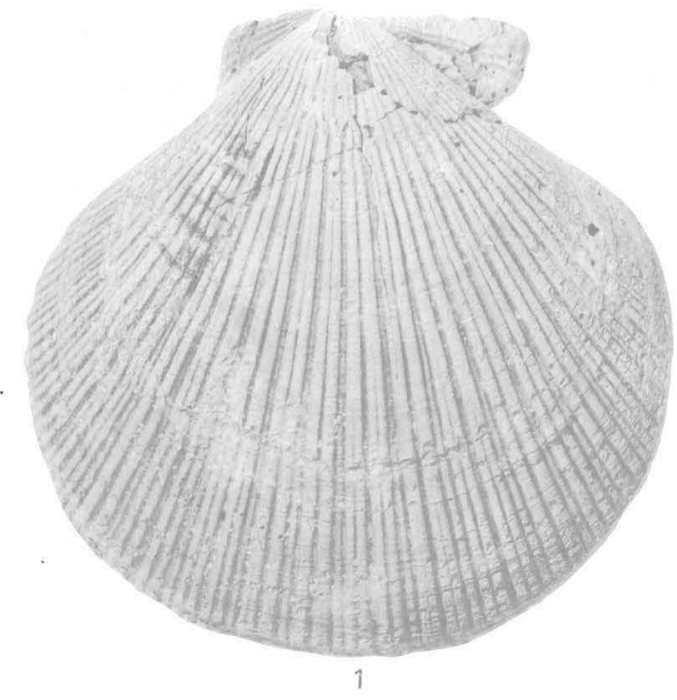

PROFESSIONAL PAPER 1228-B PLATE 7

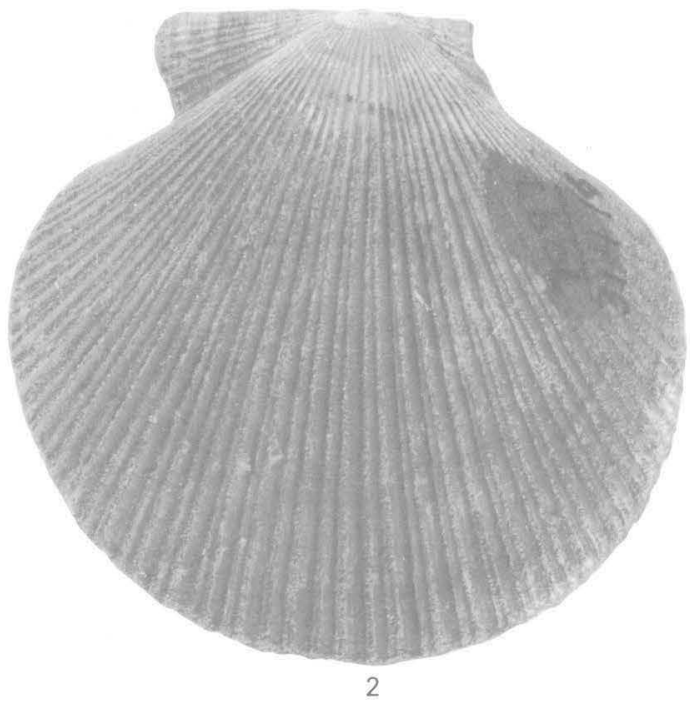

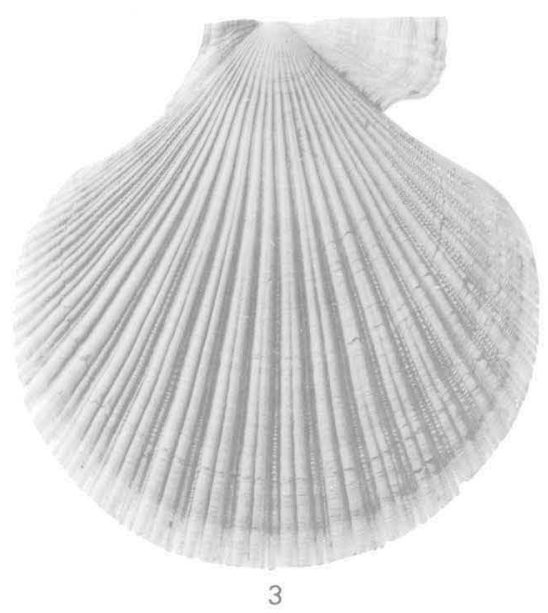
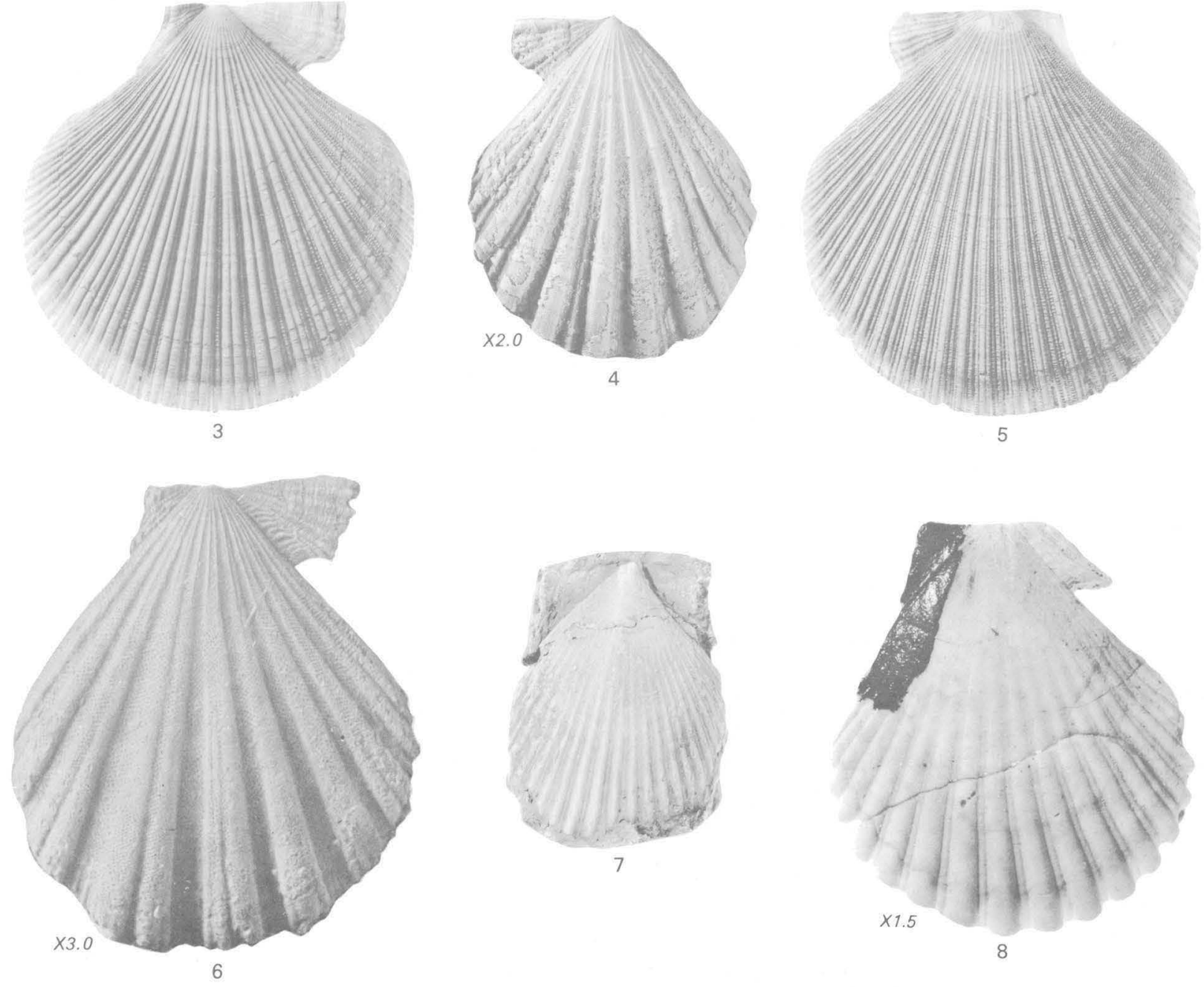

CHLAMYS, CHLAMYS? 


\section{PLATE 8}

\section{Figures}

1, 2. Leochlamys? erici (Wiedey) (p. B30).

Holotype SDNM $27(\times 1.5)$. Length $55 \mathrm{~mm}$, height $63 \mathrm{~mm}$, hinge $28 \mathrm{~mm}$ (estimated). Vaqueros Formation. Oligocene and Miocene. 3. Leochlamys? columbiana (Clark and Arnold) (p. P,30).

Holoty pe UCMP 30056 . Length $75 \mathrm{~mm}$, height $83 \mathrm{~mm}$, hinge $47 \mathrm{~mm}$ (estimated). Sooke Formation, Oligocene and Miocene, British Columbia.

4, 5. Nanaochlamys nutteri (Arnold) (p. B31).

Holotype CAS/SU 6. Height $74 \mathrm{~mm}$. Purisima Formation, Pliocene. 
GEOLOGICAL SURVEY

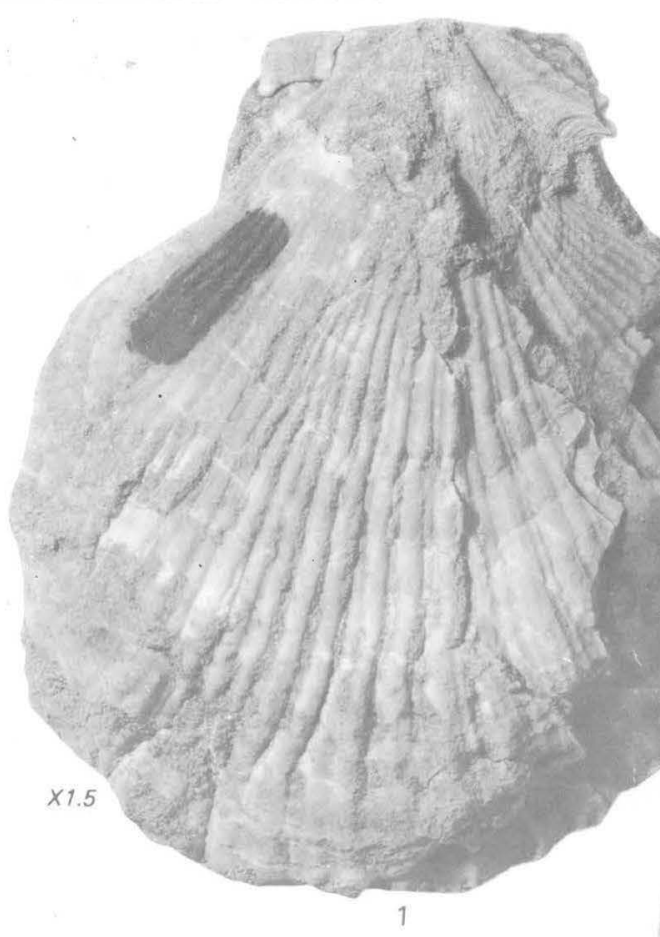

PROFESSIONAL PAPER 1228-B PLATE 8

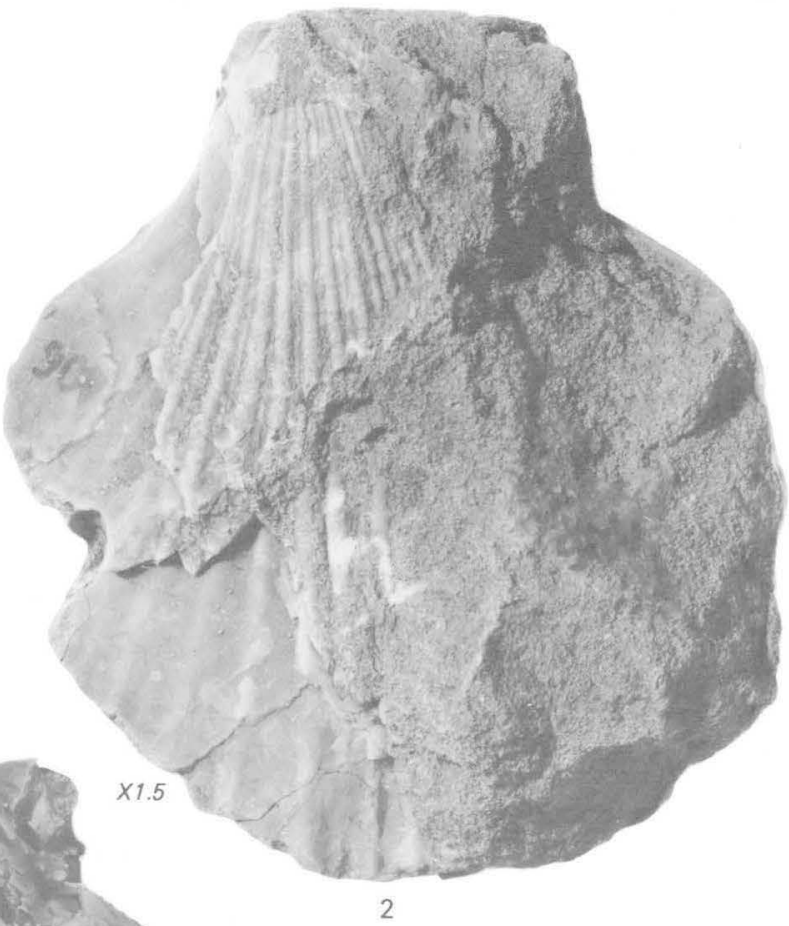

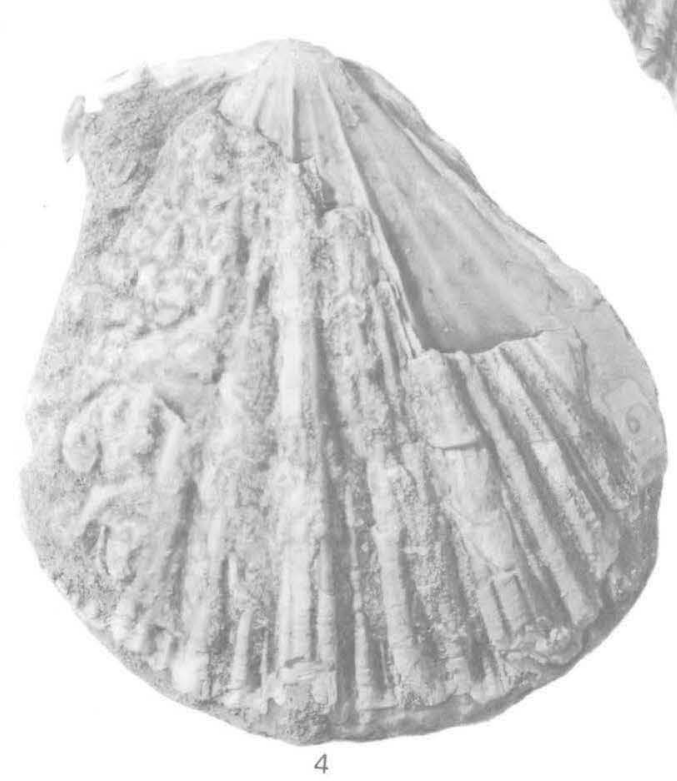

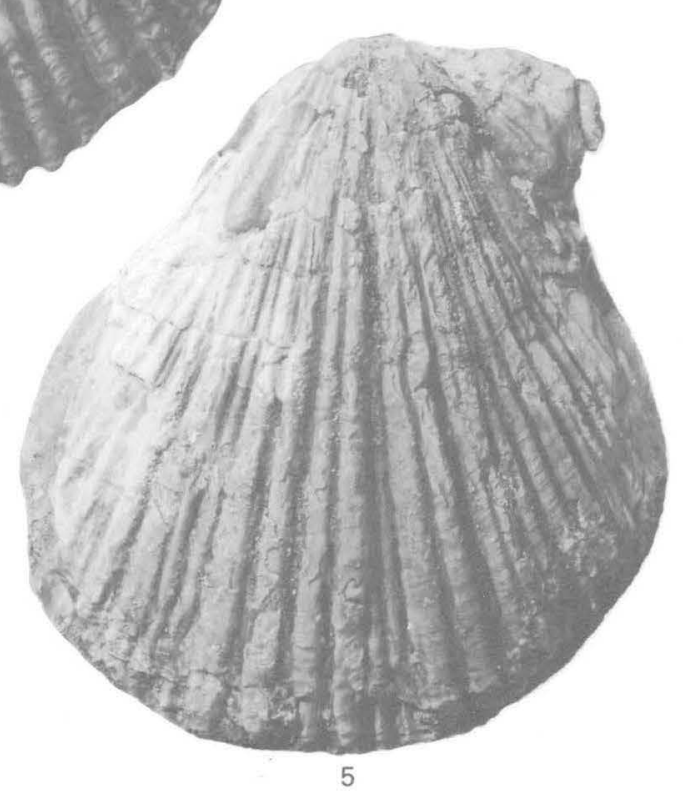

LEOCHLAMYS?, NANAOCHLAMYS 


\section{PLATE 9}

Figures $\quad$ 1, 4. Argopecten mendenhalli (Arnold) (p. B33).

Holotype USNM 164849. Height $43 \mathrm{~mm}$. Salada Formation, Pliocene.

2. Argopecten deserti (Conrad) (p. B33).

Holotype USNM $8398(\times 2.0)$. Imperial Formation, Miocene or Pliocene.

3, 6. Argopecten diminutivus (Hertlein and Jordan) (p. B32).

Holotype CAS/SU $125(\times 4.0)$. Length $9 \mathrm{~mm}$, height $9 \mathrm{~mm}$. Isidro Formation, Miocene.

5. Argopecten circularis bramkampi (Durham) (p. B35).

Holotype UCMP 30035. Length $43 \mathrm{~mm}$, height $44 \mathrm{~mm}$, hinge $23 \mathrm{~mm}$. Imperial Formation, Miocene or Pliocene.

7, 8. Argopecten circularis circularis (Sowerby) (p. B34).

7. Hypotype UCMP 15706 (Durham, 1950, pl. 10, fig. 5). Length $54 \mathrm{~mm}$, height $52 \mathrm{~mm}$, hinge $37 \mathrm{~mm}$. Marquer Formation, Pliocene.

8. UCMP 15740. Length $42 \mathrm{~mm}$, height $50 \mathrm{~mm}$, hinge $38 \mathrm{~mm}$ (estimated). Marquer Formation, Pliocene.

9. Argopecten sverdrupi (Durham) (p. B34).

Holotype UCMP 15995. Length $57 \mathrm{~mm}$, height $55 \mathrm{~mm}$, hinge $30 \mathrm{~mm}$ (estimated). Salada Formation, Pliocene.

10, 12. Aequipecten dallasi (Jordan and Hertlein) (p. B31).

Holotype CAS $1862(\times 1.5)$. Length $43 \mathrm{~mm}$, height $42 \mathrm{~mm}$. Salada Formation, Pliocene.

11. Argopecten circularis eldridgei (Arnold) (p. B36).

Holotype USNM $164580(\times 1.5)$. Height $20 \mathrm{~mm}$. Etchegoin Formation, Pliocene. 
GEOLOGICAL' SURVEY
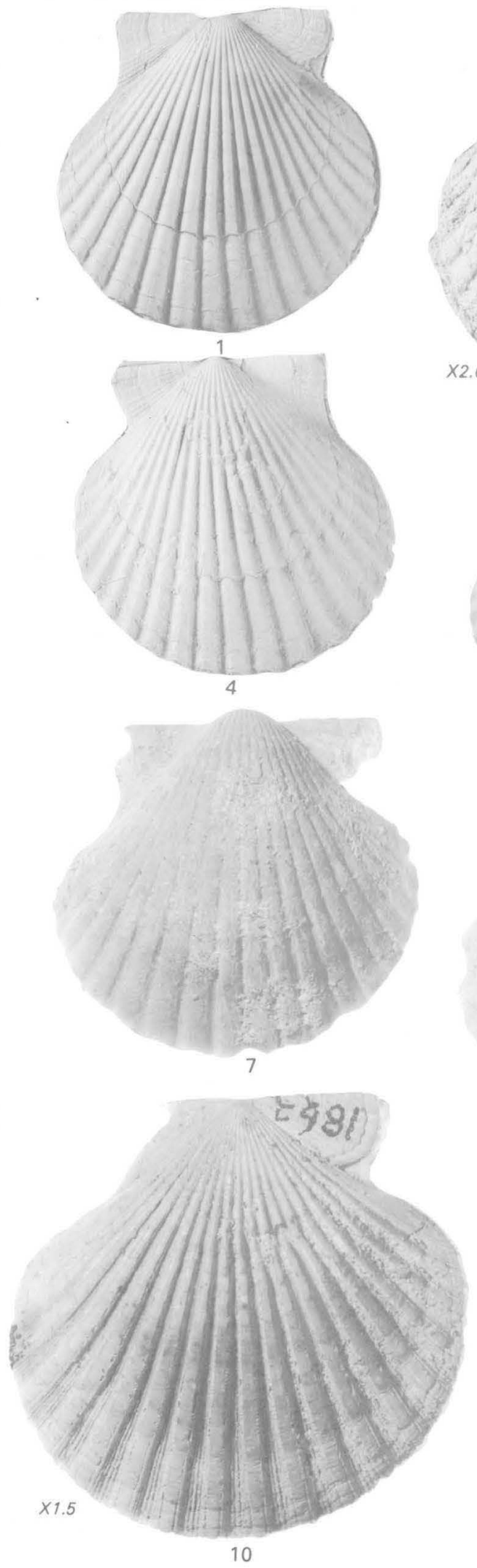

PROFESSIONAL PAPER 1228-B PLATE 9
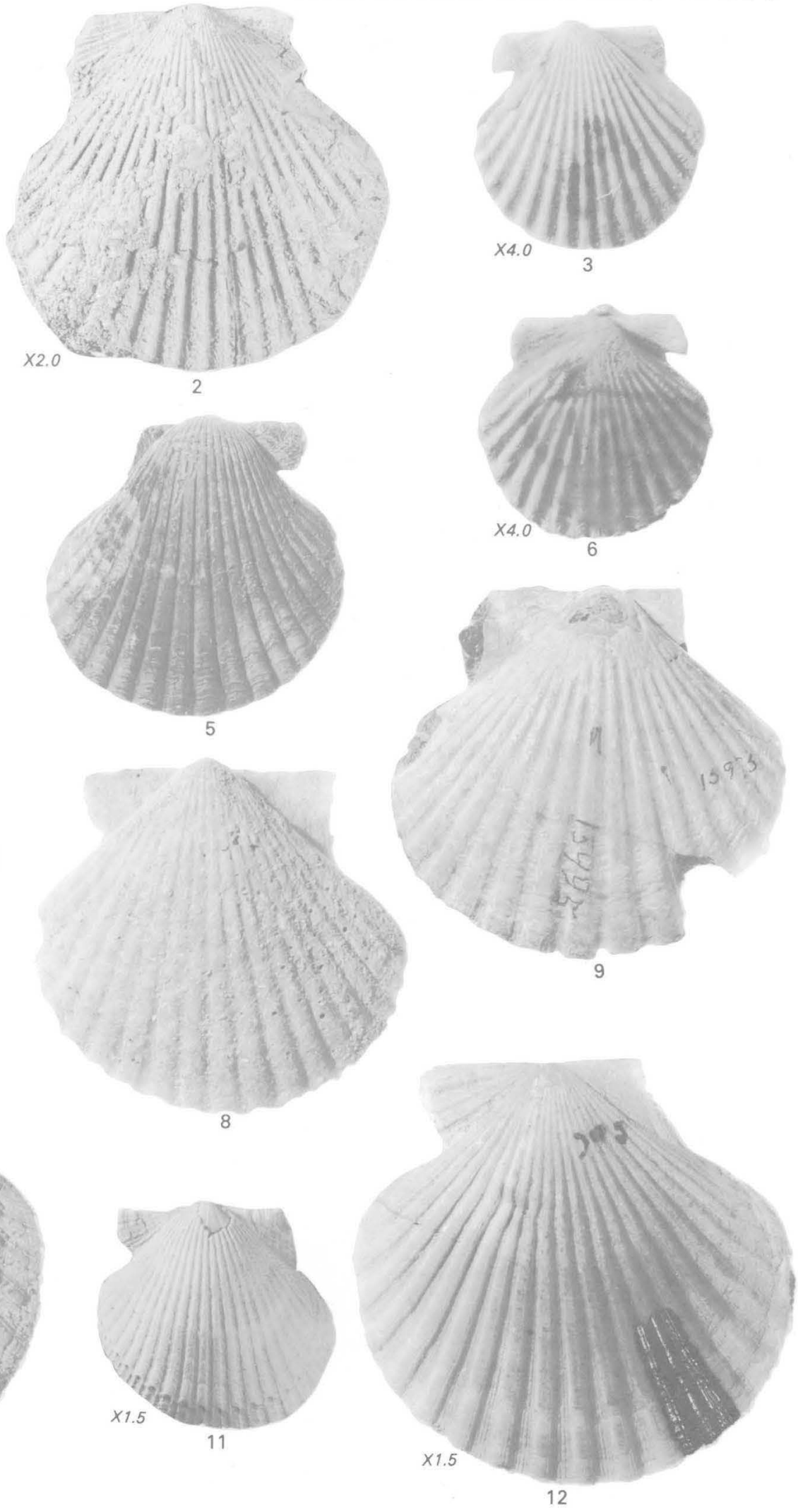

ARGOPECTEN, AEQUIPECTEN 


\section{PLATE 10}

1. Argopecten circularis imposter (G D. Hanna) (p. B36).

Holotype UCMP $11089(\times 1.5)$. Length $33 \mathrm{~mm}$, height $37 \mathrm{~mm}$, hinge $15 \mathrm{~mm}$. Upper part of Etchegoin Formation, Pliocene.

2. Argopecten circularis calli (Hertlein) (p. B35).

Holotype CAS/SU $68(\times 3.0)$. Length $24 \mathrm{~mm}$, height $24 \mathrm{~mm}$, hinge $18 \mathrm{~mm}$. Salada Formation, Pliocene.

3, 4. Argopecten subdolus (Hertlein) (p. B37).

Holotype CAS/SU 51. Length $50 \mathrm{~mm}$, height $49 \mathrm{~mm}$, hinge $25 \mathrm{~mm}$. San Diego Formation, Pliocene.

5. Argopecten invalidus (G D. Hanna) (p. B37).

Holotype CAS/SU $8(\times 1.5)$. Length $37 \mathrm{~mm}$, height $35 \mathrm{~mm}$, hinge $22 \mathrm{~mm}$ (estimated). San Diego Formation, Pliocene.

6. Argopecten percarus (Hertlein) (p. B39).

Holotype CAS/SU 42 . Length $89 \mathrm{~mm}$, height $79 \mathrm{~mm}$, hinge $45 \mathrm{~mm}$ (estimated). Almejas Formation, Pliocene.

7, 9. Argopecten callidus (Hertlein) (p. B38).

Holotype CAS/SU 53. Length $54 \mathrm{~mm}$, height $55 \mathrm{~mm}$, hinge $28 \mathrm{~mm}$. Almejas Formation, Pliocene.

8. Argopecten? crassiradiatus (Clark) (p. B42).

Holotyr - UCMP 11584. Height $45 \mathrm{~mm}$. Cierbo Sandstone, Miocene. 
GEOLOGICAL SURVEY
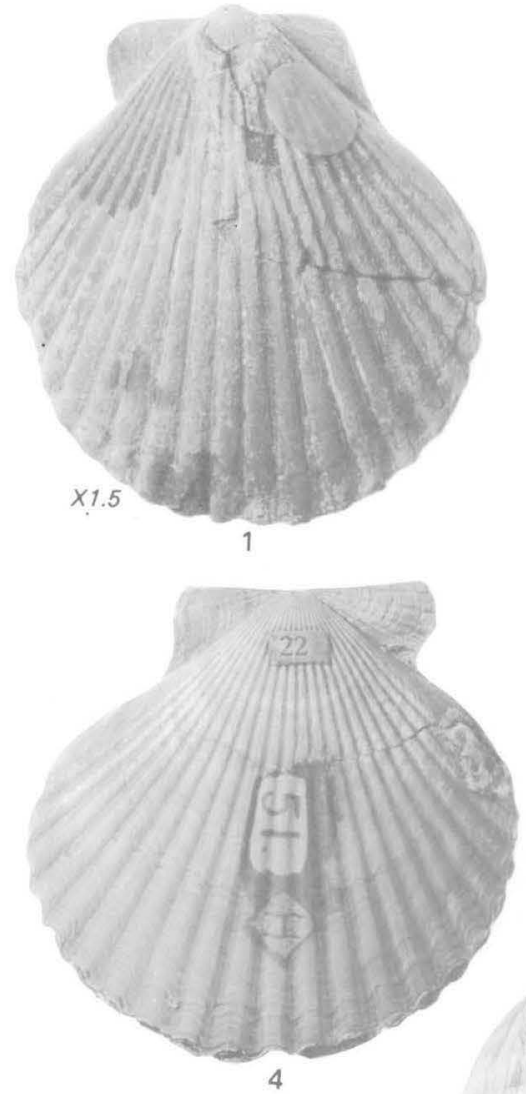

PROFESSIONAL PAPER 1228-B PLATE 10
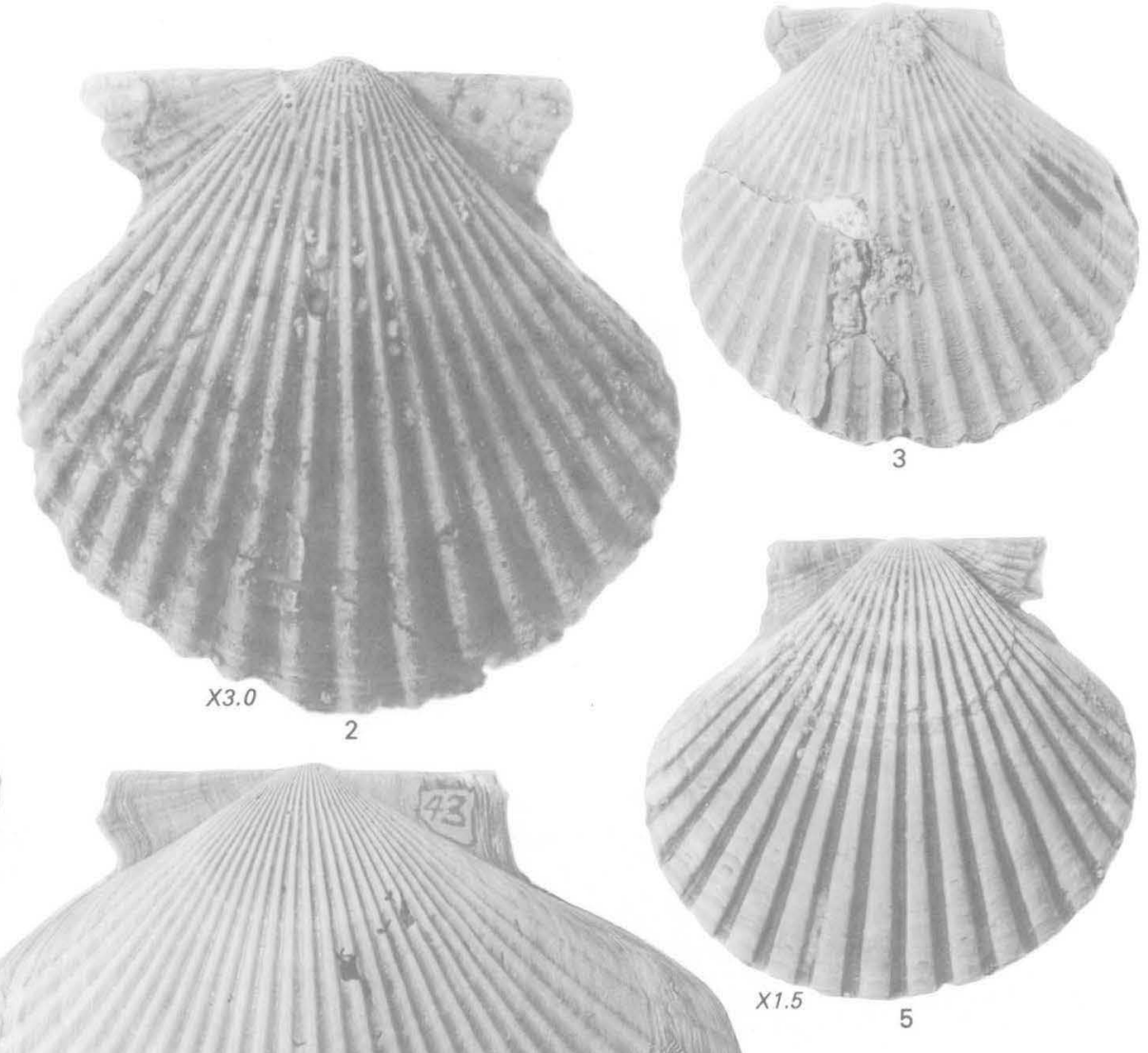
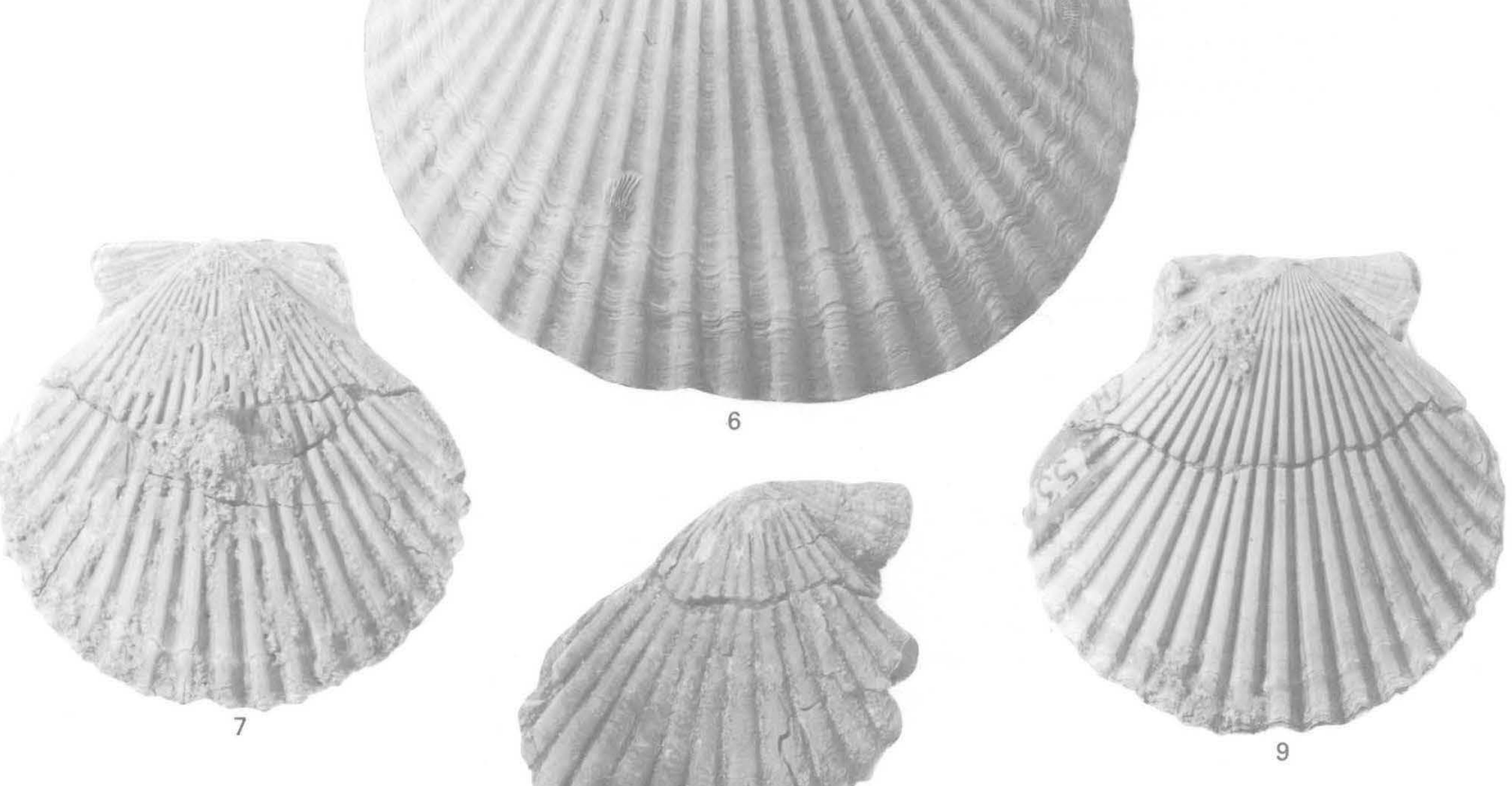

ARGOPECTEN, ARGOPECTEN? 


\section{PLATE 11}

FIGURES

1, 3. Argopecten revellei (Durham) (p. B40).

Holotype UCMP 15510. Length $60 \mathrm{~mm}$, height $58 \mathrm{~mm}$, hinge $36 \mathrm{~mm}$ (estimated). Salada Formation, Pliocene.

2. Argopecten abietis abietis (Jordan and Hertlein) (p. B41).

Holotype CAS 2079. Length $55 \mathrm{~mm}$, height $55 \mathrm{rmm}$, hinge $37 \mathrm{~mm}$ (estimated). Unnamed Pliocene strata, Isla Maria Madre, Mexico.

4, 5. Argopecten antonitaensis (Durham) (p. B41).

Holotype CAS 5957 ( $\times 1.5)$. Length $43 \mathrm{~mm}$, height $41 \mathrm{~mm}$, hinge $24 \mathrm{~mm}$. Carmen Formation, Pliocene.

6. Argopecten hakei (Hertlein) (p. B39).

Holotype CAS/SU $40(\times 0.8)$. Length $135 \mathrm{~mm}$, height $116 \mathrm{~mm}$, hinge $90 \mathrm{~mm}$ (estimated). Almejas Formation, Pliocene. 
GEOLOGICAL SURVEY
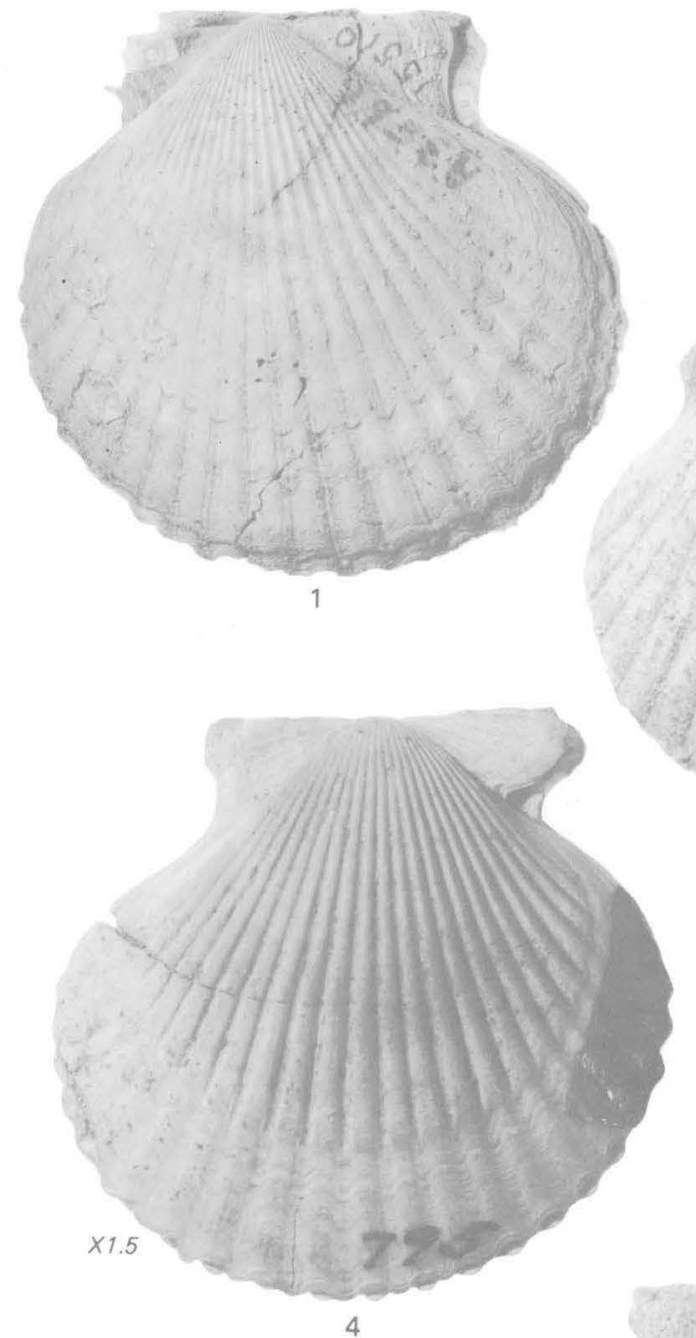

PROFESSIONAL PAPER 1228-B PLATE 11
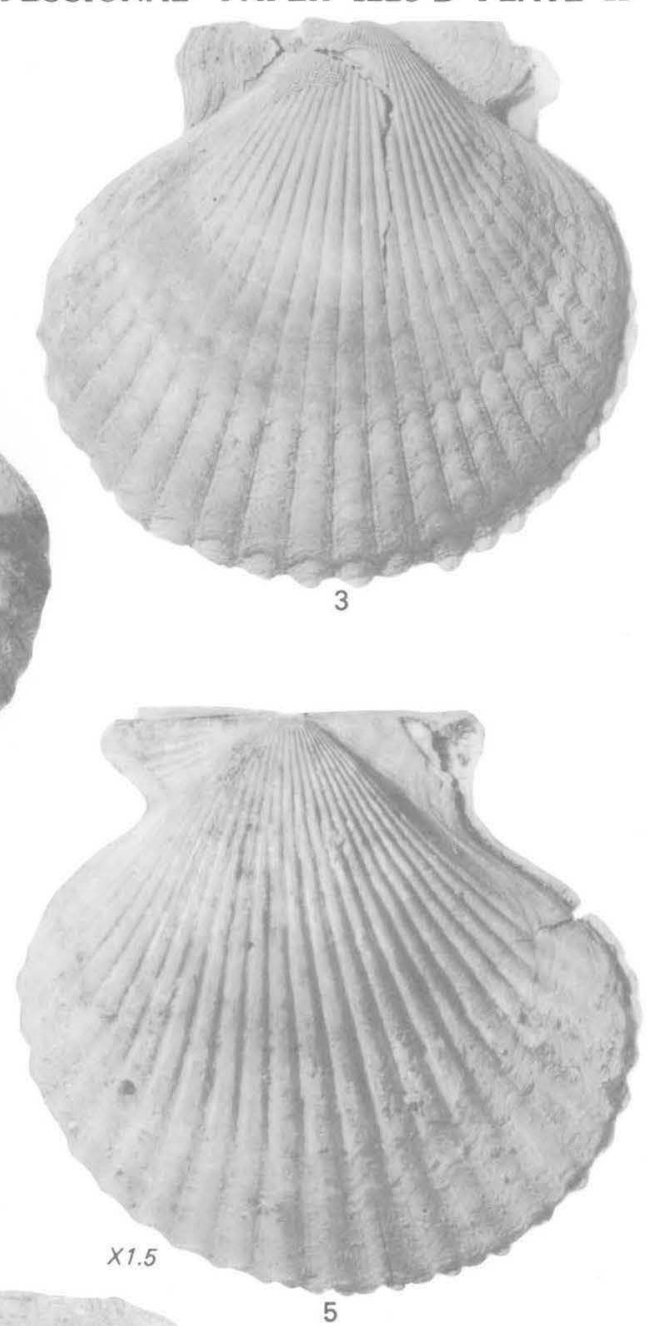

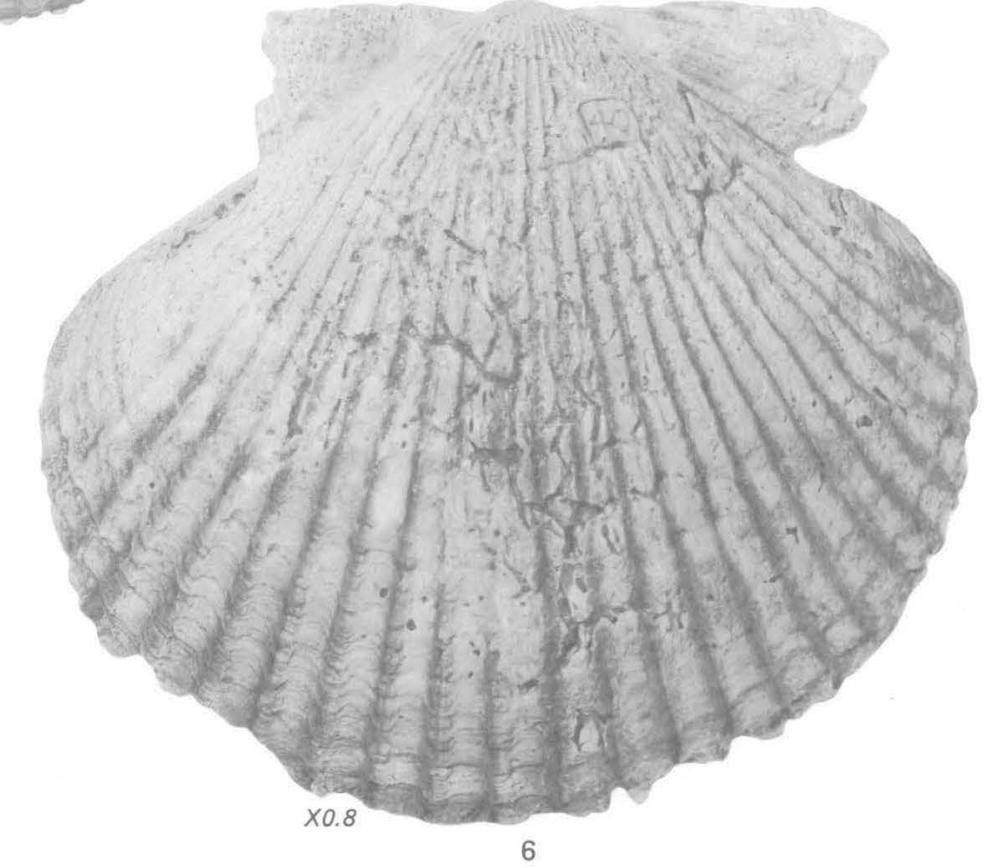

ARGOPECTEN 


\section{PLATE 12}

1, 5. Argopecten abietis abbotti (Hertlein and Grant) (p. B42).

Holotype SDNM $04334(\times 0.7)$. Length $129 \mathrm{~mm}$, height $117 \mathrm{~mm}$. San Diego Formation, Pliocene.

2. Argopecten ericellus (Hertlein) (p. B37).

Holotype CAS $2998(\times 2.0)$. Length $29 \mathrm{~mm}$, height $28 \mathrm{~mm}$, hinge $19 \mathrm{~mm}$. San Diego Formation, Pliocene.

3. Argopecten abietis abietis (Jordan and Hertlein) (p. B41).

Holotype CAS 2079. Length $66 \mathrm{~mm}$, height $64 \mathrm{~mm}$, hinge $39 \mathrm{~mm}$ (estimated). Unnamed Pliocene strata, Isla Maria Madre, Mexico.

4. Argopecten percarus (Hertlein) (p. B39).

Holotype CAS/SU 42. Length $91 \mathrm{~mm}$, height $80 \mathrm{~mm}$, hinge $43 \mathrm{~mm}$. Almejas Formation, Pliocene. 

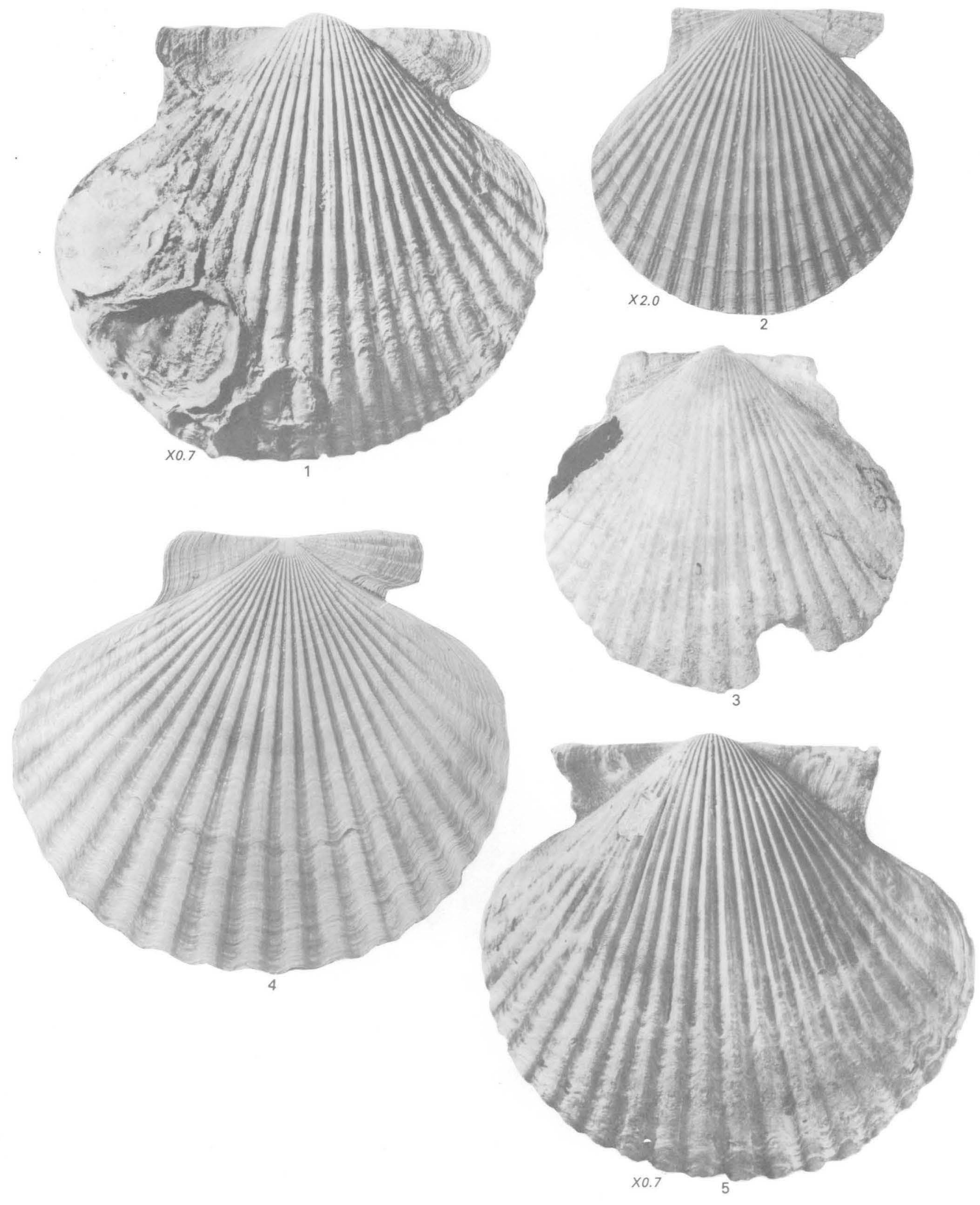


\section{PLATE 13}

Figures

1. Argopecten cristobalensis (Hertlein) (p. B40).

Holoty pe CAS/SU $36(\times 0.7)$. Length $135 \mathrm{~mm}$, height $117 \mathrm{~mm}$, hinge $50 \mathrm{~mm}$ (estimated). Almejas Formation, Pliocene.

2, 4, 5. Antipecten? praevalidus (Jordan and Hertlein) (p. B42).

Almejas Formation, Pliocene.

2. Paratype CAS 2102. Length $65 \mathrm{~mm}$, height $58 \mathrm{~mm}$, hinge $40 \mathrm{~mm}$ (estimated).

4, 5. Holotype CAS 2101. Length $51 \mathrm{~mm}$, height $47 \mathrm{~mm}$, hinge $39 \mathrm{~mm}$. 3, 6. Leptopecten bellilamellatus (Arnold) (p. B43).

Holotype CAS/SU $35(\times 3.0)$. Length $18 \mathrm{~mm}$, height $18 \mathrm{~mm}$, hinge $16 \mathrm{~mm}$. San Diego Formation, Pliocene.

7. Argopecten evermanni (Jordan and Hertlein) (p. B39).

Holotype CAS $2108(\times 0.8)$. Length $125 \mathrm{~mm}$, height $115 \mathrm{~mm}$. Almejas Formation, Pliocene. 
GEOLOGICAL SURVEY
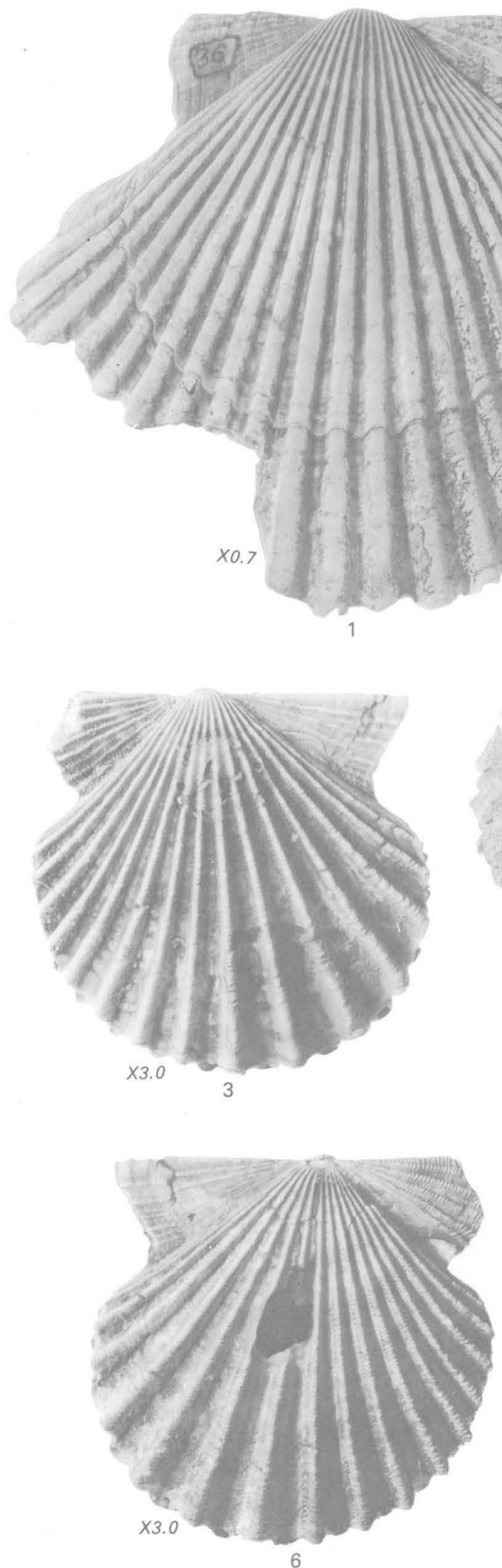

PROFESSIONAL PAPER 1228-B PLATE 13
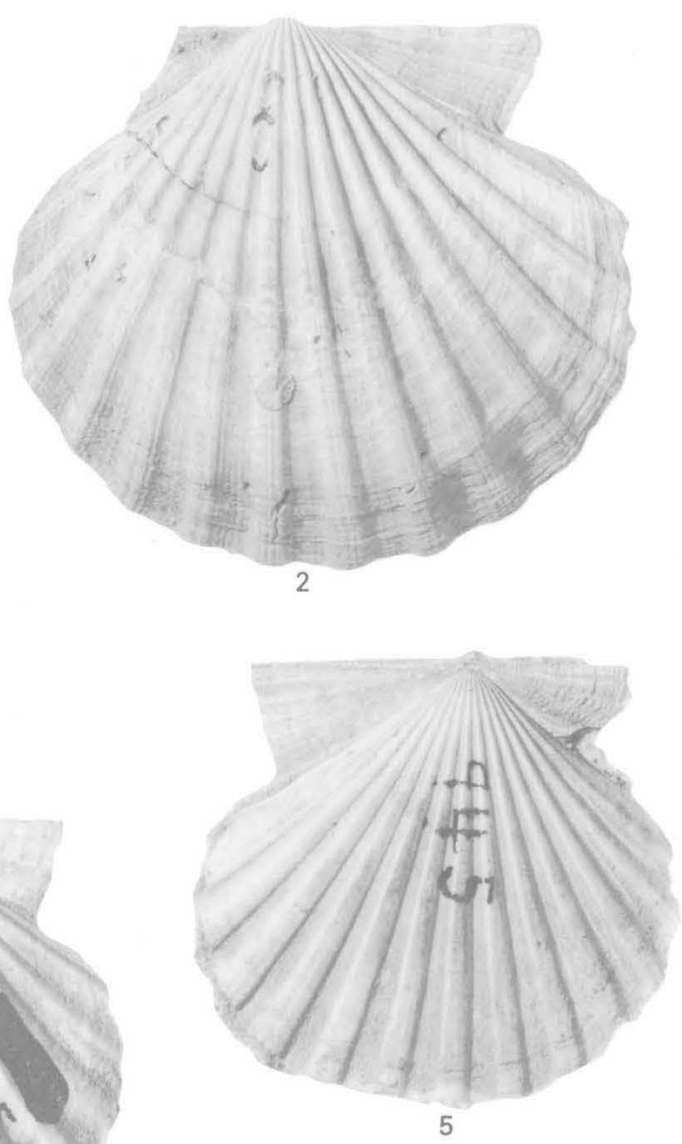

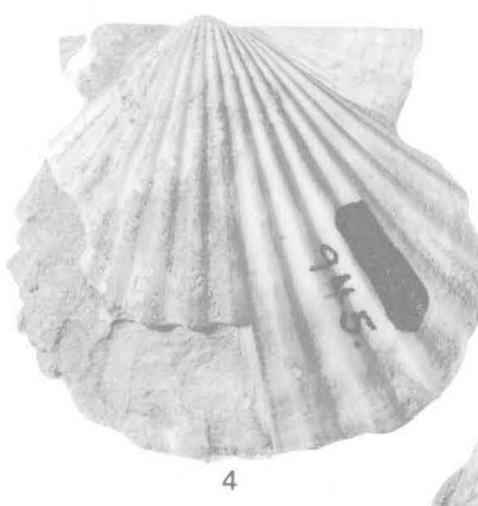

of is

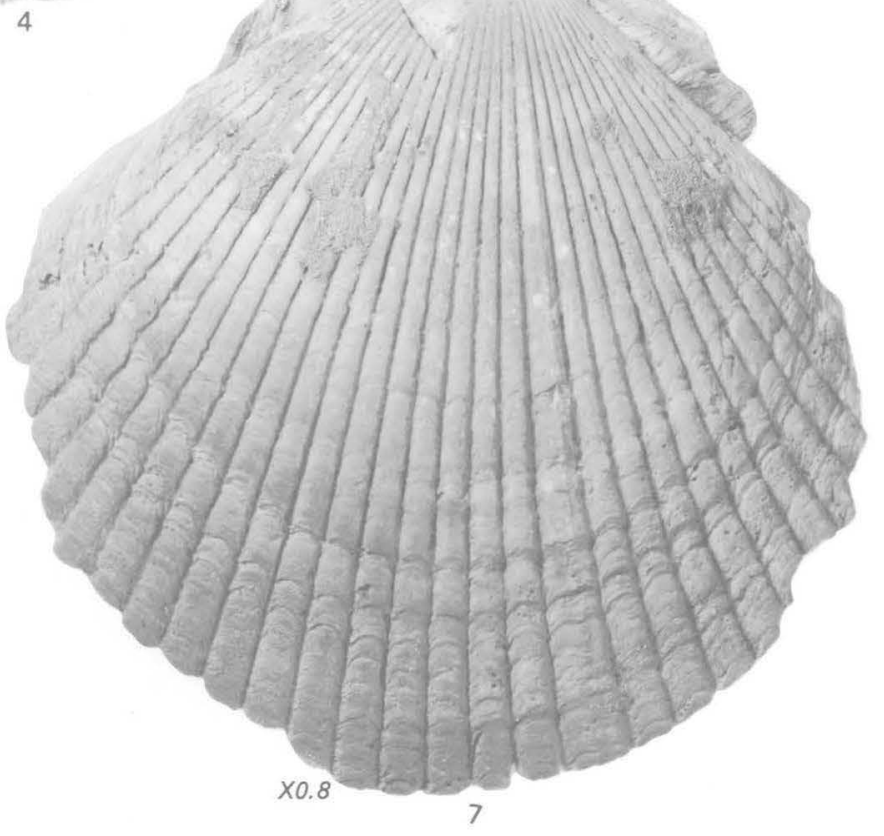

ARGOPECTEN, ANTIPECTEN ?, LEPTOPECTEN 


\section{PLATE 14}

1. Pacipecten andersoni andersoni (Anderson) (p. B45).

Holotype USNM 164932. Length $43 \mathrm{~mm}$, height $38 \mathrm{~mm}$. Monterey(?) Formation, Miocene.

2. Pacipecten tolmani (Hall and Ambrose) (p. B46)

Holotype CAS/SU 23. Length $72 \mathrm{~mm}$, height $65 \mathrm{~mm}$. Briones Sandstone, Miocene.

3-5, 7-9. Pacipecten discus (Conrad) (p. B46).

3. UCMP 11581, holotype of $P$. raymondi Clark. Length $43 \mathrm{~mm}$, height $40 \mathrm{~mm}$, hinge $21 \mathrm{~mm}$. San Pablo Group, Miocene.

4. UCMP 12370 , holotype of $P$. gonicostatus Trask $(\times 2.0)$. Length $31 \mathrm{~mm}$, height $29 \mathrm{~mm}$. Briones Sandstone, Miocene.

5. UCMP 11585, holotype of $P$. cierboensis Clark $(\times 2.0)$. Length $18 \mathrm{~mm}$, height $20 \mathrm{~mm}$. Briones Sandstone, Miocene.

7. UCMP 12368 , holotype of $P$. brionianus Trask $(\times 1.5)$. Length $37 \mathrm{~mm}$, height $37 \mathrm{~mm}$. Briones Sandstone, Miocene.

8. USNM 13335, holotype of $P$. discus. Length $53 \mathrm{~mm}$, height $47 \mathrm{~mm}$, hinge $21 \mathrm{~mm}$. Monterey(?) Formation, Miocene.

9. UCMP 12371, paratype of $P$. raymondi. Length $57 \mathrm{~mm}$, height $53 \mathrm{~mm}$, hinge $30 \mathrm{~mm}$. San Pablo Group, Miocene.

6. Pacipecten andersoni subandersoni (Loel and Corey) (p. B45).

Holotype UCMP $31741(\times 1.5)$. Length $40 \mathrm{~mm}$, height $35 \mathrm{~mm}$ (estimated), hinge $23 \mathrm{~mm}$ (estimated). Vaqueros Formation, Oligocene and Miocene. 

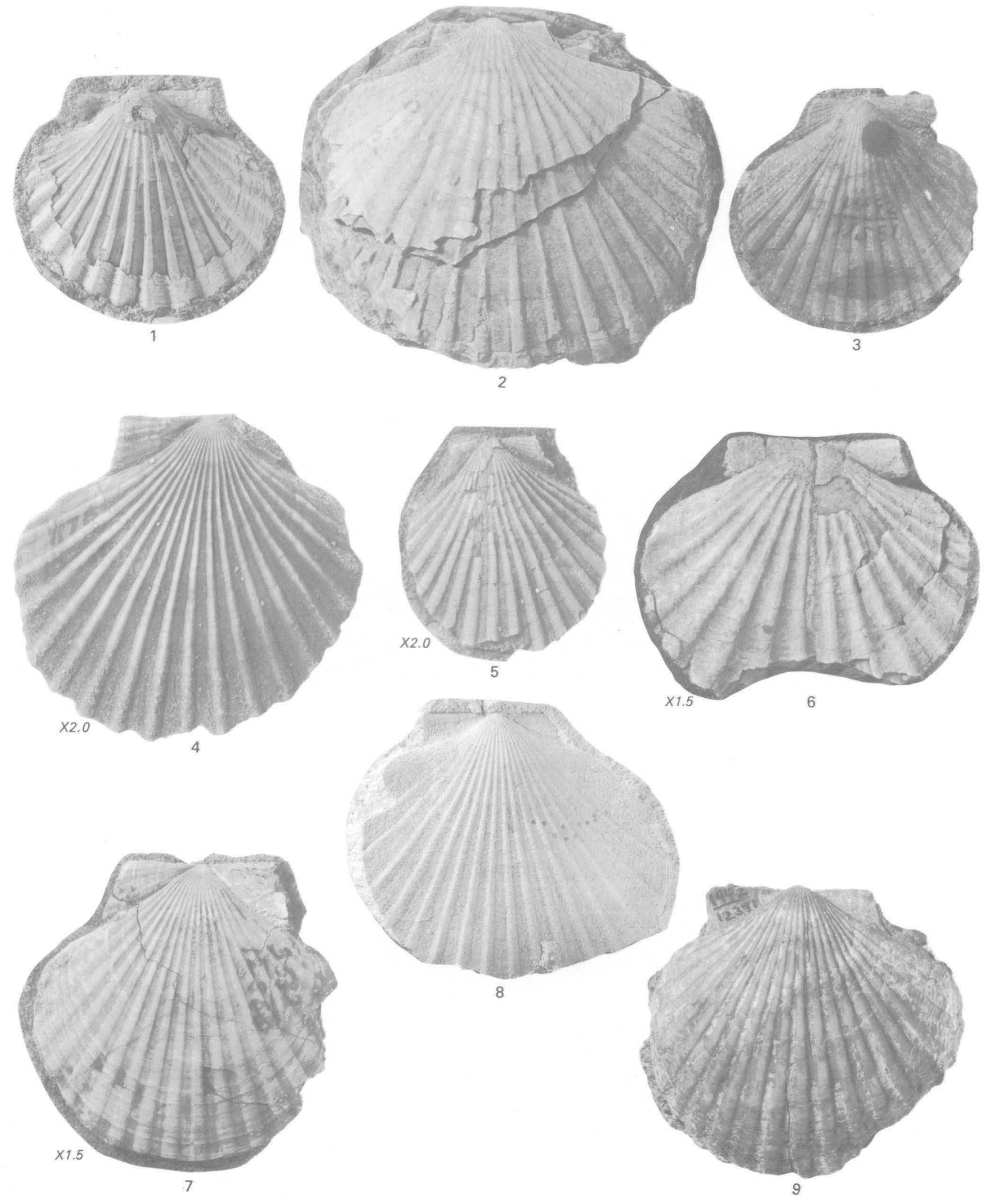

PACIPECTEN 


\section{PLATE 15}

1, 3. Pacipecten pabloensis (Conrad) of Arnold (p. B47).

1. CAS/SU $302(\times 1.5)$. Hypotype (Arnold, 1906, pl. 27, figs. 5, 5a) Length $35 \mathrm{~mm}$, height $35 \mathrm{~mm}$, hinge $20 \mathrm{~mm}$. San Pablo Formation, Miocene.

3. CAS/SU 302a ( $\times$ 1.5). Hypotype (Arnold, 1906, pl.27, figs. 6, 6a). Length $32 \mathrm{~mm}$, height $32 \mathrm{~mm}$, hinge $17 \mathrm{~mm}$ (estimated).

6. Pacipecten bilineatus (Clark) (p. B48).

Holotype UCMP 11579. Length $48 \mathrm{~mm}$, height $38 \mathrm{~mm}$, hinge $20 \mathrm{~mm}$. Cierbo Sandstone, Miocene.

2, 8. Pacipecten tumbezensis (Orbigny) (p. B49).

Tumbez, Peru, Holocene.

2. Hypotype CAS $60361(\times 3.0)$. Length $24 \mathrm{~mm}$, height $23 \mathrm{~mm}$, hinge $18 \mathrm{~mm}$.

8. Hypotype CAS $60360(\times 1.5)$. Length $39 \mathrm{~mm}$, height $38 \mathrm{~mm}$, hinge $23 \mathrm{~mm}$.

4, 5. Pacipecten weaveri (Clark) (p. B46).

Cierbo Sandstone, Miocene.

4. Syntype UCMP $11576(\times 1.5)$. Length $39 \mathrm{~mm}$, height $34 \mathrm{~mm}$.

5. Syntype UCMP $11575(\times 1.5)$. Length $48 \mathrm{~mm}$, height $40 \mathrm{~mm}$, hinge $25 \mathrm{~mm}$.

7, 9. Leptopecten latiauratus (Conrad) (p. B43).

Hypotype CAS $60358(\times 2.0)$. Length $28 \mathrm{~mm}$, height $28 \mathrm{~mm}$, hinge $22 \mathrm{~mm}$. San Diego, Calif., Holocene. 

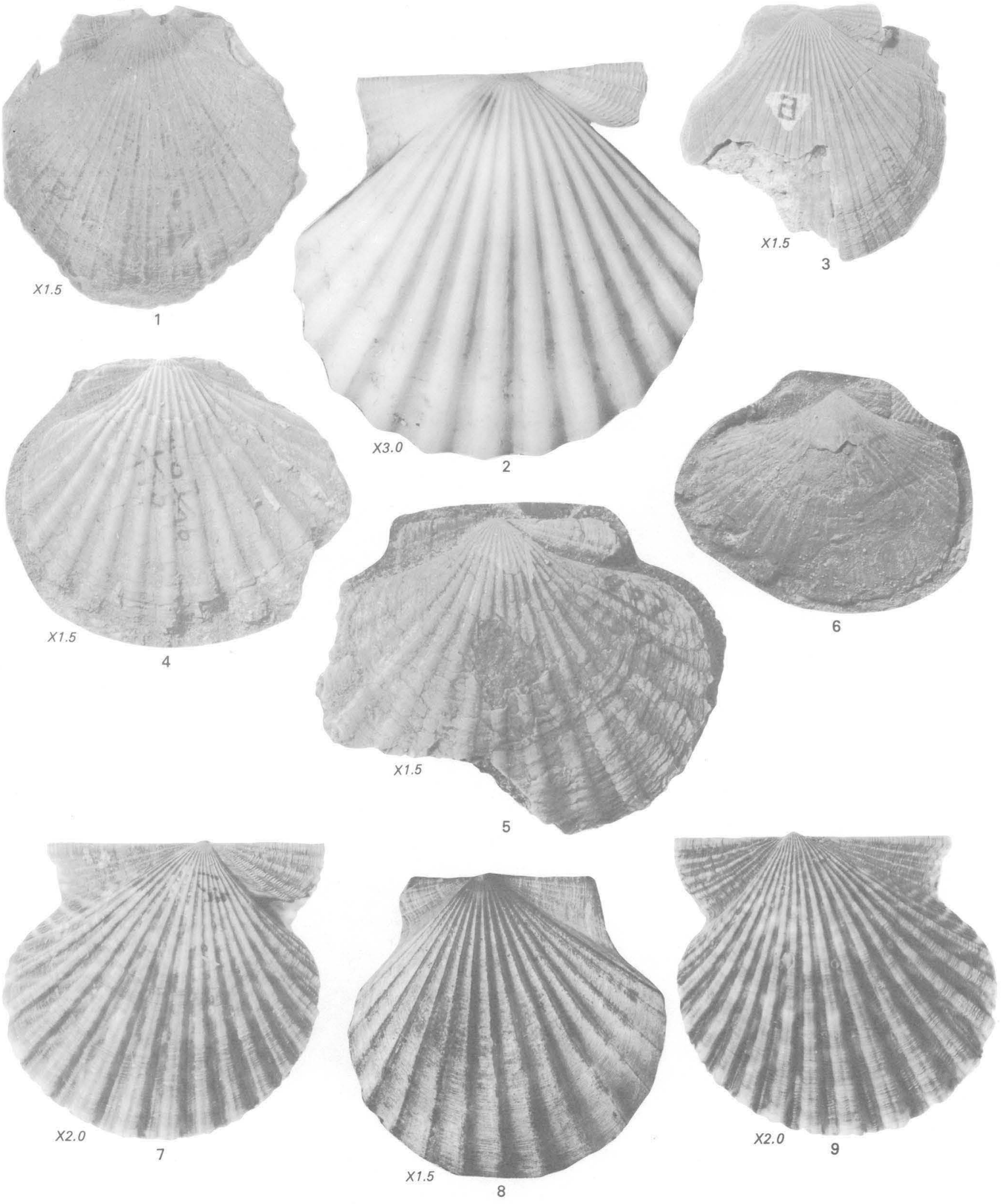

PACIPECTEN, LEPTOPECTEN 


\section{PLATE 16}

1, 2, 4. Lyropecten miguelensis (Arnold) (p. B49).

Holotype UCMP 12079. Height $110 \mathrm{~mm}$. Vaqueros Formation, Oligocene and Miocene.

3, 5. Lyropecten submiguelensis (Loel and Corey) (p. B50).

Holotype UCMP 31737 . Length $70 \mathrm{~mm}$, height $67 \mathrm{~mm}$. Vaqueros Formation, Oligocene and Miocene. 


\section{GEOLOGICAL SURVEY}
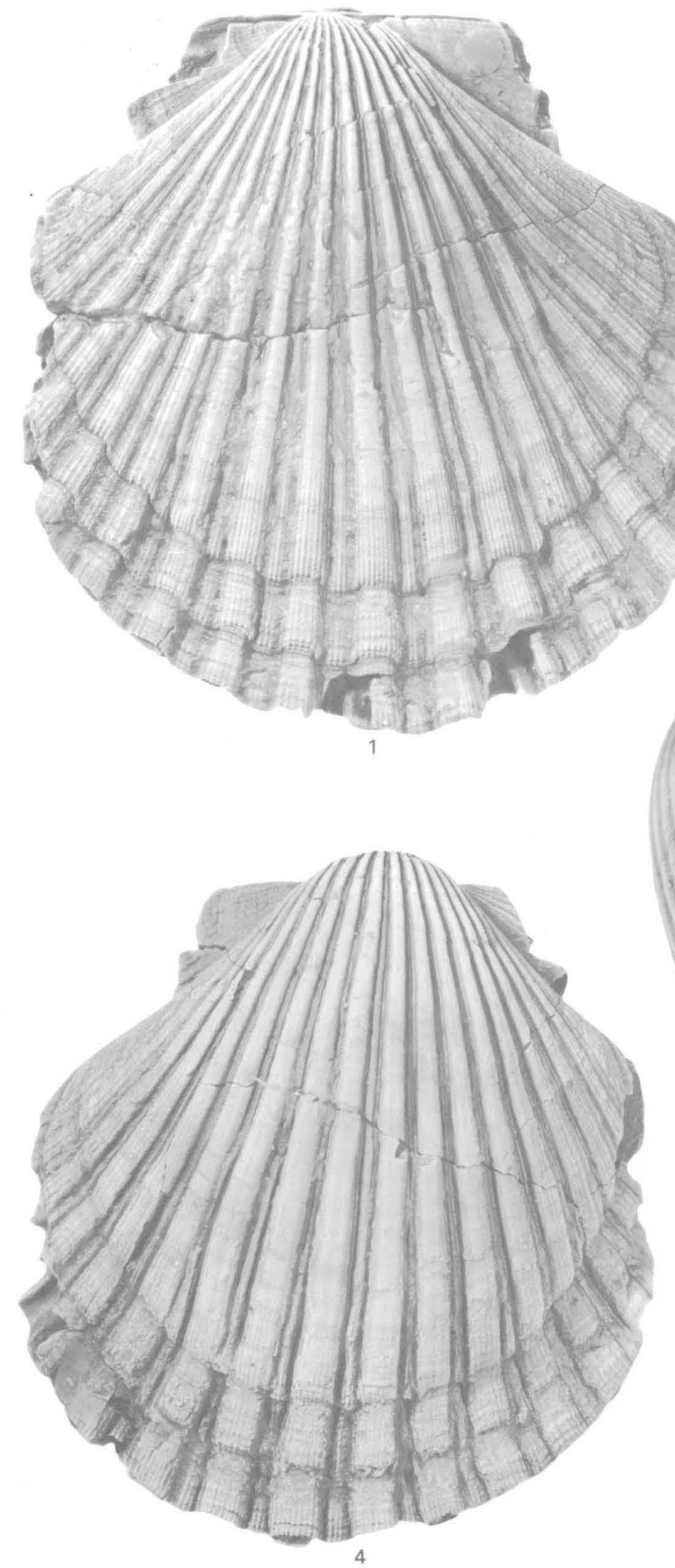

PROFESSIONAL PAPER 1228-B PLATE 16

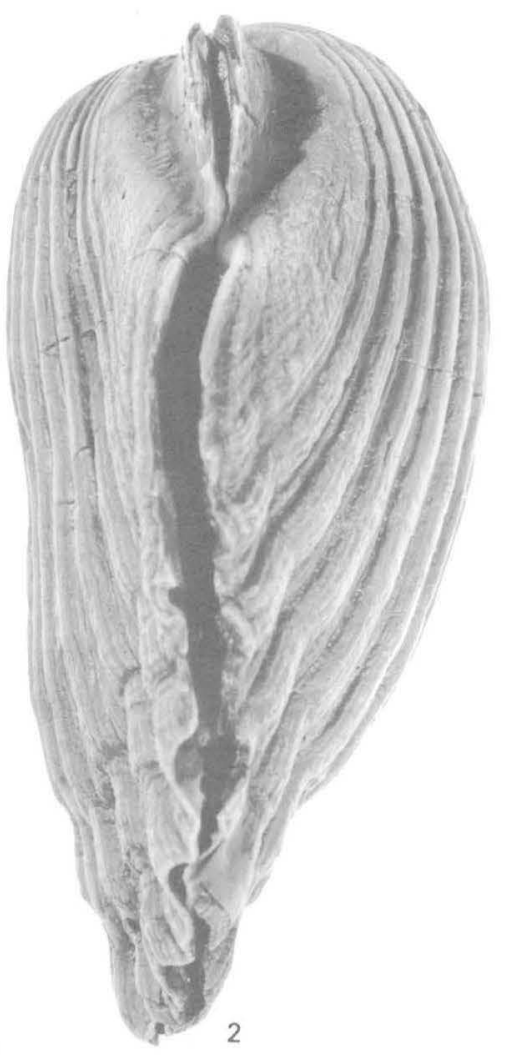

LYROPECTEN 


\section{PLATE 17}

Figures

1. Lyropecten submiguelensis (Loel and Corey) (p. B50).

Holotype UCMP 31737 . Length $70 \mathrm{~mm}$, height $67 \mathrm{~mm}$. Vaqueros Formation, Oligocene and Miocene.

2-4. Lyropecten vaughani (Arnold) (p. B50).

Holotype CAS/SU 9. Height $37 \mathrm{~mm}$. Vaqueros Formation, Oligocene and Miocene.

5, 8. Lyropecten pretiosus (Hertlein) (p. B51).

Isidro Formation, Miocene.

5. Holotype CAS/SU $38(\times 2.0)$. Length $29 \mathrm{~mm}$, height $27 \mathrm{~mm}$, hinge $18 \mathrm{~mm}$.

8. Paratype CAS/SU $89(\times 2.0)$. Length $47 \mathrm{~mm}$, height $32 \mathrm{~mm}$.

6, 7. Lyropecten crassicardo (Conrad) (p. B51).

6. Holotype of Lyropecten nomlandi (Hertlein), UCMP. 11308

Length $114 \mathrm{~mm}$, height $92 \mathrm{~mm}$, hinge $65 \mathrm{~mm}$ (estimated). Santa Margarita Formation, Miocene.

7. Holotype of Lyropecten vickeryi (Trask), CAS/SU 26. Length $106 \mathrm{~mm}$ (estimated), height $99 \mathrm{~mm}$. Briones Sandstone, Miocene. 
GEOLOGICAL SURVEY
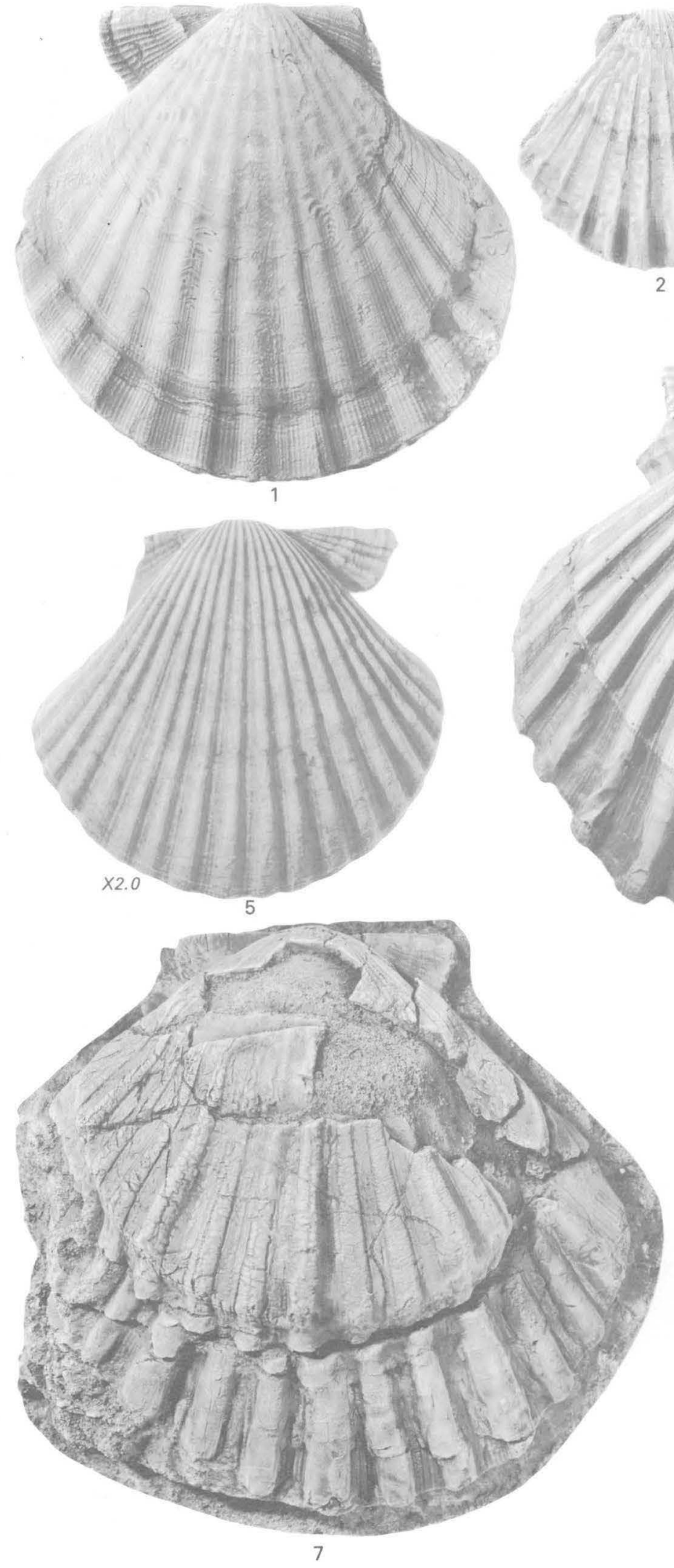

PROFESSIONAL PAPER 1228-B PLATE 17
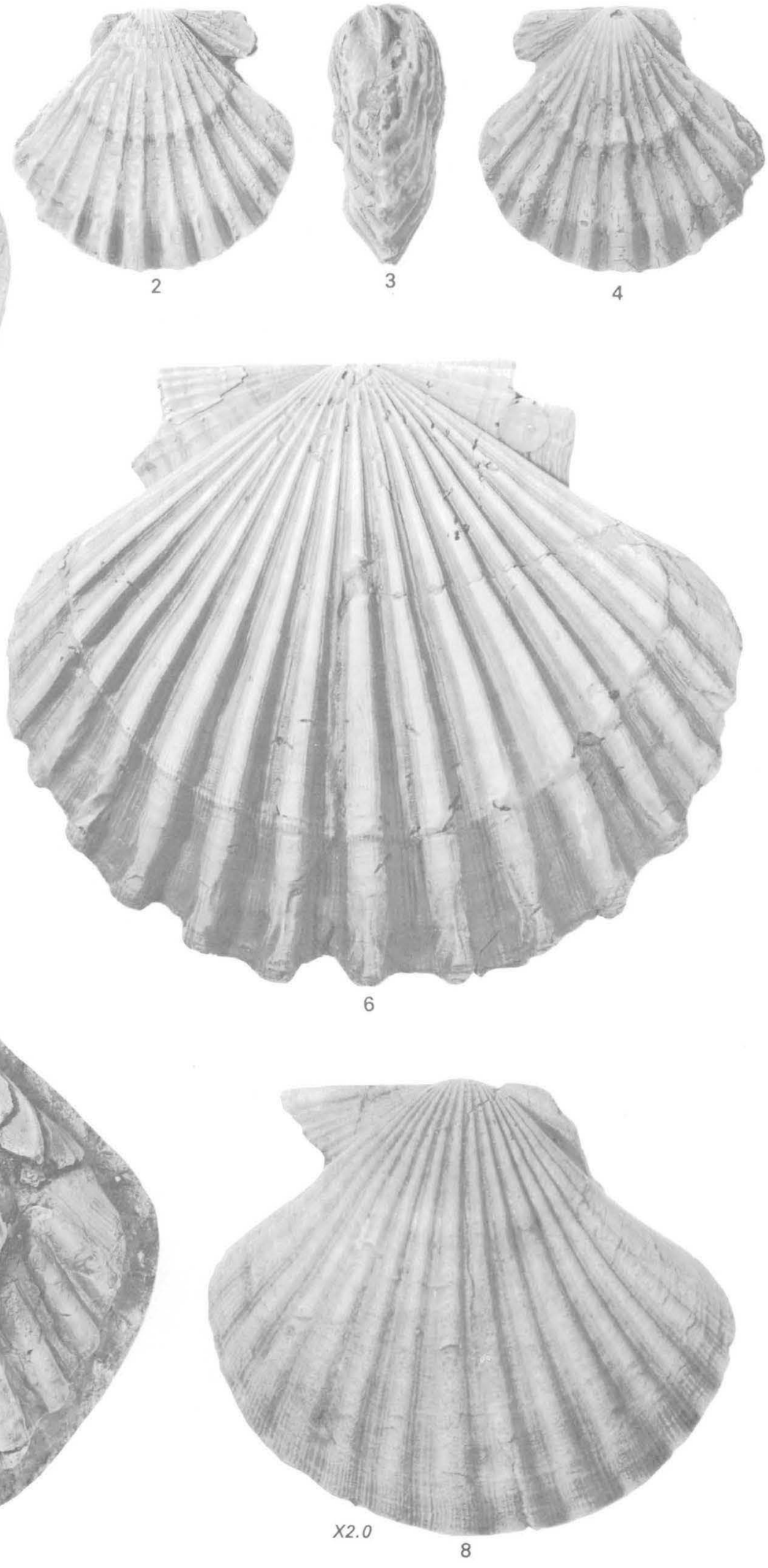


\section{PLATE 18}

1-3, 5. Lyropecten crassicardo (Conrad) (p. B51).

1. Holotype of Lyropecten ricei (Trask), UCMP 12364. Length $53 \mathrm{~mm}$ (estimated), height $54 \mathrm{~mm}$. Briones Sandstone, Miocene.

2, 5. Lectotype of L. crassicardo, ANSP 30745a ( $\times 0.7)$. Length $135 \mathrm{~mm}$, height $138 \mathrm{~mm}$. Santa Margarita Formation, Miocene.

3. Holotype of Lyropecten hamiltoni (Arnold), USNM 164845. Height $40 \mathrm{~mm}$. Briones Sandstone, Miocene.

4, 6. Lyropecten catalinae (Arnold) (p. B53).

San Onofre(?) Breccia, Miocene.

4. Paratype CAS/SU 561 (photograph copied from Arnold, 1906 , pl. 20, fig. 4). Hinge $30 \mathrm{~mm}$.

6. Holotype CAS/SU 30 . Length $74 \mathrm{~mm}$, height $76 \mathrm{~mm}$. 
GEOLOGICAL SURVEY
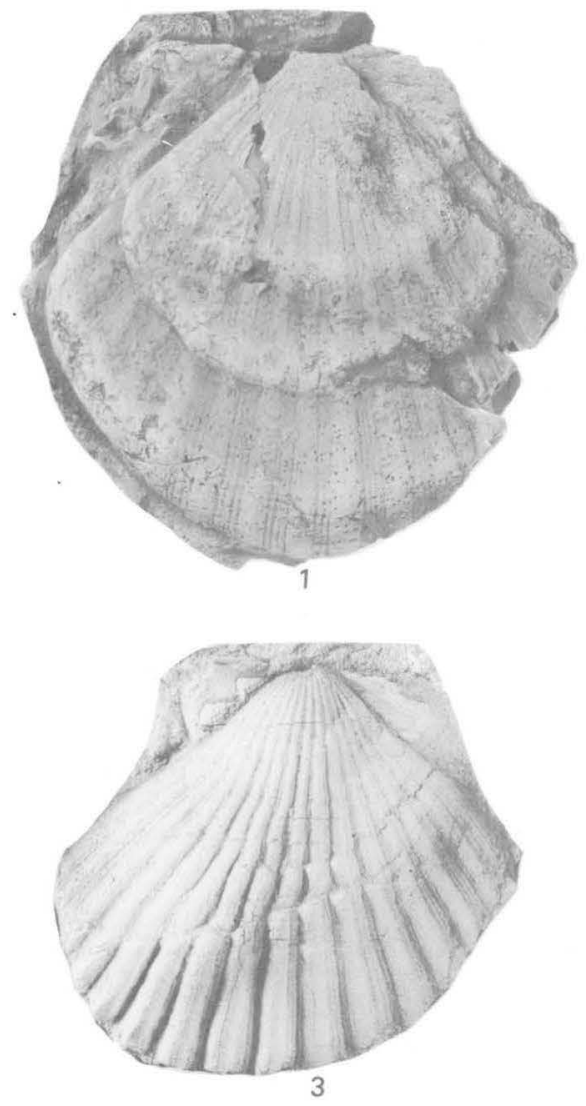

PROFESSIONAL PAPER 1228-B PLATE 18
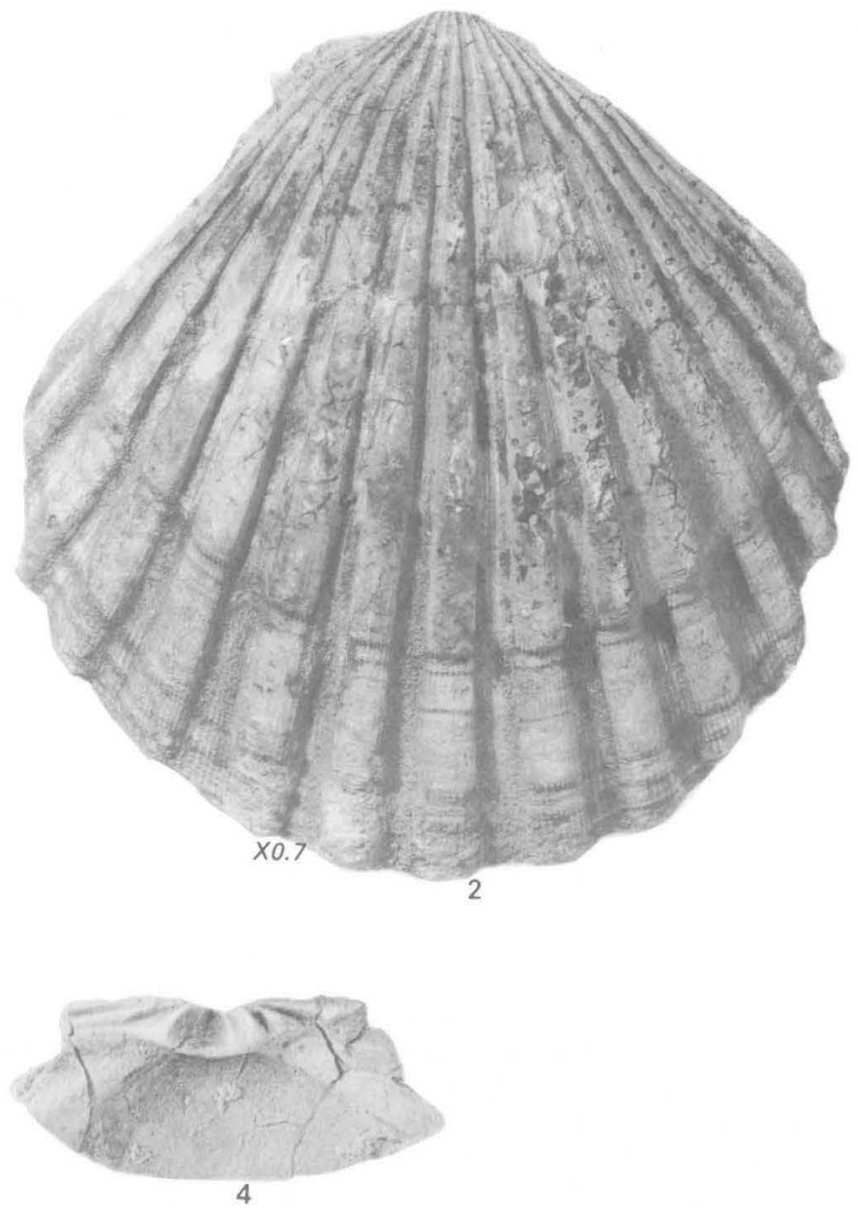
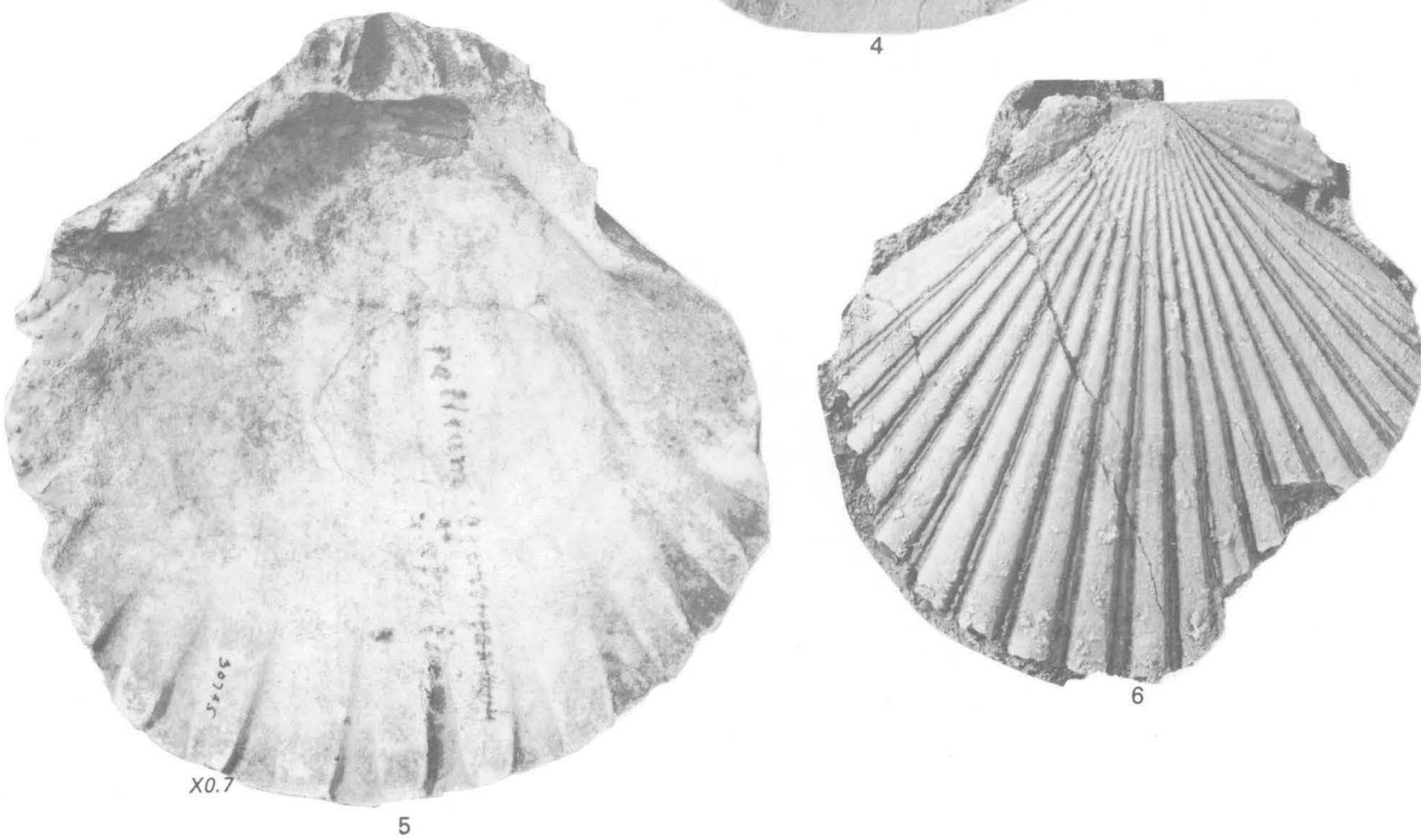

LYROPECTEN 


\section{PLATE 19}

Figures $\quad 1,5 . \quad$ Lyropecten terminus (Arnold) (p. B54).

Holotype UCMP 11662. Height $70 \mathrm{~mm}$. Pancho Rico Formation, Pliocene.

2. Lyropecten estrellanus (Conrad) (p. B53).

Lectotype USNM 13317. Height $90 \mathrm{~mm}$. Santa Margarita Formation, Miocene.

3. Lyropecten gallegosi (Jordan and Hertlein) (p. B54).

Holotype CAS $2096(\times 0.7)$. Length $138 \mathrm{~mm}$, height $125 \mathrm{~mm}$. Almejas Formation, Pliocene.

4. Lyropecten modulatus (Hertlein) (p. B55).

Holotype CAS/SU 39. Length $60 \mathrm{~mm}$, height $58 \mathrm{~mm}$. Almejas Formation, Pliocene. 


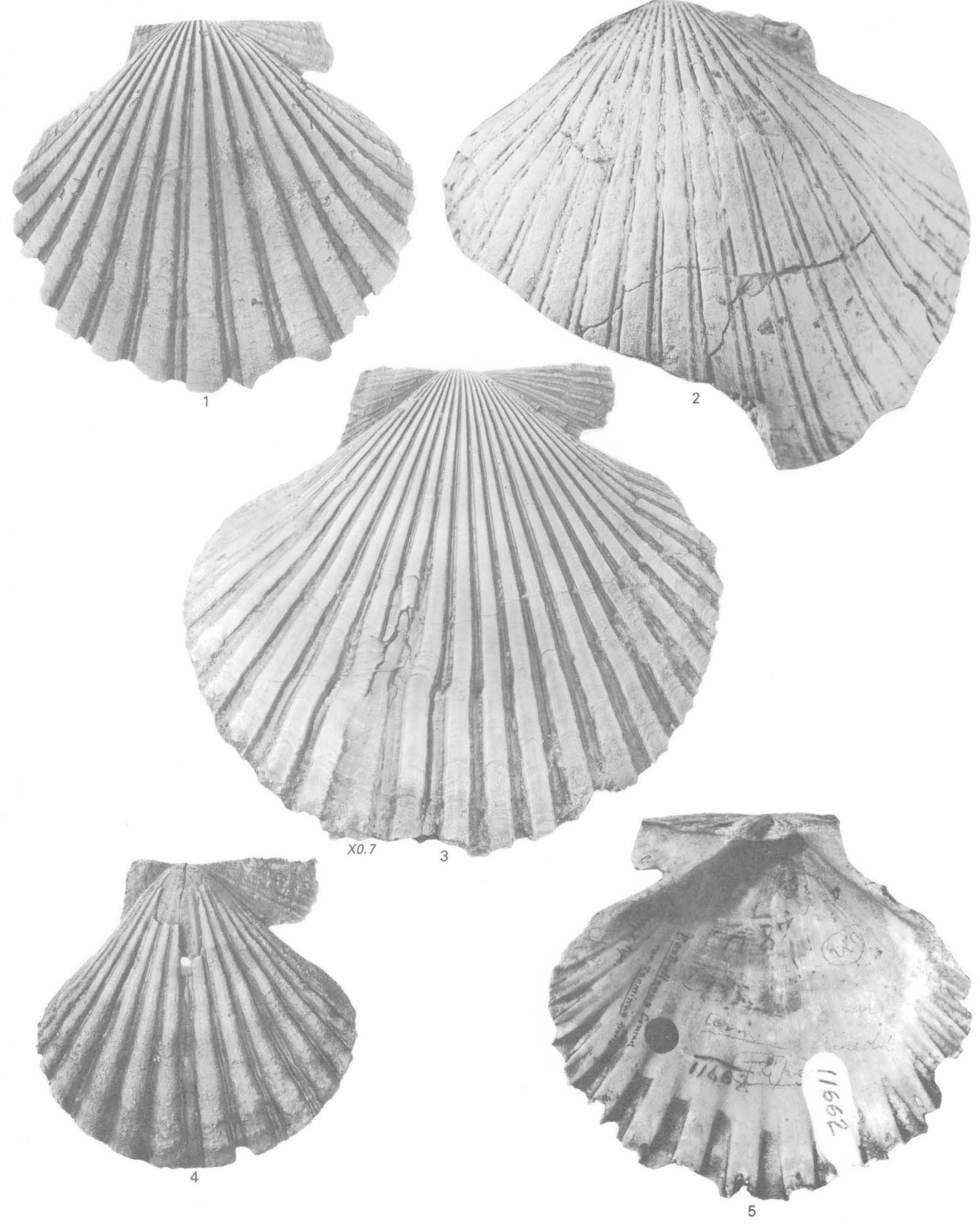




\section{PLATE 20}

1, 3, 4. Lyropecten cerrosensis (Gabb) (p. B55).

1, 4. Holotype UCMP $32669(\times 0.5)$. Length $226 \mathrm{~mm}$, height $210 \mathrm{~mm}$. Almejas Formation, Pliocene.

3. UCMP 12082, holotype of L. ashleyi $(\times 0.5)$. Almejas Formation, Pliocene.

2, 5. Pacipecten andersoni barkerianus (Arnold) (p. B45).

2. Photograph copied from Arnold (1906, pl. 26, fig. 9); specimen lost. Height $40 \mathrm{~mm}$.

5. Hypotype CAS/SU 6588 (Schenck and Keen, 1940, pl. 39, fig. 5) $(\times 2.0)$. 


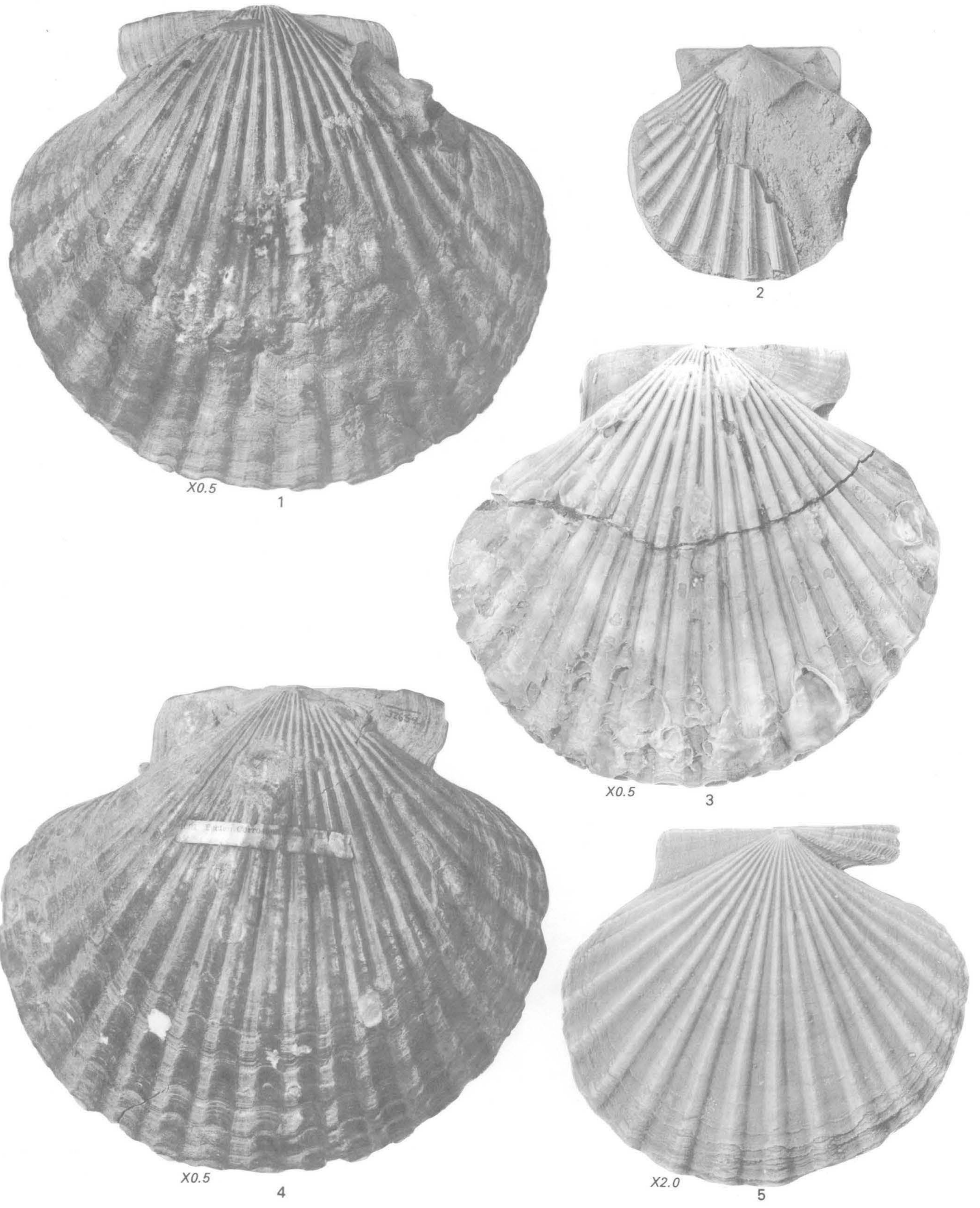

LYROPECTEN, PACIPECTEN 


\section{PLATE 21}

FiguRES

1. Lyropecten cerrosensis (Gabb) (p. B55).

Holotype of $L$. ashleyi, UCMP $32669(\times 0.5)$. Height $155 \mathrm{~mm}$. Almejas Formation, Pliocene:

2. Vertipecten diabloensis (Clark) (p. B64).

Holotype UCMP 11138. Length $46 \mathrm{~mm}$, height $55 \mathrm{~mm}$. San Ramon Sandstone, Miocene.

3. Lyropecten crassicardo (Conrad) (p. B51).

Holotype of Swiftopecten adekunbiana Adegoke, UCMP 36639. Length $41 \mathrm{~mm}$, height $43 \mathrm{~mm}$. Santa Margarita Formation, Miocene.

4, 5. Macrochlamis magnolia (Conrad) (p. B56).

4. Lectotype USNM 13325. Vaqueros Formation, Oligocene and Miocene.

5. Holotype of M. emigdioensis, UCMP 11417 ( $\times 2.0)$. Length $23 \mathrm{~mm}$, height $21 \mathrm{~mm}$. Vaqueros Formation, Oligocene and Miocene. 

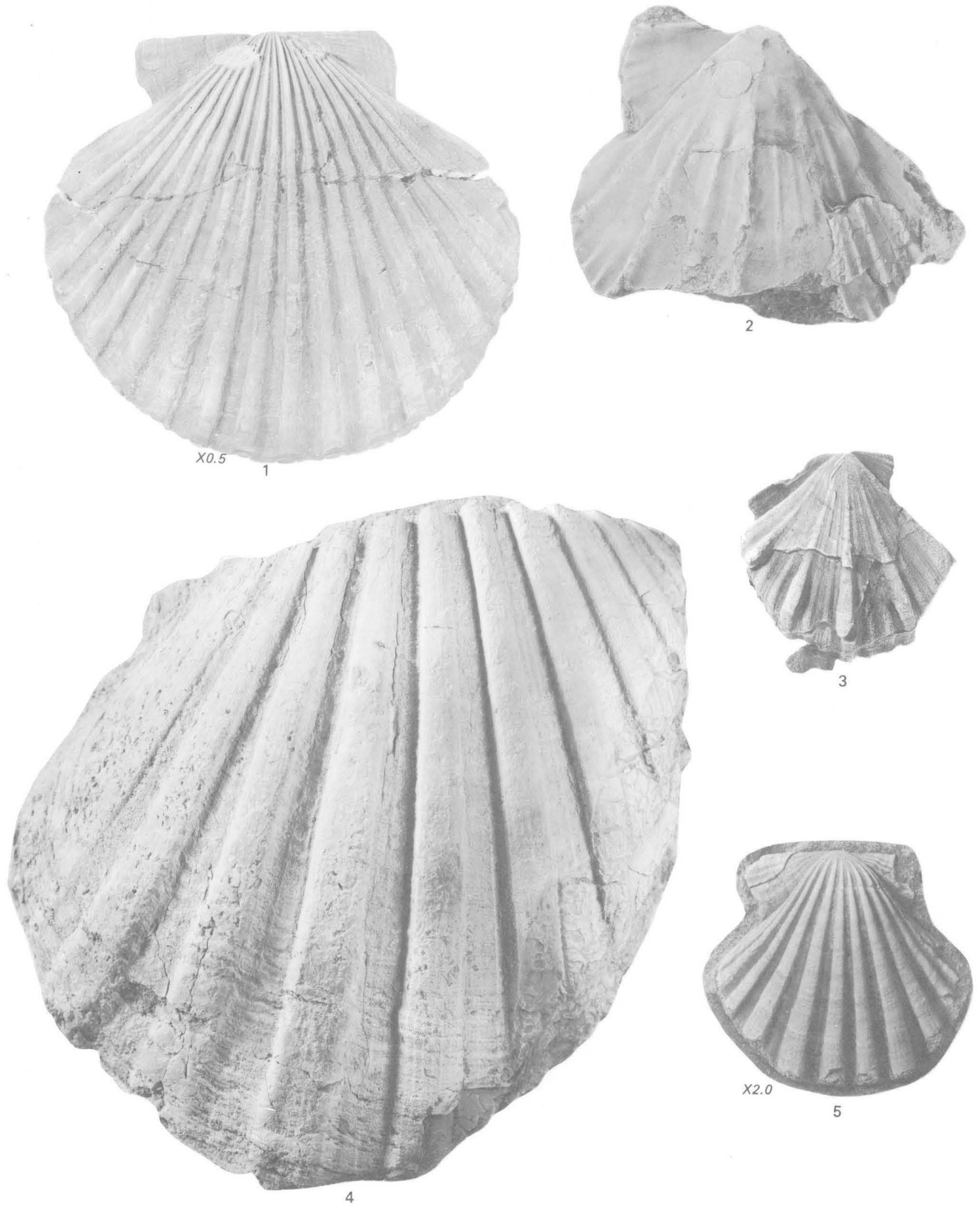

LYROPECTEN, VERTIPECTEN, MACROCHLAMIS 


\section{PLATE 22}

Figures

1. Nodipecten subnodosus intermedius (Conrad) (p. B58).

Height $112 \mathrm{~mm}$. West coast of Mexico, Holocene. Photograph copied from Arnold (1906, pl. 52, fig. 1).

2, 3. Swiftopecten parmeleei etchegoini (Anderson) (p. B60).

2. Holotype CAS 55. Etchegoin Formation, Pliocene.'

3. USNM 164929, holotype of S. morani. Height $63 \mathrm{~mm}$. Etchegoin Formation, Pliocene. (Photograph copied from Arnold, 1906, pl. 10, fig. 3.)

4. Nodipecten veatchii (Gabb) (p. B58).

Holotype UCMP $12078(\times 0.6)$. Height $130 \mathrm{~mm}$. Almejas Formation, Pliocene. 


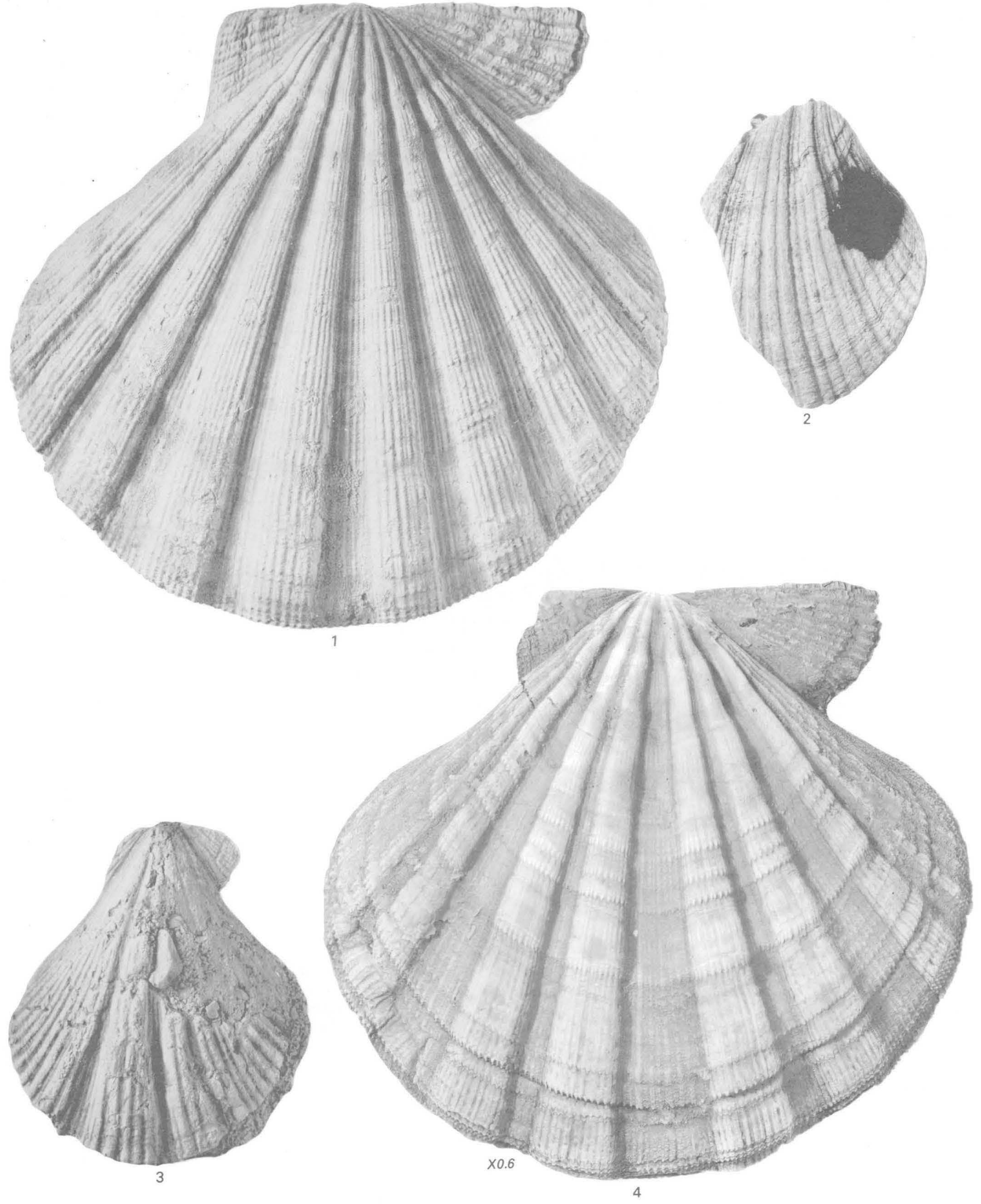

NODIPECTEN, SWIFTOPECTEN 


\section{PLATE 23}

Figures

1, 3, 4. Swiftopecten parmeleei parmeleei (Dall) (p. B59).

1. USNM 164842, hypotype (Arnold, 1906, pl. 12, fig. 5). Height $70 \mathrm{~mm}$. Wildcat Group, Pliocene and Pleistocene.

3. Photograph copy of Arnold (1906, pl. 41, fig. 1), holotype of S. wattsi, missing and presumed lost. Height $65 \mathrm{~mm}$. Etchegoin Formation, Pliocene.

4. Holotype USNM $154479(\times 1.5)$. Height $45 \mathrm{~mm}$. San Diego Formation, Pliocene.

2. Nodipecten veatchii (Gabb) (p. B58).

Holotype UCMP $12078(\times 0.6)$. Height $130 \mathrm{~mm}$. Almejas Formation, Pliocene.

5. Nodipecten subnodosus intermedius (Conrad) (p. B58).

Height $112 \mathrm{~mm}$. West coast of Mexico, Holocene. Photograph copied from Arnold (1906, pl. 53, fig. 1). 
GEOLOGICAL SURVEY

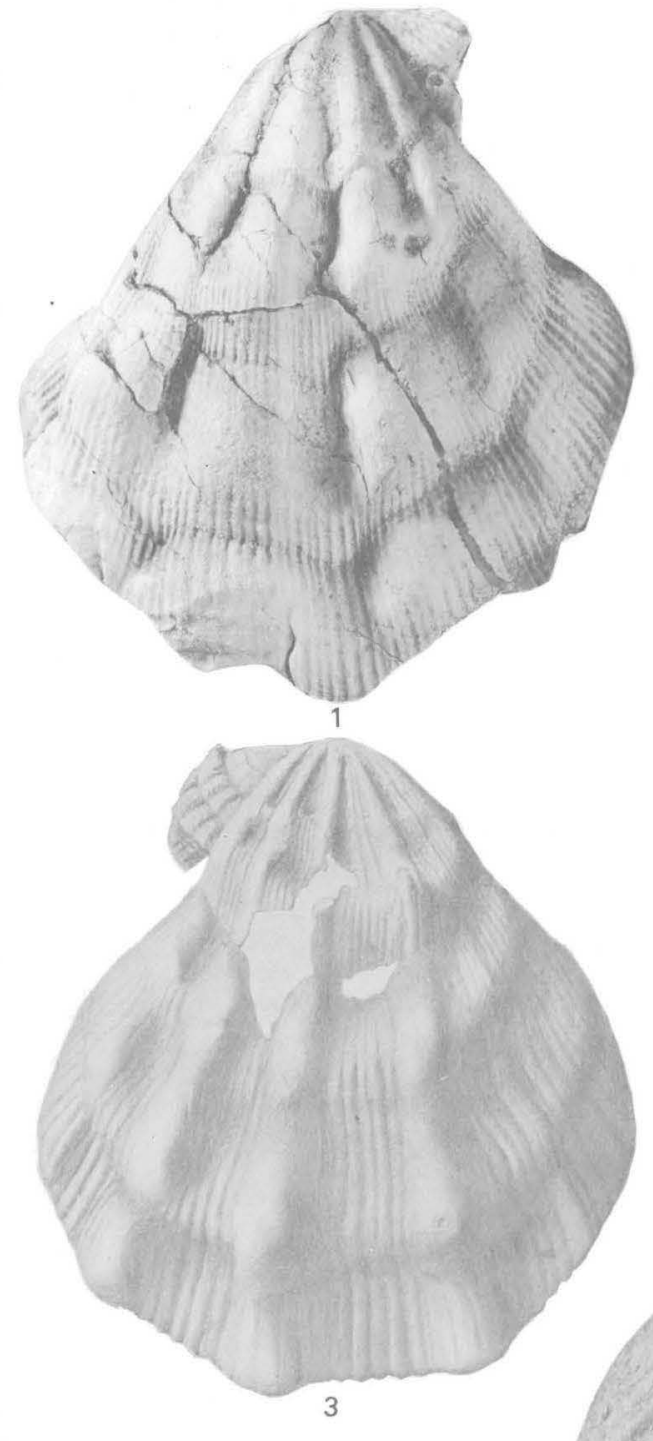

PROFESSIONAL PAPER 1228-B

PLATE 23
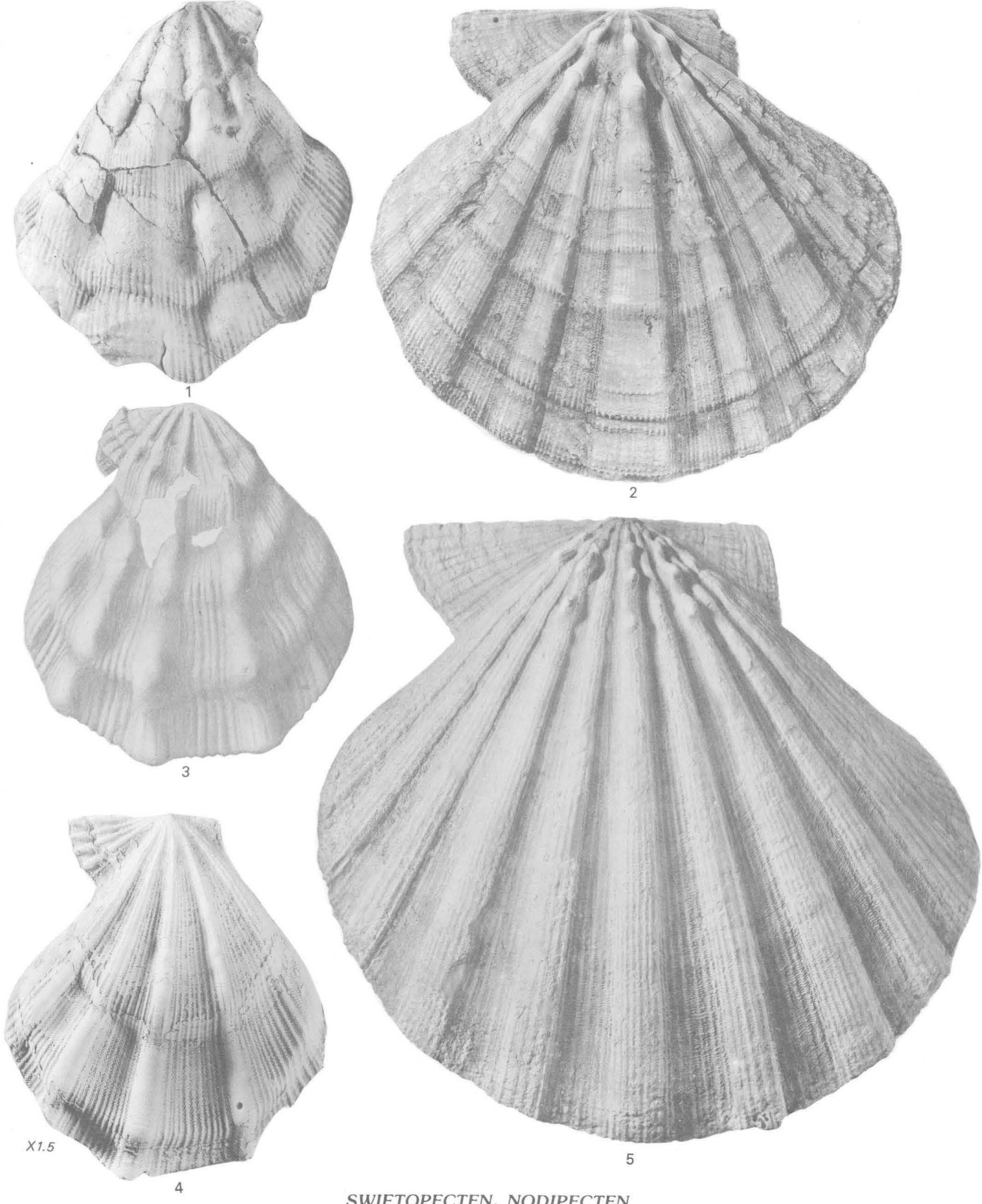

SWIFTOPECTEN, NODIPECTEN 


\section{PLATE 24}

Figures 1,2,4. Vertipecten alexclarki Addicott (p. B61).

1. Paratype USNM 646529. Length $63 \mathrm{~mm}$, height $82 \mathrm{~mm}$. Wygal Sandstone Member, Temblor Formation, Oligocene.

2. Hypotype CAS 60682 . Length $68 \mathrm{~mm}$, height $75 \mathrm{~cm}$. Wygal Sandstone Member, Temblor Formation, Oligocene.

4. Lectotype USNM 646531 . Length $66 \mathrm{~mm}$, height $69 \mathrm{~mm}$. Wygal Sandstone Member, Temblor Formation, Oligocene.

3. Vertipecten yneziana subyneziana (Weaver and Kleinpell) (p. B61).

Holotype CAS/SU $9265(\times 1.5)$. Photograph of rubber cast from holotype mold. Coldwater Sandstone, Eocene.

5. Swiftopecten? hamlini (Arnold) (p. B60).

Holotype USNM 164844. Height $50 \mathrm{~mm}$. Santa Margarita(?) Formation, Miocene.

6. Vertipecten bowersi (Arnold) (p. B62).

Holotype UCMP $12075(\times 0.7)$. Height $150 \mathrm{~mm}$. Topanga(?) Formation, Miocene. 
GEOLOGICAL SURVEY

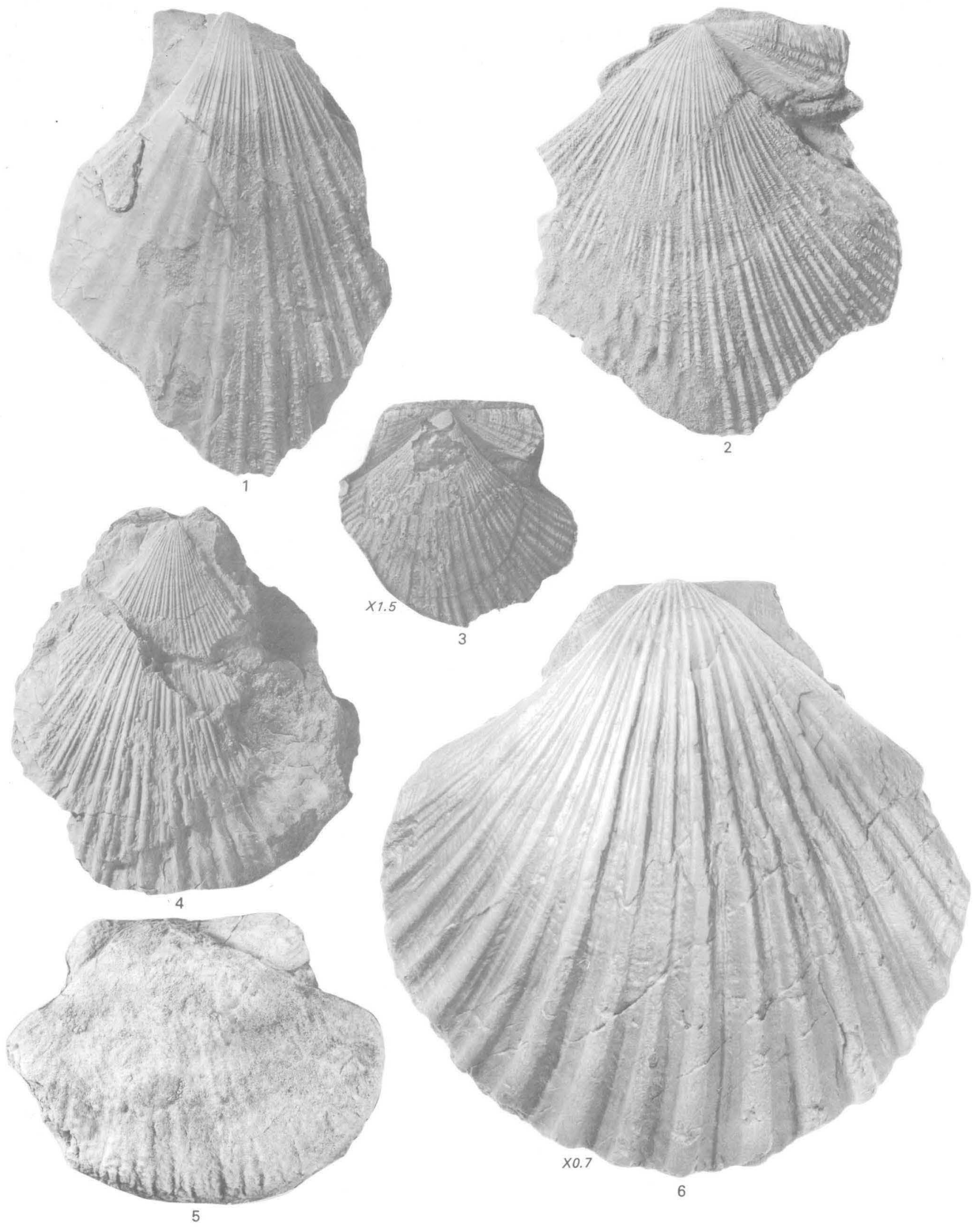

VERTIPECTEN, SWIFTOPECTEN? 


\section{PLATE 25}

1. Vertipecten bowersi (Arnold) (p. B62).

Holotype UCMP $12075(\times 0.7)$. Height $150 \mathrm{~mm}$. Topanga(?) Formation, Miocene.

2,3. Vertipecten yneziana yneziana (Arnold) (p. B61).

2. Paratype USNM 165313. Hinge $25 \mathrm{~mm}$. Gaviota Formation, Eocene.

3. Holotype USNM 165313a. Height $64 \mathrm{~mm}$. Gaviota Formation, Eocene.

4-6. Vertipecten perrini (Arnold) (p. B62)

Holotype CAS/SU $13(\times 0.5)$. Height $150 \mathrm{~mm}$. Vaqueros Formation, Oligocene and Miocene. 


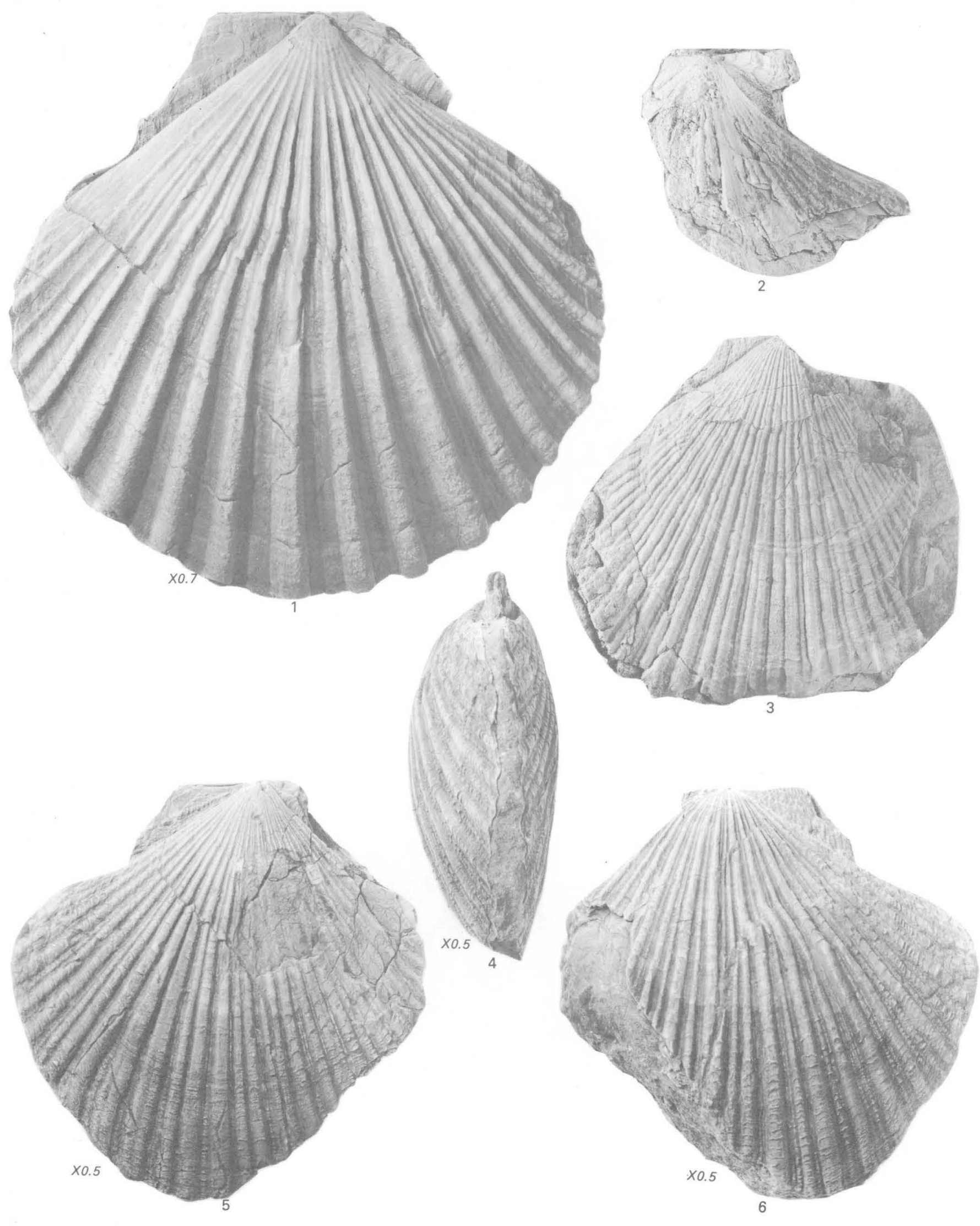




\section{PLATE 26}

1, 5. Hinnites giganteus (Gray) (p. B65).

1. USNM 13336. Holotype of $H$. crassa Conrad. Height $110 \mathrm{~mm}$. Santa Margarita Formation, Miocene.

5. USNM 13336a. Paratype of $H$. crassa Conrad. Santa Margarita Formation, Miocene.

2. Hinnites benedicti Adegoke (p. B65)

Holotype UCMP 36638. Length $36 \mathrm{~mm}$, height $47 \mathrm{~mm}$, hinge $22 \mathrm{~mm}$. Santa Margarita Formation, Miocene.

3, 4. Vertipecten fucanus (Dall) (p. B63).

3. Latex cast of holotype mold (USNM 107790). Length $82 \mathrm{~mm}$, height $84 \mathrm{~mm}$. Clallam Formation, Washington, Miocene.

4. USNM 3558, right valve. (Figured by Arnold, 1906, pl. 9, figs. 1, 1a, as Patinopecten propatulus.) 

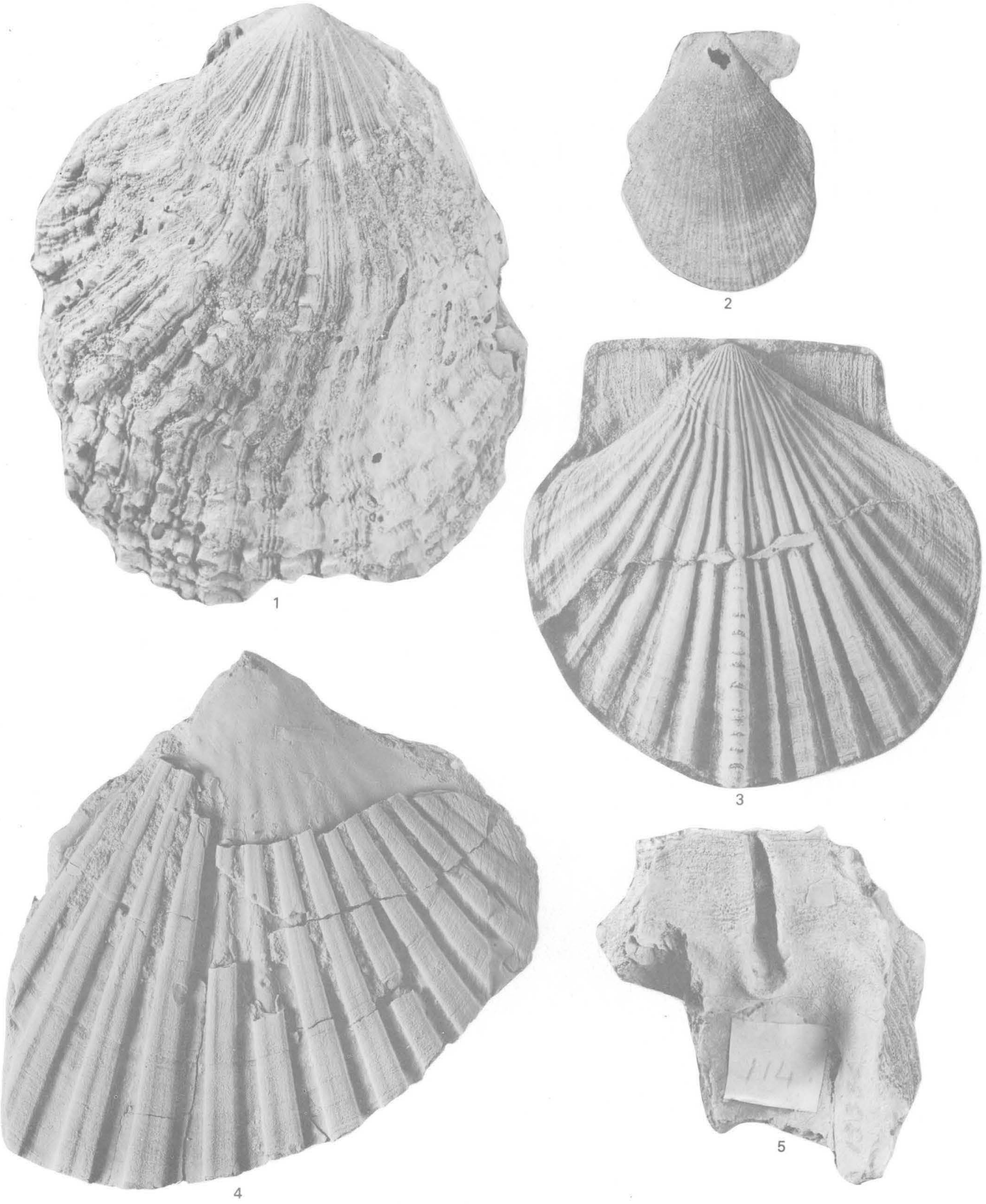

HINNITES, VERTIPECTEN 


\section{PLATE 27}

Figures

1. Vertipecten fucanus (Dall) (p. B63).

USNM 563250 hypotype (Moore, 1963, pl. 21, fig. 1). Length $108 \mathrm{~mm}$, height $111 \mathrm{~mm}$. Astoria Formation, Oregon, Miocene. 2-4. Hinnites giganteus (Gray) (p. B65).

2, 3. USNM 74166 hypotype (Arnold, 1906, pl. 29, figs. 2, 2a). Height $70 \mathrm{~mm}$. San Diego, Calif., Holocene.

4. USNM 13336, holotype of $H$. crassa Conrad. Height $110 \mathrm{~mm}$. Santa Margarita Formation, Miocene. 


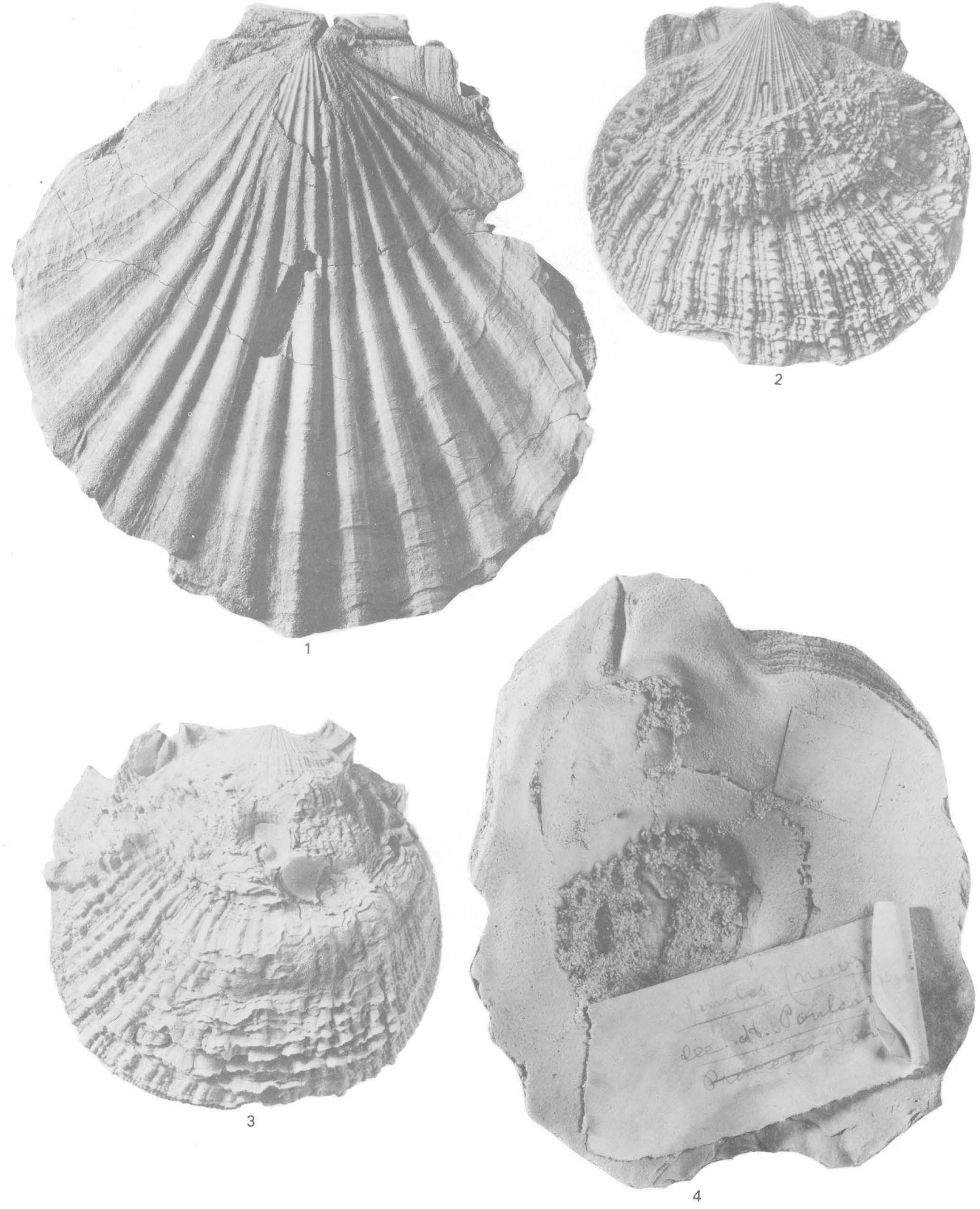

HINNITES, VERTIPECTEN 


\section{PLATE 28}

Figures

1. Lyropecten crassicardo (Conrad) (p. B51).

Holotype of Pecten holwayi Clark, UCMP 11580. Length $90 \mathrm{~mm}$, height $85 \mathrm{~mm}$. Cierbo Sandstone, Miocene.

2, 5. Pecten (Pecten) lecontei Arnold (p. B68).

Holotype CAS/SU 4. Height $59 \mathrm{~mm}$. Almejas Formation, Pliocene.

3, 4. Pecten (Pecten) aletes Hertlein (p. B67).

Salada Formation, Pliocene.

3. Holotype CAS/SU 44. Length $65 \mathrm{~mm}$, height $62 \mathrm{~mm}$.

4. Paratype CAS/SU $45(\times 1.5)$. Length $43 \mathrm{~mm}$.

6. Vertipecten kernensis (Hertlein) (p. B64).

Holotype CAS/SU 128. Monterey Formation, Miocene. 


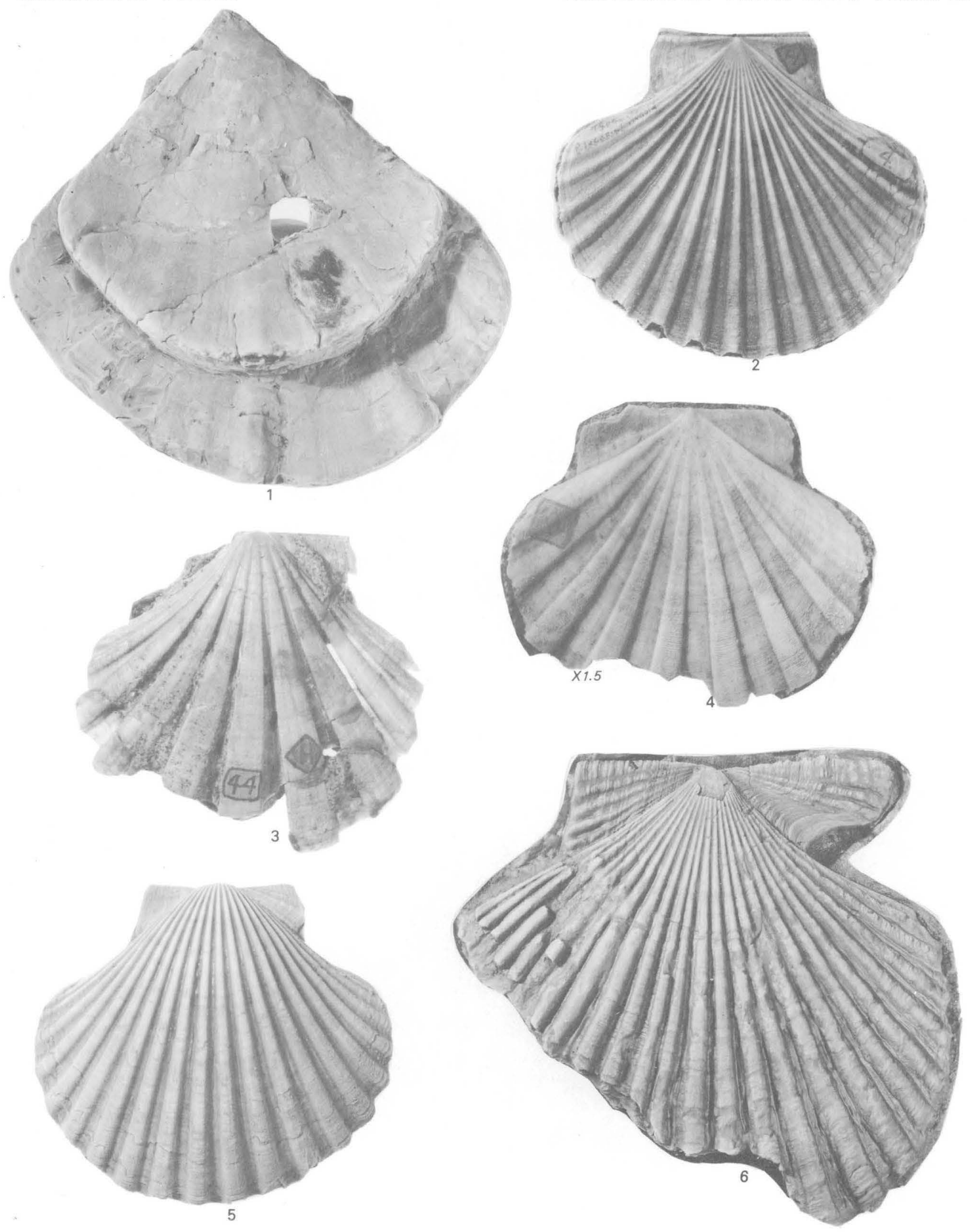

LYROPECTEN, PECTEN, VERTIPECTEN 


\section{PLATE 29}

1-4. Pecten (Pecten) bellus (Conrad) (p. B68).

1, 4. Neotype ANSP 960. Length $100 \mathrm{~mm}$, height $94 \mathrm{~mm}$. Santa Barbara Formation, Pliocene and Pleistocene.

2, 3. USNM 7943, holotype of $P$. hemphillii. Length $63 \mathrm{~mm}$, height $56 \mathrm{~mm}$, hinge $28 \mathrm{~mm}$. San Diego Formation, Pliocene.

5. Amussiopecten vanvlecki (Arnold) (p. B69).

Holotype USNM 165305. Height $64 \mathrm{~m}$. Vaqueros Formation, Oligocene and Miocene. 
GEOLOGICAL SURVEY
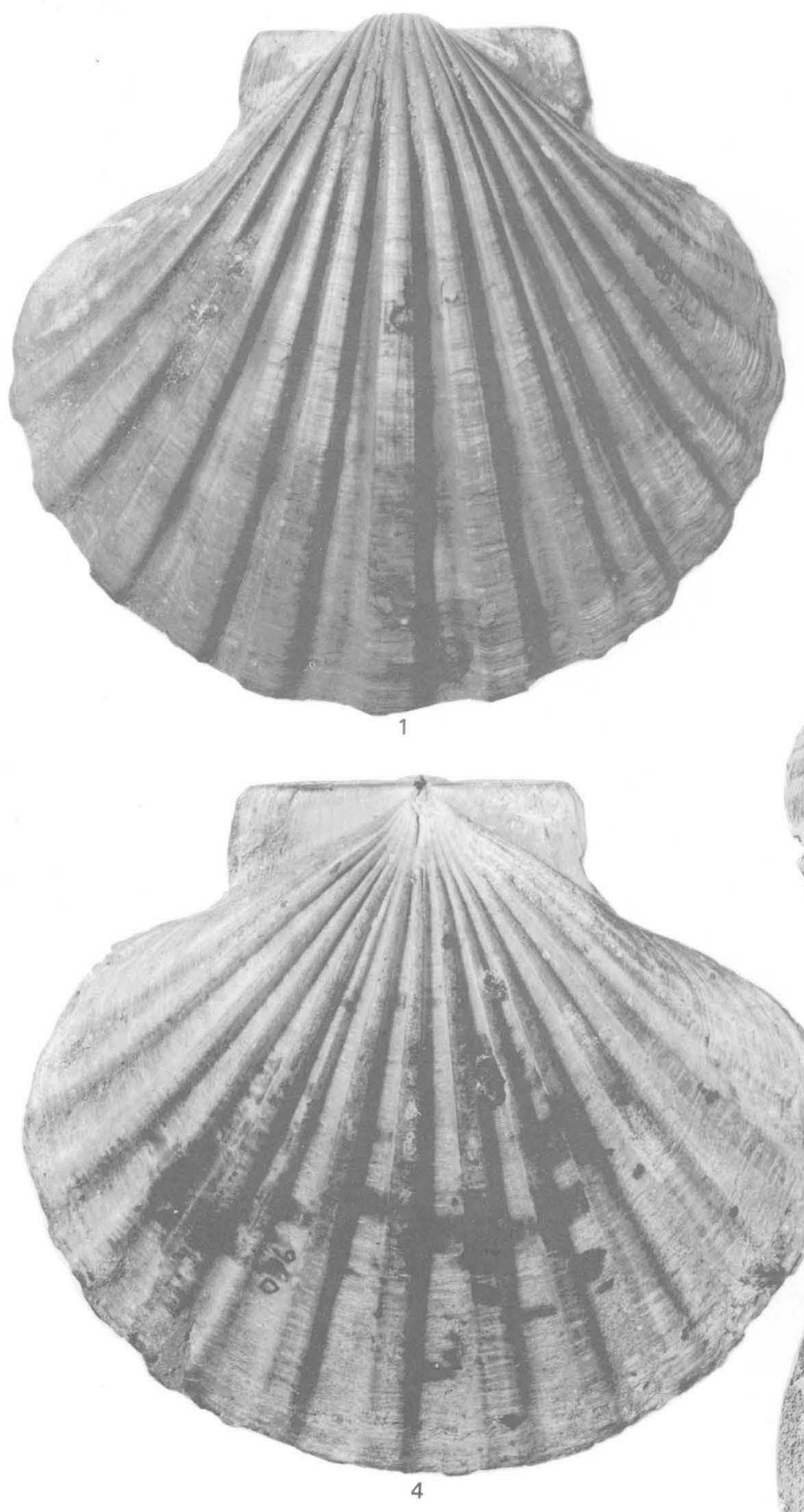

PROFESSIONAL PAPER 1228-B PLATE 29
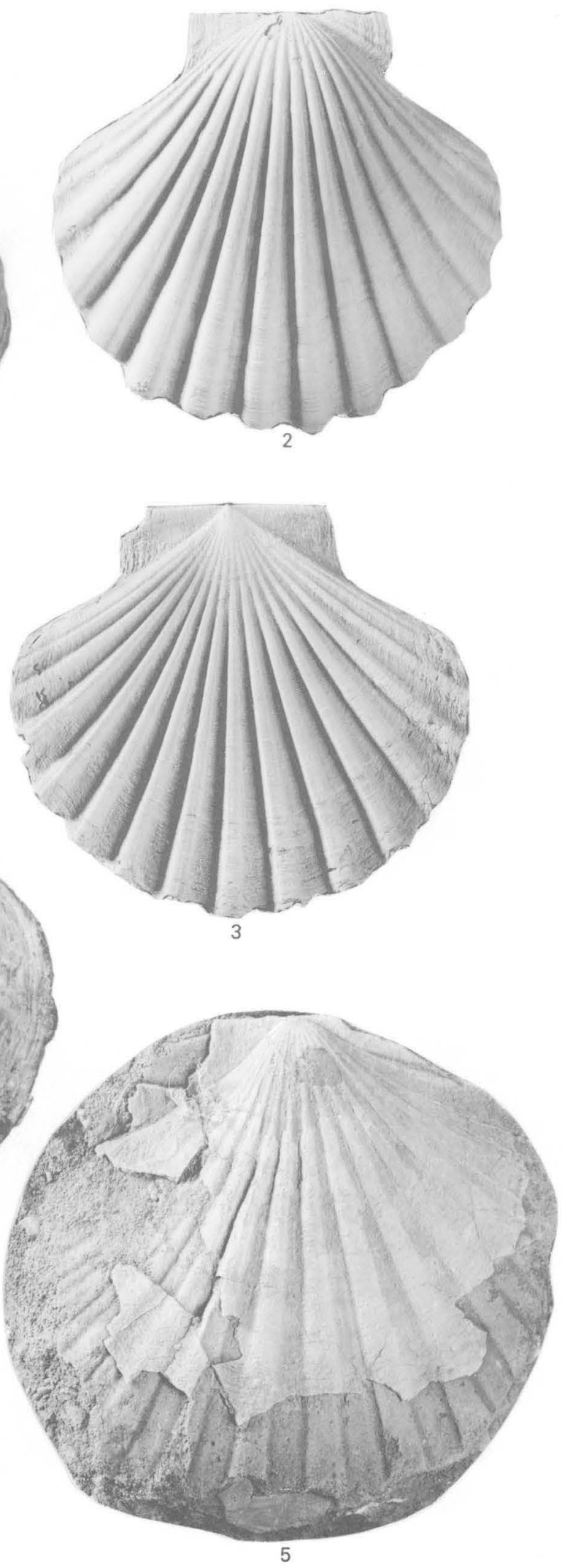

PECTEN, AMUSSIOPECTEN 


\section{PLATE 30}

1. Amussiopecten vanvlecki (Arnold) (p. B69).

Paratype USNM 165306. Height $72 \mathrm{~mm}$. Vaqueros Formation, Oligocene and Miocene.

2-4. Euvola refugioensis (Hertlein) (p. B71).

Salada Formation, Pliocene.

2. Paratype CAS/SU 50. Length $82 \mathrm{~mm}$, height $80 \mathrm{~mm}$.

3, 4. Holotype CAS/SU 49. Length $57 \mathrm{~mm}$, height $56 \mathrm{~mm}$.

5, 6. Euvola keepi (Arnold) (p. B70).

Holotype CAS/SU 5 . Length $74 \mathrm{~mm}$, height $75 \mathrm{~mm}$. Imperial Formation, Miocene or Pliocene. 


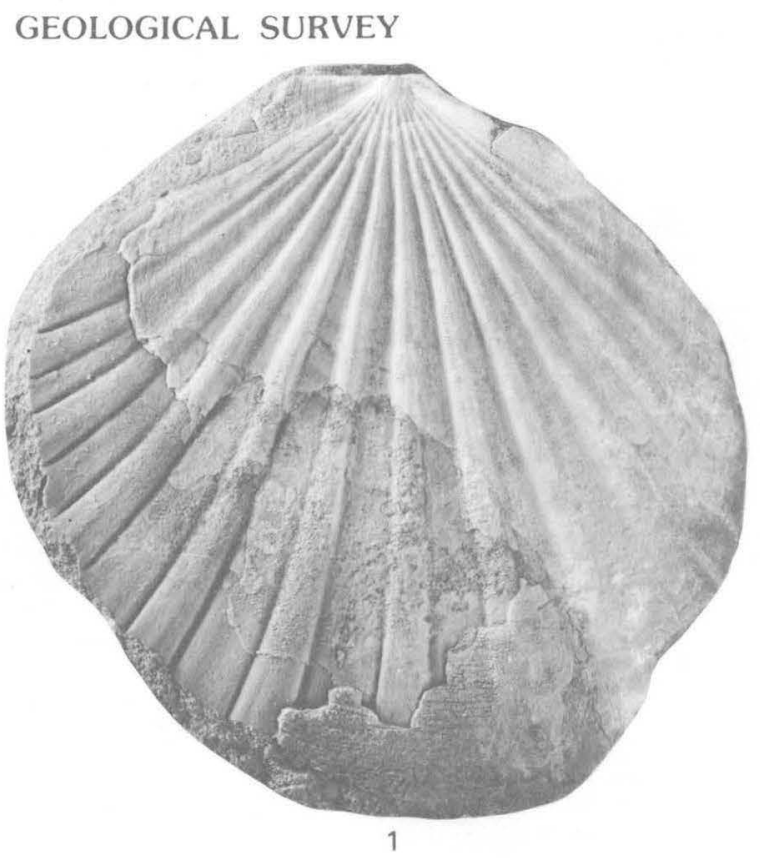

PROFESSIONAL PAPER 1228-B PLATE 30
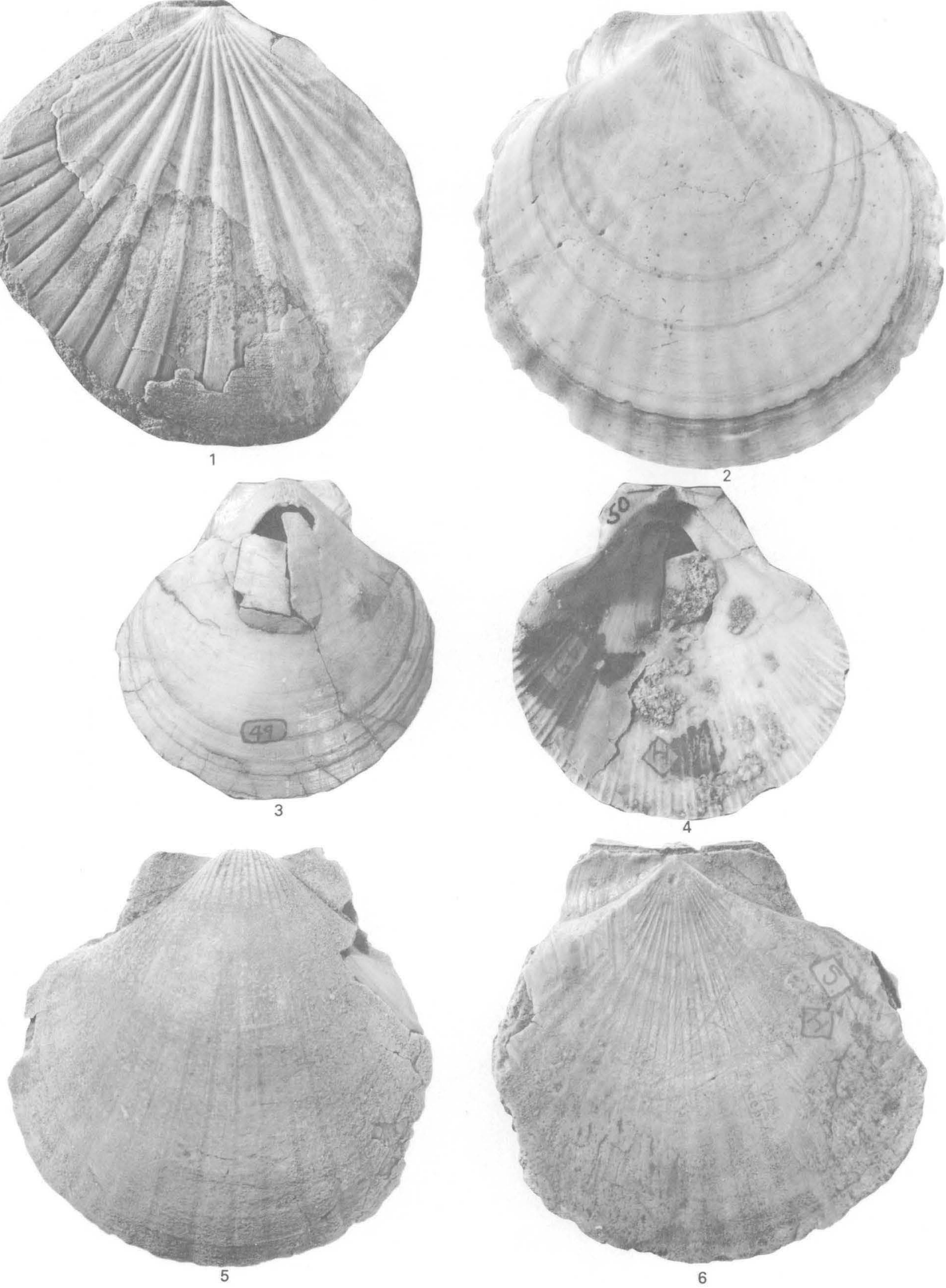

AMUSSIOPECTEN, EUVOLA 


\section{PLATE 31}

1. Flabellipecten? hawleyi (Hertlein) (p. B74).

Holotype CAS/SU $19(\times 1.5)$. Length $34 \mathrm{~mm}$, height $32 \mathrm{~mm}$. Vaqueros Formation, Oligocene and Miocene.

2. Flabellipecten diegensis (Dall) (p. B73).

Hypotype USNM 150980 (photograph copied from Arnold, 1906, pl. 51, fig. 1). Height $86 \mathrm{~mm}$. San Pedro, Calif., Holocene.

3, 5. Flabellipecten beali (Hertlein) (p. B73).

Holotype CAS/SU 55 . Length $56 \mathrm{~mm}$, height $55 \mathrm{~mm}$. Salada Formation, Pliocene.

4, 6. Flabellipecten carrizoensis (Arnold) (p. B71).

Holotype CAS/SU $11(\times 1.5)$. Length $42 \mathrm{~mm}$, height $36 \mathrm{~mm}$. Imperial Formation, Miocene or Pliocene.

7, 8. Flabellipecten stearnsii (Dall) (p. B72).

Holotype USNM $7942(\times 0.7)$. Length $100 \mathrm{~mm}$, height $90 \mathrm{~mm}$, hinge $34 \mathrm{~mm}$. San Diego Formation, Pliocene. 


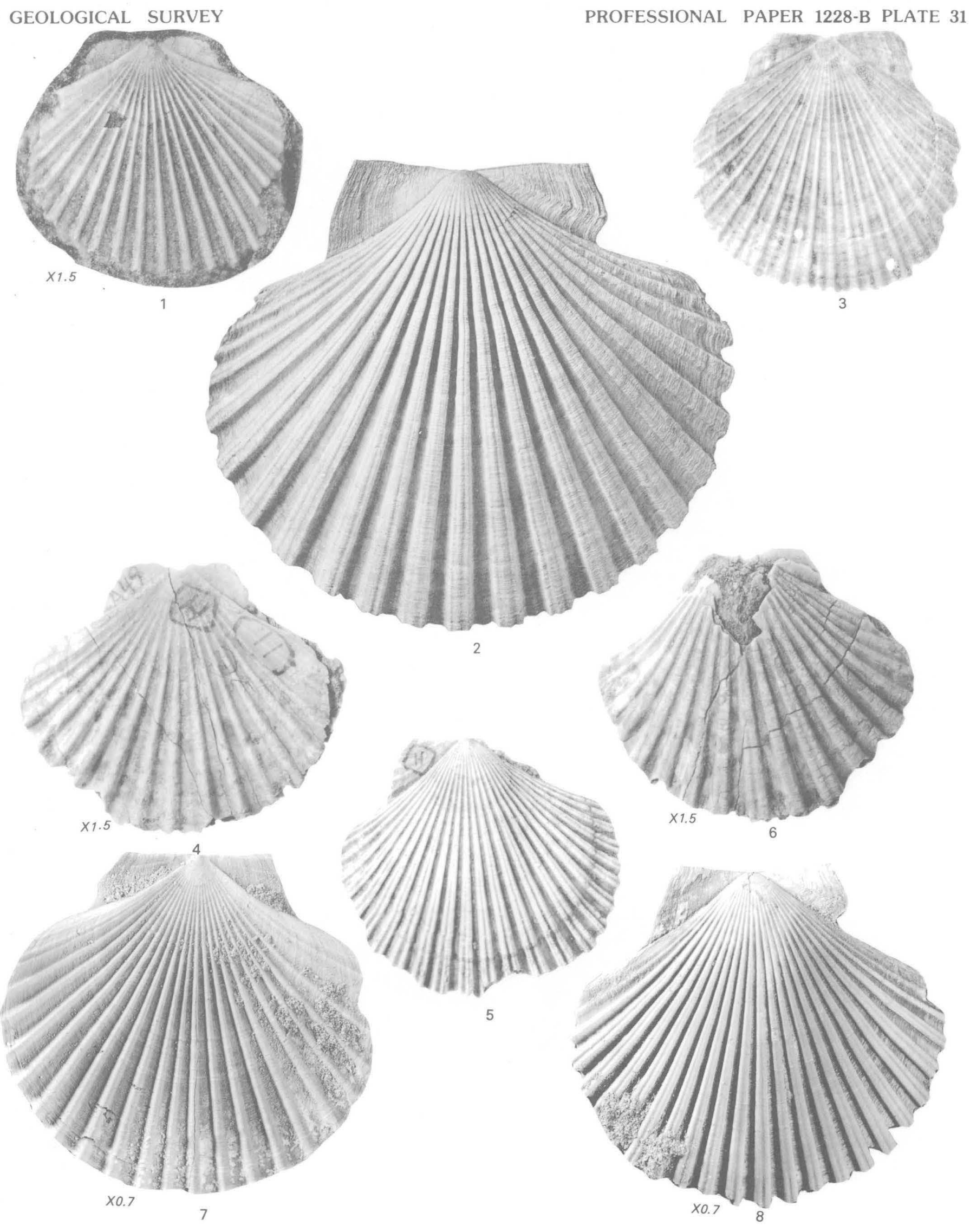

FLABELLIPECTEN 
PLATE 32

FIGURES

1,2. Flabellipecten bosei (Hanna and Hertlein) (p. B72).

Salada Formation, Pliocene.

1. Syntype CAS 2215 . Length $74 \mathrm{~mm}$, height $66 \mathrm{~mm}$, hinge $28 \mathrm{~mm}$.

2. Syntype CAS 2216 . Length $82 \mathrm{~mm}$, height $78 \mathrm{~mm}$.

3. Oppenheimopecten sanctaecruzensis (Arnold) (p. B75).

UCMP 11416, holotype of $P$. dickersoni $(\times 2.0)$. Length $19 \mathrm{~mm}$, height $19 \mathrm{~mm}$. Pleito Formation. Oligocene.

4. Flabellipecten diegensis (Dall) (p. B73).

Hypotype USNM 150980 (photograph copied from Arnold, 1906, pl. 51, fig. 1a). Height $86 \mathrm{~mm}$. San Pedro, Calif., Holocene.

5. Flabellipecten? merriami (Arnold) (p. B74).

Holotype UCMP 12086, left valve $(\times 0.8)$. Height $120 \mathrm{~mm}$. Pico Formation, Pliocene and Pleistocene. 

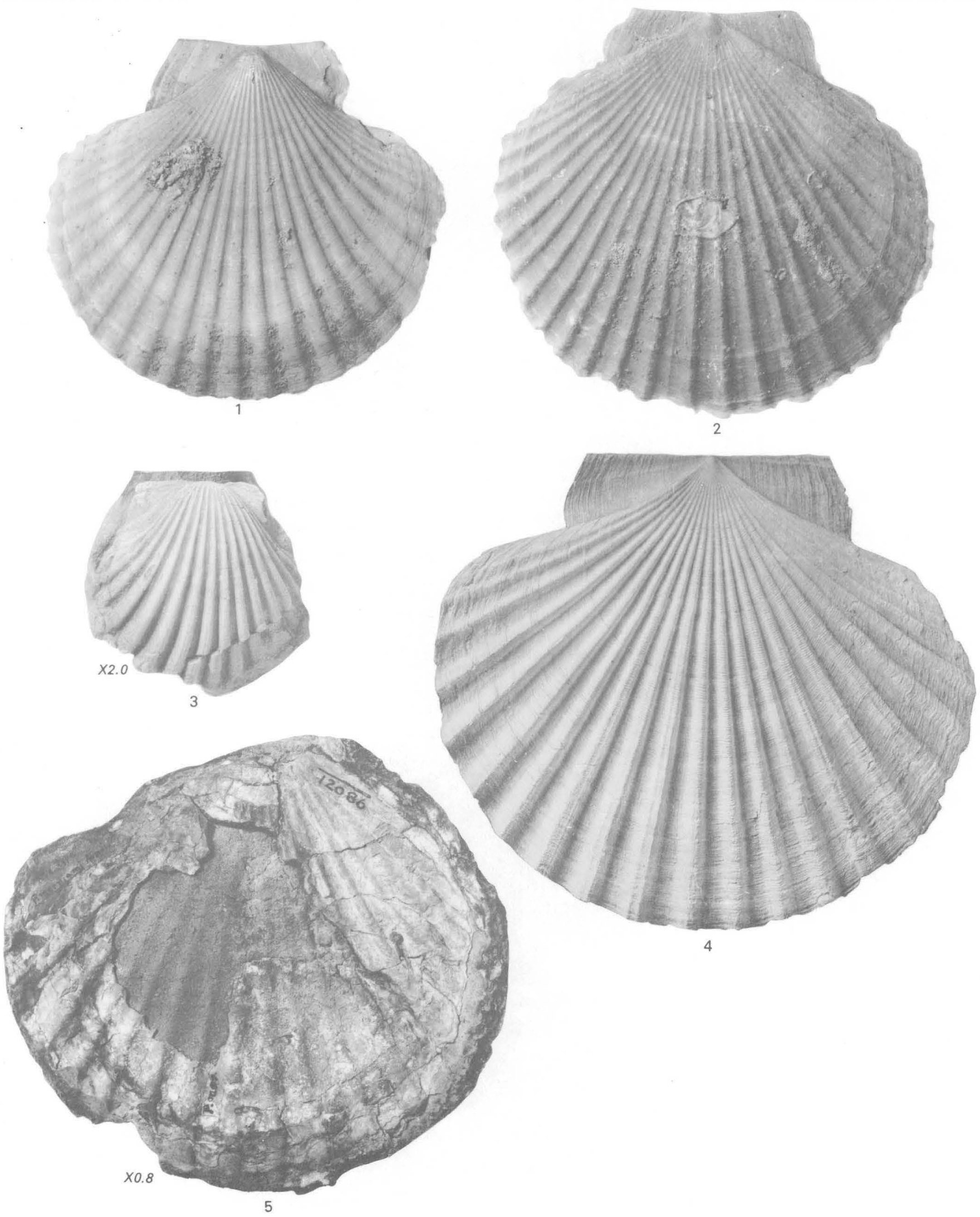

FLABELLIPECTEN, FLABELLIPECTEN?, OPPENHEIMOPECTEN 


\section{PLATE 33}

FiguRES

1. Flabellipecten? merriami (Arnold) (p. B74).

Holotype UCMP 12086, right valve $(\times 0.8)$. Height $120 \mathrm{~mm}$. Pico Formation, Pliocene and Pleistocene.

2. Oppenheimopecten sanctaecruzensis (Arnold) (p. B75).

Holotype CAS/SU $360(\times 1.5)$. Photograph of latex impression of holotype mold. Height $52 \mathrm{~mm}$. Vaqueros Formation, Oligocene and Miocene.

3. Oppenheimopecten coalingaensis (Arnold) (p. B76).

Lectotype CAS/SU $7(\times 1.5)$. Length $54 \mathrm{~mm}$, height $46 \mathrm{~mm}$. Etchegoin Formation, Pliocene.

4. Oppenheimopecten hartmanni (Hertlein) (p. B76).

Holotype CAS/SU 48. Length $65 \mathrm{~mm}$, height $75 \mathrm{~mm}$. Almejas Formation, Pliocene.

5. Oppenheimopecten juanensis (Grant and Stevenson) (p. B75).

Holotype UCLA 10441. Length $57 \mathrm{~mm}$, height $54 \mathrm{~mm}$. Neroly Sandstone, Miocene.

6. Oppenheimopecten heimi (Hertlein) (p. B77).

Holotype CAS/SU 46. Length $85 \mathrm{~mm}$, height $75 \mathrm{~mm}$. Salada Formation, Pliocene. 
GEOLOGICAL SURVEY

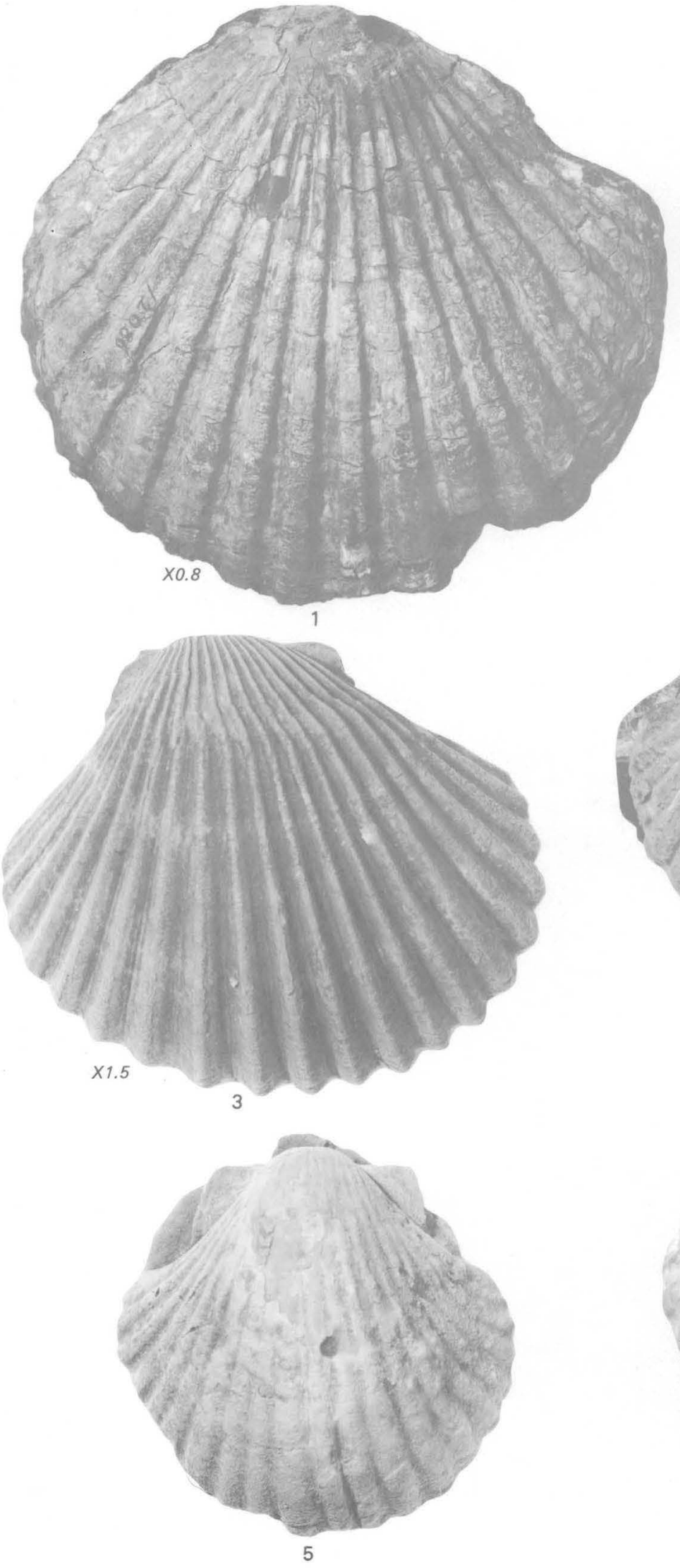

PROFESSIONAL PAPER 1228-B PLATE 33

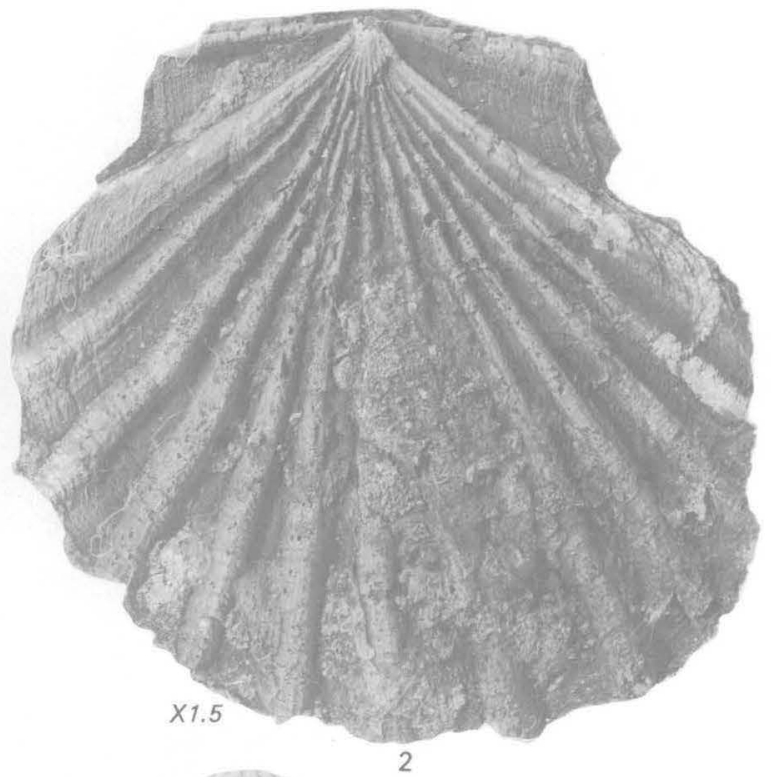

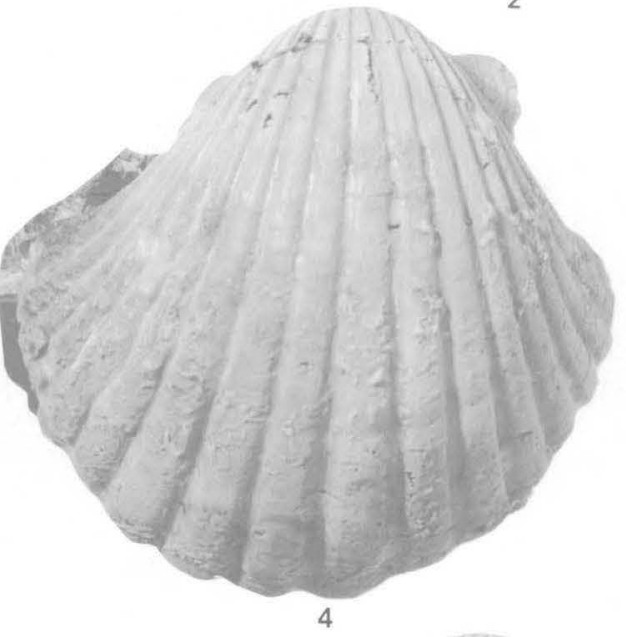

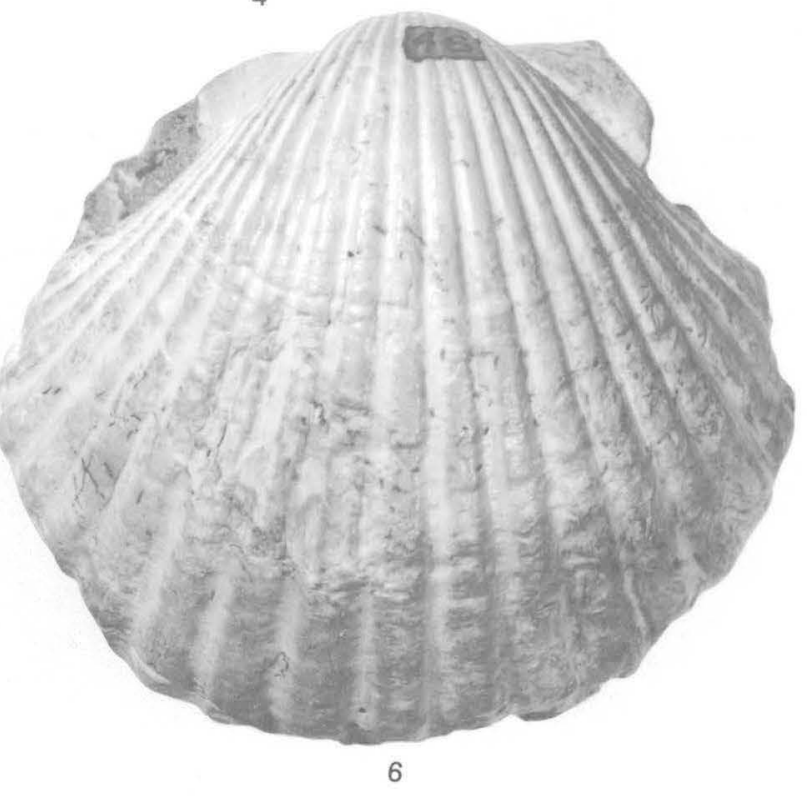

FLABELLIPECTEN?, OPPENHEIMOPECTEN 


\section{PLATE 34}

Figures 1, 4, 6. Patinopecten propatulus (Conrad) (p. B79). Astoria Formation, Miocene, Oregon.

1, 6. Lectotype USNM 3504. Length $102 \mathrm{~mm}$, height $103 \mathrm{~mm}$.

4. Hypotype (Moore, 163 pl. 16, fig. 2) USNM $563234(\times 2.0)$

2. Patinopecten lohri (Hertlein) (p. B80)

Holotype UCMP 12081. Height $85 \mathrm{~mm}$. Tinaquaic Sandstone Member, Sisquoc Formation, Pliocene.

3. Patinopecten healeyi (Arnold) (p. B81).

Hypotype (Moore, 1979, pl. 13, fig. 2) LAM $5254(\times 0.7)$. Hinge $95 \mathrm{~mm}$. San Diego Formation, Pliocene.

5. Oppenheimopecten vogdesi (Arnold) (p. B77).

Holotype CAS/SU 4. Length $73 \mathrm{~mm}$, height $69 \mathrm{~mm}$. Upper part of San Pedro Formation, Pleistocene. 
GEOLOGICAL SURVEY
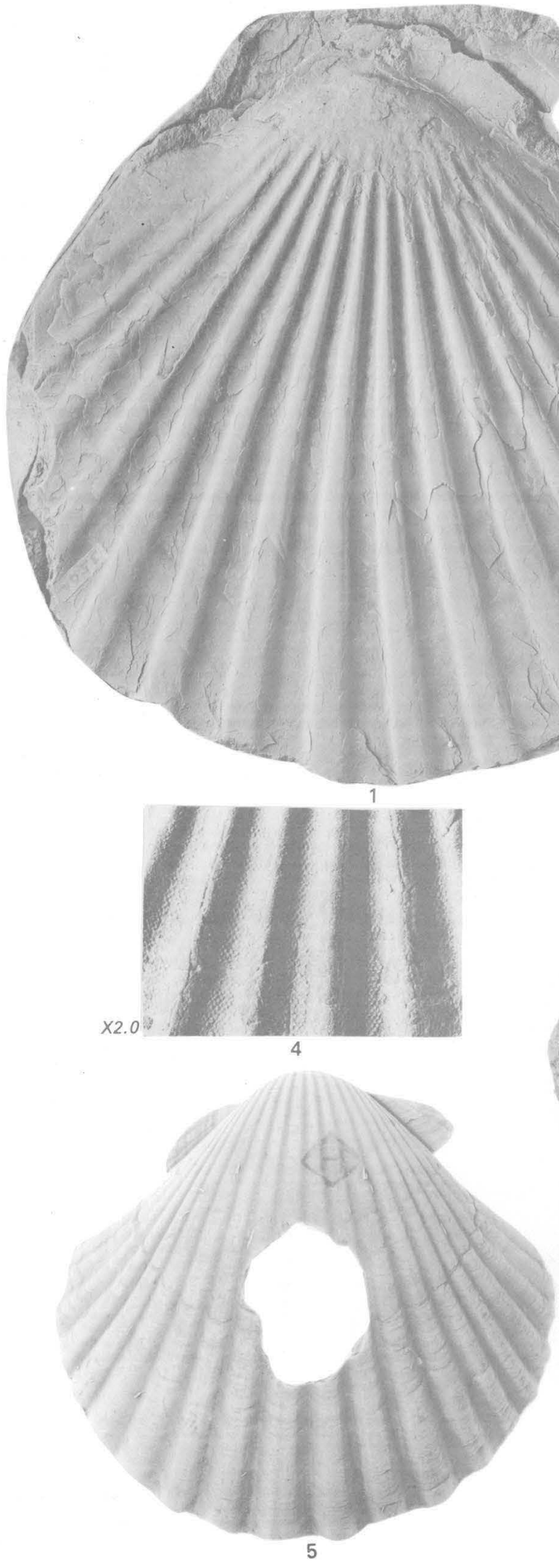

PROFESSIONAL PAPER 1228-B PLATE 34
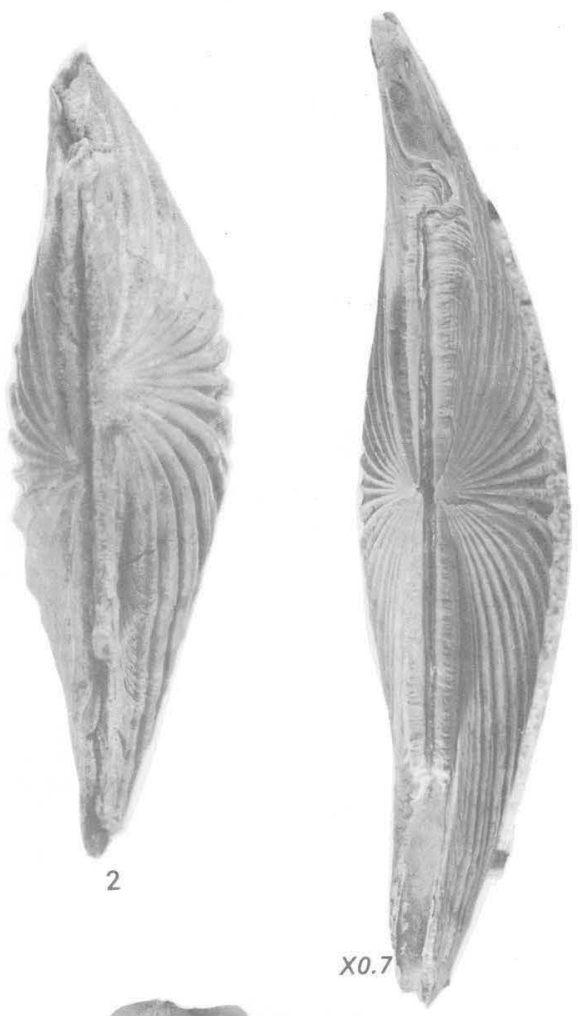

3

PATINOPECTEN, OPPENHEIMOPECTEN 


\section{PLATE 35}

Figures

1, 2. Patinopecten propatulus (Conrad) (p. B79).

Hypotype (Moore, 1963, pl. 17, fig. 3) USNM $563236(\times 2.0)$. Length $75 \mathrm{~mm}$, height $77 \mathrm{~mm}$. Astoria Formation, Miocene, Oregon.

3. Patinopecten healeyi (Arnold) (p. B81).

Hypotype (Moore, 1979, pl. 1, fig. 3) LAM 5221 (× 1.5). San Diego Formation, Pliocene.

4. Patinopecten haywardensis (Lutz). (p. B80).

Plaster cast of holotype mold UCMP $341133(\times 0.7)$. Length $130 \mathrm{~mm}$, height $112 \mathrm{~mm}$. Sobrante Sandstone, Miocene.

5, 6. Patinopecten calaverasensis (Hall) (p. B80).

5. Holotype CAS/SU 8442 . Length $88 \mathrm{~mm}$, height $76 \mathrm{~mm}$, hinge $47 \mathrm{~mm}$. Oursan Sandstone, Miocene.

6. Specimen on underside of holotype, CAS/SU 8442, presumed left-valve fragment. 
GEOLOGICAL SURVEY
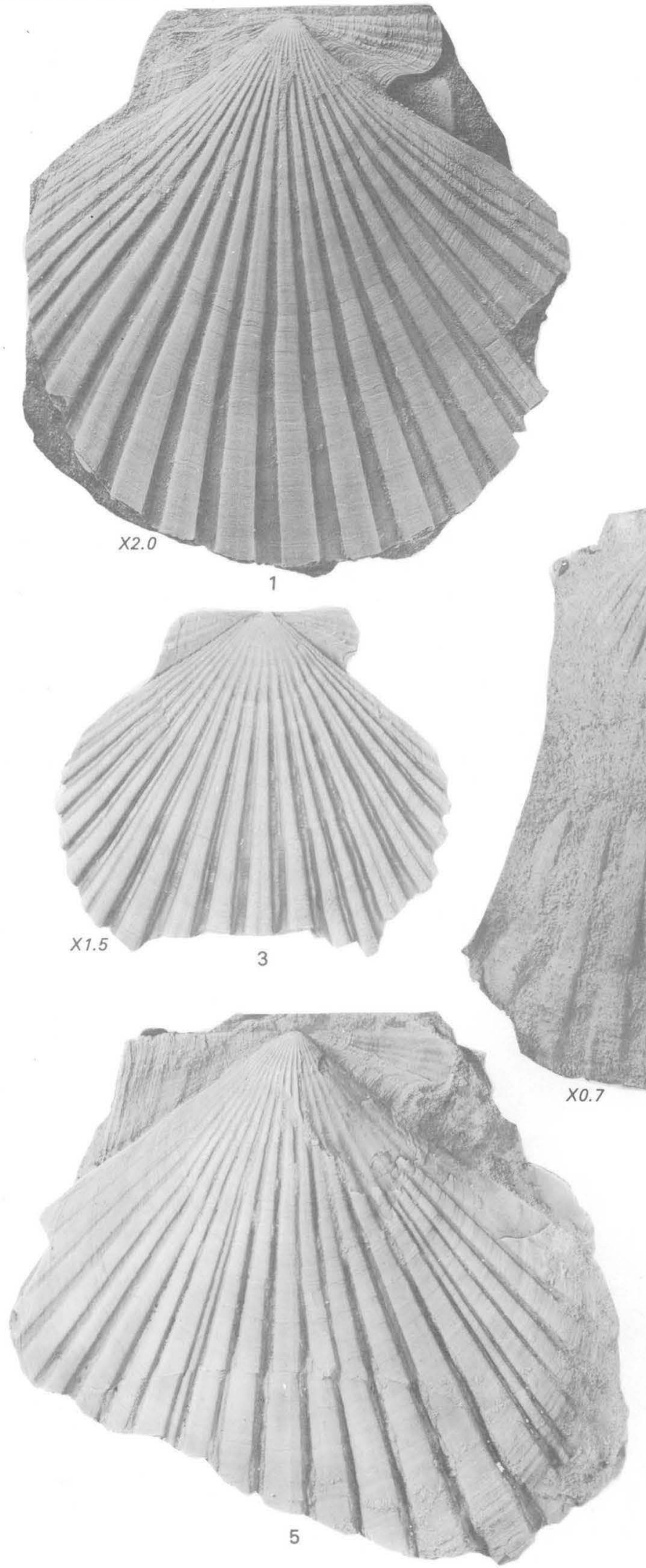

PROFESSIONAL PAPER 1228-B PLATE 35
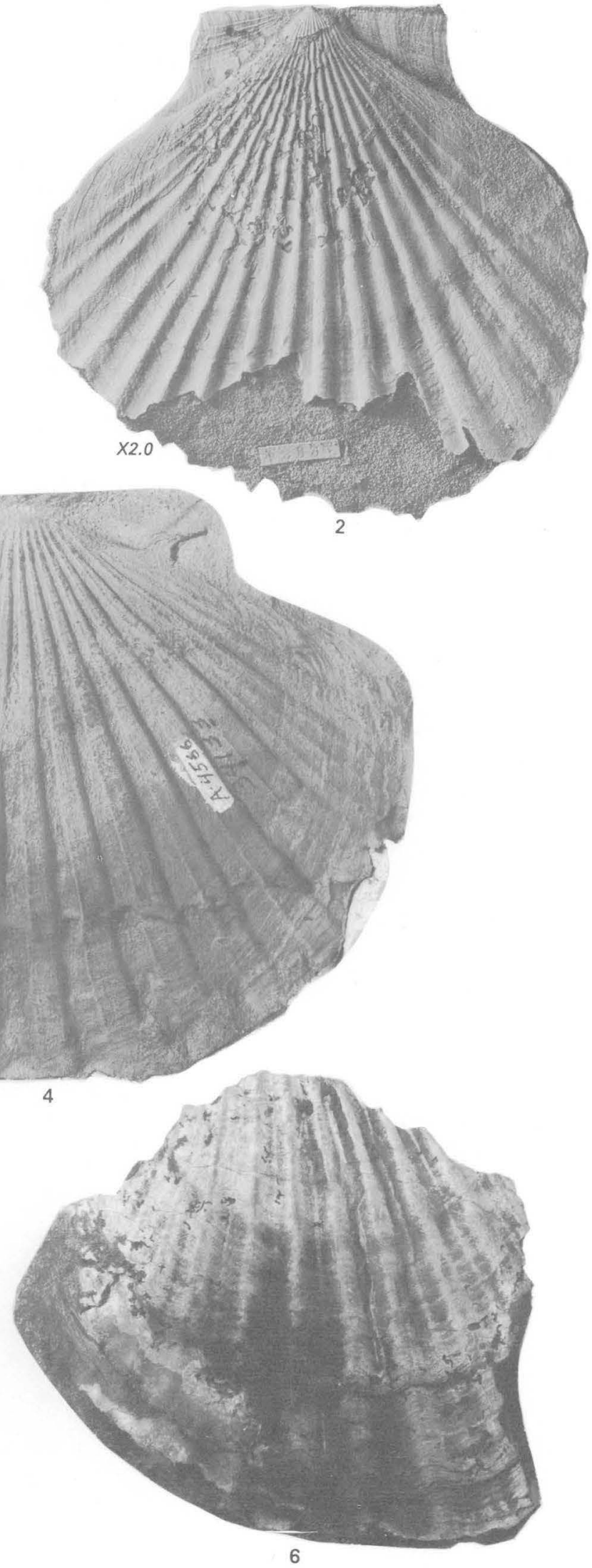

PATINOPECTEN 


\section{PLATE 36}

Figures

1. Patinopecten haywardensis (Lutz) (p. B80).

Plaster cast of paratype mold UCMP 34134. Sobrante Sandstone, Miocene.

2, 3. Patinopecten lohri (Hertlein) (p. B80).

Holotype UCMP 12081. Length $88 \mathrm{~mm}$, height $87 \mathrm{~mm}$, hinge $47 \mathrm{~mm}$. Tinaquaic Sandstone Member, Sisquoc Formation, Pliocene.

4. Patinopecten healeyi (Arnold) (p. B81).

Hypotype (Moore, 1979, pl. 14, fig. 3) LAM $5254(\times 0.5)$. Length $210 \mathrm{~mm}$, height $190 \mathrm{~m}$, hinge $95 \mathrm{~mm}$. San Diego Formation, Pliocene. 


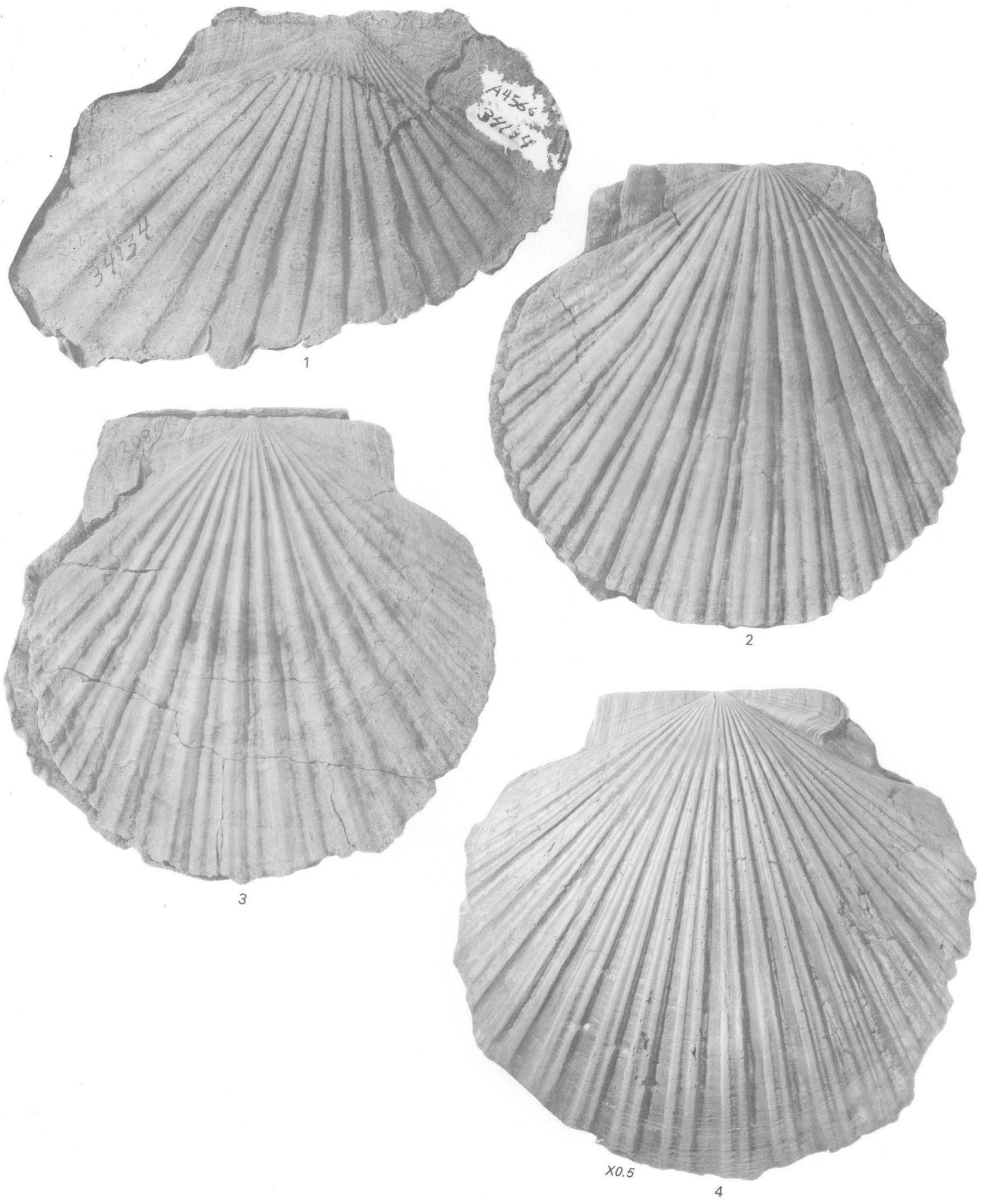

PATINOPECTEN 


\section{PLATE 37}

Figures

1, 2. Lituyapecten turneri (Arnold) (p. B87).

Merced Formation, Pliocene and Pleistocene.

1. Paratype CAS/SU 430-A.

2. Holotype CAS/SU 430. Height $65 \mathrm{~mm}$.

3. Patinopecten healeyi (Arnold) (p. B81).

Paratype USNM 154162. Height $141 \mathrm{~mm}$. San Diego Formation, Pliocene. 
GEOLOGICAL SURVEY

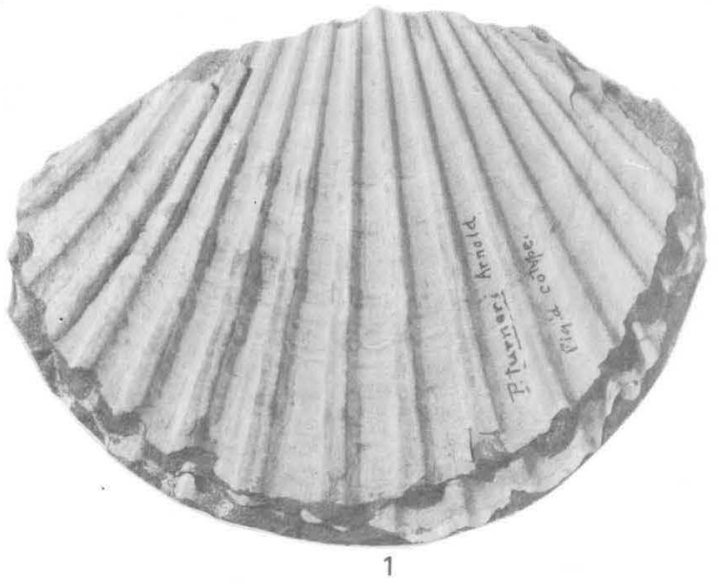

PROFESSIONAL PAPER 1228-B PLATE 37

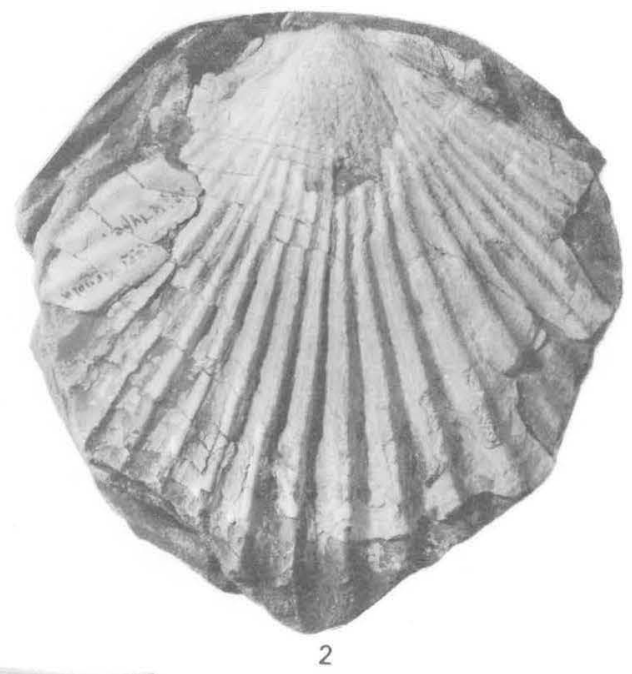

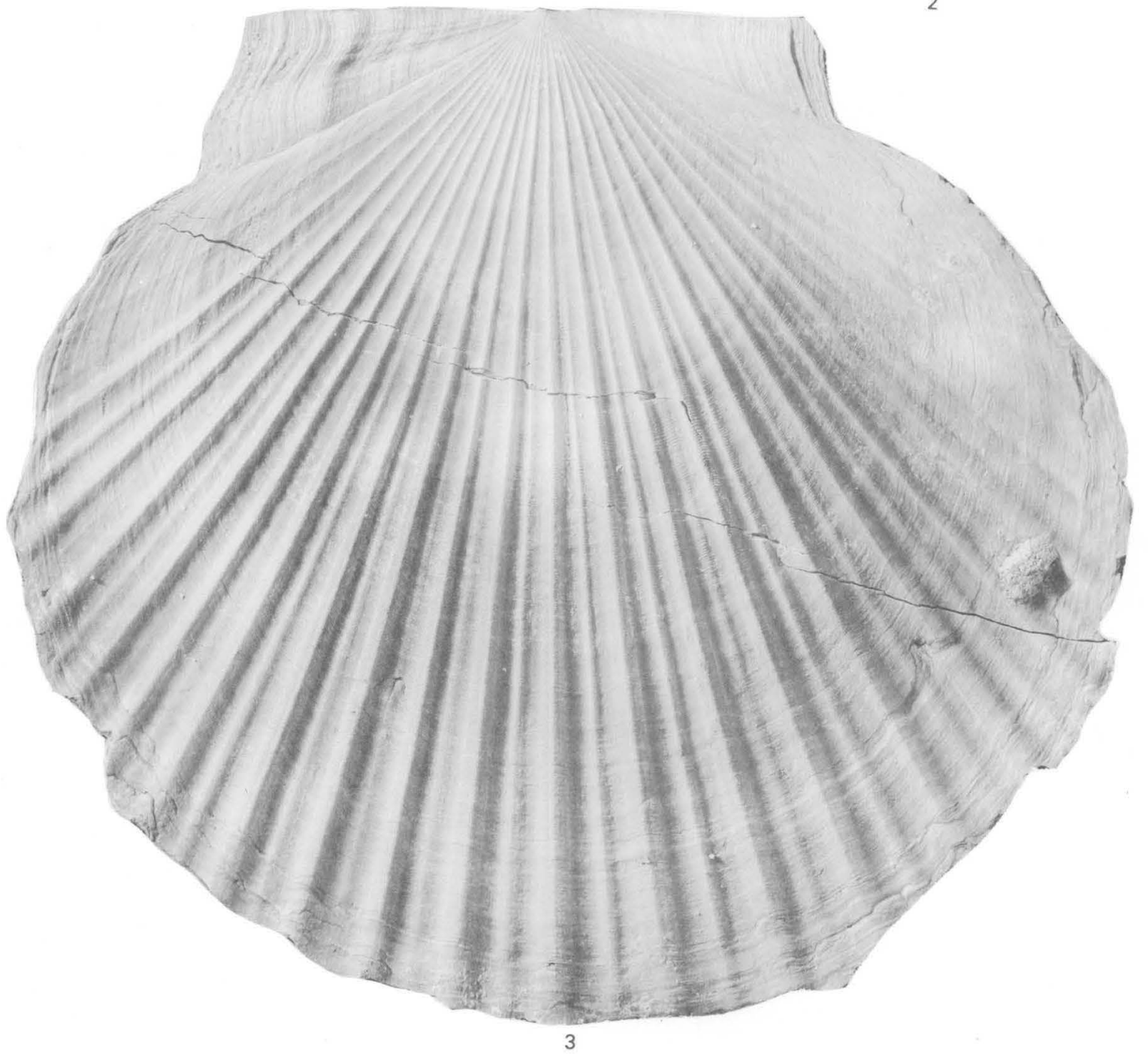

LITUYAPECTEN, PATINOPECTEN 


\section{PLATE 38}

1. Patinopecten caurinus (Gould) (p. B83).

CAS $60359(\times 0.7)$. Length $155 \mathrm{~mm}$, height $145 \mathrm{~mm}$, hinge $74 \mathrm{~mm}$. Puget Sound, Washington, Holocene.

2-5. Patinopecten healeyi (Arnold) (p. B81).

2. Hypotype (Moore, 1979, pl. 1, fig. 2) LAM $5220(\times 2.0)$. Length $30 \mathrm{~mm}$, height $31 \mathrm{~mm}$, hinge $16 \mathrm{~mm}$. San Diego Formation, Pliocene.

3. Hypotype (Moore, 1979, pl. 2, fig. 6) USNM 235592. Length $50 \mathrm{~mm}$, height $50 \mathrm{~mm}$, hinge $23 \mathrm{~mm}$. Unnamed Pliocene strata, San Clemente Island, Calif.

4. Holotype USNM 148012. Height $121 \mathrm{~mm}$. San Diego Formation, Pliocene.

5. Hypotype (Moore,1979, pl. 1, fig. 4) LAM $5222(\times 3.0)$. Length $13 \mathrm{~mm}$, height $13 \mathrm{~mm}$, hinge $8 \mathrm{~mm}$. San Diego Formation, Pliocene. 

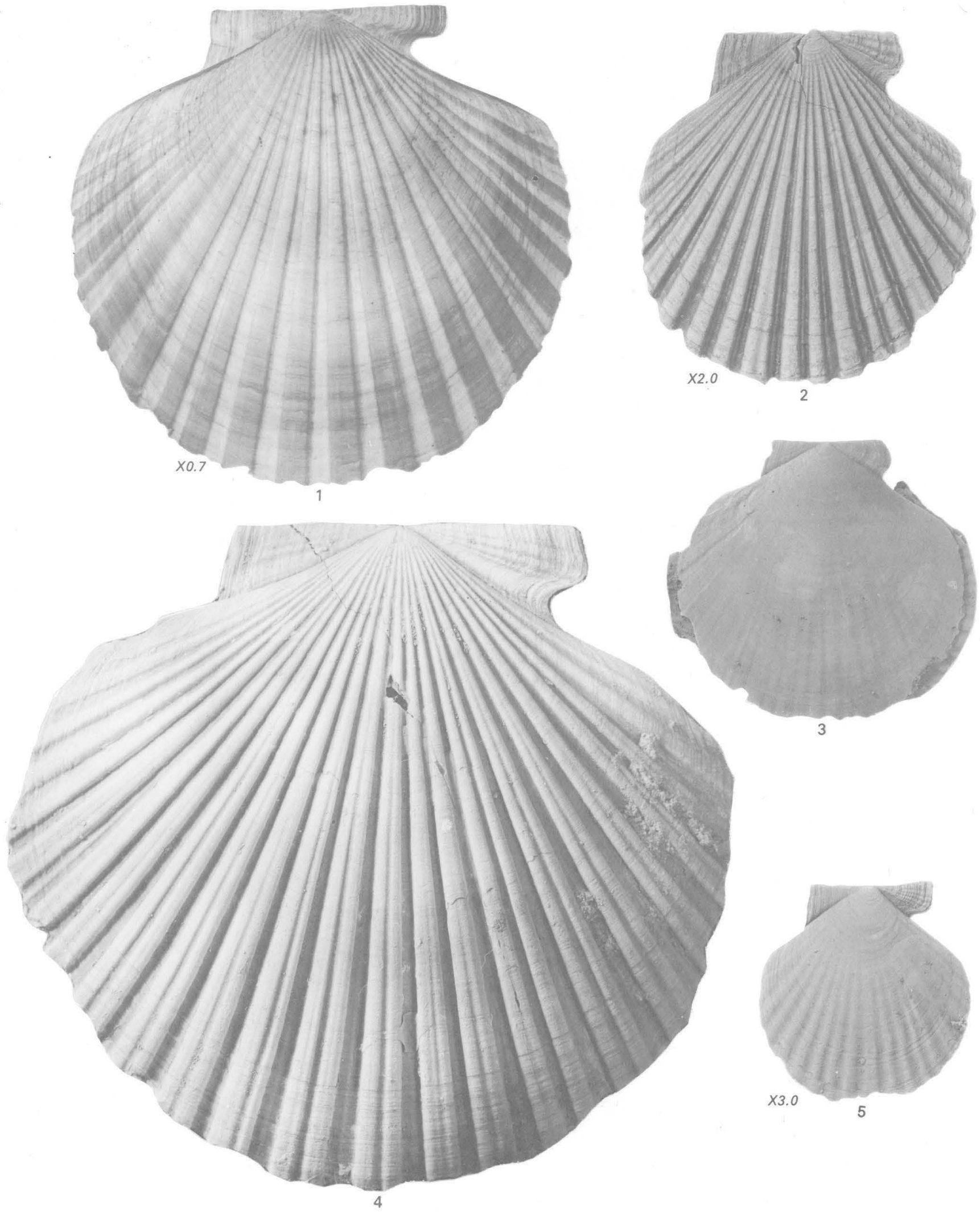

PATINOPECTEN

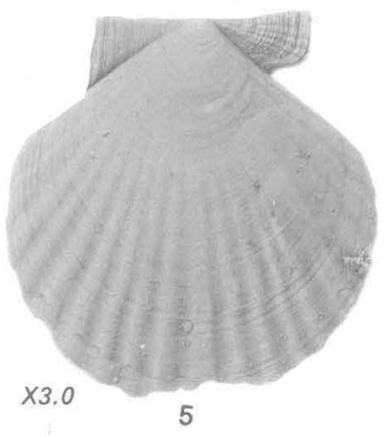




\section{PLATE 39}

1. Patinopecten healeyi (Arnold) (p. B81).

Hypotype (Moore, 1979, pl. 4, fig. 5) LAM 5228. Length $48 \mathrm{~mm}$, height $50 \mathrm{~mm}$, hinge $22 \mathrm{~mm}$. San Diego Formation, Pliocene.

2. Leopecten bakeri diazi (Durham) (p. B85).

Holotype UCMP $15968(\times 0.7)$. Length $135 \mathrm{~mm}$, height $123 \mathrm{~mm}$, hinge $53 \mathrm{~mm}$. Carmen Formation, Pliocene.

3. Leopecten marquerensis (Durham) (p. B85).

Holotype UCMP 15475 ( $\times 0.5$ ). Length $176 \mathrm{~mm}$, height $155 \mathrm{~mm}$, hinge $72 \mathrm{~mm}$. Marquer Formation, Pliocene.

4. Vertipecten diabloensis (Clark) (p. B64).

Paratype UCMP $11139(\times 1.5)$. Length $50 \mathrm{~mm}$, height $51 \mathrm{~mm}$. San Ramon Sandstone, Miocene.

5. Patinopecten caurinus (Gould) (p. B83).

CAS $60359(\times 0.8)$. Length $148 \mathrm{~mm}$, height $137 \mathrm{~mm}$, hinge $73 \mathrm{~mm}$. Puget Sound, Washington, Holocene. 

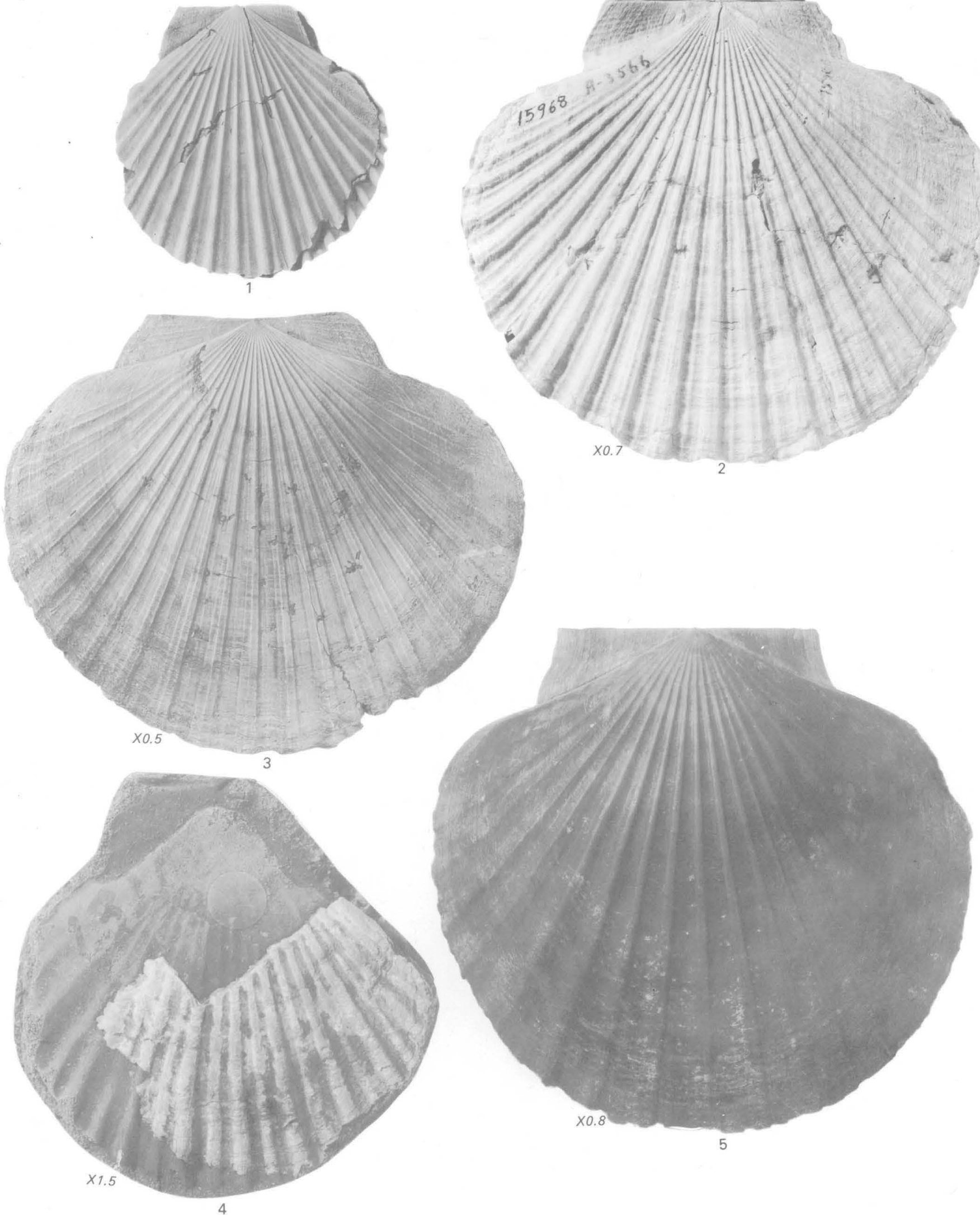

PATINOPECTEN, LEOPECTEN, VERTIPECTEN 


\section{PLATE 40}

1. Leopecten marquerensis (Durham) (p. B85).

Holotype UCMP $15475(\times 0.5)$. Length $176 \mathrm{~mm}$, height $155 \mathrm{~mm}$, hinge $72 \mathrm{~mm}$. Marquer Formation, Pliocene.

2. Leopecten bakeri diazi (Durham) (p. B85).

Holotype UCMP $15968(\times 0.8)$. Length $135 \mathrm{~mm}$, height $123 \mathrm{~mm}$, hinge $53 \mathrm{~mm}$. Carmen Formation, Pliocene.

3. Patinopecten yessoensis (Jay). (p. B78).

Hypotype (Moore, 1979, pl. 14, fig. 1) (× 1.5). Exterior of right valve enlarged to show imbricated microsculpture. CAS 58773.

4. Leopecten bakeri bakeri (Hanna and Hertlein) (p. B85).

Holotype CAS $1865(\times 0.7)$. Length $150 \mathrm{~mm}$, height $130 \mathrm{~mm}$, hinge $66 \mathrm{~mm}$. San Marcos Formation, Pliocenè.

5. Patinopecten healeyi (Arnold) (p. B81).

Hypotype (Moore, 1979, pl. 10, fig. 4) LAM $5253(\times 3.0)$. Length $21 \mathrm{~mm}$, height $21 \mathrm{~mm}$, hinge $10 \mathrm{~mm}$. San Diego Formation, Pliocene. 

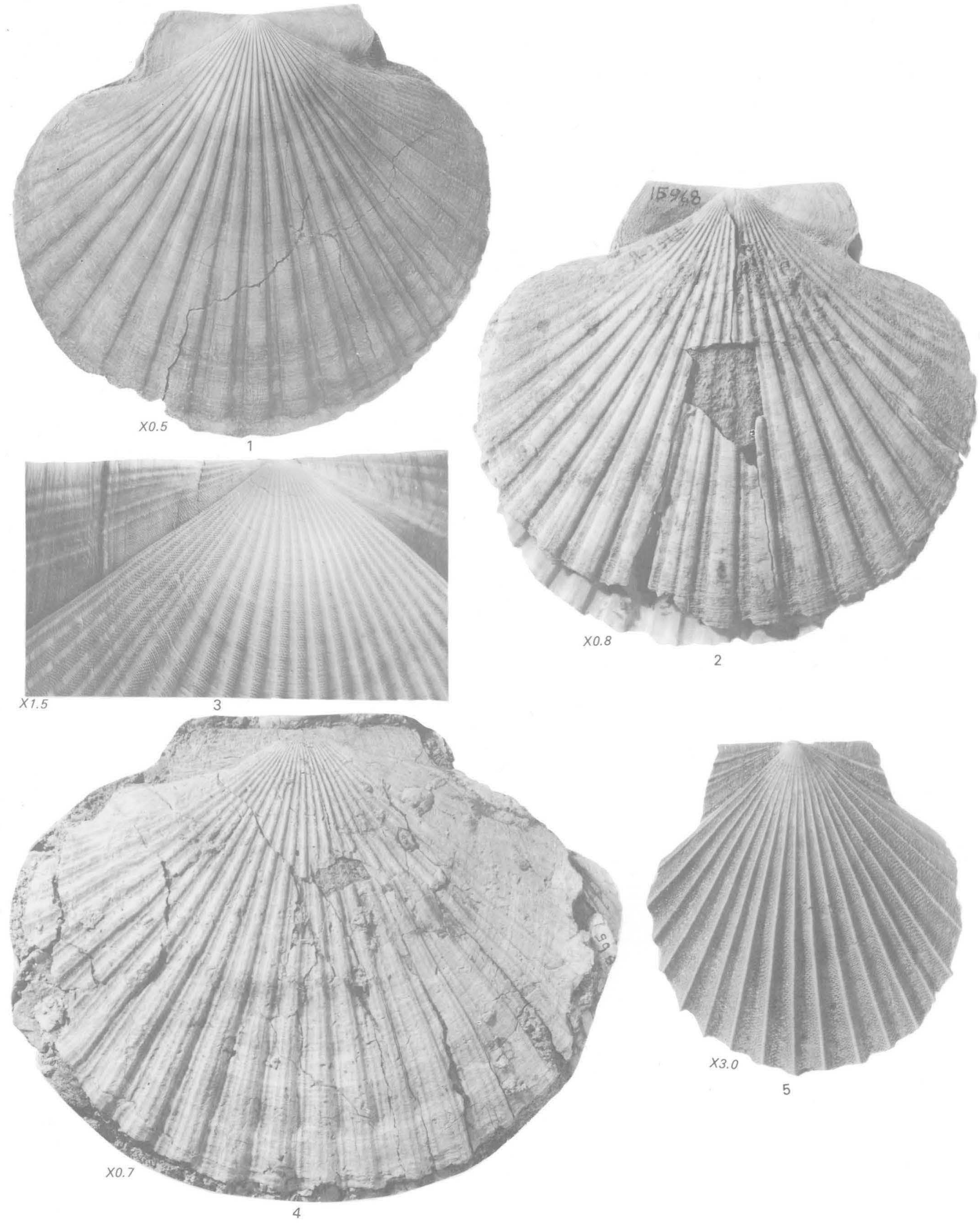

PATINOPECTEN, LEOPECTEN 


\section{PLATE 41}

Figures

1, 5. Lituyapecten falorensis (MacNeil) (p. B86).

Holotype UCMP 34172. Length $105 \mathrm{~mm}$, height $99 \mathrm{~mm}$. Falor Formation, Pliocene.

2. Patinopecten healeyi (Arnold) (p. B81).

Hypotype (Moore, 1979, pl. 4, fig. 7) LAM $5229(\times 3.0)$. Enlargement of right anterior auricle showing ctenolium. Right anterior auricle $17 \mathrm{~mm}$ long.

3, 4. Lituyapecten purisimaensis (Arnold) (p. B87).

Holotype CAS/SU $3(\times 0.7)$. Length $121 \mathrm{~mm}$, height $124 \mathrm{~mm}$. Purisima Formation, Pliocene. 
GEOLOGICAL SURVEY

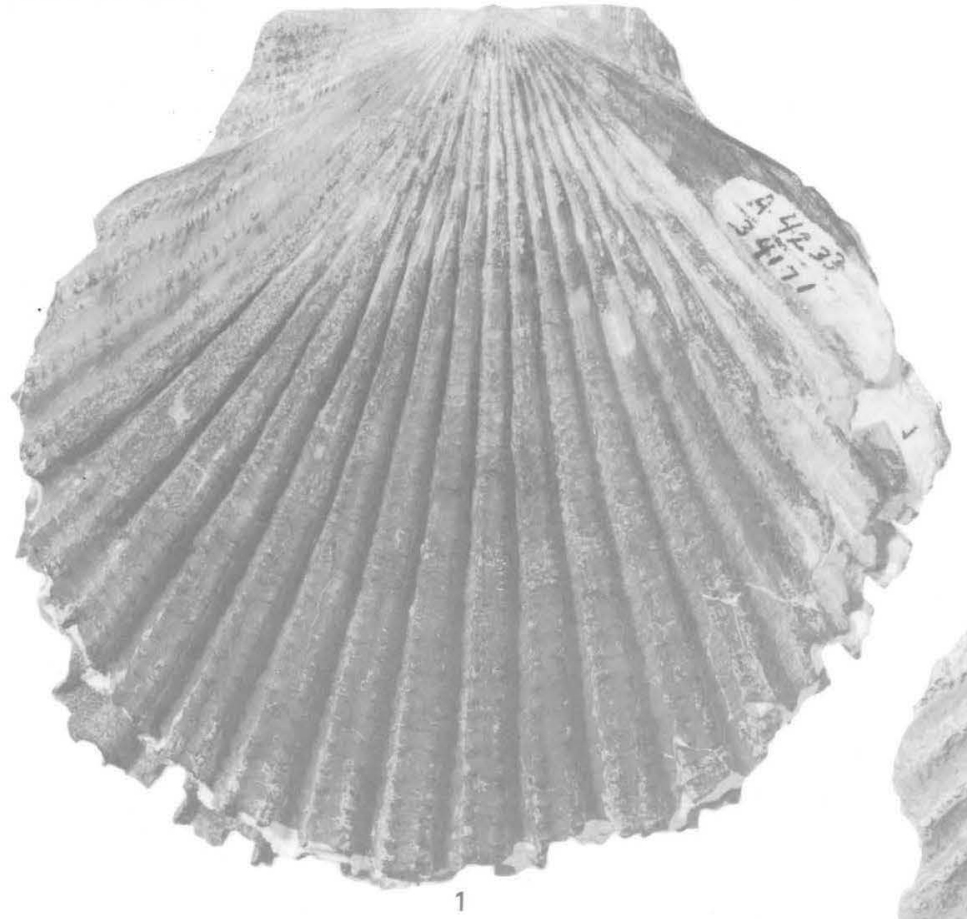

PROFESSIONAL PAPER 1228-B PLATE 41
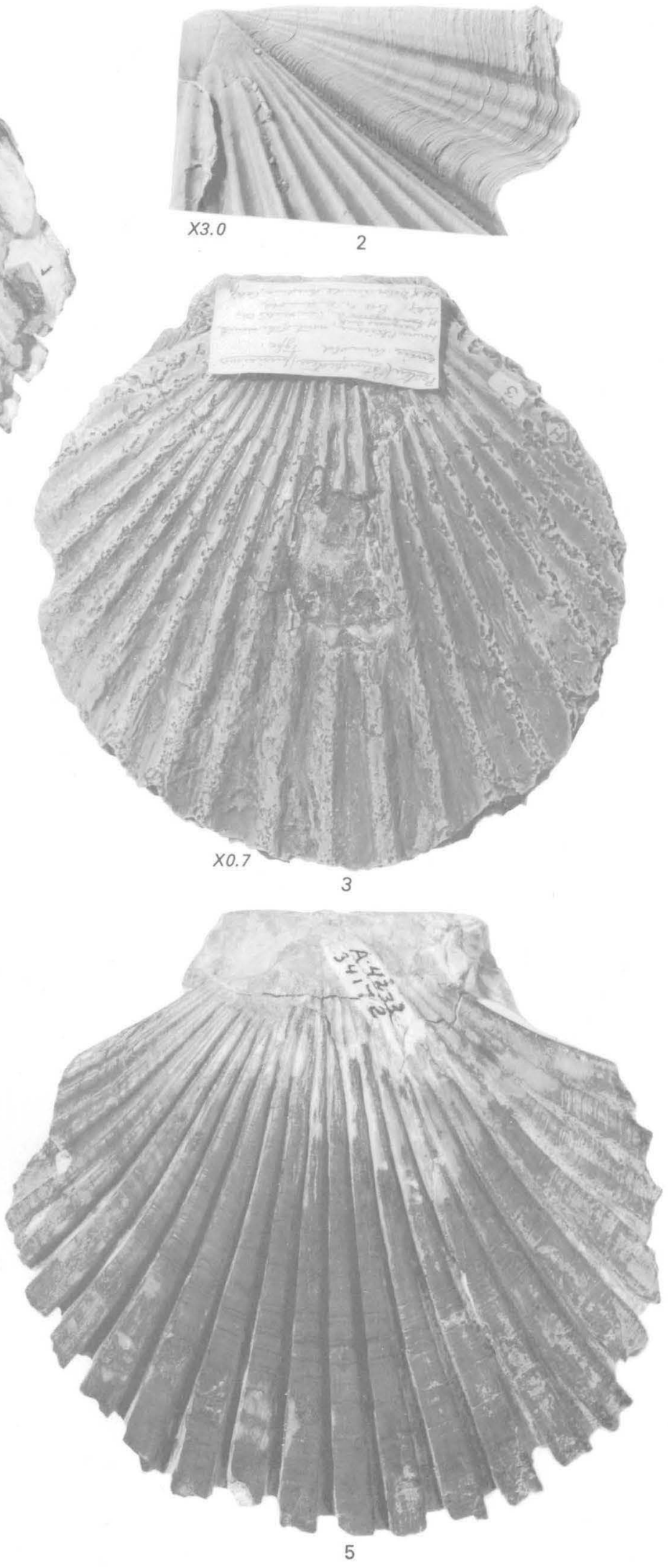


\section{PLATE 42}

Figures 1-3. Patinopecten healeyi (Arnold) (p. B81).

San Diego Formation, Pliocene.

1. Hypotype (Moore, 1979, pl. 5, fig. 1) LAM $5231(\times 0.8)$. Length $106 \mathrm{~mm}$, height $105 \mathrm{~mm}$, hinge $52 \mathrm{~mm}$.

2. Hypotype (Moore, 1979, pl. 10, fig. 1) LAM $5250(\times 2.5)$. Length $36 \mathrm{~mm}$, height $37 \mathrm{~mm}$.

3. Hypotype (Moore, 1979, pl. 4, fig. 3) LAM 5228. Length $48 \mathrm{~mm}$, height $50 \mathrm{~mm}$, hinge $22 \mathrm{~mm}$.

4. Lituyapecten dilleri (Dall) (p. B88).

Lectotype USNM 164846. Length $160 \mathrm{~mm}$. Rio Dell Formation, Pliocene and Pleistocene. 
GEOLOGICAL SURVEY

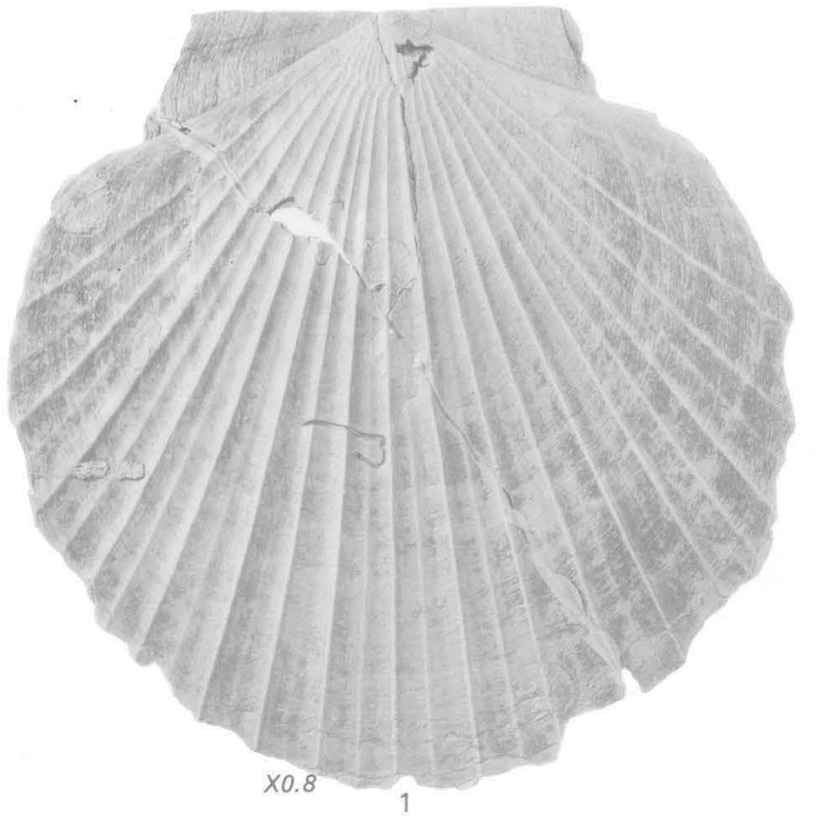

PROFESSIONAL PAPER 1228-B PLATE 42
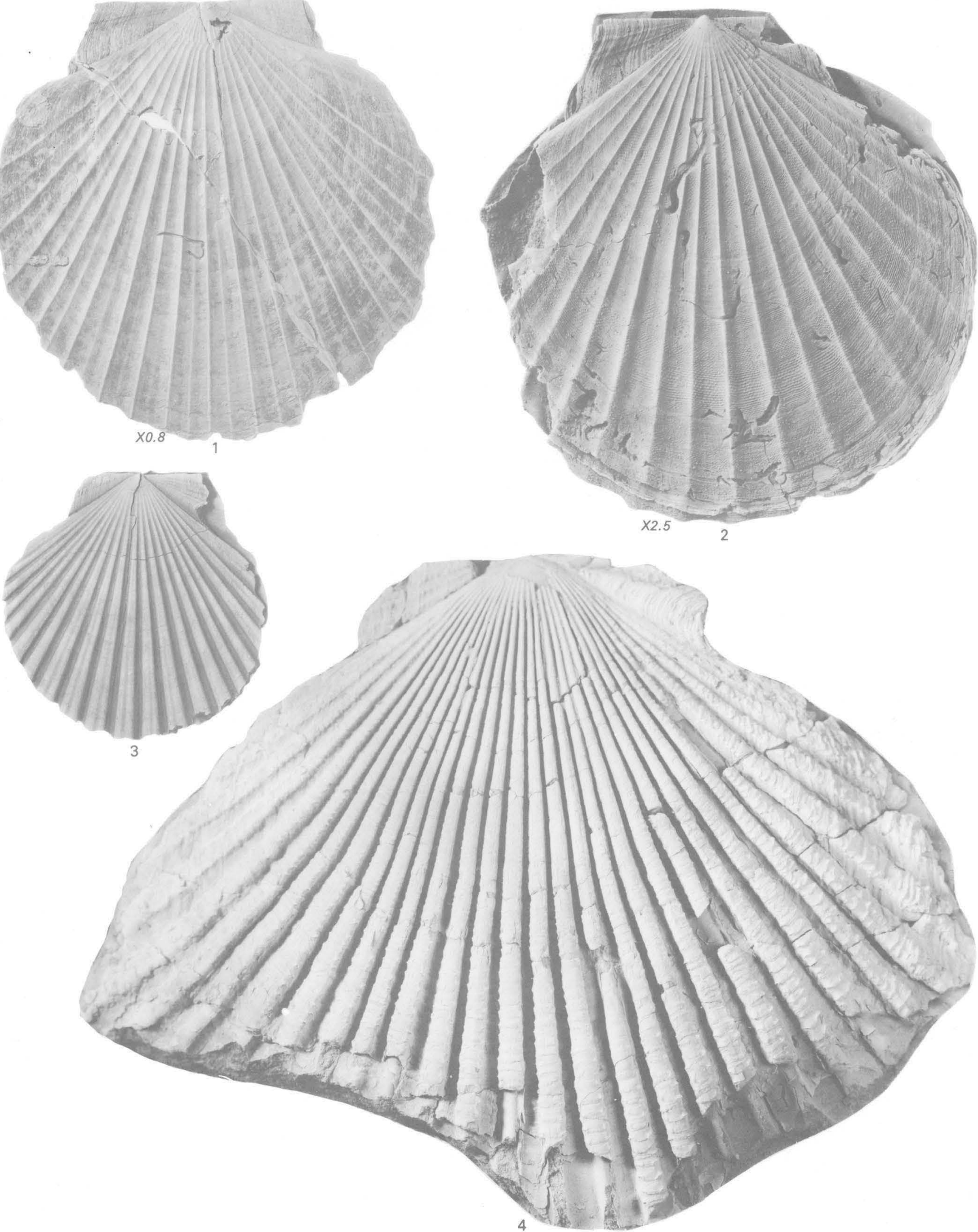

LITUYAPECTEN, PATINOPECTEN 